\title{
The role of firm life cycle in the functioning of capital markets
}

Citation for published version (APA):

Hamers, L. J. P. (2017). The role of firm life cycle in the functioning of capital markets. [Doctoral Thesis, Maastricht University]. Datawyse / Universitaire Pers Maastricht. https://doi.org/10.26481/dis.20170203/h

Document status and date:

Published: 01/01/2017

DOI:

10.26481/dis.20170203lh

Document Version:

Publisher's PDF, also known as Version of record

\section{Please check the document version of this publication:}

- A submitted manuscript is the version of the article upon submission and before peer-review. There can be important differences between the submitted version and the official published version of record.

People interested in the research are advised to contact the author for the final version of the publication, or visit the DOI to the publisher's website.

- The final author version and the galley proof are versions of the publication after peer review.

- The final published version features the final layout of the paper including the volume, issue and page numbers.

Link to publication

\footnotetext{
General rights rights.

- You may freely distribute the URL identifying the publication in the public portal. please follow below link for the End User Agreement:

www.umlib.nl/taverne-license

Take down policy

If you believe that this document breaches copyright please contact us at:

repository@maastrichtuniversity.nl

providing details and we will investigate your claim.
}

Copyright and moral rights for the publications made accessible in the public portal are retained by the authors and/or other copyright owners and it is a condition of accessing publications that users recognise and abide by the legal requirements associated with these

- Users may download and print one copy of any publication from the public portal for the purpose of private study or research.

- You may not further distribute the material or use it for any profit-making activity or commercial gain

If the publication is distributed under the terms of Article $25 \mathrm{fa}$ of the Dutch Copyright Act, indicated by the "Taverne" license above, 


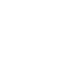

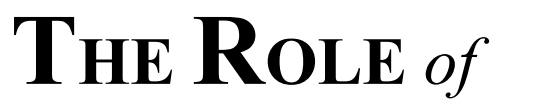

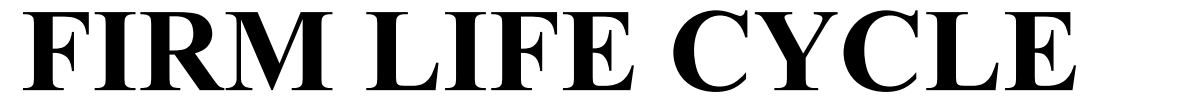

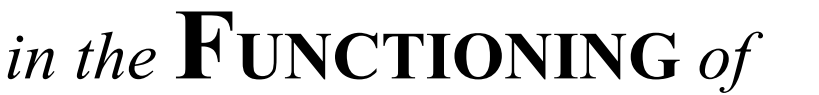

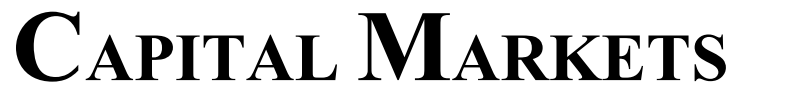

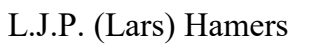

$\square$

$\square$

$\square$ 


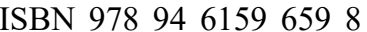

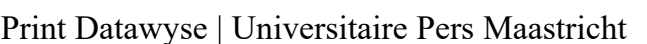

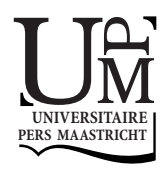


$\square$

$\square$

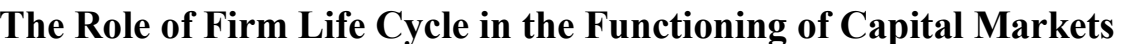

$\square$
$\square$
$\square$
$\square$
$\square$
$\square$
$\square$

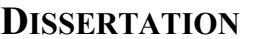

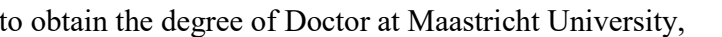

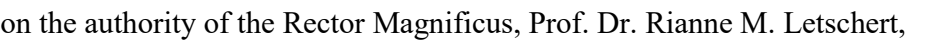

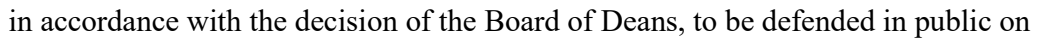

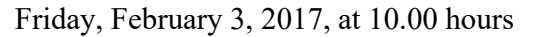

$\square$

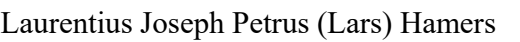

$\square$

$\square$ 


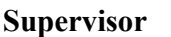

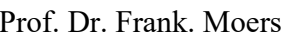

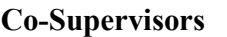

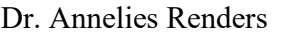

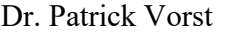

$\square$

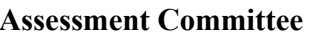

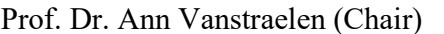

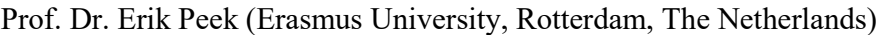

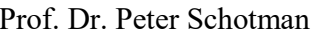

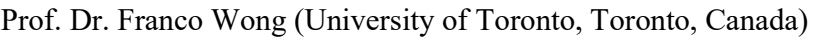


$\square$

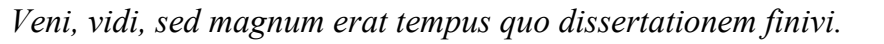

$\square$

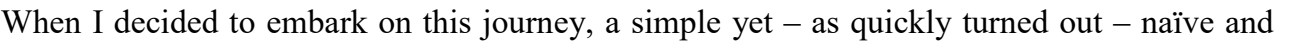

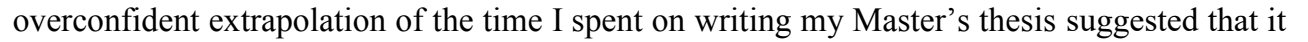

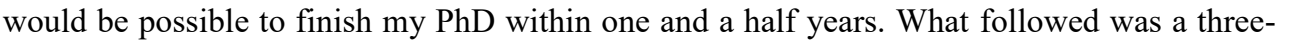

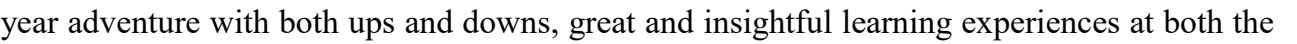

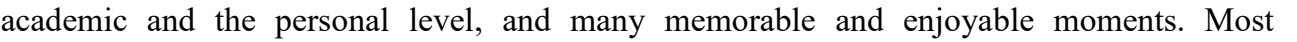

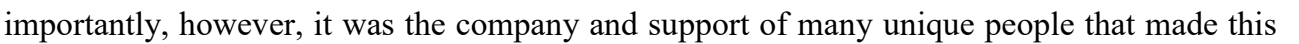

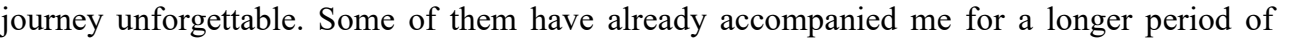
ம

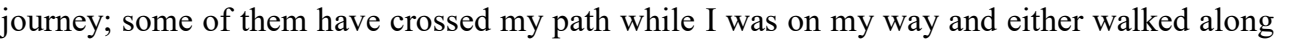

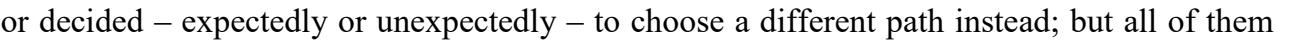

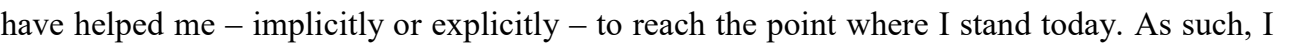

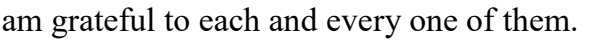

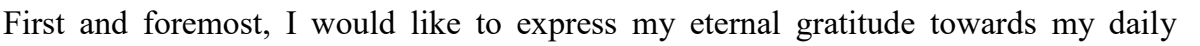

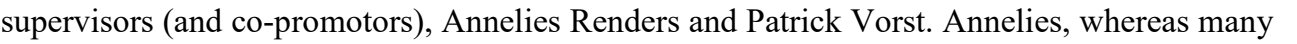

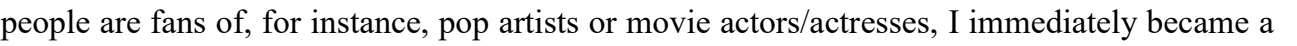

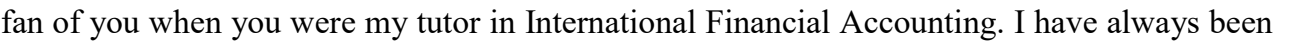

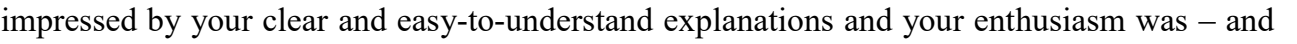

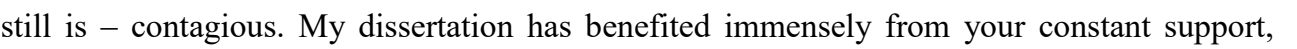

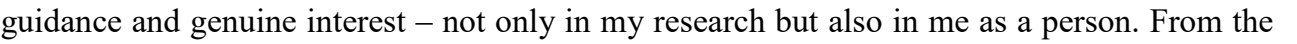

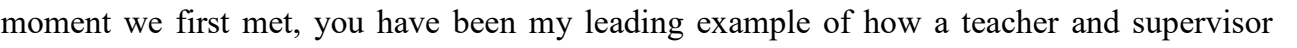

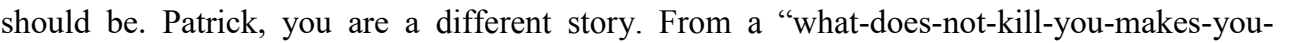
stronger" "

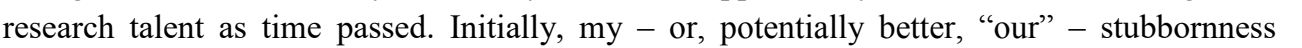

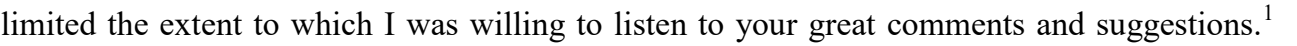

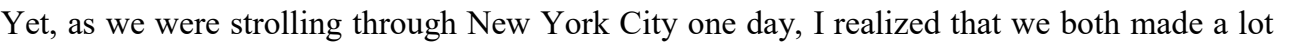

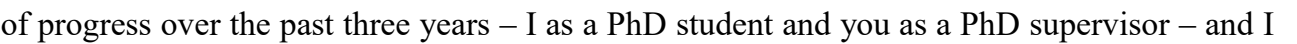

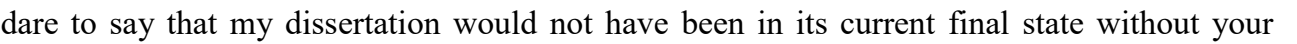

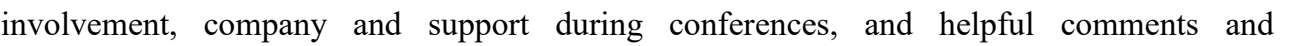

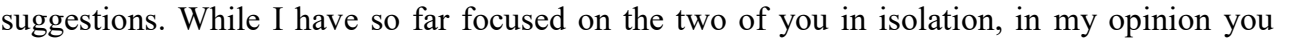

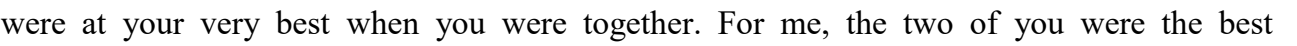

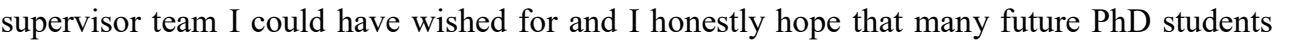

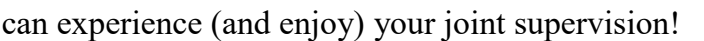

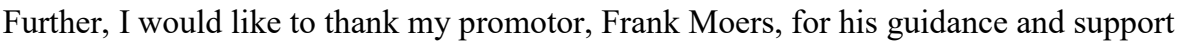

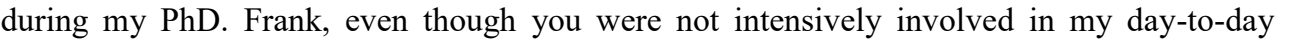

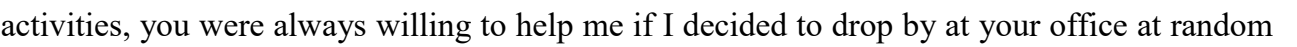

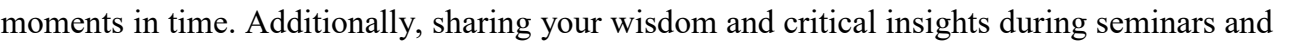

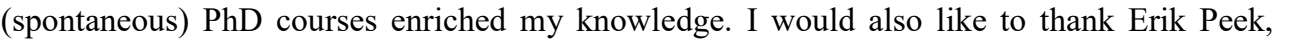

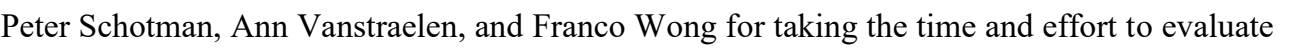

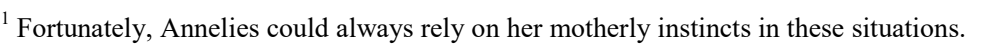




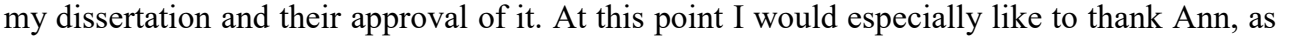

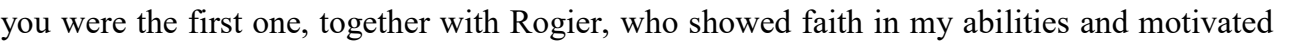
me to pursue a PhD after I had finished my Bachelor's s

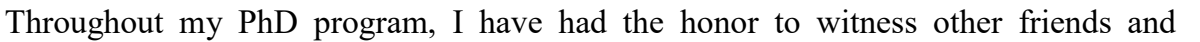

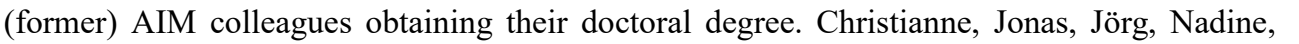

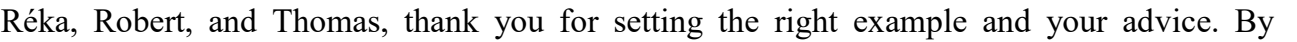

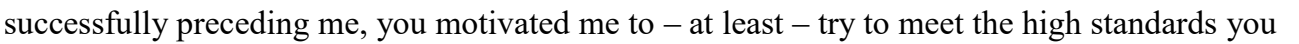

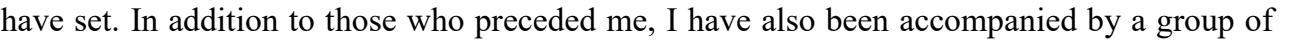

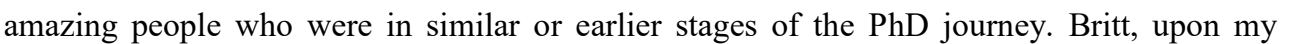

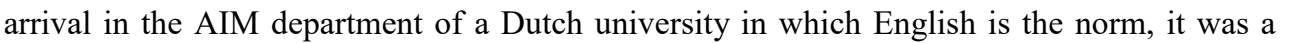

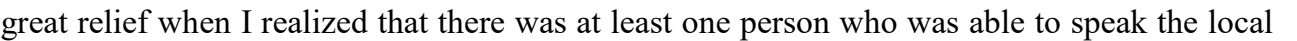

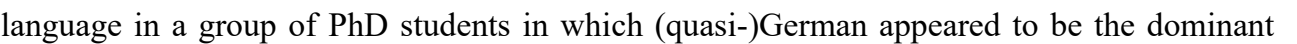
ए ए।

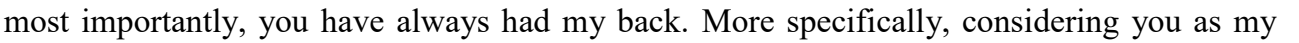

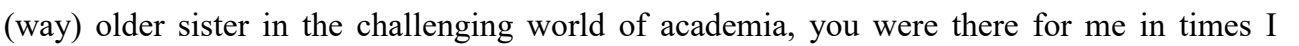

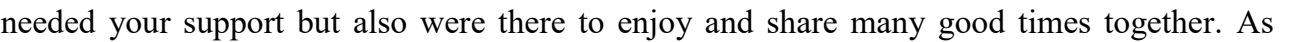

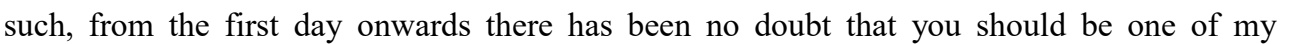

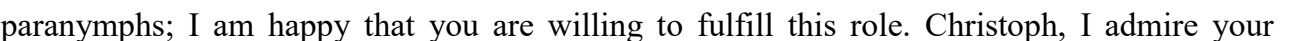
working attitude, motivation, and perseverance. Being the most senior of "our generation",

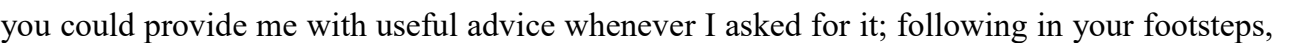
पnding the right path became a lot easier. Judith, my "honorary" paranymph, I guess that

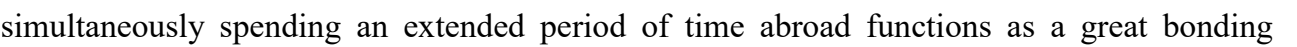

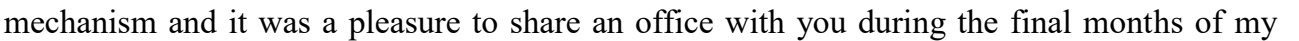

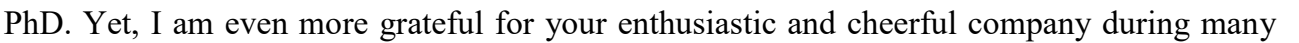

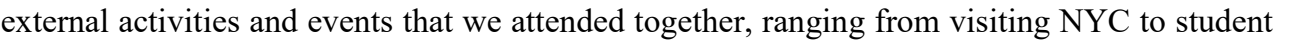

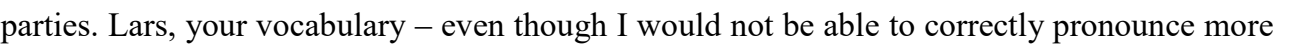
ए ए।

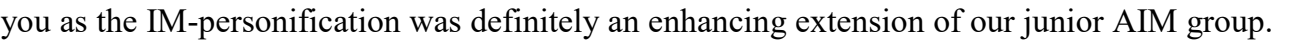

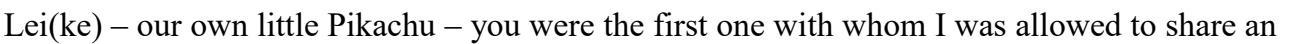

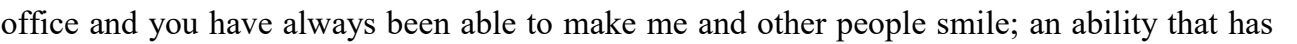

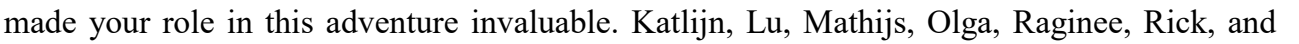

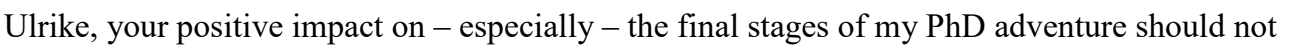

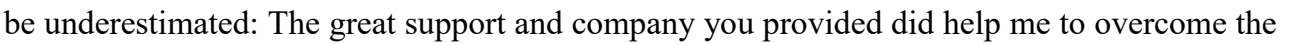

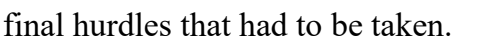

ए

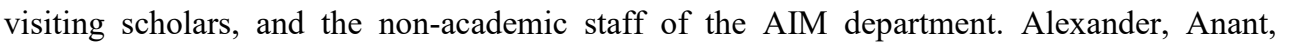

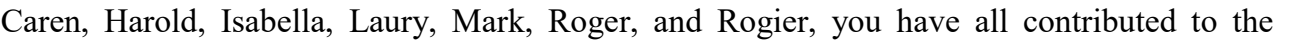

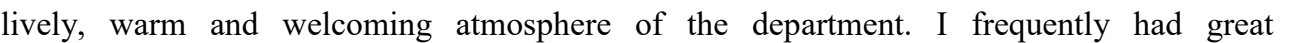

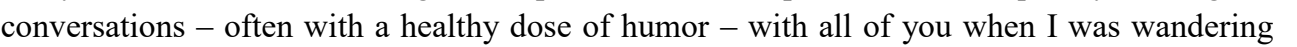
through the corridors or "camping" in one of the coffee corners. With the benefit of hindsight,

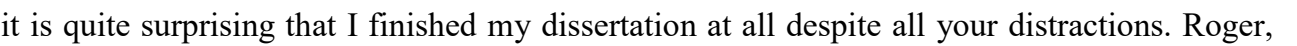

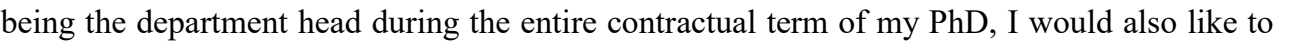

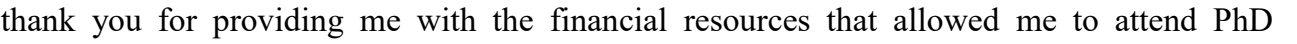

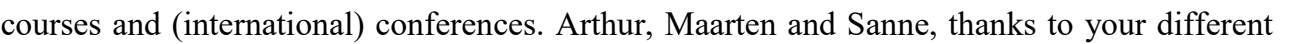




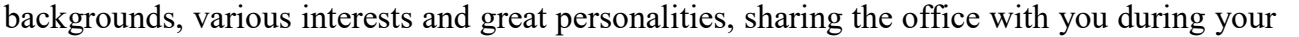

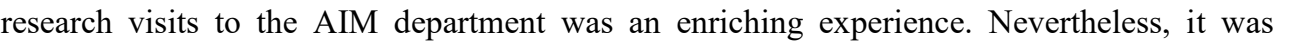
sometimes nice and maybe even necessary to "escape the academic bubble" during working

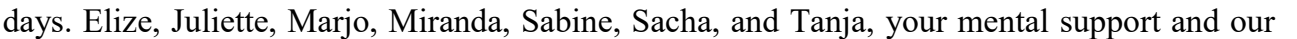

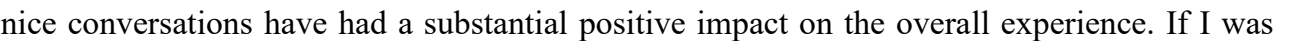

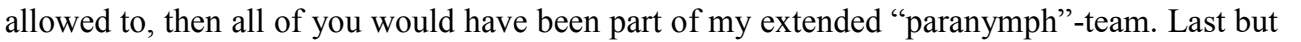

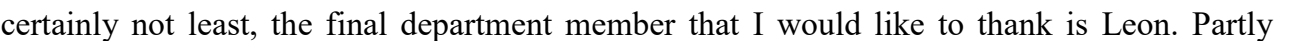

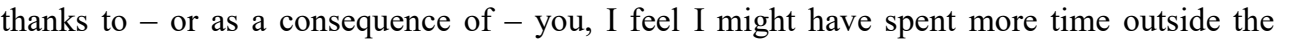

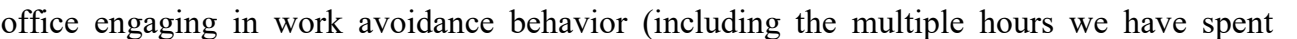

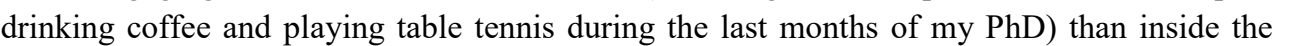

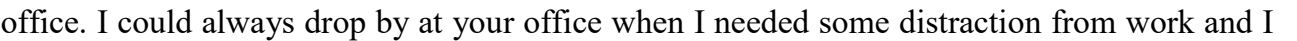
am convinced that my dissertation has immensely benefited from your "help". $\square \square$

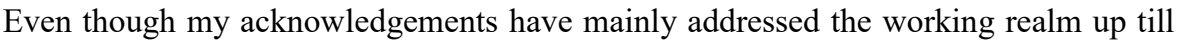

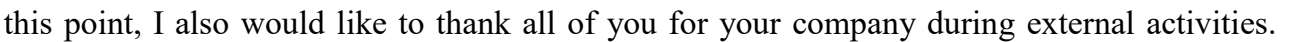

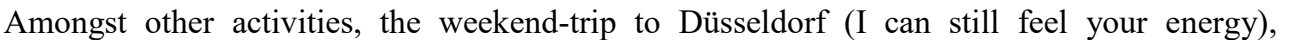

Christoph's wedding in Vienna, the Oktoberfest in München (even though I do not remember

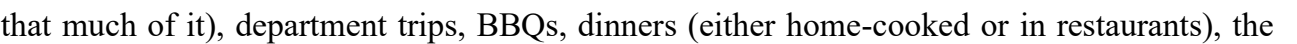

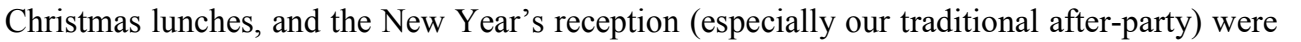

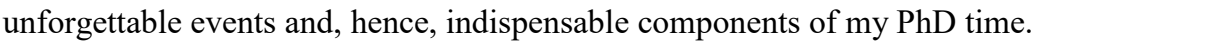

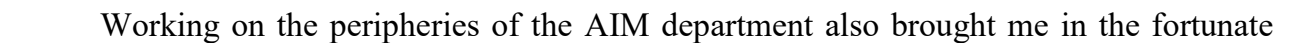

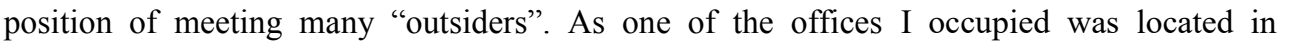
between two O\&S offices, it was inevitable to meet members of other departments... and, if

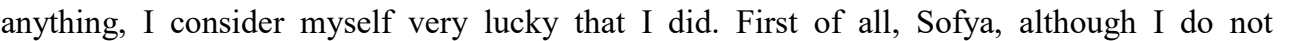

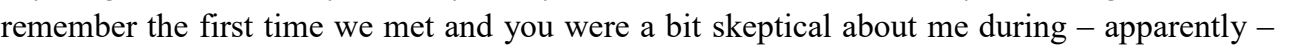

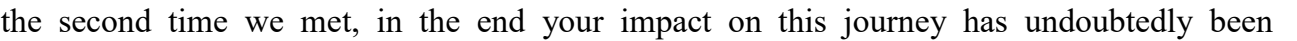
ए

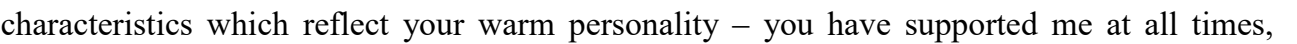
ए

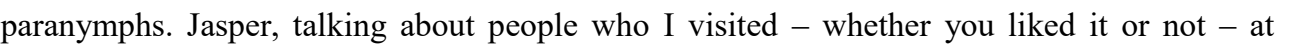

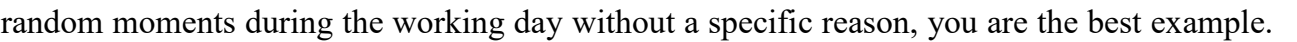

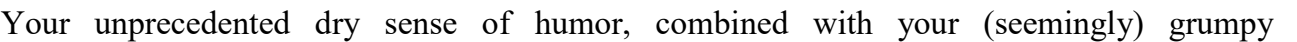

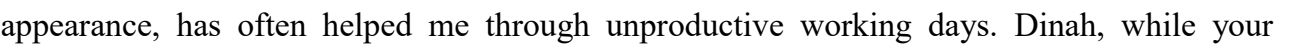

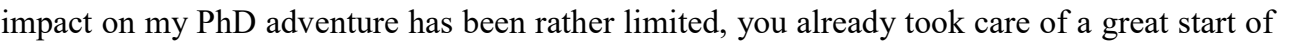

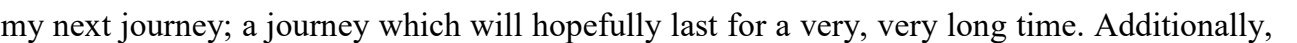
प

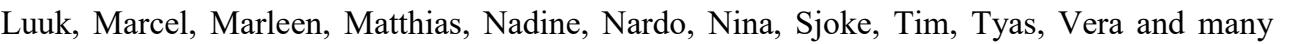

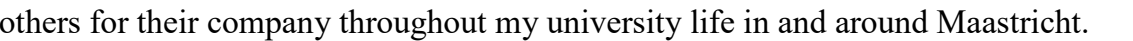

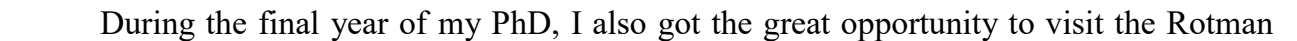

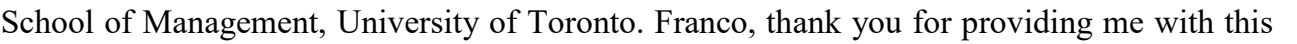

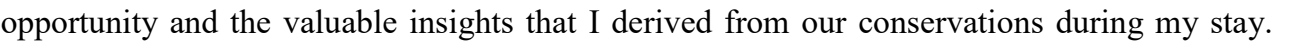

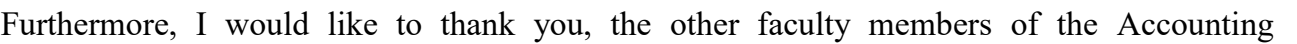

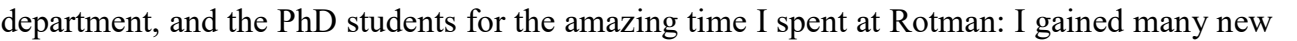
ए ए

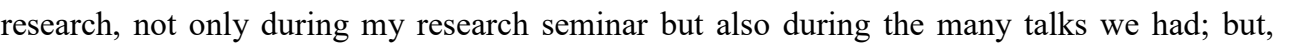




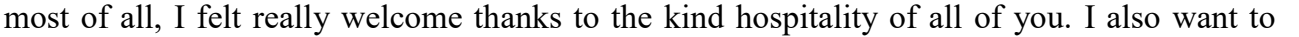

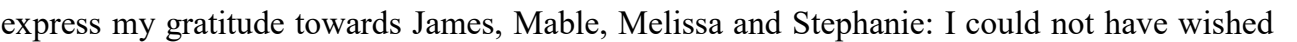
ए

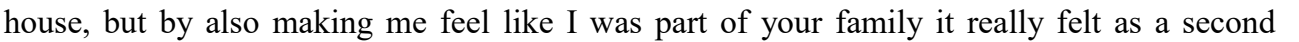

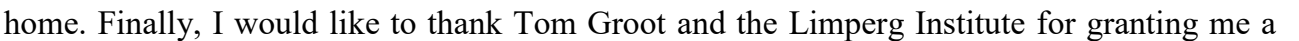

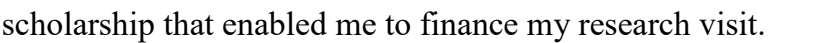

$\square \quad$ Zo... En dan na ietwat meer dan drie pagina's “acknowledgements" zijn er $\square \square \square \square \square$

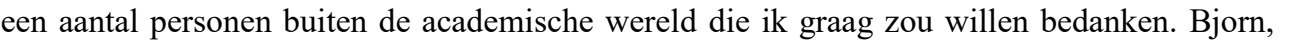

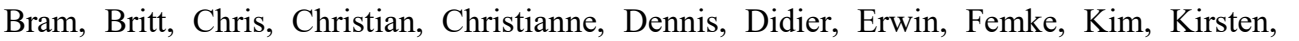

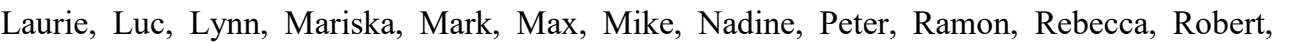

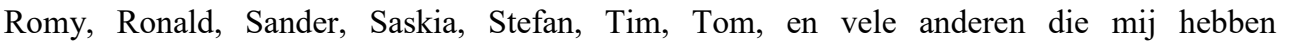
"bijgestaan" tijdens mijn avonturen: ook al is ju

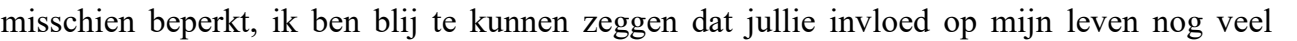

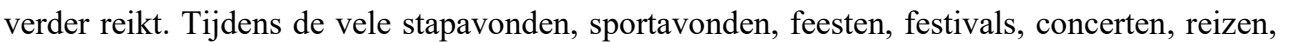

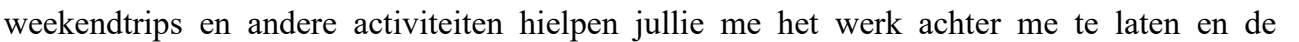

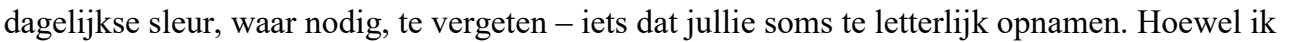

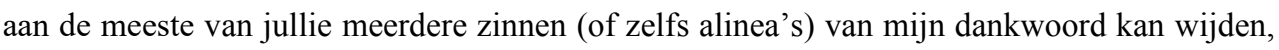

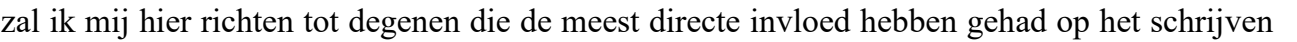

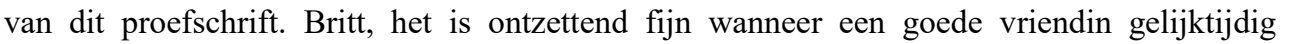
hetzelfde proces doorloopt en je ‘academische' ervaringen kunt delen -

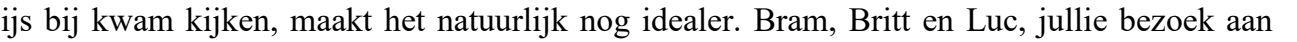

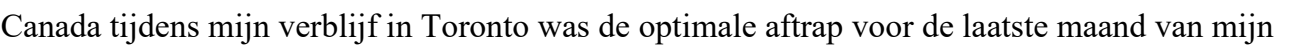

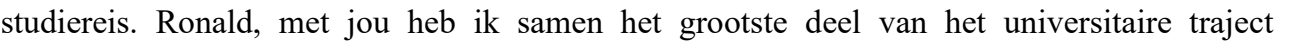

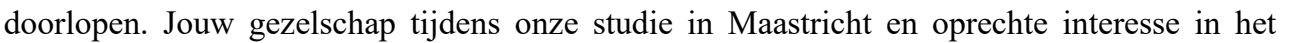

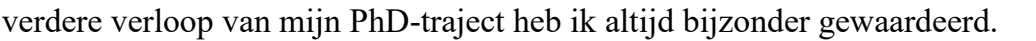

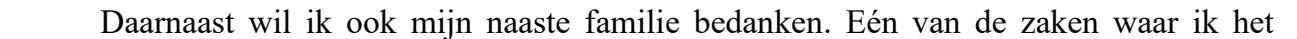

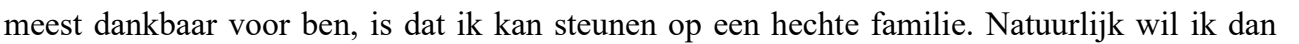

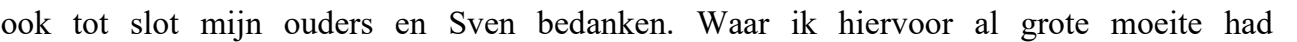

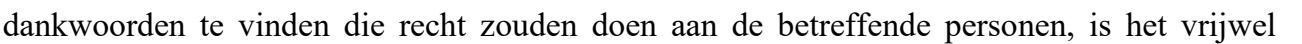
onmogelijk om in woorden uit te drukken hoe veel jullie voor mij hebben betekend... toch zal

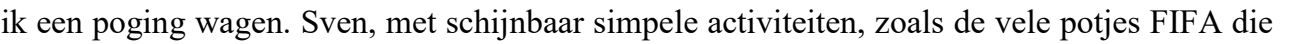

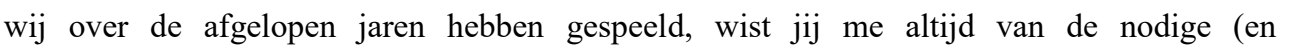

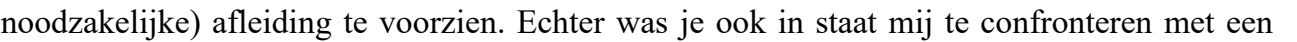

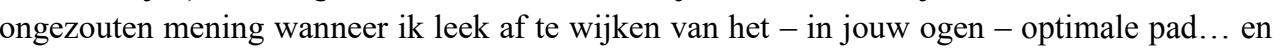

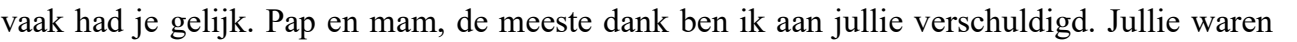

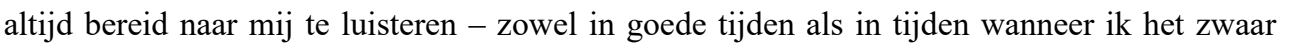

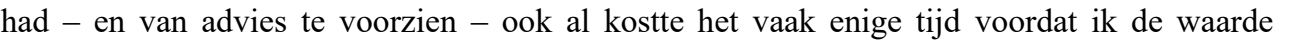

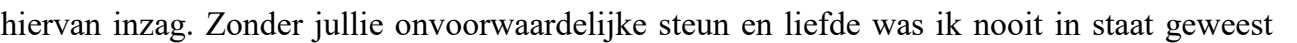

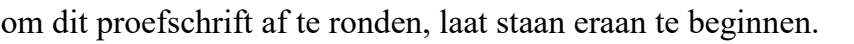
$\square$ 


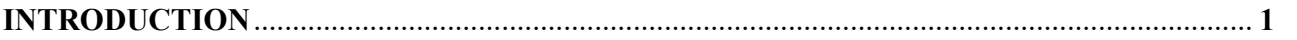

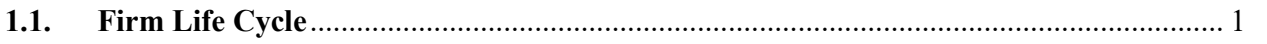

प

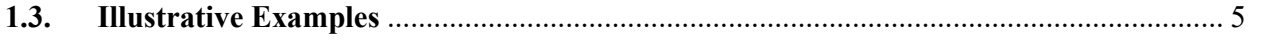

प

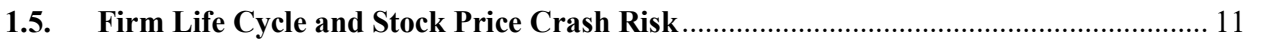
प

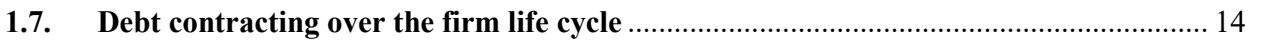

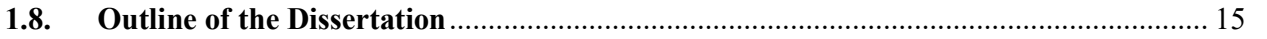

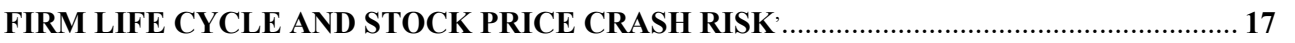
प

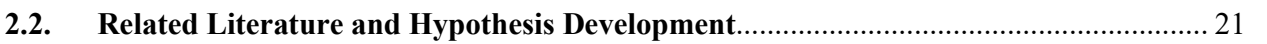

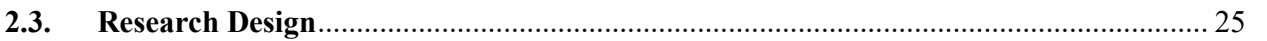

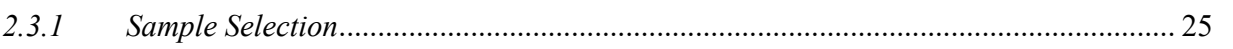

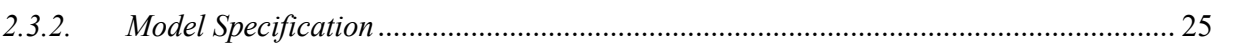

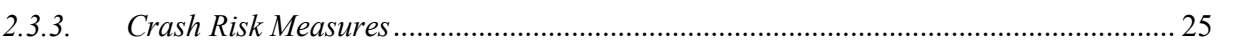

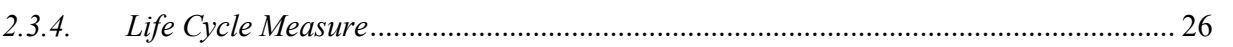

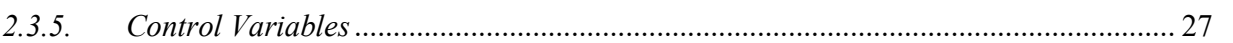

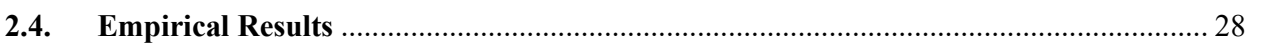

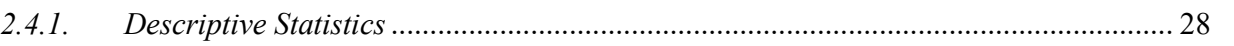

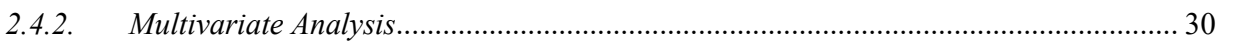

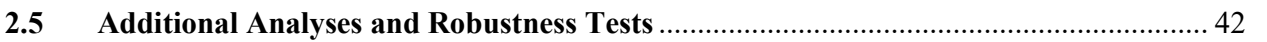

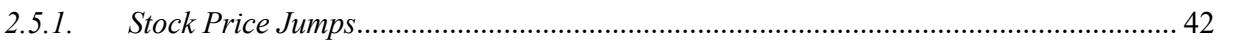

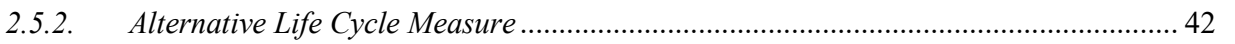

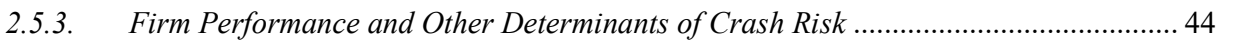
प

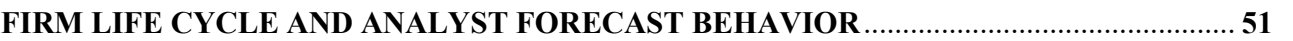

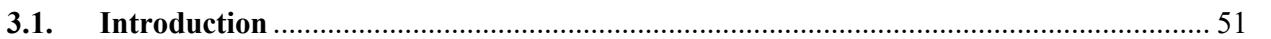

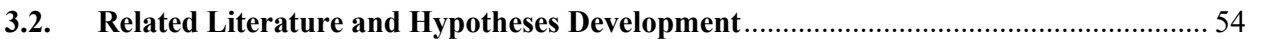

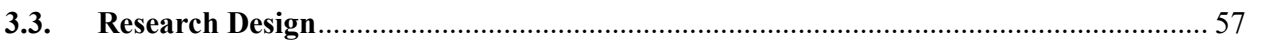
प

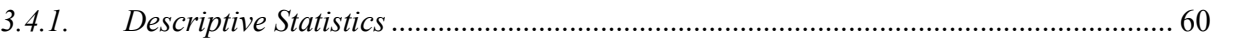

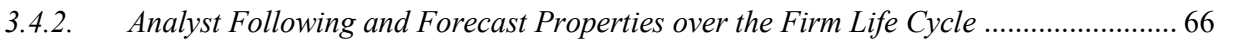

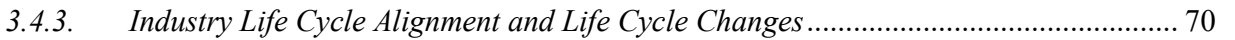




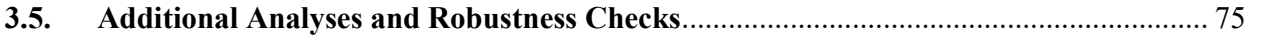

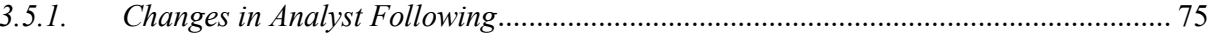

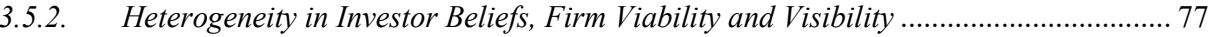

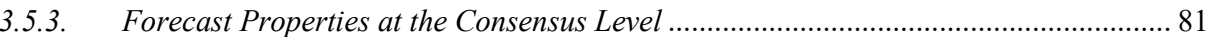

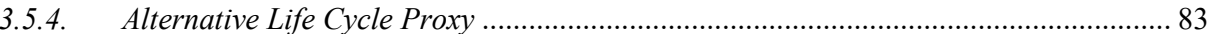

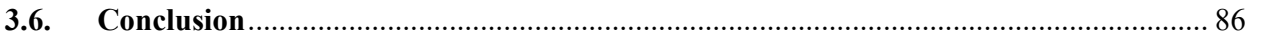
b

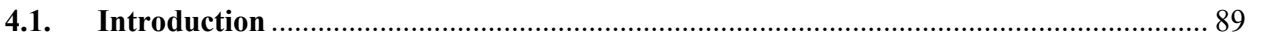

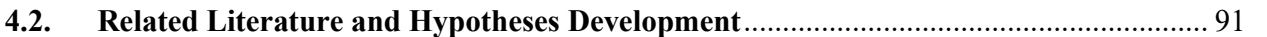
पणाm

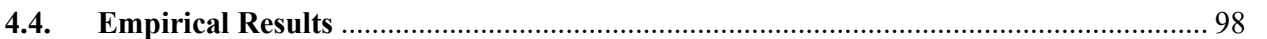

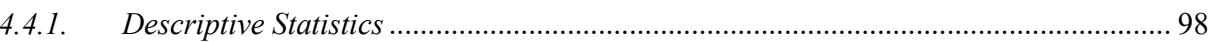

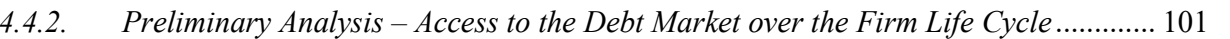

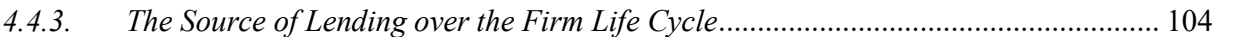

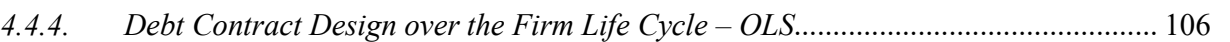

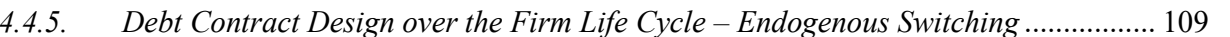

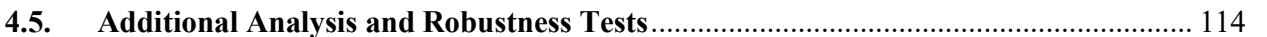

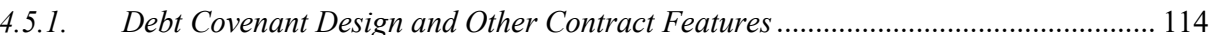

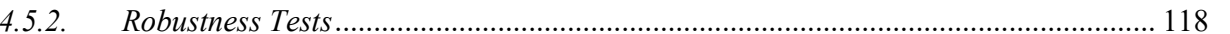

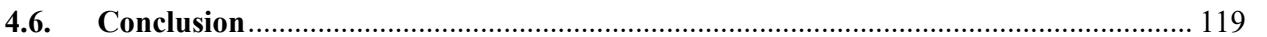

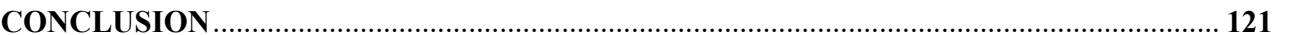

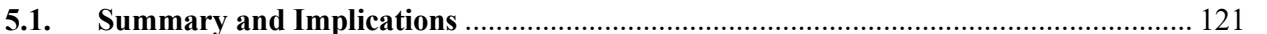

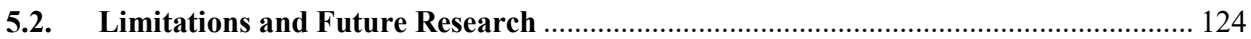
$\square$

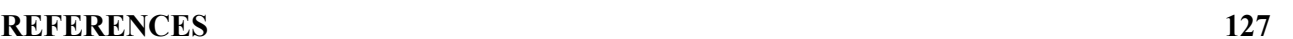
$\square$
घ

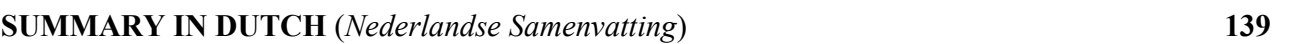

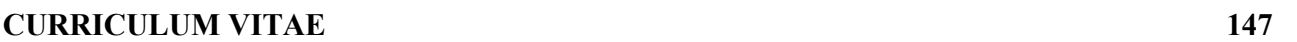




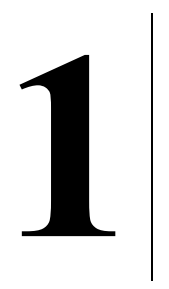

밈 $\square \square \square \square \square \square \square$

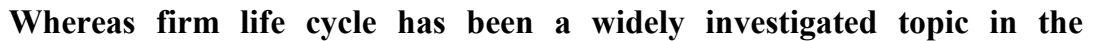

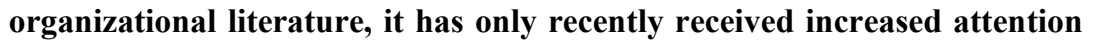

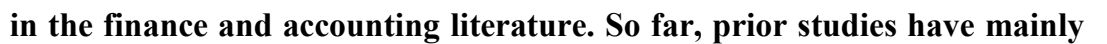

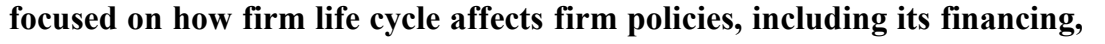

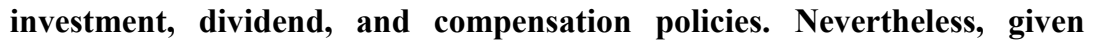

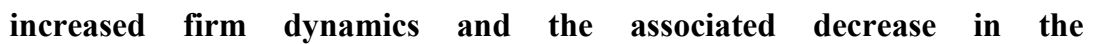

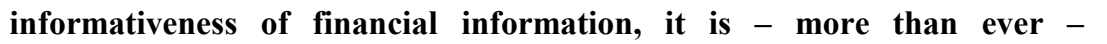

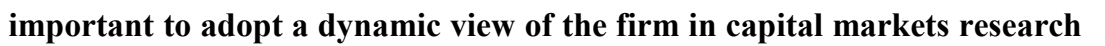

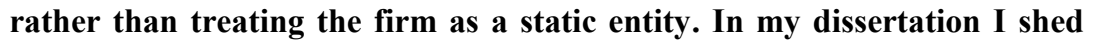

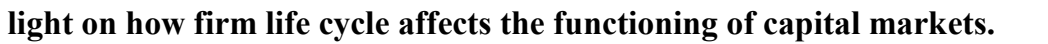

$\square$

"Like people and plants, organizations have a life cycle. They have a green

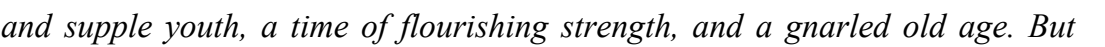
organizations differ from people and plants in that their life cycle isn't even

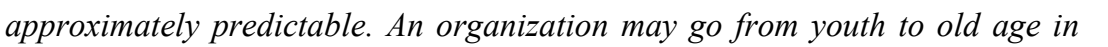

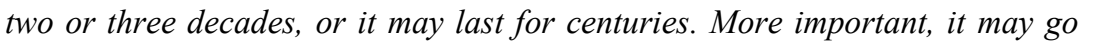

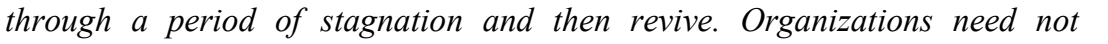

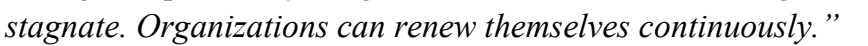

$\square$

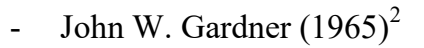

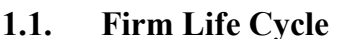

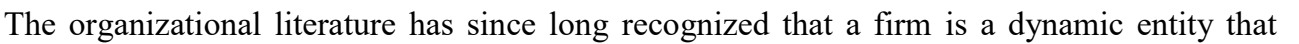

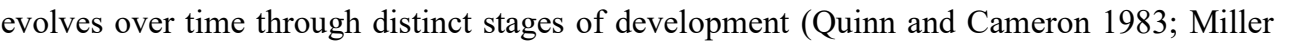

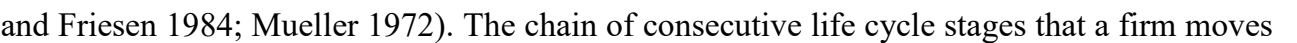

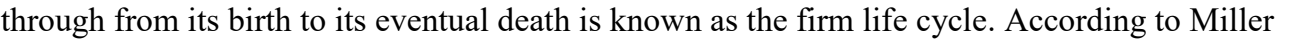

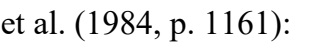

$\square$

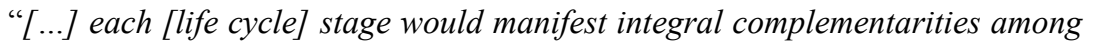
variables of environment ("situation”), strategy, structure and decision making methods... [O]rganizational growth and increasing environmental $\square \square \square \square \square \square$

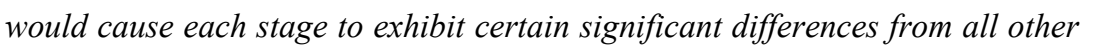
stages along these four classes of variables...".

$\square$

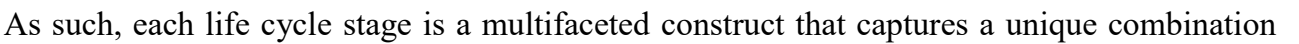

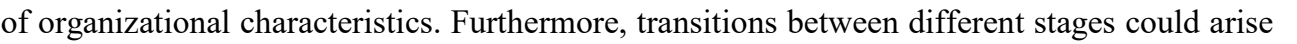

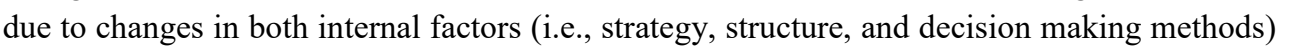

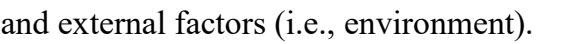

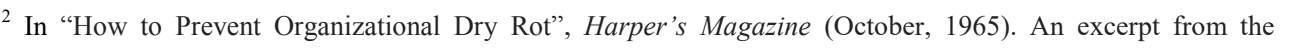

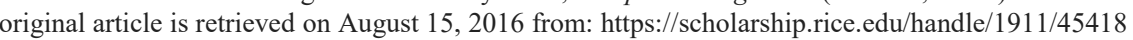




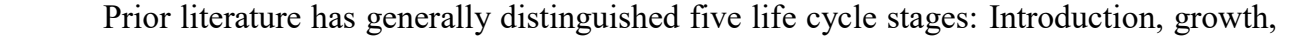

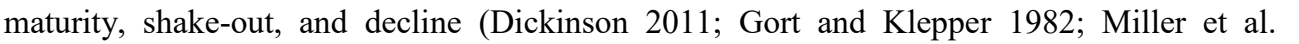

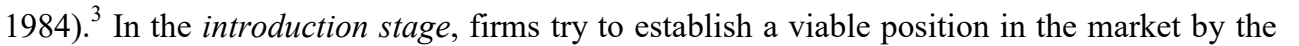

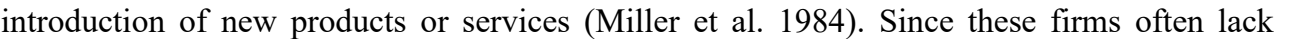
पा

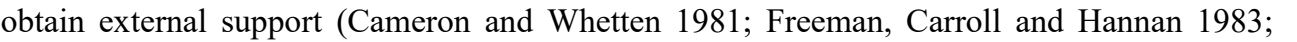

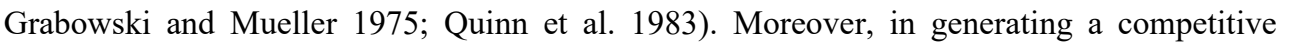

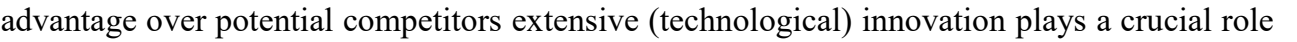

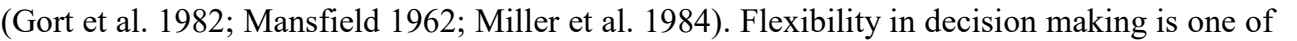

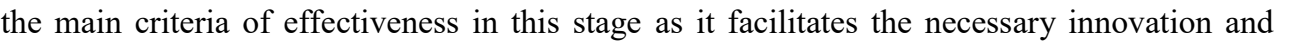

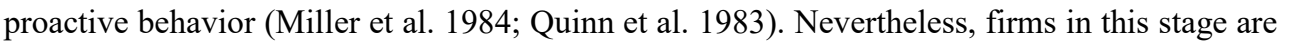

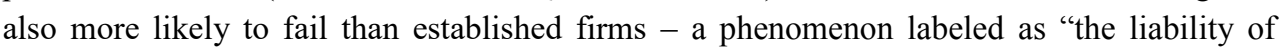

newness"

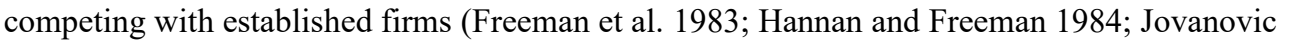
$\square 111 \| m$

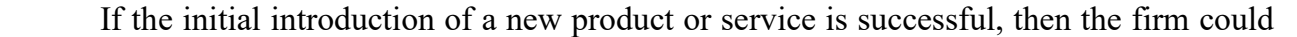

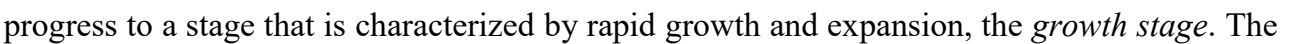

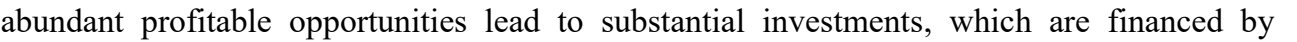

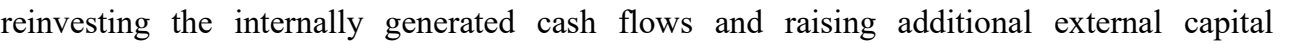

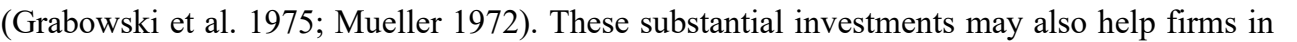

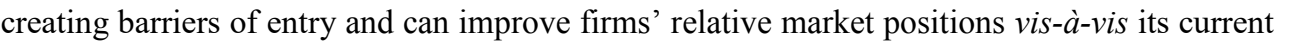

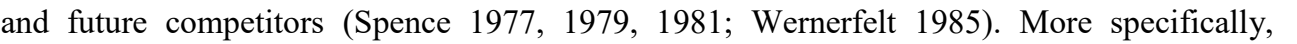

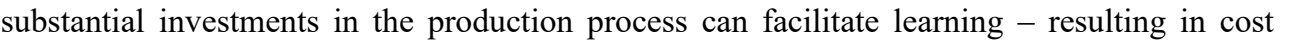

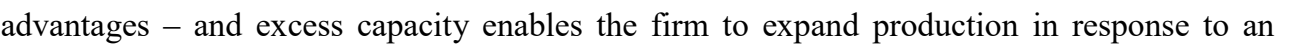

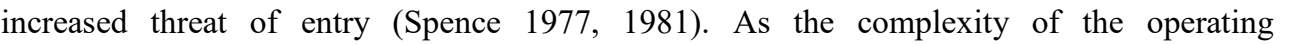

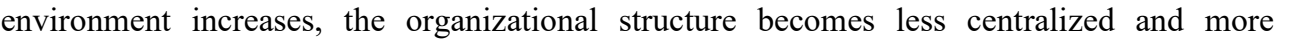

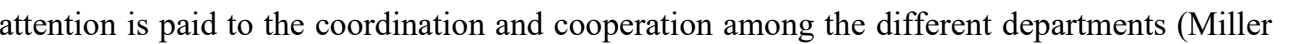

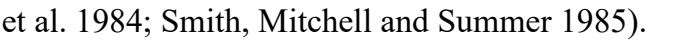

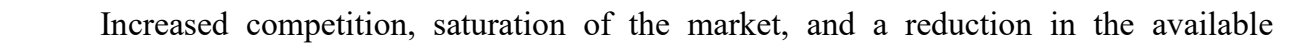
ए ए।

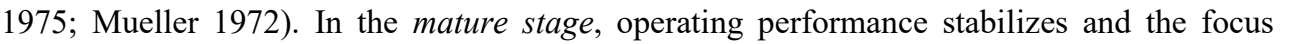

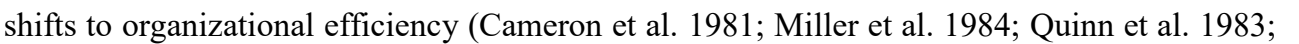

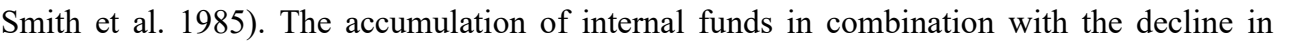

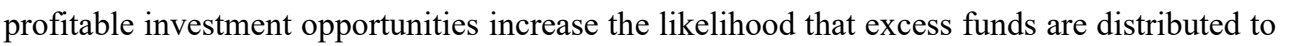

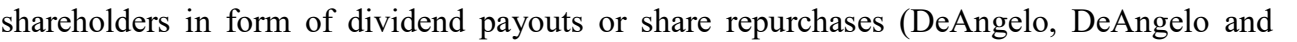

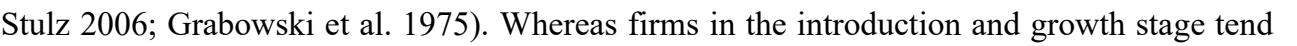

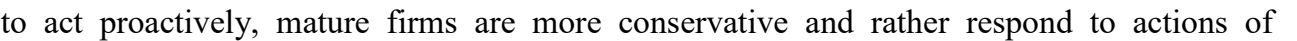

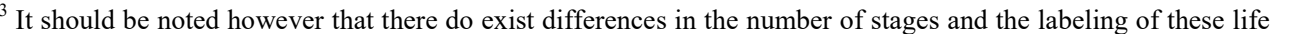
प

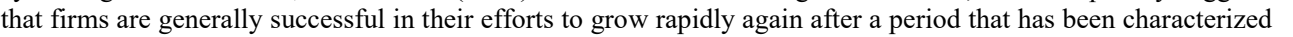

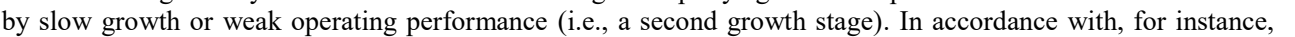

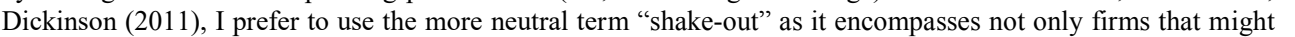

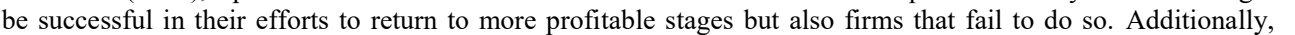

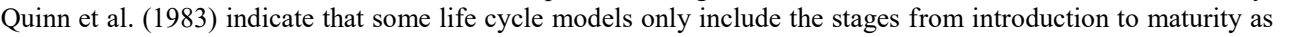

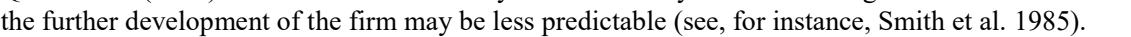




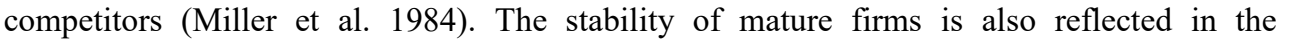

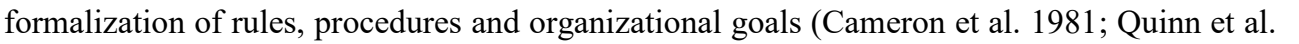

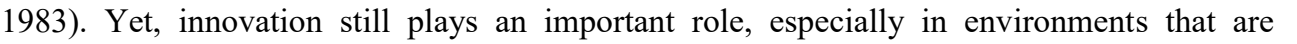

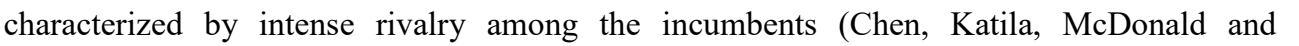

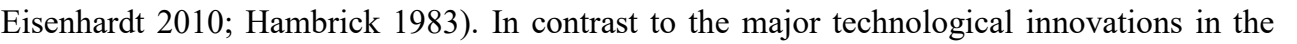
introduction stage, however, the innovation in mature firms is more likely to arise from firms'

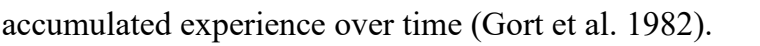

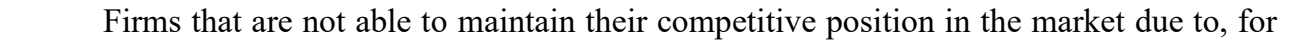

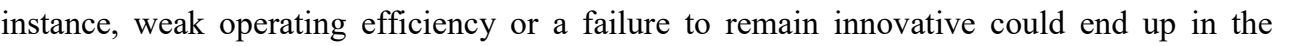

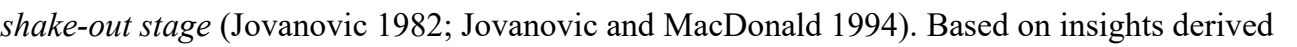

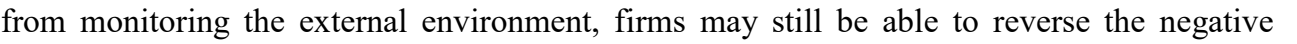
ए

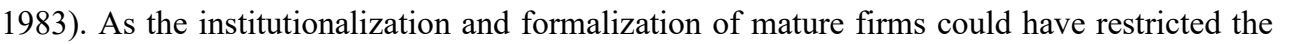

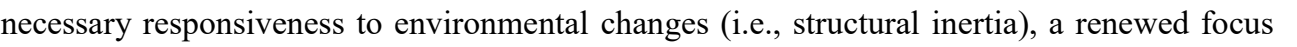

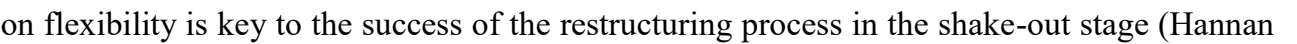

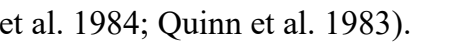

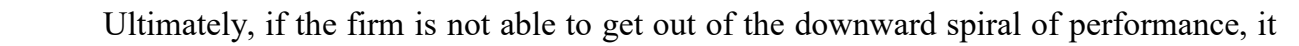

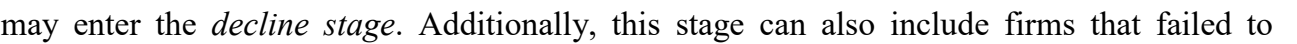
establish a viable position in their introduction stage as a consequence of their "liabi $\square \square \square \square$

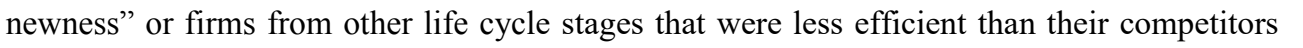

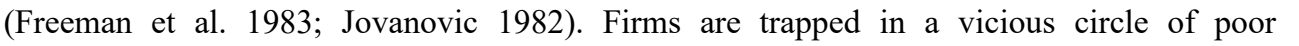

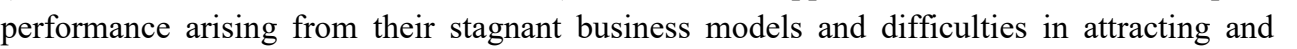

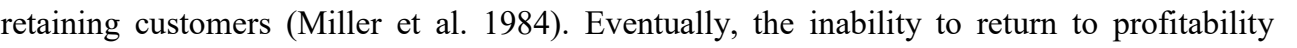

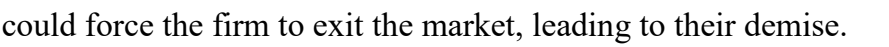

एा山ा山

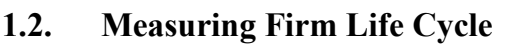

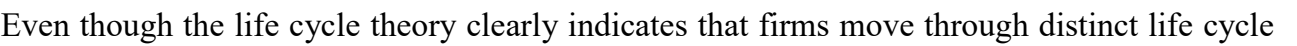

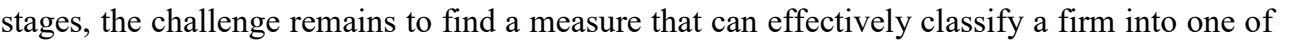

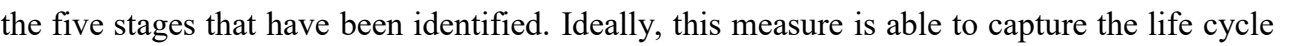

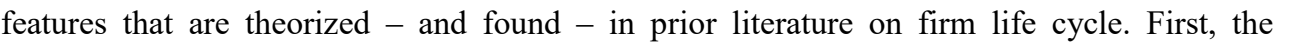

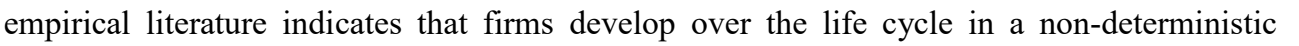

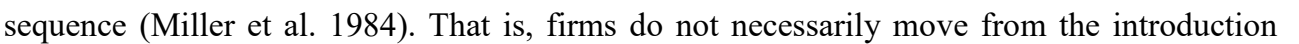

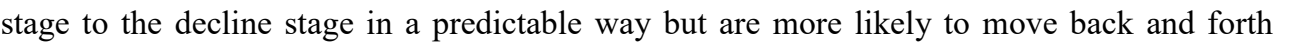

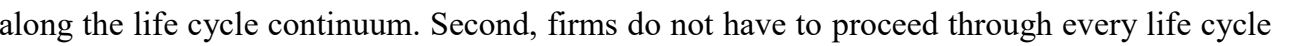
$\square \square \square($ Gort et al. 1982). The "liability of newness" phenomenon, for instance, relates to a

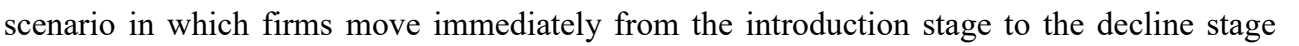
प

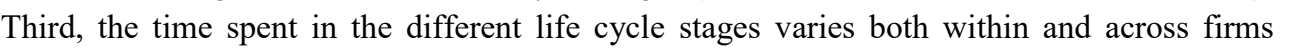

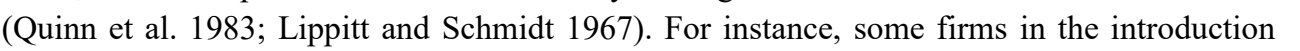

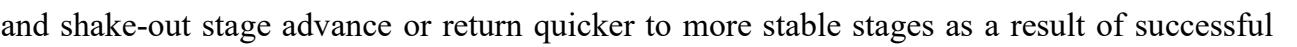

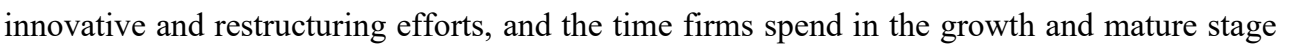
ए

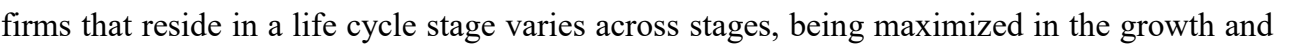




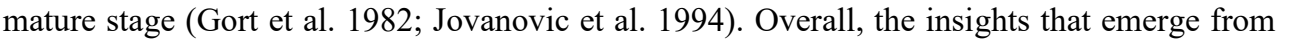

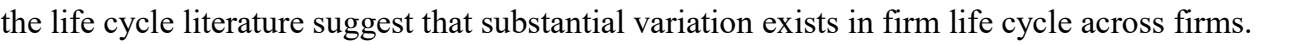

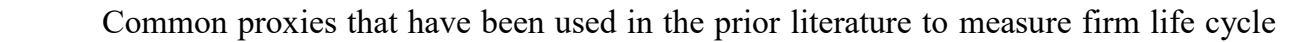

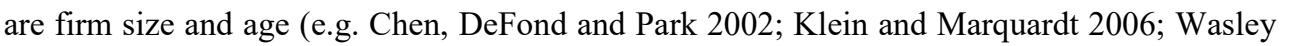

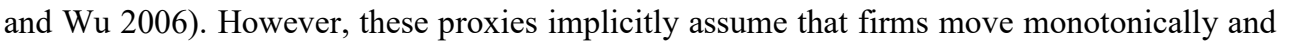

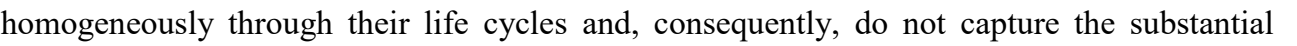

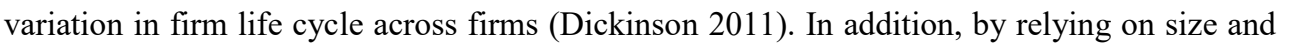

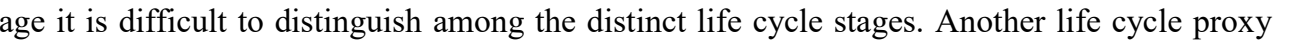

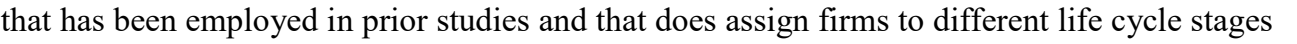

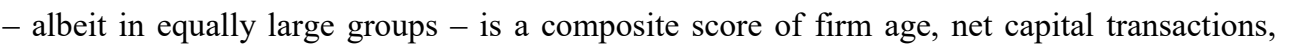

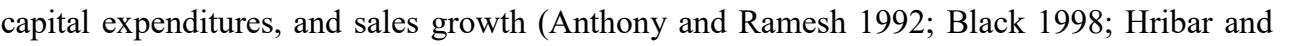

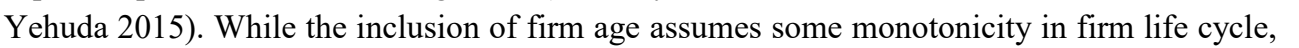

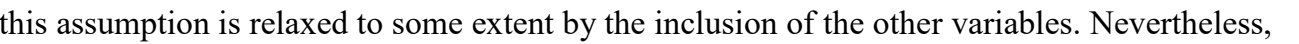

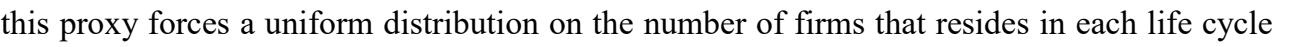

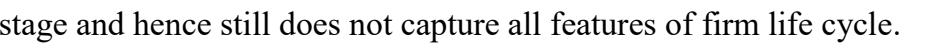

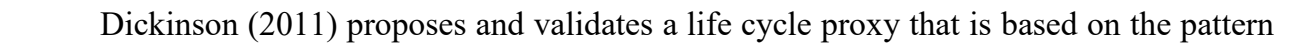

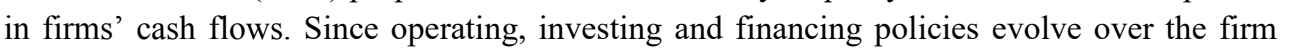

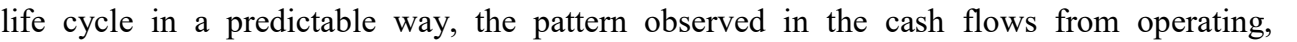

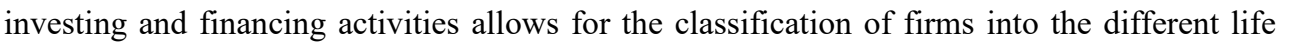

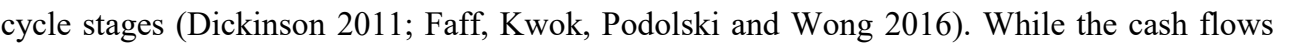

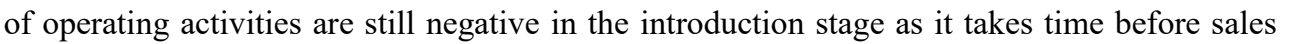

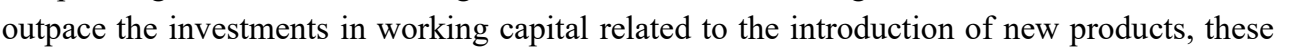

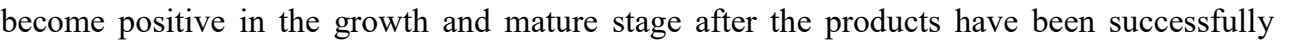

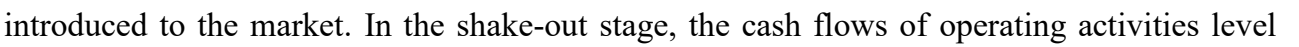

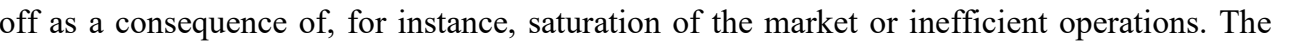

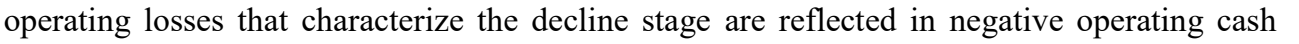
एवाएणाए

\begin{aligned} \hline \\ \hline\end{aligned}

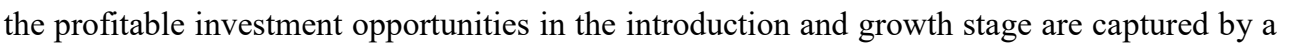

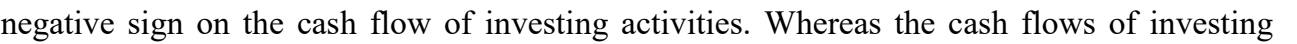

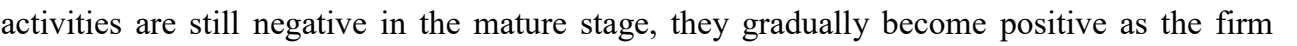

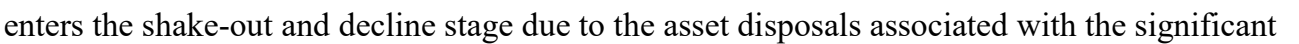

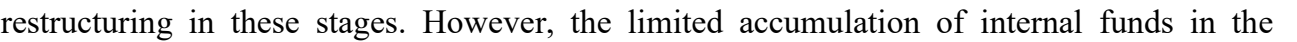

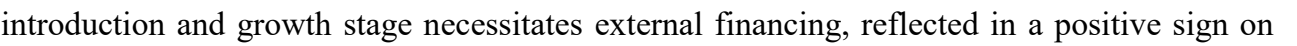

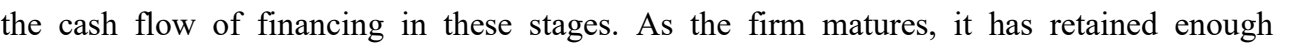

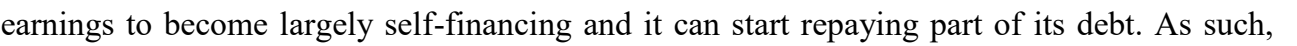

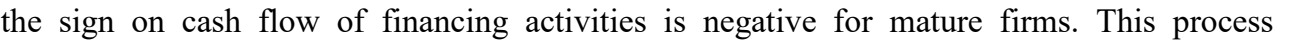

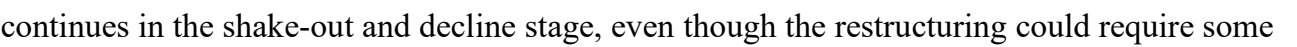

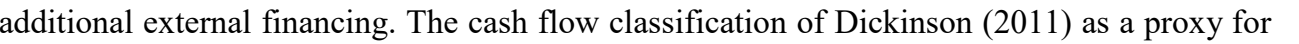

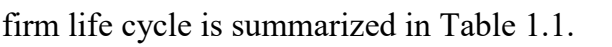

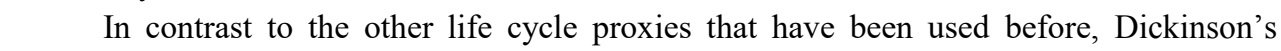

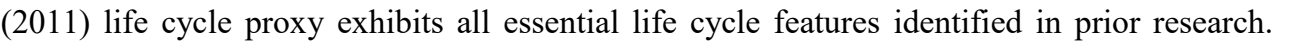

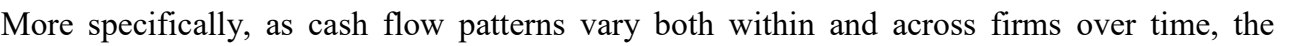

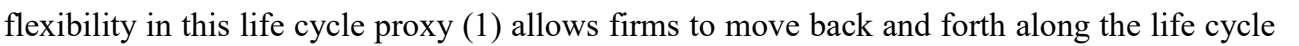




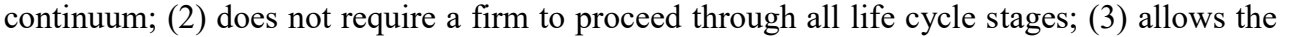

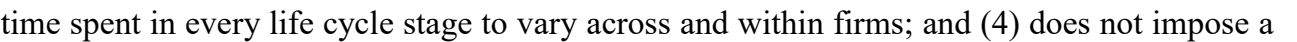

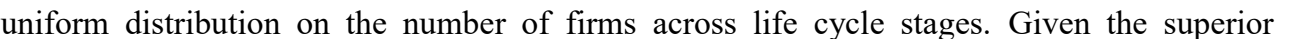
features of Dickinson's (2011) life cycle proxy, I mainly rely on this measure to classify firm $\square$

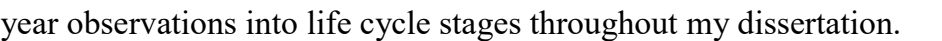
$\square$

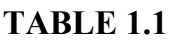

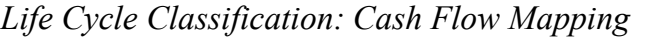

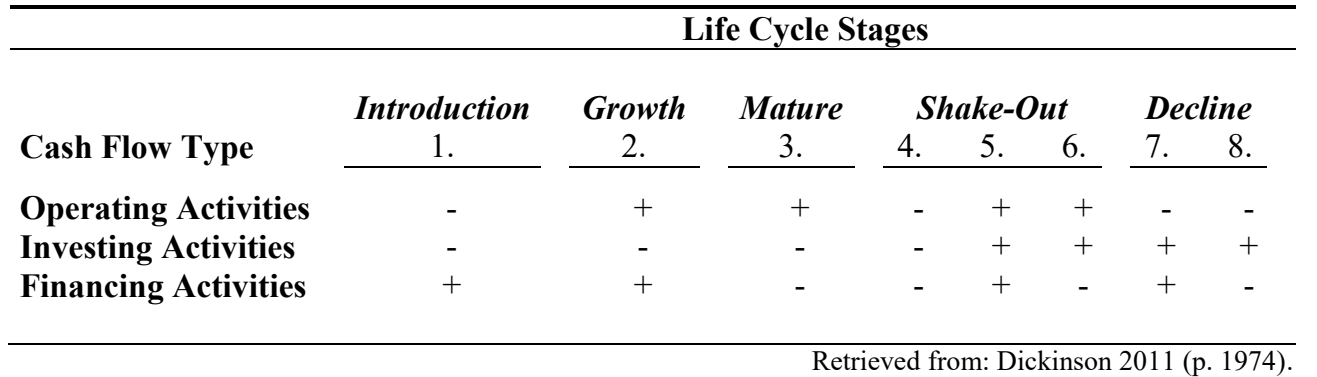

$\square \quad \square \quad \square$

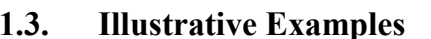

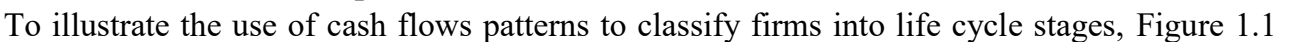

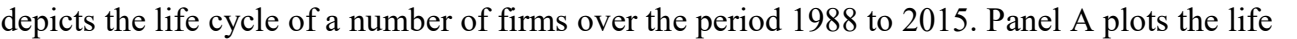

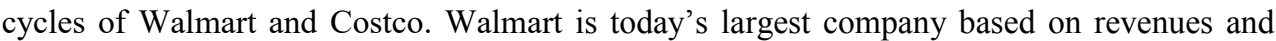

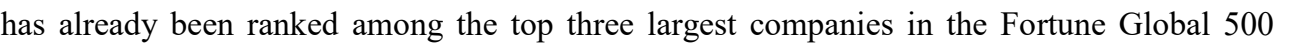

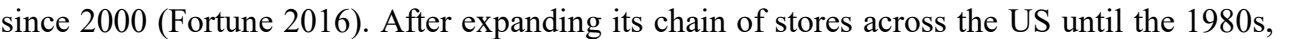

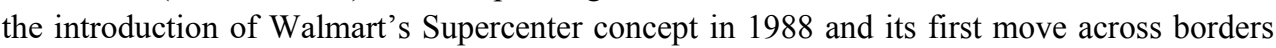

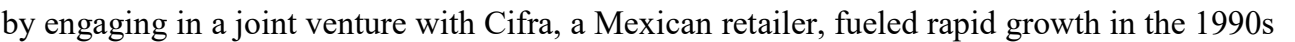

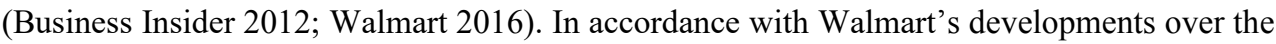

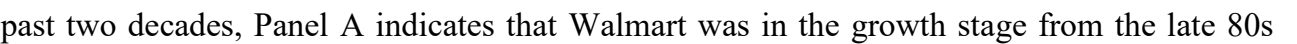

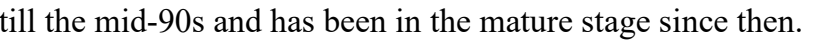

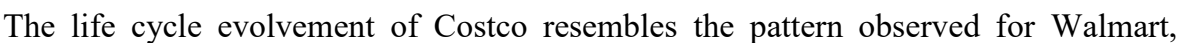

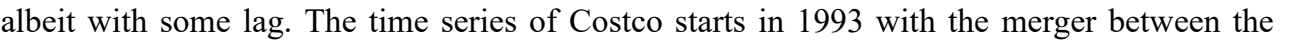

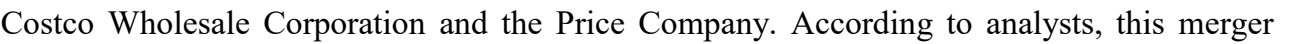

"would offer an intriguing marriage of strengths and personalities" by combining the superior

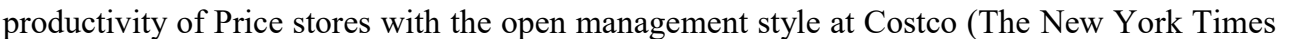

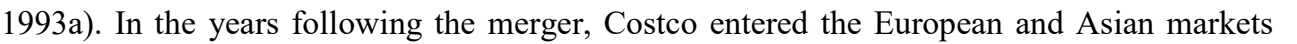

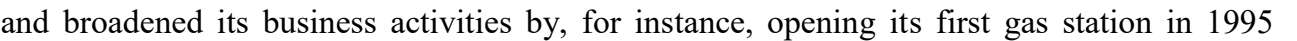

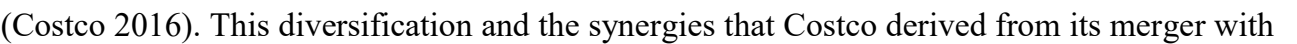

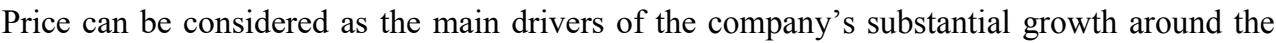

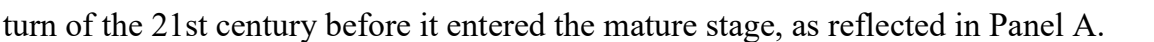

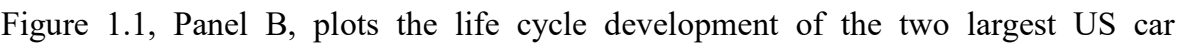

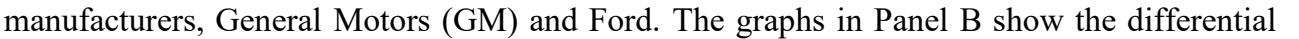

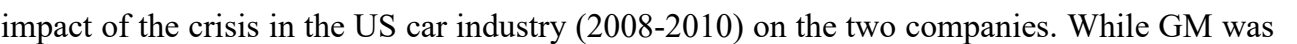

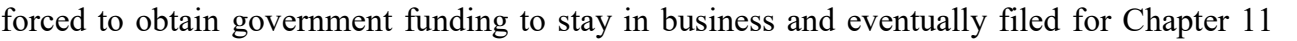

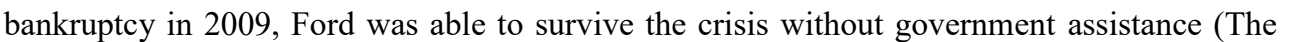




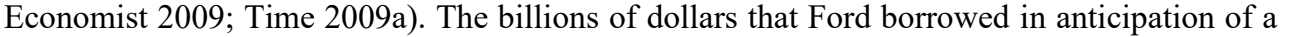

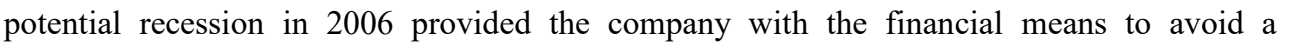

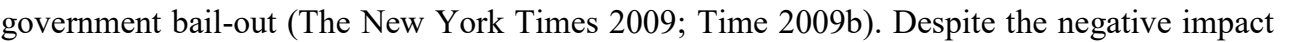

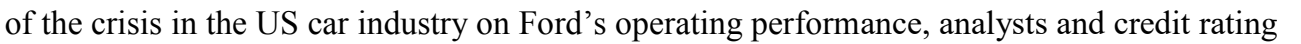

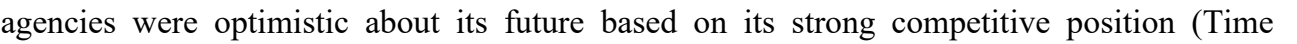

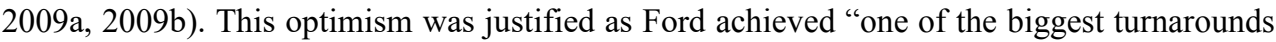
in American business history", which can b

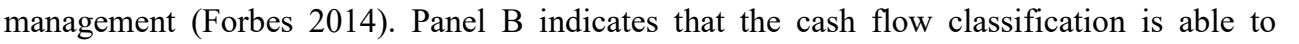

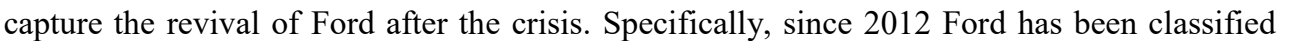

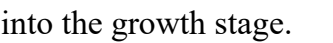

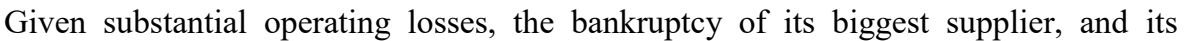

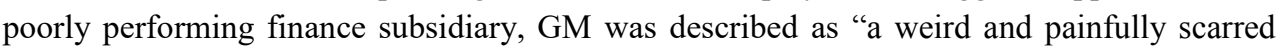

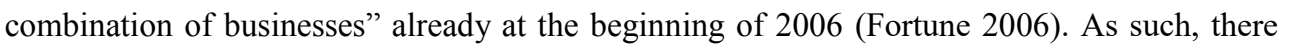
were already clear indications for GM's bankruptcy before the onset of the crisis in 2008 .

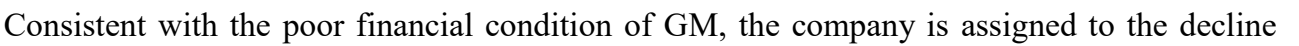

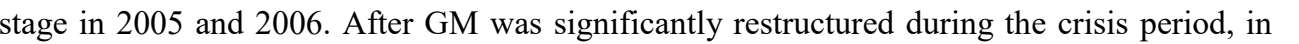

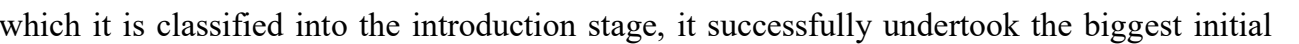

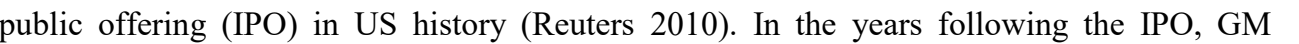

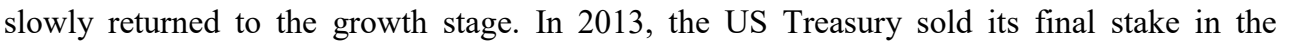
company and GM's decision to start with a major overhaul of its product range helped the

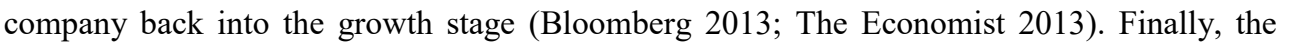

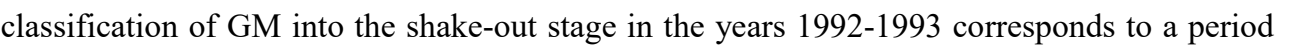

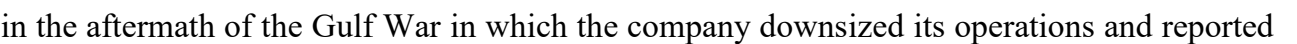

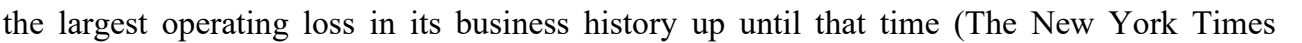
पामाणामाणाए

The life cycles of Starbucks and McDonald's, two successful US franchise companies,

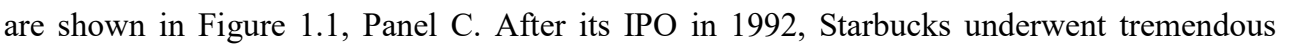

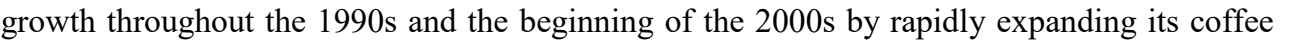

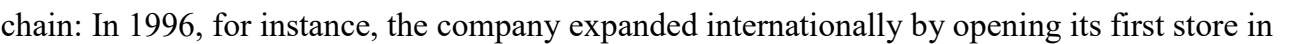

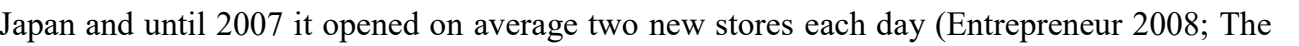

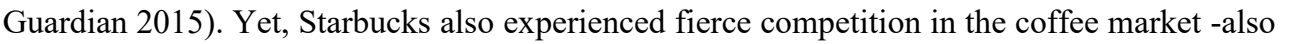

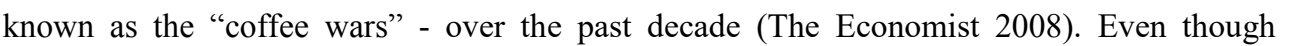

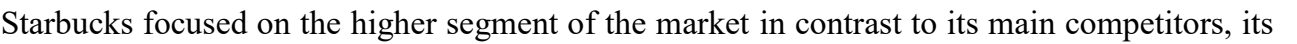

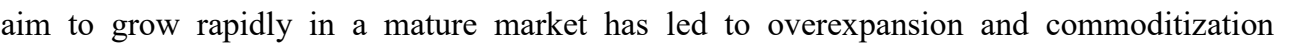

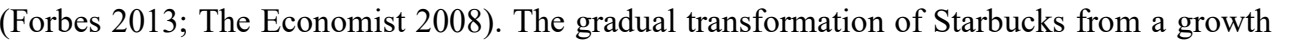

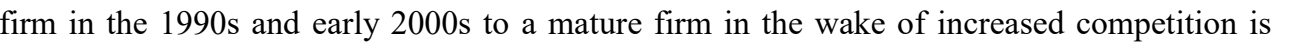

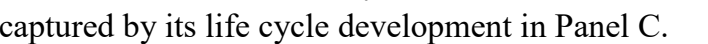

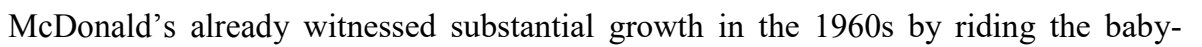

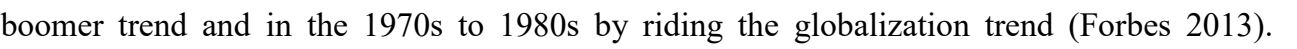

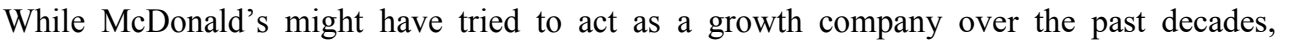

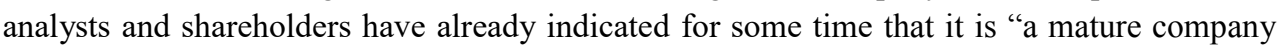

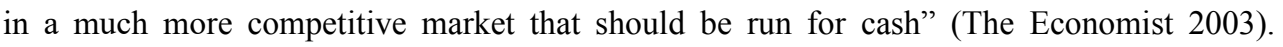
Despite competitive pressures, McDonald's has been able to keep up with its main $\square$

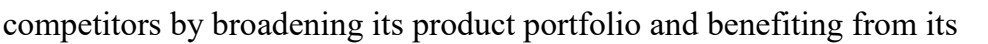




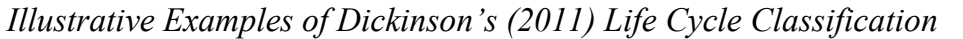

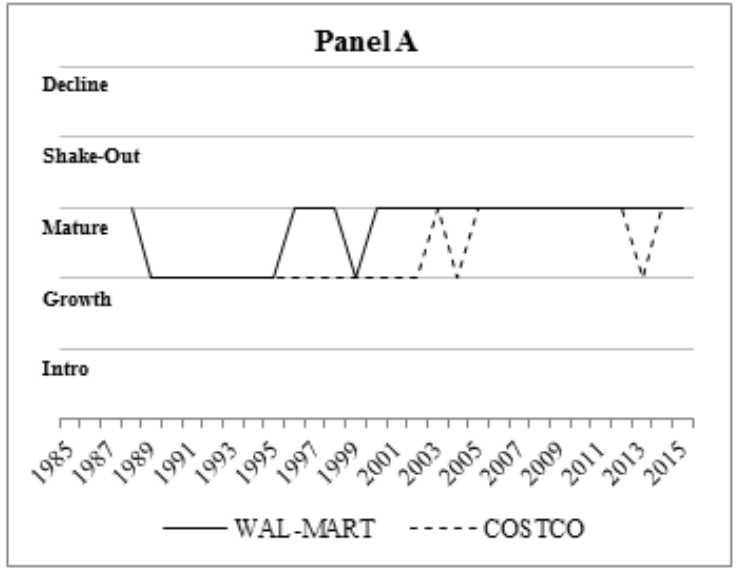

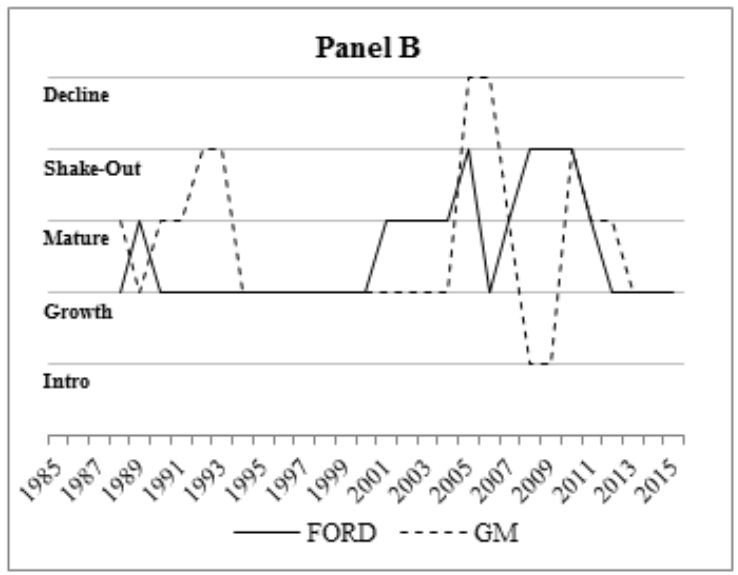

\begin{tabular}{|c|}
\hline Panel C \\
\hline Decline \\
\hline Shake-Out \\
\hline Mature \\
\hline Growth \\
\hline Intro \\
\hline 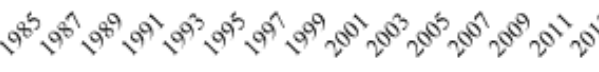 \\
\hline —STARBUCKS $\quad-\cdot--$ MCDONALD'S \\
\hline
\end{tabular}




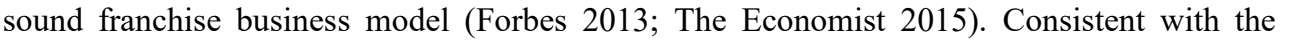
company's business developments over the past three decades, McDonald's life cycle

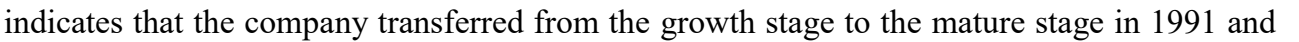

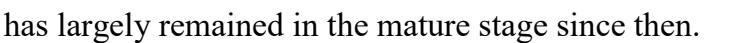

$\square \quad \square \square\|\| \| T$ he examples above provide some anecdotal evidence that Dickinson's (2011) cash flow classification is able to capture firms' developments over their life cycle. As the

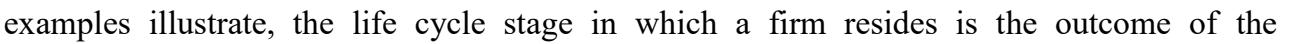

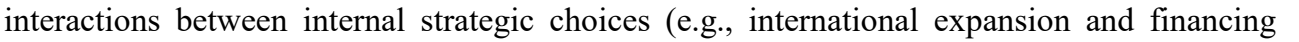

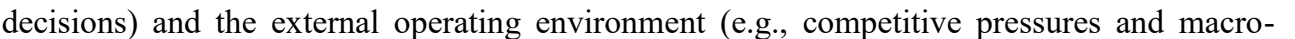

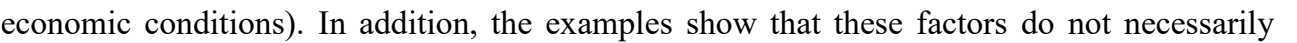

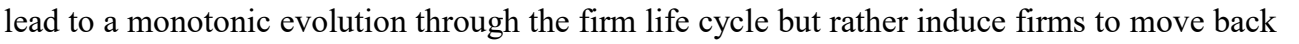

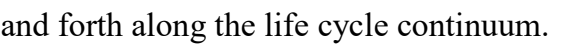

$\square$

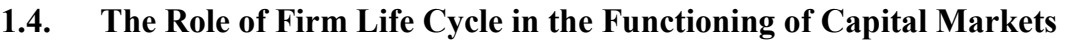

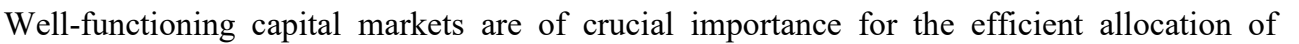

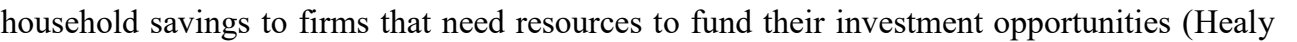

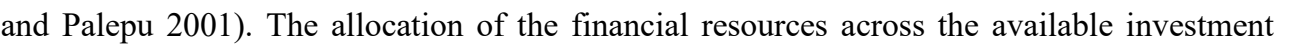

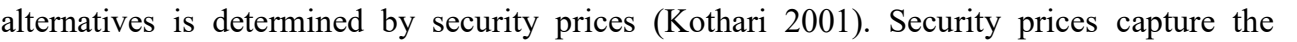

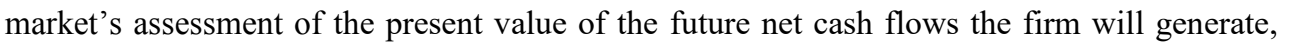

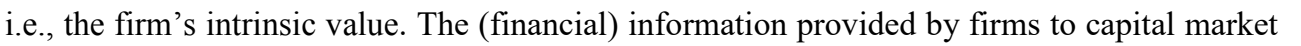

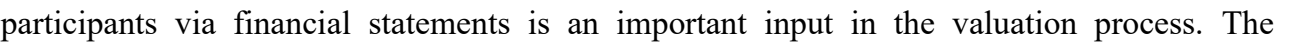

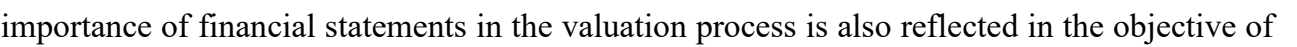

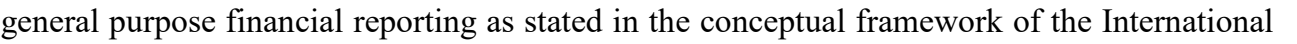

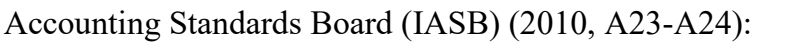

$\square$

"The objective of general purpose financial reporting is to provide financial

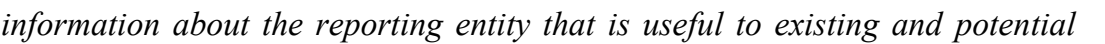

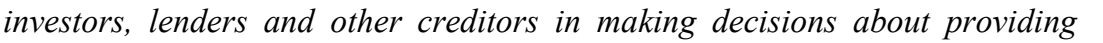
resources to the entity. [...] Investors', lenders' and other creditors'

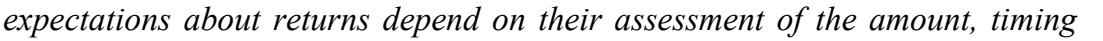

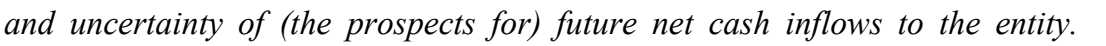

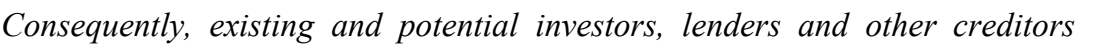

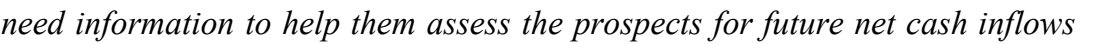

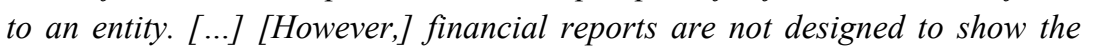

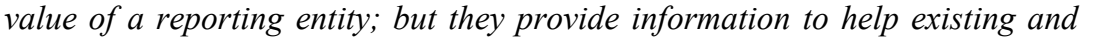

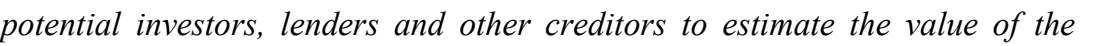
reporting entity." $\square$

$\square$

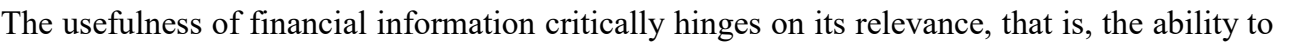

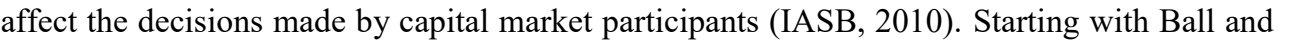

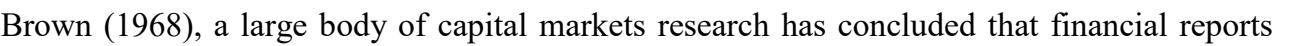

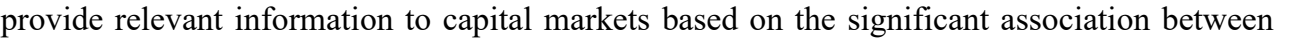

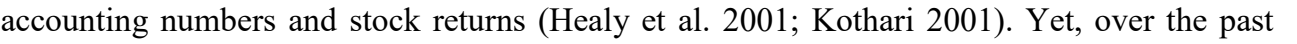

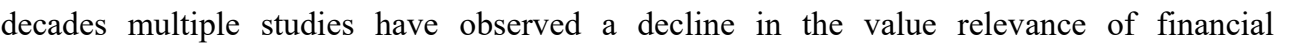




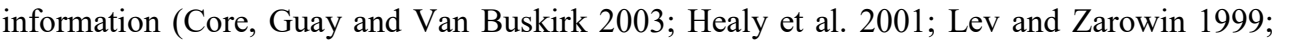

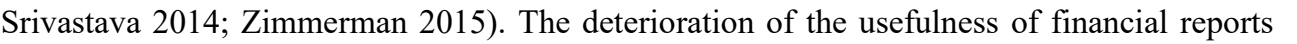

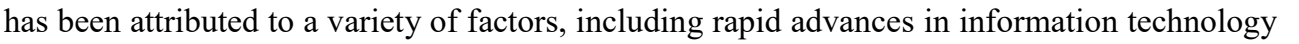

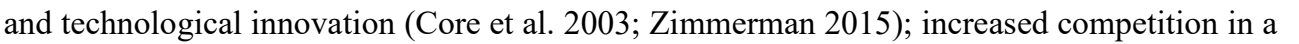

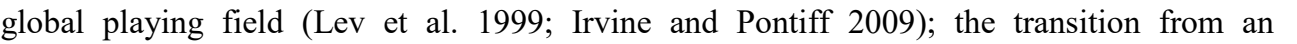

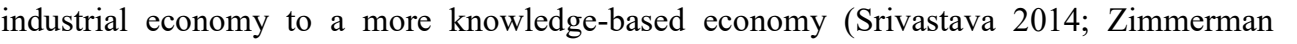

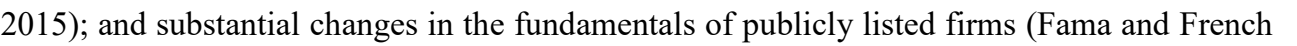

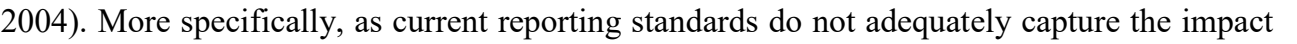

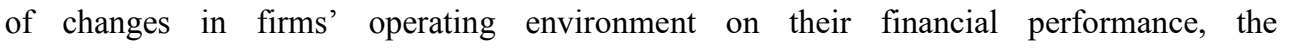

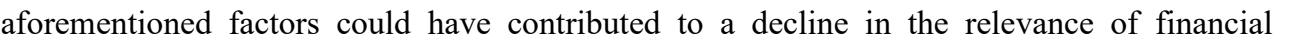

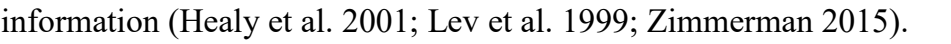

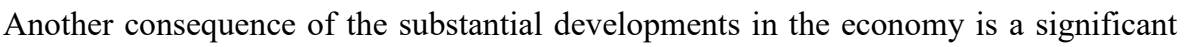

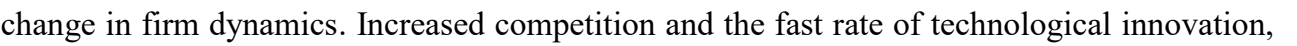
ए ए

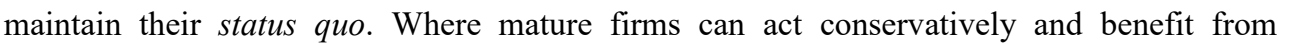

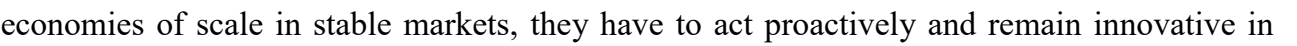

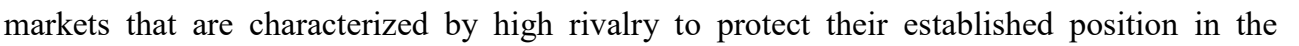

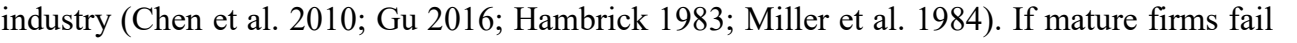

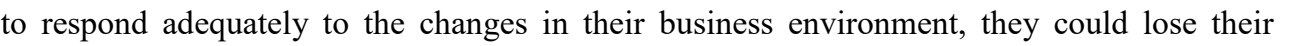

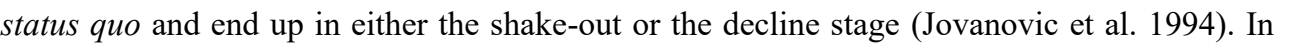

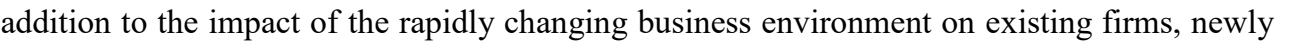

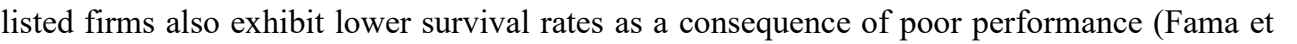

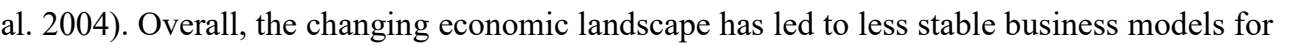

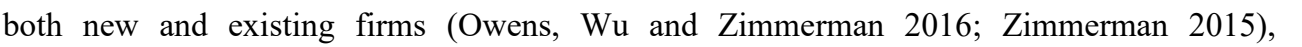

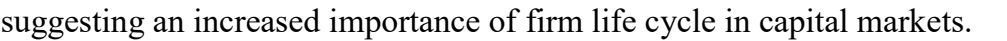

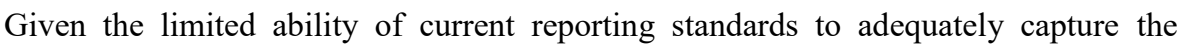

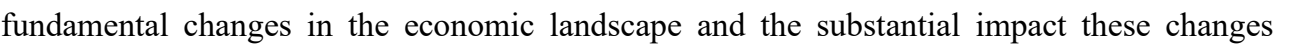

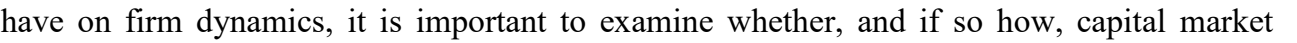

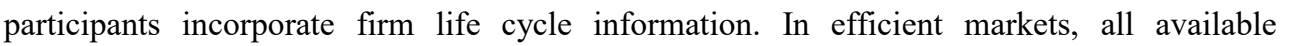

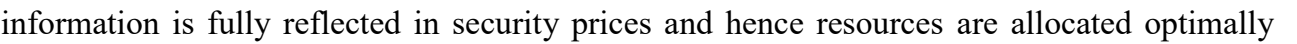

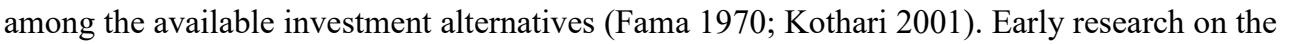

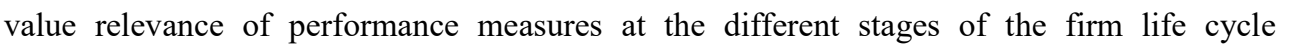

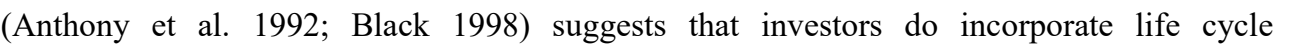

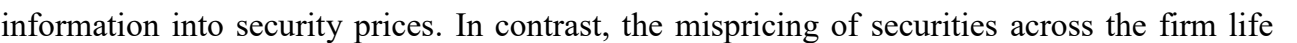
cycle observed in more recent studies casts substantial doubt on investor's understanding of

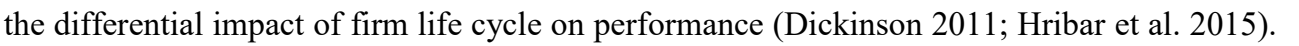

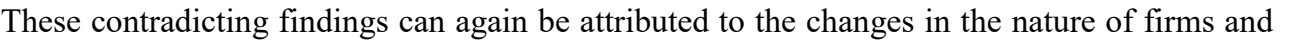

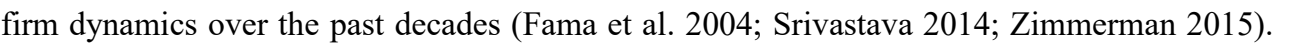

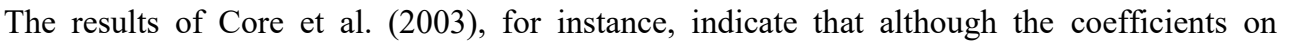

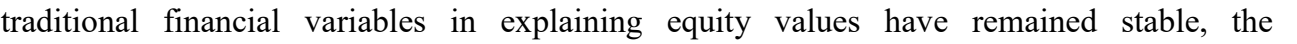

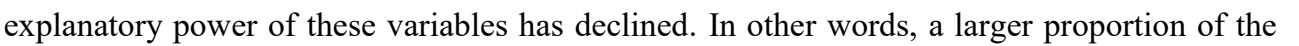

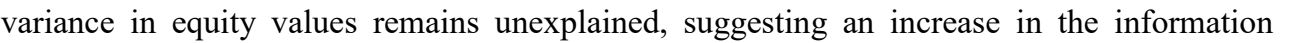
asymmetries between the firm and investors attributable to managers' superior information about the firm's prospects. $\square$ 


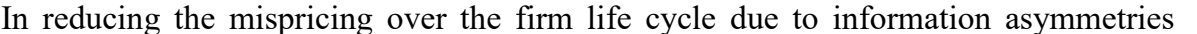
between the firm and investors and investors' lack of sophistication, information

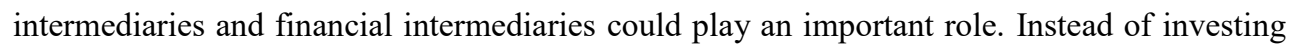

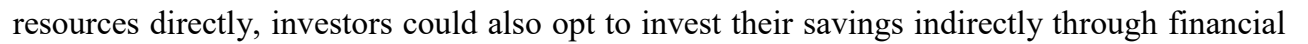

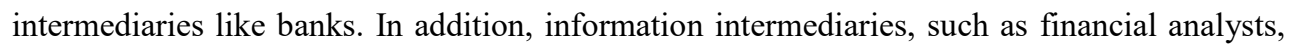

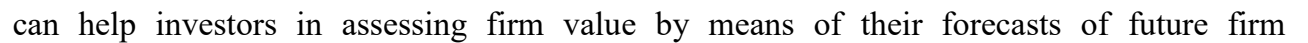

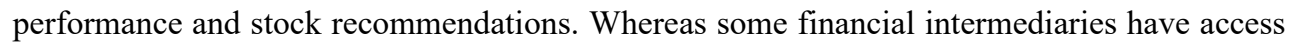

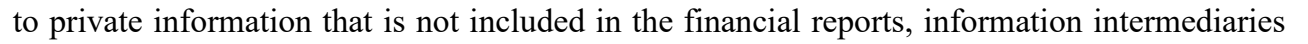

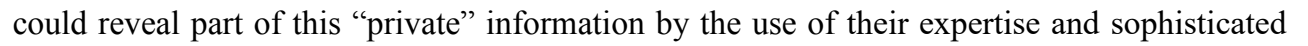

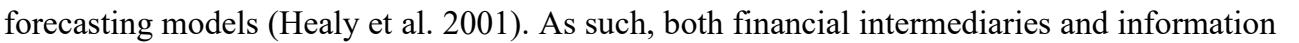

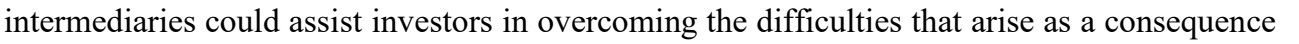

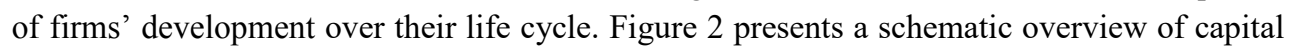

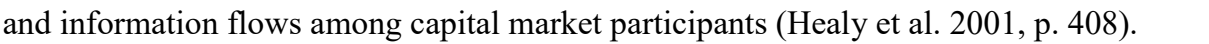
$\square$
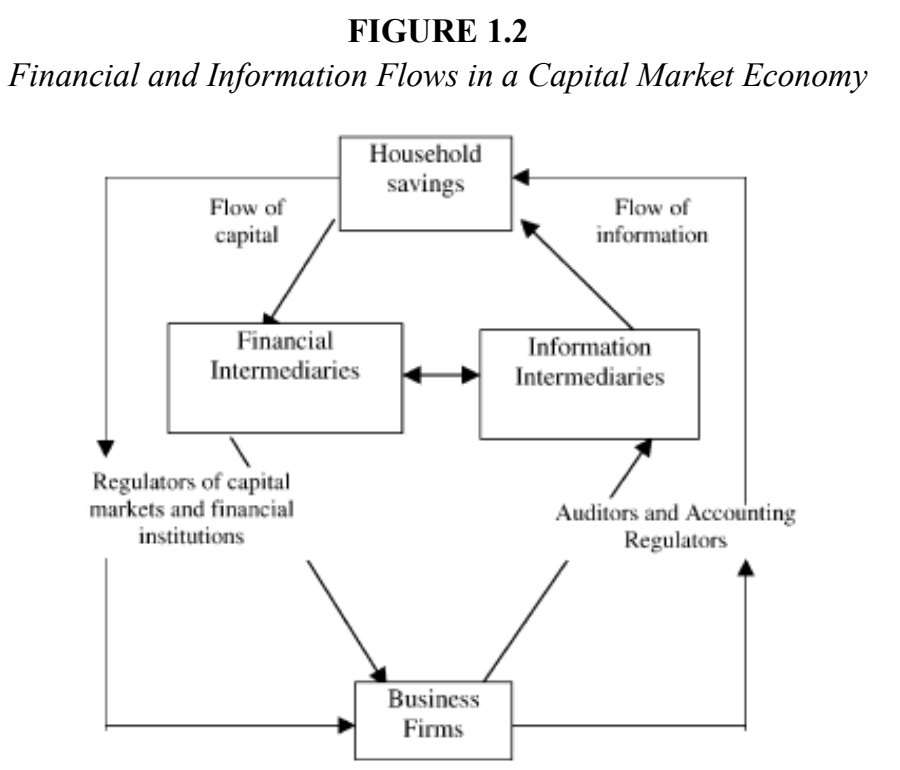

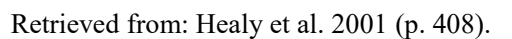

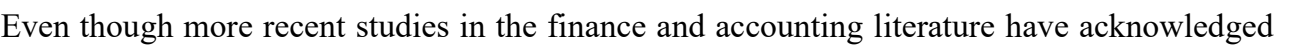

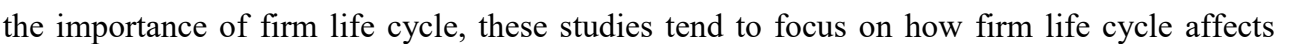

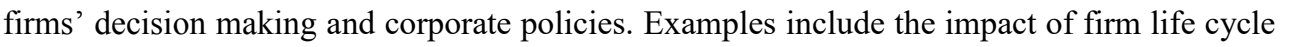

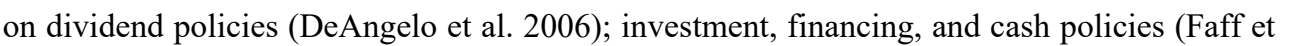

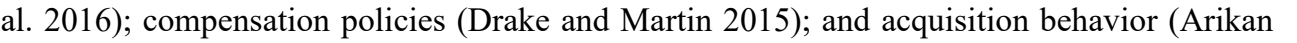

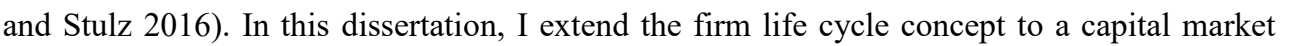

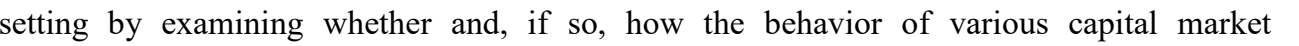

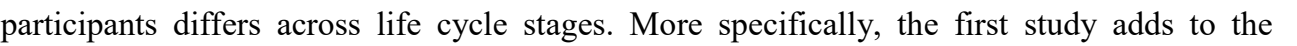

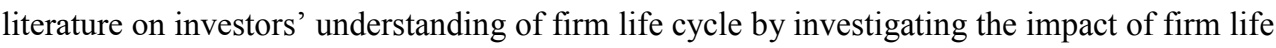

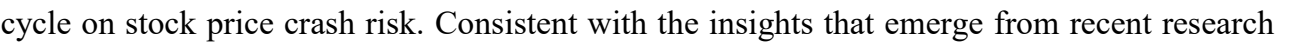

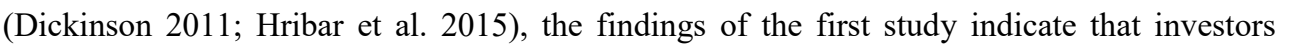




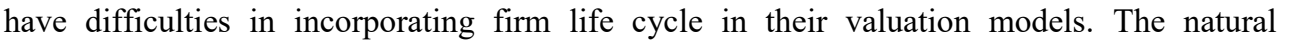

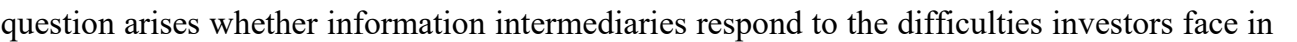

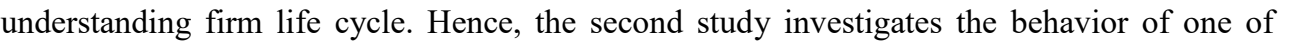

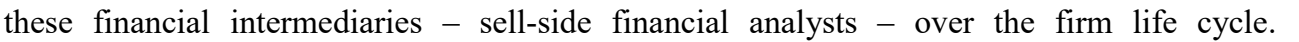

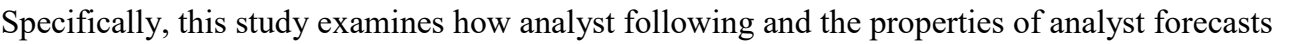

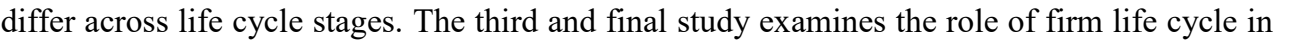

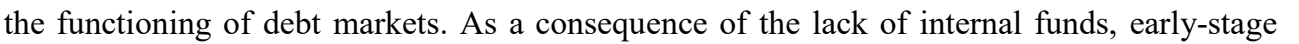

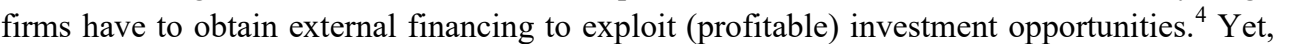
the substantial growth opportunities of these firms also complicate lenders' assessment of borrowers' future value. Th

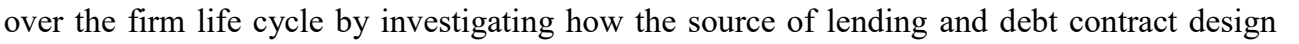

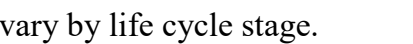

$\square$

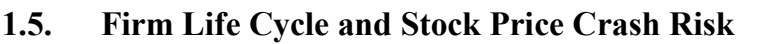

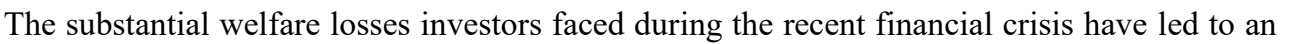

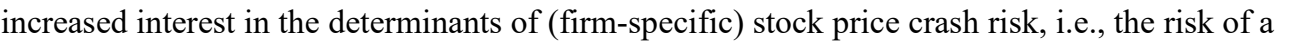

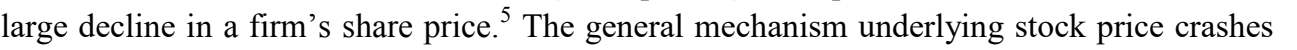

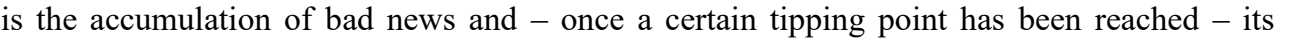

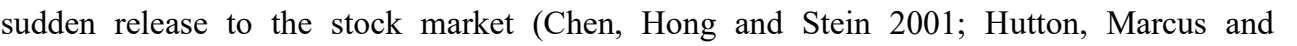

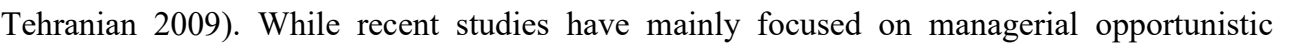

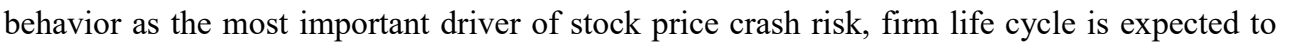

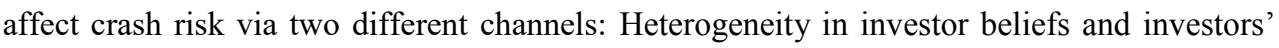

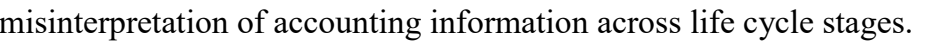

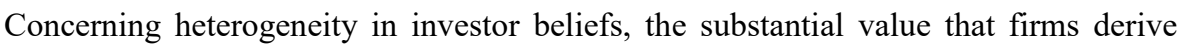

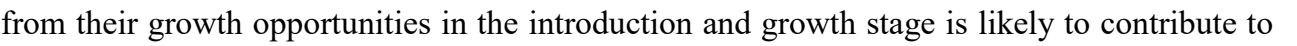

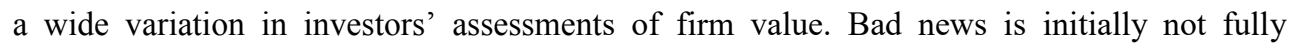

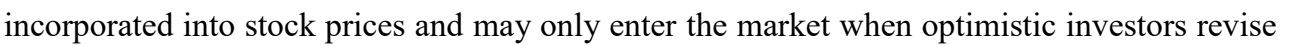
ए ए

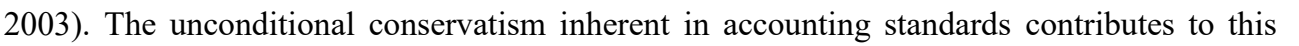

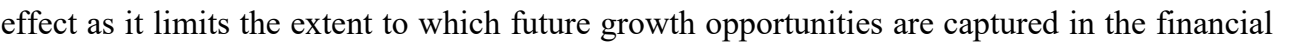

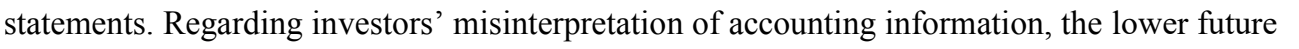

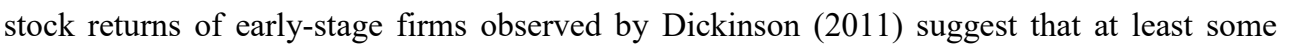

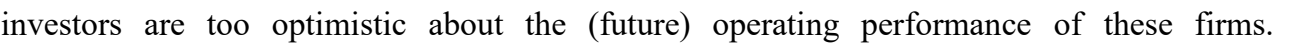

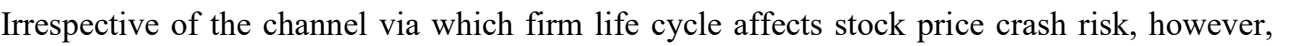

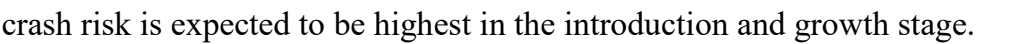

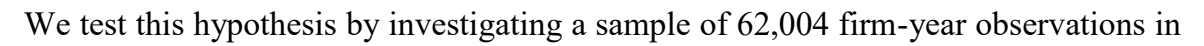

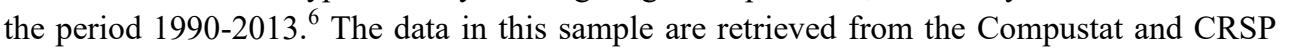

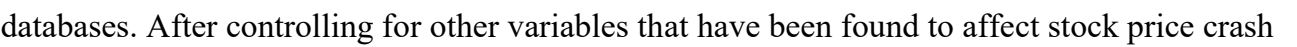

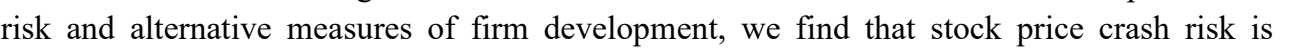

\footnotetext{
I use the term "early stage" throughout this dissertation to refer to firms in the introduction and growth stage.

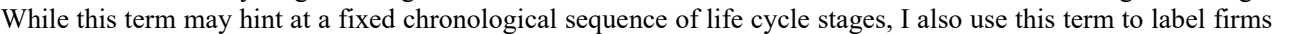

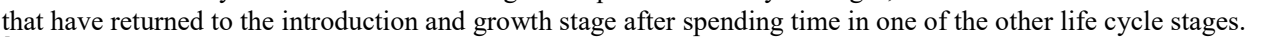

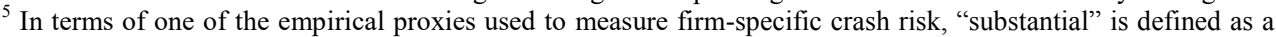

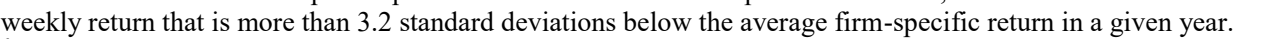

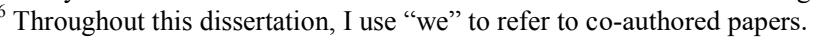


पा ए।

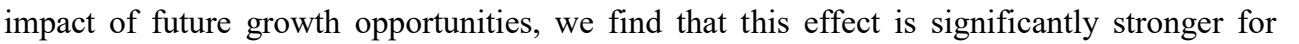

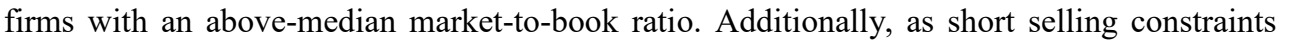

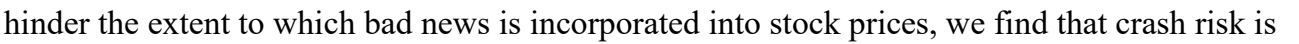

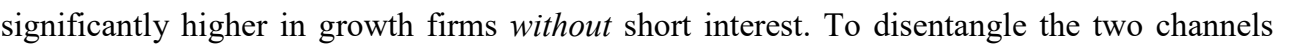

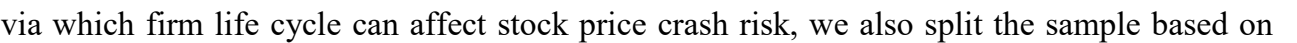

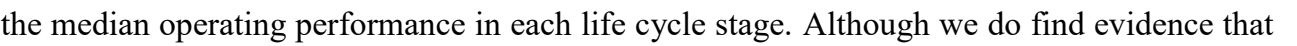

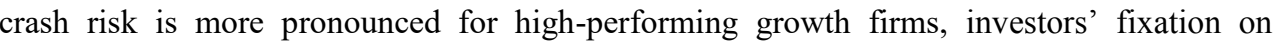

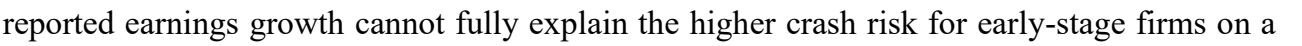

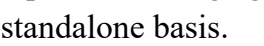

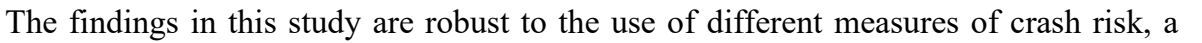

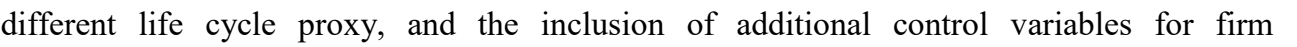

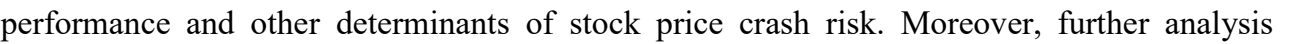

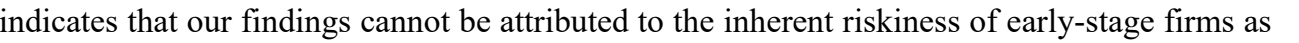

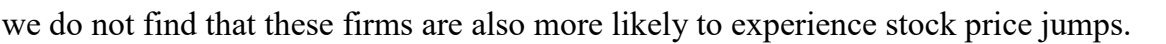

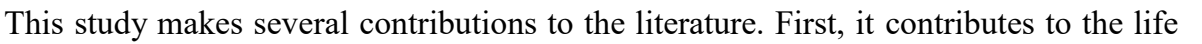

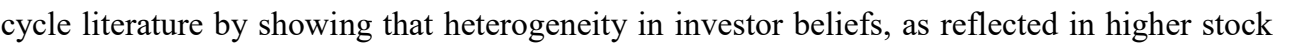

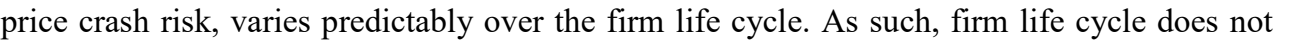

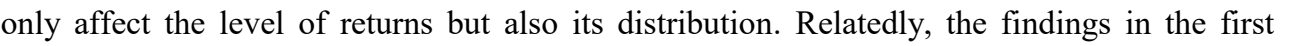

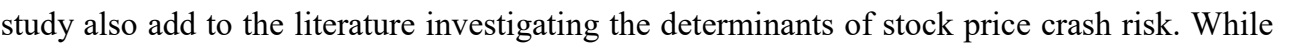

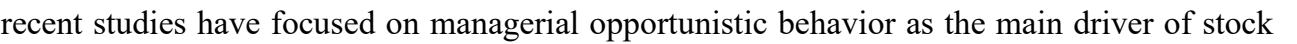

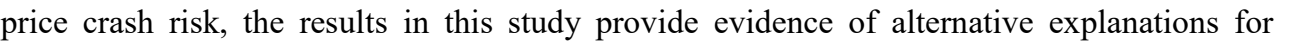
increased crash risk (i.e., heterogeneity in investor beliefs and investors' misinterpretation of

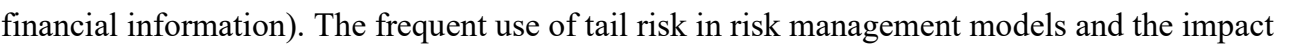

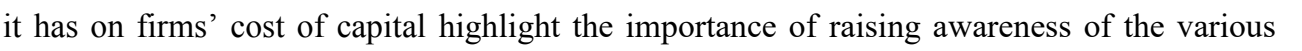

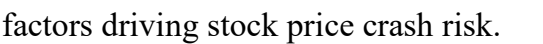

$\square \square$

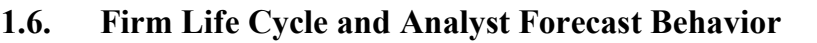

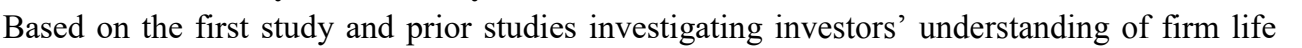

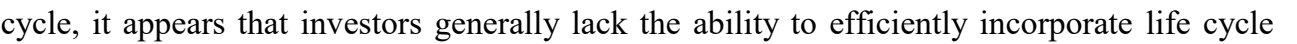
ए

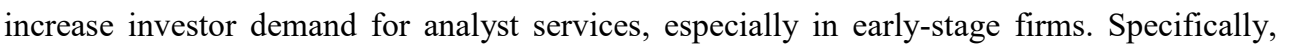

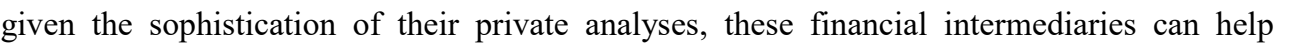

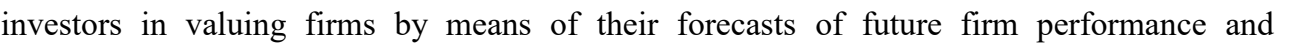

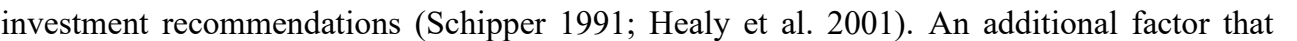
contributes to an increased demand for analyst services are firms' visibility concerns at the far

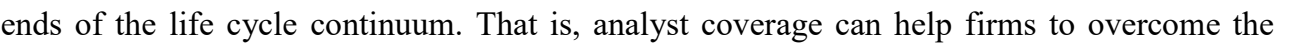

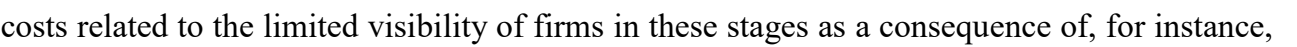

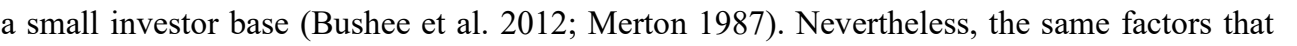

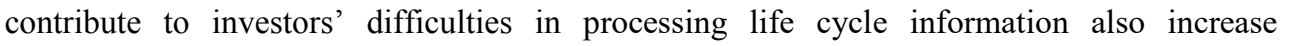
forecasting difficulty and firms' limited visibility could reduce the benefits that analyst can

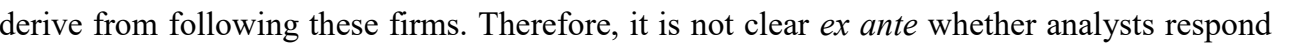

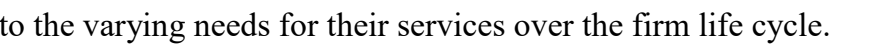




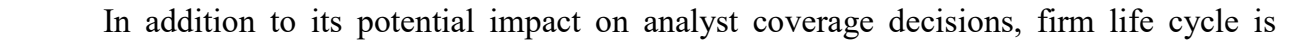

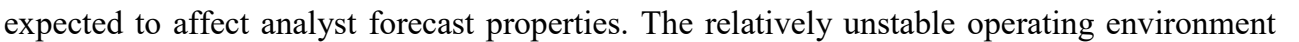

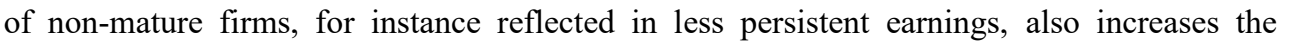

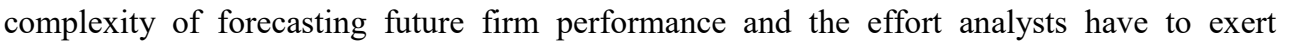

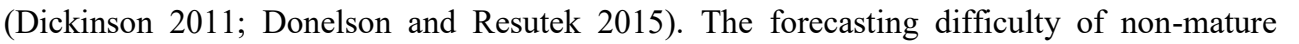

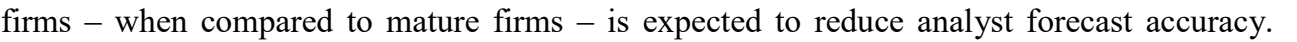

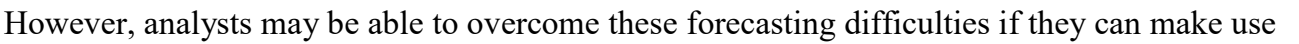

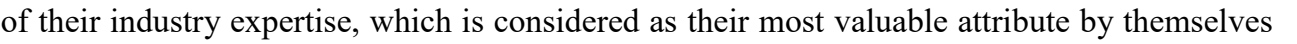

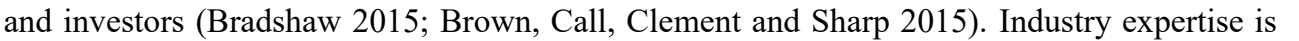

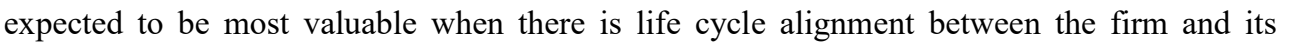

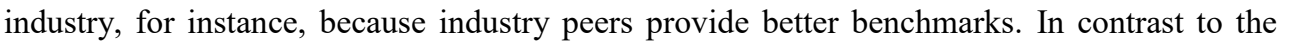

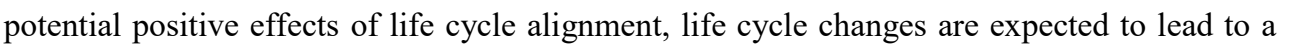

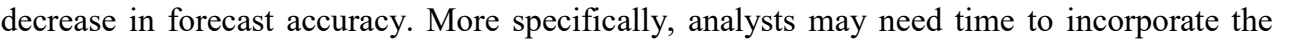

\section{changes in the earnings generating process following a firm's transition between life cycle}

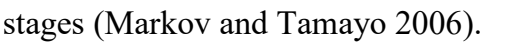

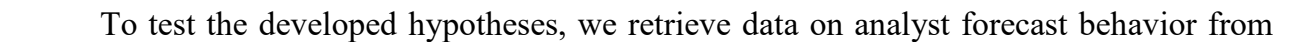

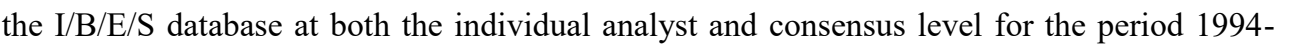

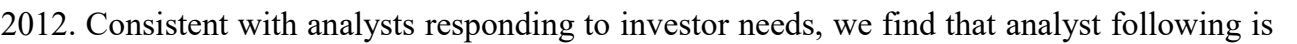

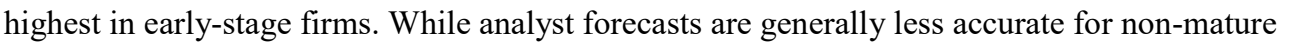

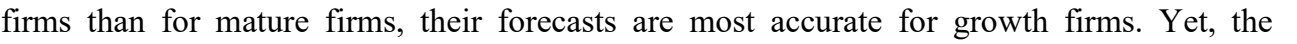

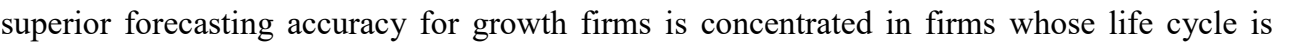

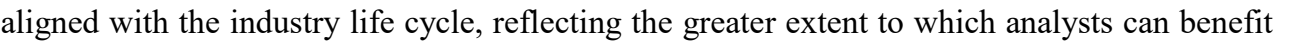

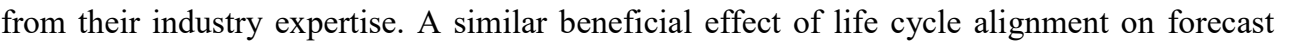

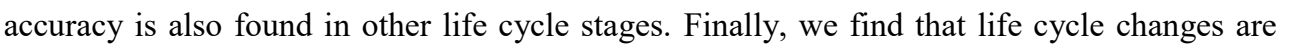
ए

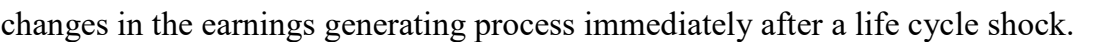

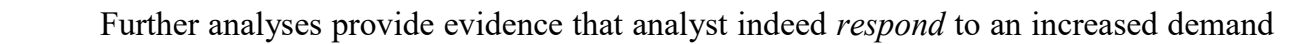
ए ए

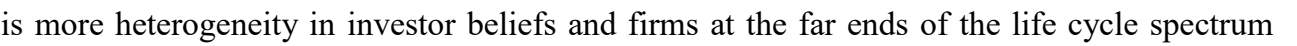

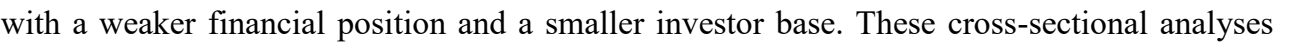

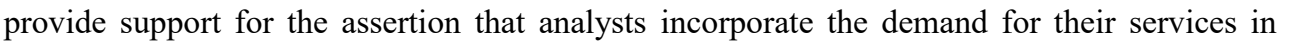

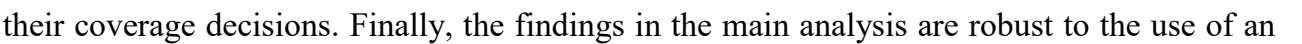

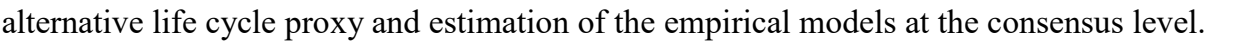

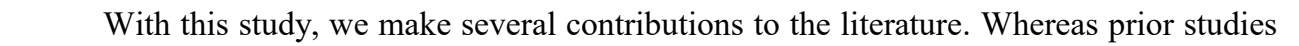

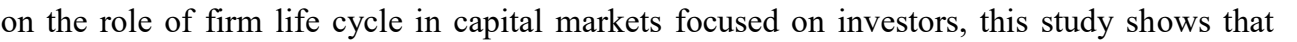
ए

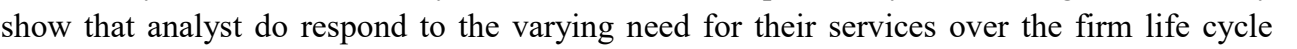

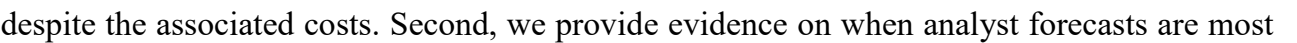

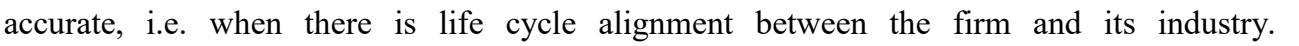

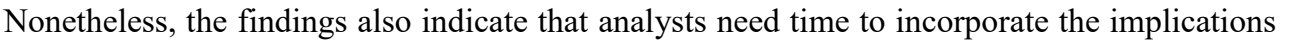

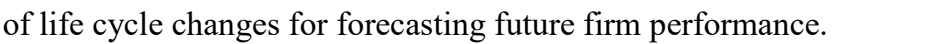
$\square$

$\square$ 


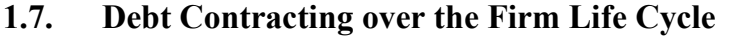

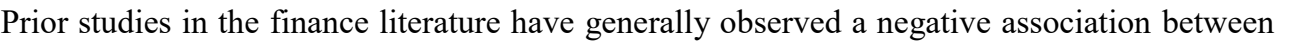

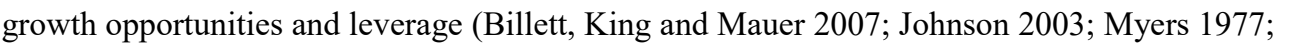

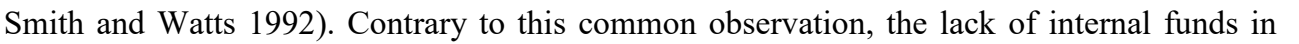

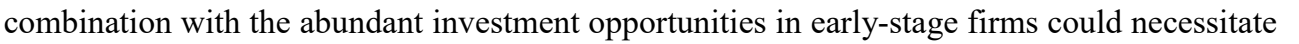

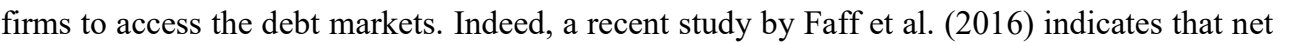

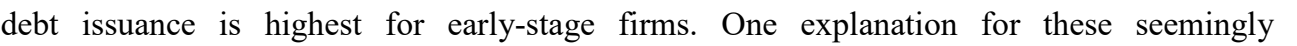

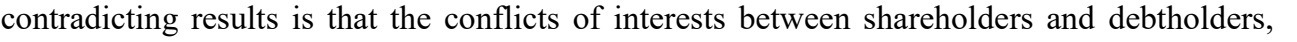

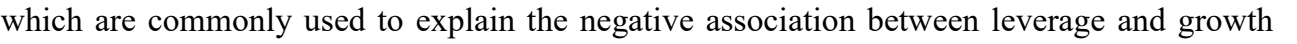

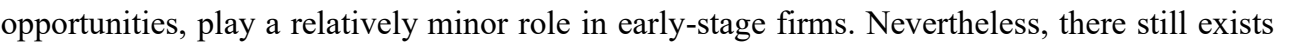
substantial uncertainty concerning the borrower's future value. As a consequence $\square \square \square \square \square$

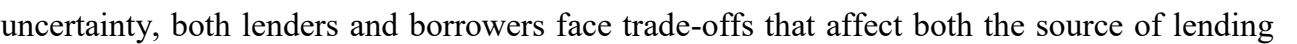

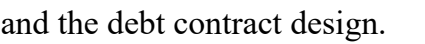

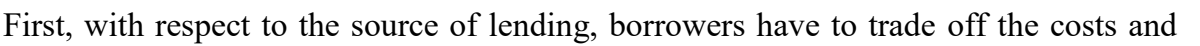

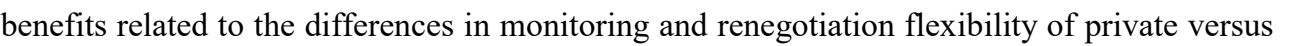

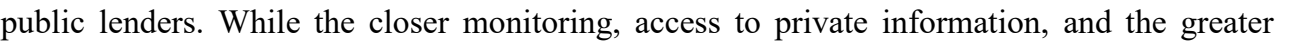

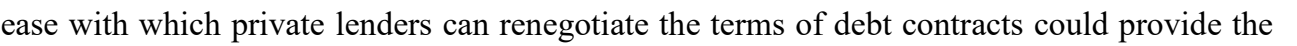

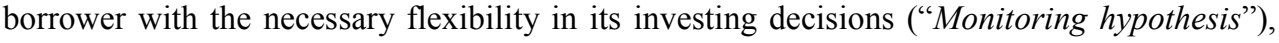

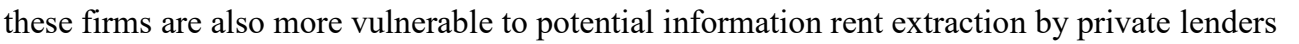
(“

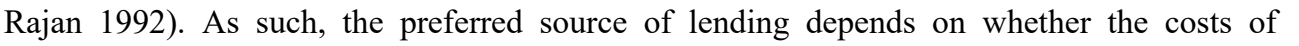

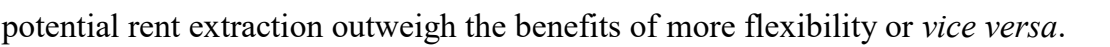

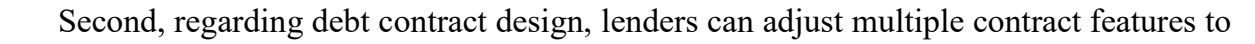

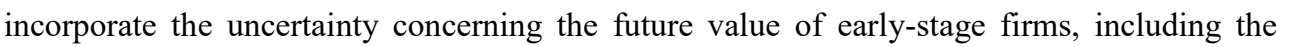

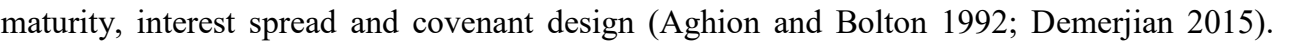

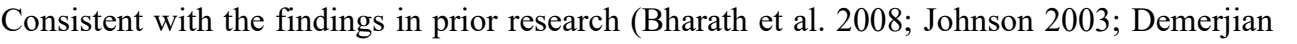

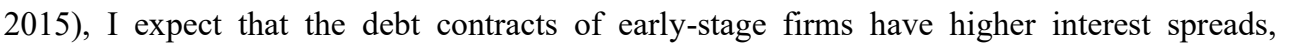

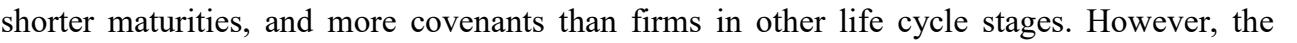

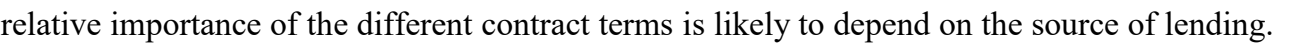

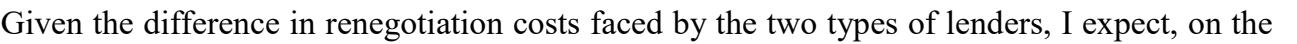

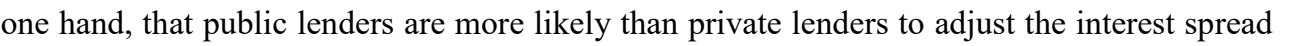

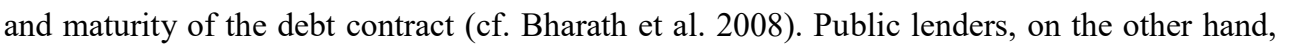

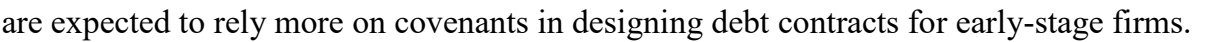

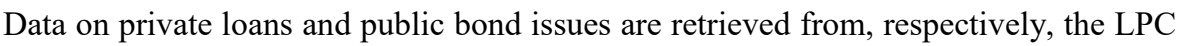

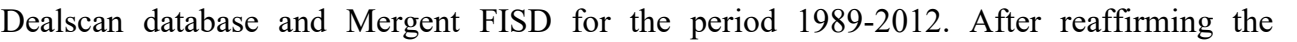

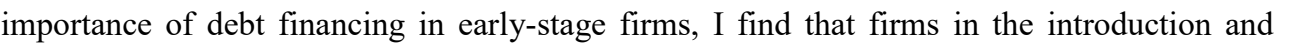
growth stage prefer public debt to private debt. This finding is in accordance with the " $\square \square \square \square$

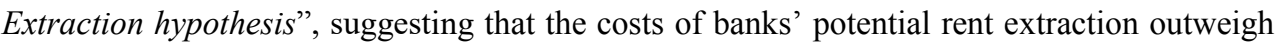

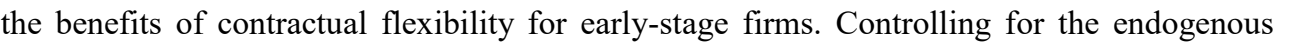

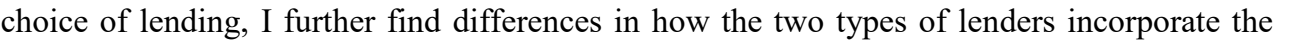

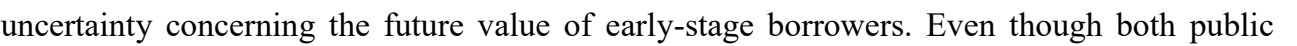

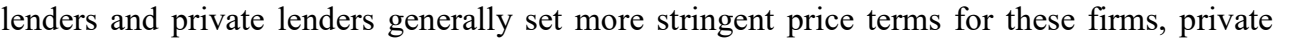

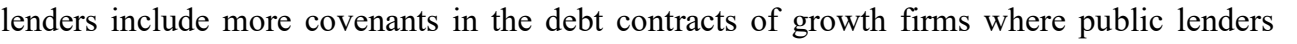

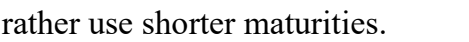




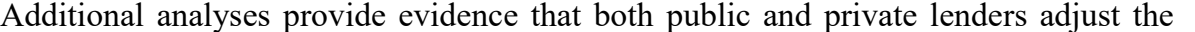
covenant design to incorporate borrowers' needs and the different informativeness $\square \square \square$

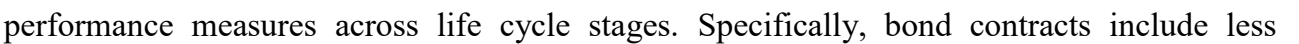
ए ए।

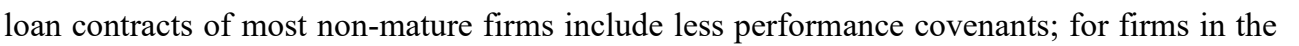

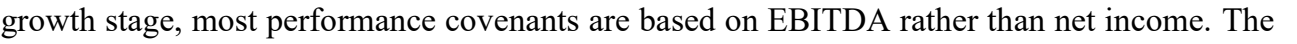

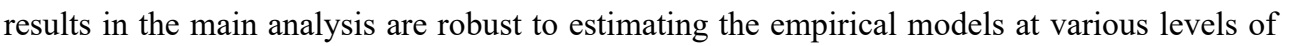

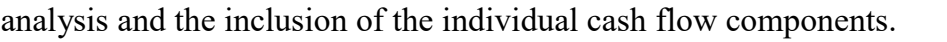

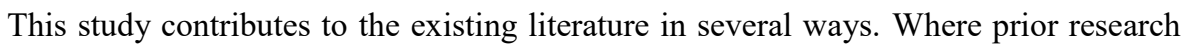

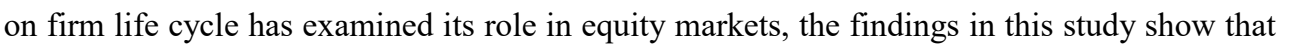

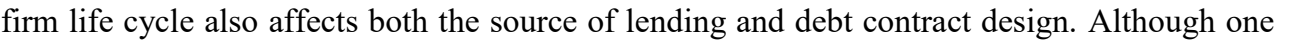

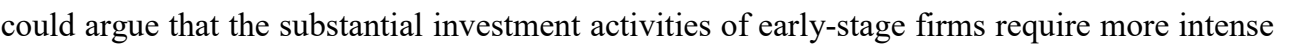

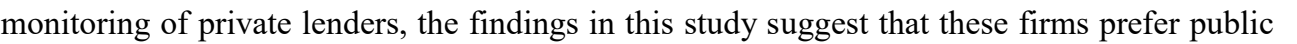

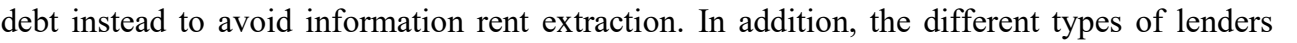

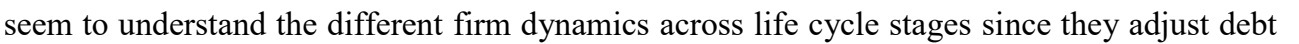

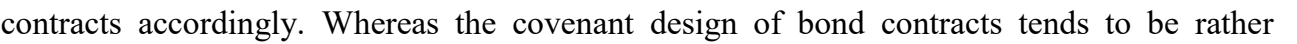

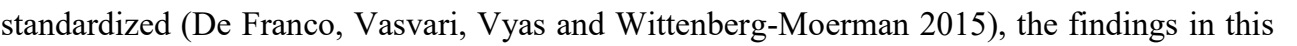

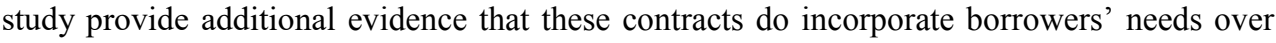

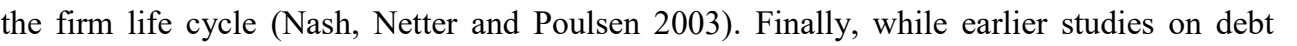

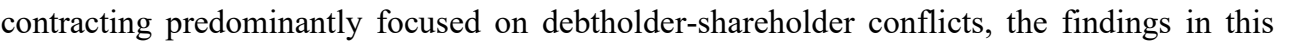
study add to recent findings that uncertainty concerning borrowers' future value also affects

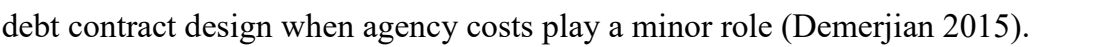

$\square$

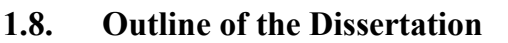

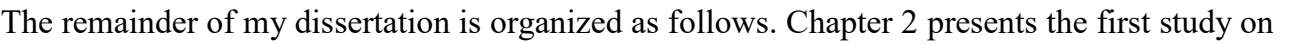

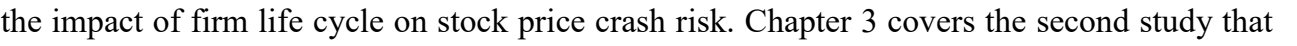

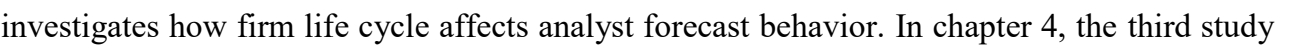

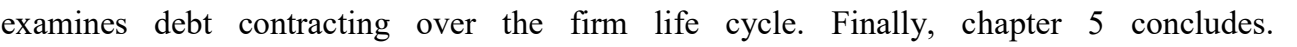



$\square$

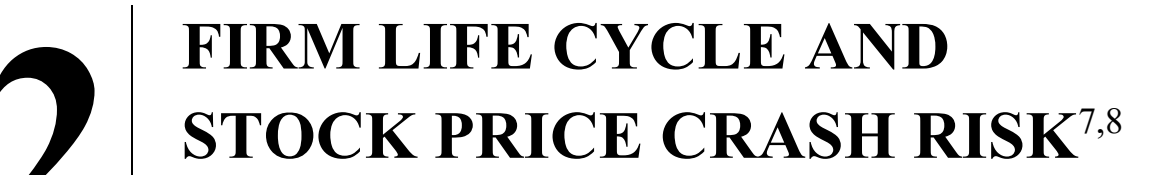

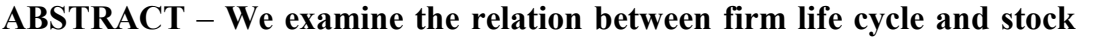

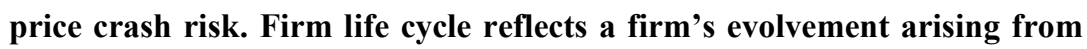

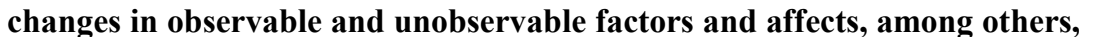

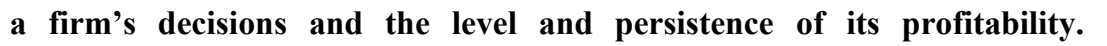

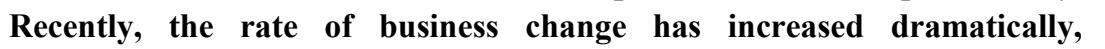

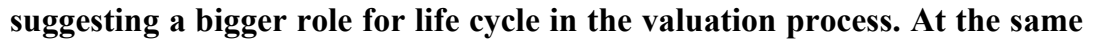

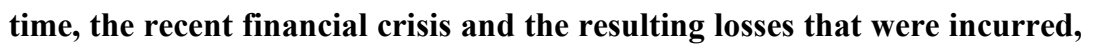

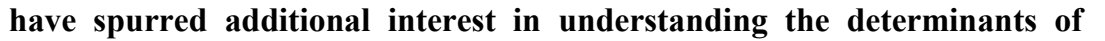

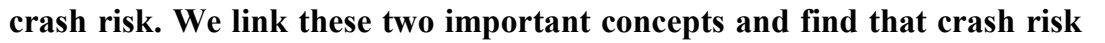
ए

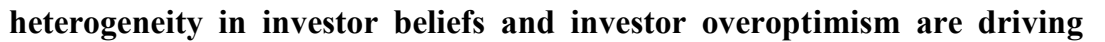

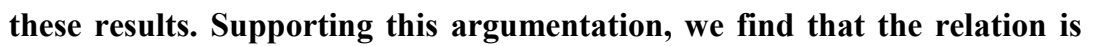

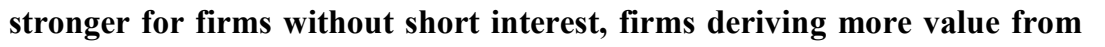

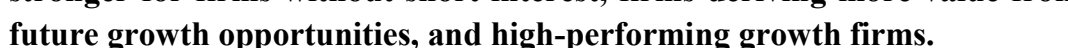

$\square$

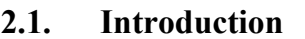

$\square \mathbb{1}$ is study, we investigate how a firm's stock price crash risk evolves over the corporate life $\square \amalg \Pi$ Firm life cycle represents a firm's evolvement arising from changes in internal factors,

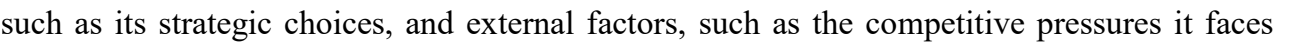
प

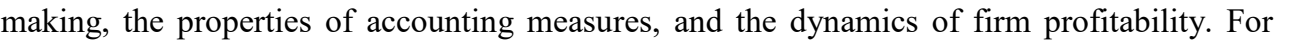

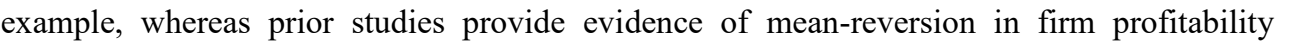

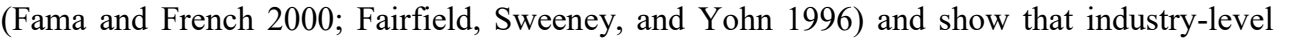

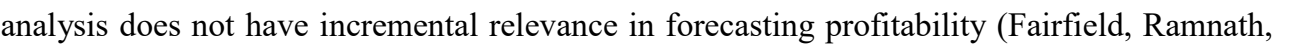

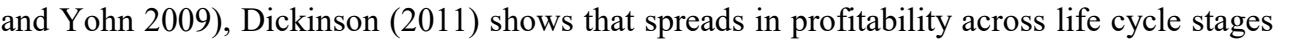

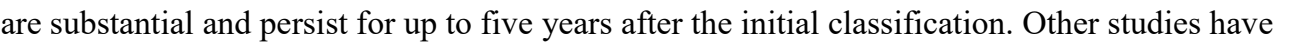
used life cycle theory to explain a firm's dividend policy (Grullon, Michaely, and

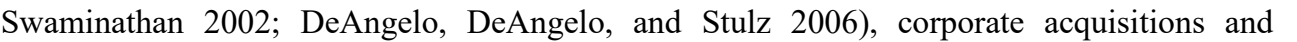

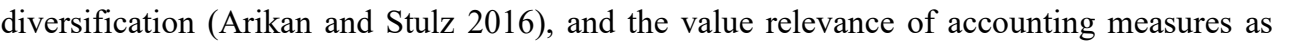

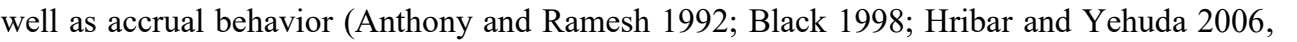
$\square 11 \| m$

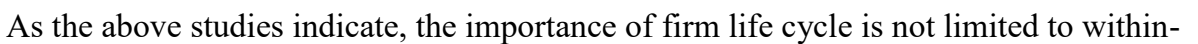
प

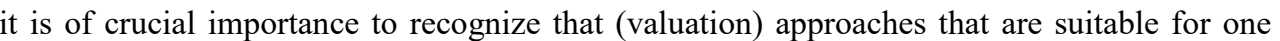

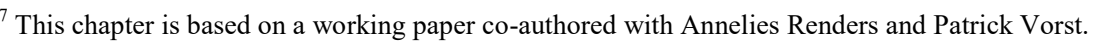

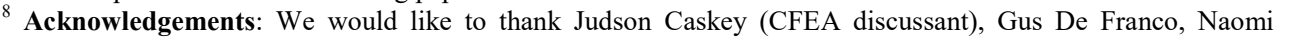

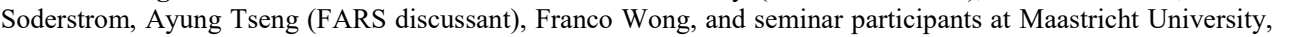

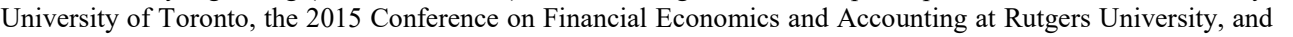

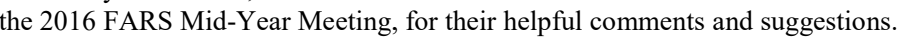




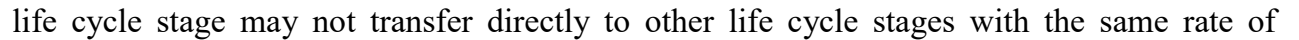

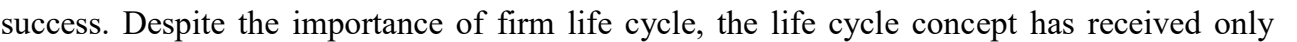

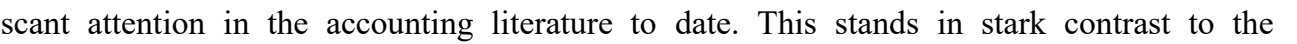

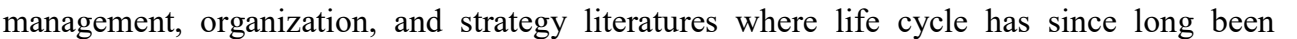

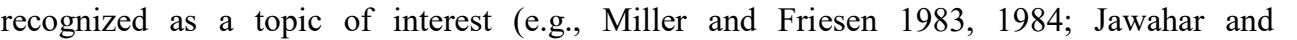

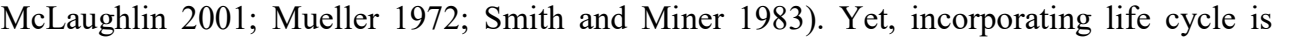

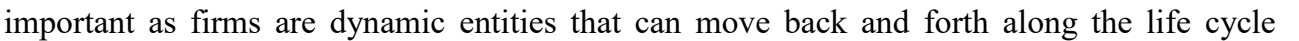

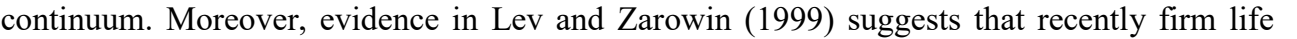

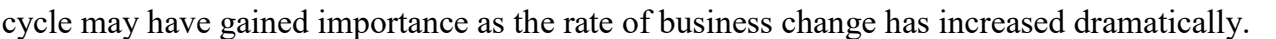

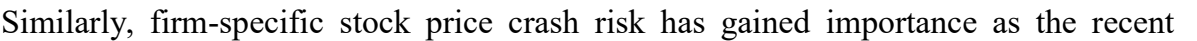
ए

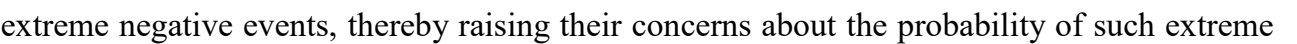

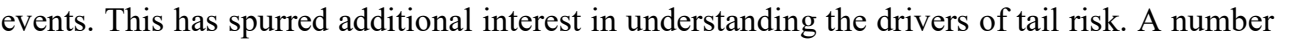

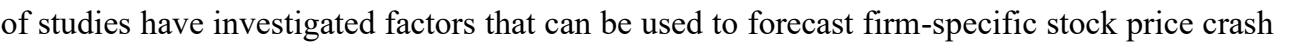

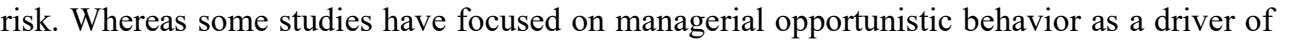

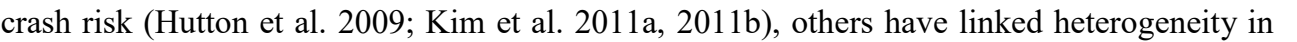

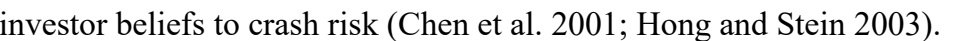

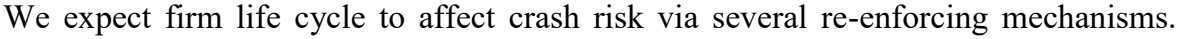

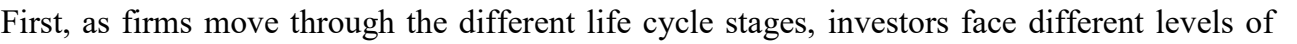

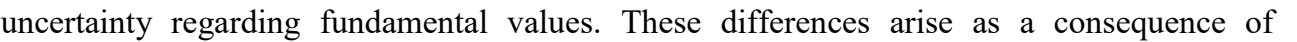

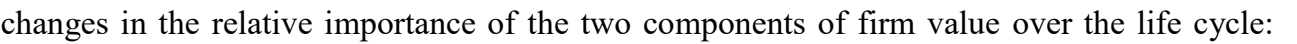
The value of a firm's assets in place

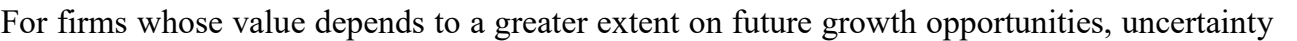

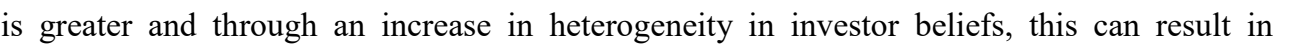
ए

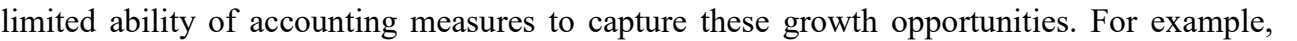

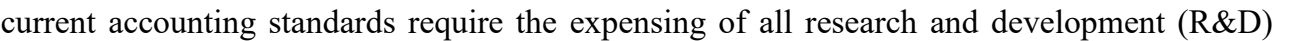

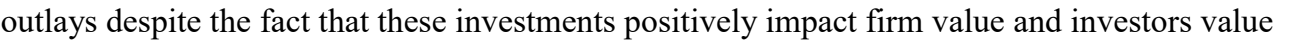

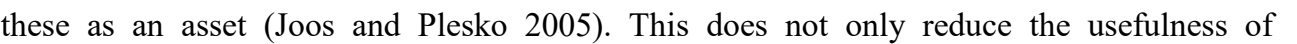

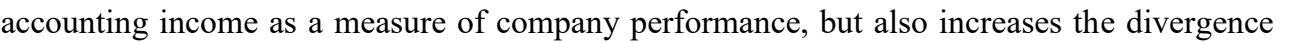

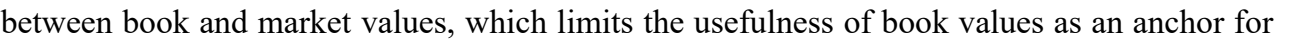

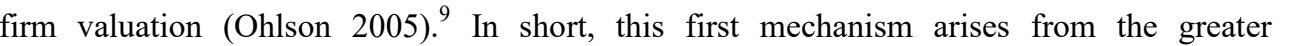

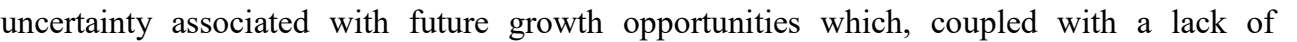

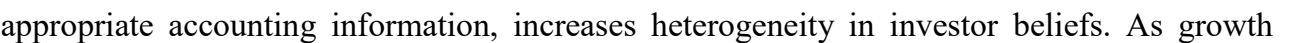

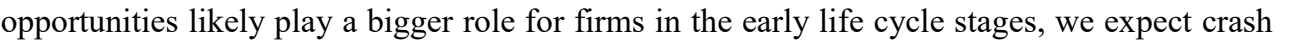

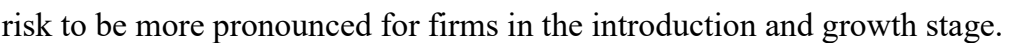

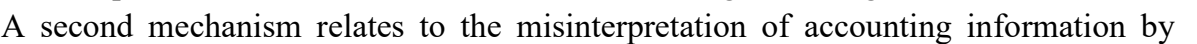

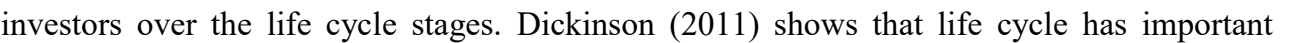

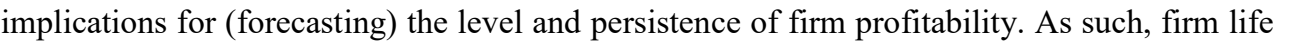

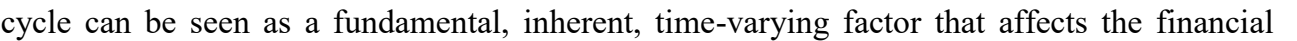

\footnotetext{
The starting point in any residual income/abnormal earnings valuation model is the firm's current book value. If all assets are recognized at fair value there would be no difference between a firm's market value and a firm's

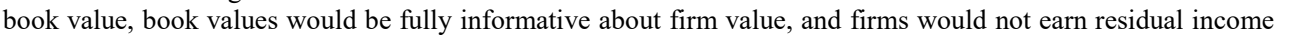

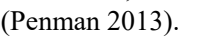




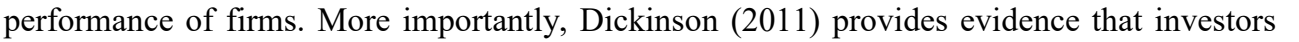
पाएव

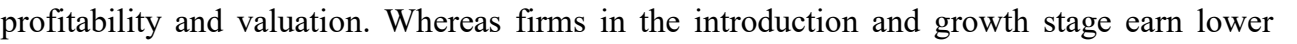

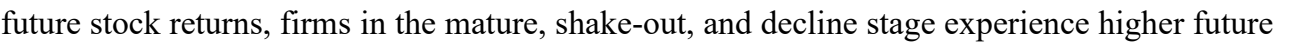

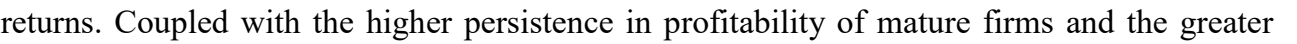

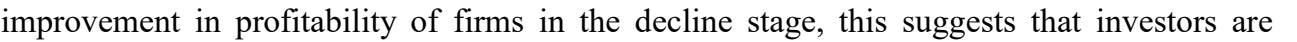

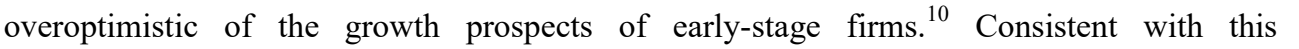

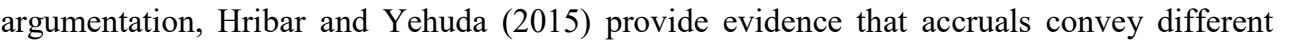

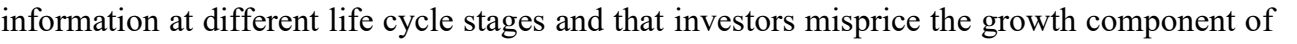

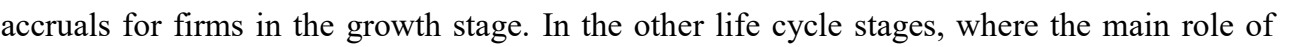

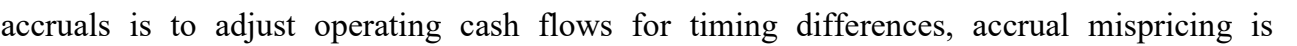

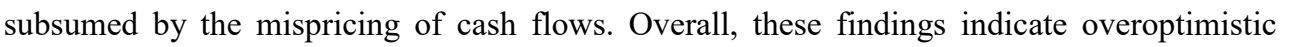

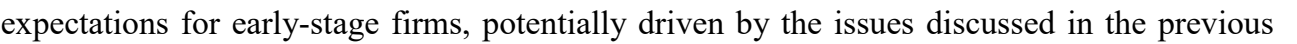

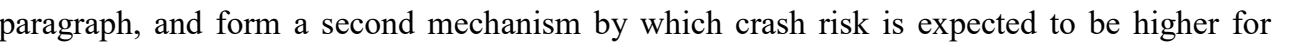

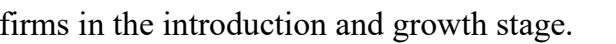

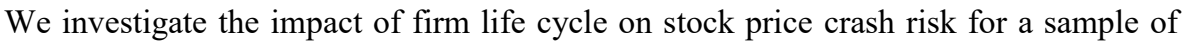

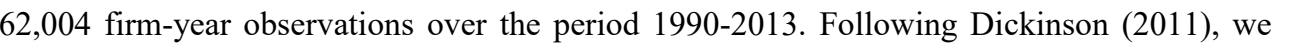

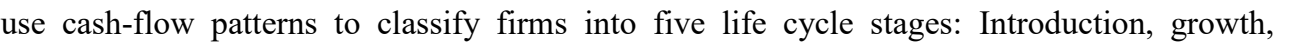

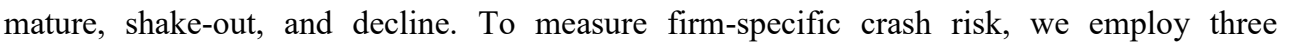

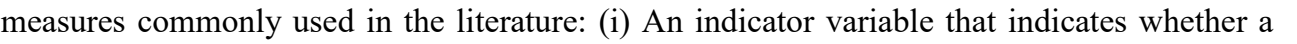

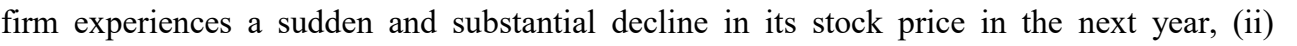

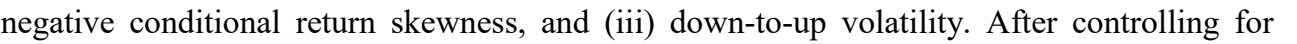

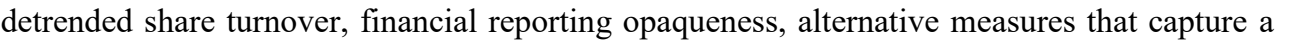

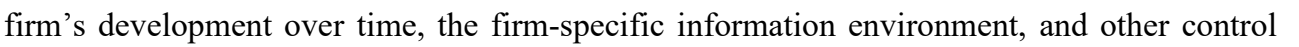

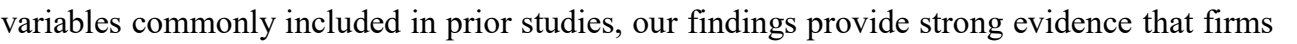

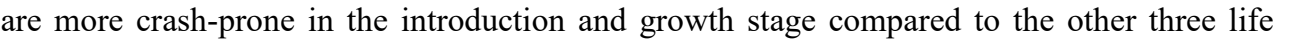

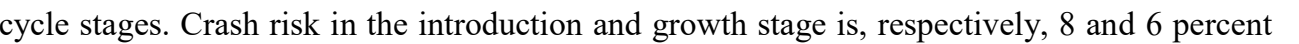

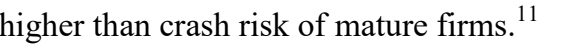

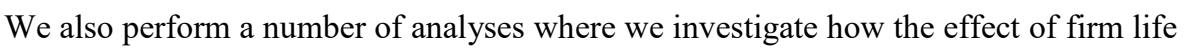

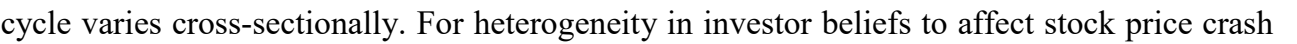

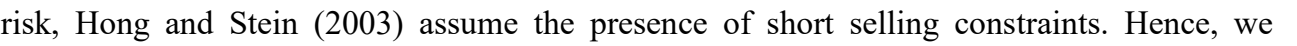

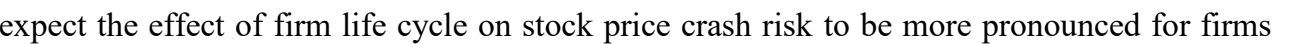

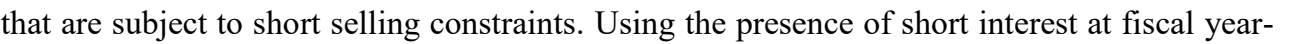

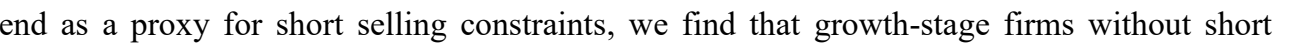

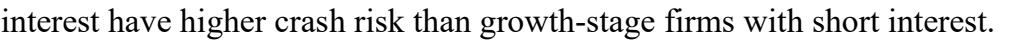

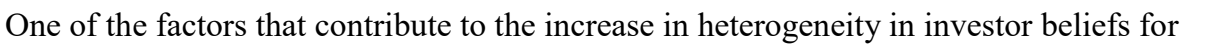

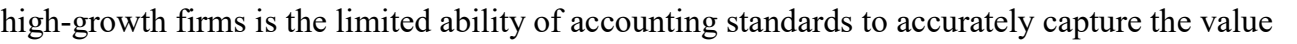

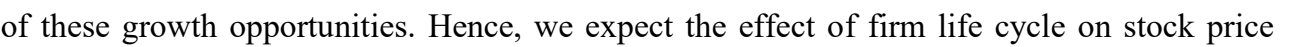

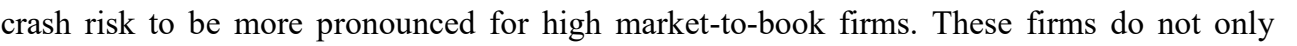

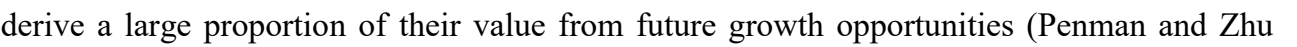

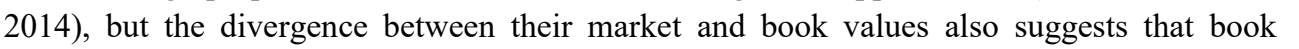

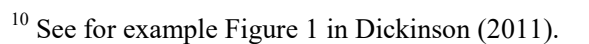

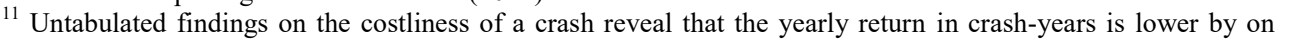

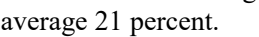




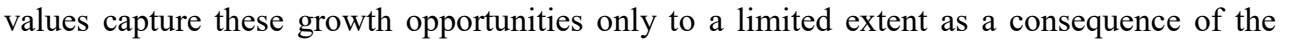

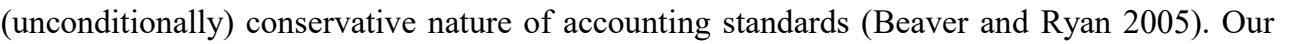

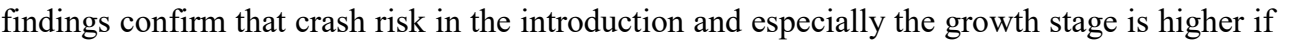

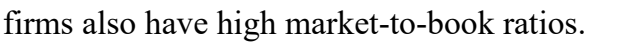

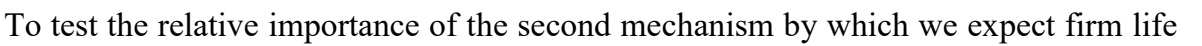

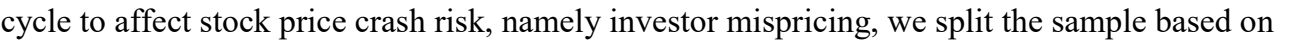

firms' return on net operating assets. Firm life cycle is not only an important determinant of

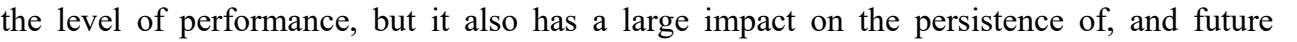

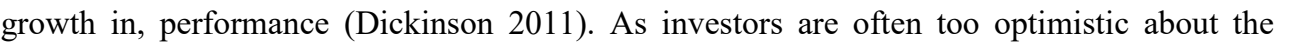

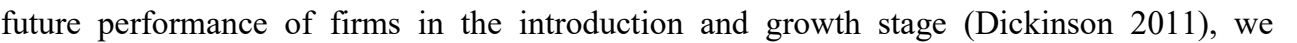

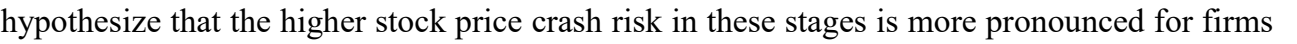

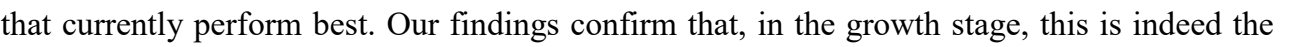

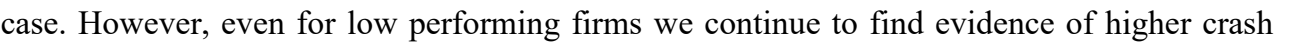

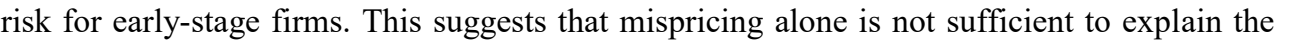

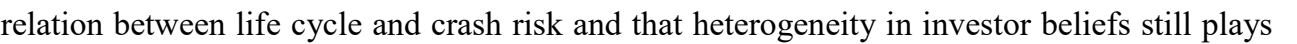

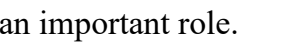

एव

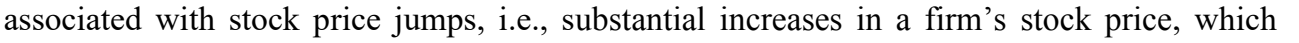

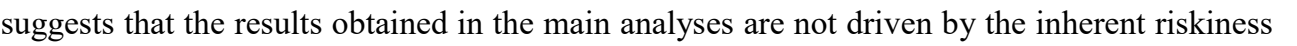

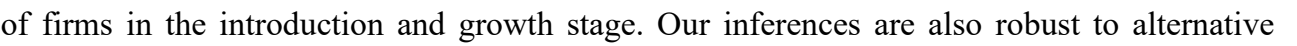

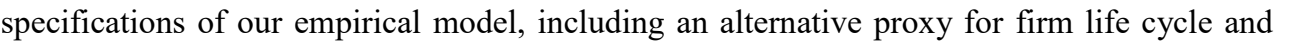

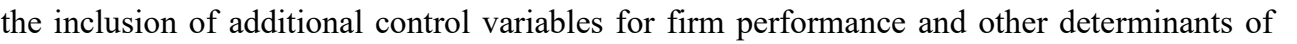

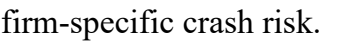

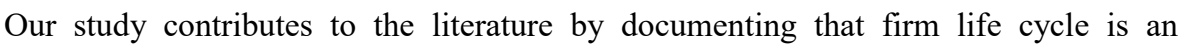
प

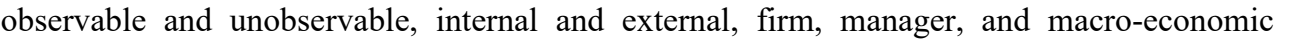

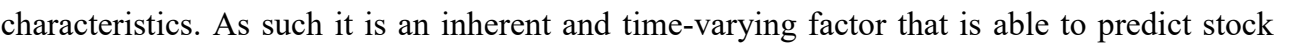

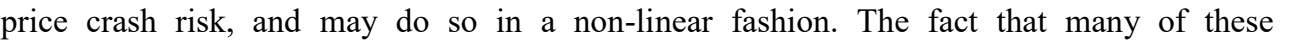

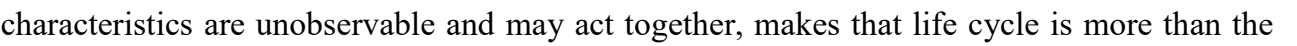

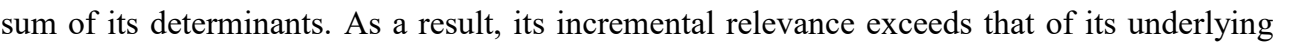

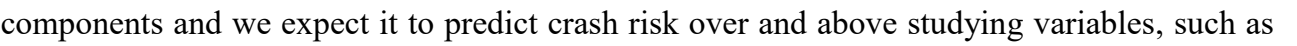
प

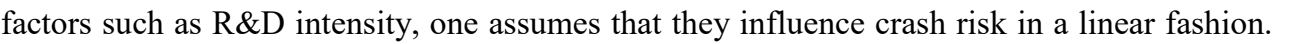

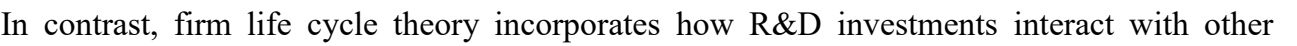

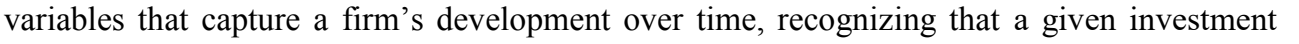

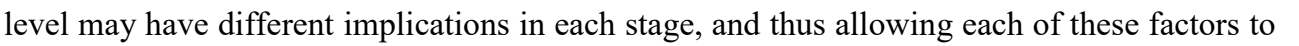

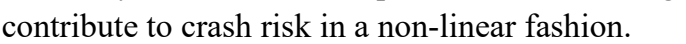

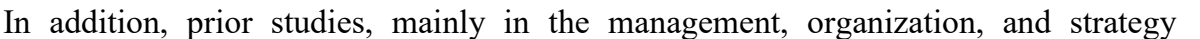

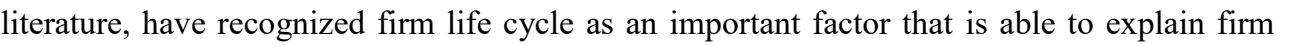

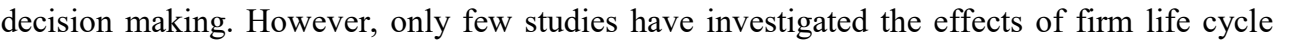

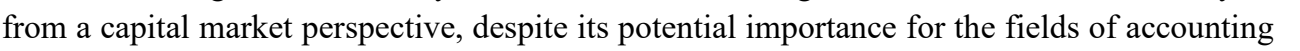

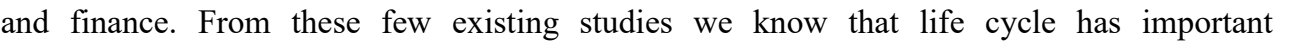

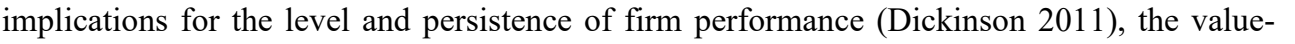

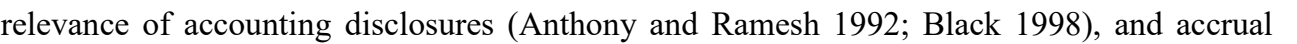




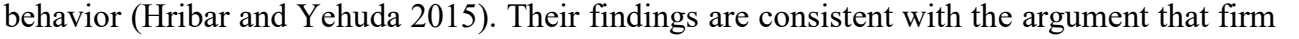

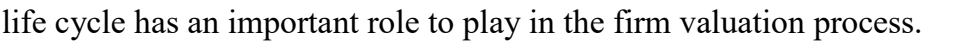

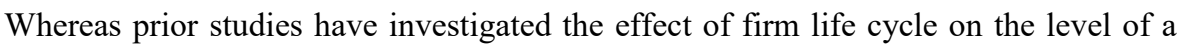
firm's returns (Dickinson 2011; Hribar and Yehuda 2015), in this study we link firm life cycle

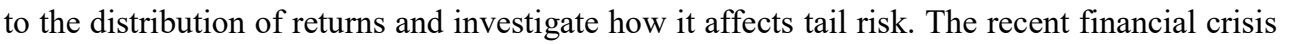

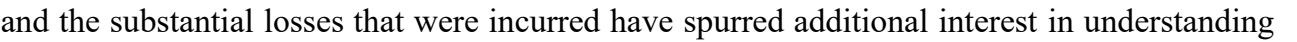

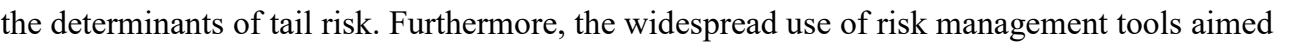

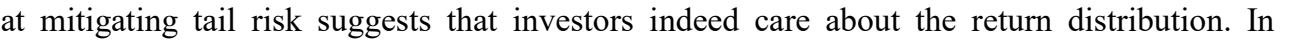

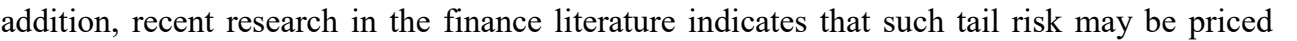
and thus affect a firm's cost of capital. For example, in the cumulative prospect theory base $\square$

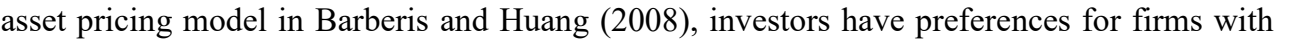

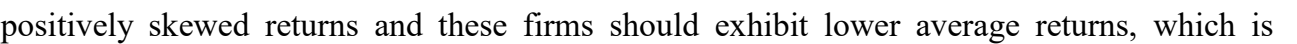

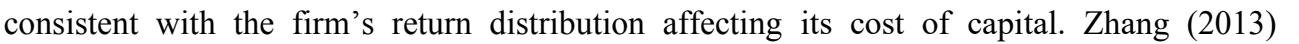

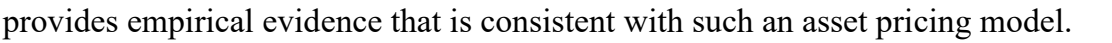

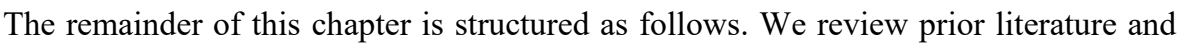

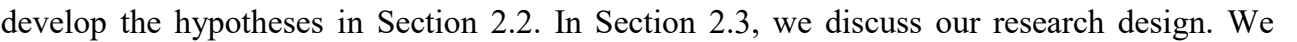

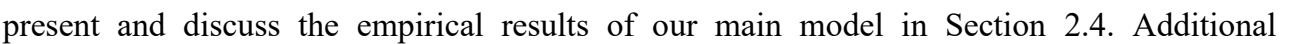

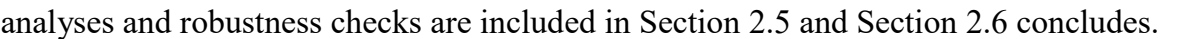
$\square$

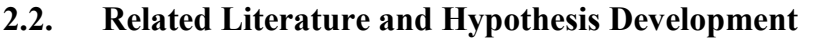

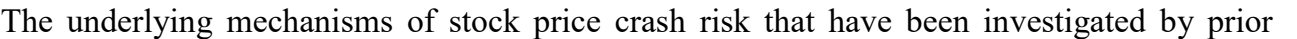

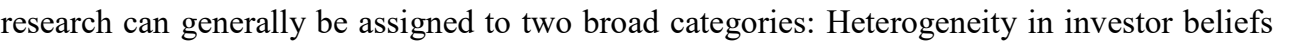

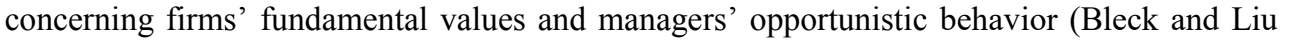

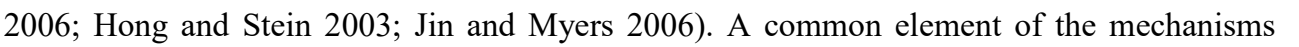
underlying stock price crash risk is the presence and accumulation of bad news about firms'

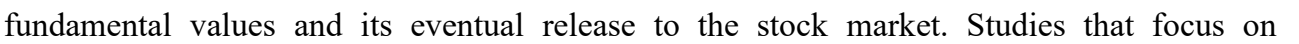
managers' opportunistic behavior argue that managers intentionally engage in bad news

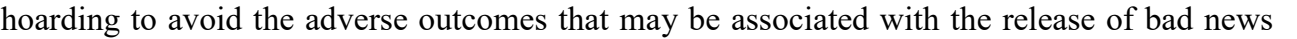

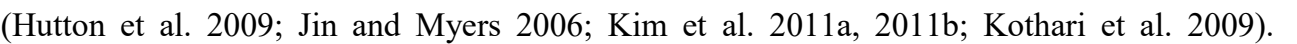

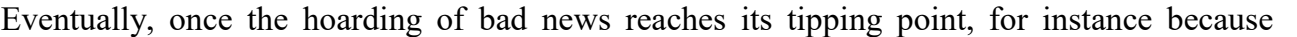
managers' willingness to withhold bad news has reached its limit, the sudden release of the

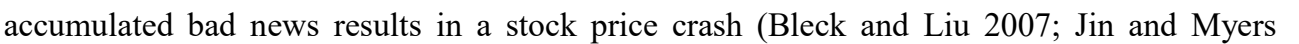
पामालाए

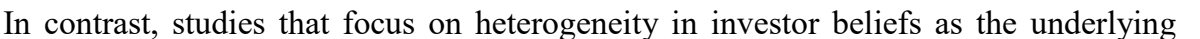

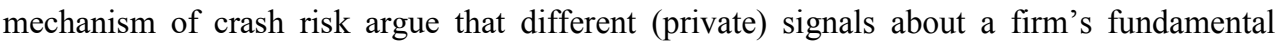

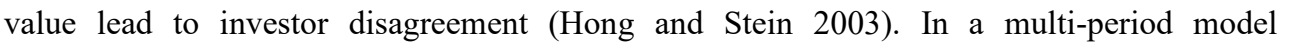

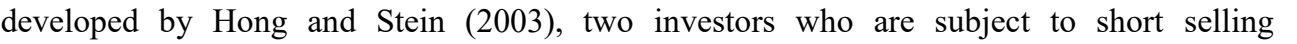

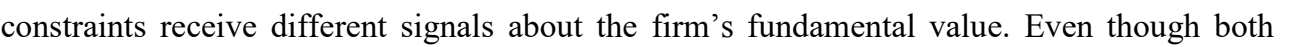

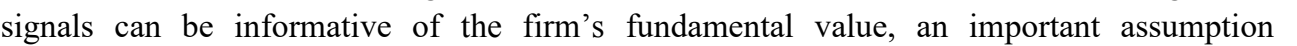

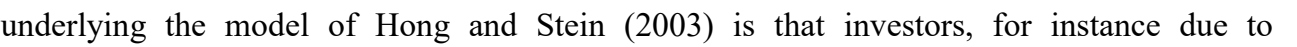

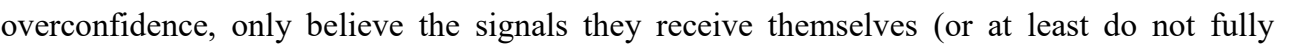
ए

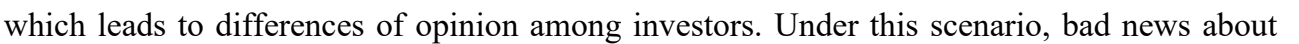
the firm's fundamental value may not be fully revealed to the market immediately. Only when 
the investor who initially received an optimistic signal about the firm's fundamental value

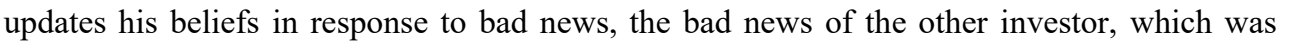

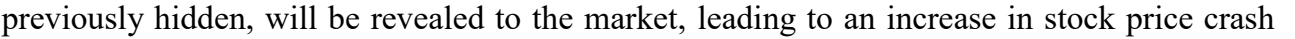

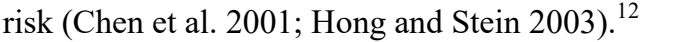

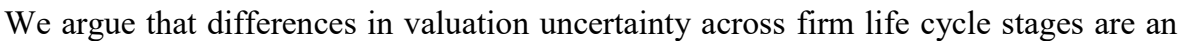

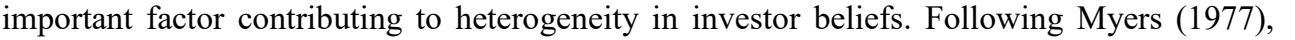

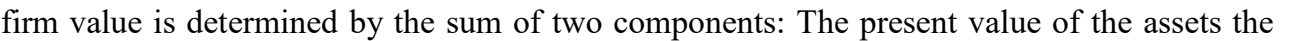

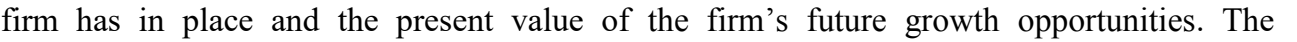

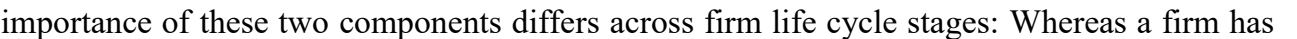
प

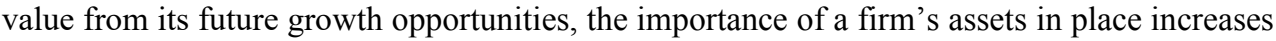

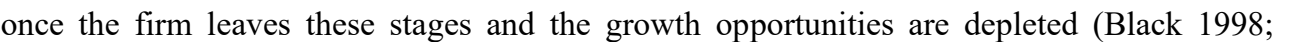

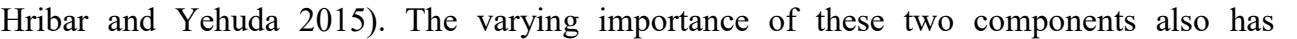

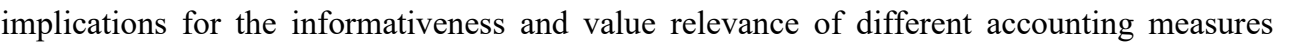

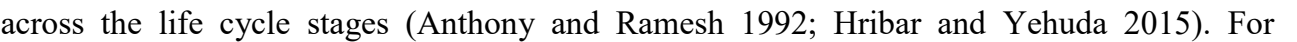
ए ए

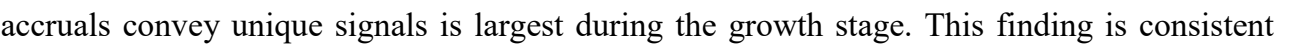

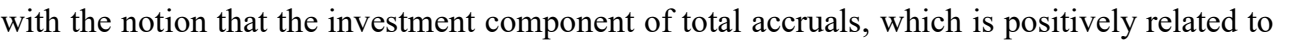

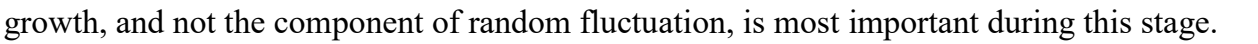

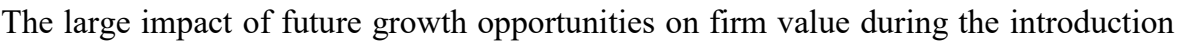

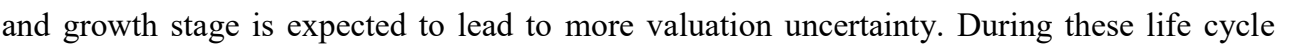

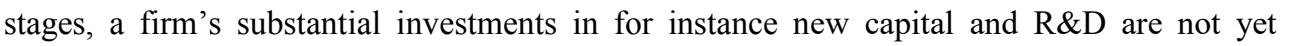

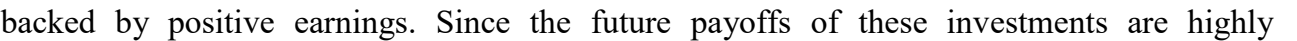

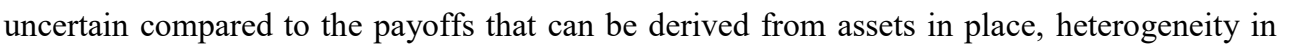

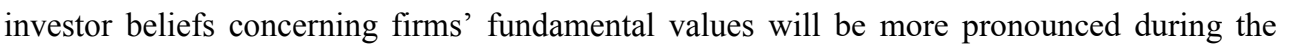

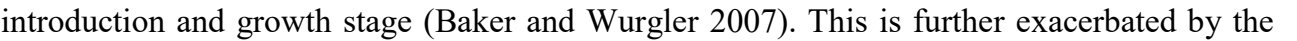

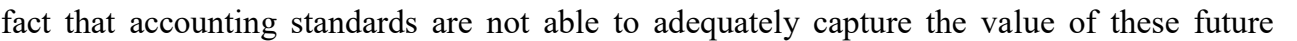

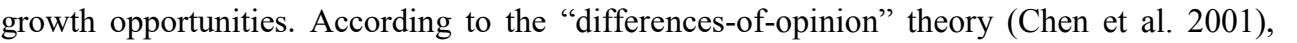

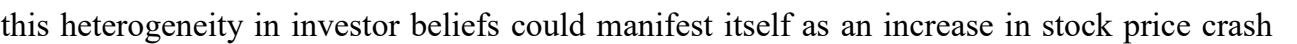
पाणाणा

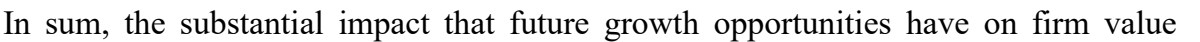

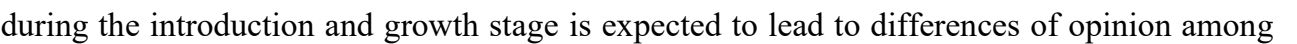

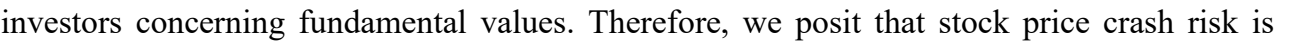

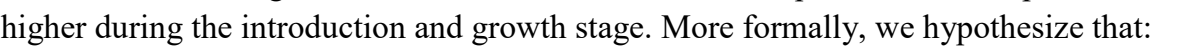
$\square$

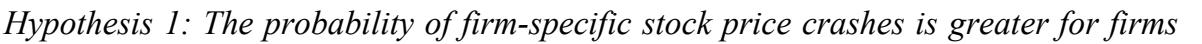

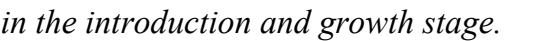

\footnotetext{
Assume that the signals that A and B receive about the firm's fundamental value (i.e., $S_{\square}$ पाता

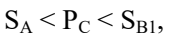

प

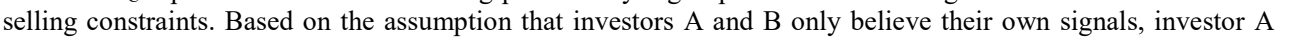
ב

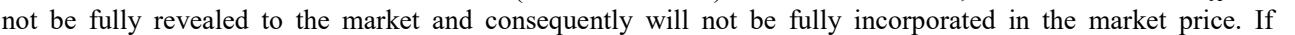
प

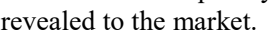




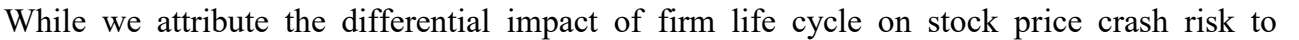
heterogeneity in investor beliefs, managers' opportunistic behavior may also vary over the

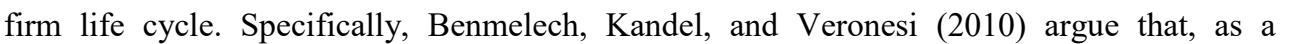

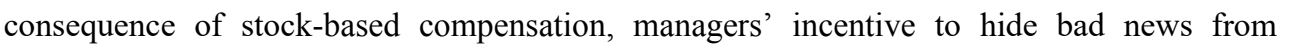
investors is highest when firms' investment opportunities decline. Under the life cycle

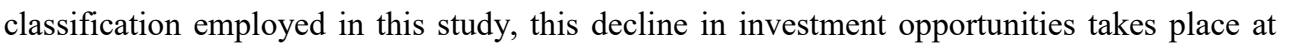

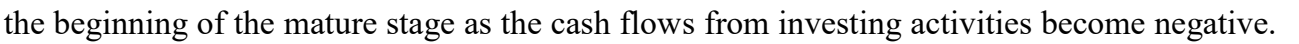

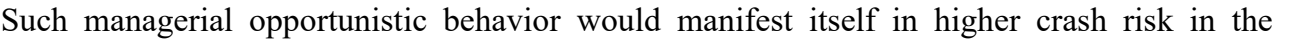

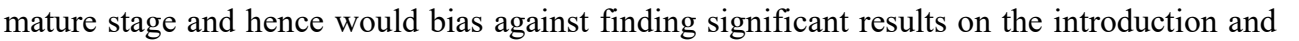
एणमाणामाण

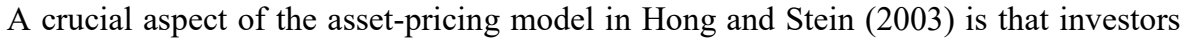
are subject to short selling constraints. Combined with investors' overreliance on their own

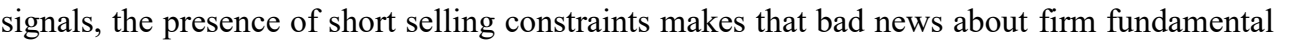

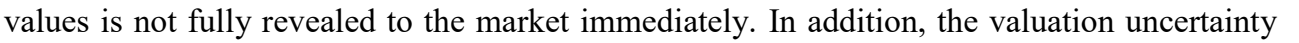
and the subsequent heterogeneity in investor beliefs also affect investors' ability to sell short

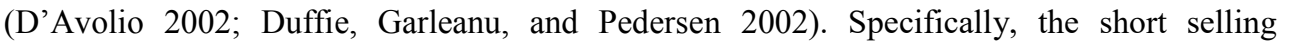
constraints faced by investors are increasing in investors' uncertainty concerning firm value

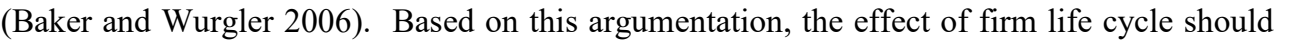

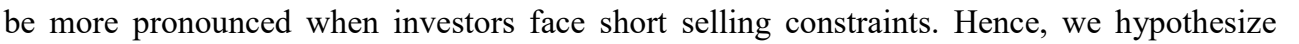
एाणाण

$\square$

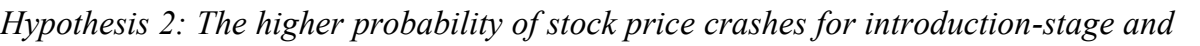

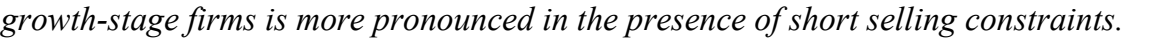

$\square$

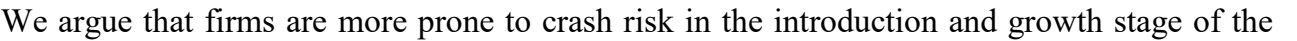
प

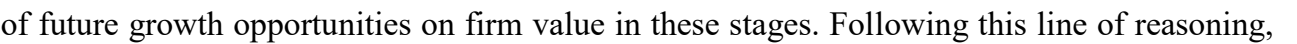

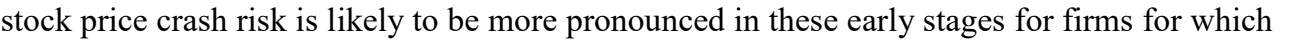

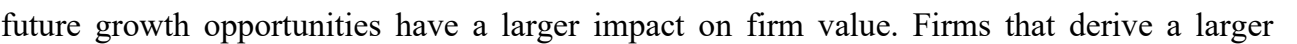

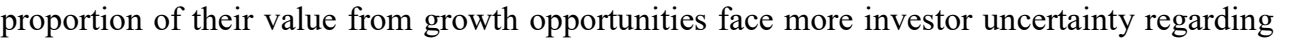

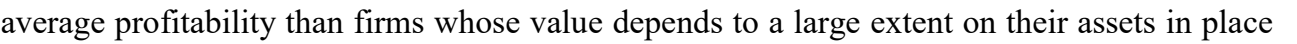

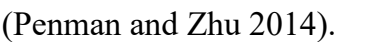

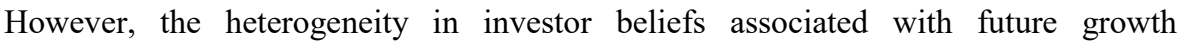

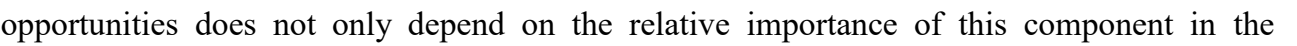

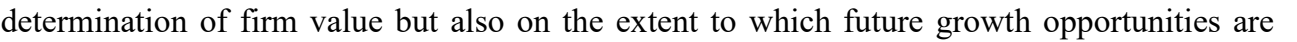
captured in the firm's book value

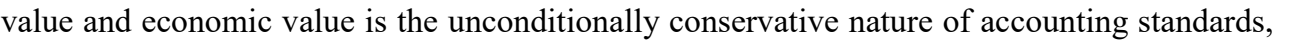

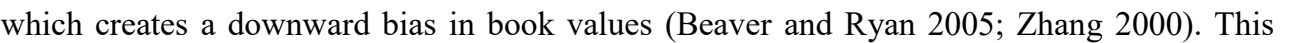

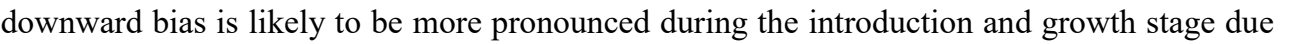

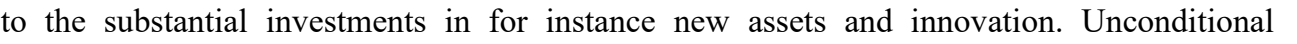

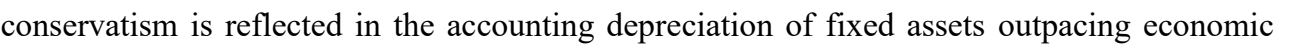

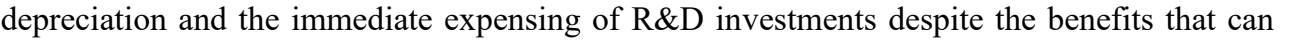

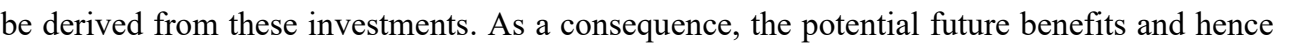

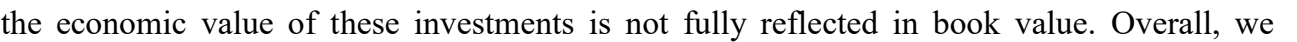




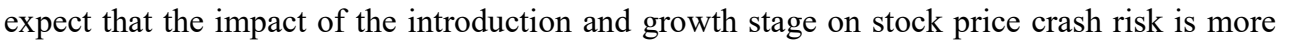

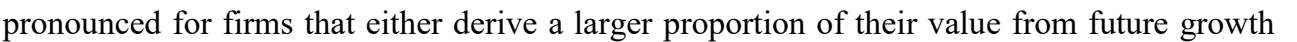

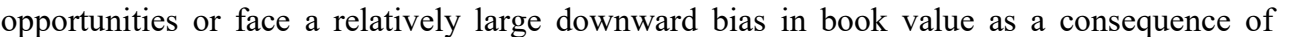

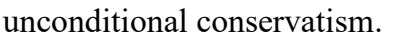

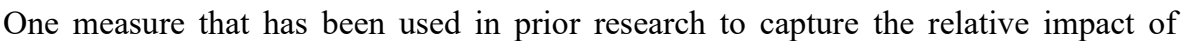

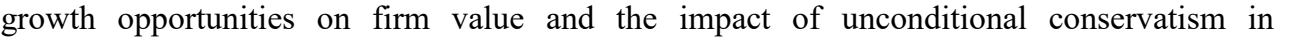

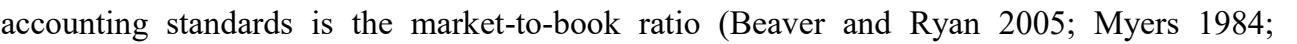

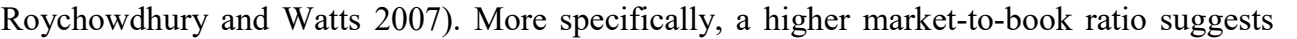

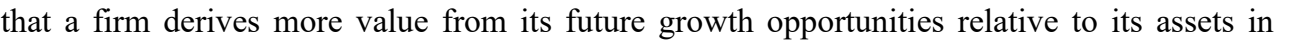

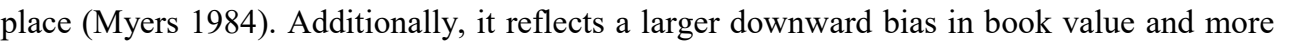

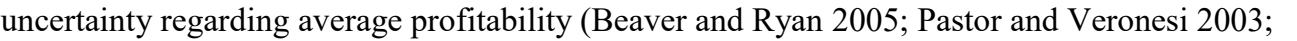

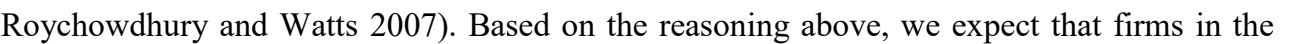
ए

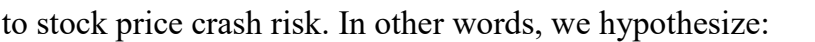

$\square$

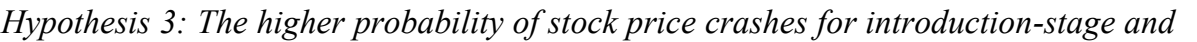

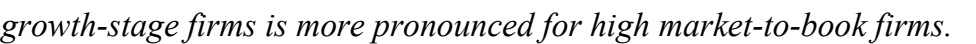

$\square$

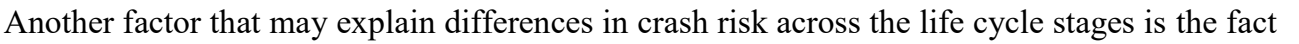

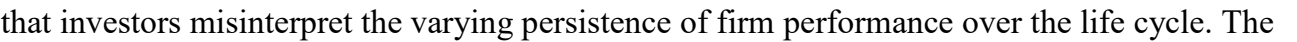

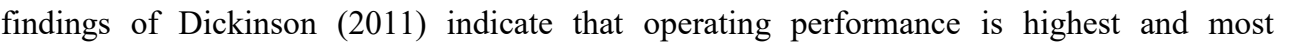

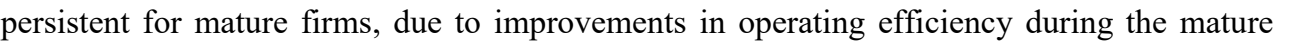

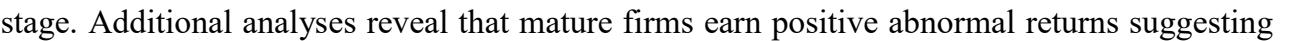

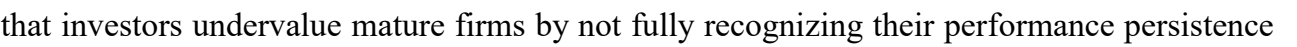

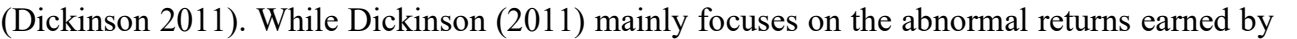

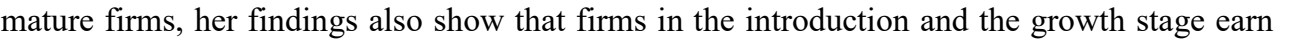

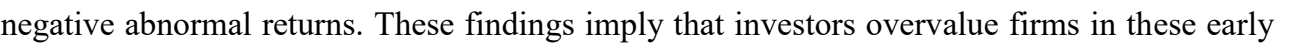
ए

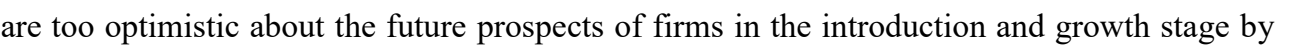

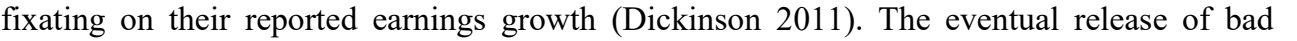

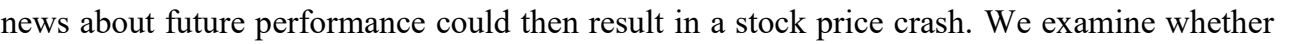

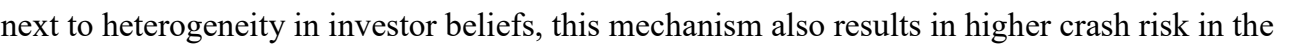

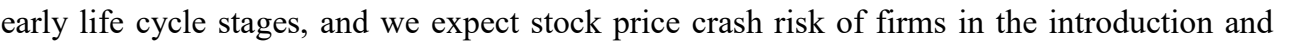

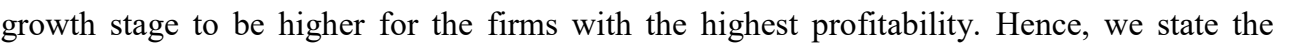

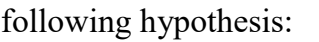

$\square$

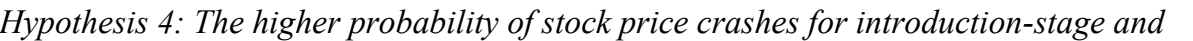

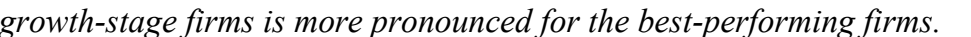

$\square$ 
$\square$

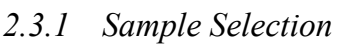

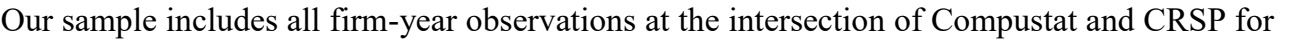

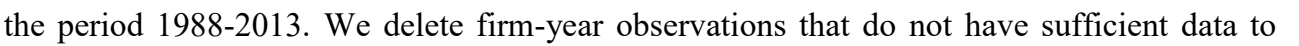

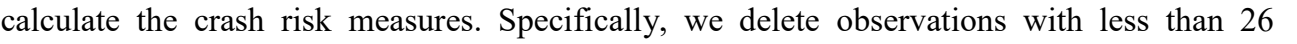

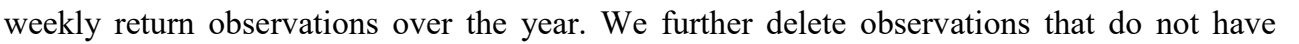

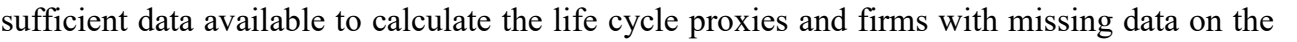

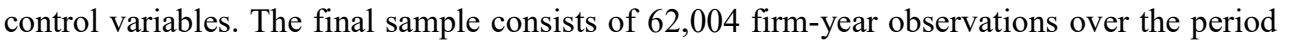
$\square \mid \Pi\|\| \| \square$

$\square$

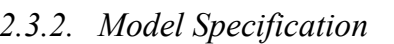

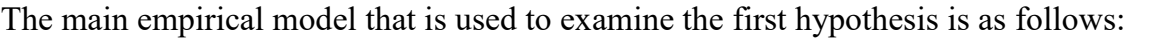
$\square$

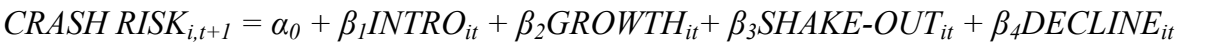

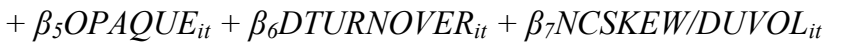

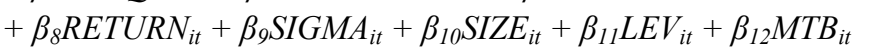

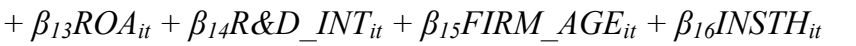

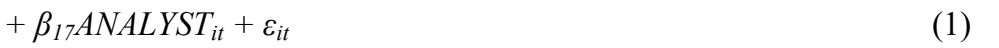

$\square$

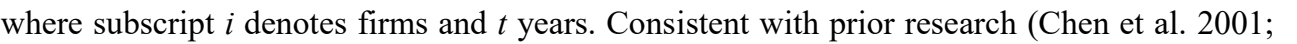

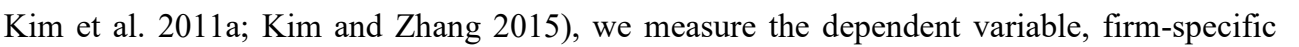

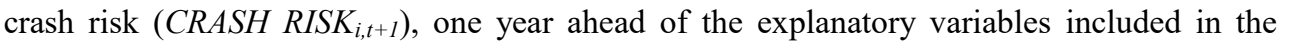
model. This model specification ensures that we forecast firms' stock price crashes rath $\square \| \amalg \square$

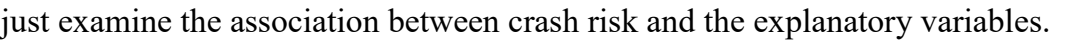
$\square$

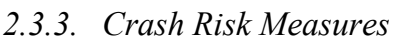

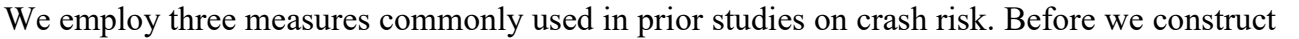

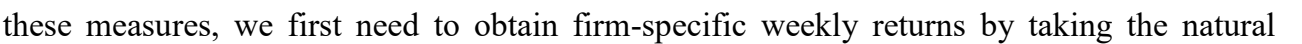

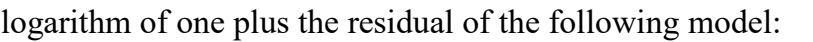

$\square$

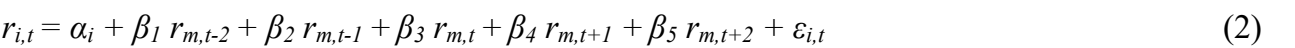
$\square$

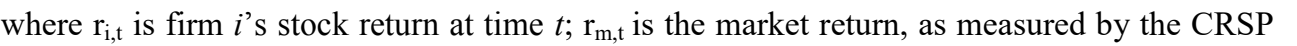

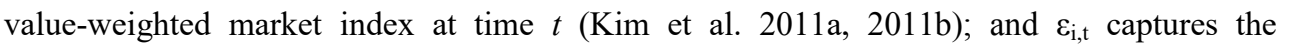

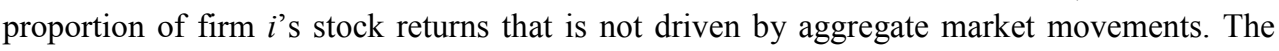

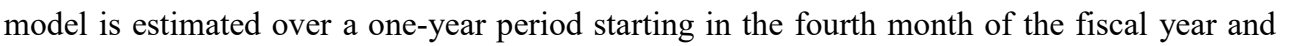

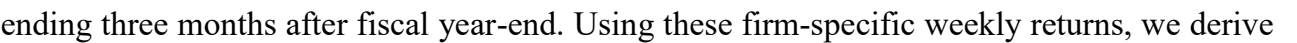

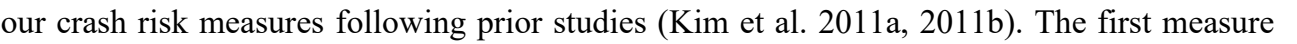

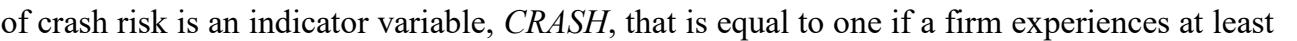

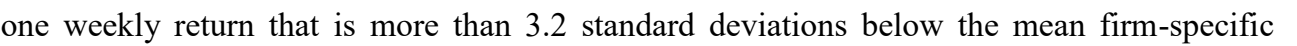

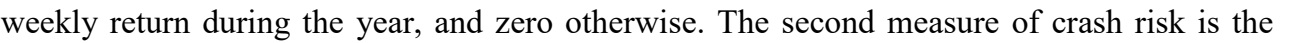

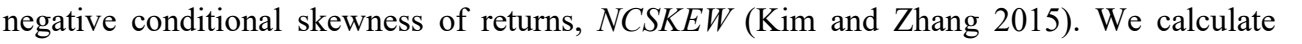

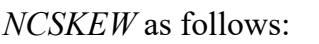


$\square$

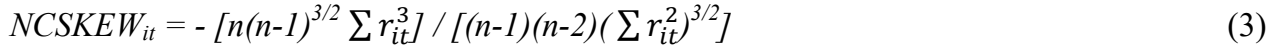
$\square$

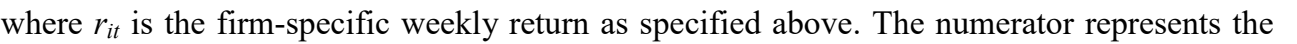

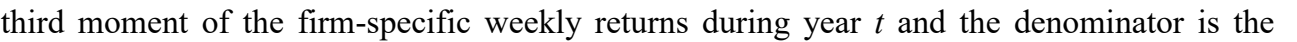

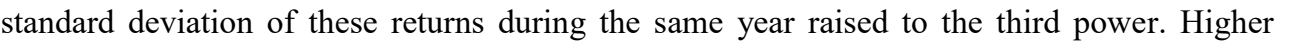

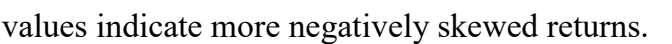

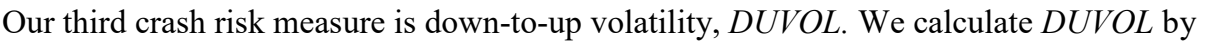

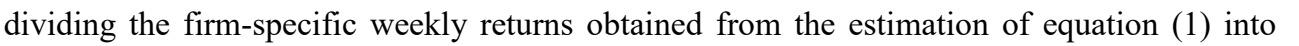

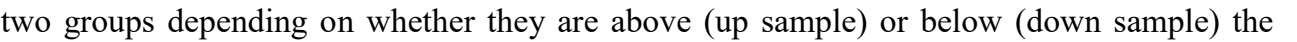

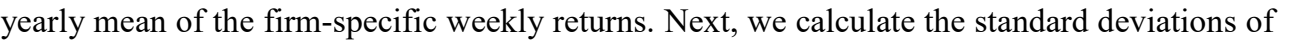
ए

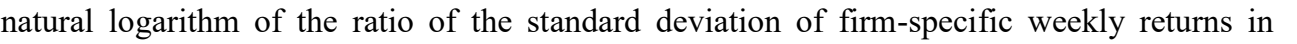

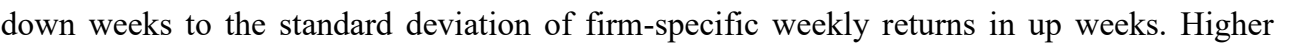

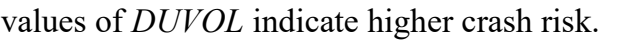

$\square$

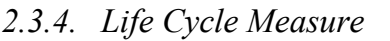

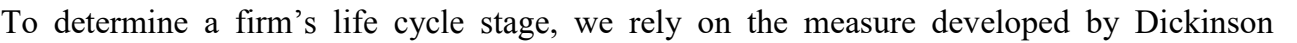

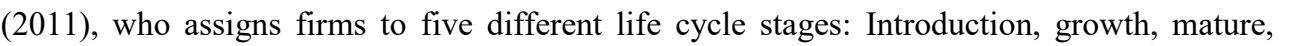

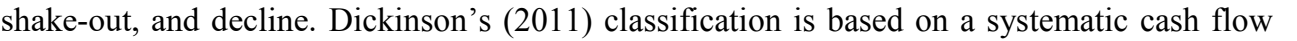

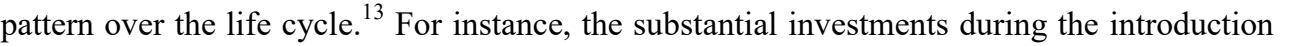

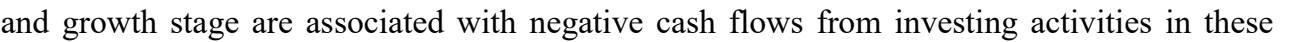

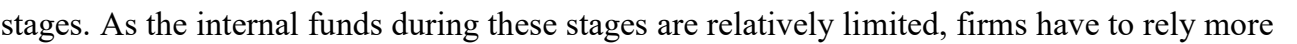

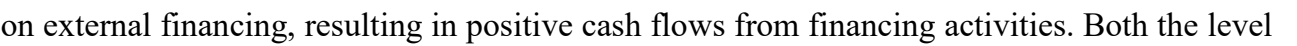

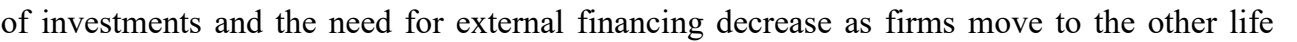

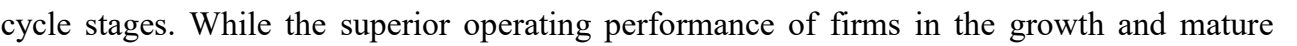

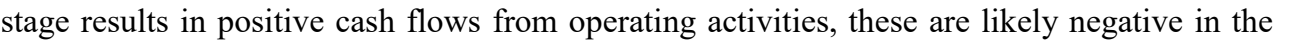
पणएणाणाएणाए

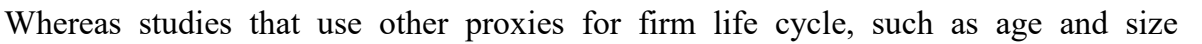

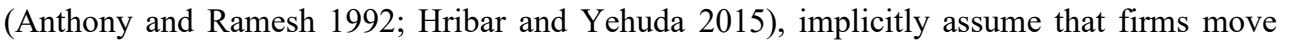

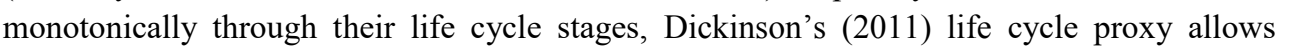

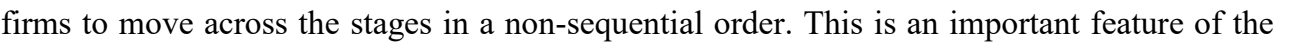

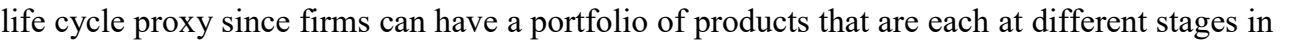

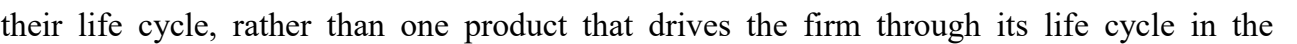

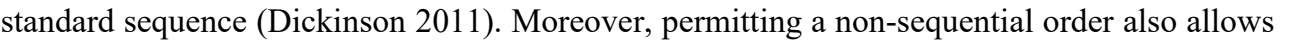

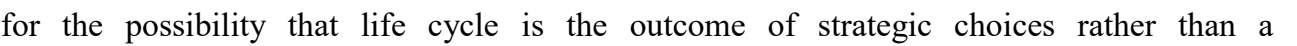

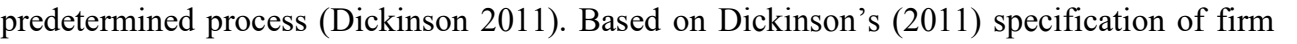

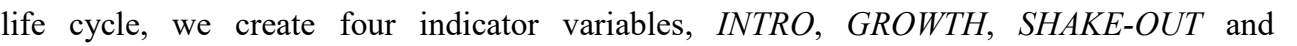

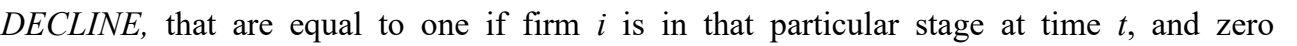

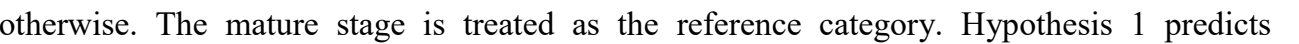

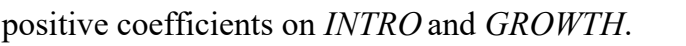

$\square$

$\square$

See Table 1.1 (p. 5) for Dickinson's (2011) classification scheme.

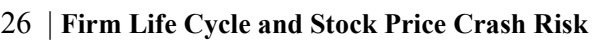




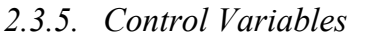

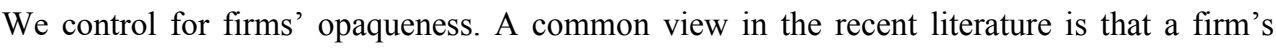

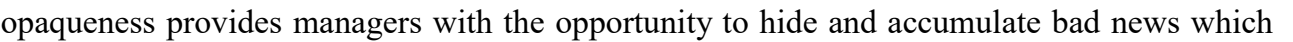

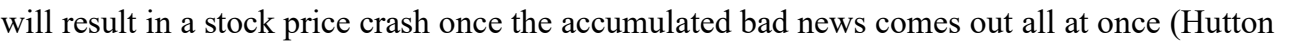

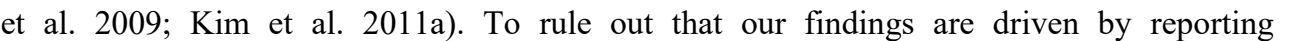
opaqueness rather than investor uncertainty about firm fundamentals, we control for a firm's

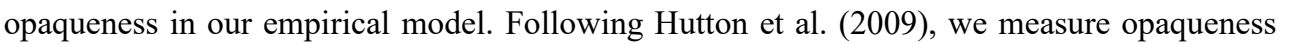
प

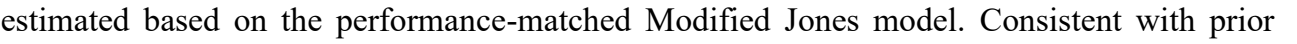

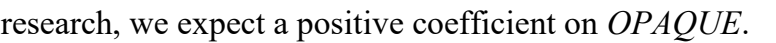

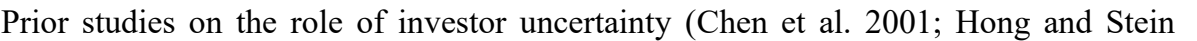

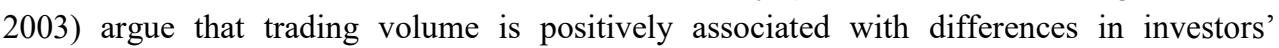

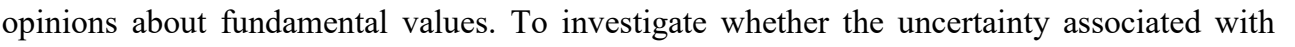

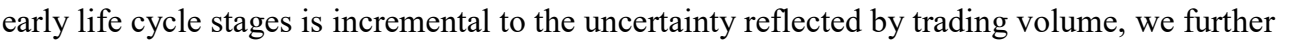

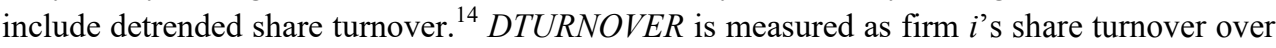

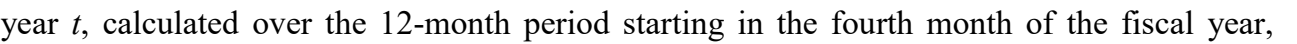

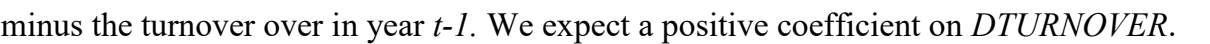

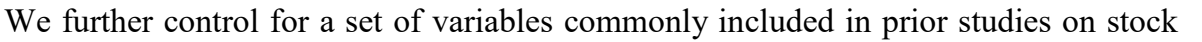

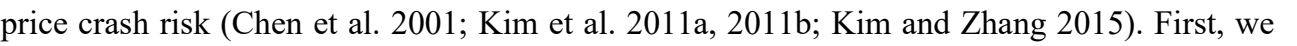

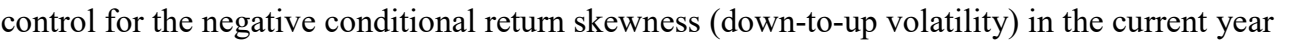

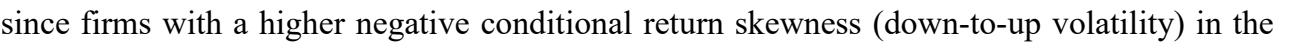

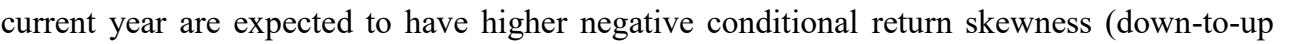

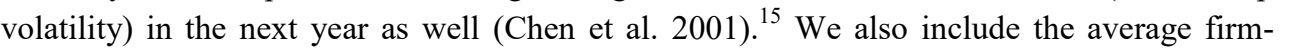

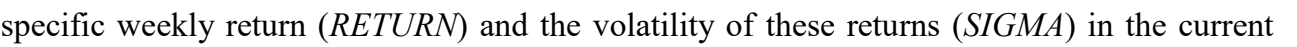

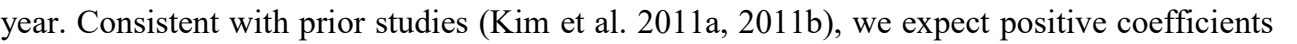

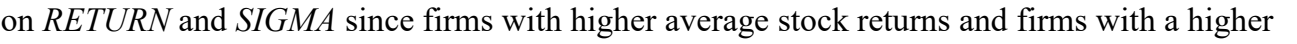

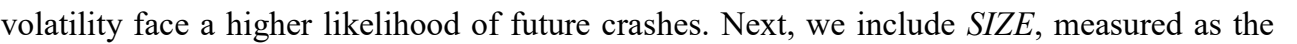

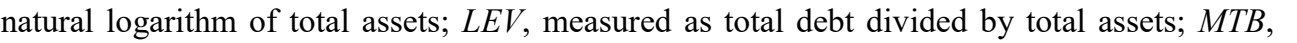

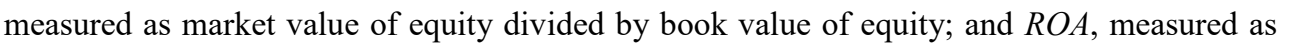

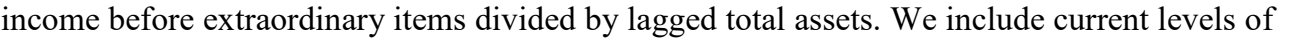

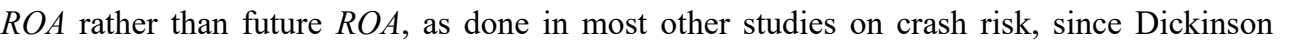

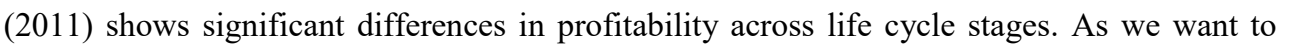
ए

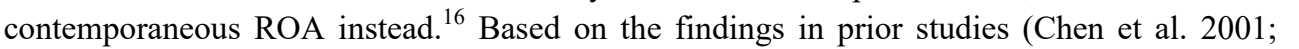

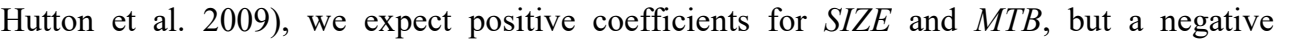

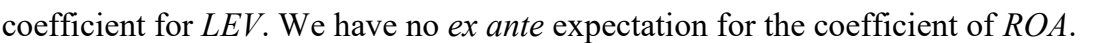

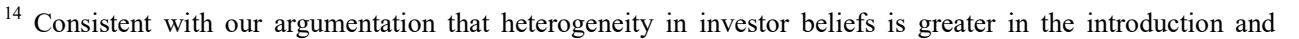

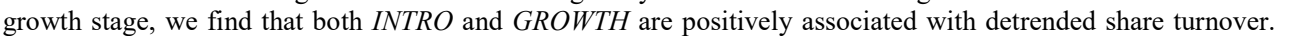
प

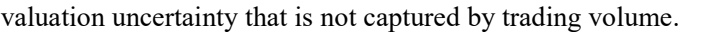

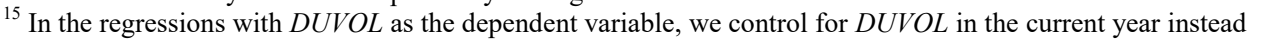

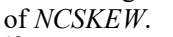

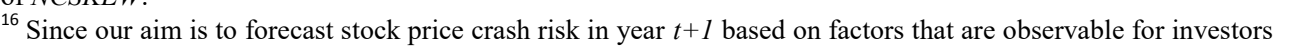

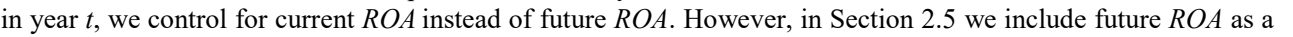

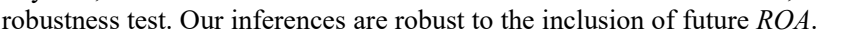




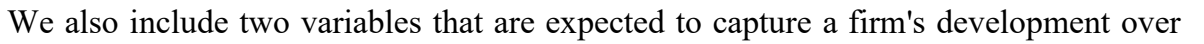

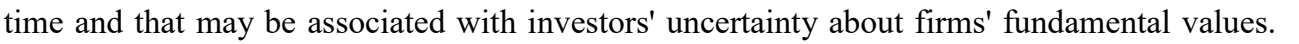

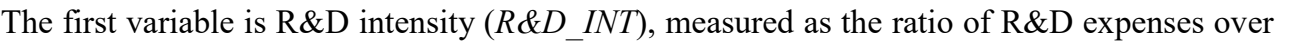

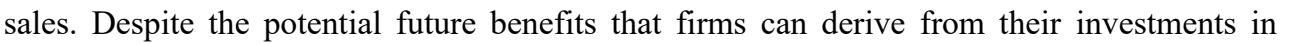

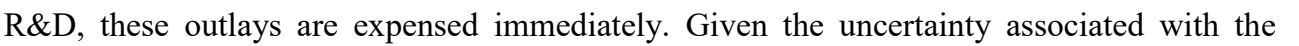

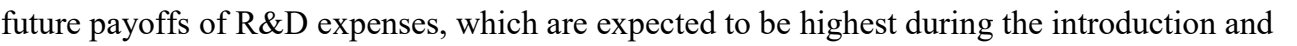

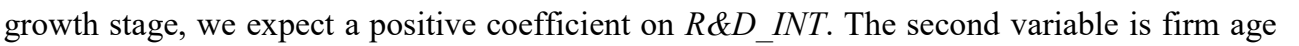

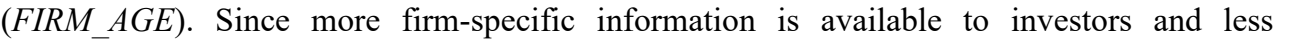

uncertainty exists among investors about firms' reporting quality as firms grow older $(\square \square \square \square$

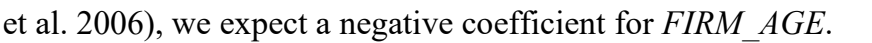

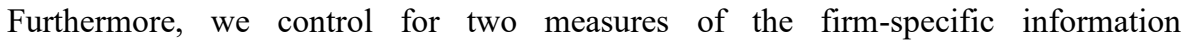

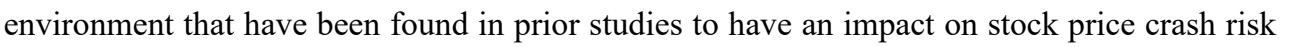

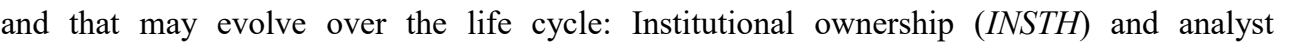
ए

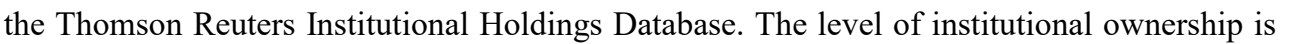

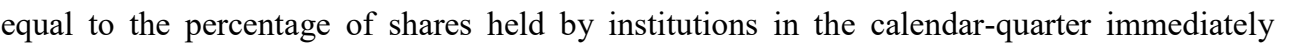

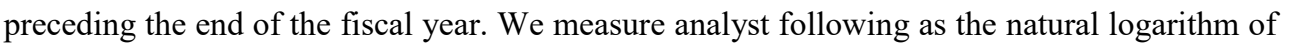
ए एव

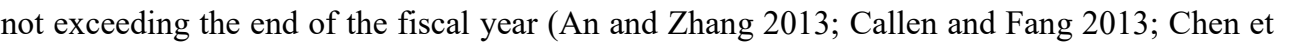

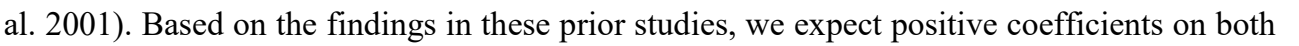

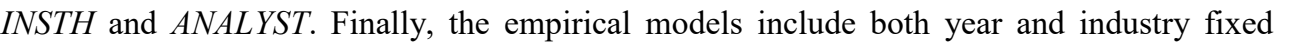

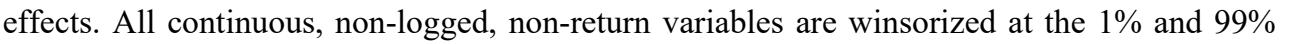

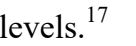

$\square$

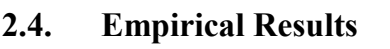

$\square$

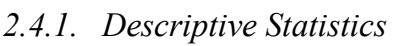

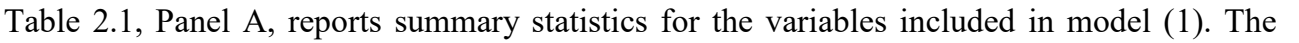

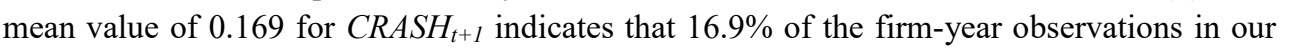

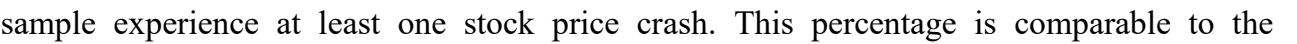

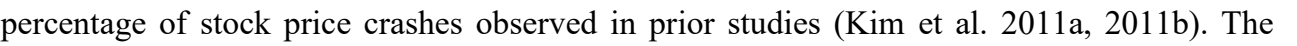

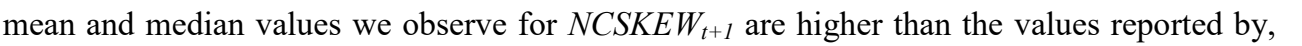

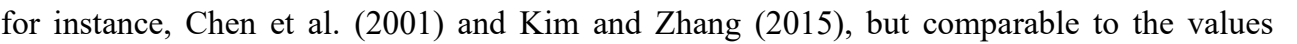

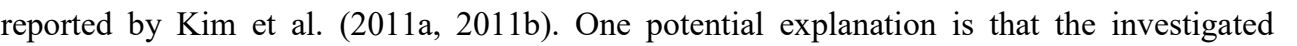

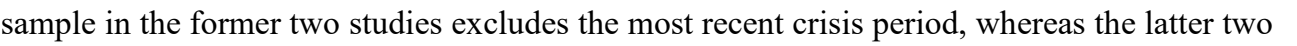

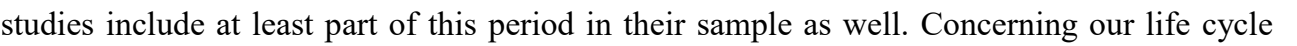

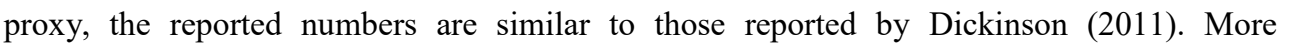

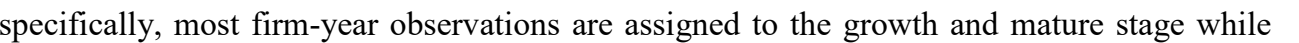

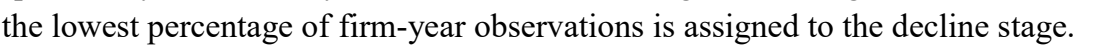

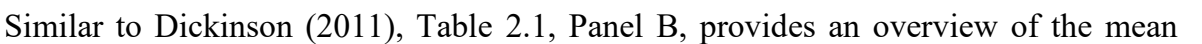

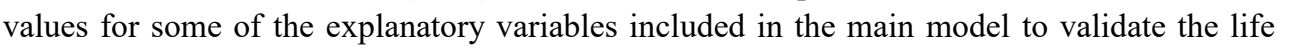

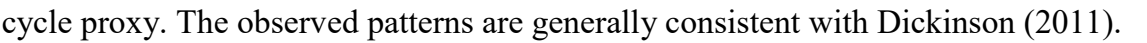

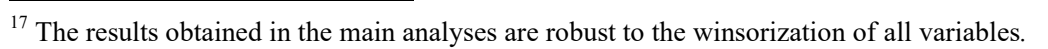




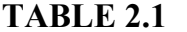

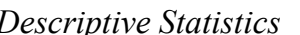

\begin{tabular}{|c|c|c|c|c|c|c|}
\hline \multicolumn{7}{|c|}{ Panel A: Descriptive Statistics } \\
\hline पपाणाप & $\square \square$ & $\square \square \square$ & 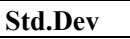 & $\square \square \square$ & 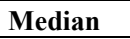 & $\square \square$ \\
\hline 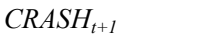 & $\square\|\Pi\| \square$ & $\square \square \square$ & 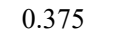 & 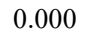 & $\square \square \square$ & 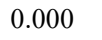 \\
\hline$\square \square \square \square \square(\mathbb{m a}$ & $\square \square \square$ & एणाए & 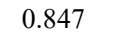 & पाणा & पाणाए & $\square \square \square$ \\
\hline 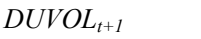 & $\square \square \square$ & एणाए & पण口卄 & एण口 & एपाए & पाए \\
\hline 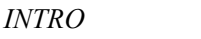 & $\square \square \mid \square$ & 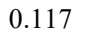 & 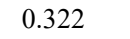 & पणा & 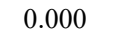 & एणा \\
\hline 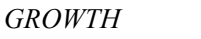 & $\square \square \square$ & $\square \amalg$ & पण口卄 & $\square \square \square$ & 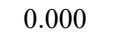 & $\square \square \square$ \\
\hline 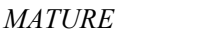 & $\square \square ण \square$ & $\square \square \square$ & 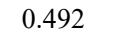 & पणाप & एणा & एणा \\
\hline 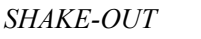 & $\square \square \square$ & $\square \amalg \square$ & 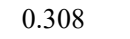 & $\square \square \square$ & 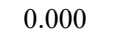 & 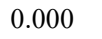 \\
\hline 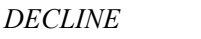 & $\square \square \square$ & 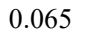 & 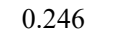 & पण口 & पण口 & $\square \square \square$ \\
\hline प्वपणिए & $\square \square \square$ & एणाम & 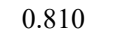 & घण口卄 & एण口冋 & 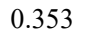 \\
\hline 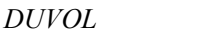 & $\square \square \square$ & एणाए & 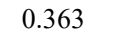 & खणा। & एणाए & $\square \square \square$ \\
\hline 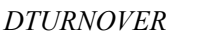 & $\square \square \square \square$ & 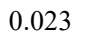 & पणाए & पाणाए & एणाम & $\square \square \square$ \\
\hline$\square \mathbb{\square \square \square}$ & 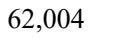 & 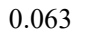 & 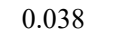 & एणा & पणाए & 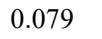 \\
\hline 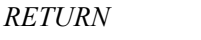 & पाणाप & घणाप & पाणाए & पाणाए & पाणाए & पाणा| \\
\hline 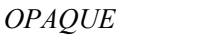 & 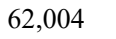 & 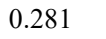 & 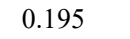 & एणा & पणाए & 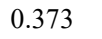 \\
\hline$\square \square \square \square$ & $\square \square \square$ & 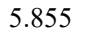 & 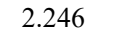 & $\square \square \square$ & 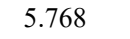 & $\square \square \square$ \\
\hline प्व० & $\square \square \square \square$ & $\square \square \square$ & 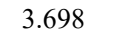 & पणाए & पणाए & पण口 \\
\hline$\square \square \square \square$ & 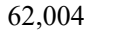 & पामा & पणाए & पामा & पामा & पामा \\
\hline प्र०० & $\square \square \square$ & 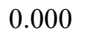 & 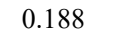 & पाणा & $\square \amalg$ & 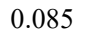 \\
\hline पापिए & $\square \square \square$ & 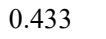 & पण口 & पणा & एणाए & 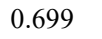 \\
\hline 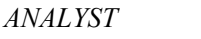 & $\square \square \square \square$ & पामा & पामा & पणाप & पाएम & 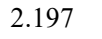 \\
\hline 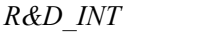 & पामाप & पामा & पामा & पणाए & पामा & पामा \\
\hline 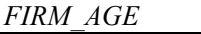 & $\square\|\Pi\| \square$ & $\square \square \| \square$ & 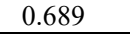 & 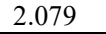 & 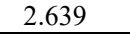 & 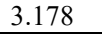 \\
\hline
\end{tabular}

Panel B: Firm Characteristics by Life Cycle Stages

\begin{tabular}{|c|c|c|c|c|c|c|c|c|c|c|c|}
\hline 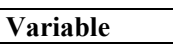 & प्माणा। & II & 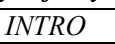 & $\mathbb{I}$ & 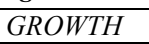 & $\mathbb{I}$ & 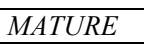 & $\mathbb{I I}$ & 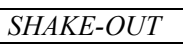 & $\mathbb{I}$ & 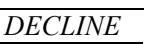 \\
\hline 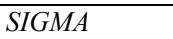 & 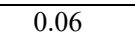 & $\square$ & 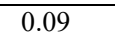 & $\square$ & 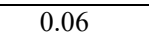 & $\square$ & 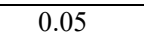 & & 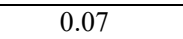 & 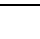 & 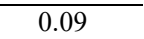 \\
\hline$\square \mathbb{\square \square} \square$ & पण口 & $\sqcap$ & $\square \mathrm{पाए}$ & $\square$ & पणा & $\sqcap$ & 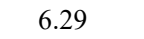 & $\sqcap$ & 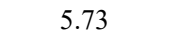 & $\sqcap$ & $\square ण 1$ \\
\hline$\square \square \square$ & पणा & $\square$ & $\square \mathrm{पाप}$ & 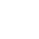 & पणा & $\sqcap$ & 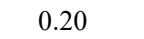 & & 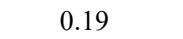 & 1 & पणा \\
\hline$\square \square \square \square$ & पण口 & $\sqcap$ & $\square \amalg \square$ & $\sqcap$ & 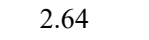 & $\sqcap$ & 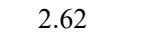 & $\sqcap$ & $\square \square \square$ & $\Pi$ & $\square \square \square$ \\
\hline प्म० & पणा & $\square$ & पाए। & П & पाए & $\square$ & पाण & & 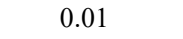 & 7 & पाण \\
\hline 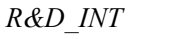 & पाण & $\sqcap$ & पापा & $\sqcap$ & 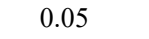 & $\sqcap$ & 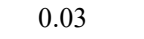 & $\sqcap$ & 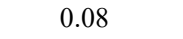 & $\sqcap$ & $\square \square \square$ \\
\hline 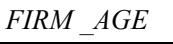 & $\square \square$ & $\square$ & $\square ण 1$ & $\square$ & $\square[1$ & $\Pi$ & 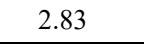 & $\sqcap$ & $\begin{array}{lll}101 \\
\end{array}$ & $\square$ & 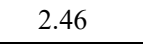 \\
\hline 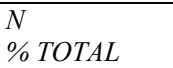 & 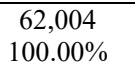 & $\sqcap$ & 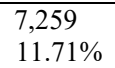 & $\sqcap$ & 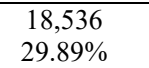 & $\sqcap$ & $\begin{array}{l}\square \mid ⿴ 囗 十 ~ \\
\square \square \square \square \square\end{array}$ & $\square$ & $\begin{array}{l}\square \square \square \\
\square \square \square \square\end{array}$ & $\sqcap$ & $\begin{array}{l}\square|\square| \\
\square \square \square \square\end{array}$ \\
\hline
\end{tabular}

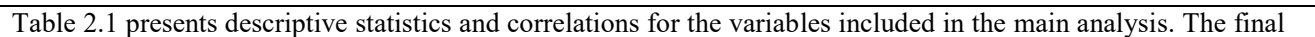

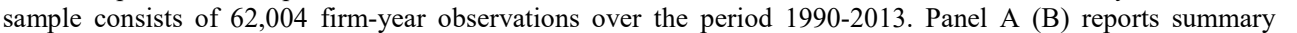

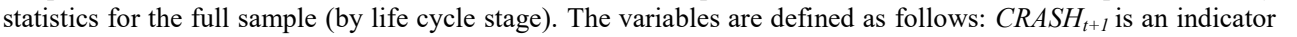

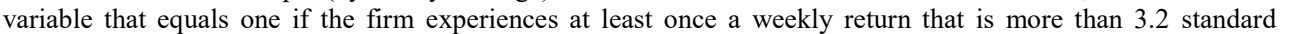

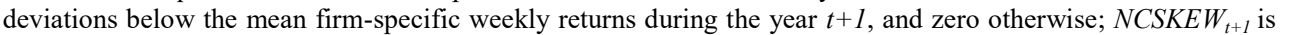

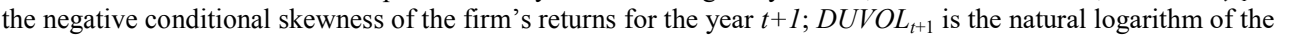
प

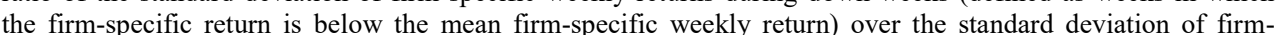

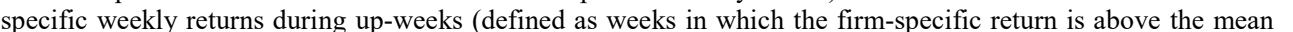

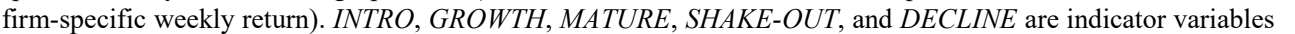
that equal one if the firm is in the particular life cycle stage based on Dickinson's (2011) life cycle stage

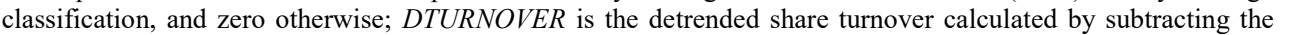
firm's sh

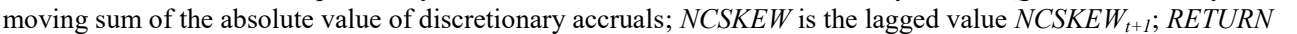

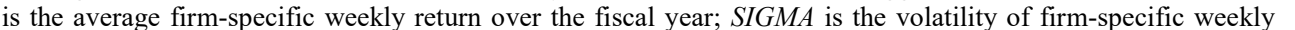

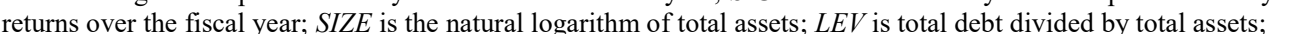




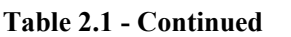

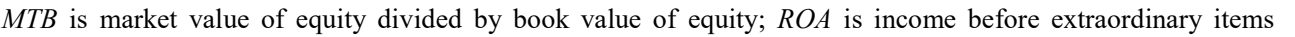

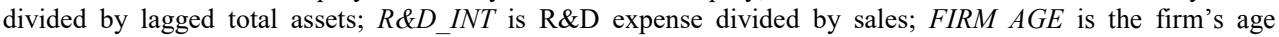

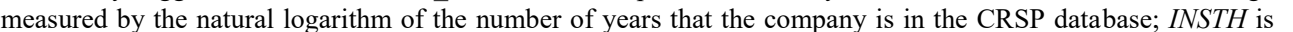

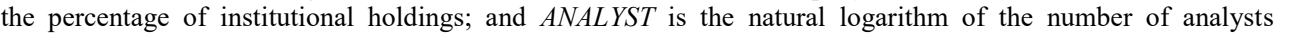

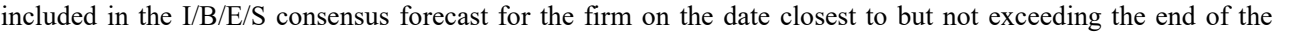

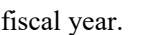

$\square$

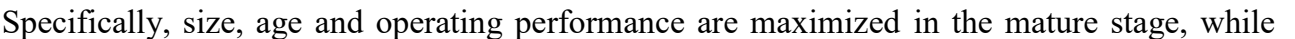
the volatility of firms' stock prices is at its minimum during this stage. These patterns can be

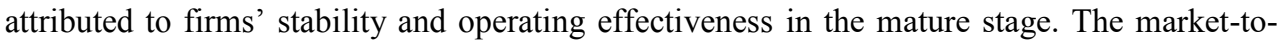

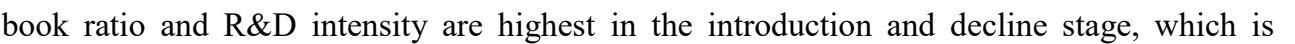

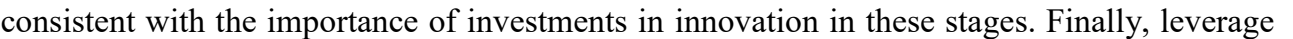

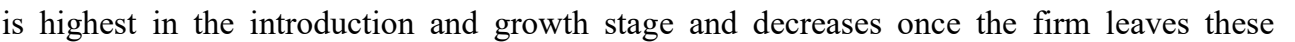

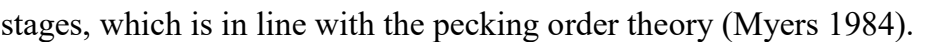
$\square$

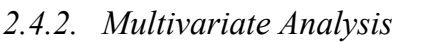

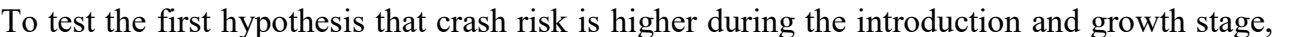

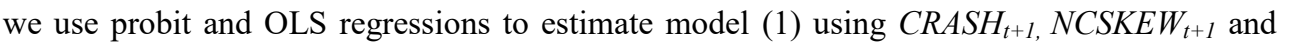

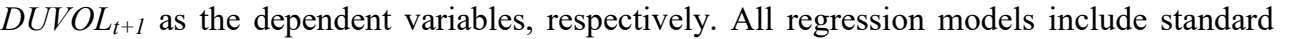

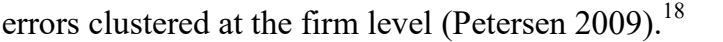

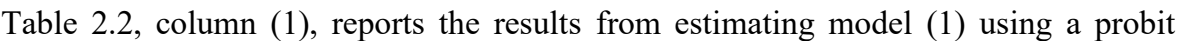

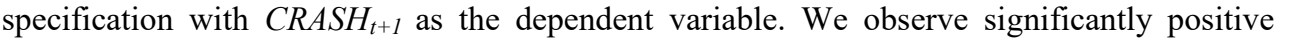

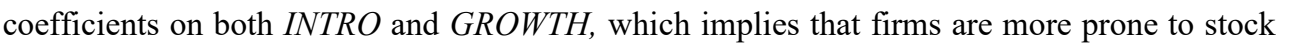

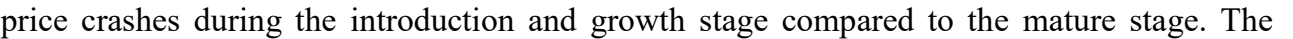

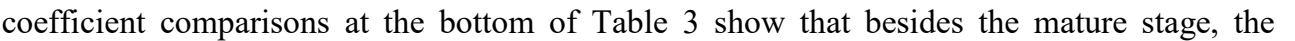

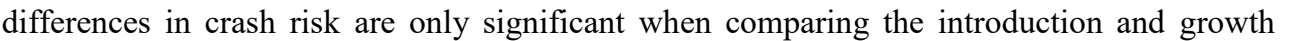

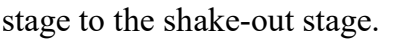

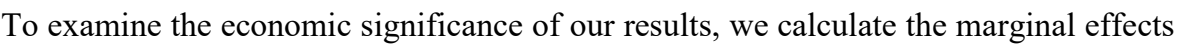

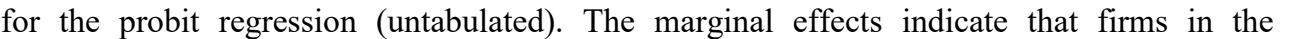

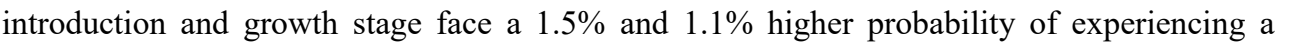

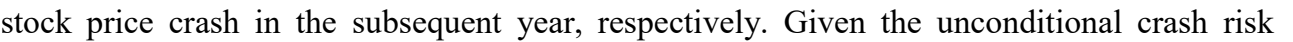

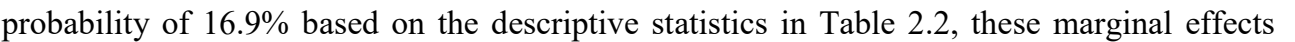

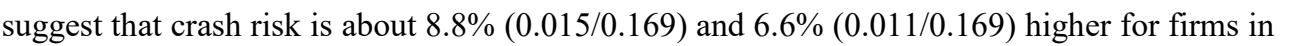
प ए

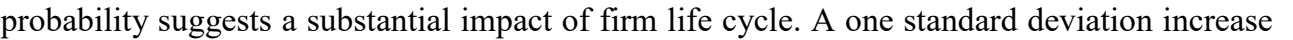

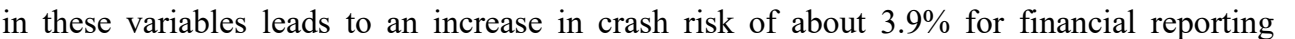

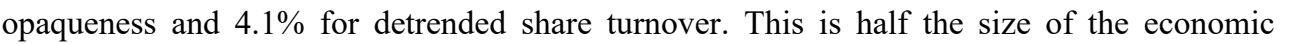

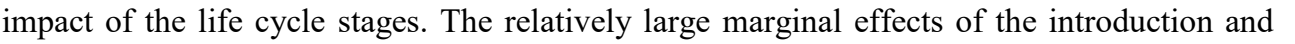

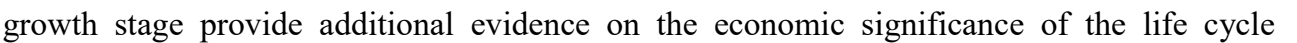
एणाएापा

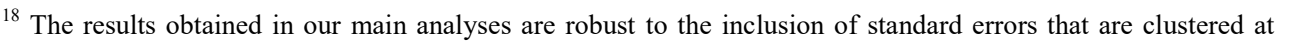

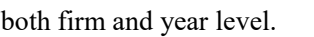




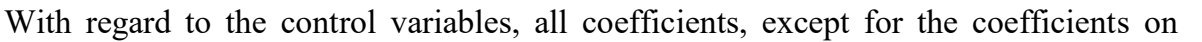

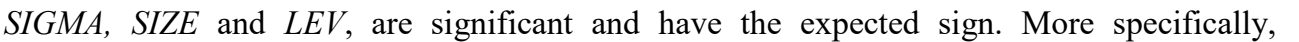

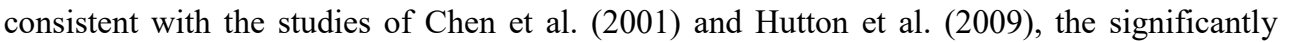

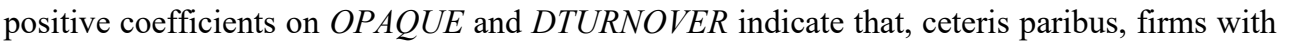

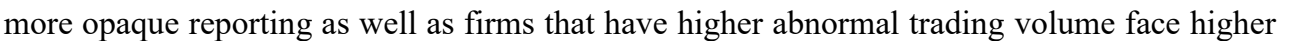

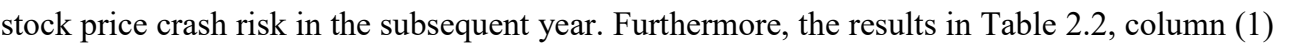

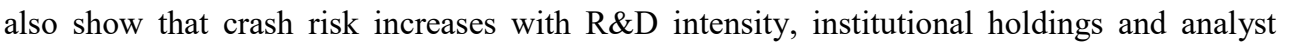

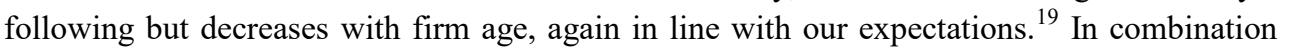

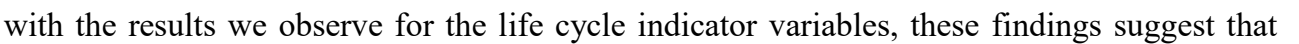

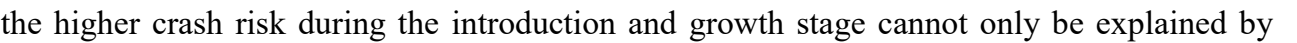
firms's substantial investments in R\&D

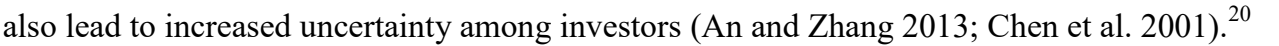

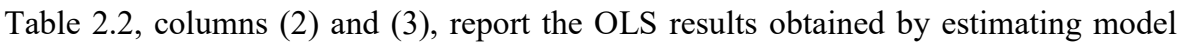

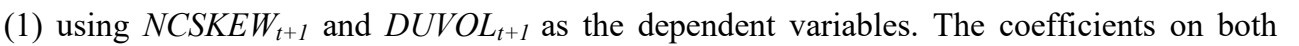

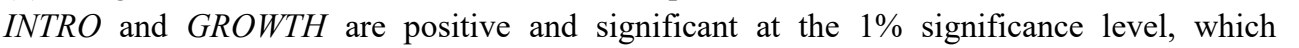

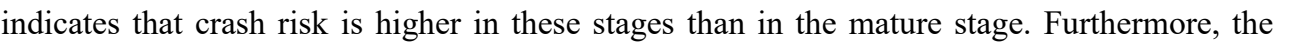

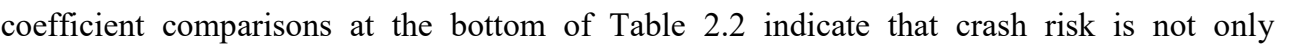

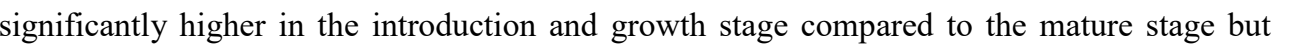

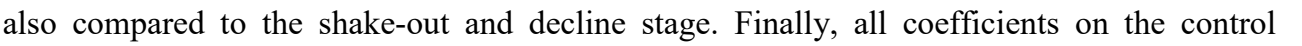

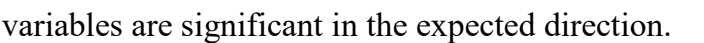

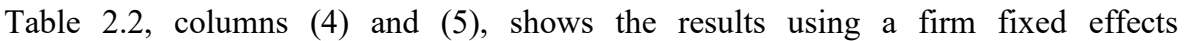

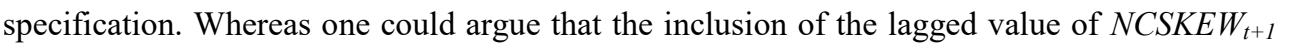

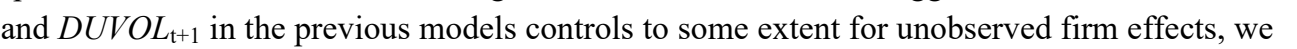

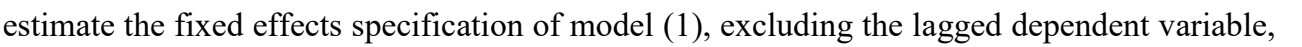

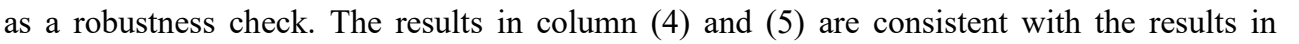

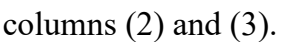

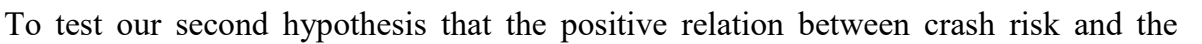

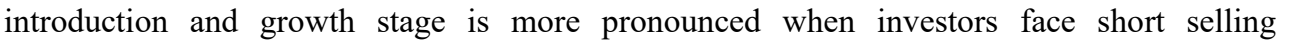

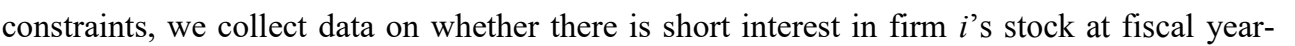
end. We obtain data on short interest from Compustat's Supplemental Short Interest File. We

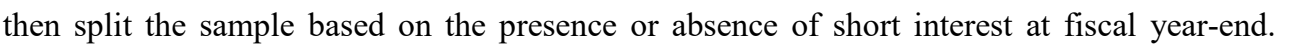

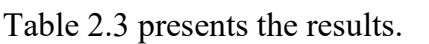

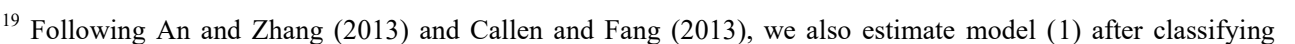

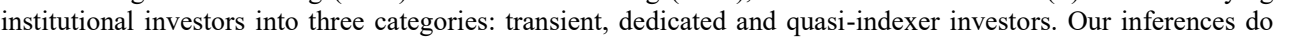

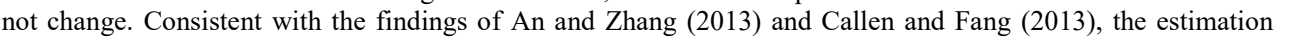
ए एव

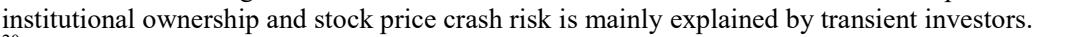

एBy using Dickinson's (2011) life cycle classification it

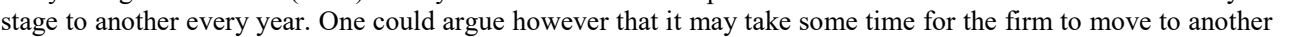

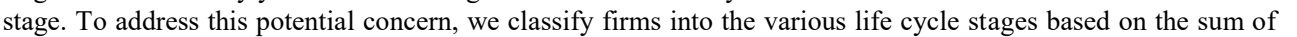

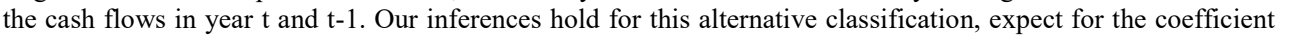

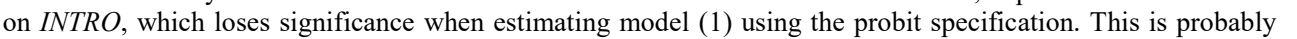

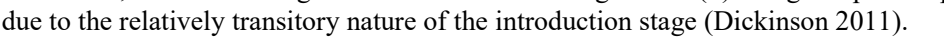




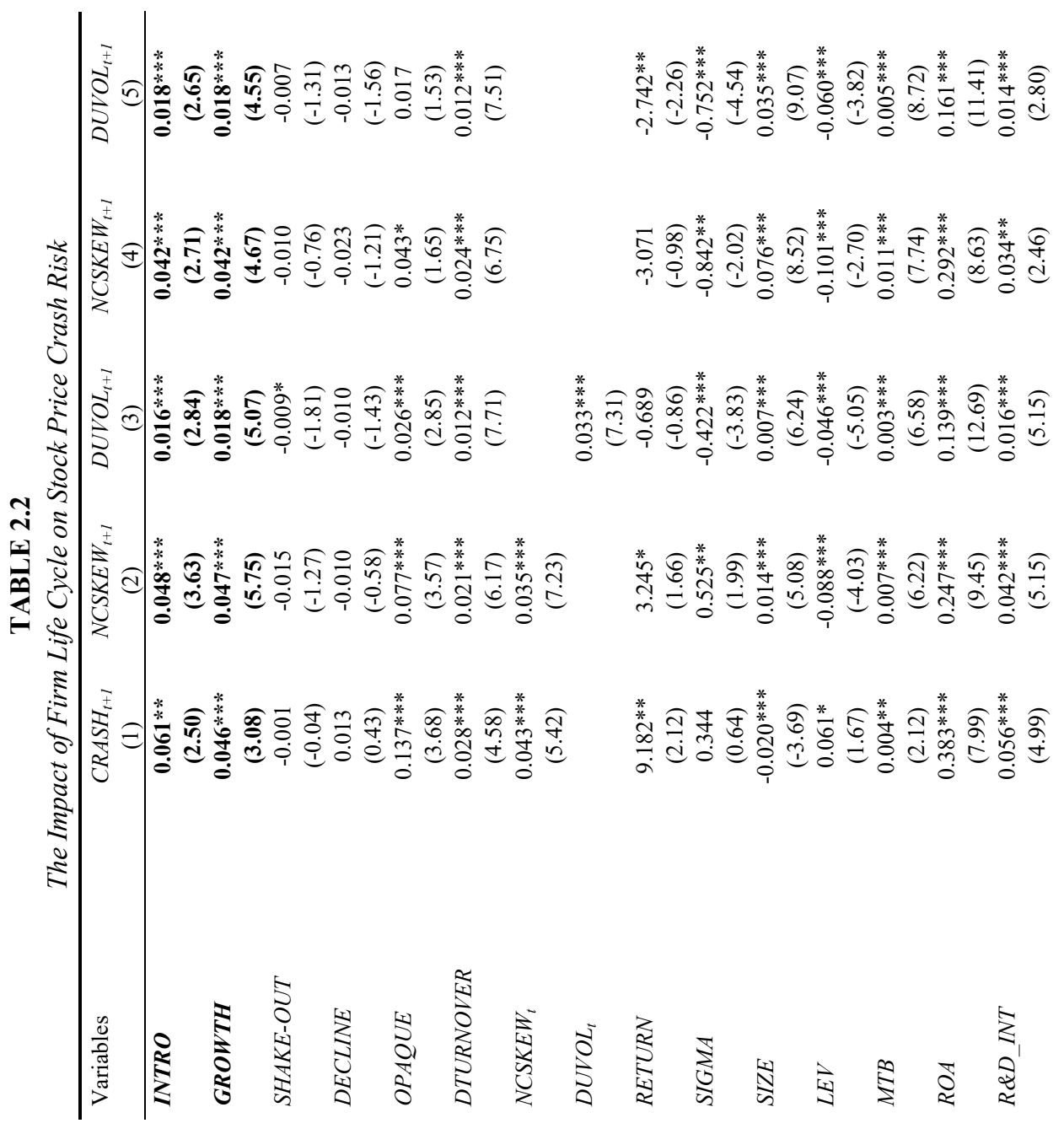




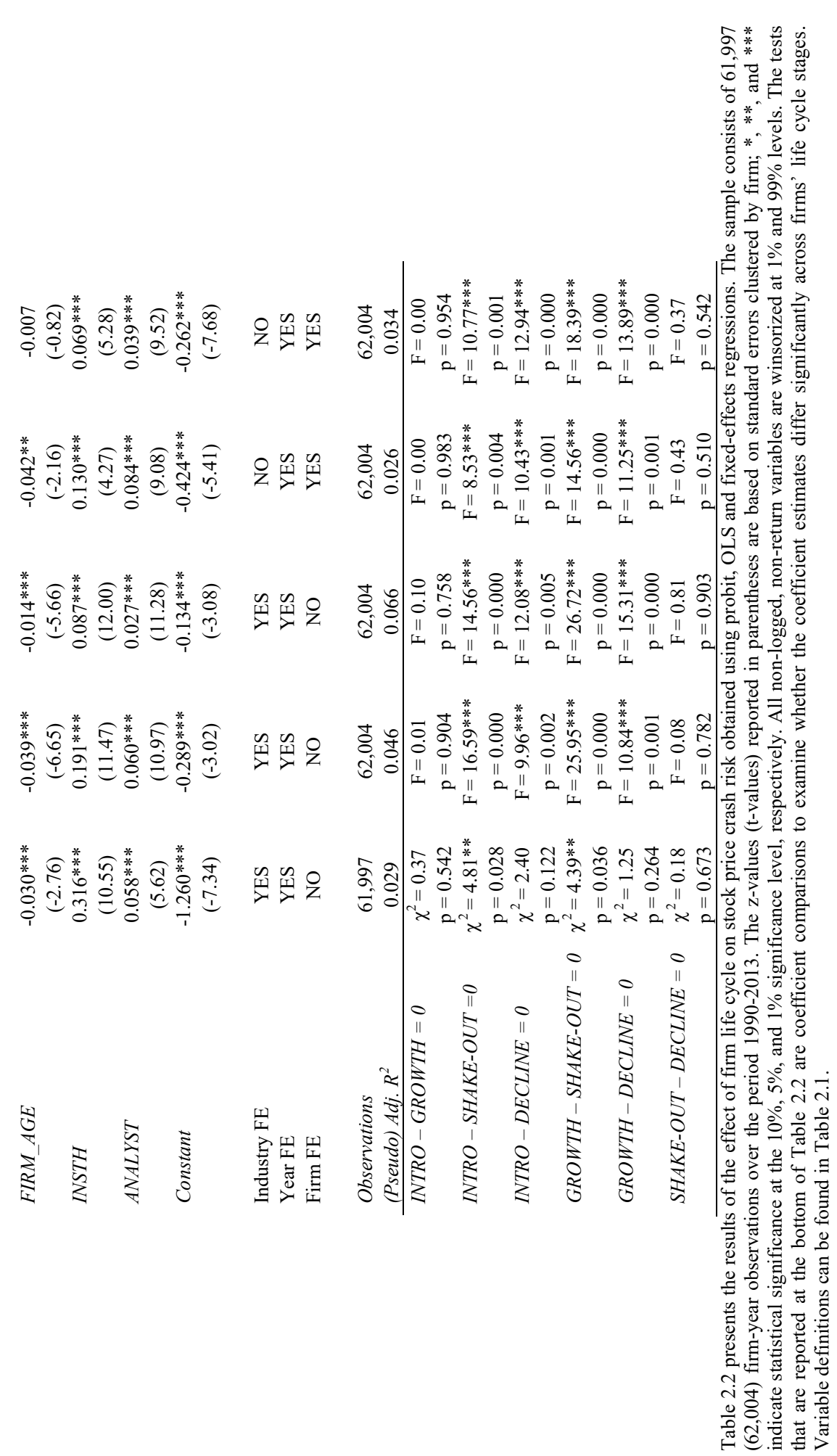




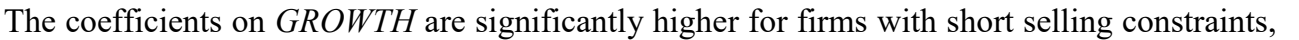

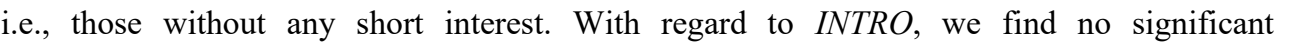

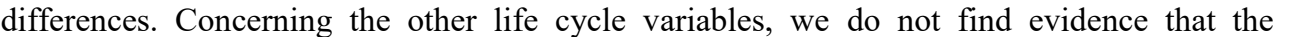

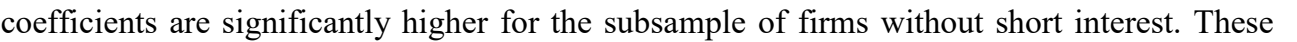
ए

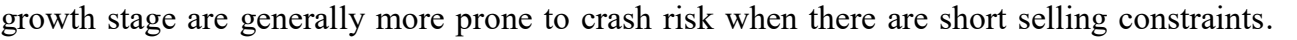

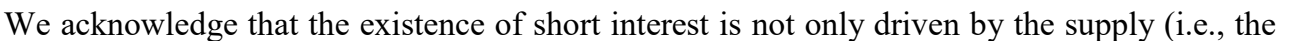

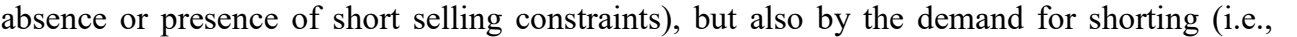
ए ए।

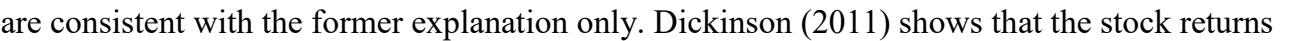

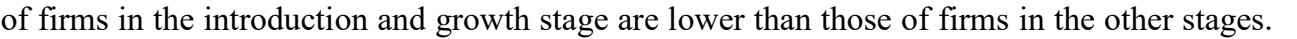

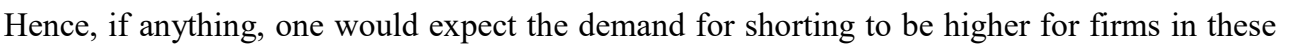

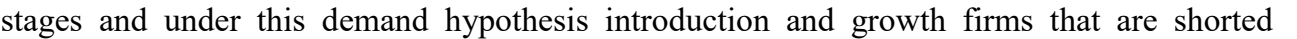

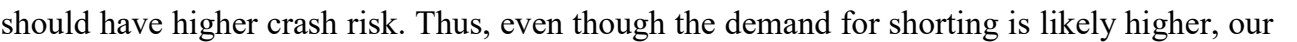

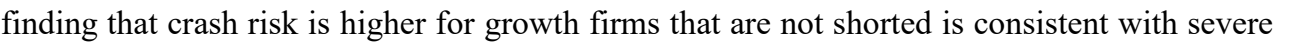

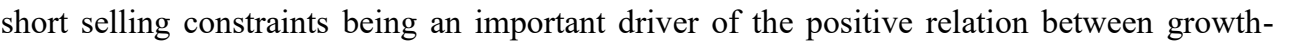

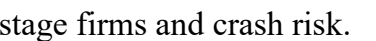

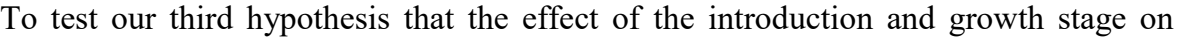

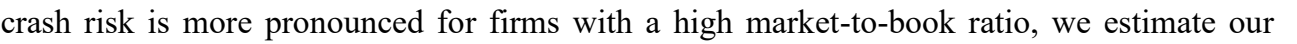

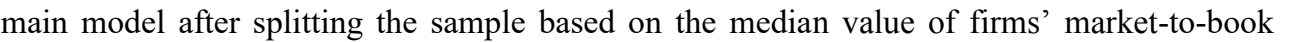

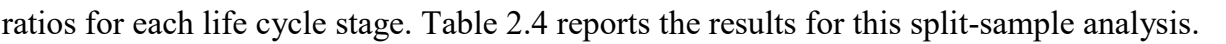

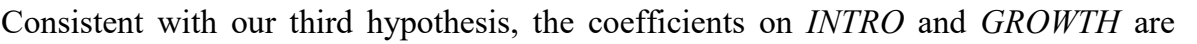

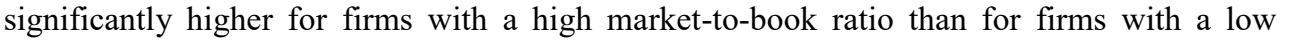

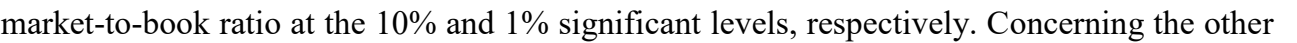

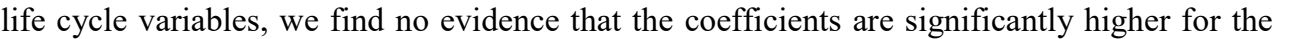

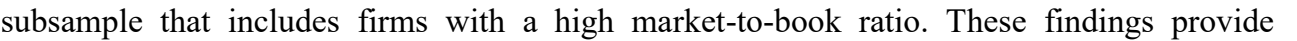

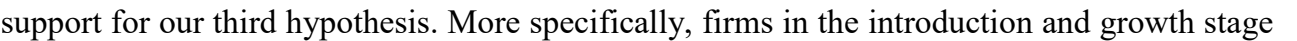

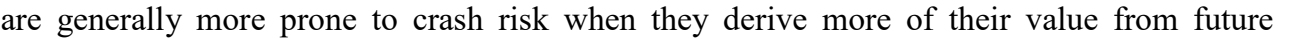

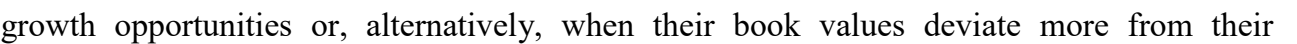
एणापणाणाप 


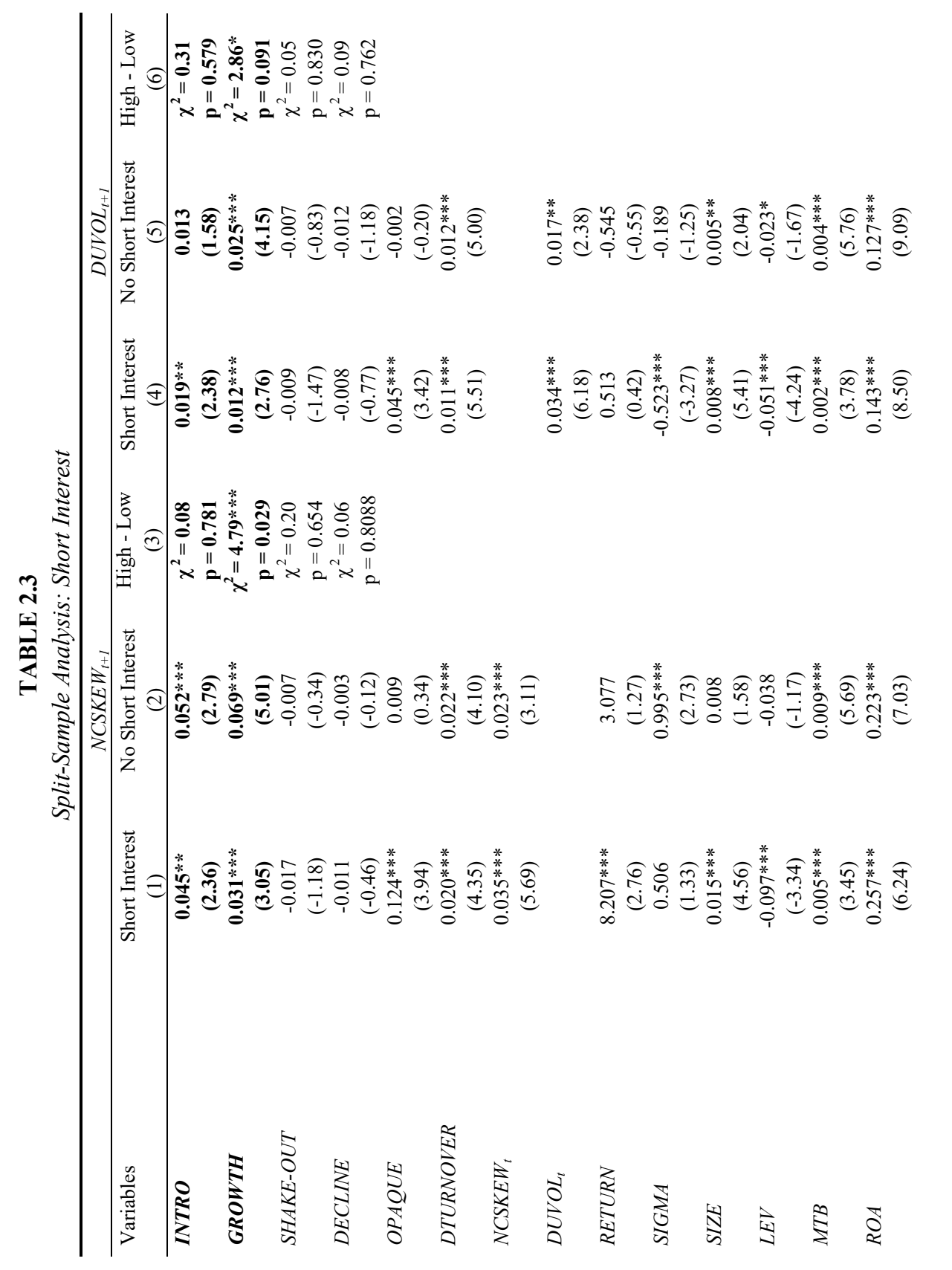




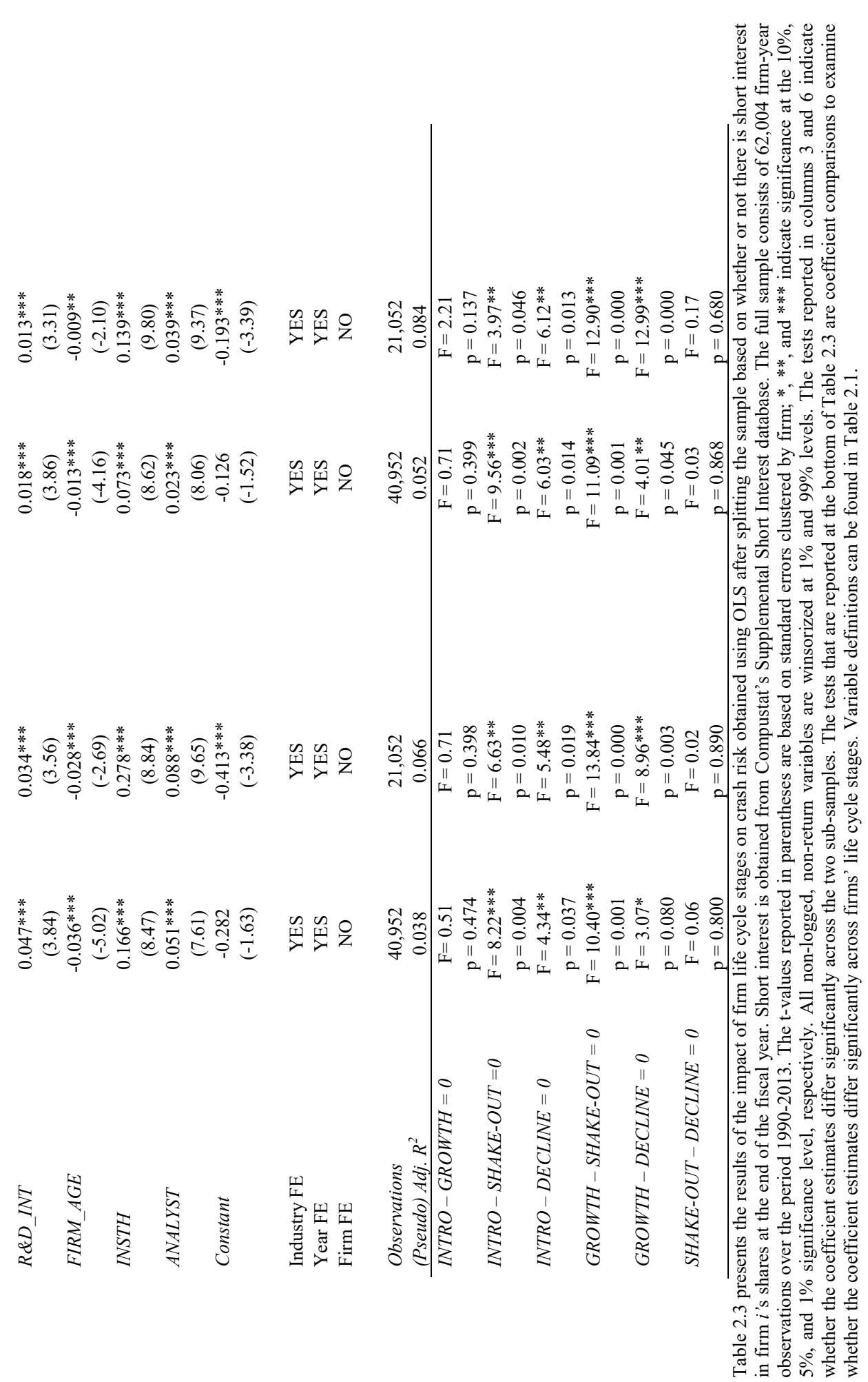




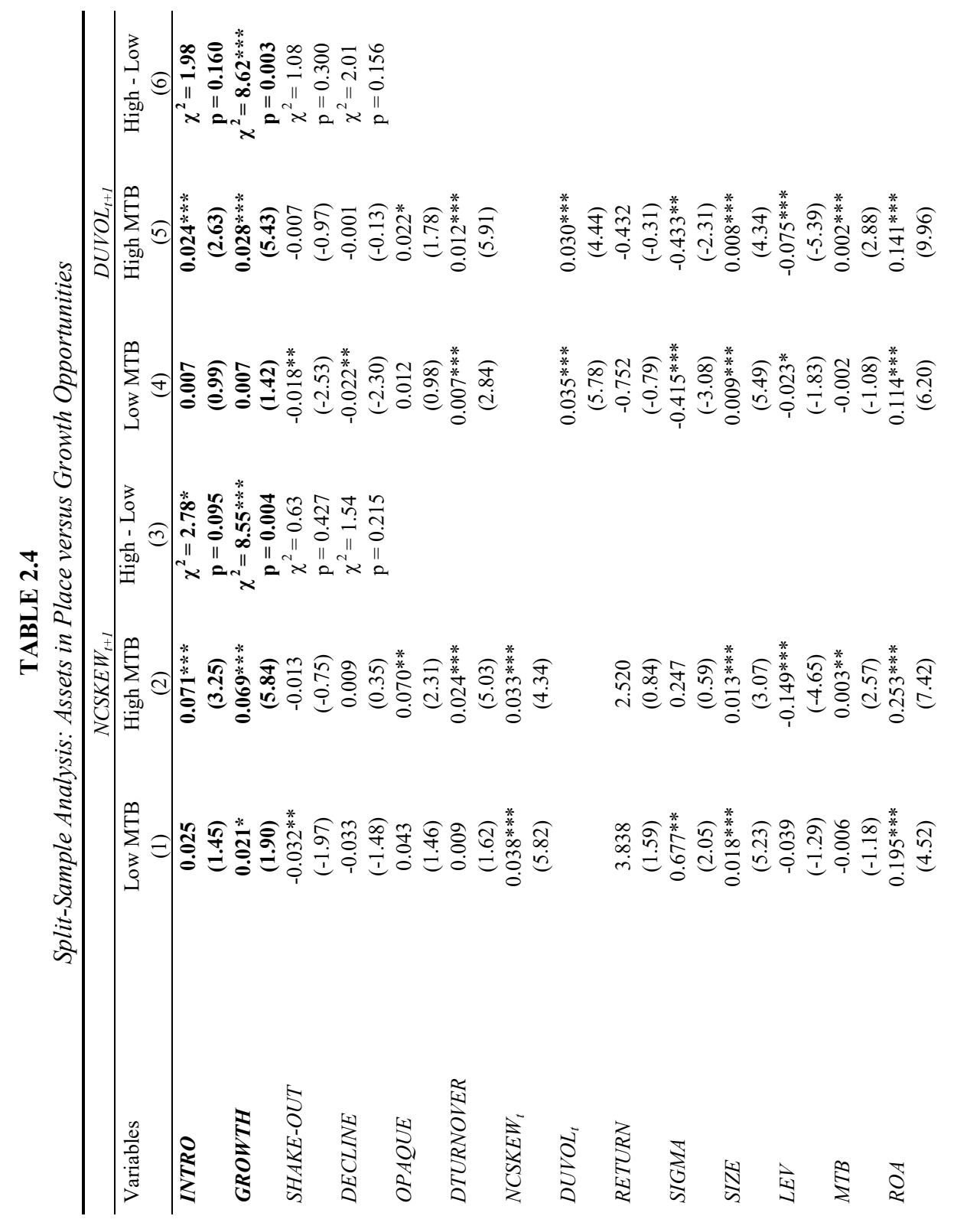




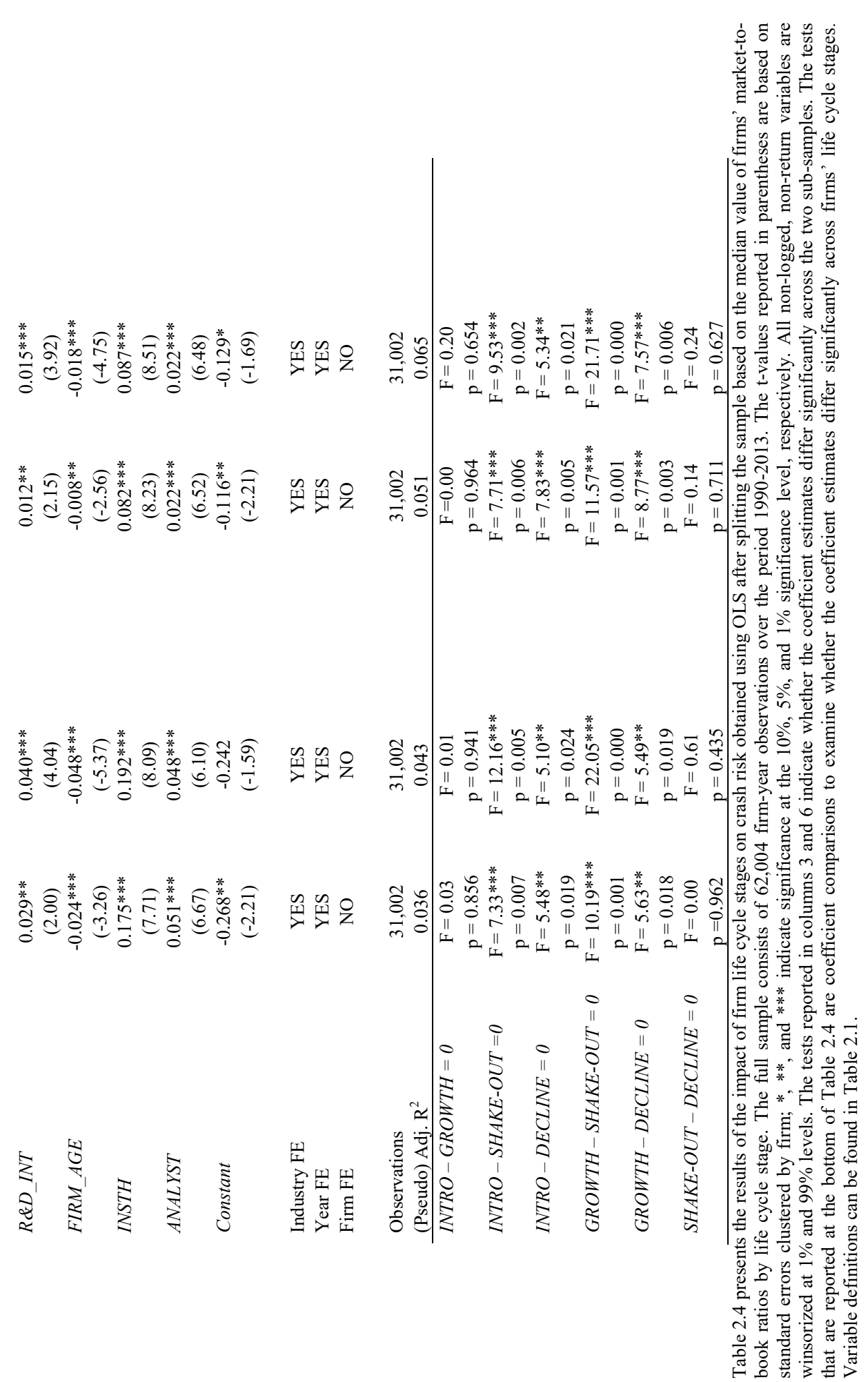




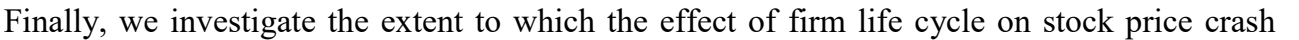
ए

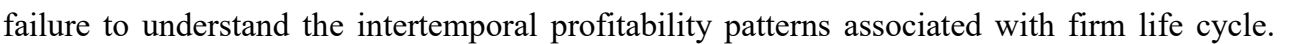

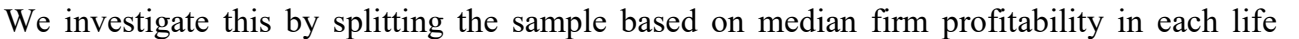

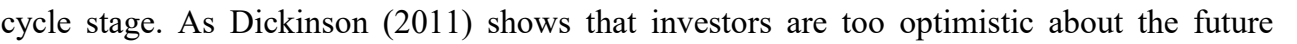

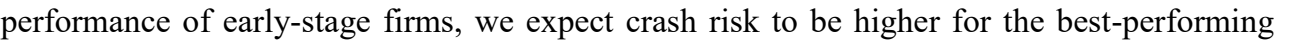

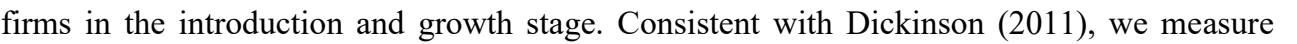

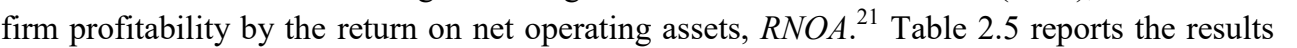

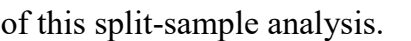

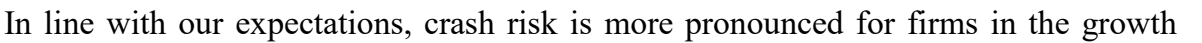

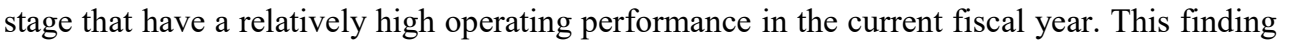

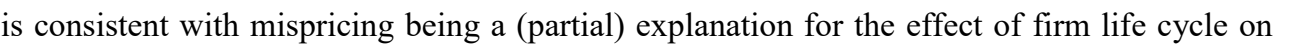
ए

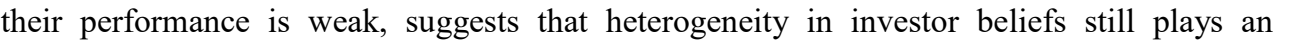

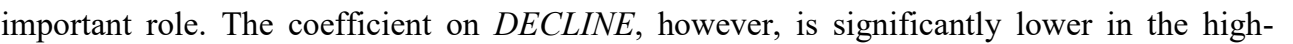

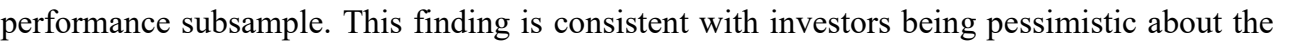
ए एव

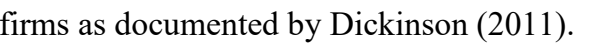

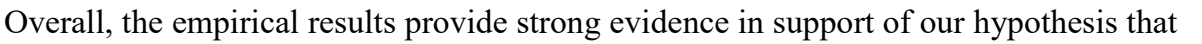

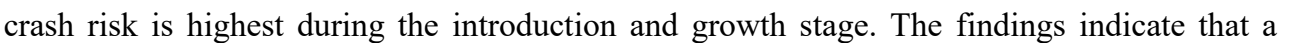

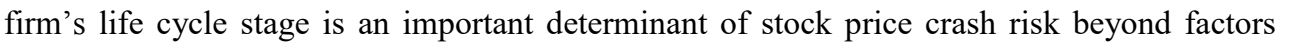

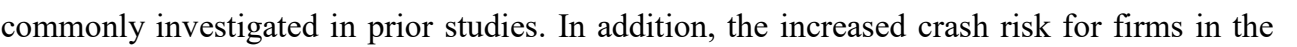

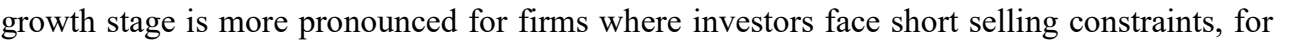

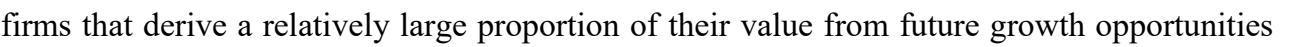

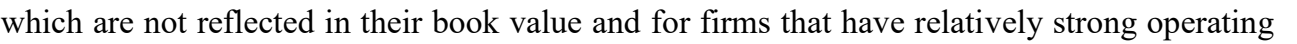

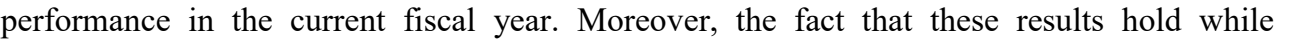
पा

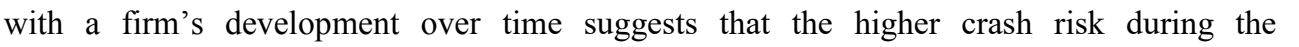

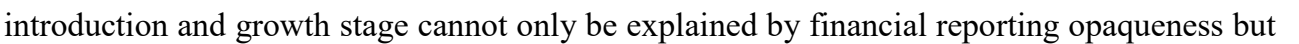

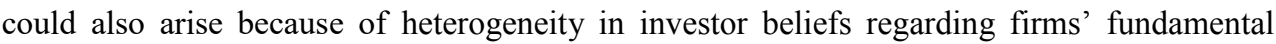

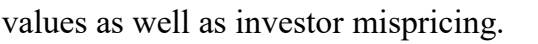
$\square$

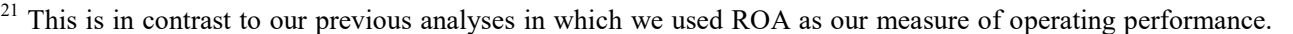

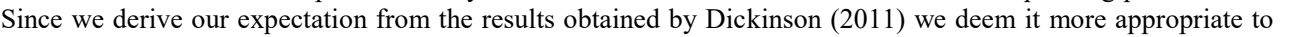

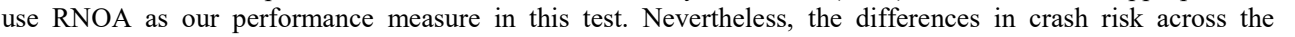

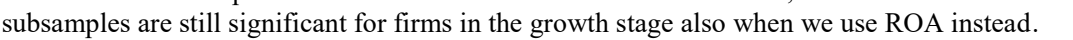




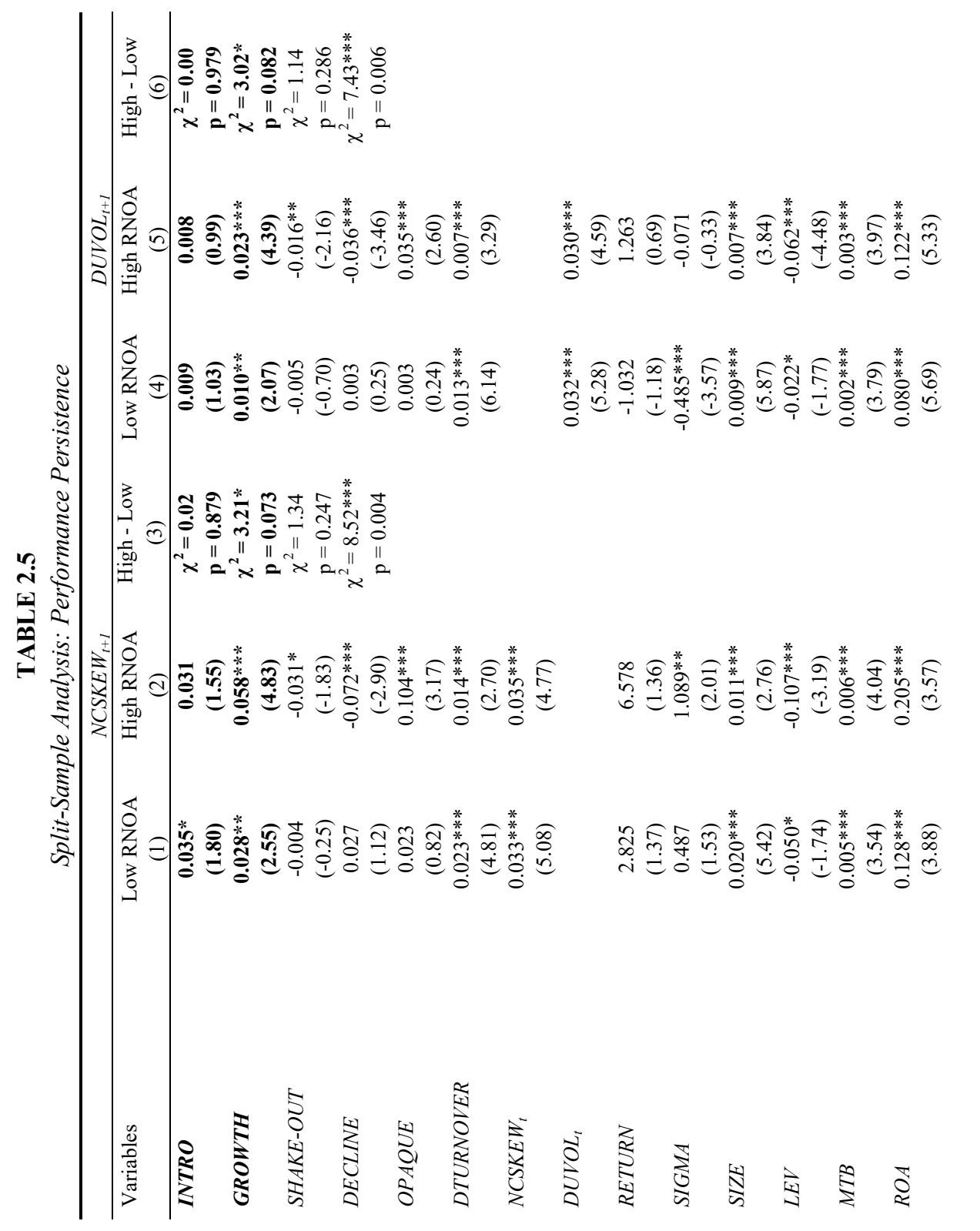




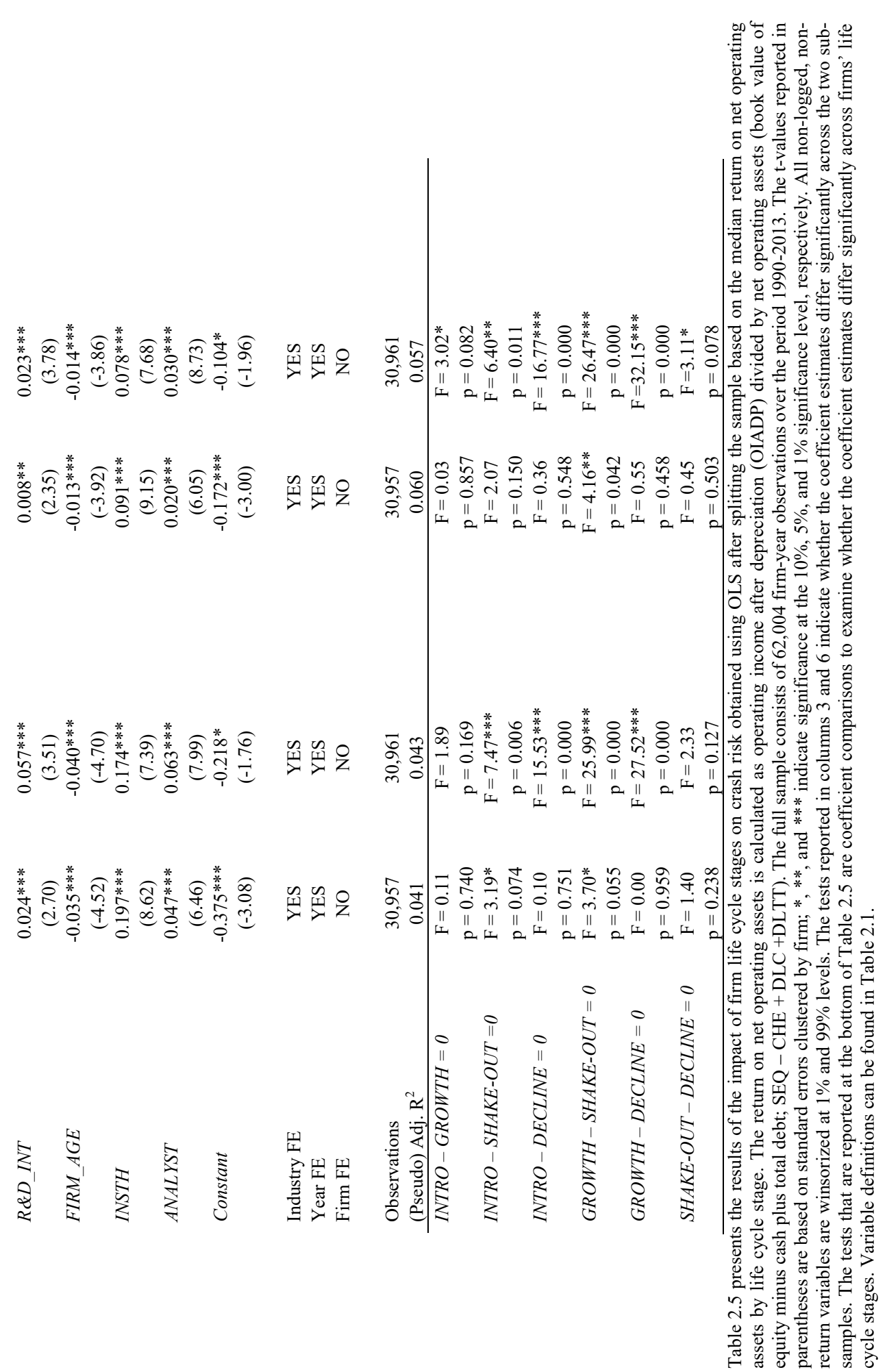


$\square$

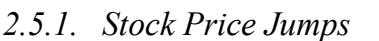

Heterogeneity in investor beliefs and investors' overoptimism

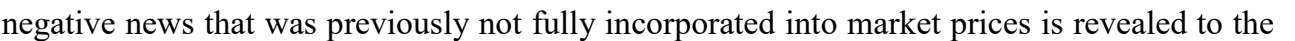

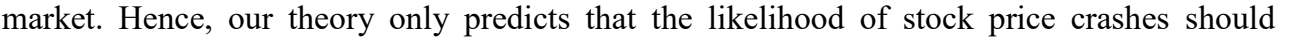

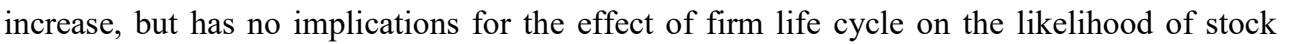

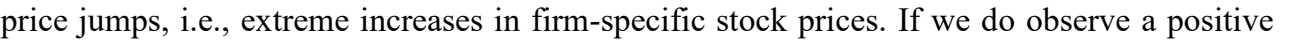

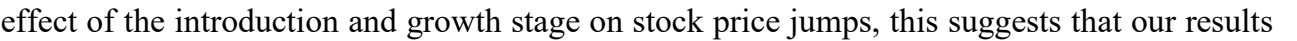

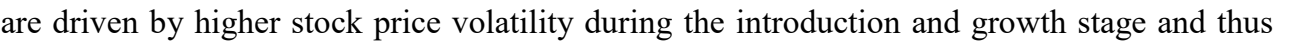

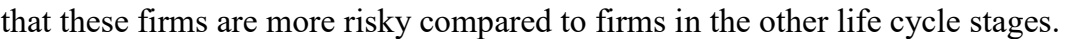

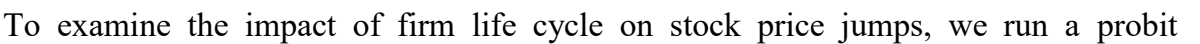

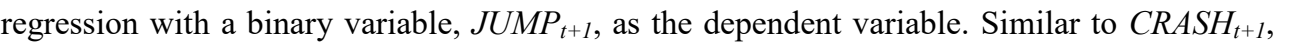

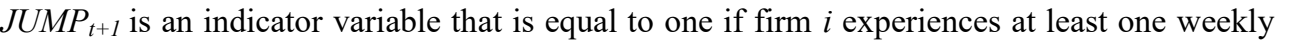

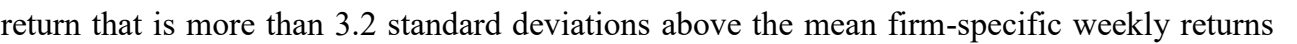

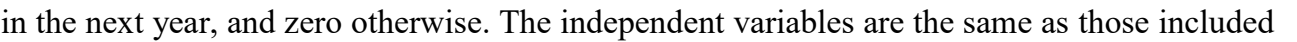

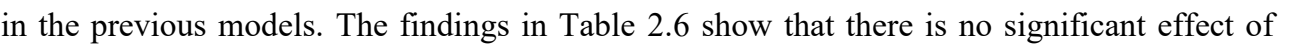

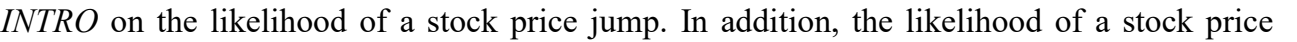

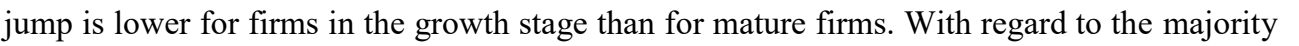

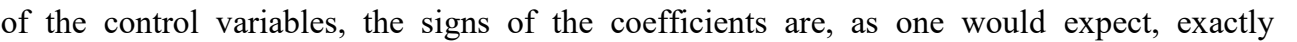

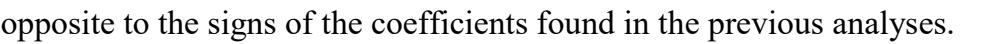
$\square$

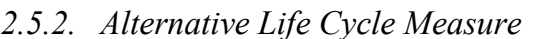

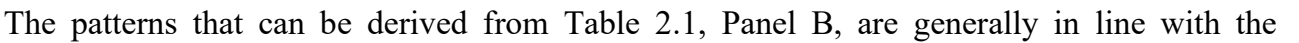

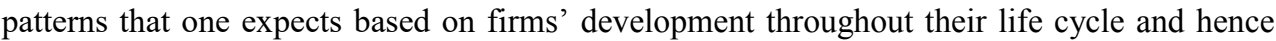
provide support for using Dickinson's (2011) approach to classify firms into the various life $\square \Pi$ stages. However, since Dickinson's (2011) approach is based on cash flows, a potential

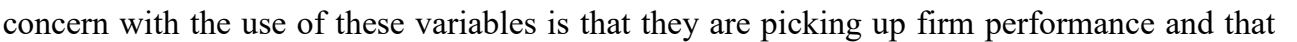
प एव

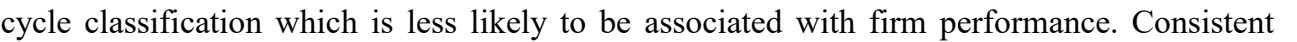

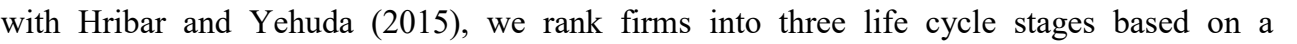

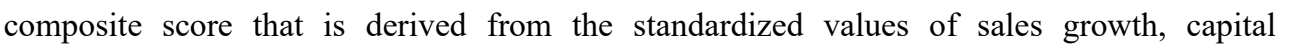

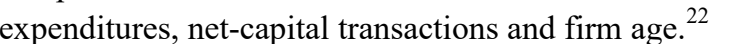

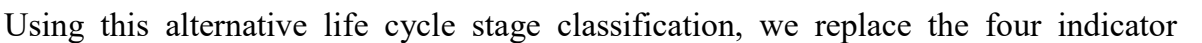

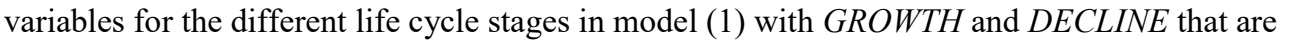

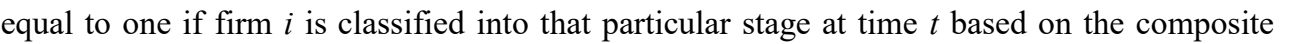

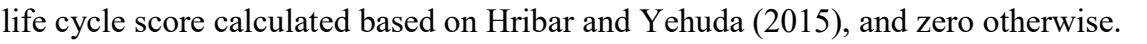
$\square$

$\square$

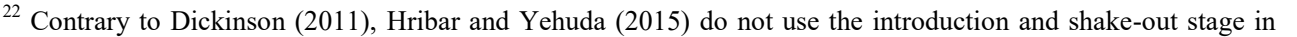

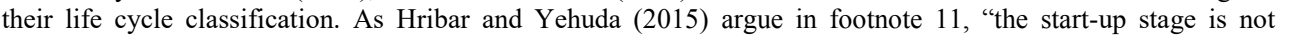

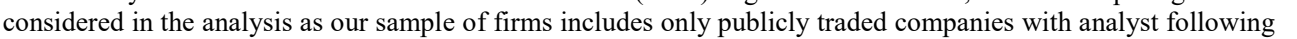

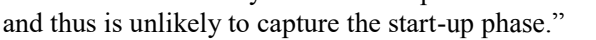




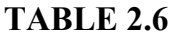

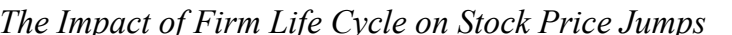

\begin{tabular}{|c|c|}
\hline पणमाणाप & $\square \square \square \operatorname{ma}$ \\
\hline \multirow[t]{2}{*}{ INTRO $\square$} & 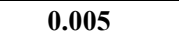 \\
\hline & पणाए \\
\hline \multirow[t]{2}{*}{ GROWTH $\square$} & एपायाए \\
\hline & पण口णाप \\
\hline 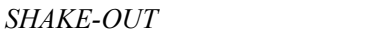 & $\square ण \square$ \\
\hline$\square$ & पाणाए \\
\hline 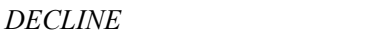 & पणापए \\
\hline$\square$ & पाणाए \\
\hline \multirow[t]{2}{*}{ 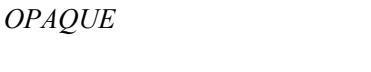 } & पाणामा \\
\hline & पाणाएा \\
\hline \multirow[t]{2}{*}{ 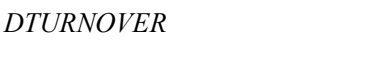 } & पाणामा \\
\hline & पण口णाप \\
\hline \multirow[t]{2}{*}{ 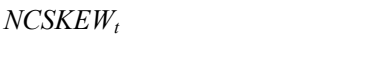 } & पणामाप \\
\hline & एणाणाए \\
\hline \multirow[t]{2}{*}{ 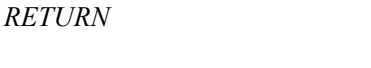 } & पाणाए \\
\hline & 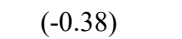 \\
\hline \multirow[t]{2}{*}{$\square \square \square \square \square$} & पणाए \\
\hline & पणाए \\
\hline \multirow[t]{2}{*}{$\square[\square \square$} & पाणाया \\
\hline & पण口卄ाण \\
\hline \multirow[t]{2}{*}{$\square \square \square \square$} & पालापा \\
\hline & पाणाए \\
\hline \multirow[t]{2}{*}{$\square \square \square \square$} & एणापाए \\
\hline & एणा।ण \\
\hline \multirow[t]{2}{*}{ प्व० } & पामापा \\
\hline & एणाएा \\
\hline 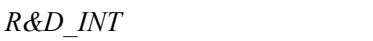 & एवाए \\
\hline$\square$ & पणाणाए \\
\hline 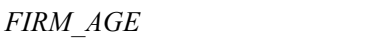 & पणामा \\
\hline$\square$ & एणाए \\
\hline 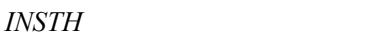 & एणामाए \\
\hline$\square$ & एणाएा \\
\hline \multirow[t]{2}{*}{ 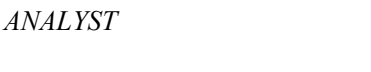 } & पापाया \\
\hline & पण口卄ाप \\
\hline पणापाण & एायाता \\
\hline$\square$ & पण口卄ाण \\
\hline$\square$ & $\square$ \\
\hline 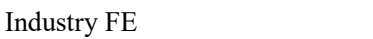 & 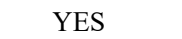 \\
\hline 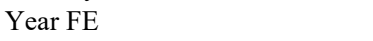 & प्वप्र \\
\hline 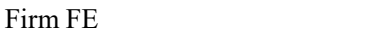 & $\square \square \square$ \\
\hline$\square$ & $\square$ \\
\hline 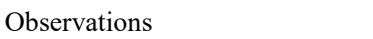 & पामा \\
\hline 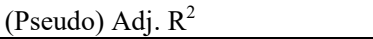 & 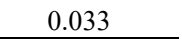 \\
\hline 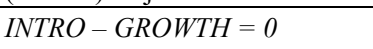 & $\chi^{\mathbb{\square} \square \square \square ा म ा प ~}$ \\
\hline$\square$ & पापाणापा \\
\hline 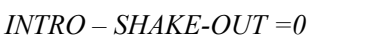 & $\chi^{\square \square \square म ~}$ \\
\hline$\square$ & 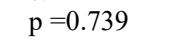 \\
\hline 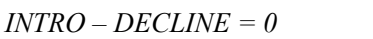 & $\chi^{\square \square} \square\|\| \| \square$ \\
\hline$\square$ & 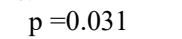 \\
\hline 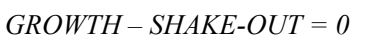 & 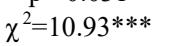 \\
\hline$\square$ & 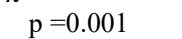 \\
\hline
\end{tabular}




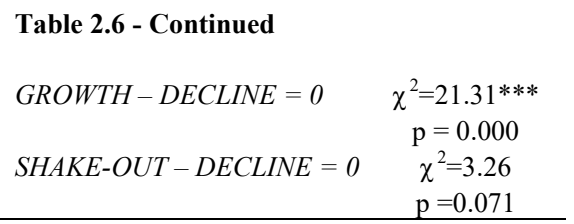

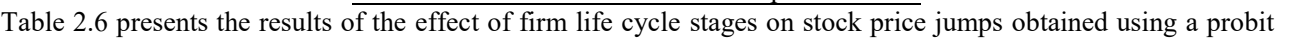

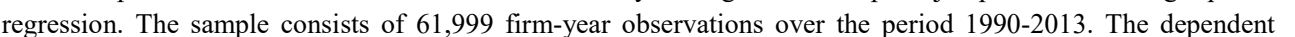

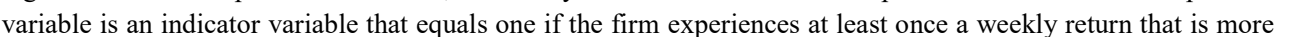

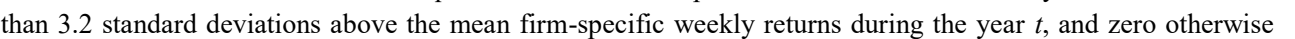

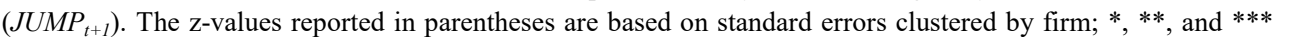

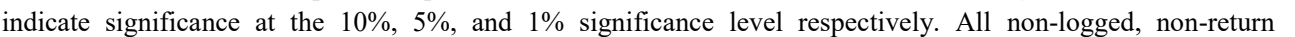

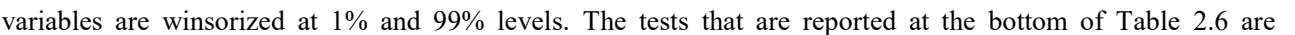
coefficient comparisons to examine whether the coefficient estimates differ significantly across firms' life cycle

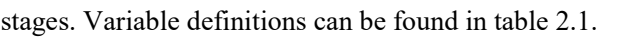

$\square$

$\square$

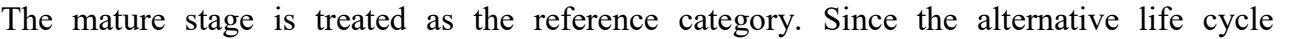

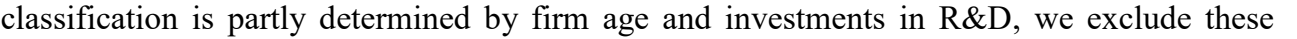

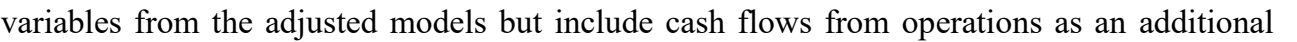

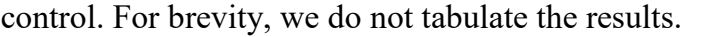

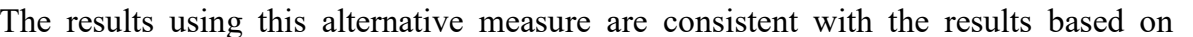

Dickinson's (2011) life cycle classification. Specifically, crash risk is highest during the

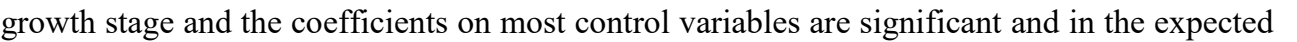

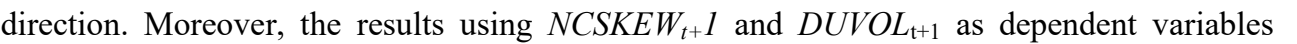

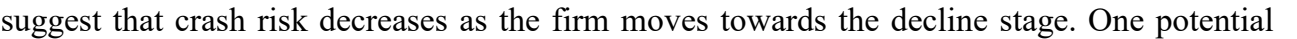

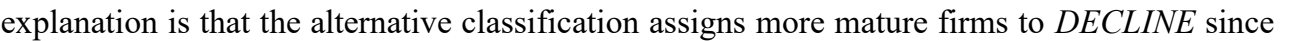

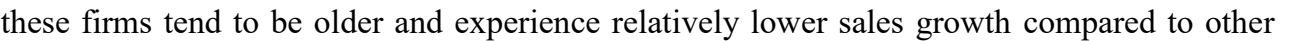

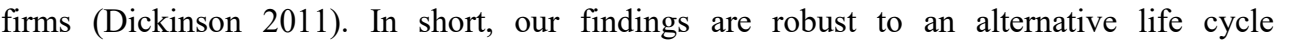

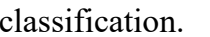

$\square$

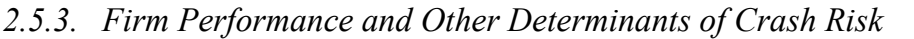

Since Dickinson's (2011) life cycle classification is based on cash flow patterns, $\square \mid\|\| \| \square \square \square$

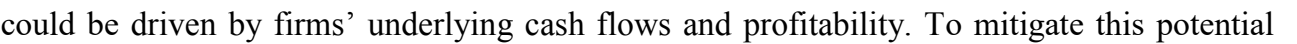

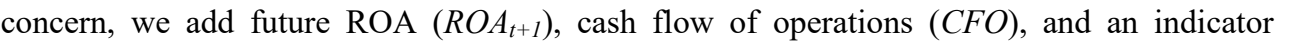

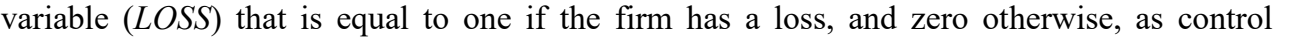

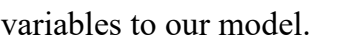

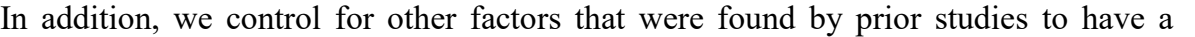

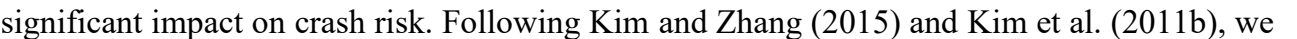

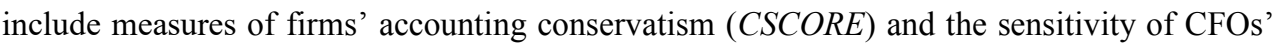

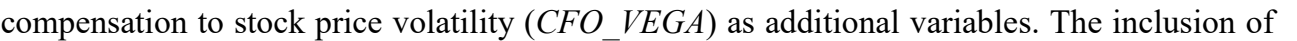

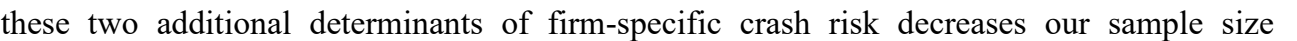

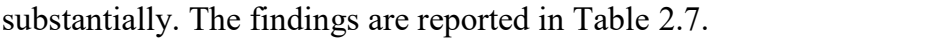
$\square$ 


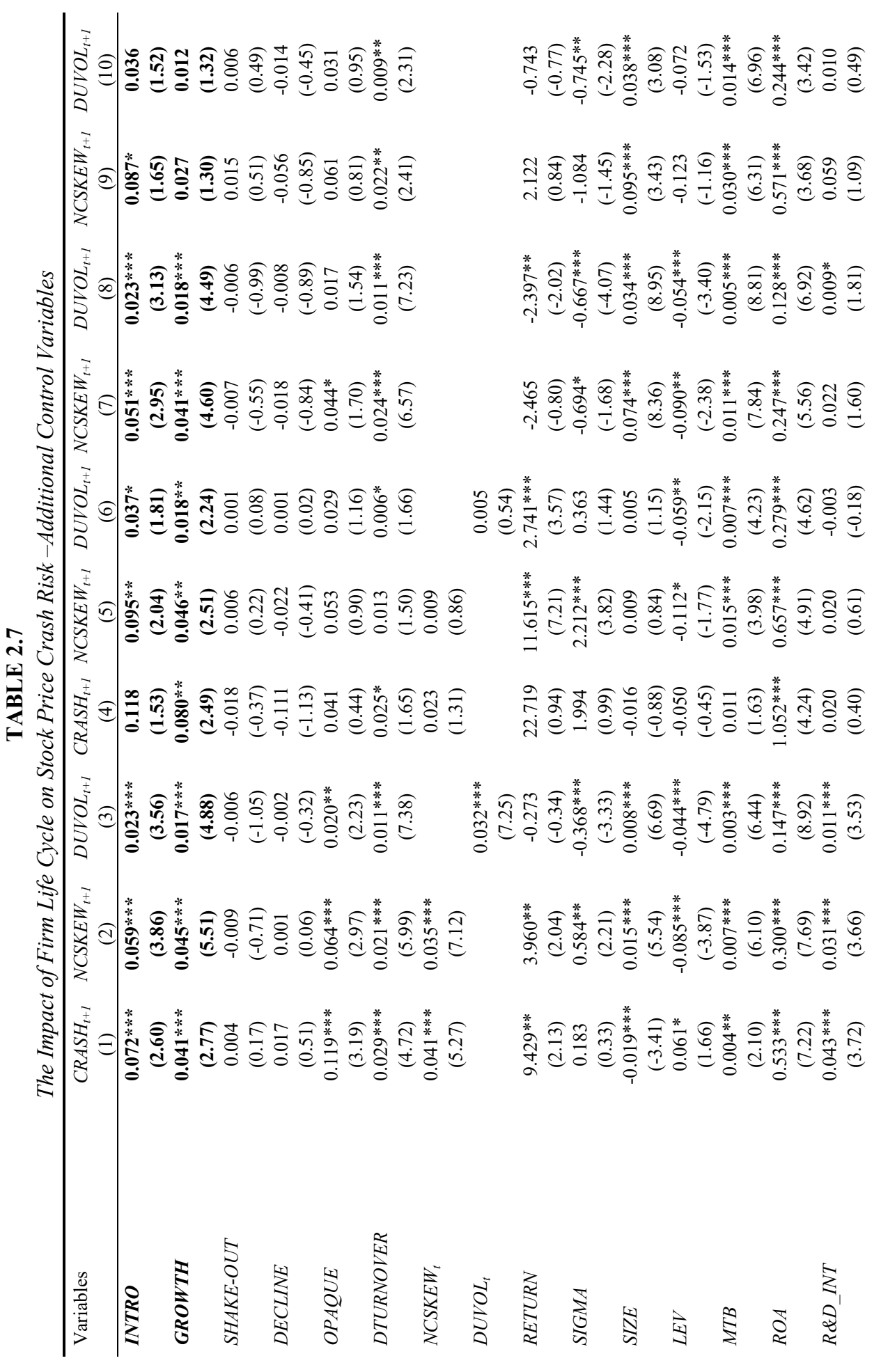




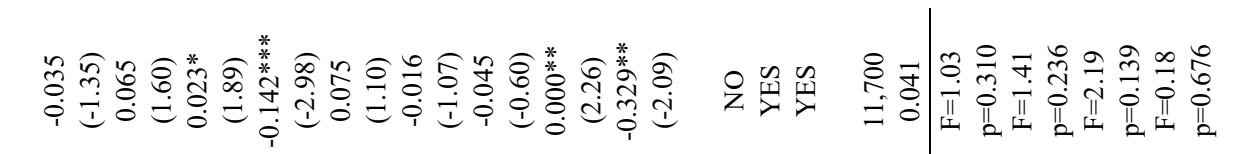

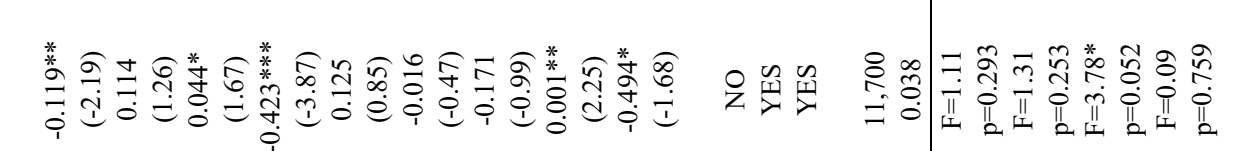

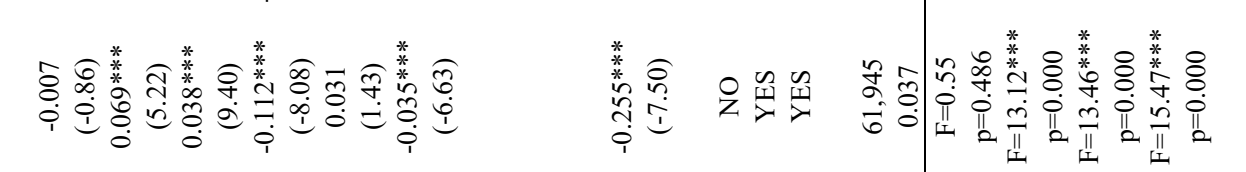

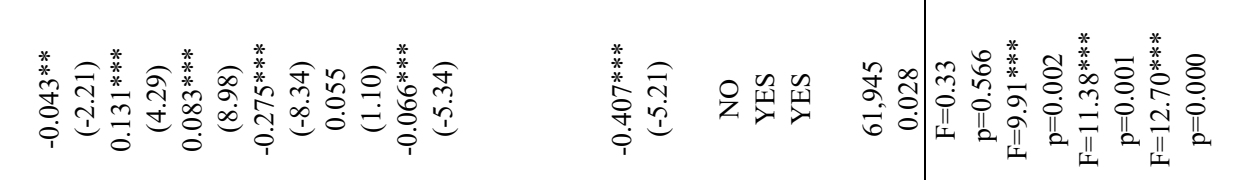

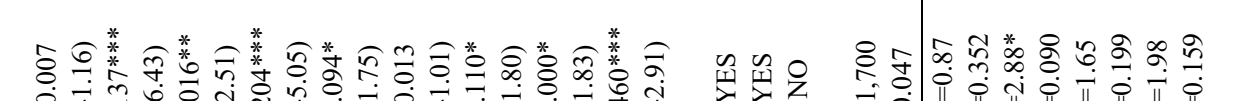

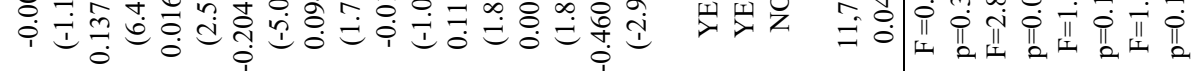

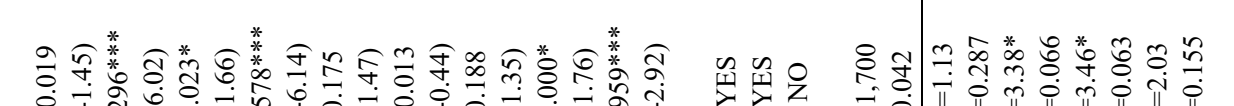

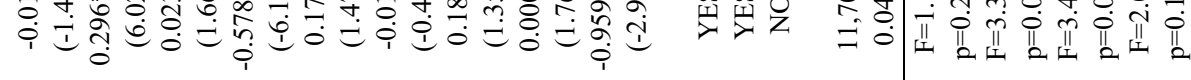

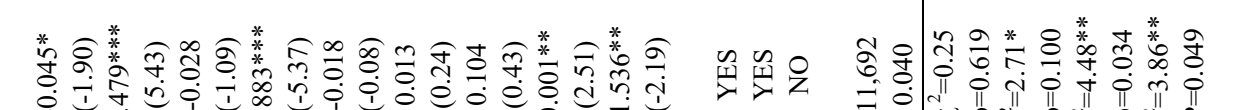

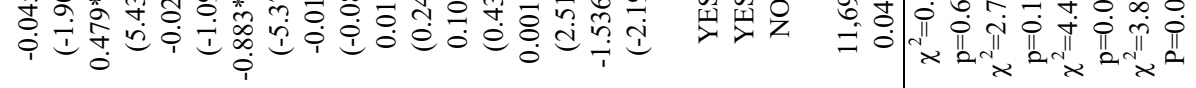

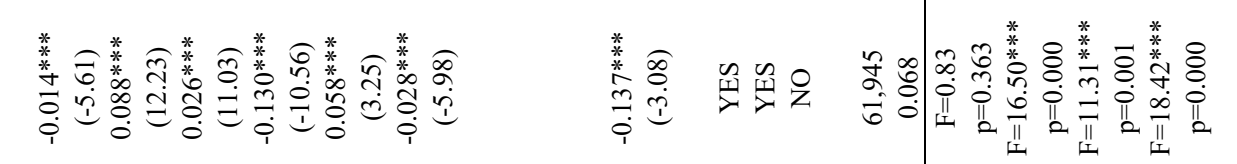

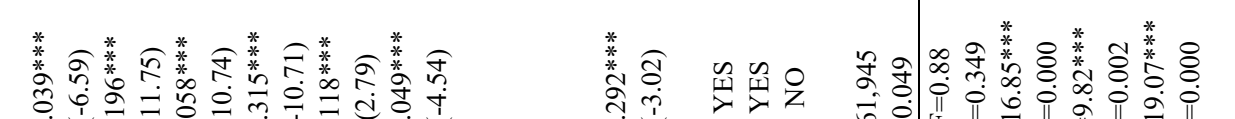
自自自目自自自目自目

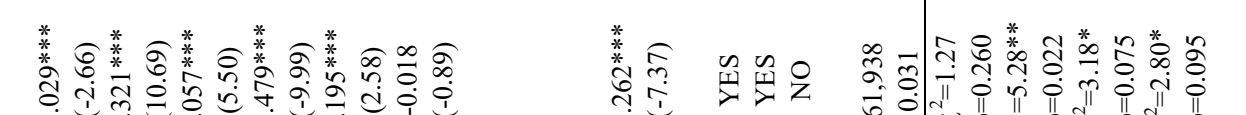

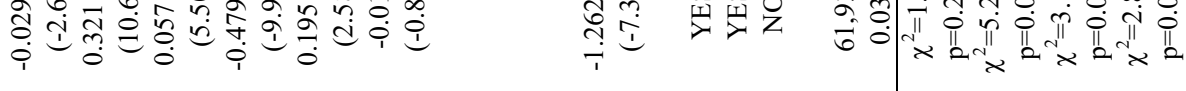

目

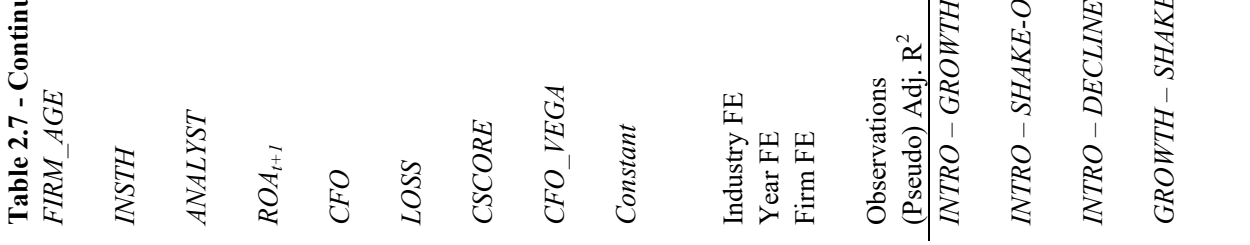




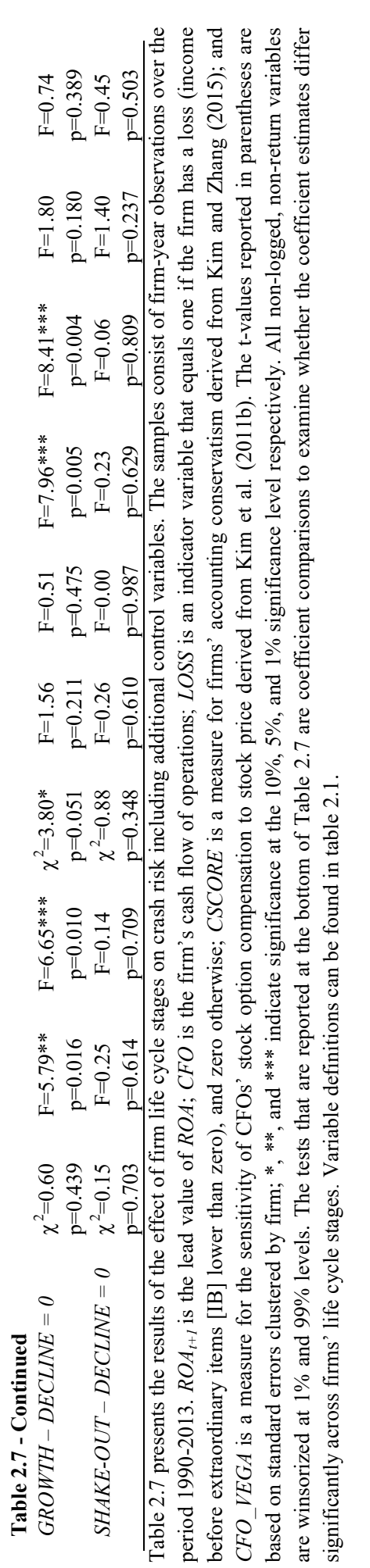




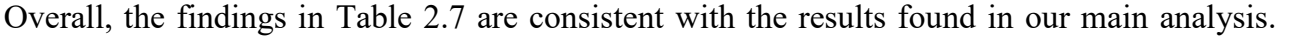

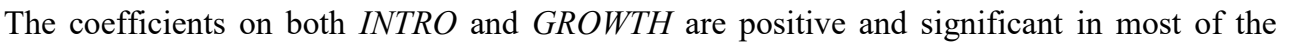

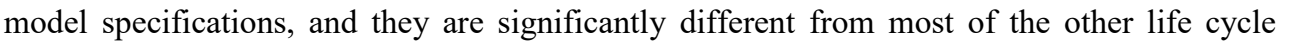

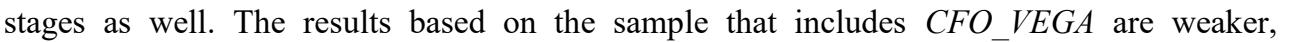

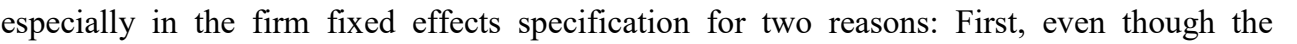

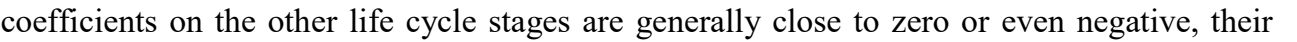

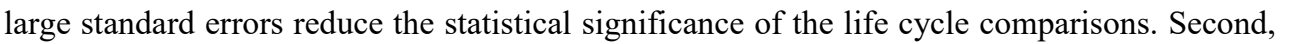

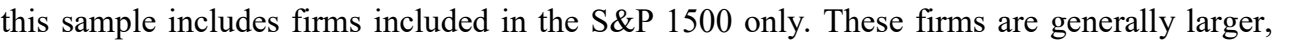

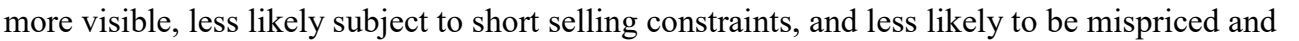

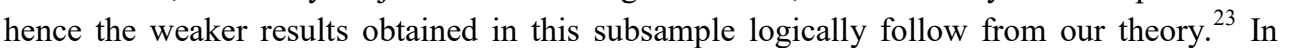

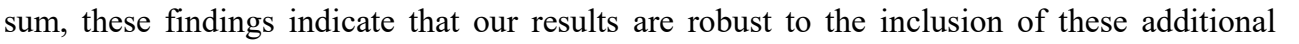
पाणाणाएँ

$\square$

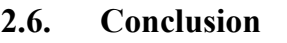

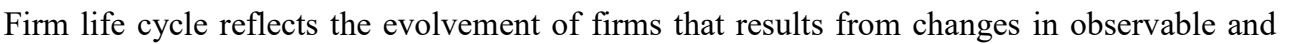
unobservable factors. In addition, some of the factors, such as a firm's strategy and its

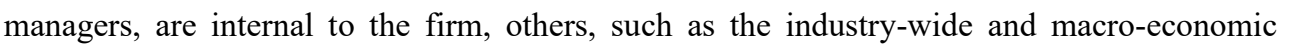

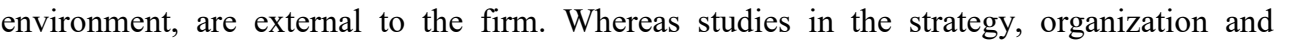

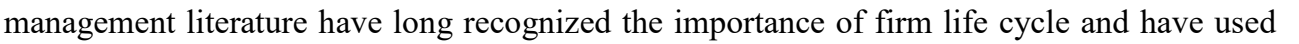

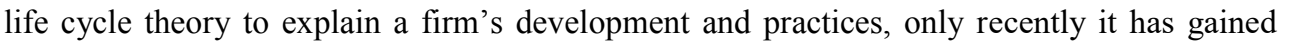

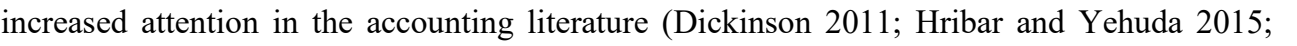

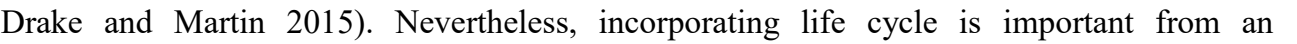

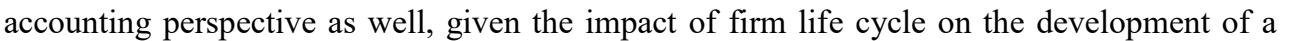
firm's profitability and the usefulness of its accounting disclosures (Dickinson 2011; Anthony

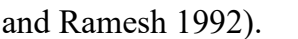

प

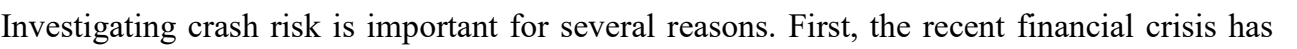

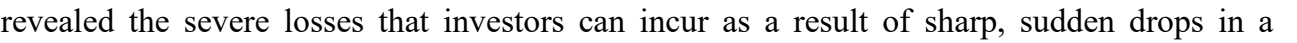
company's stock price. The widespread availability and use of tools and instruments to

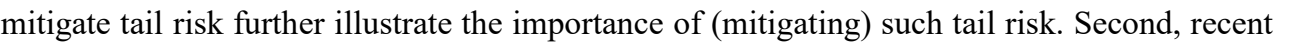

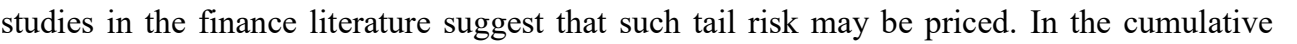

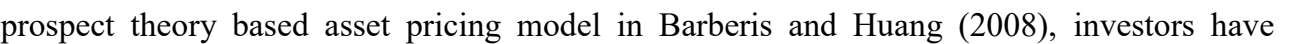

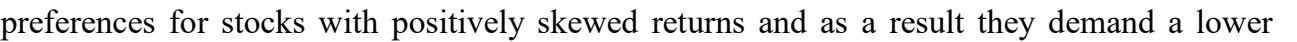
return on such stocks. Hence, tail risk has direct implications for a firm's cost of capital.

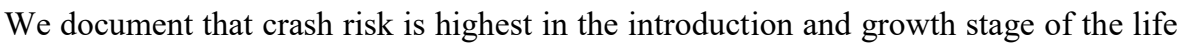

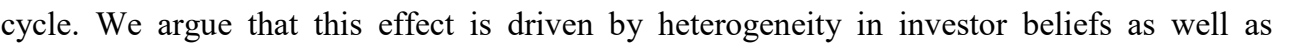

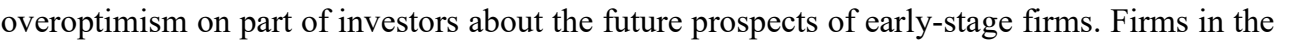

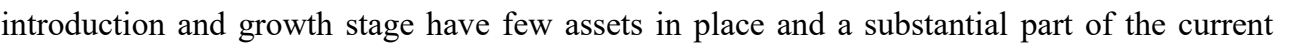

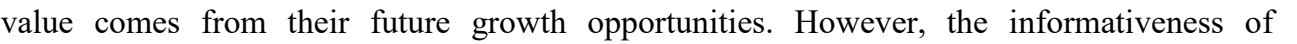

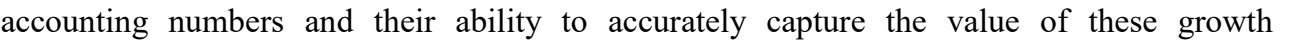

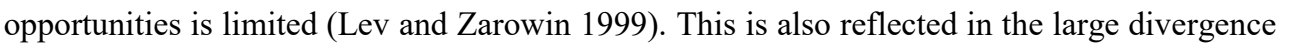

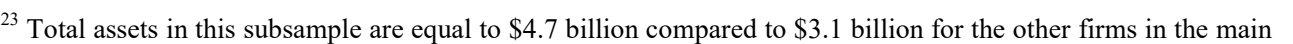

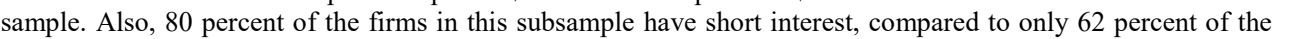

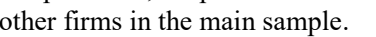


between a firm's book and market values, which further illustrates the reduced usefulness of

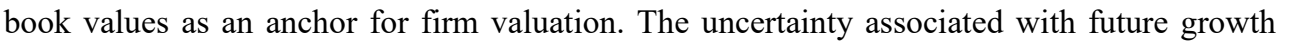

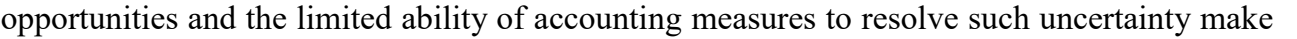
ए

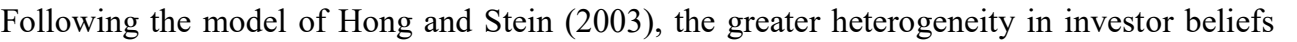
पा

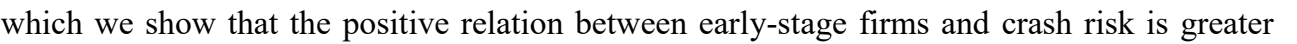

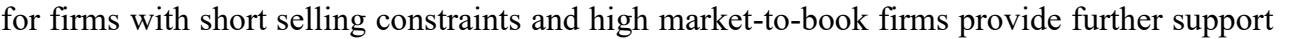

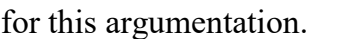

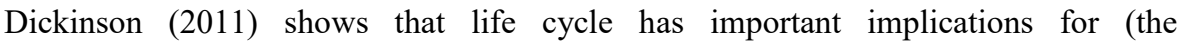
development of) a firm's profitability. Furthermore, her findings suggest that investors are $\square \square \square$

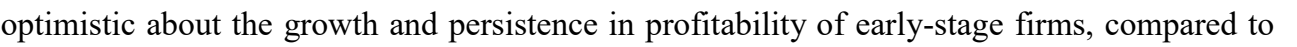

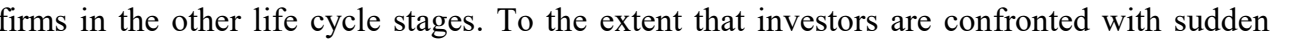

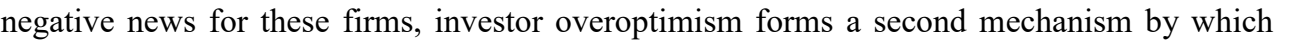

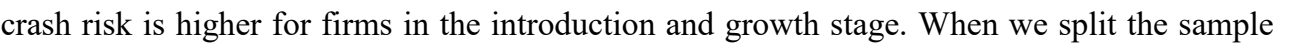

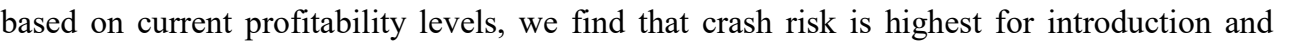

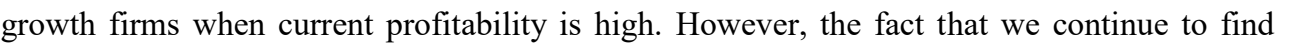

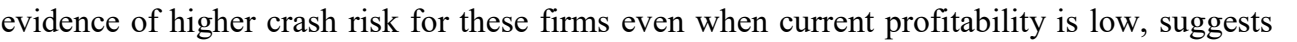

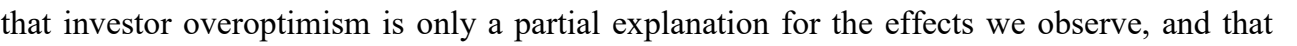

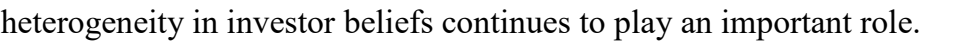

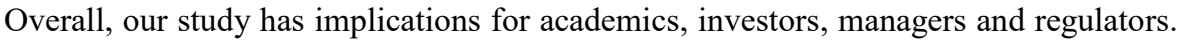

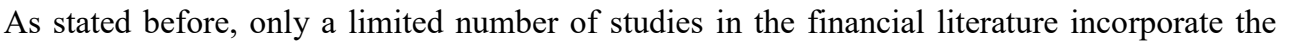

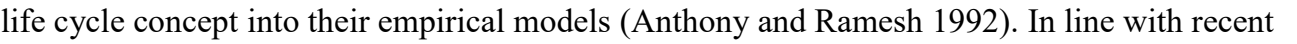

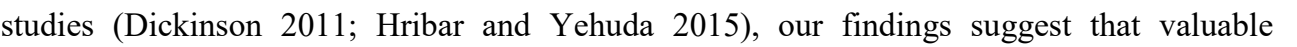
ए ए

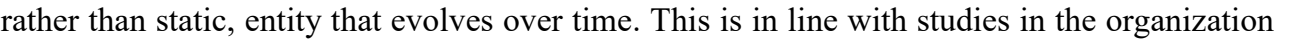

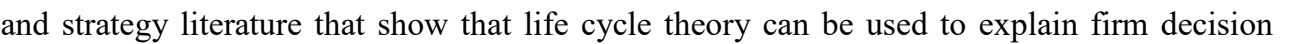

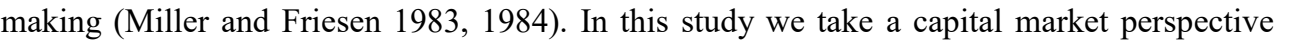

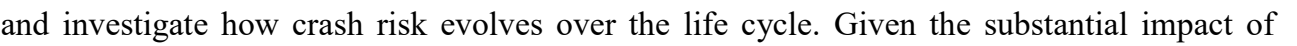
ए

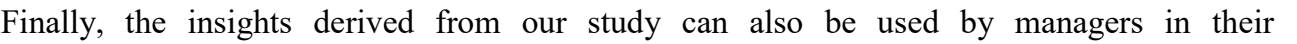

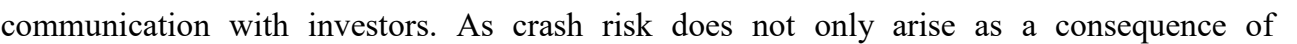
managers' opportunistic behavior

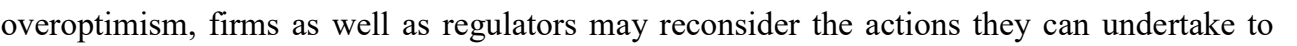

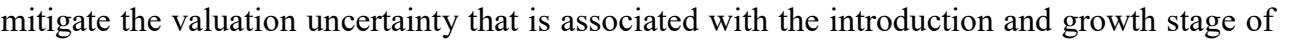

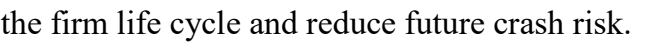




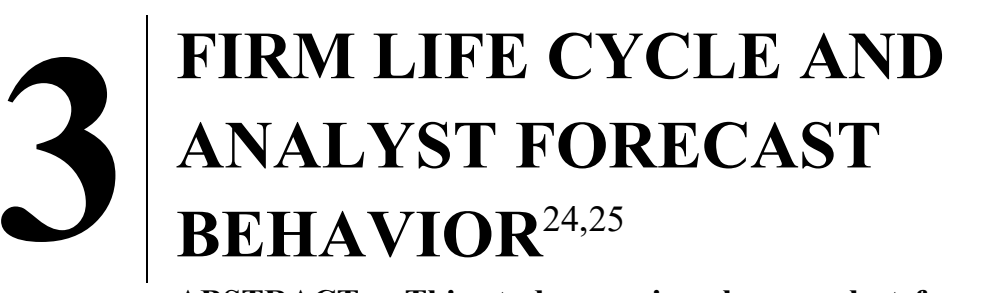

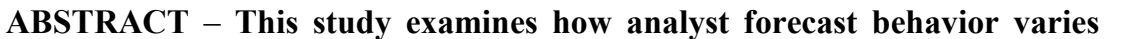

over the firm life cycle. While mispricing by investors and firms' visibility

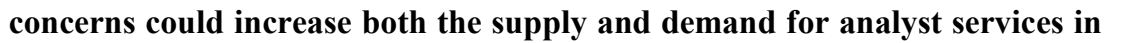

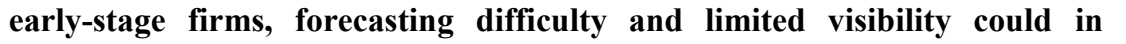

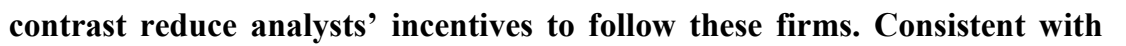

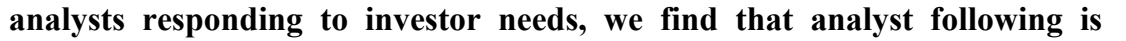

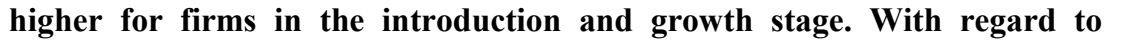

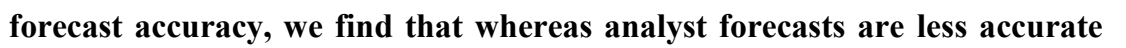

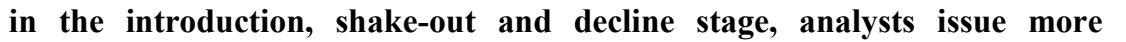

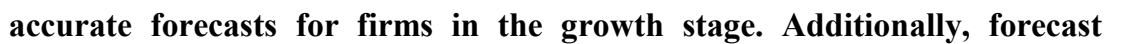

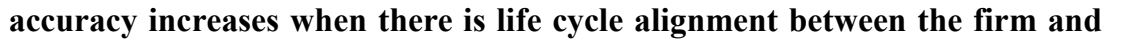

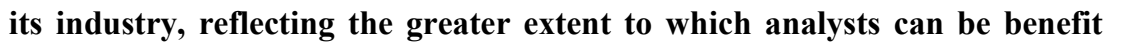

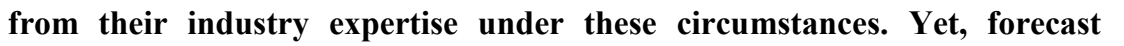

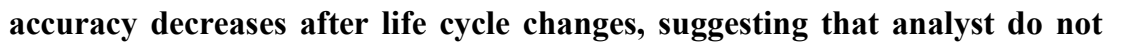

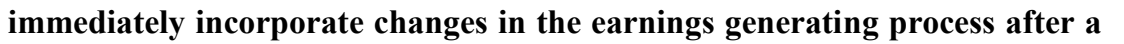

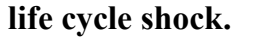

"[S]killed analysts must view companies from a perspective that identifies where they stand in their life cycle, realizing that companies refusing to 'act their age' can destroy value." $\square$

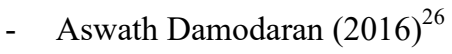

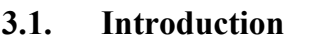

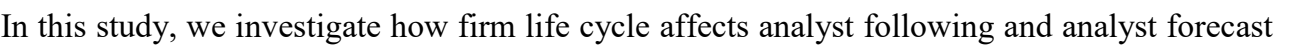

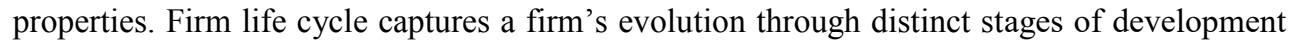
over time due to changes in both inherent firm characteristics, including the firm's business strategy and its innovative efforts, and the firm's operating environment, including

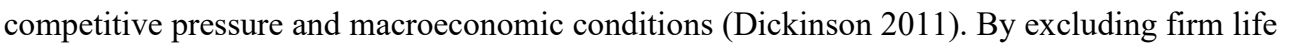

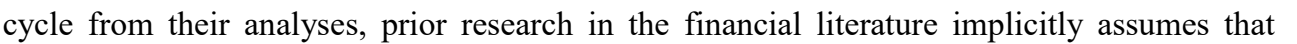

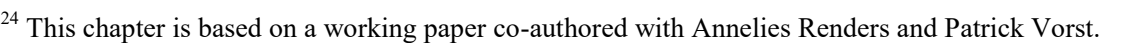

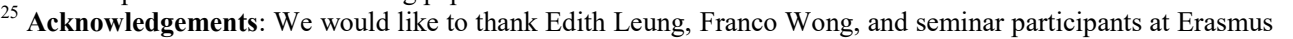

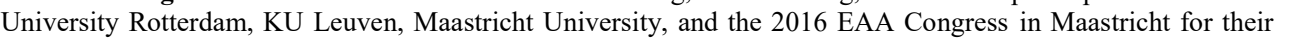

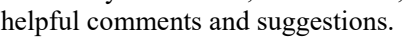

As cited by P.M.J. Gross, in “Insights from India: Opportunities, Aging Gracefully, and Averting Crisis", $\square \square \square \square$

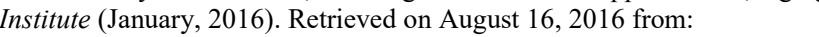

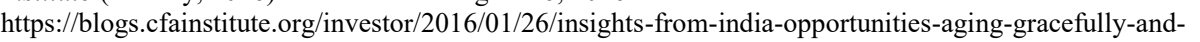
प10
} 


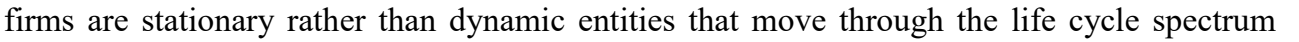

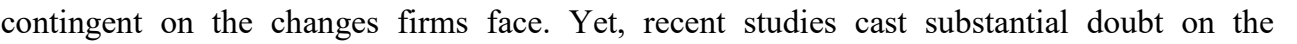

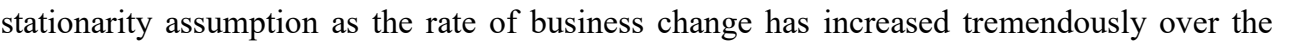

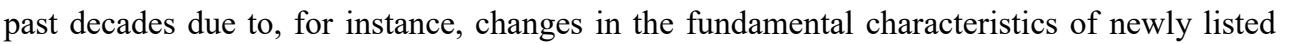
ए

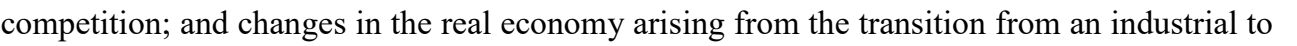

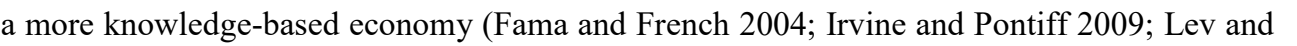

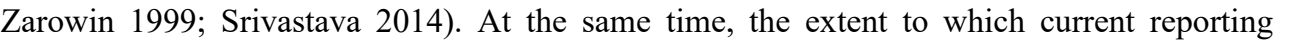

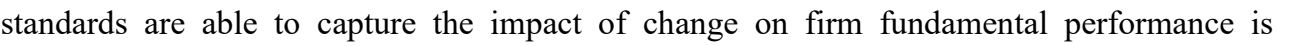

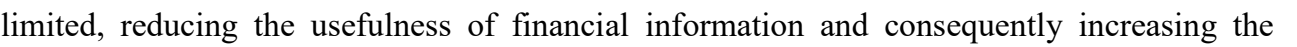

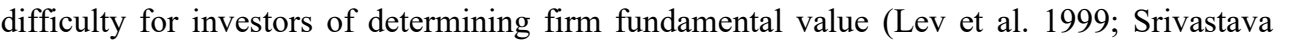

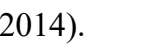

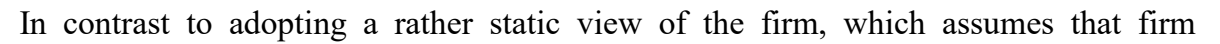

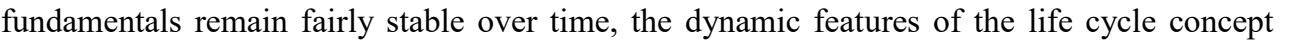

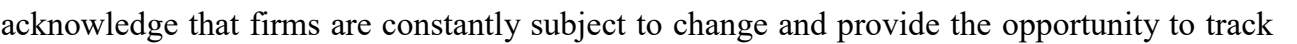

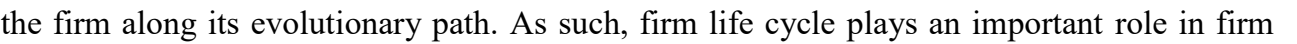

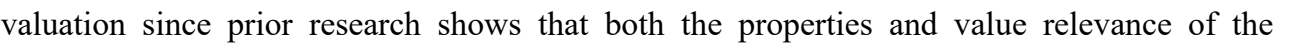

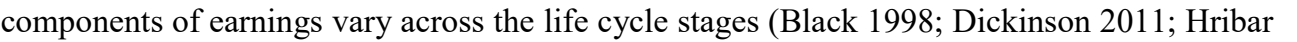

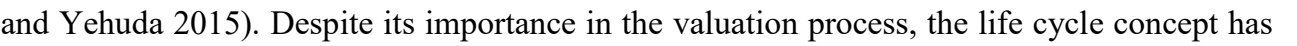

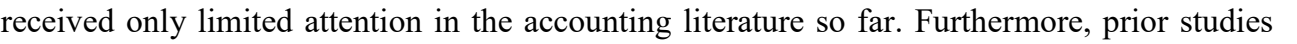

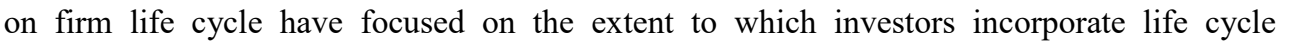
information in determining firms' stock prices (Dickinson 2011; Hribar et al. 2015). $\square \square$ rding to early studies that examine investors' understanding of firm life cycle, investors

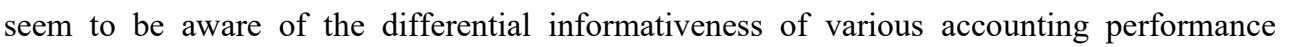

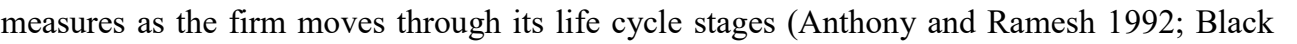

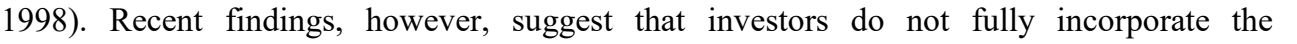

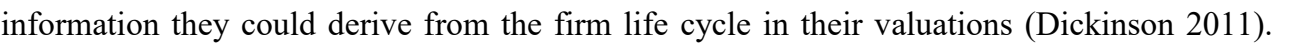

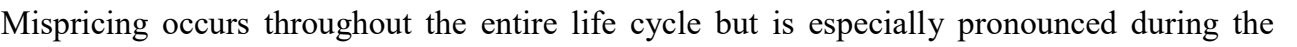

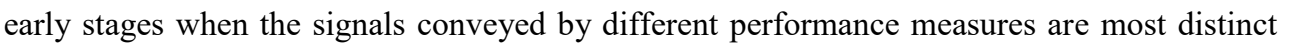

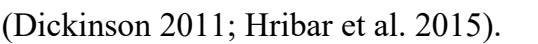

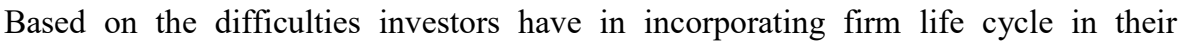

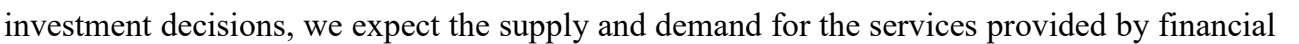

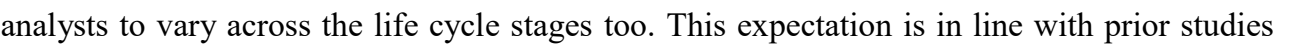

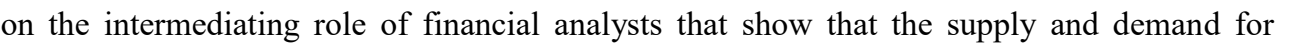

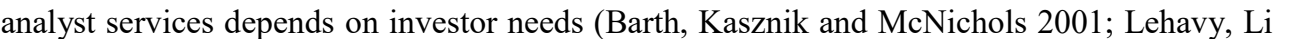
and Merkley 2011). In addition to investor needs, firms' visibility concerns could also

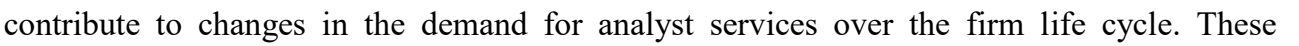

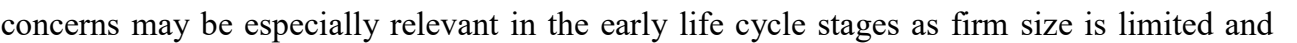

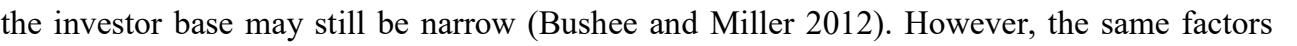
that contribute to investors' mispricing of firms over

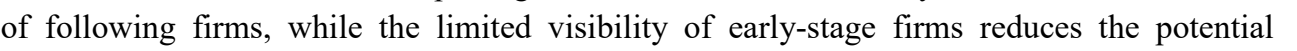

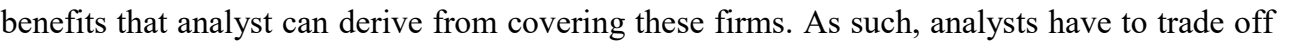

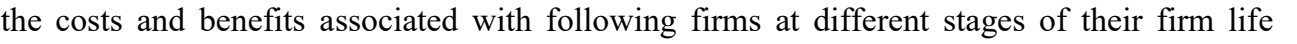




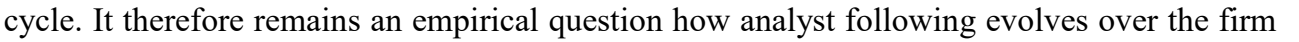
पाणाणाणाए

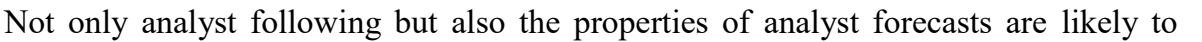

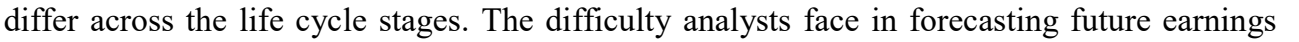

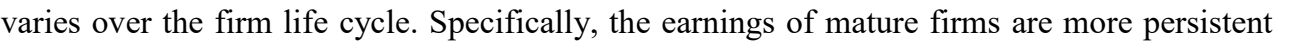

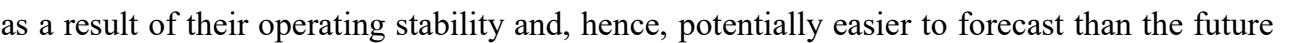

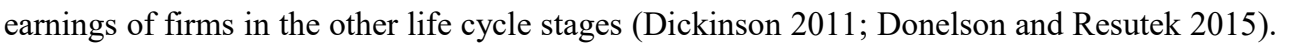

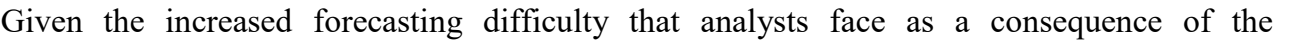

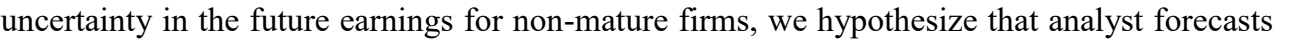

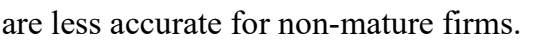

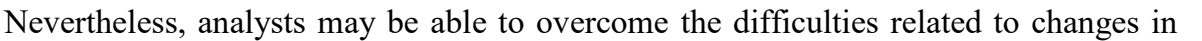

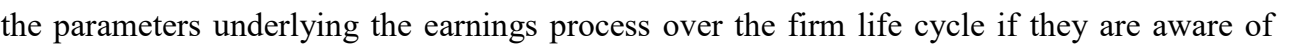
firms' evolvement over time. Two important attributes that can reduce forecast $\square\|\| \square \square \| \square \square \square$

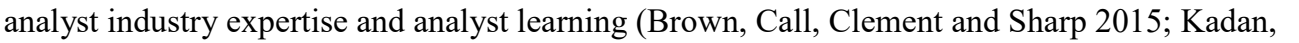

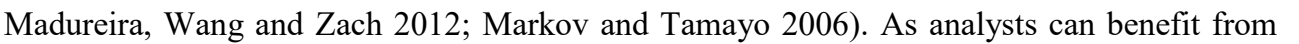

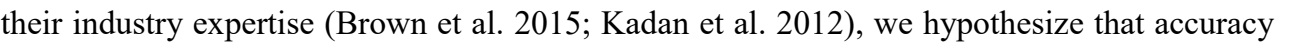

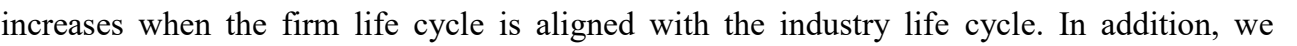

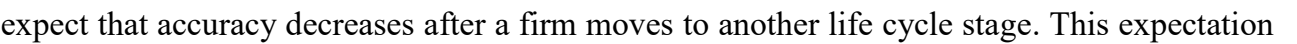

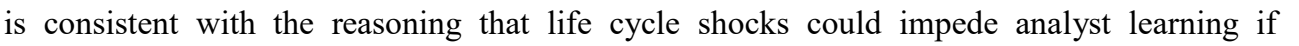

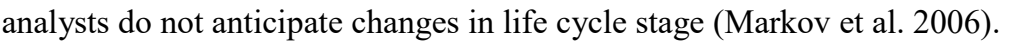

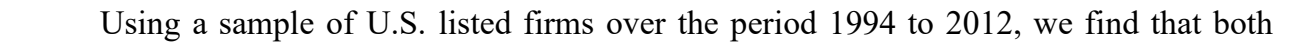

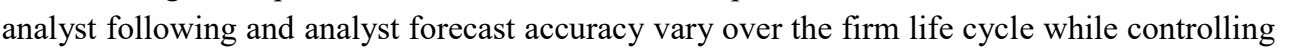

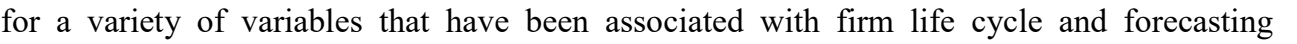

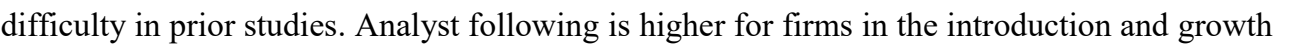

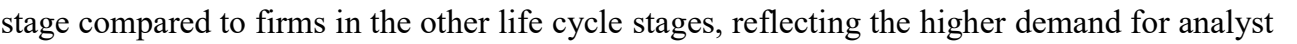

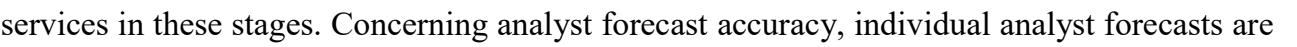

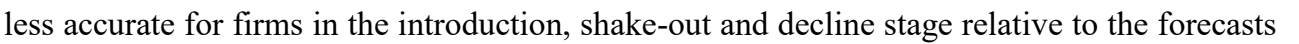
ए

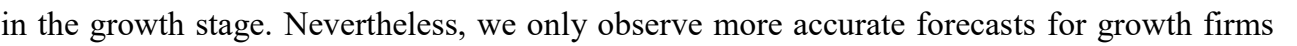

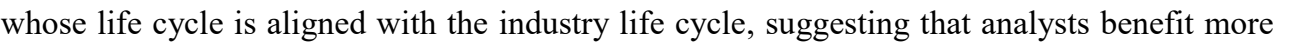

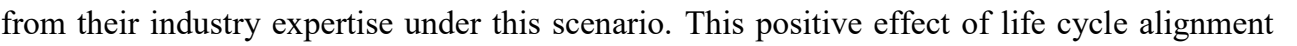

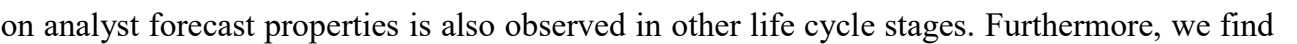

that forecast accuracy decreases after a firm

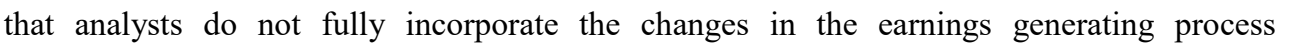

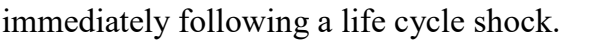

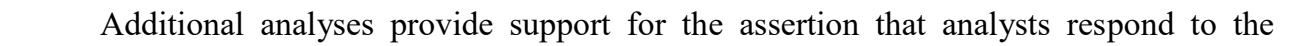

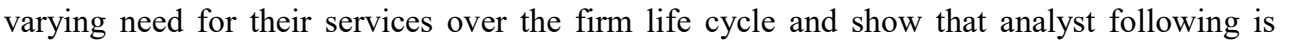

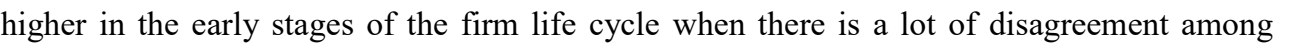

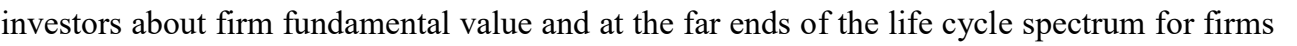

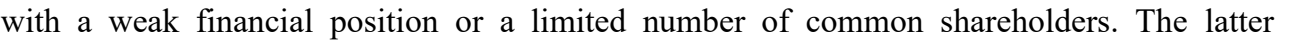

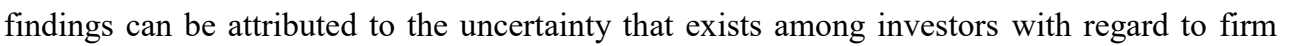

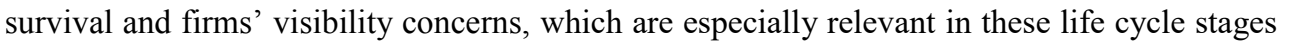

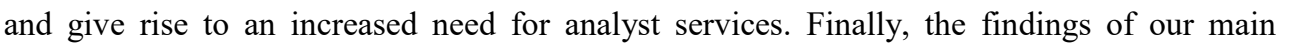

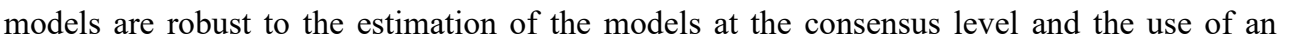




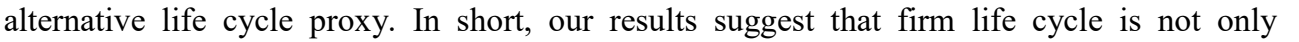

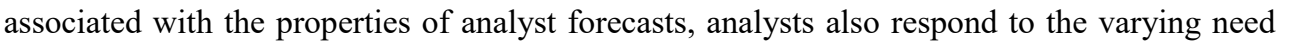

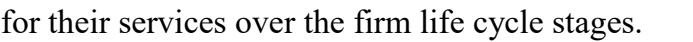

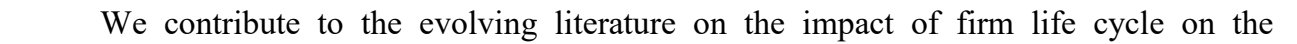

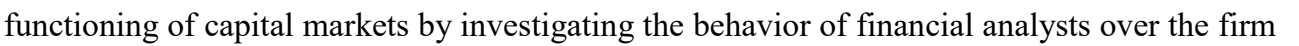

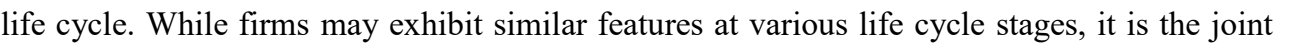

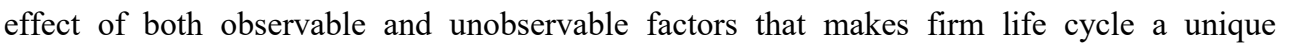

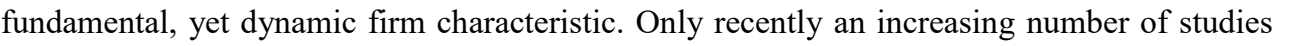

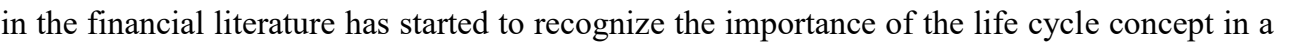

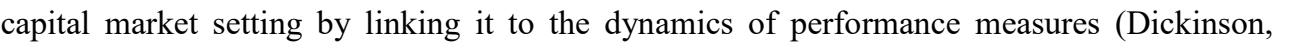

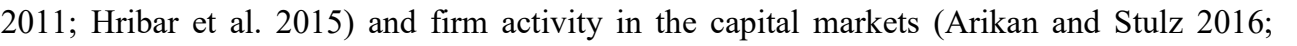

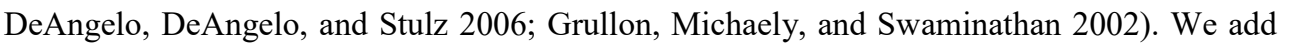
ए एव

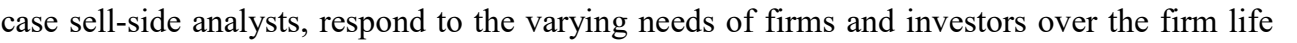

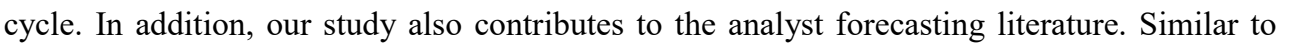

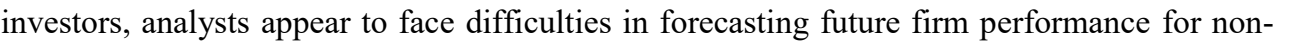

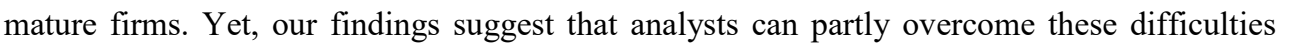

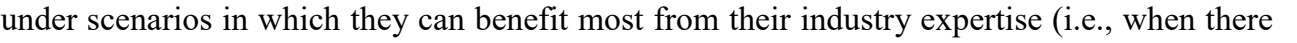
ए

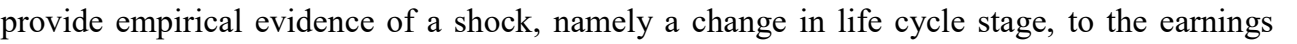

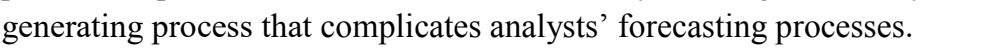

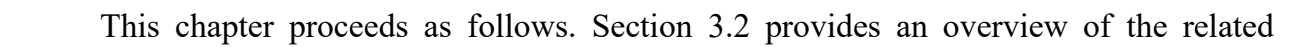

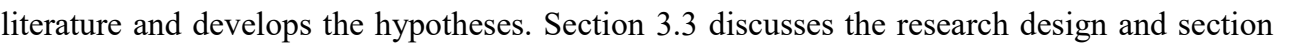

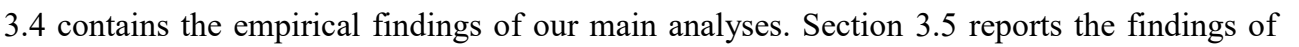

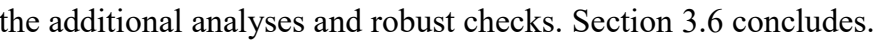

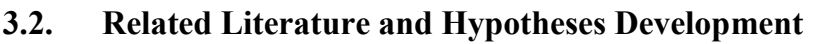

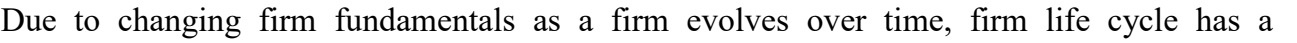

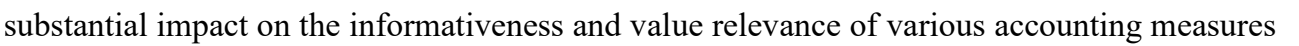

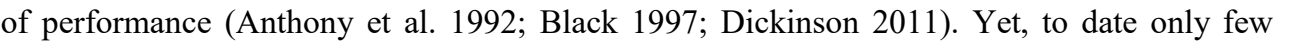

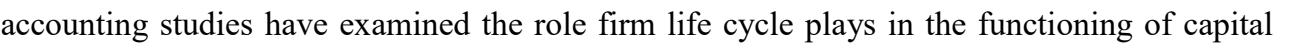

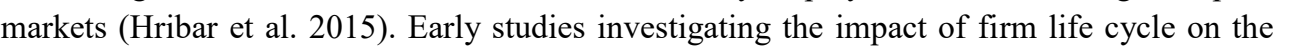

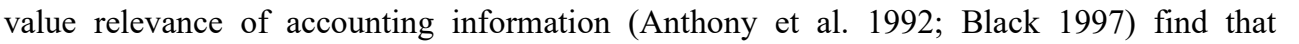
investors' reactions to various performance measures differ across the life cycle stages.

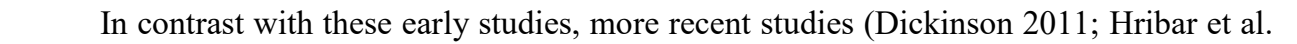

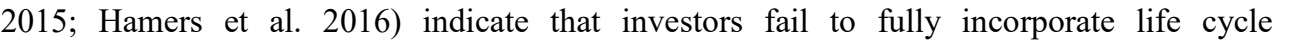

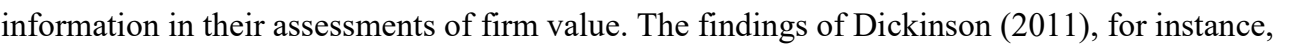

suggest that mispricing occurs throughout the firm life cycle as a consequence of investors'

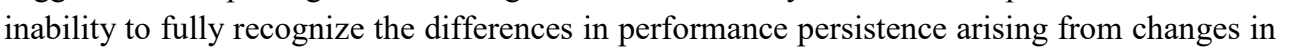
firms' operating efficiency. In a study on the misp

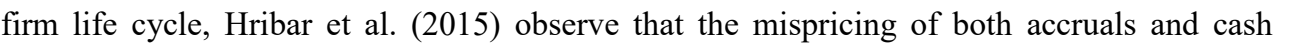
ए ए

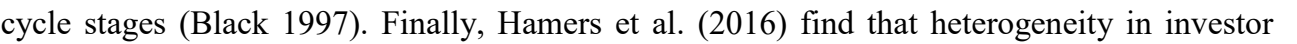




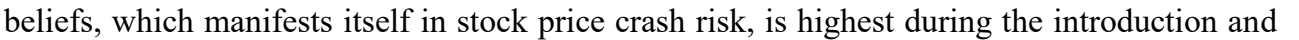

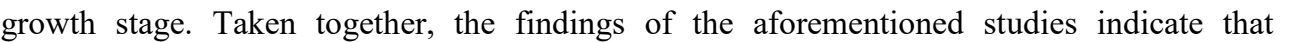

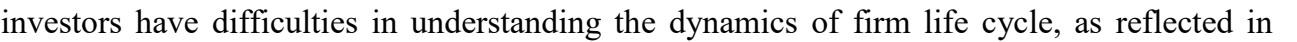

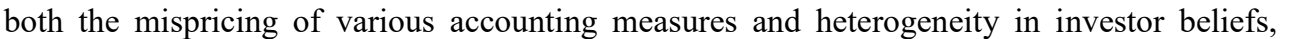

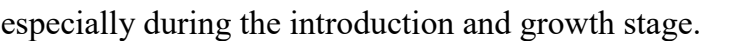

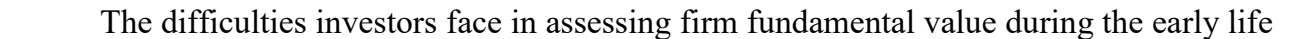

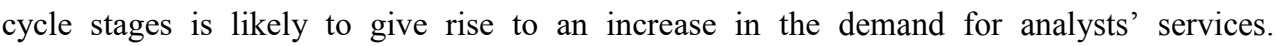

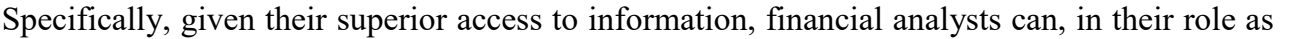

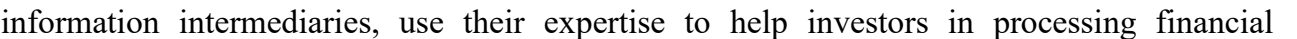
प

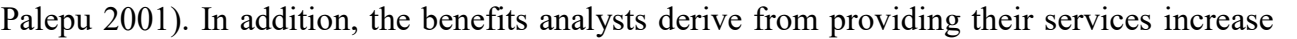

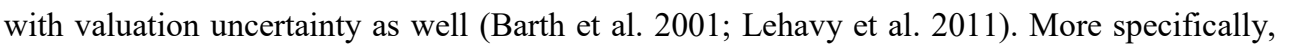

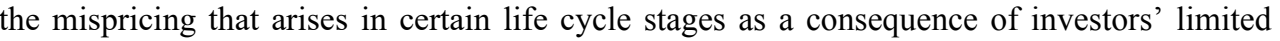

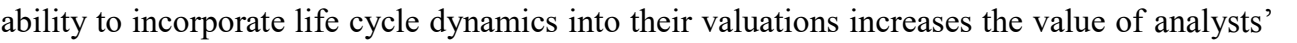

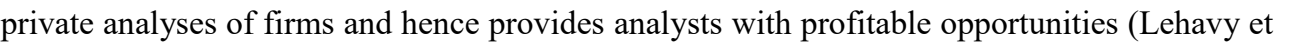

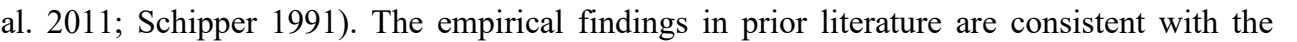

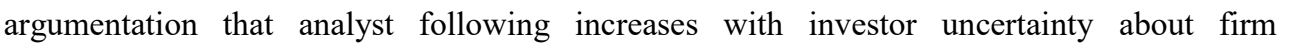

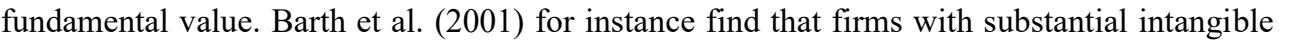
assets are followed by more analysts, which reflects analysts' response to the uncertainty concerning the value of firms' intangible assets and the information asymmetry between

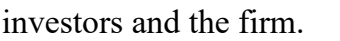

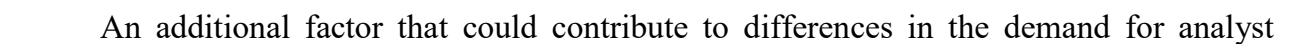
services over the firm life cycle are firms' visibility concerns. These are most pronounced at

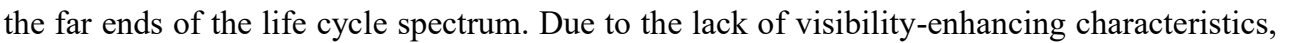

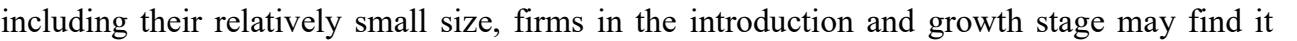

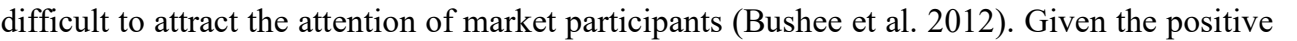

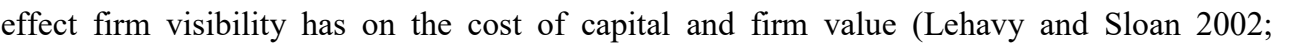

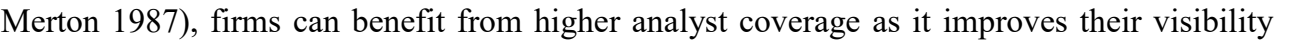

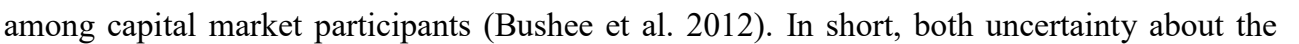

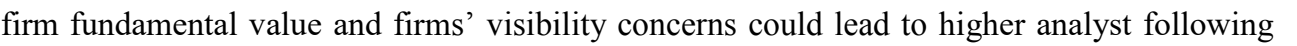

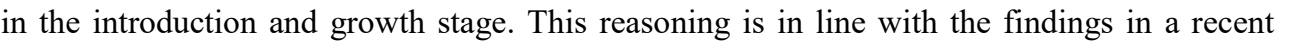

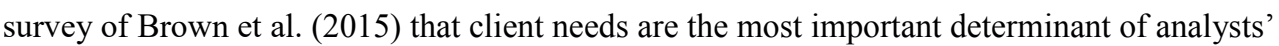

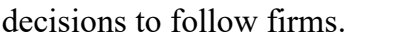

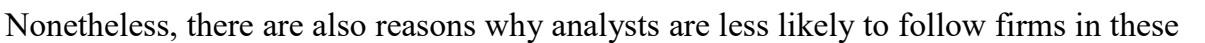

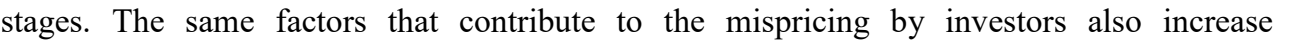

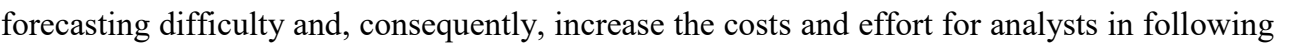

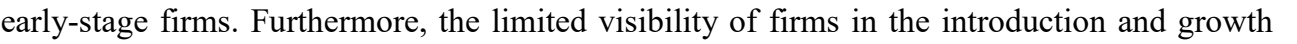

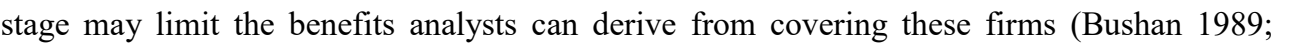

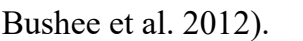

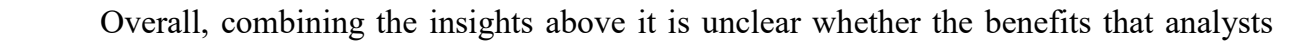

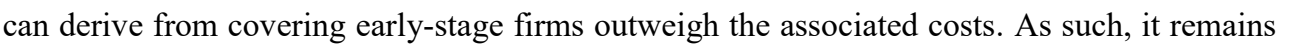

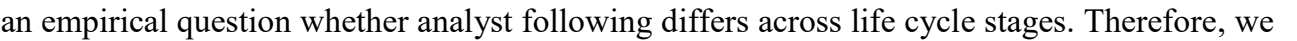

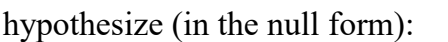

$\square$ 


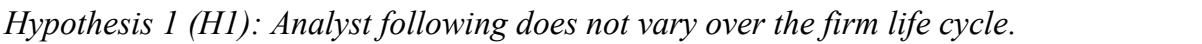
$\square$

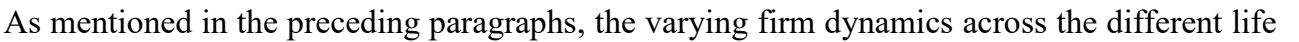

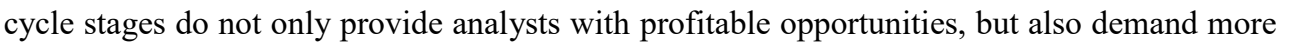

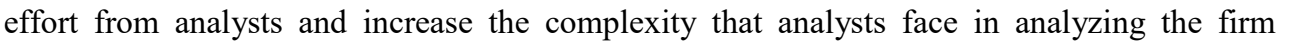

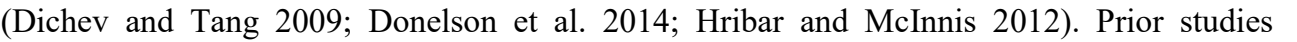

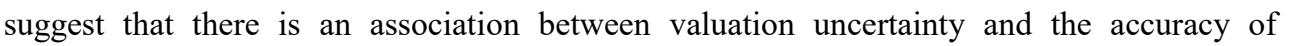
analysts' forecasts (Hribar et al. 2012). After establishing a link between earnings volatility and earnings predictability, Dichev et al. (2009) find that analysts' forecast errors are

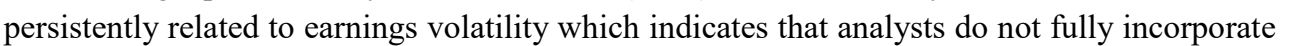

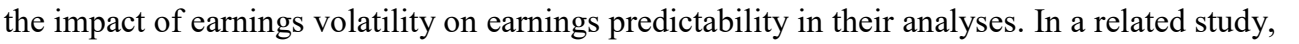

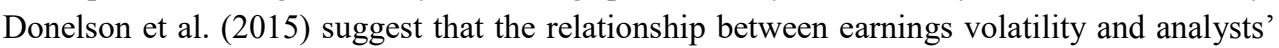

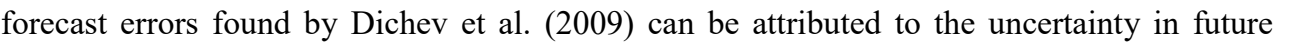

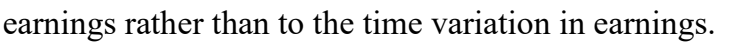

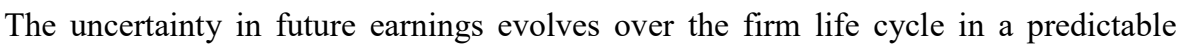

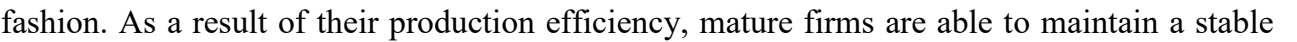
ए ए ए।

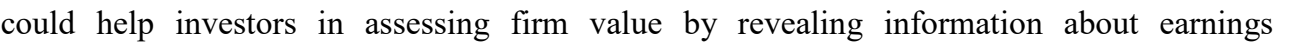

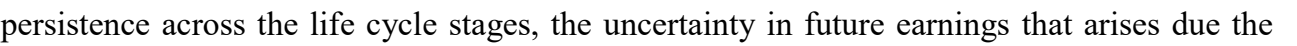

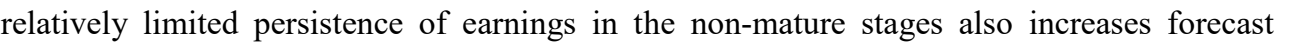

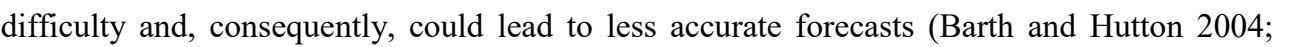

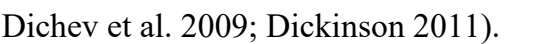

Based on the insights above, we argue that analysts' forecasts are less accurate $\square \square$

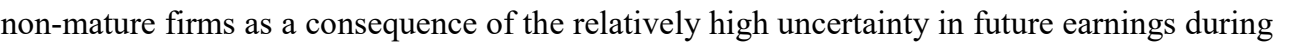

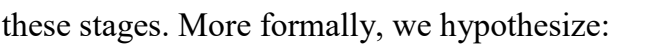

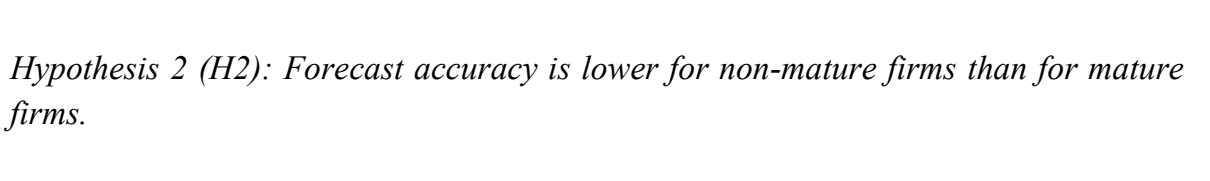

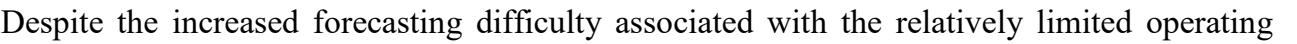

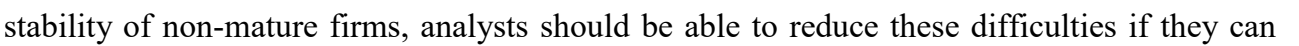

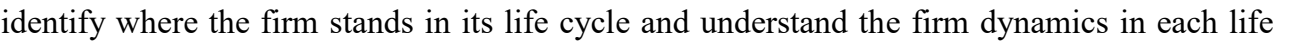

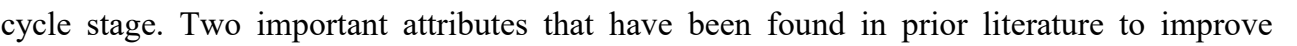

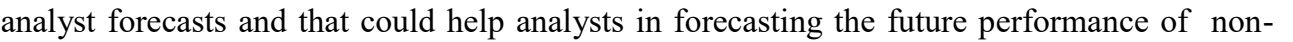

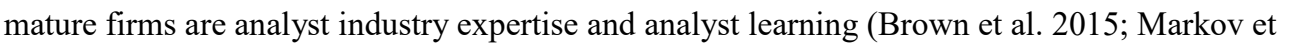
पा山ापाणा

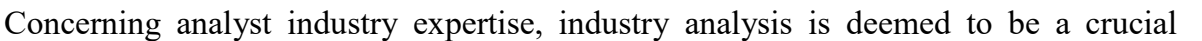
aspect in forecasting earnings and valuing firms and hence analysts' industry knowledge is

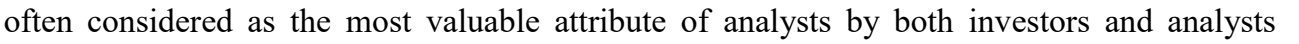

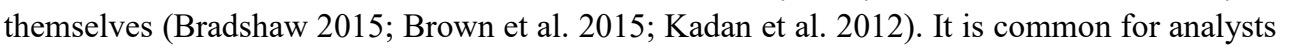
to specialize in an industry and to benchmark firms' performance against their industry peer $\square$

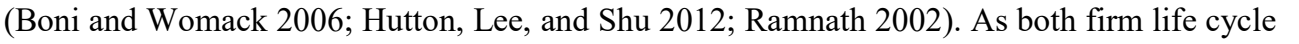

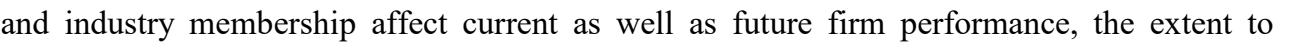




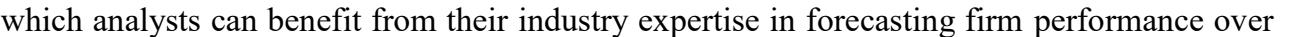
the firm life cycle depends on the alignment between a firm's life cycle stage and that of the

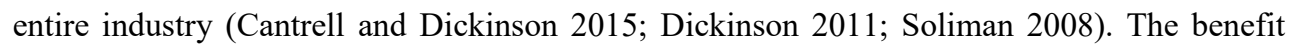

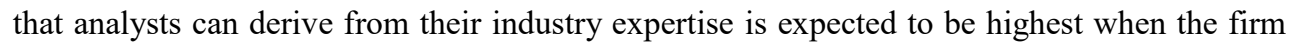
life cycle is in line with the evolvement of the industry, for instance because the firm's

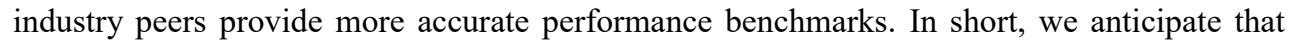

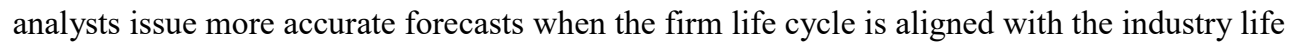

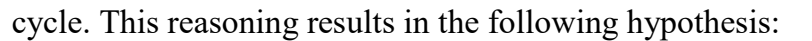

$\square$

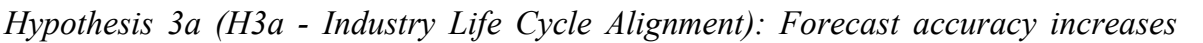

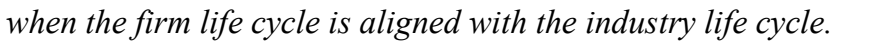

$\square$

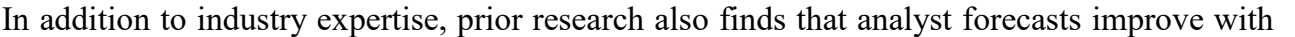

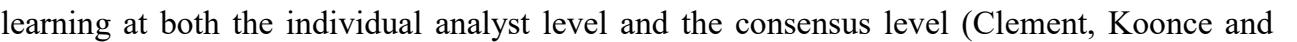

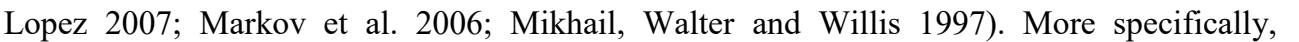

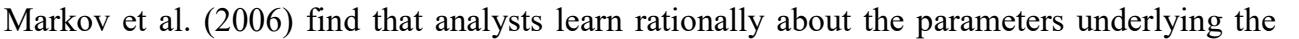

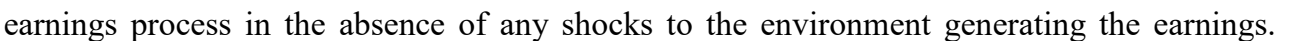

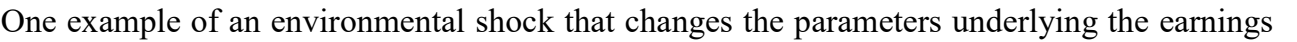

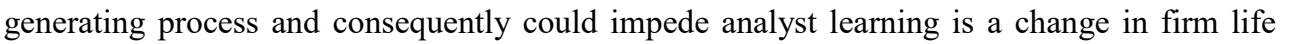

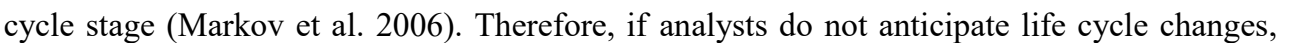

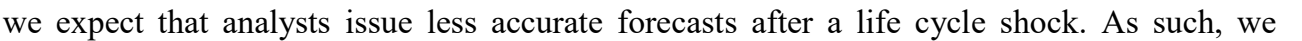
पाणाणाणाए

एा]

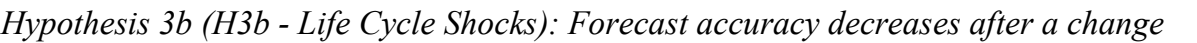

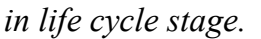

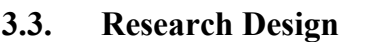

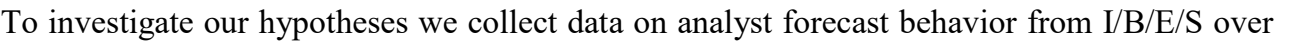

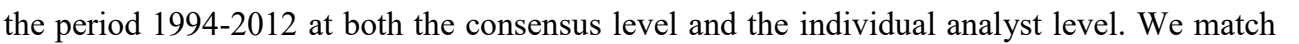
ए एव

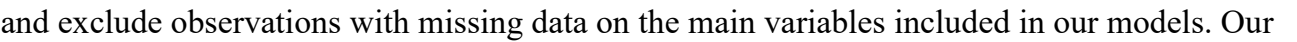

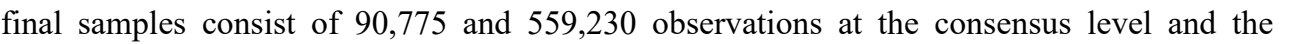

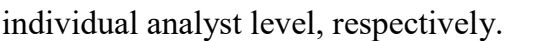

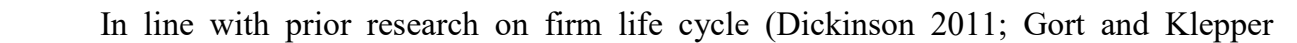

1982), we distinguish five different life cycle stages to capture a firm's evolvement over time:

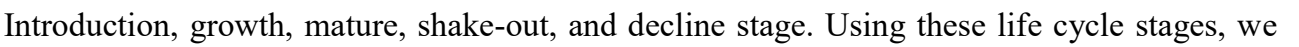

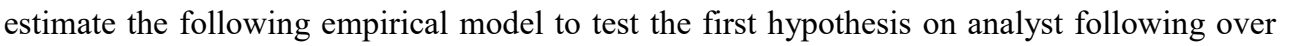

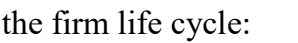

$\square$

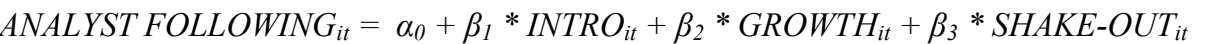

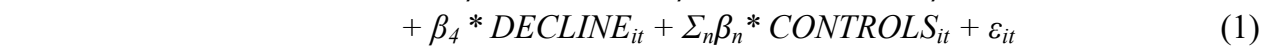
$\square$

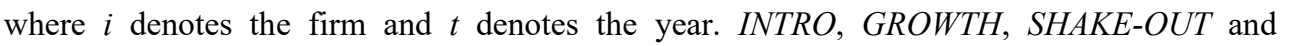

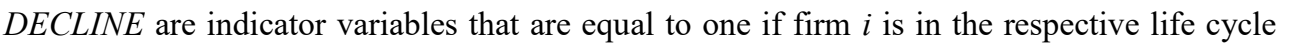




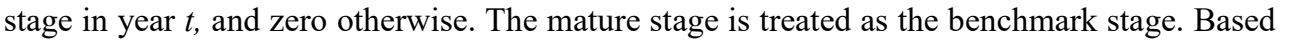

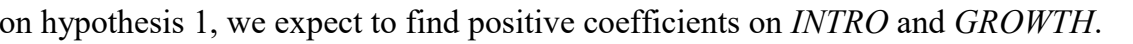

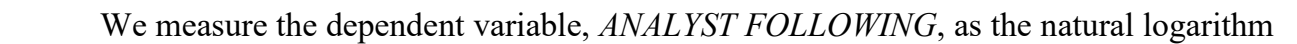

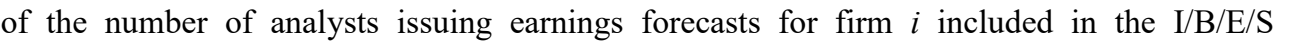

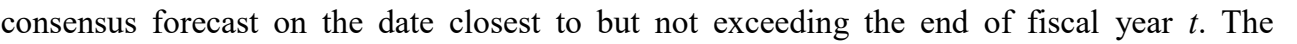
ए ए।

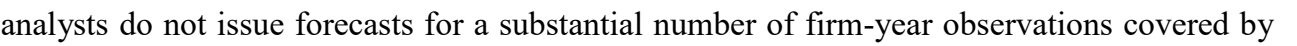

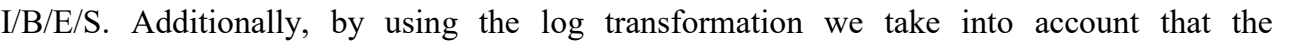

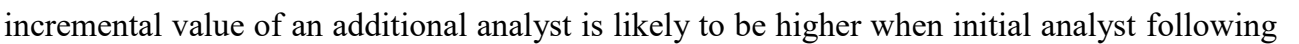
is low (O’Brien and Bhushan 1990). $\square$

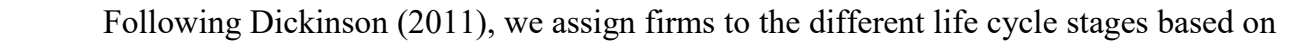

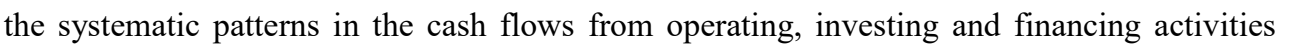

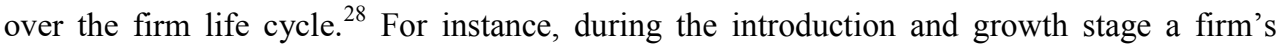

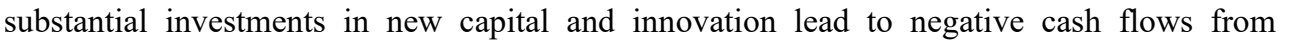

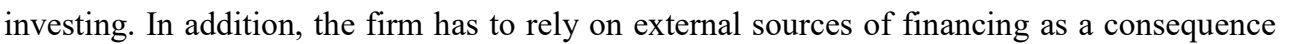

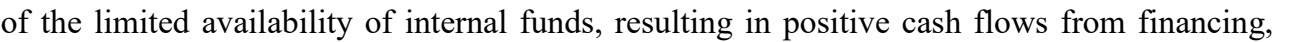

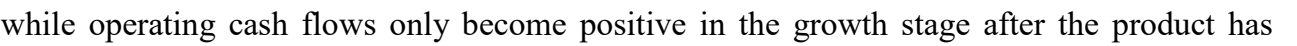

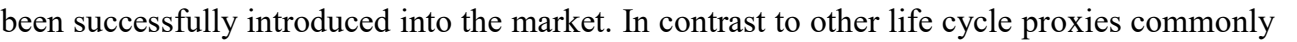

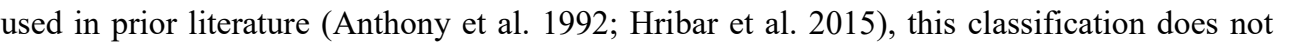

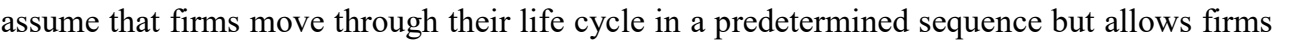
ए एव

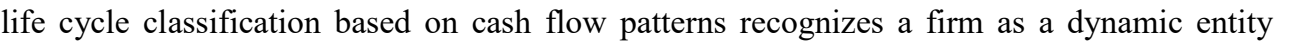

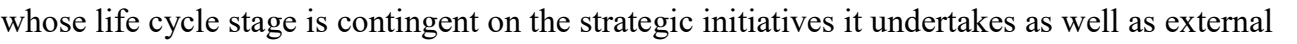

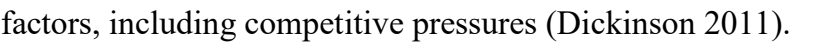

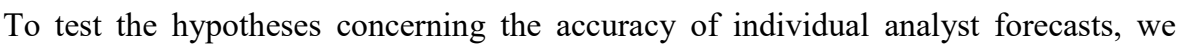

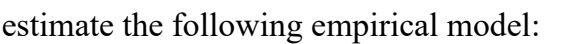

$\square$

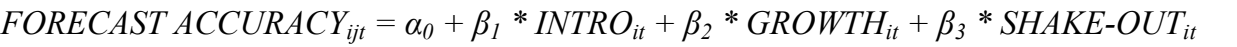

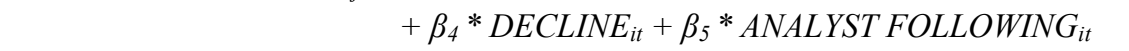

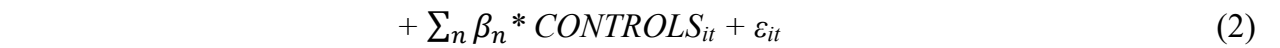
$\square$

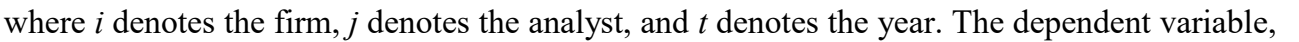

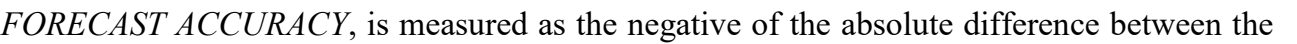

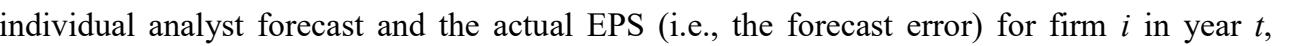

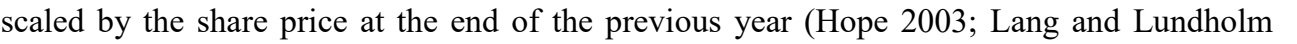
$\square 11 \mathrm{~m}$

$\square$

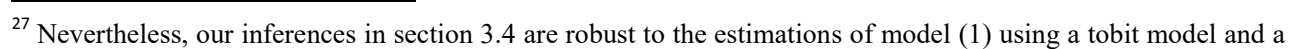

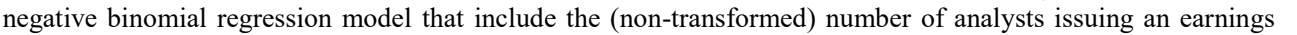

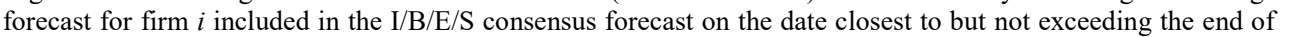

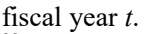

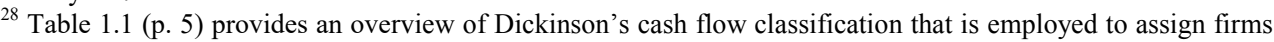

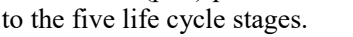
$\square$ 


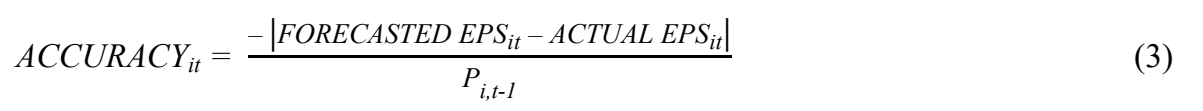
$\square$

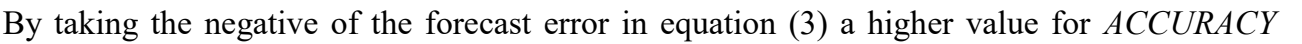

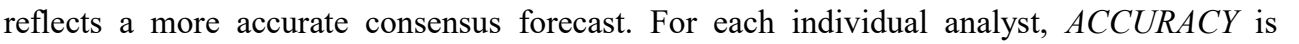

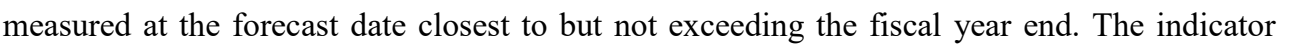

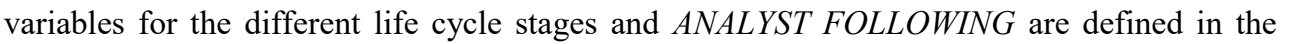

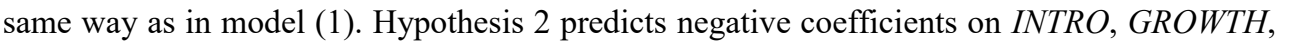

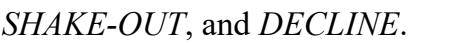

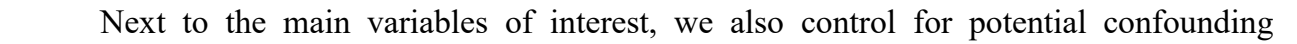

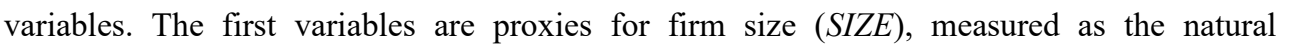

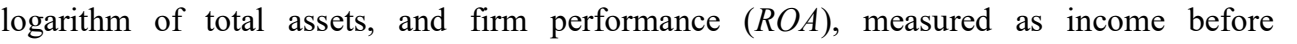

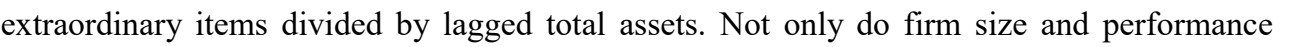

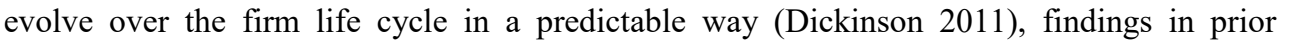

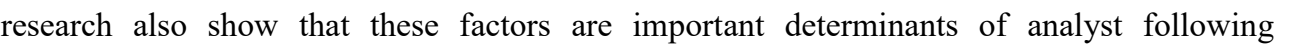

(Bhushan 1989; McNichols and O'Brien 1997; O'Brien et al. 1990).

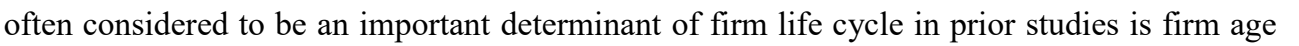
田

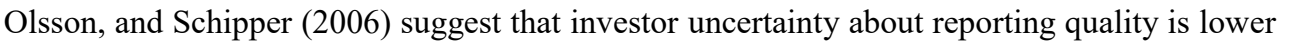

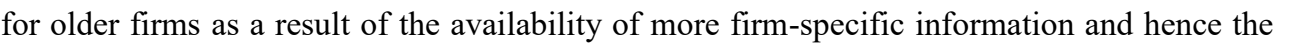

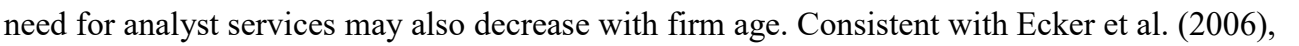
एव

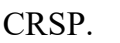

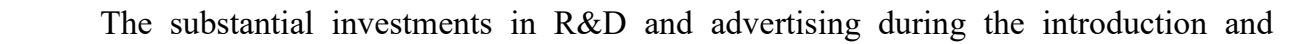

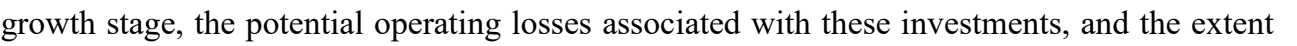

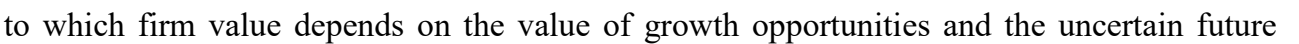

benefits that can be derived from these investments could also contribute to investors'

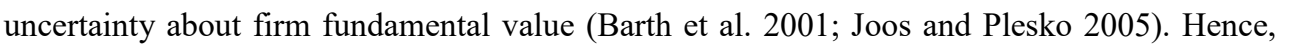

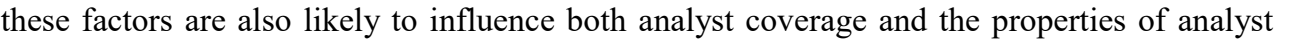

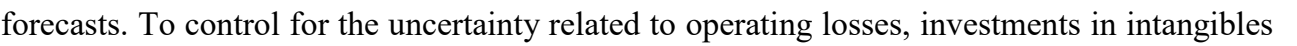

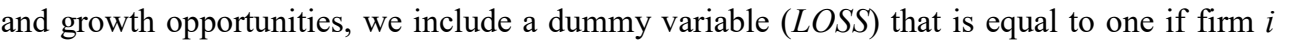
प एव

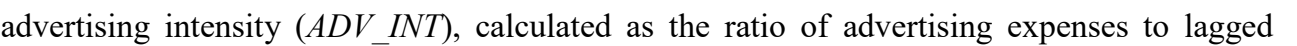

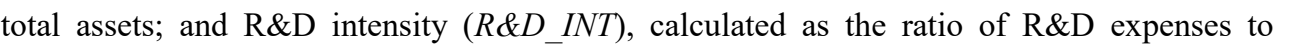

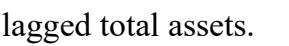

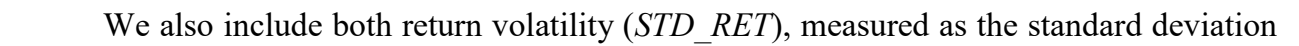

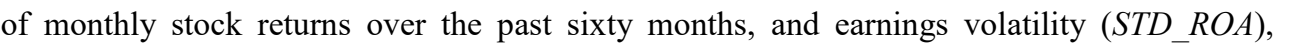

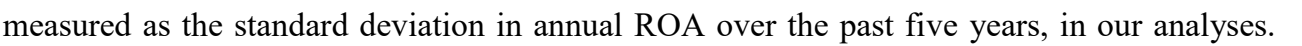

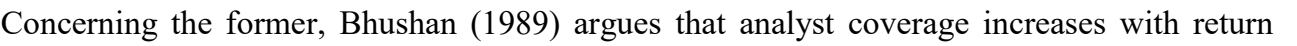

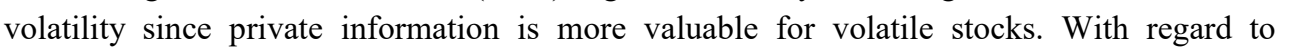

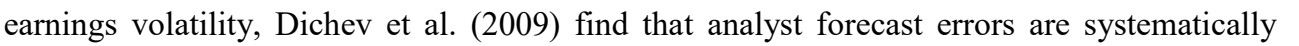

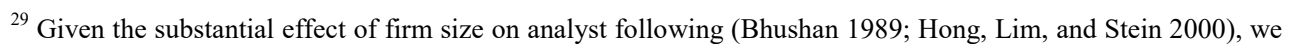

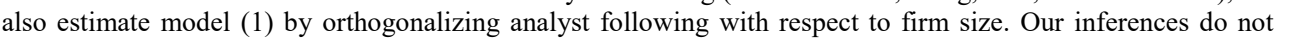

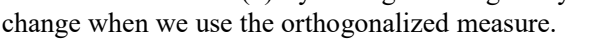




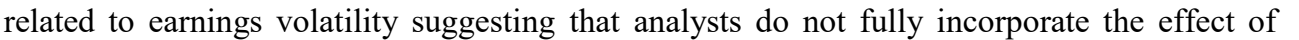

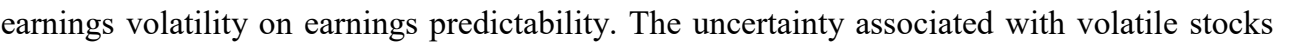

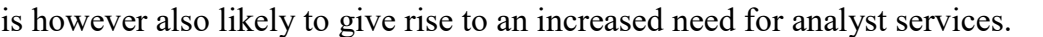

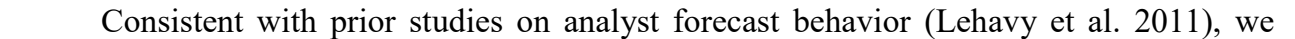

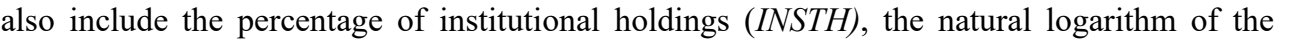

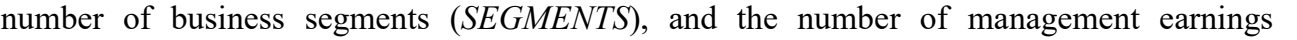

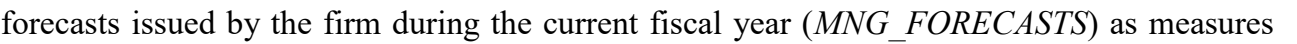

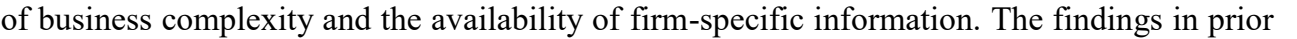

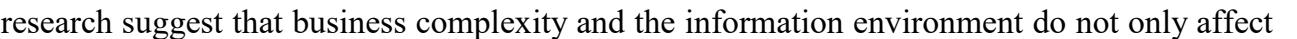

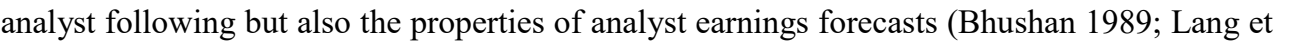

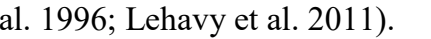

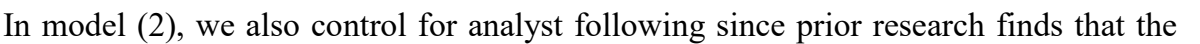

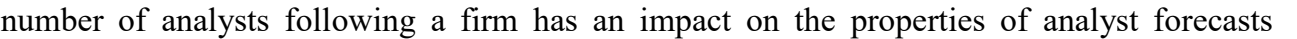

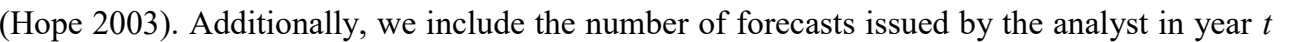

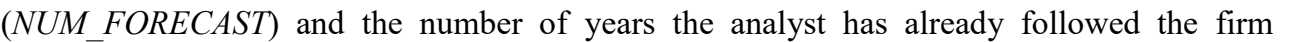

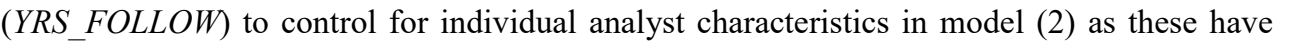

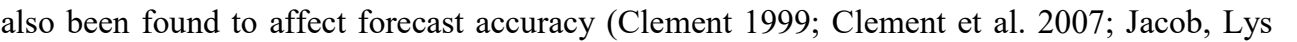
पाप⿴囗णाणमाण

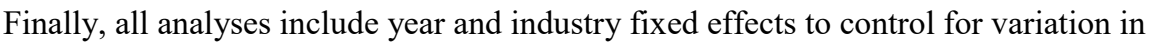

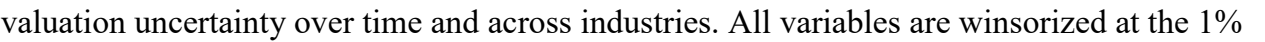

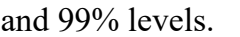

$\square$

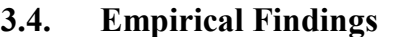

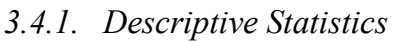

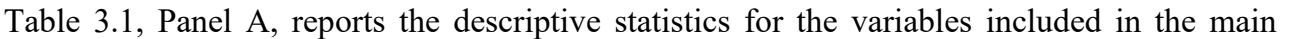

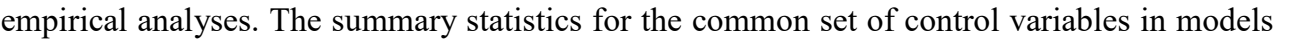
ए

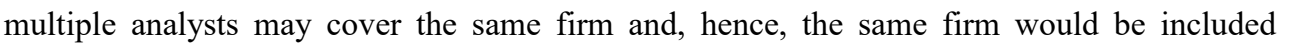

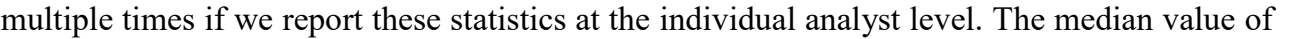

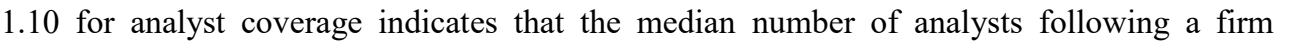

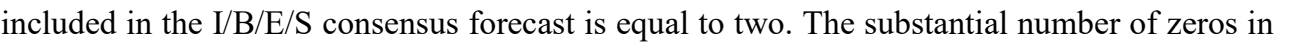

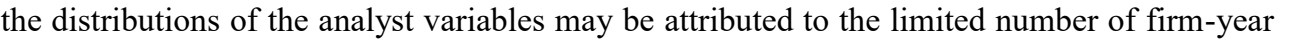

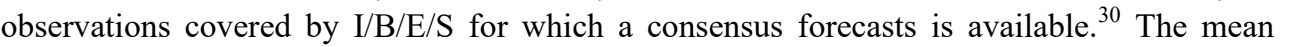

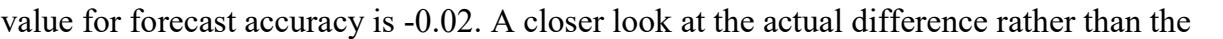

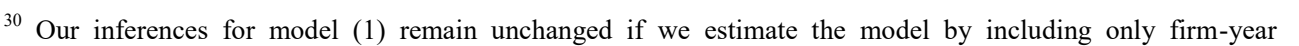

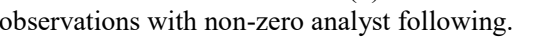




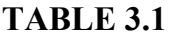

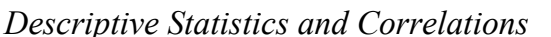

\section{Panel A: Summary Statistics}

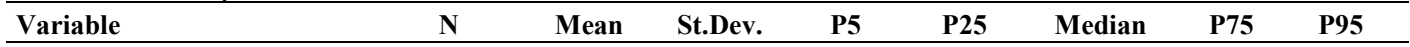

\begin{tabular}{|c|c|c|c|c|c|c|c|c|c|c|c|c|c|c|c|c|}
\hline 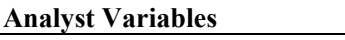 & $\mathbb{E}$ & 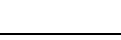 & $\square$ & 四 & $\mathbb{L}$ & $\square$ & $\llbracket$ & 四 & $\square$ & $\square$ & $\square$ & $\square$ & $\square$ & $\square$ & $\llbracket$ & $\square \quad \square$ \\
\hline 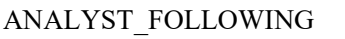 & & $\square \square \square$ & & $\square \square$ & & $\square \square$ & & $\square \square \square$ & & $\square \square$ & & $\square \square$ & & पाण & & $\square ण 1$ \\
\hline 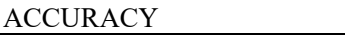 & & $\square\|\| \| \mid \square$ & & एणाए & & 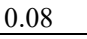 & & पाणा & & पाणाए & & $\square[11$ & & 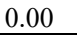 & & $\square \Pi 1$ \\
\hline 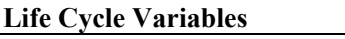 & $\mathbb{Z}$ & 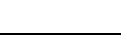 & $\square$ & 口 & $\llbracket$ & 四 & 【 & 口 & $\square$ & $\square$ & $\square$ & $\square$ & $\square$ & 四 & $\llbracket$ & $\mathbb{\square} \square$ \\
\hline एविएव & & 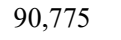 & & $\square \square$ & & पाए & & $\square$ & & $\square$ & & $\square$ & & $\square$ & & $\square$ \\
\hline प्व० प्र० & & 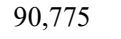 & & पाए & & पाए & & $\square$ & & $\square$ & & $\square$ & & $\square$ & & $\square$ \\
\hline प्रणिमण & & 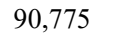 & & पण口 & & पणा & & $\square$ & & $\square$ & & $\square$ & & $\square$ & & $\square$ \\
\hline 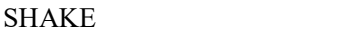 & & 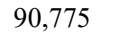 & & पण口 & & पणा & & $\square$ & & $\square$ & & $\square$ & & $\square$ & & $\square$ \\
\hline 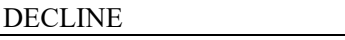 & & 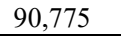 & & $\square \amalg \square$ & & \begin{tabular}{ll|}
10 \\
\end{tabular} & & $\square$ & & $\square$ & & $\square$ & & $\square$ & & $\square$ \\
\hline 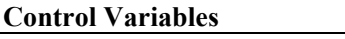 & 世 & 四 & $\square$ & 四 & $\llbracket$ & 四 & 【 & 口 & $\square$ & $\square$ & 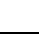 & $\square$ & $\square$ & 四 & $\llbracket$ & $\square \quad \square$ \\
\hline$\square \square \square \square$ & & पाणा & & एण & & पणा & & 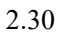 & & पाण & & $\square \square$ & & पाए & & $\square \square \square$ \\
\hline प००० & & 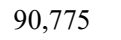 & & एणा & & एणा & & पाण & & एणा & & एणा & & पणा & & $\square \amalg$ \\
\hline$\square \mathbb{Q} \square \square \square \square$ & & 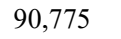 & & पण口 & & एणा & & $\square \square$ & & $\square \square$ & & पणा & & पाण & & $\square \amalg$ \\
\hline$\square \square \square \square$ & & 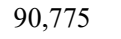 & & पाण & & पणा & & $\square$ & & $\square$ & & $\square$ & & $\square$ & & $\square$ \\
\hline$\square \square \square \square$ & & 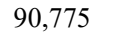 & & पाण & & पणा & & $\square \square \square$ & & $\square \square \square$ & & $\square \square$ & & पाए & & $\square \amalg$ \\
\hline 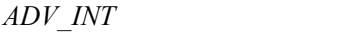 & & 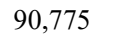 & & पाण & & एणा & & $\square ण \square$ & & $\square \square$ & & एणा & & पणा & & $\square \square$ \\
\hline 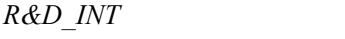 & & 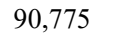 & & पण口 & & एणा & & $\square \square$ & & $\square \square$ & & पणा & & पाण & & $\square \amalg$ \\
\hline$\square \square \square \square \square \square$ & & पाणम & & $\square \square$ & & एणा & & 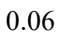 & & पणा & & 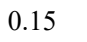 & & पणा & & $\square \square$ \\
\hline 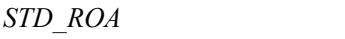 & & 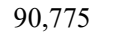 & & पाप & & पणा & & $\square \square \square$ & & $\square \square \square$ & & $\square \square$ & & पाए & & 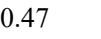 \\
\hline 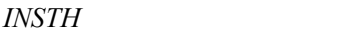 & & $\square \square \square \square$ & & $\square \square$ & & $\square \square$ & & $\square \square \square$ & & $\square \square \square$ & & $\square \square \square$ & & पाए & & 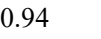 \\
\hline 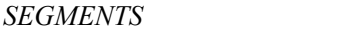 & & 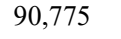 & & पाए & & पाए & & $\square[11$ & & 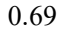 & & पाणा & & पाणा & & $\square$ पाI \\
\hline 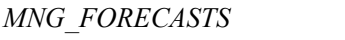 & & 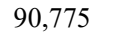 & & 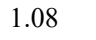 & & पाए & & $\square$ & & $\square$ & & $\square$ & & $\square$ & & $\square$ \\
\hline 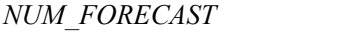 & & $\square \square \square \square$ & & पाण & & पाए & & $\square$ & & $\square$ & & $\square$ & & $\square$ & & $\square$ \\
\hline \begin{tabular}{ll|l|l|l|l|l|} 
\\
\end{tabular} & & 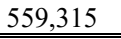 & & 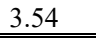 & & 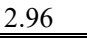 & & $\square$ & & $\square$ & & $\square$ & & $\square$ & & $\square \square$ \\
\hline
\end{tabular}

\section{Panel B: Summary Statistics by Life Cycle Stage}

\begin{tabular}{|c|c|c|c|c|c|c|}
\hline पपाणाणा & $\square \square \square|ण| \square$ & 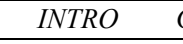 & 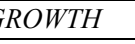 & $\square \square \square(\square \square \square \square$ & 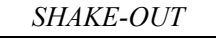 & 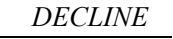 \\
\hline 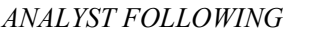 & पाए & पाए। & $\square \square$ & पण口 & पाए & पणा। \\
\hline 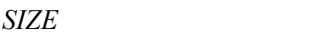 & $\square \square \square$ & 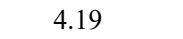 & $\square \square \square$ & 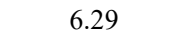 & पाए & $\square \square \square$ \\
\hline प्र०० & पाण & पाण & $\square \square \square$ & 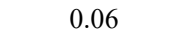 & एण口 & पाण \\
\hline 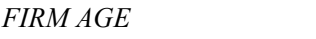 & 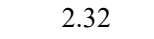 & $\square \square \square$ & $\square \square$ & पा। & पाए & पणा। \\
\hline$\square \square \square$ & $\square ण 1$ & पण口 & पणा & पण口 & एणा & 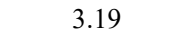 \\
\hline 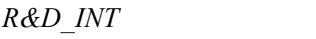 & $\square \square$ & $\square \square \square$ & पाए & पाए & 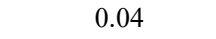 & 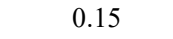 \\
\hline 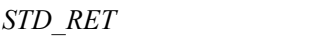 & $\square \square \square$ & 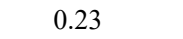 & $\square \square$ & 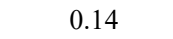 & $\square \square \square$ & 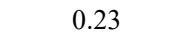 \\
\hline$\square \square$ & ए पापापा & $\ulcorner\square \mid \square ा \square \square$ & 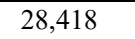 & $\square \| \square \square$ & 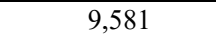 & 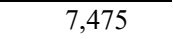 \\
\hline$\square \square \square \square \square \square \square$ & $\sqsubset \square\|\| \| \square$ & $\sqsubset \square \| \square \square \sqsubset \square$ & $\square\|\| \square \square$ & $\ulcorner\quad \square \mid \square \square \square$ & $\square ा \| \square \square$ & $\square \square \square \square$ \\
\hline
\end{tabular}




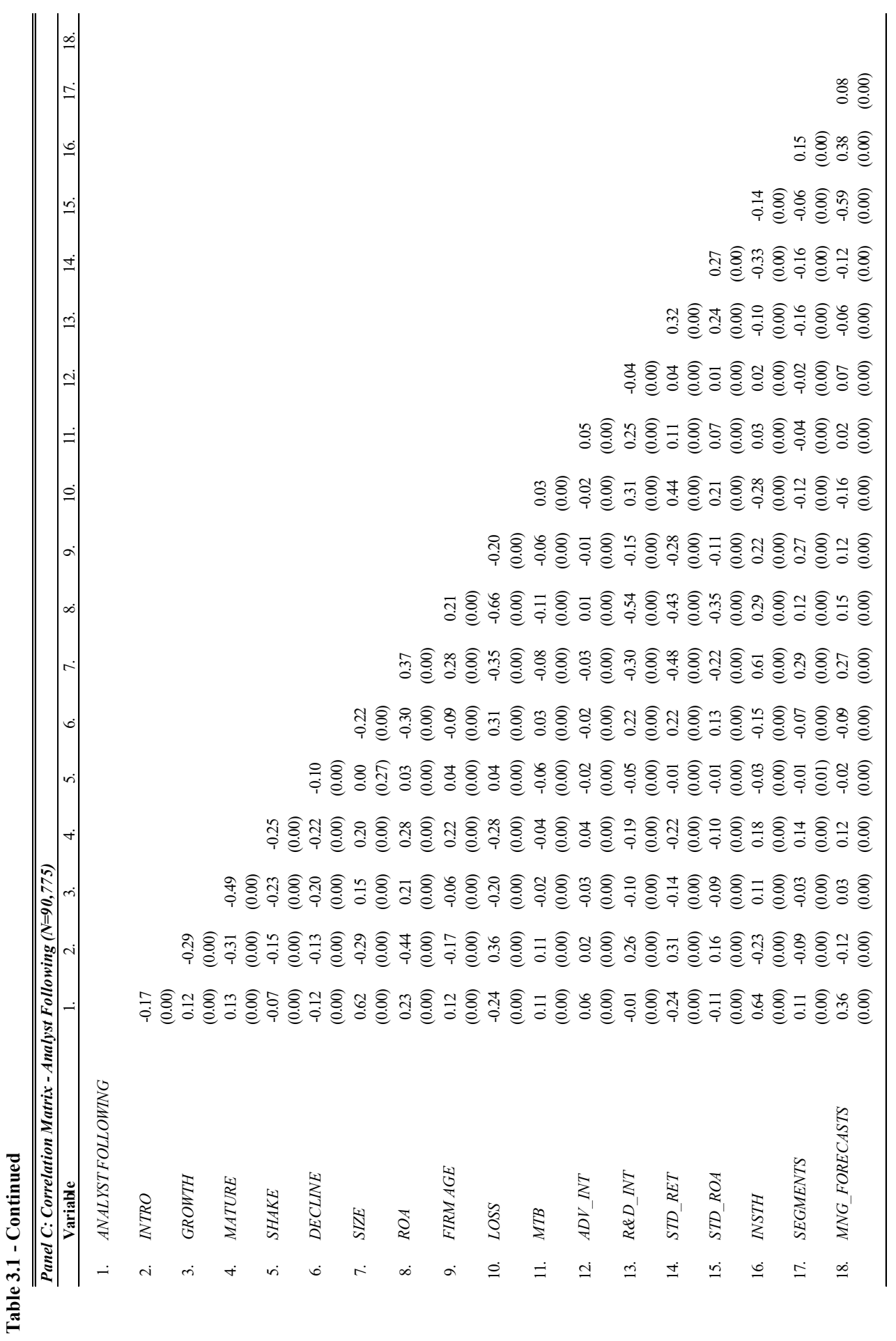




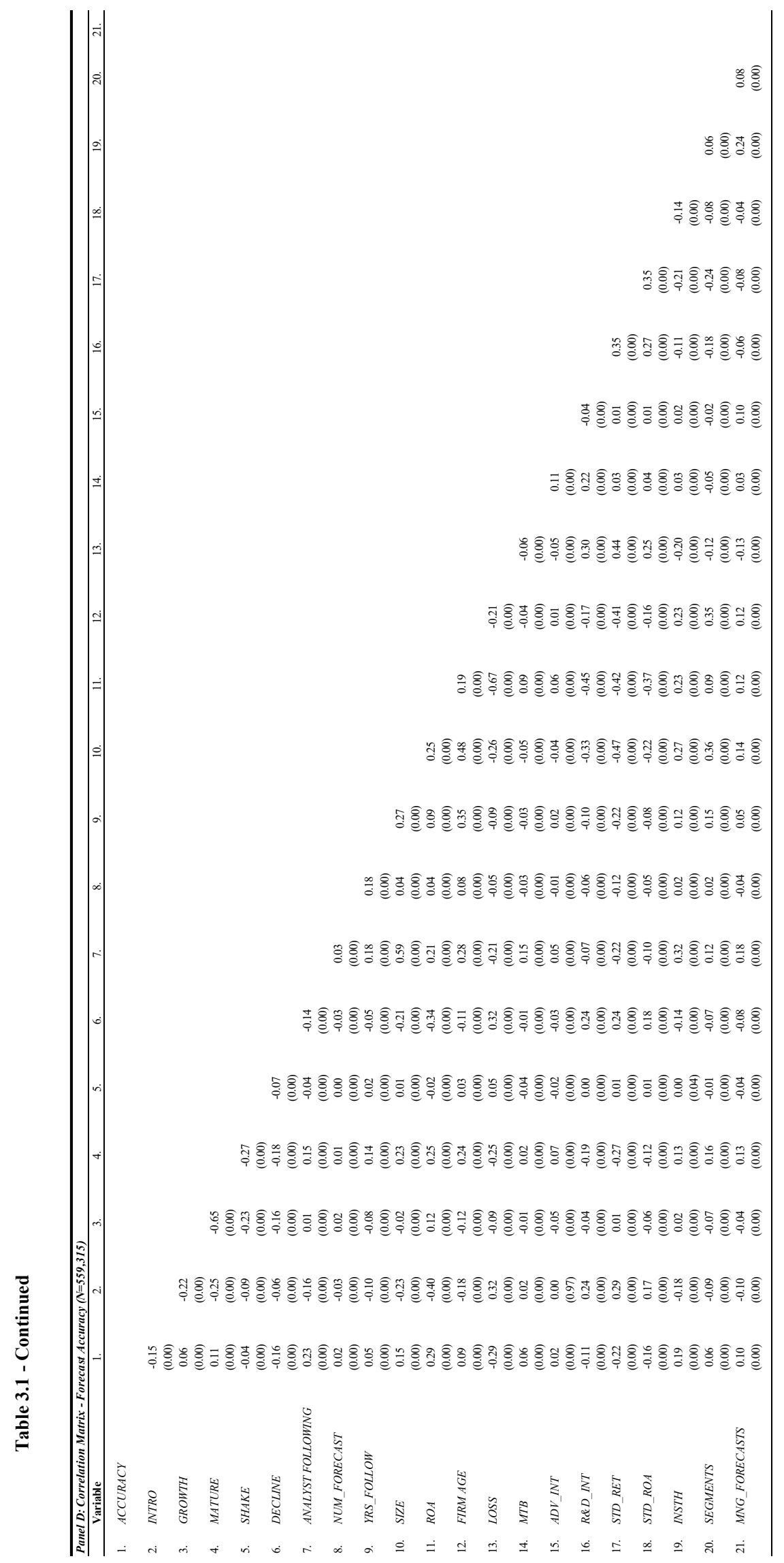




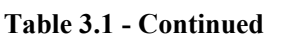

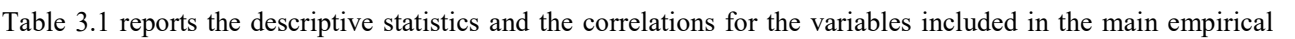

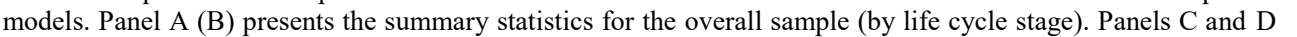

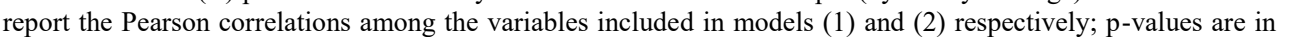

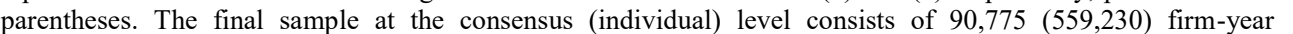

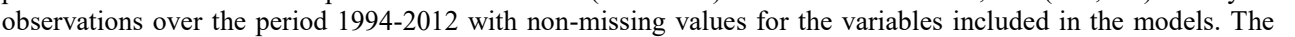

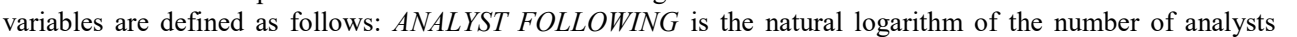

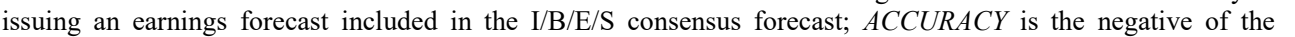

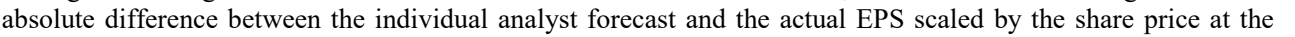

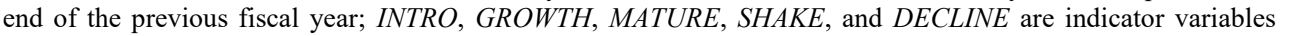
(1)

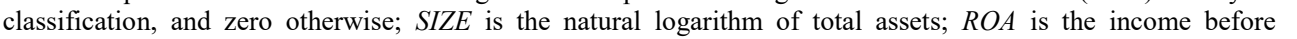

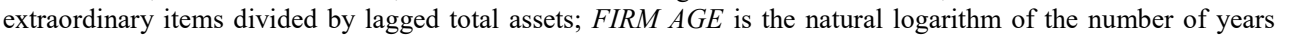

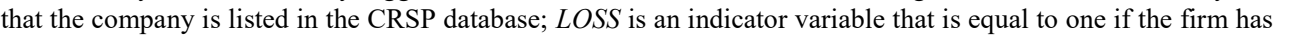

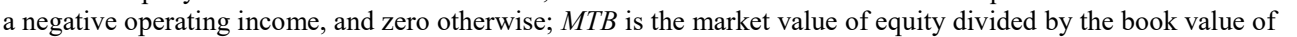

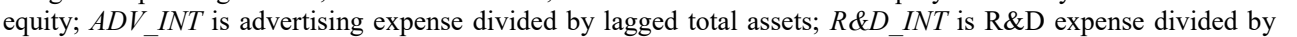
ए

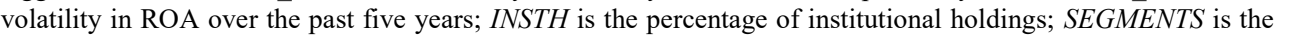

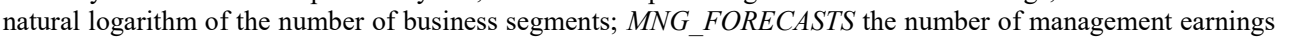

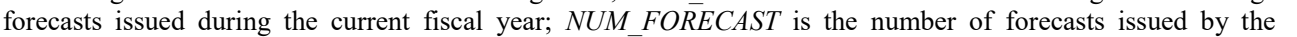

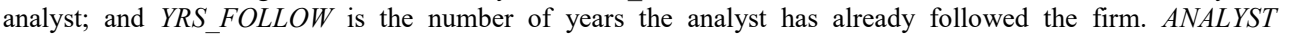

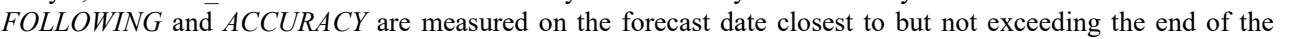

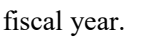

$\square$

$\square$

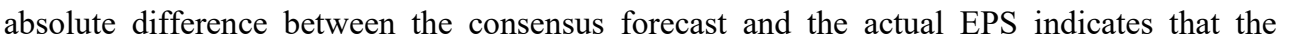

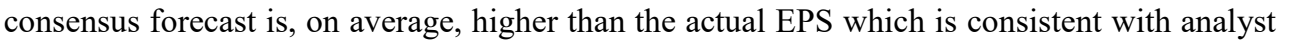

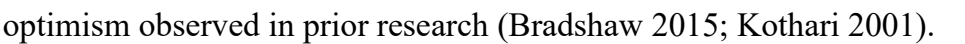

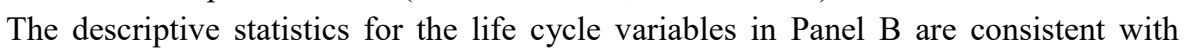

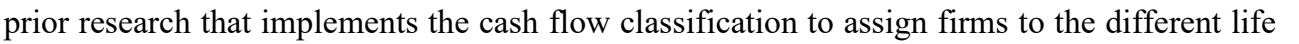

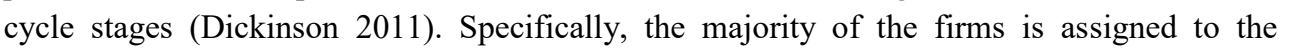

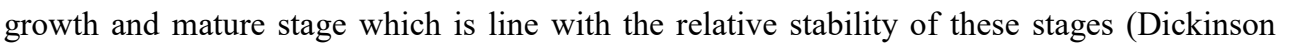

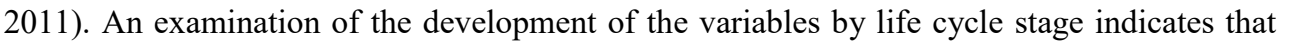

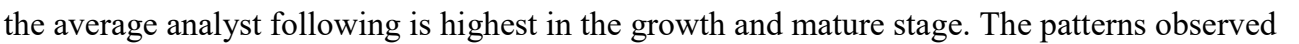
for the other variables across life cycle stages provide support for the validity of Dickinson's

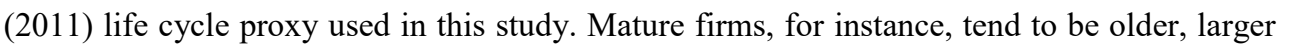

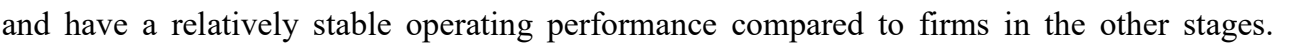
\begin{aligned} \hline \\ \hline\end{aligned}

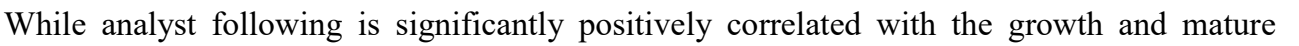

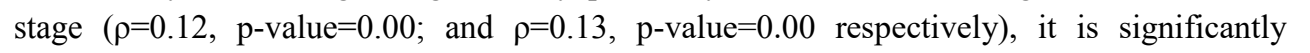

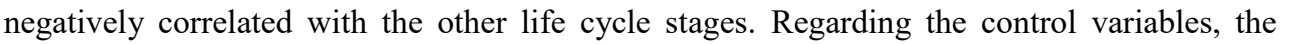

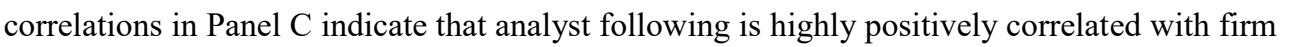

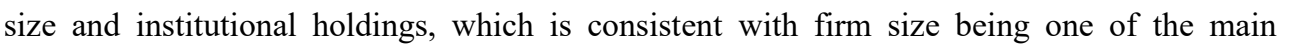

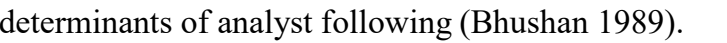

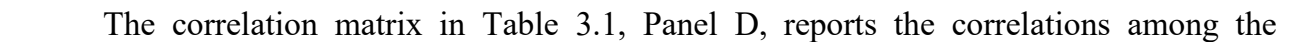

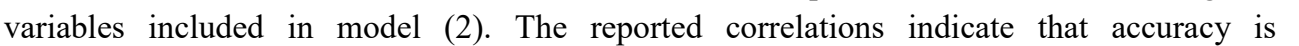
significantly positively correlated with the growth and mature stage $(\rho=0.06, p \square|\Pi| \square \square \square \square$

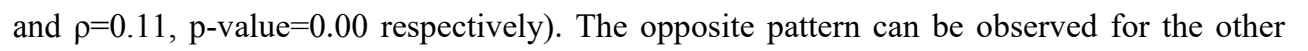

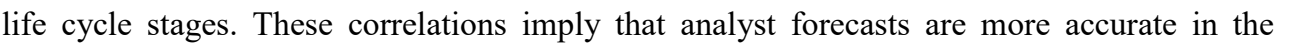

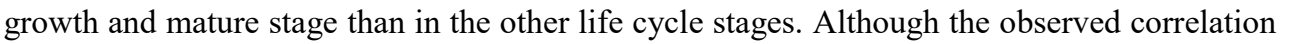




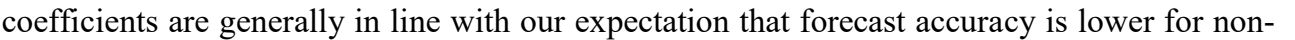

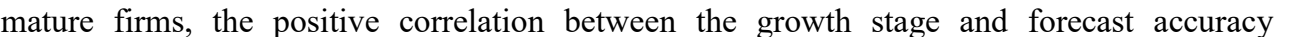

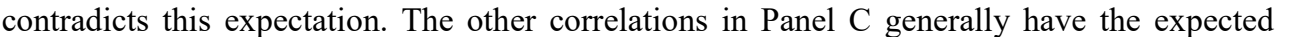

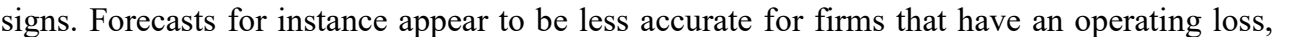

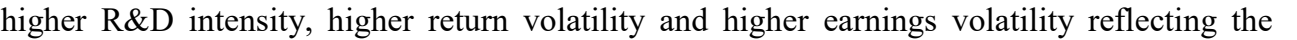

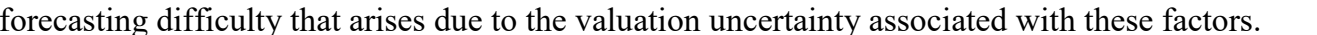
$\square$

$\square$

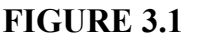

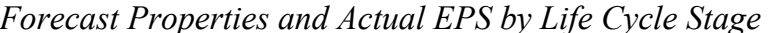

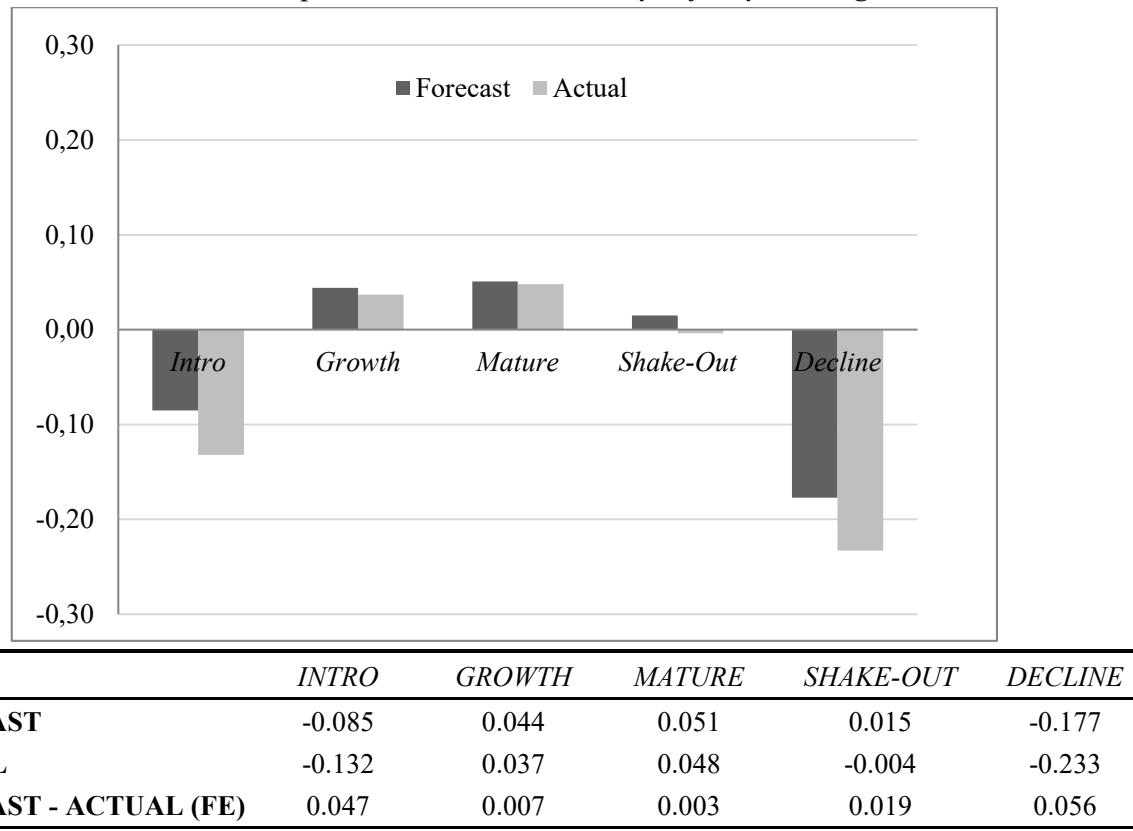

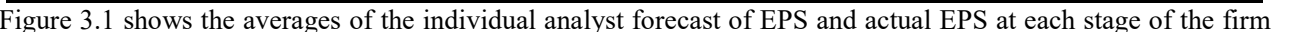
|

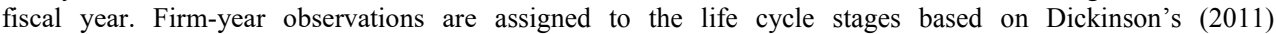

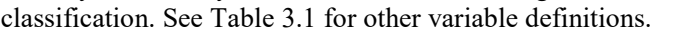
$\square$

$\square$

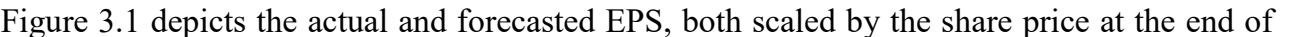
प

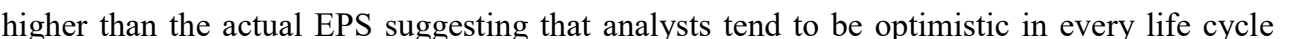

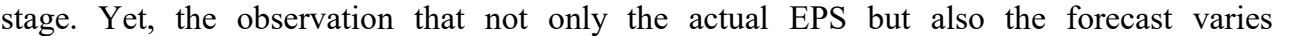

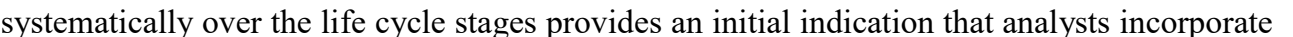

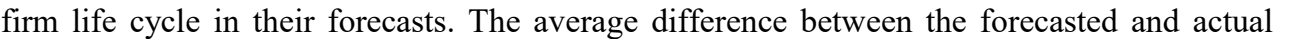

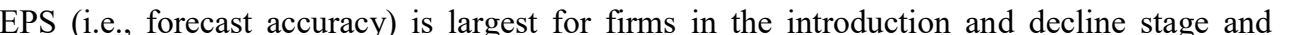

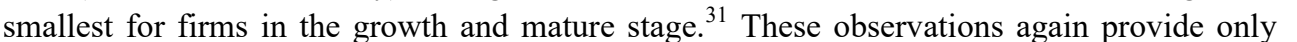

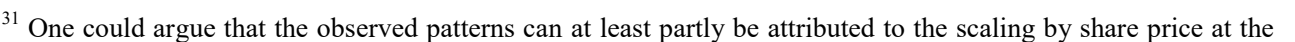

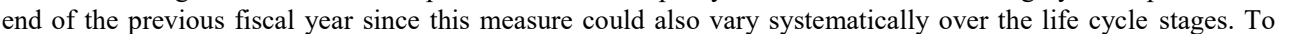




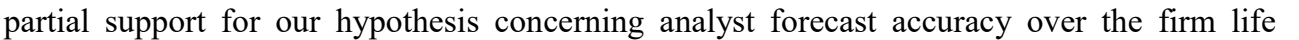

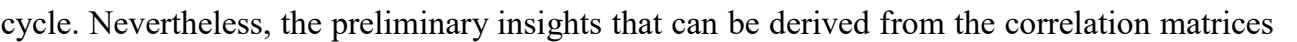

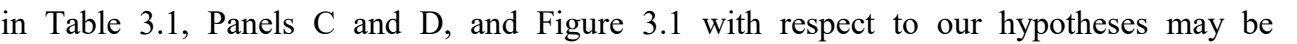

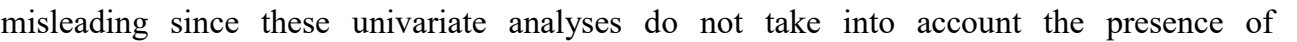

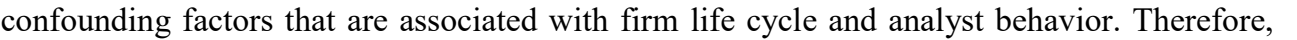

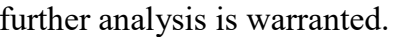

$\square$

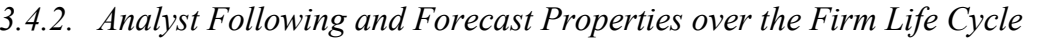

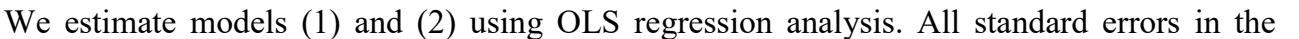

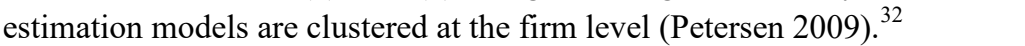

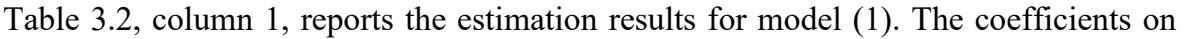

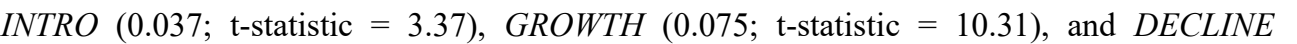
ए

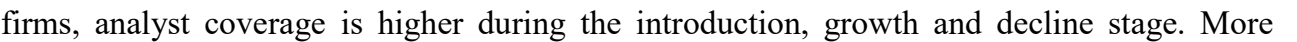

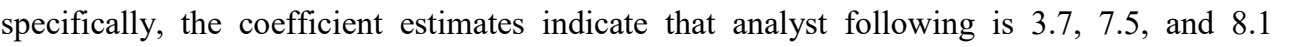

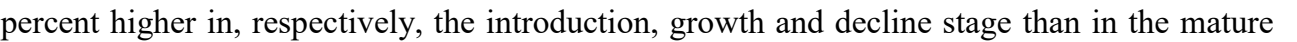

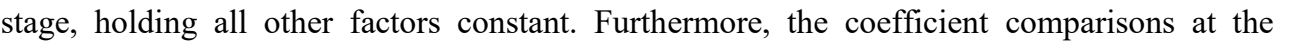

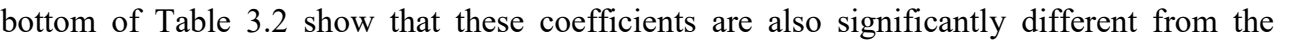

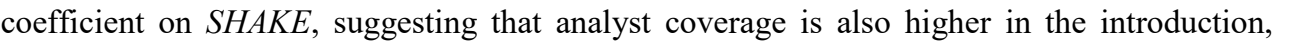

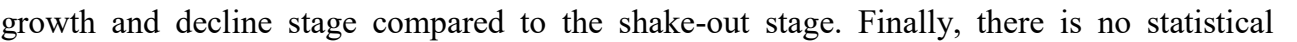

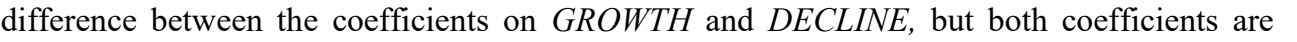

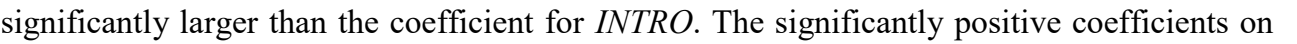

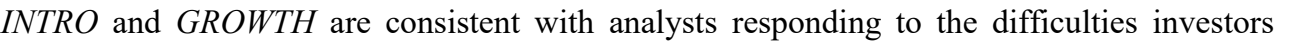

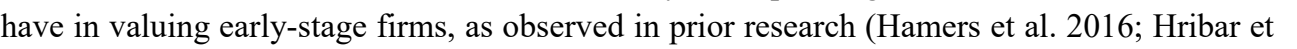

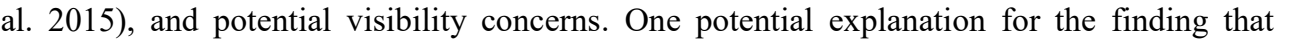

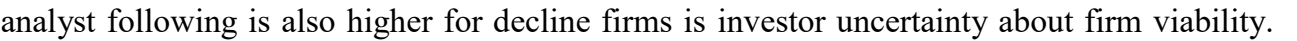

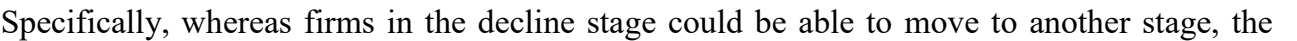
ए

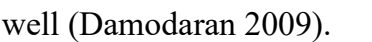

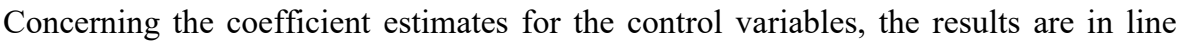

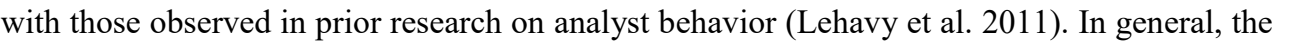

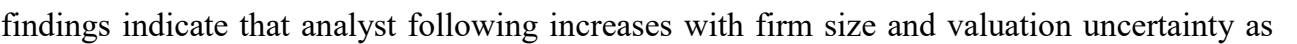

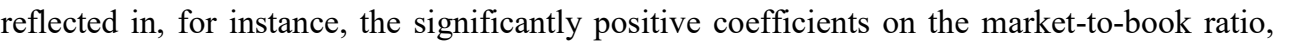

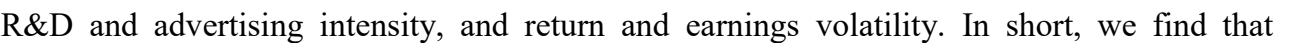

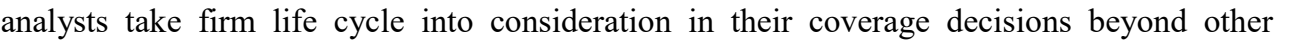

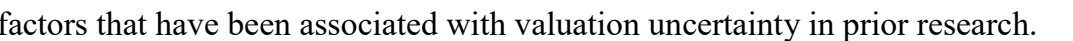

$\square$

$\square$

$\square$

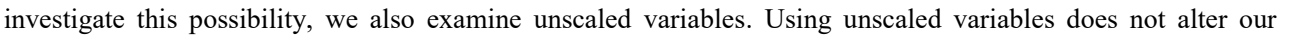

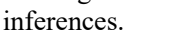

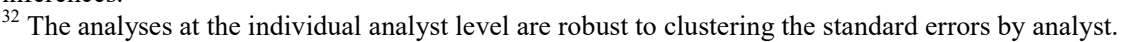




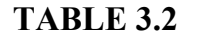

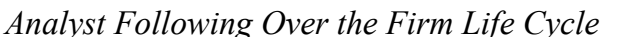

\begin{tabular}{|c|c|c|}
\hline \multirow{2}{*}{ 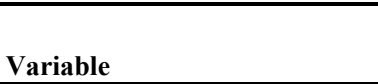 } & \multicolumn{2}{|c|}{ 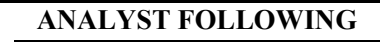 } \\
\hline & पाII & पाणा \\
\hline \multirow[t]{2}{*}{ एविएव } & $\square \square 11111$ & 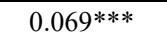 \\
\hline & पाणाய & पापाण \\
\hline \multirow[t]{2}{*}{ 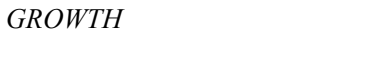 } & एवाओाए & पाणाए \\
\hline & एणाणाण & एणाण \\
\hline \multirow[t]{2}{*}{ प } & एणाए & एणा।ाए \\
\hline & 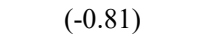 & पण口卄ा \\
\hline \multirow[t]{2}{*}{ 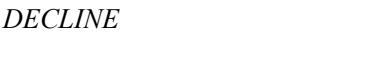 } & एणा1ाए & एणा11 \\
\hline & एवाण & पण口卄ाण \\
\hline \multirow{2}{*}{ 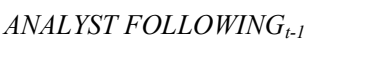 } & & एणाएए \\
\hline & & 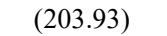 \\
\hline \multirow[t]{2}{*}{$\square \square \square \square$} & पणाएाए & 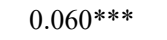 \\
\hline & एणाण & एणाய \\
\hline \multirow[t]{2}{*}{$\square \square \square \square$} & पाणाए & पणागाए \\
\hline & एणाणाण & पापाएा \\
\hline \multirow{2}{*}{ 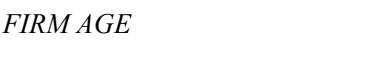 } & एणाणा & एणाएा \\
\hline & पण口णाए & एणाणाण \\
\hline \multirow[t]{2}{*}{ प्माए } & पणाएा & पाणा1ाए \\
\hline & पणाणा & पण口卄ाण \\
\hline \multirow[t]{2}{*}{$\square \square \square$} & पणाएा & पणाएा \\
\hline & एवाणाए & पाणाए \\
\hline \multirow[t]{2}{*}{ 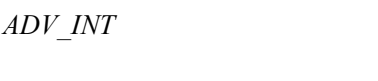 } & पाणाणा & पाणाणा \\
\hline & 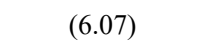 & एणाए \\
\hline \multirow[t]{2}{*}{ 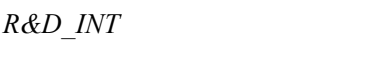 } & पणाएाए & पालाएा \\
\hline & एाणाए & एणाएण \\
\hline \multirow[t]{2}{*}{ 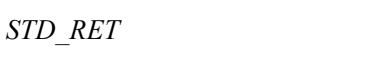 } & पणाएाए & पालाएा \\
\hline & पाणाण & पाणाण \\
\hline \multirow{2}{*}{ 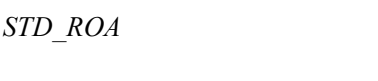 } & एणाणाए & पणाणाए \\
\hline & एणाए & एणाए \\
\hline \multirow[t]{2}{*}{ प्राप्र } & पणामाए & पणाएा \\
\hline & एवाणाण & एणाயण \\
\hline \multirow[t]{2}{*}{ 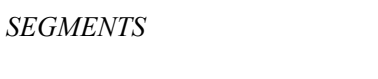 } & யणाणा & खणाणा \\
\hline & एणाणाण & पणाणा \\
\hline \multirow[t]{2}{*}{ 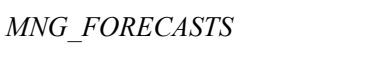 } & पणामाप & पाणामाप \\
\hline & एापाणा & एणाणा \\
\hline \multirow[t]{2}{*}{ 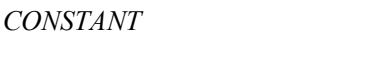 } & एवापाए & एापायाए \\
\hline & एणाणा & पण口卄ा \\
\hline 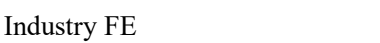 & $\square \square \square \square$ & $\square \square \square \square$ \\
\hline 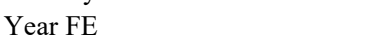 & $\square \square \square$ & $\square \square \square \square$ \\
\hline 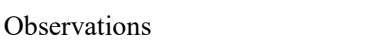 & पाणा & पण口 \\
\hline 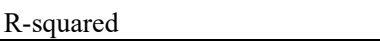 & पाणप्र & 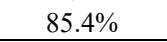 \\
\hline 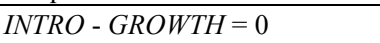 & 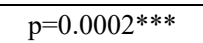 & पापामाप \\
\hline 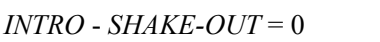 & $\square \square\|ा\| \square$ & पमाणाएा \\
\hline 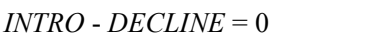 & 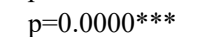 & एवाणाए \\
\hline 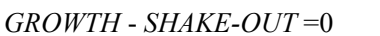 & पाणाणापा & पणाणाएा \\
\hline 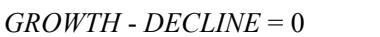 & पाणाणा & एवाणाए \\
\hline 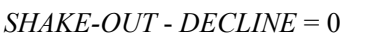 & पापाणाापा & पाणाणा \\
\hline
\end{tabular}

$\square$ 


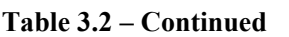

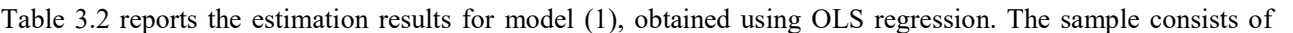

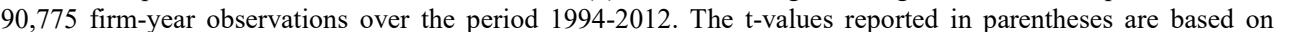

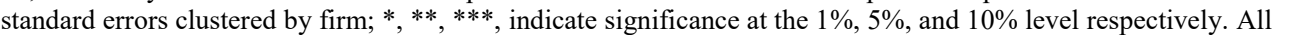

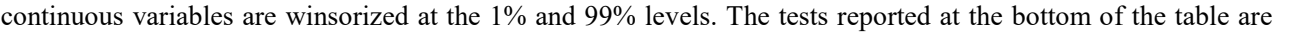

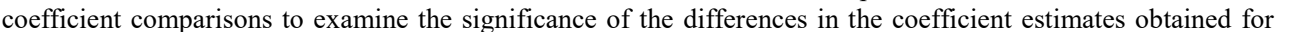

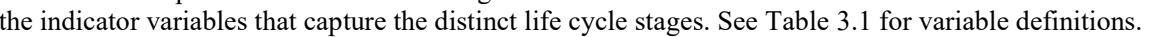

$\square$

$\square$

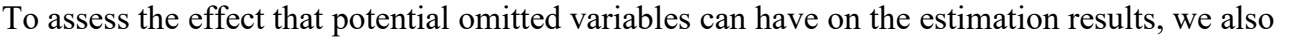

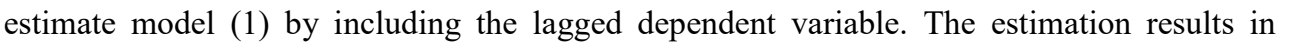

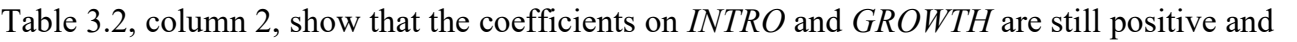

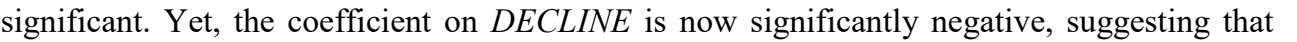
ए

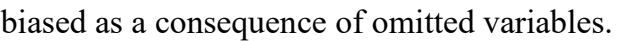

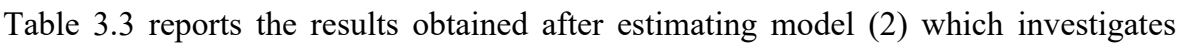

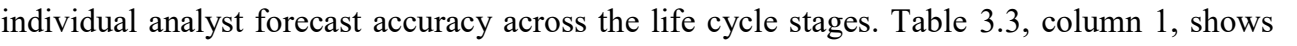

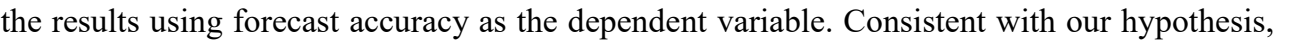

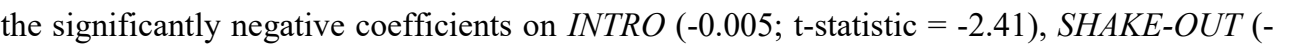

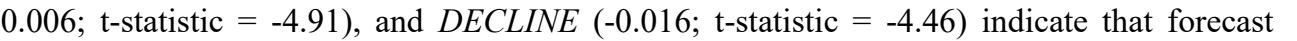

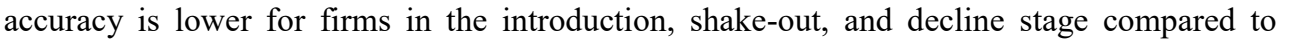

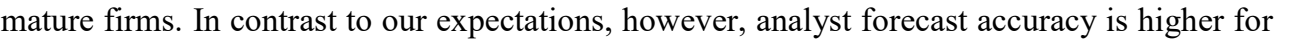

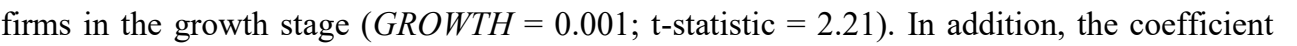

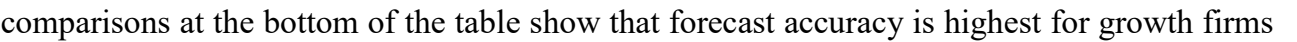

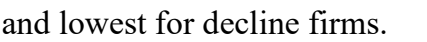

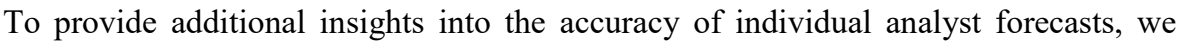

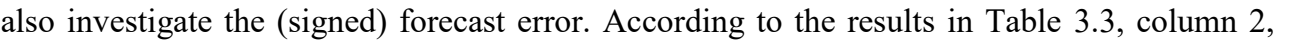

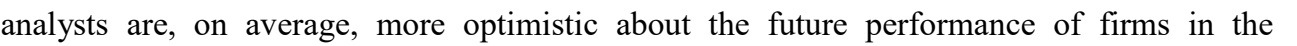
प एव

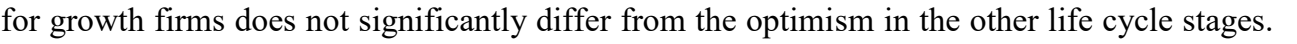

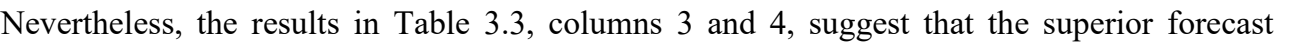

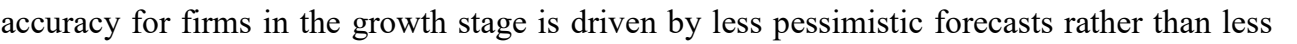

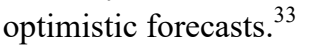

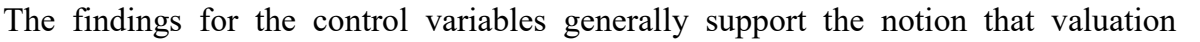

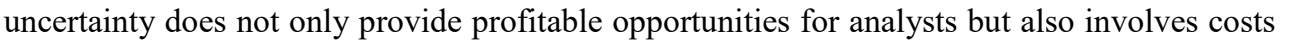

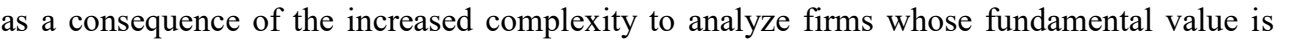

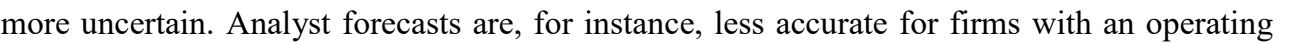
ए ए

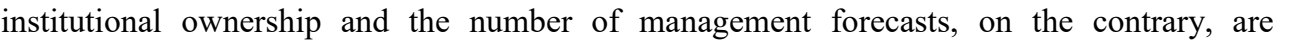

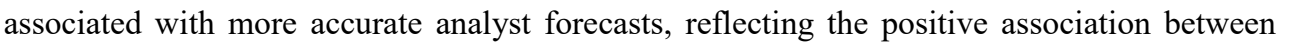

\section{analyst performance and firms' information environments (Lang et al. 1996). $\square$}

$\square \quad \square$

$\square$

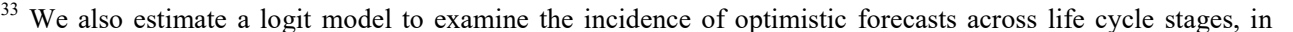

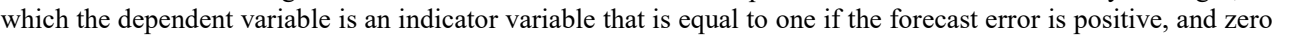

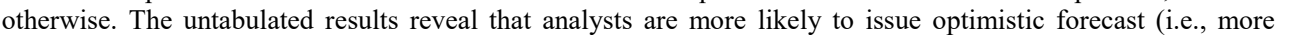

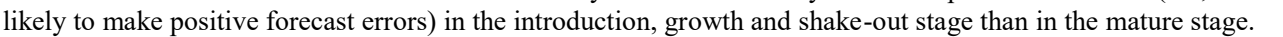




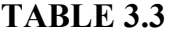

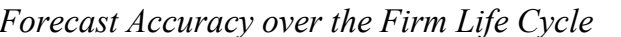

\begin{tabular}{|c|c|c|c|c|c|c|c|c|c|}
\hline 四 & $\square$ & & & 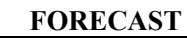 & II) & 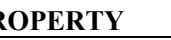 & & & 四 \\
\hline & & $\square 10$ & & $\square$ & & $\mathbb{\square} 1 \mathbb{1}$ & & पा山 & \\
\hline 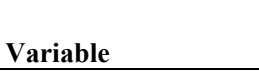 & $\square$ & 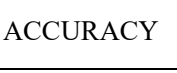 & $\square$ & 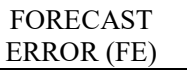 & $\mathbb{1}$ & 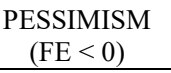 & $\mathbb{Z}$ & 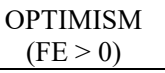 & 四 \\
\hline 맘ㅁ & & एाणापा & & 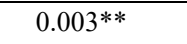 & & 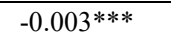 & & 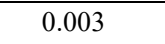 & \\
\hline & & पणाणाए & & पाणापा & & पण口ापा & & पाणाए & \\
\hline प्व०००० & & पाणामा & & पाम & & पागामा & & एणाए & \\
\hline & & एणाए & & एणाए & & पाणा & & पणाएा & \\
\hline 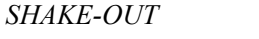 & $\sqcap$ & पाणम|णमा & & पाIIDा & & पामामाम & & पामामा & \\
\hline & & पण口冋ए। & & पाणा10 & & पण口冋ाए & & पाणाए & \\
\hline 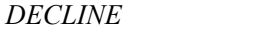 & $\sqcap$ & पामामाम & & पणामा & & पाणामाप & & पामामा & \\
\hline & & एणाएा & & एणाएा & & एणाएा & & पाणाए & \\
\hline 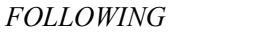 & & पामामा & & पणमापा & & एवामाए & & पाणामा & \\
\hline & & एापाए & & एणाणाए & & पापाए & & एणाणाए & \\
\hline 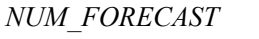 & & पामापा & & एामाए & & पणमापा & & पामामा & \\
\hline & & पाणाए & & पण口卄ा1 & & पापापा & & पणाणा & \\
\hline 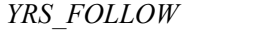 & & पापमामा & & पापामा & & पापामाम & & पाएा1ए & \\
\hline & & एणाएा & & एणाएा & & एणाएा & & एणाएा & \\
\hline 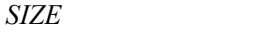 & $\sqcap$ & पामामामा & & पामामा & & घमामामा & & पामामा & \\
\hline & & पण口ाप & & पण口卄ा1 & & पण口冋ाए & & एवापा & \\
\hline प००० & $\sqcap$ & पामामा & & 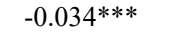 & & पामाप & & पाणमापए & \\
\hline & & पाणाए & & पण口णाए & & पाणाए & & पण口冋ाए & \\
\hline 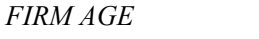 & $\sqcap$ & पापामापा & & पामा|म & & घणम|णमा & & पामापा & \\
\hline & & पण口冋ाए & & पण口ाप & & पण口冋|ण & & पाणाए & \\
\hline प०णा & & 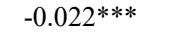 & & पामा|म & & एवाण|मा & & पामापा & \\
\hline & & पण口|णा|ण & & प्माणाप & & 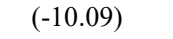 & & पापापा & \\
\hline 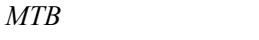 & $\sqcap$ & पामा & & 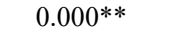 & & पामापा & & पायामा & \\
\hline & & पाणाए & & पण口卄10 & & पणा।ाप & & पण口冋ाए & \\
\hline 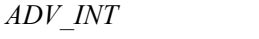 & $\sqcap$ & पाणा & & पामा|म & & पाणा & & पामा & \\
\hline & & एणाणाए & & पण口卄10 & & पणा।ाप & & पणा।ाप & \\
\hline 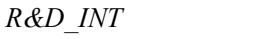 & $\sqcap$ & $\square ण \square$ & & एणामाप & & एणामाण & & पामाणम & \\
\hline & & पण口ाप & & काणा10 & & 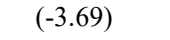 & & पण口卄ा & \\
\hline 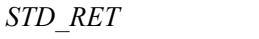 & & पाणम||मा & & पामा|म & & पापा|मा & & पामापा & \\
\hline & & पण口冋ाए & & पणा।ा & & एण|ण10 & & पणा।ाप & \\
\hline 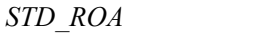 & & पाणम||मा & & पणाए & & 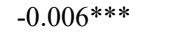 & & पणमापा & \\
\hline & & पणमाण & & पणा।ा & & एणाणा & & पाणाणा & \\
\hline 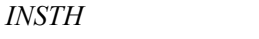 & & पामामा & & पामामा & & पामापा & & एवामाप & \\
\hline & & पण口冋|ण & & 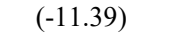 & & 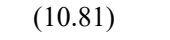 & & पण口卄10 & \\
\hline 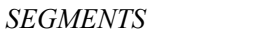 & & पणमा & & एणापाए & & 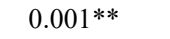 & & घणाए & \\
\hline & & 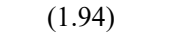 & & पण口卄ा & & पण口ाप & & पण口卄ा1 & \\
\hline 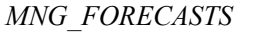 & & पामामा & & पामाप & & पामापा & & पामापा & \\
\hline & & पाणाए & & एणाणाए & & 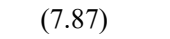 & & 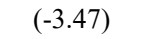 & \\
\hline 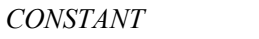 & & एणाए & & एणा & & एणाए & & पामापा & \\
\hline & & पणाणाए & & 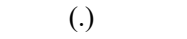 & & पण口卄ा & & ए।पाए & \\
\hline 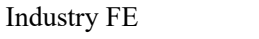 & & $\square \square \square \square$ & & $\square \square \square \square$ & & $\square \square \square \square$ & & $\square \square \square \square$ & \\
\hline पणामणन & & $\square \square \square \square$ & & $\square \square \square \square$ & & $\square \square \square \square$ & & $\square \square \square \square$ & \\
\hline 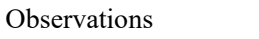 & & पाणाप & & 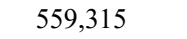 & & पाणाप & & 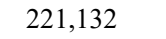 & \\
\hline पषणमाणम & & पाणिए & & 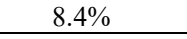 & & पाणा प & & पापि & \\
\hline$\square$ & $\square$ & $\square$ & [ & $\square$ & $\square$ & $\square$ & $\square$ & $\square$ & L \\
\hline$\square$ & $\square$ & $\square$ & ᄃ & $\square$ & $\square$ & $\square$ & $\square$ & $\square$ & \\
\hline
\end{tabular}




\begin{tabular}{|c|c|c|c|c|c|}
\hline 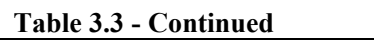 & 四 & 四 & $\mathbb{I}$ & $\mathbb{1}$ & \\
\hline 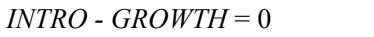 & $\square \square\|\square\| \square$ & 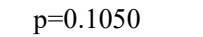 & 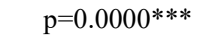 & $\square \square \square ा 11 \square$ & 四 \\
\hline 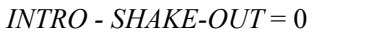 & पाणाएण & पणाणए & एवाणए & पा山ाएए & \\
\hline 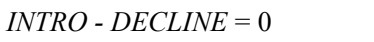 & $\square \square\|\| \| ा$ & पणागाप & पवाणापा & पाणाणापा & \\
\hline 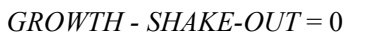 & $\square \square\|ा\| ा प$ & पाणाएम & पवाणापा & पाणाणाए & \\
\hline प्रण & $\square \square\|\| \| \square$ & पमाणाप & पवाणापा & पाणापाए & \\
\hline 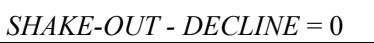 & प पायायाप & पा पाणाणा & 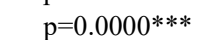 & 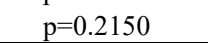 & $\mathbb{1}$ \\
\hline
\end{tabular}

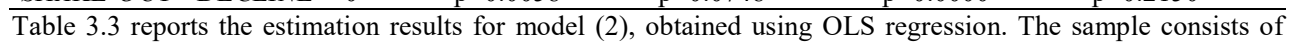

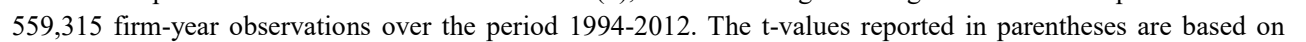

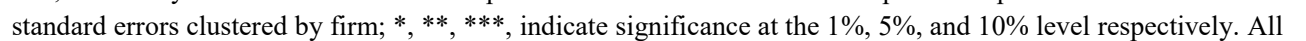

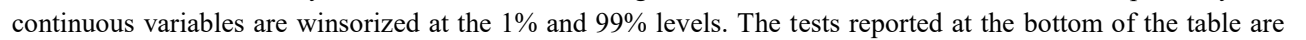
ए एव

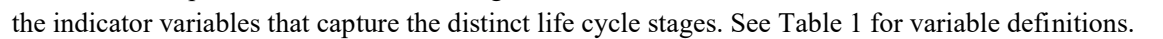
$\square$

$\square$

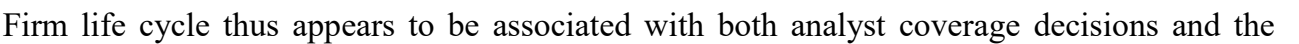

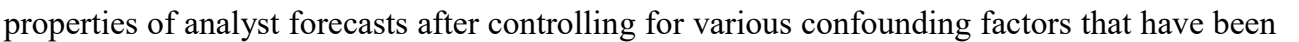

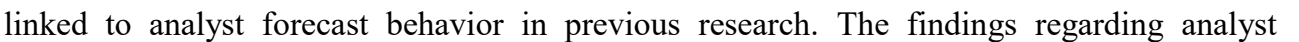

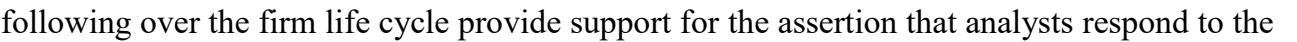

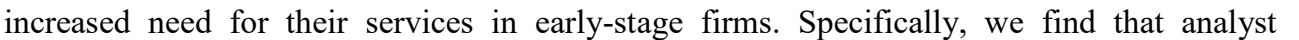

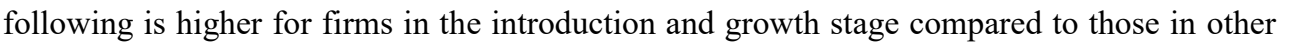

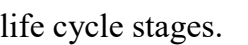

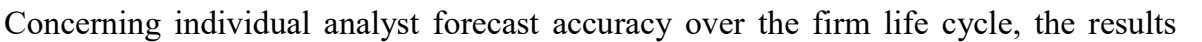

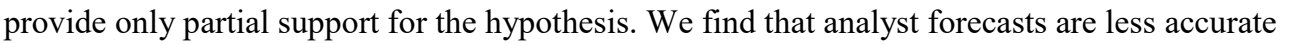
ए ए

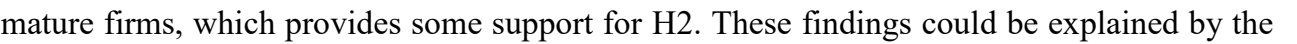

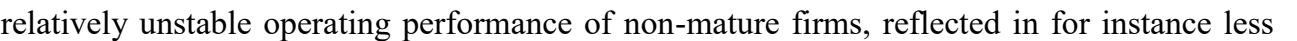

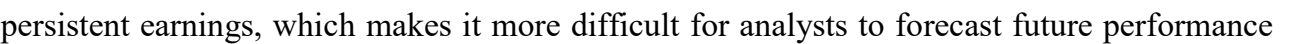

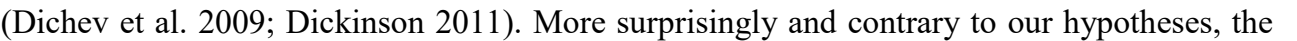

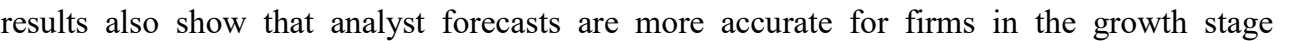

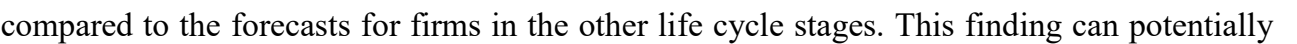

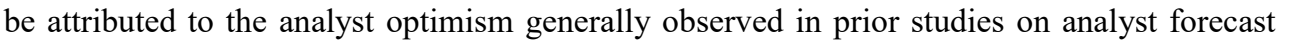

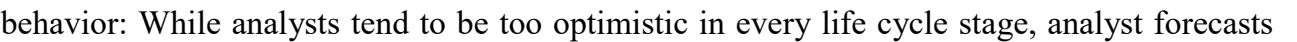

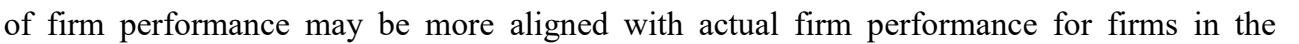

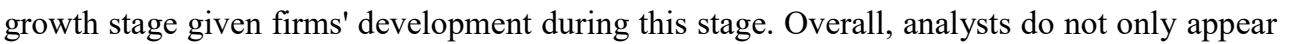
ए ए

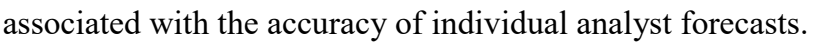

$\square$

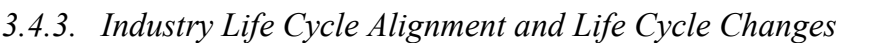

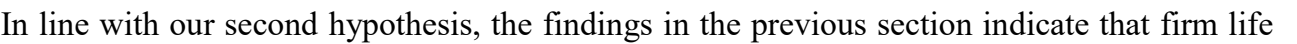

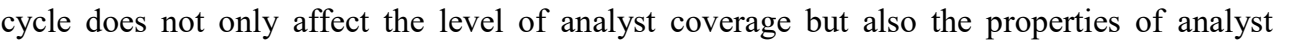

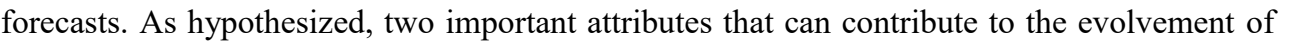

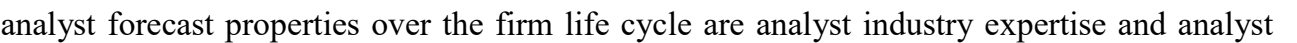

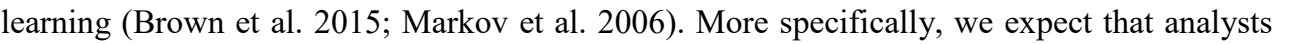

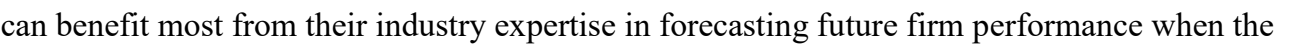

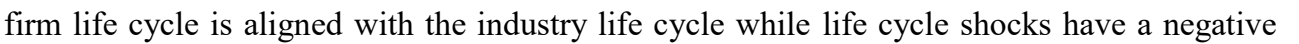




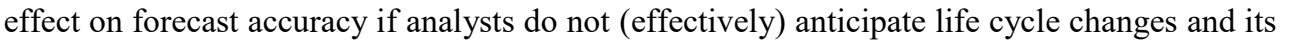

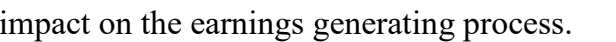

\begin{aligned} \hline \\ \hline\end{aligned}

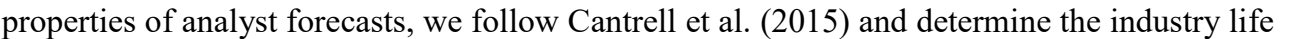

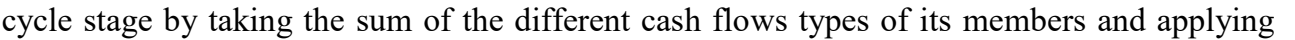

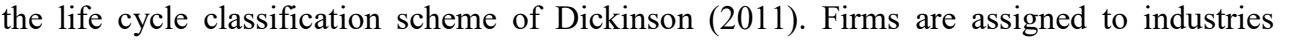

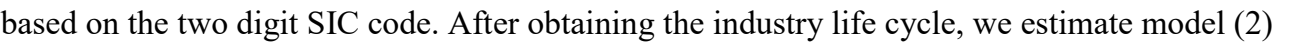

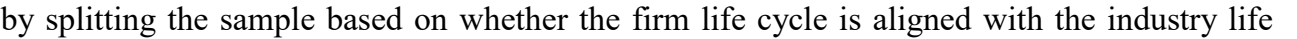

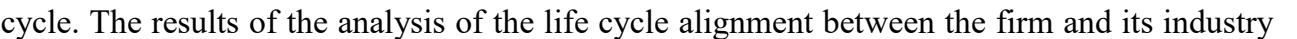

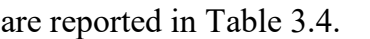

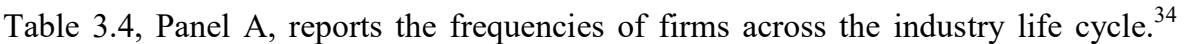

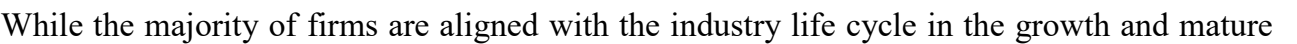

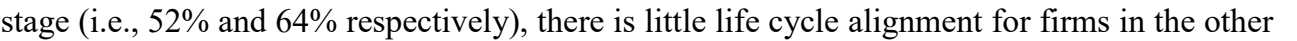

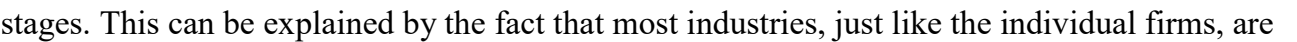

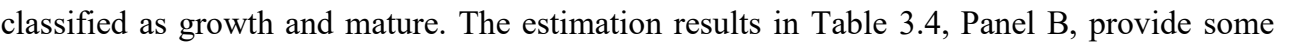

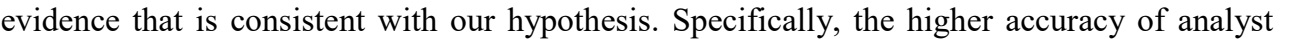

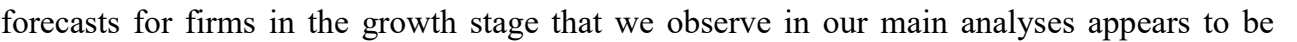

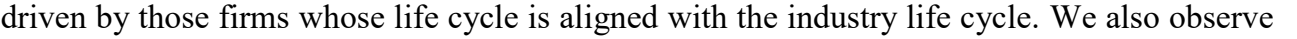
ए

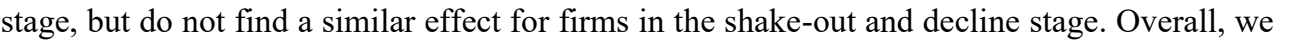

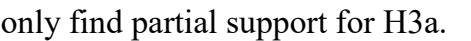

$\square$

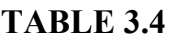

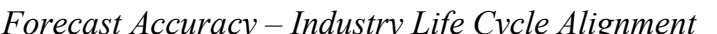

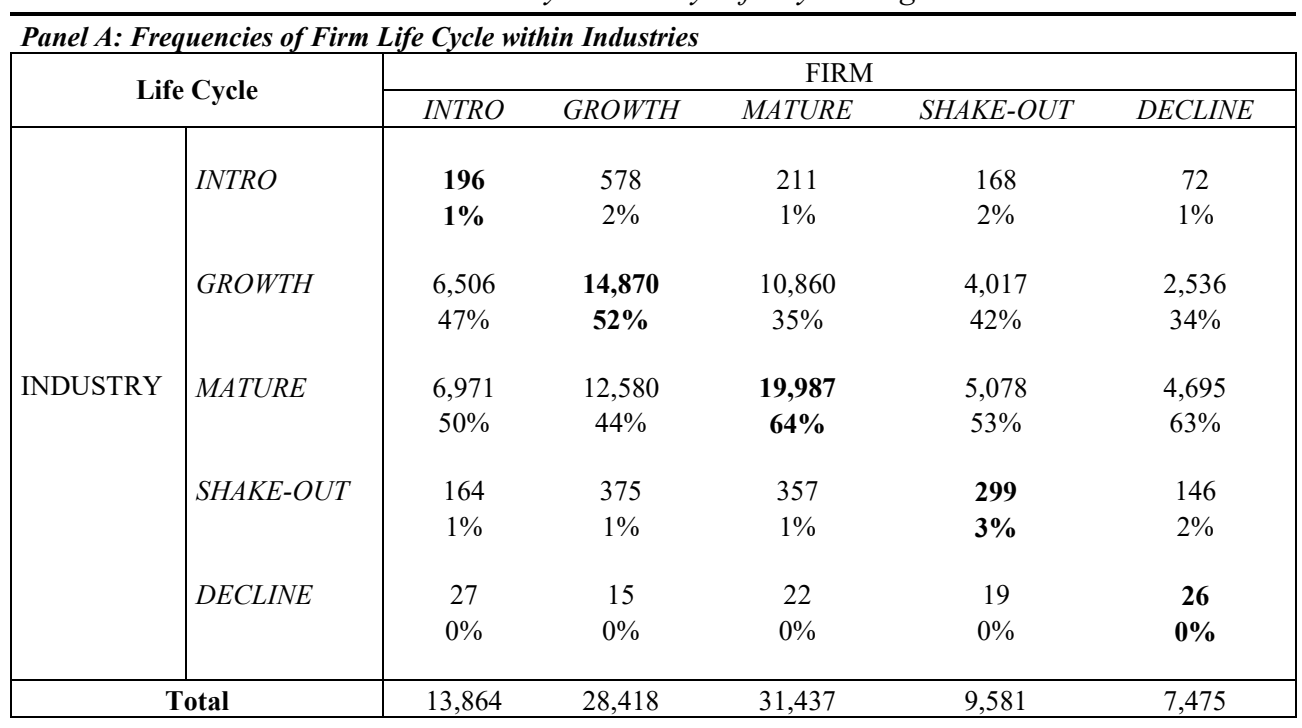

$\square$

$\square$

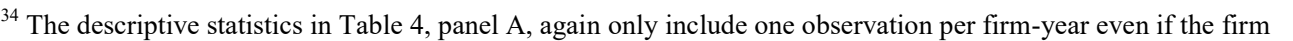

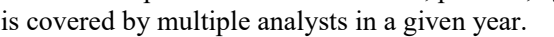




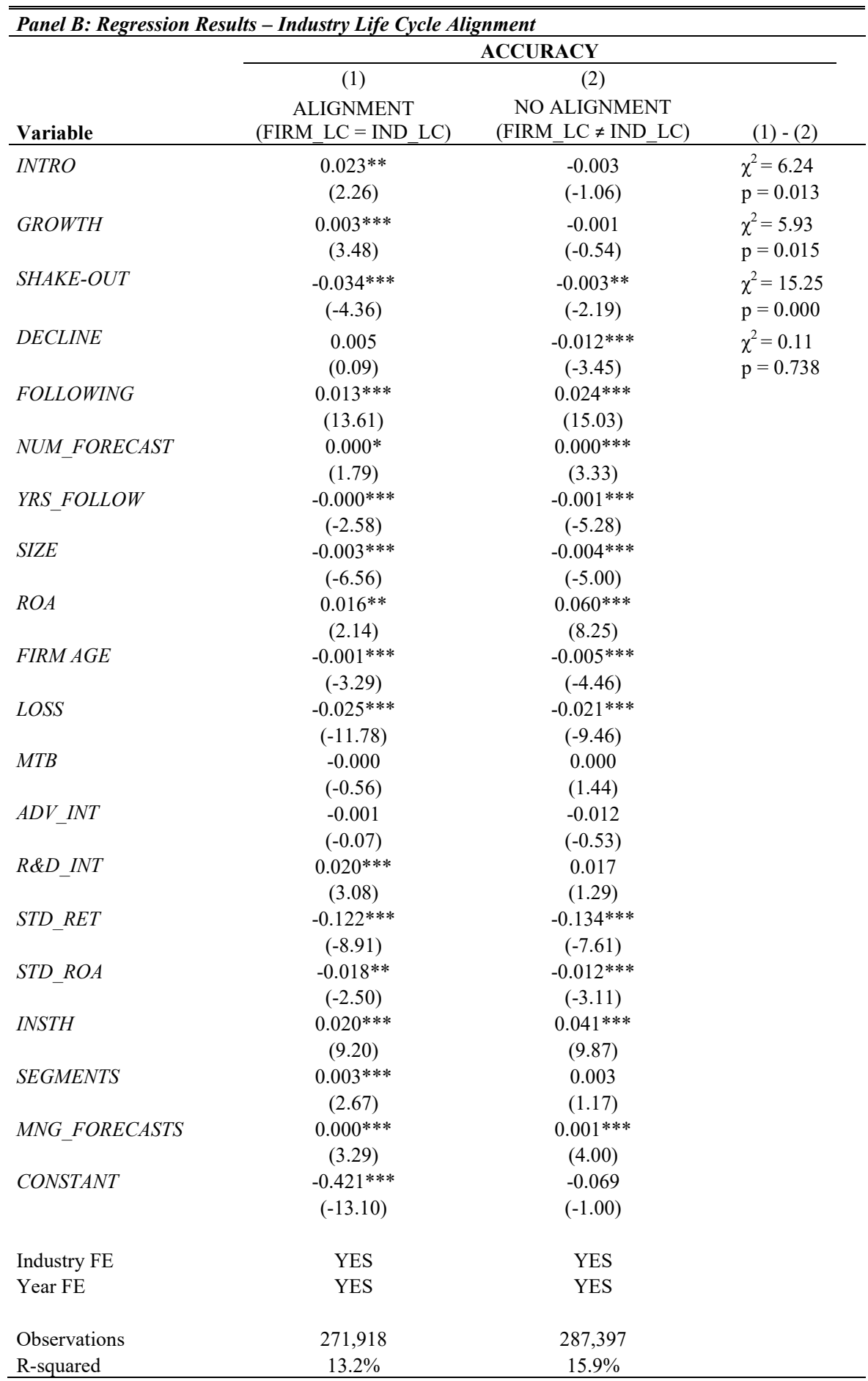




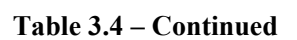

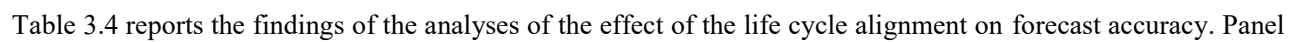
口

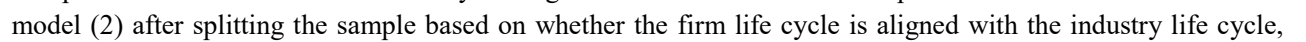

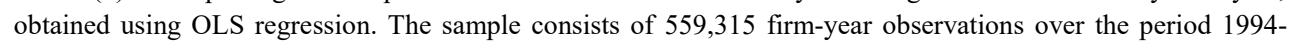
2012. Industries are assigned to the different life cycle stages based on Cantrell et al.'s (2015) cash flow

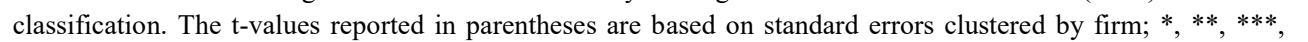

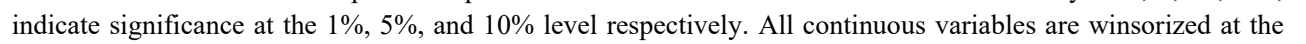

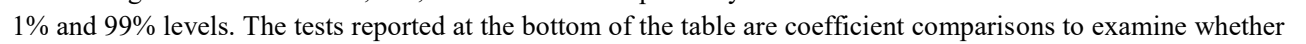

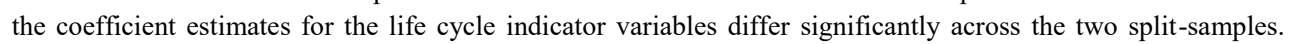

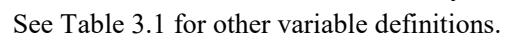

$\square$

$\square$

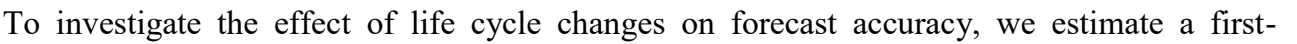

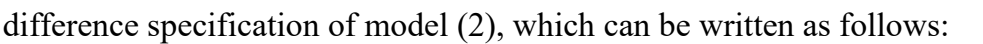
$\square$

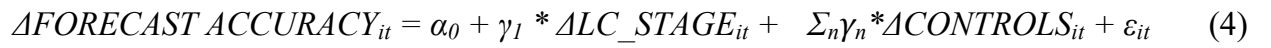
$\square$

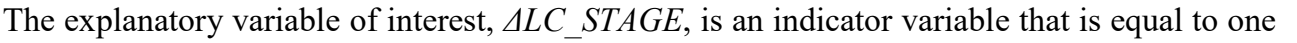

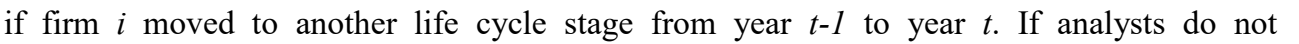

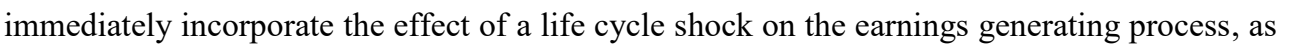

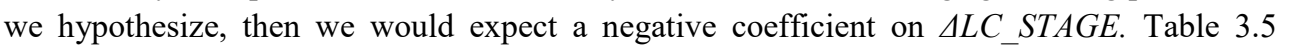
पाए पाणापाप्या

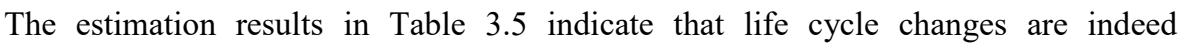

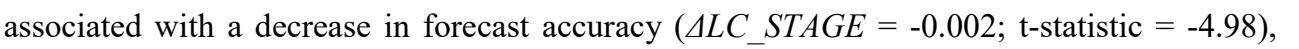

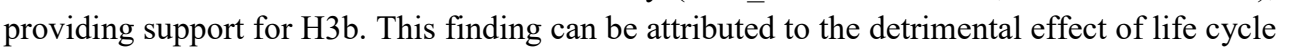
changes on analysts' ability to learn about the parameters underlying the earnings process at

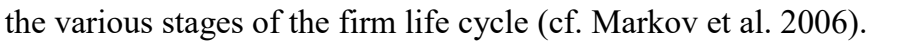

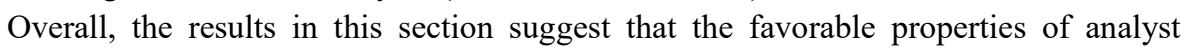

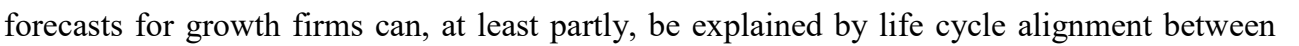

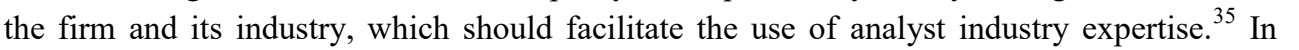

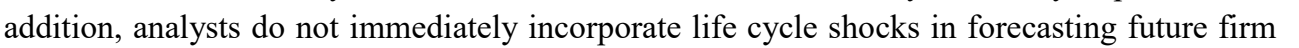

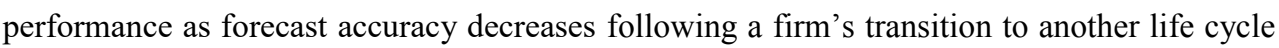
पाणाण

$\square$

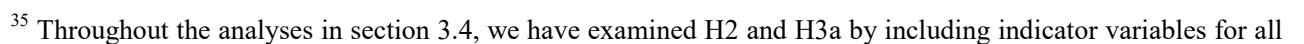

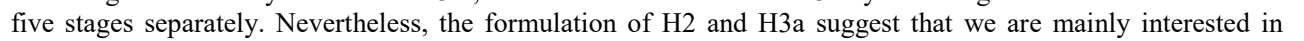

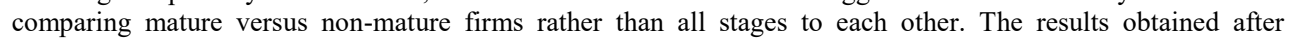

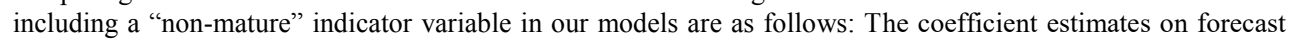

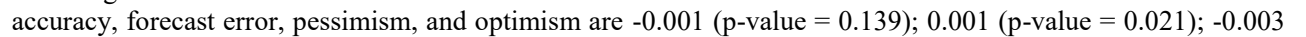
ए एव

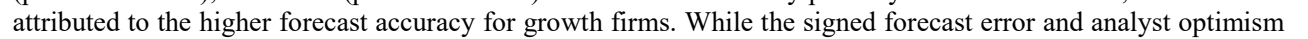

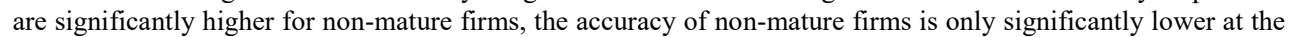

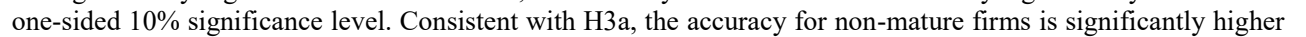

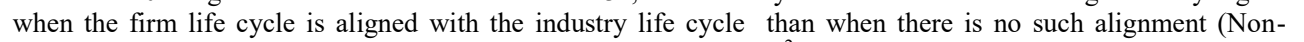

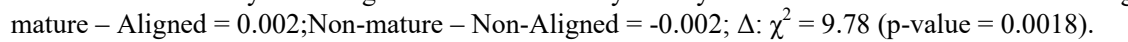




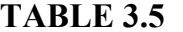

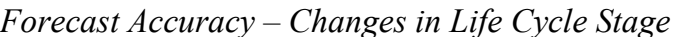

\begin{tabular}{|c|c|}
\hline 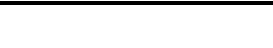 & 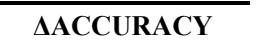 \\
\hline 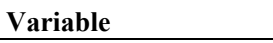 & 마 \\
\hline$\triangle L C \_S T A G E \square$ & 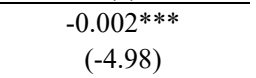 \\
\hline$\triangle F O L L O W I N G \square$ & $\begin{array}{l}\text { पणाПए } \\
\text { एणाएण }\end{array}$ \\
\hline$\triangle N U M_{-} F O R E C A S T \square$ & 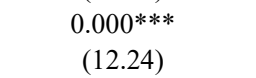 \\
\hline$\triangle S I Z E \square$ & $\begin{array}{l}\text { पागाणा } \\
\text { एणाणा }\end{array}$ \\
\hline$\triangle R O A \square$ & $\begin{array}{l}\text { पाणाएा } \\
\text { एणाणा }\end{array}$ \\
\hline$\triangle F I R M A G E \square$ & 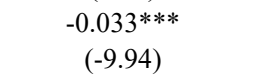 \\
\hline$\triangle L O S S \square$ & 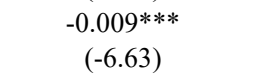 \\
\hline$\triangle M T B \square$ & 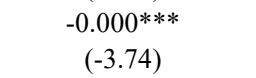 \\
\hline$\triangle A D V_{-} I N T \square$ & 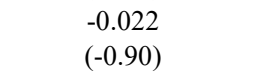 \\
\hline$\triangle R \& D_{-} I N T \square$ & 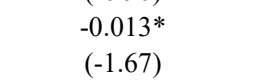 \\
\hline$\triangle S T D \_R E T \square$ & $\begin{array}{l}\text { एवाणाए } \\
\text { एणाएाए }\end{array}$ \\
\hline$\triangle S T D \_R O A \square$ & 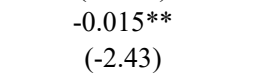 \\
\hline$\triangle I N S T H \square$ & $\begin{array}{l}\text { पाणाएा } \\
\text { पाणाण }\end{array}$ \\
\hline$\triangle S E G M E N T S \square$ & 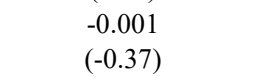 \\
\hline$\triangle M N G \_F O R E C A S T S \sqsubset$ & 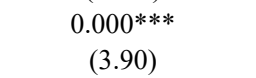 \\
\hline 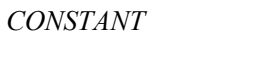 & 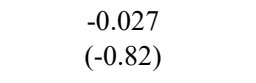 \\
\hline 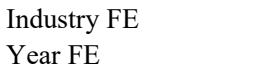 & $\begin{array}{l}\square \square \square \square \\
\square \square \square \square\end{array}$ \\
\hline 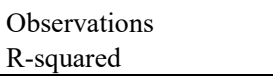 & 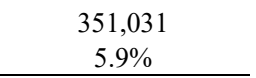 \\
\hline
\end{tabular}

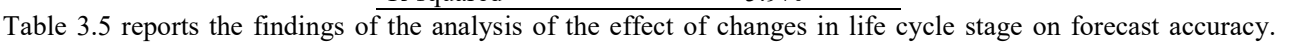

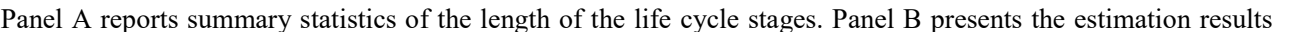

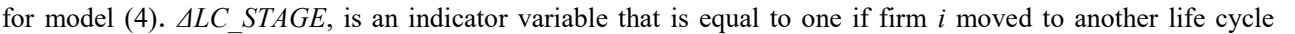

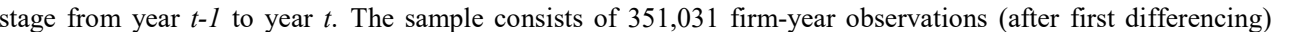

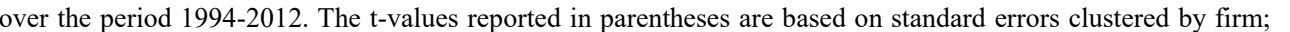

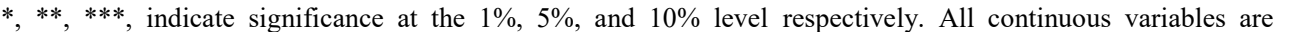

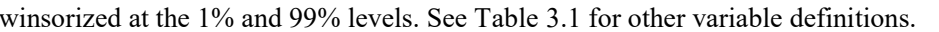
$\square$ 


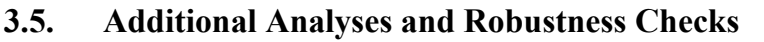

$\square$

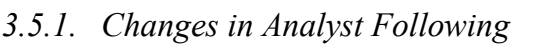

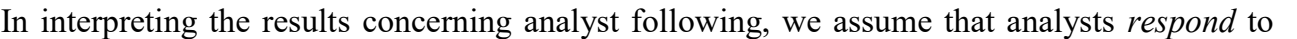

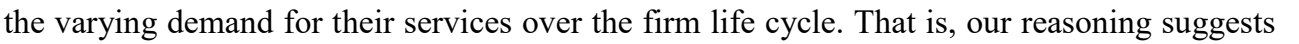

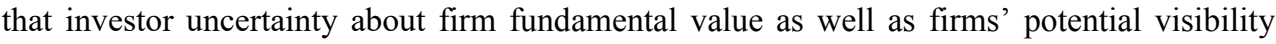

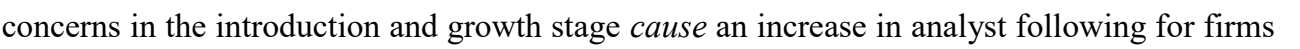
ए ए

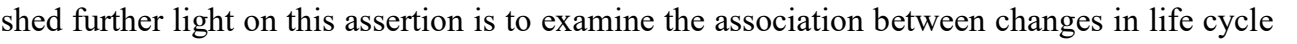

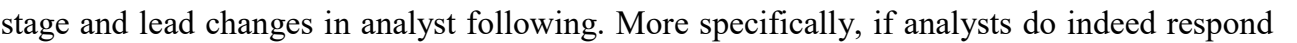

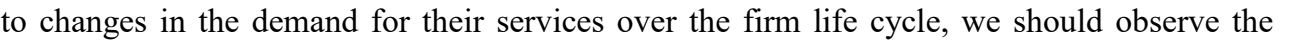

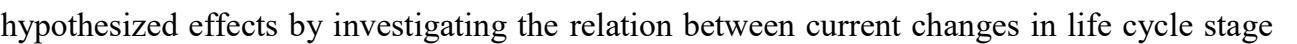

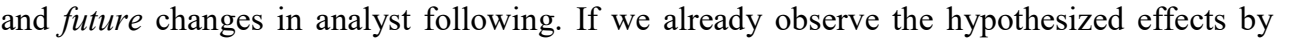

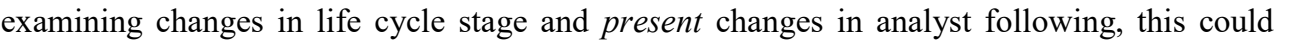

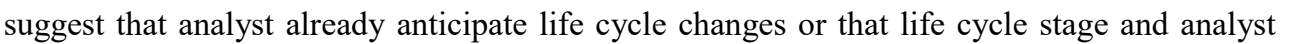

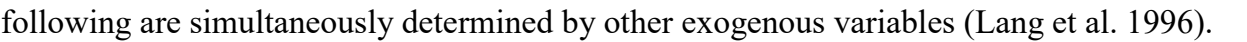

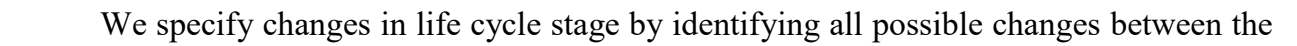

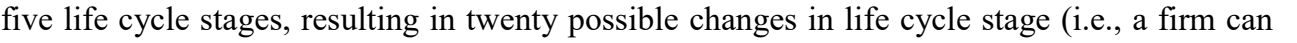

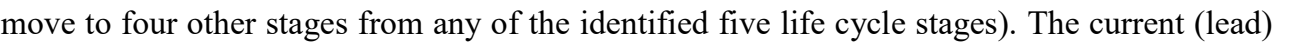

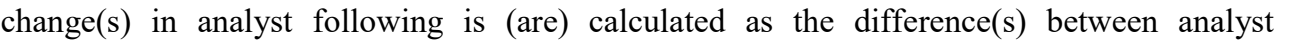

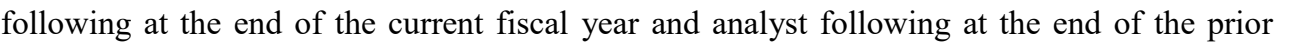

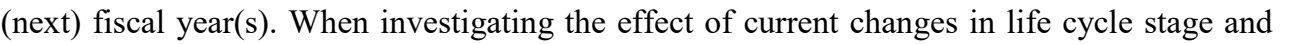

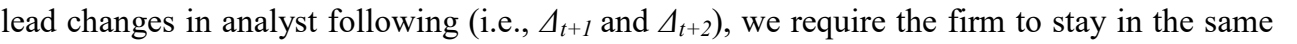

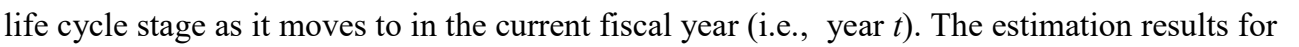

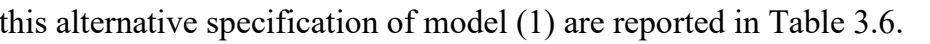

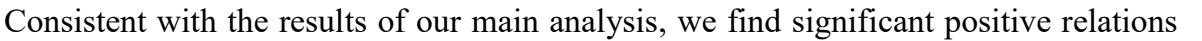

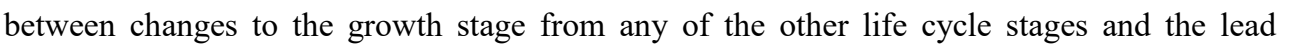

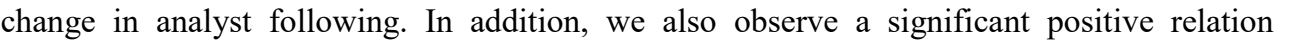

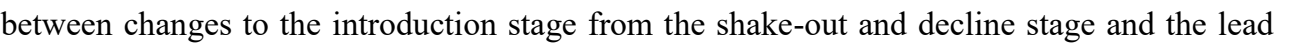

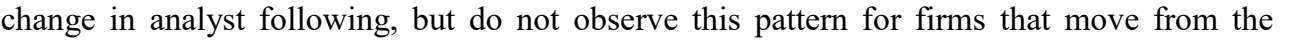

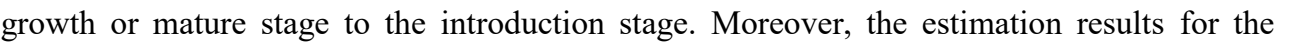

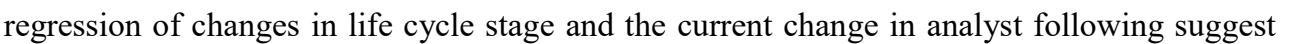

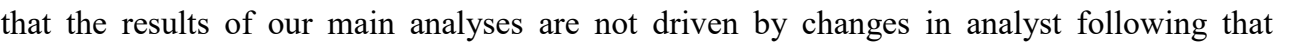

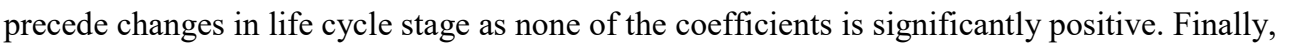
ए

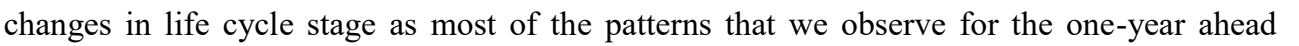

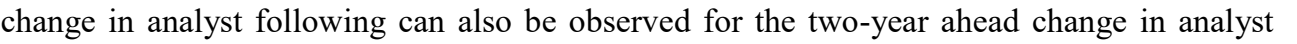

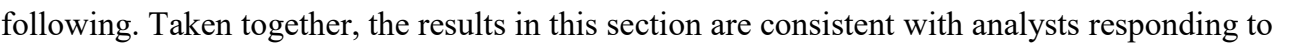

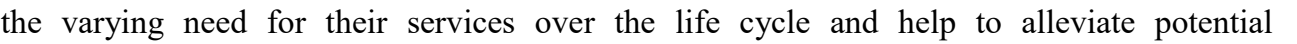

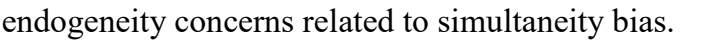

$\square$ 


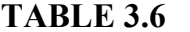

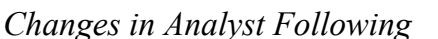

\begin{tabular}{|c|c|c|c|c|c|c|}
\hline 四 & $\square$ & & $\Delta \mathbf{A N}$ & LYST FOLLOWII & $\mathbf{G} \square$ & \\
\hline 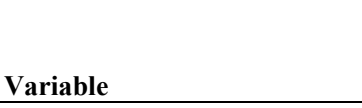 & $\mathbb{1}$ & $\begin{array}{c}\square \square \\
\triangle \text { ANALYST } \\
\square \square \square \square \square \square \square \square\end{array}$ & $\mathbb{I}$ & 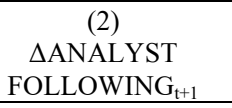 & $\mathbb{I}$ & 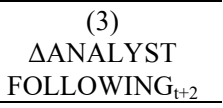 \\
\hline 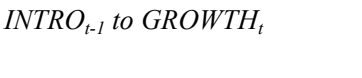 & & 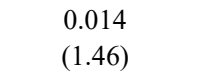 & & 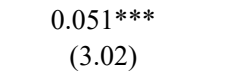 & & $\begin{array}{l}\text { पणाए } \\
\text { एणाणा }\end{array}$ \\
\hline 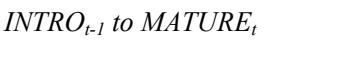 & & 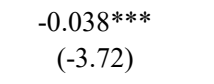 & & 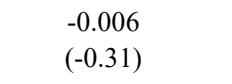 & & 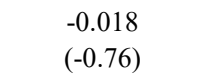 \\
\hline 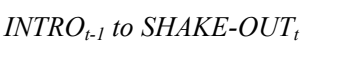 & & 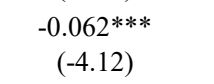 & & 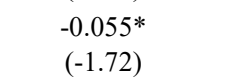 & & 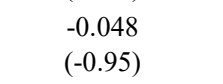 \\
\hline 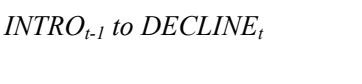 & & 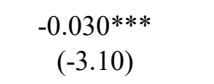 & & 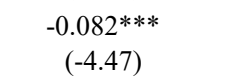 & & 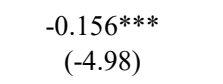 \\
\hline 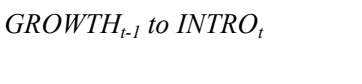 & & $\begin{array}{l}\square \square \square \square ~ \\
\text { एाणाण }\end{array}$ & & 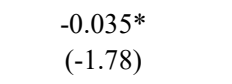 & & 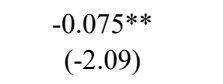 \\
\hline 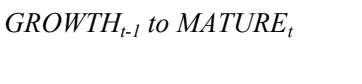 & & 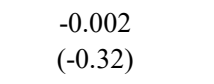 & & 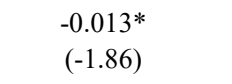 & & 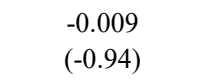 \\
\hline 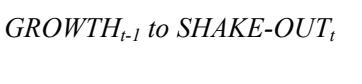 & & 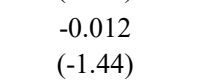 & & 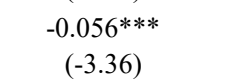 & & 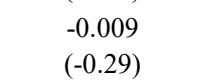 \\
\hline 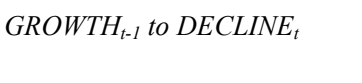 & & 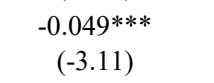 & & 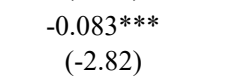 & & 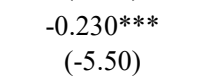 \\
\hline 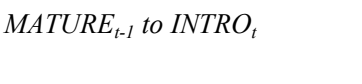 & & 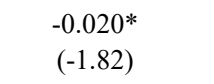 & & 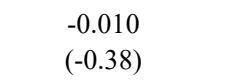 & & 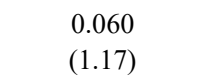 \\
\hline 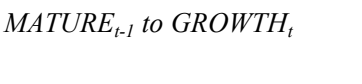 & & $\begin{array}{l}\text { एवाणा } \\
\text { एणाणाण }\end{array}$ & & 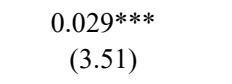 & & 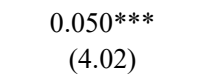 \\
\hline 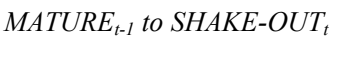 & & 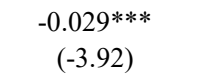 & & 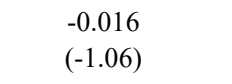 & & 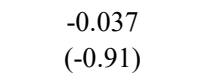 \\
\hline 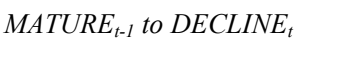 & & 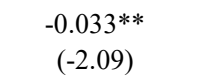 & & 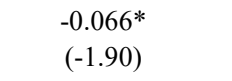 & & $\begin{array}{l}\text { एवाणा } \\
\text { एणाणा }\end{array}$ \\
\hline 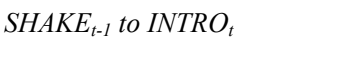 & & $\begin{array}{l}\text { एवाणाए } \\
\text { एणाणाए }\end{array}$ & & $\begin{array}{l}\text { पणाणा } \\
\text { एणाणा }\end{array}$ & & 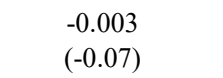 \\
\hline 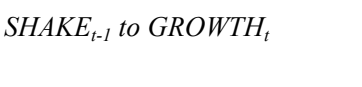 & & 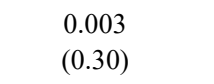 & & 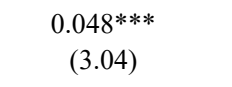 & & $\begin{array}{l}\text { पणाणा } \\
\text { पाणाण }\end{array}$ \\
\hline 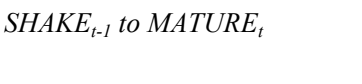 & & $\begin{array}{l}\text { पणाए } \\
\text { एणाणाण }\end{array}$ & & $\begin{array}{l}\text { पणाए } \\
\text { एणाणा }\end{array}$ & & $\begin{array}{l}\text { पणाणा } \\
\text { एणा।णा }\end{array}$ \\
\hline 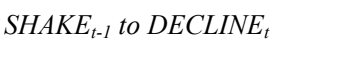 & & 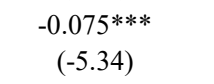 & & 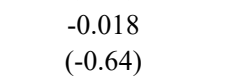 & & 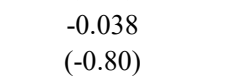 \\
\hline 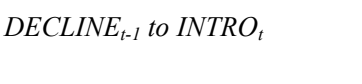 & & 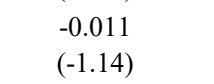 & & $\begin{array}{l}\text { एणाणाए } \\
\text { एाणाण }\end{array}$ & & $\begin{array}{l}\text { एणाणाए } \\
\text { एाणाण }\end{array}$ \\
\hline 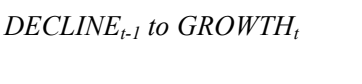 & & 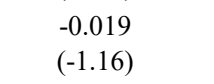 & & $\begin{array}{l}\text { पणाणा } \\
\text { एाणाण }\end{array}$ & & $\begin{array}{l}\text { पणाणाए } \\
\text { एणाणा }\end{array}$ \\
\hline 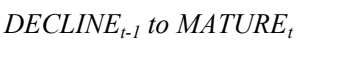 & & 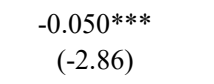 & & 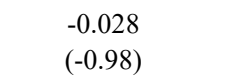 & & 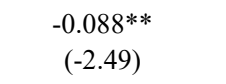 \\
\hline 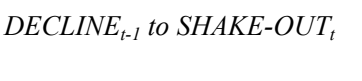 & & 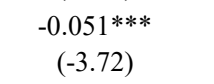 & & $\begin{array}{l}\text { एवाणा } \\
\text { एणाणा }\end{array}$ & & 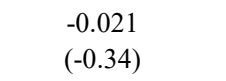 \\
\hline$\triangle S I Z E \square$ & & 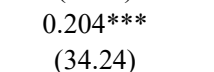 & & 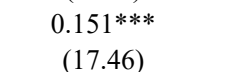 & & 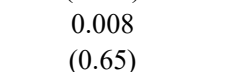 \\
\hline$\triangle R O A \square$ & & 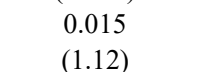 & & 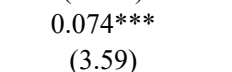 & & 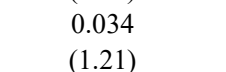 \\
\hline$\triangle F I R M A G E \square$ & & $\begin{array}{l}\text { पणाए } \\
\text { एणाण }\end{array}$ & & $\begin{array}{l}\text { एवाणाए } \\
\text { एणाएा }\end{array}$ & & $\begin{array}{l}\text { एणाए } \\
\text { एणाएा }\end{array}$ \\
\hline
\end{tabular}




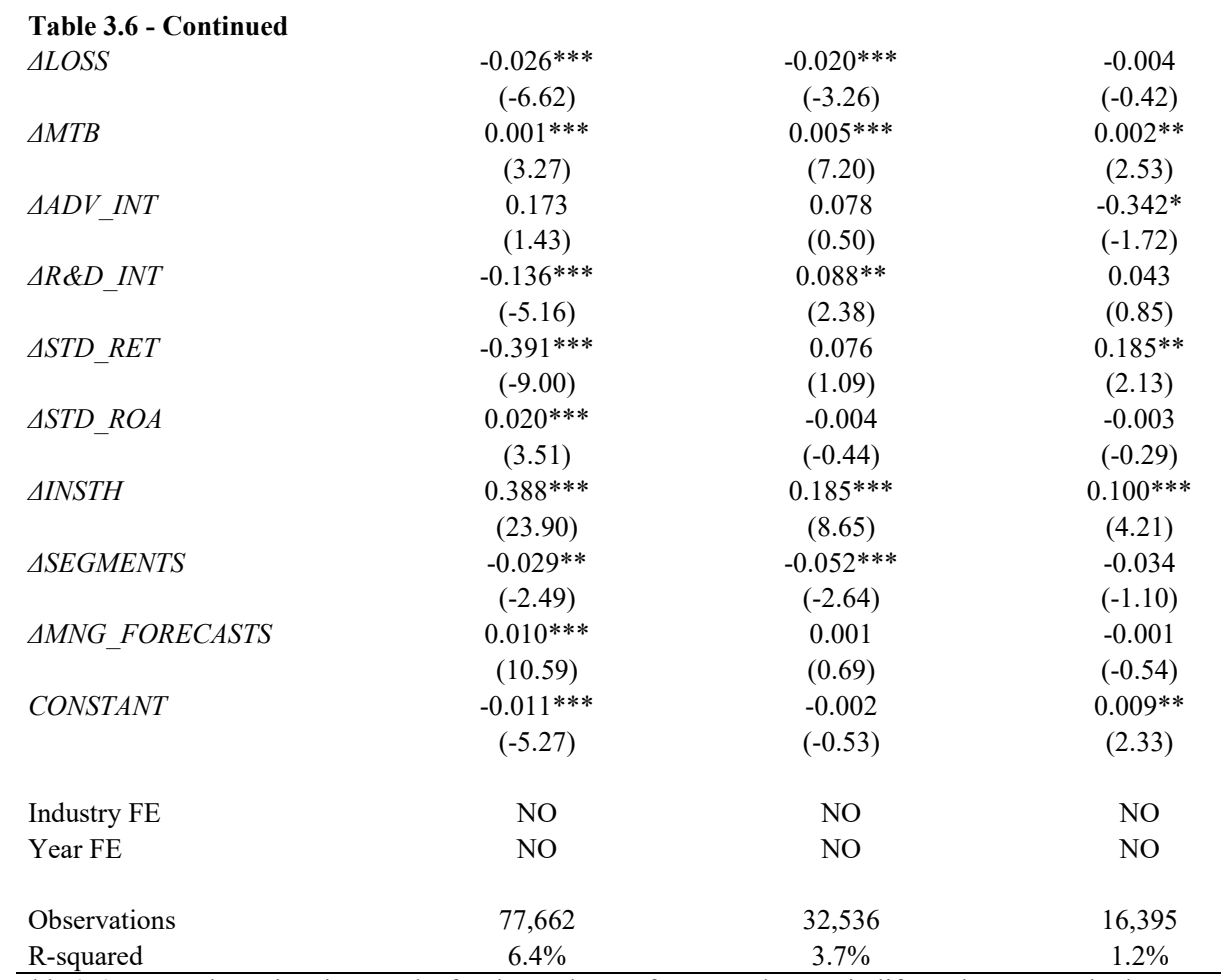

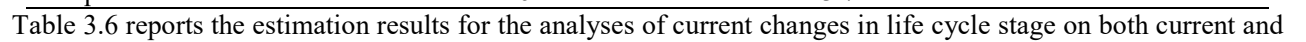

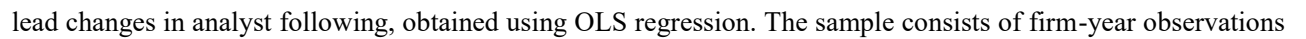

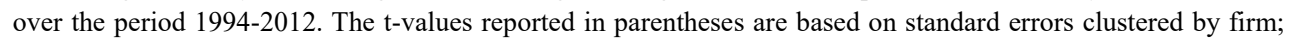

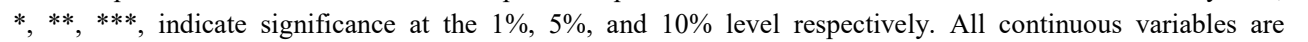

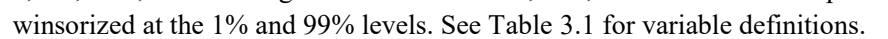

$\square$

$\square$

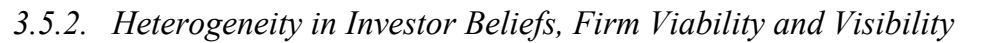

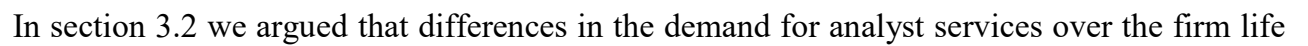

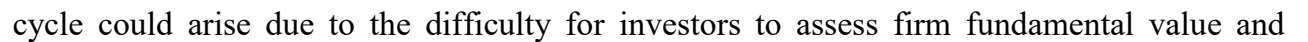

firm's visibility concerns. To further substantiate the validity of our findings, we run some $\square$

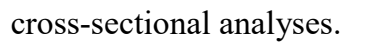

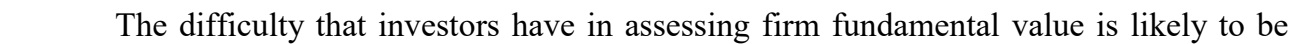

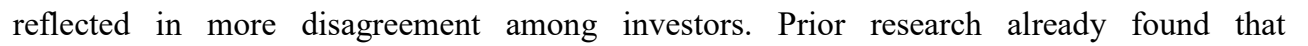

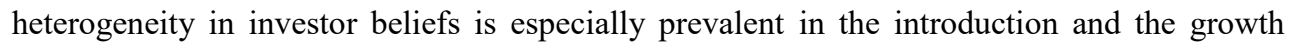

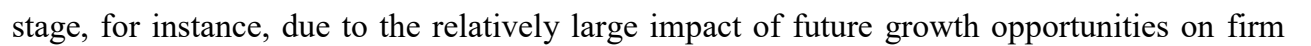

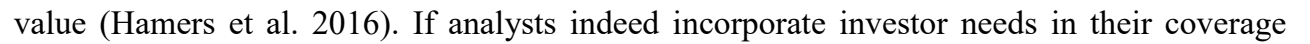

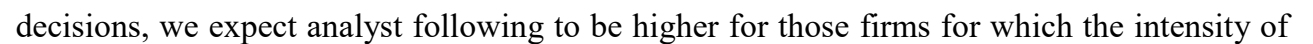

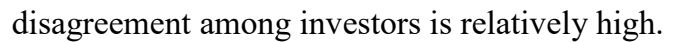

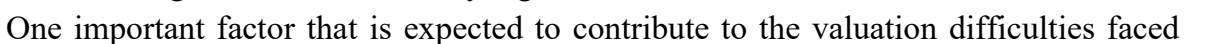

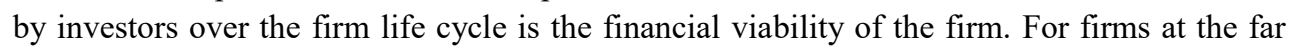

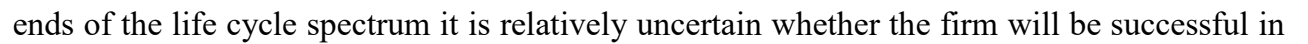

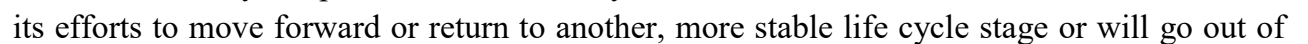




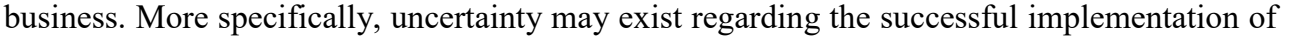
new business ideas or firms' ability to cope with declining business opportunities for firms $\square$

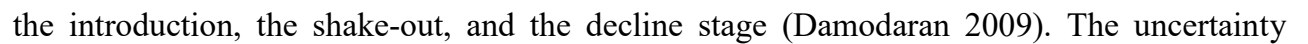

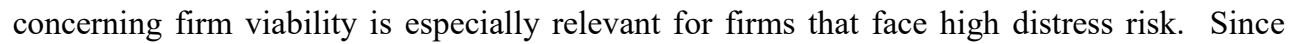

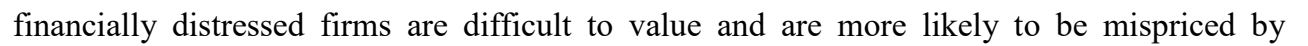

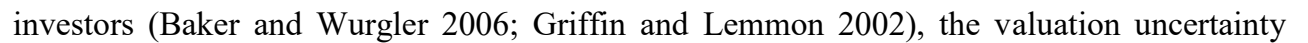

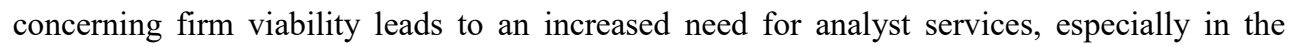

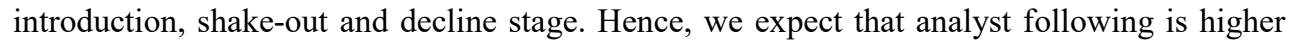

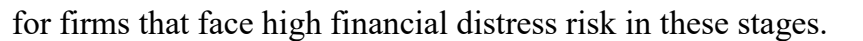

With regard to firms' visibility concerns, firms that have relatively little visibility in

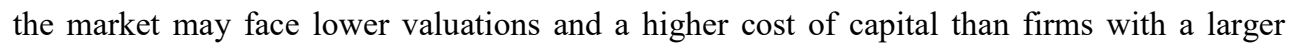

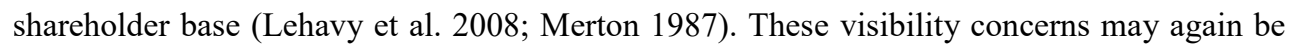

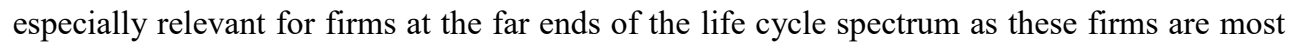

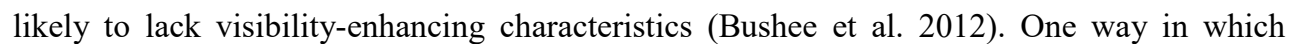

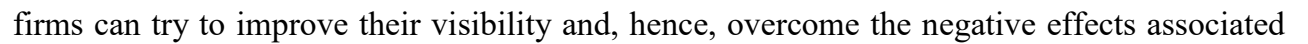

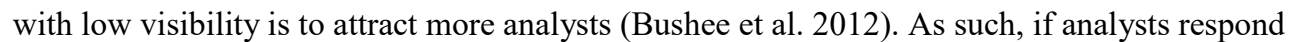
to the increased demand for their services arising from firms' visibility concerns, we would

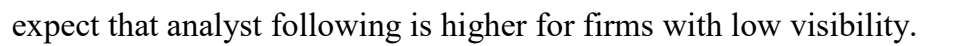

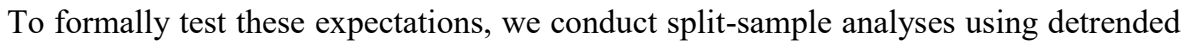

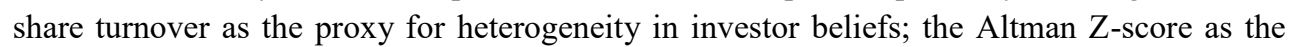

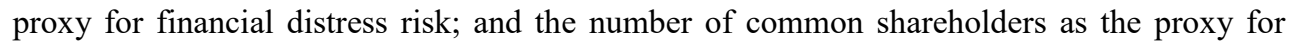

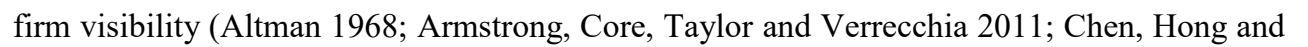

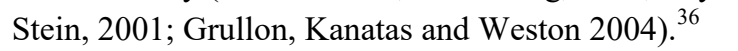

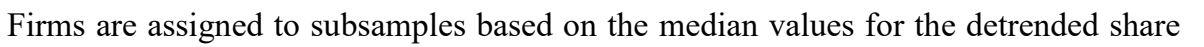

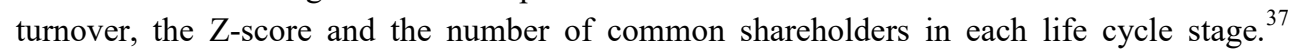

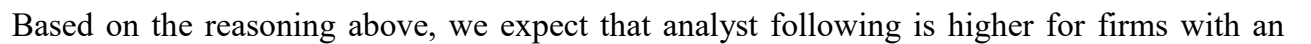

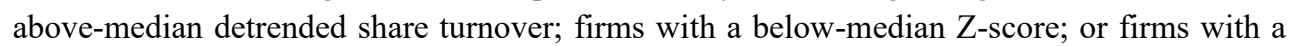

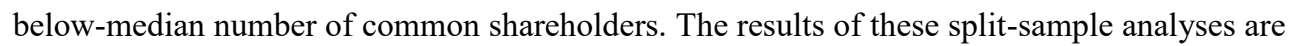

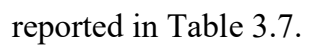

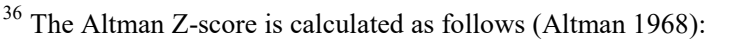

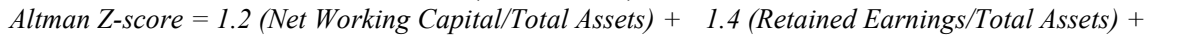
ए

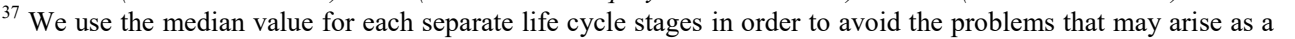

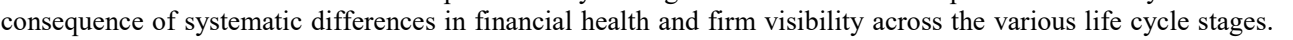

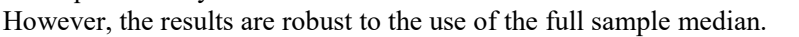




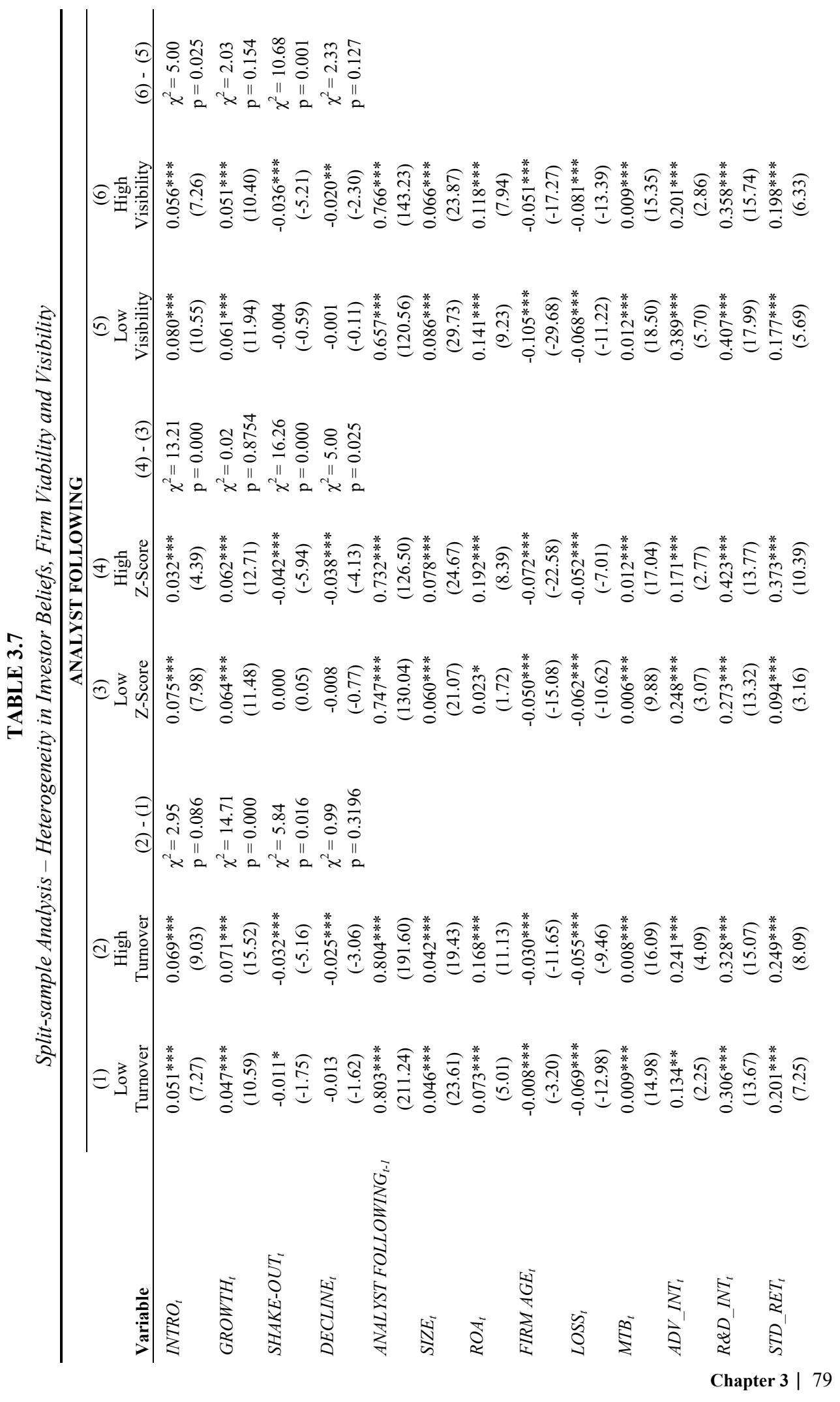




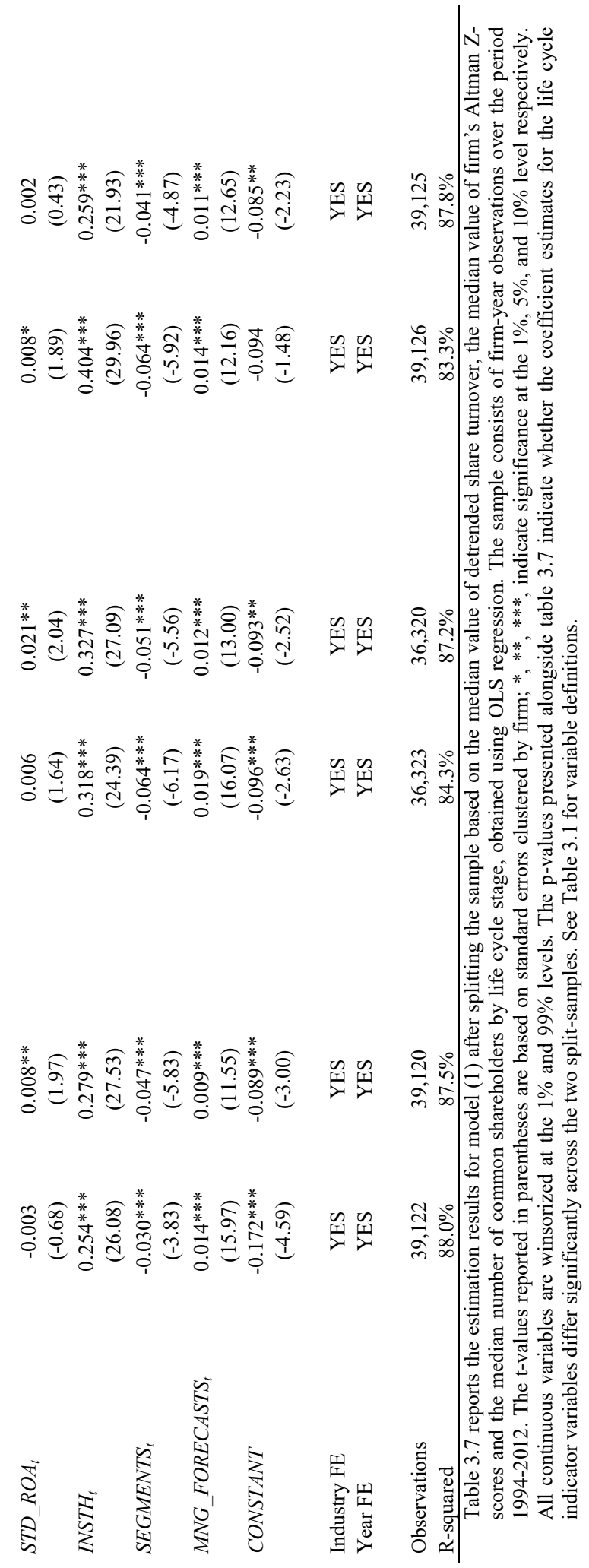




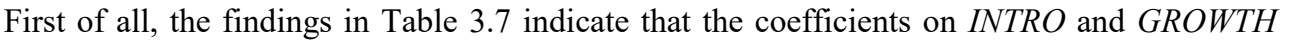

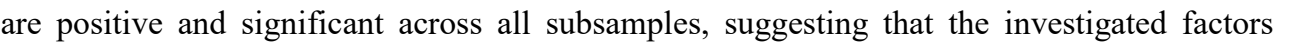

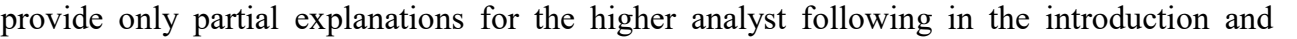

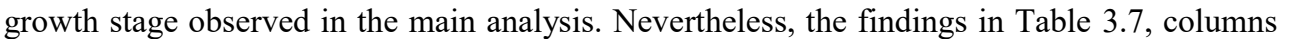

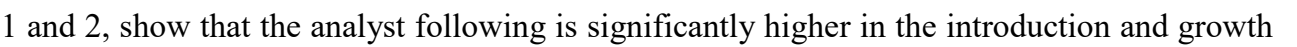

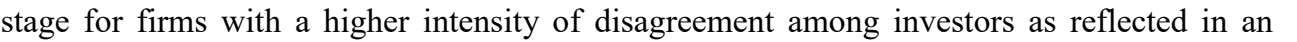

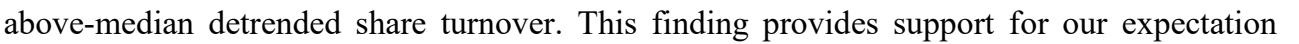

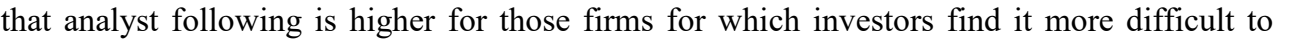

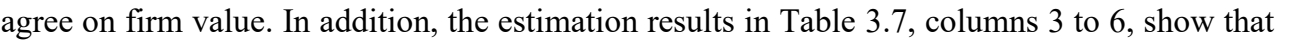

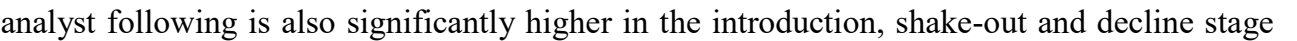

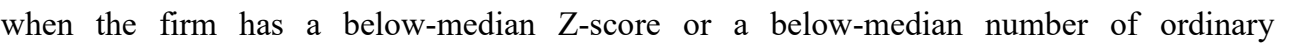

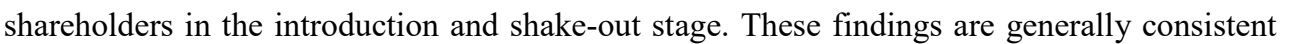

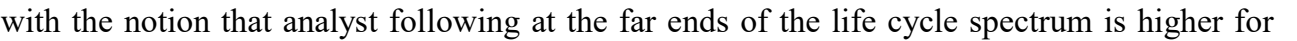

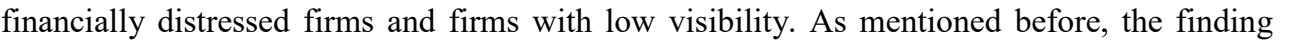

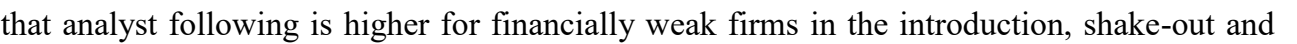

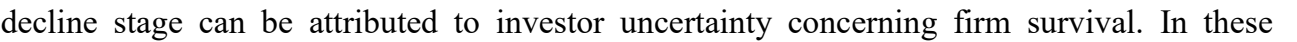

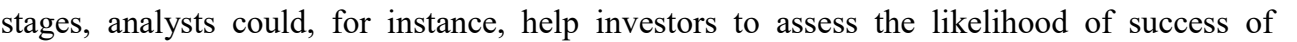

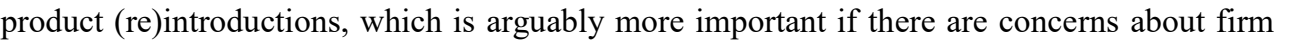

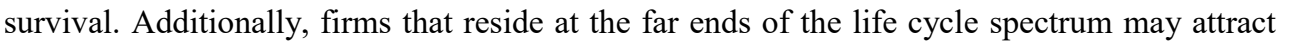

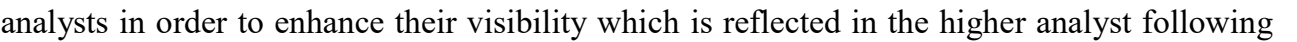

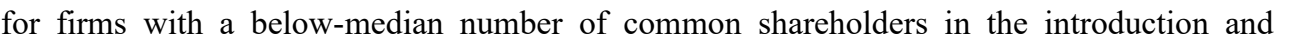

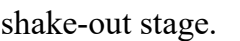

$\square$

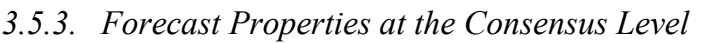

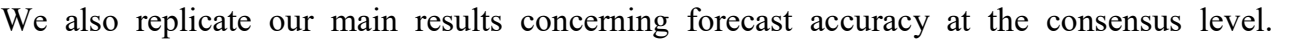

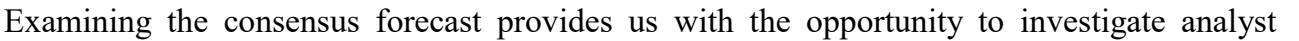

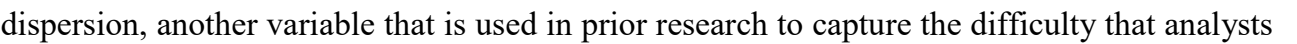

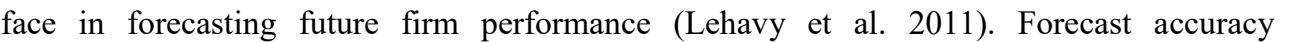

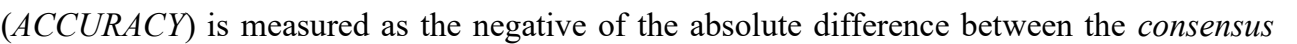
ए

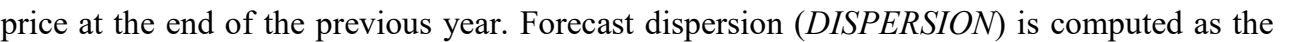

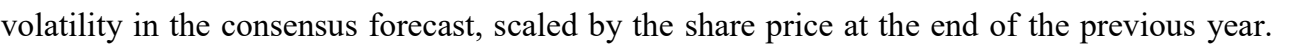

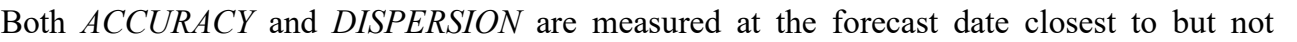

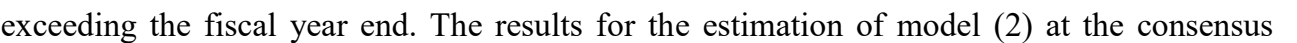

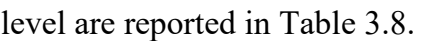

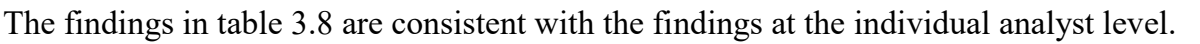

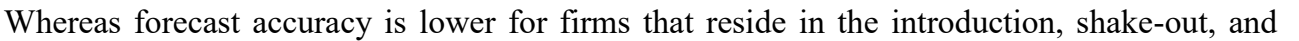

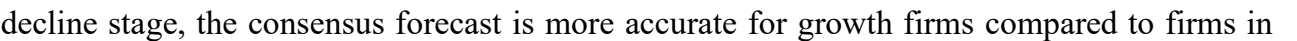
ए

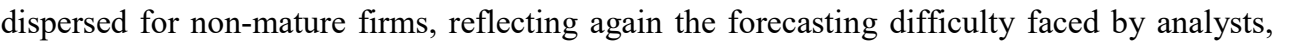

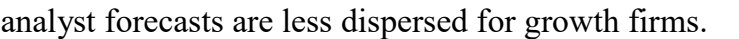

$\square$

$\square$ 


\begin{tabular}{|c|c|c|}
\hline \multirow[t]{2}{*}{ प1] } & \multicolumn{2}{|c|}{ 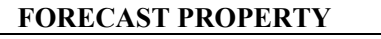 } \\
\hline & पाण & पाI \\
\hline 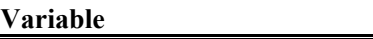 & \multicolumn{2}{|c|}{ 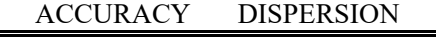 } \\
\hline \multirow[t]{2}{*}{ 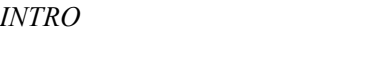 } & एणामा & 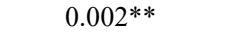 \\
\hline & 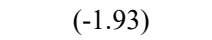 & पाणाए \\
\hline \multirow[t]{2}{*}{ 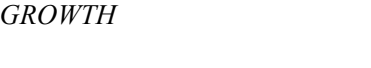 } & पामाएा & पाणाए \\
\hline & पाणाप & एणाएा \\
\hline \multirow[t]{2}{*}{ 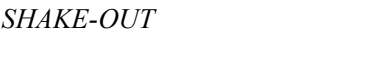 } & एमापामा & $\square[111$ \\
\hline & एणाएण & 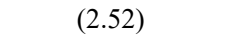 \\
\hline \multirow[t]{2}{*}{ 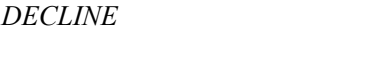 } & 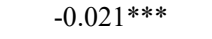 & पामामा \\
\hline & 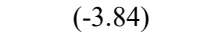 & पाणापा \\
\hline \multirow[t]{2}{*}{ 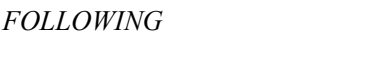 } & पामामा & 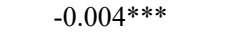 \\
\hline & एापाएव & 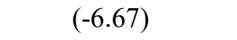 \\
\hline \multirow[t]{2}{*}{ पापिए } & एमापामा & 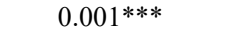 \\
\hline & पाणाण & पाणाए \\
\hline \multirow[t]{2}{*}{ प००० } & पापामा & पाणमामा \\
\hline & पाणापा & एणाएा \\
\hline \multirow[t]{2}{*}{ 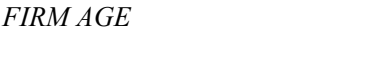 } & घमापाम & 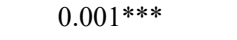 \\
\hline & पण口冋ाए & पाणाप \\
\hline \multirow[t]{2}{*}{ प्पण } & एामामाप & 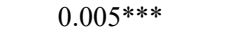 \\
\hline & पण口卄ा & पाणाप \\
\hline \multirow[t]{2}{*}{$\begin{array}{l}\square \square \\
\end{array}$} & पामाप & पाणाए \\
\hline & पाणा1 & पण口卄ा1 \\
\hline \multirow[t]{2}{*}{ 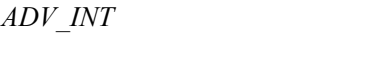 } & एणाए & पाणा \\
\hline & पा山ाएा & पाणाप \\
\hline \multirow[t]{2}{*}{ 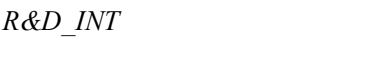 } & पण口|ण & पाणा \\
\hline & 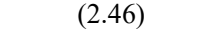 & पाणाप \\
\hline \multirow[t]{2}{*}{ 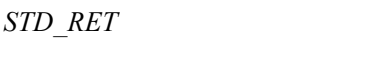 } & घमापामा & 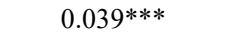 \\
\hline & एणीणाए & एवाणा \\
\hline \multirow[t]{2}{*}{ पमणप्र } & एमापामा & पाणाप \\
\hline & एणाएा & एणाएा \\
\hline \multirow[t]{2}{*}{ पापणि } & पामापा & 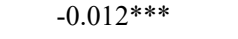 \\
\hline & एण口冋 & 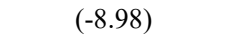 \\
\hline \multirow[t]{2}{*}{ 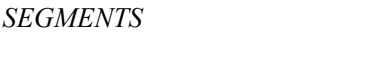 } & पाणा & पाणाए \\
\hline & एणापाप & 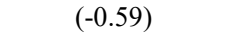 \\
\hline \multirow[t]{2}{*}{ 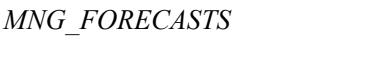 } & पाणा & पामापा \\
\hline & पाणाए & पण口卄ा \\
\hline \multirow[t]{2}{*}{ 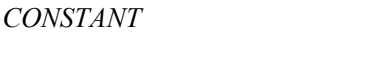 } & पामाप & पामा \\
\hline & एवाणा & 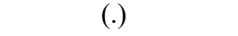 \\
\hline 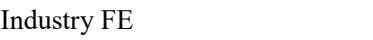 & $\square \square \square \square$ & $\square \square \square \square$ \\
\hline 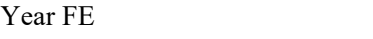 & $\square \square \square \square$ & $\square \square \square \square$ \\
\hline 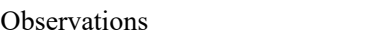 & पायाम & $\square \| \square \square$ \\
\hline 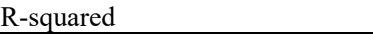 & पाणिए & पापिए \\
\hline 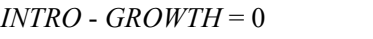 & पापापामा & $\llbracket \square \square \square \square ा \square \quad \llbracket$ \\
\hline 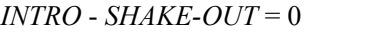 & पापाएा & पापाएण \\
\hline 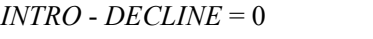 & 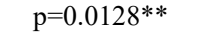 & पणाएापाए \\
\hline 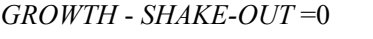 & पपापाया & पवापामा \\
\hline 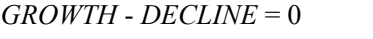 & पणामापा & पणामापए \\
\hline 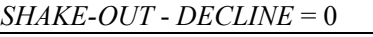 & 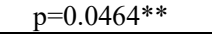 & 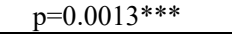 \\
\hline
\end{tabular}




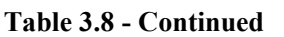

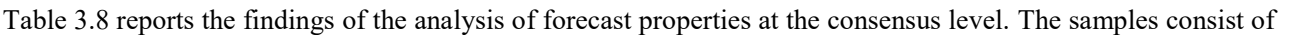
ए ए एव

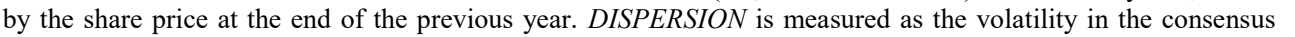

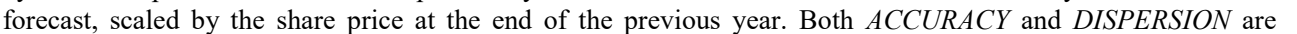

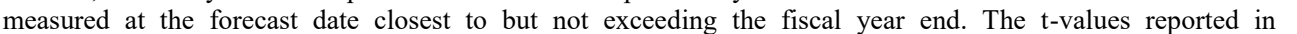

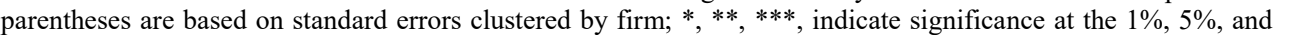

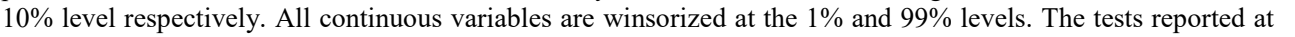

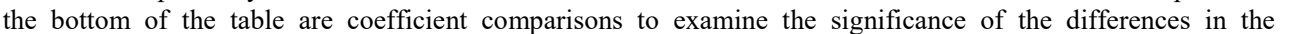

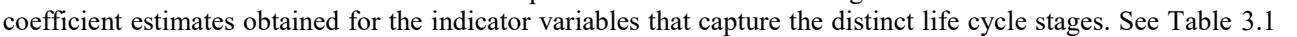

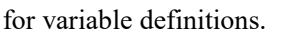

$\square$

$\square$

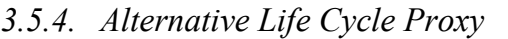

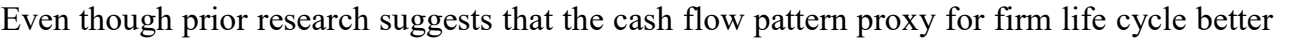

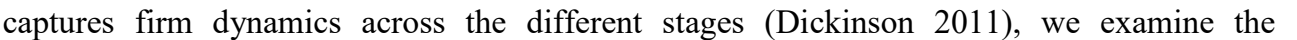

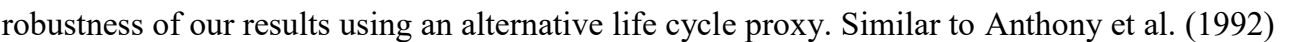

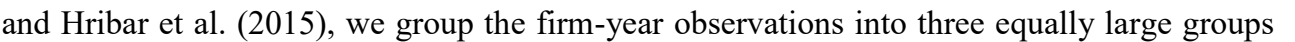

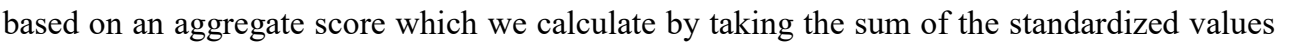

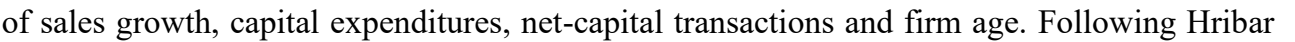

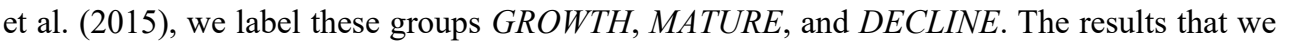

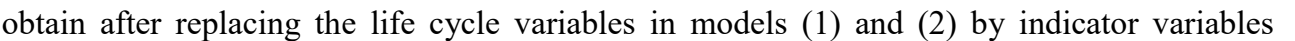

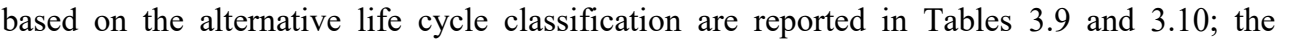

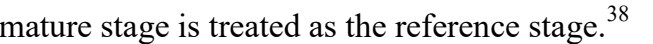

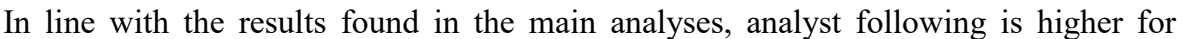

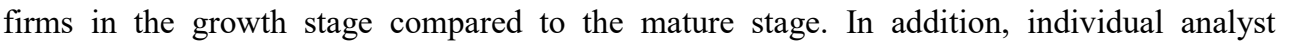

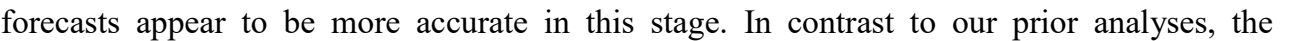

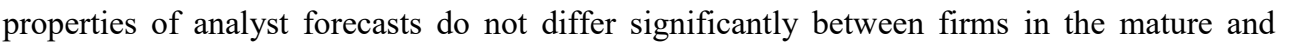

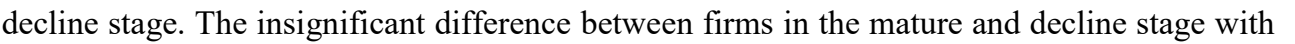

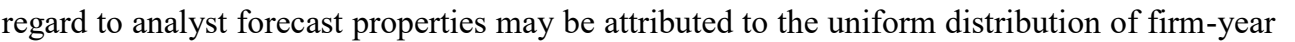

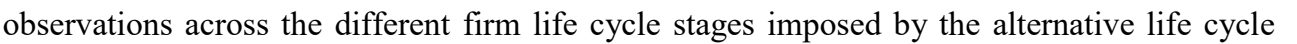

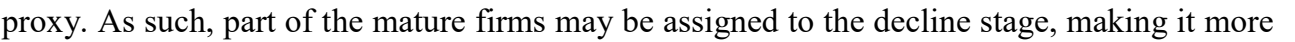

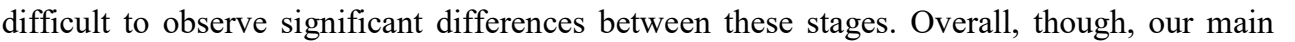

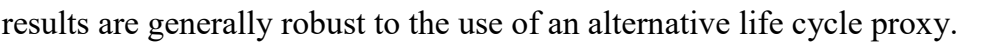

$\square$

$\square$

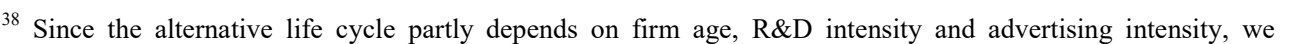

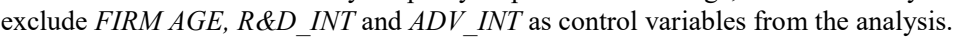


प्रणमाणा

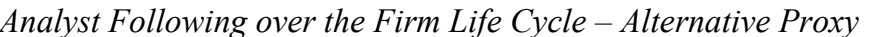

\begin{tabular}{|c|c|}
\hline $\mathbb{U}$ & 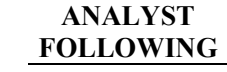 \\
\hline पणाणाप & पाण \\
\hline 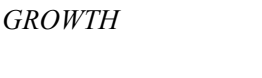 & 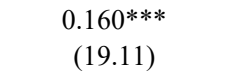 \\
\hline 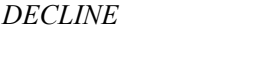 & 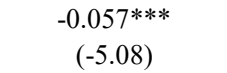 \\
\hline एाणिए & 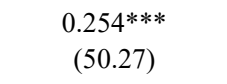 \\
\hline प्म०० & 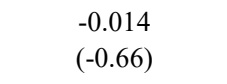 \\
\hline$\square \square \square$ & 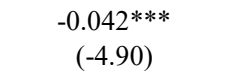 \\
\hline$\square \square \square$ & 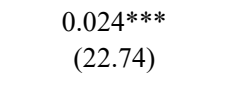 \\
\hline 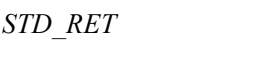 & $\begin{array}{l}\text { पणाणा } \\
\text { एणाणा }\end{array}$ \\
\hline एवपणमए & 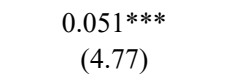 \\
\hline पापण口 & 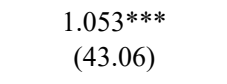 \\
\hline 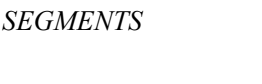 & 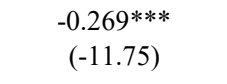 \\
\hline 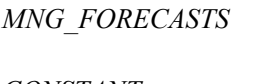 & 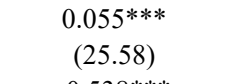 \\
\hline 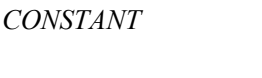 & 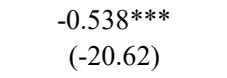 \\
\hline$\square$ & $\sqsubset$ \\
\hline 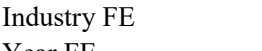 & 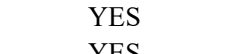 \\
\hline 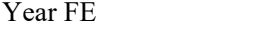 & $\begin{array}{l}\square \square \square \\
\end{array}$ \\
\hline 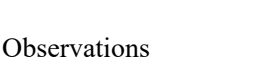 & $\stackrel{\square}{\square \square \square \square}$ \\
\hline पाणामाणा & $\square ा \Pi \square \square$ \\
\hline
\end{tabular}

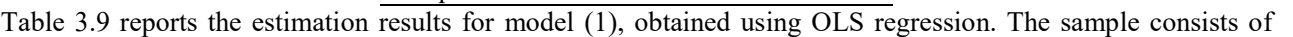

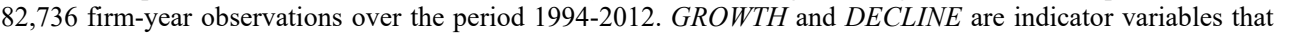

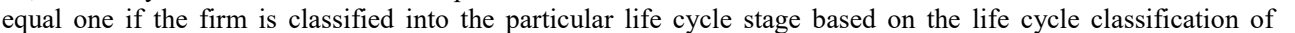

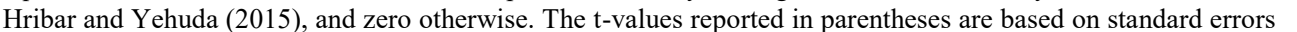

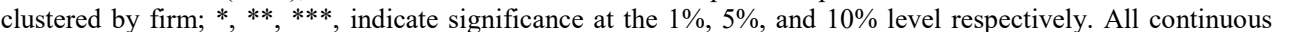

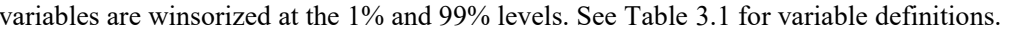

$\square$

$\square$ 
प्रणमाणाए

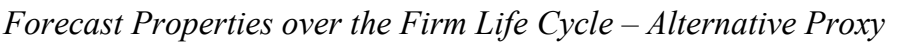

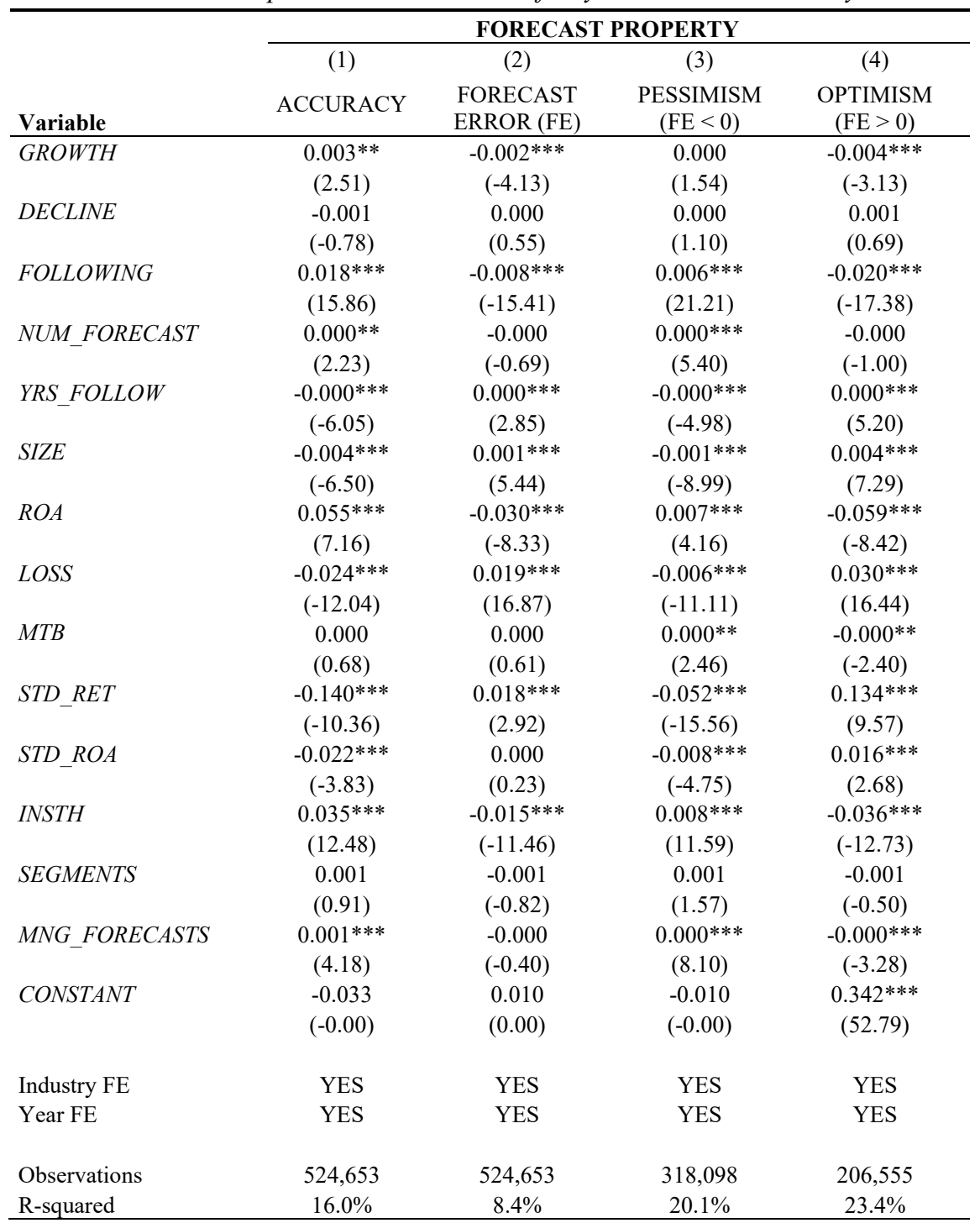

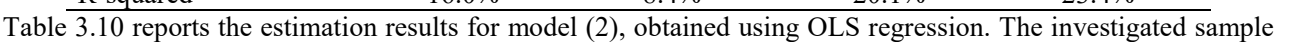

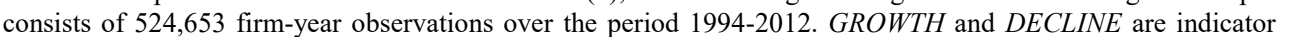

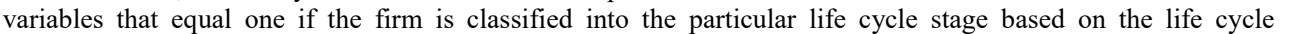

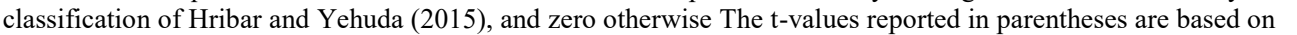

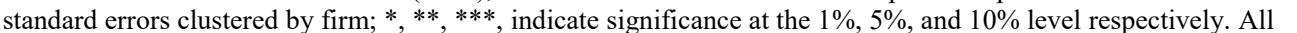

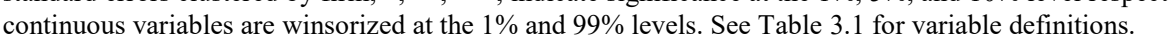




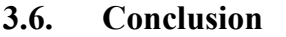

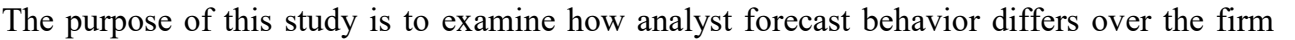

life cycle. Investors' limited ability to incorporate firm life cycle information gives rise to an

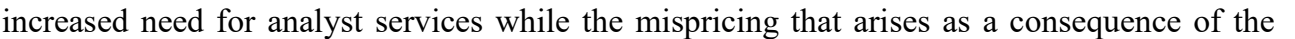

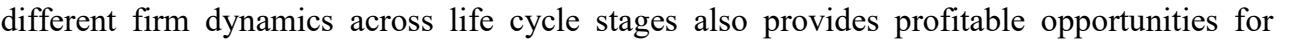

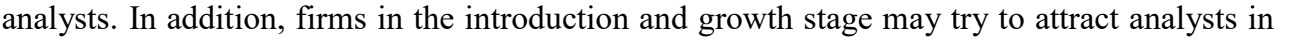

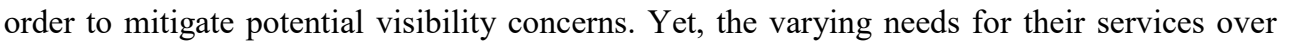

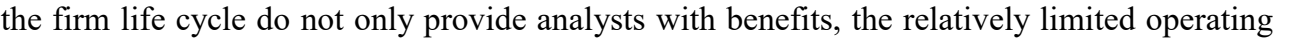

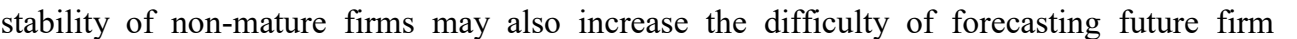
पाणापाएा

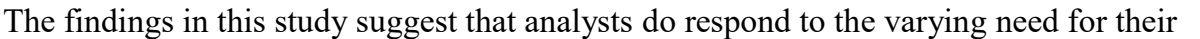

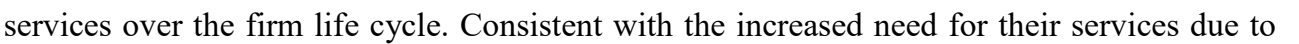

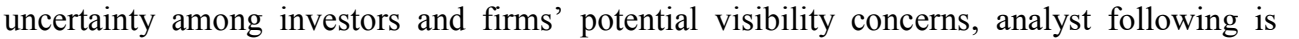

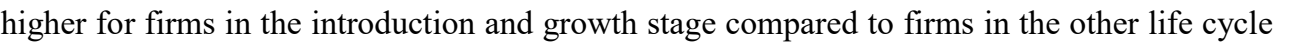

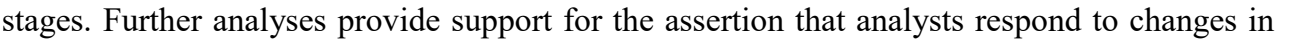

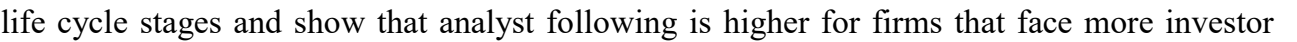

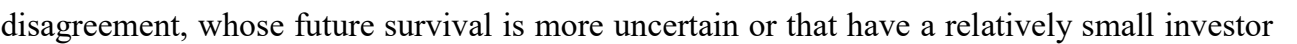

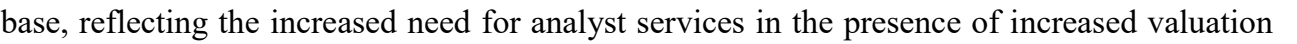

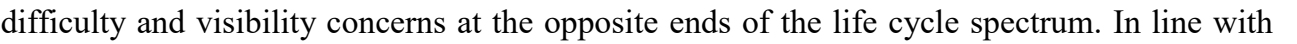

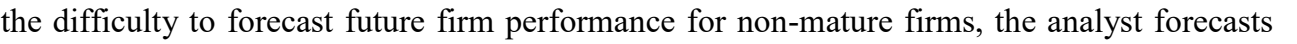

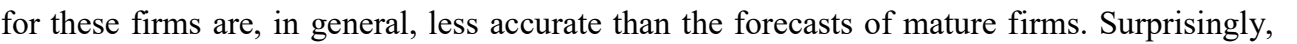

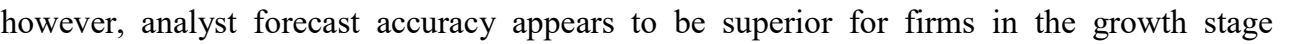

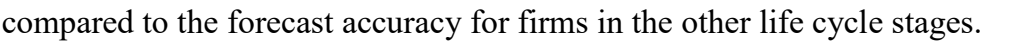

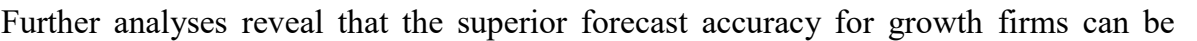

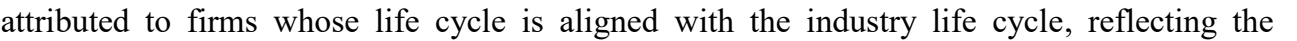

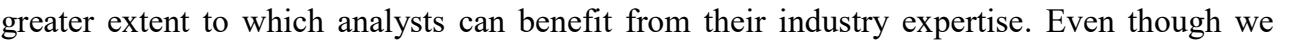

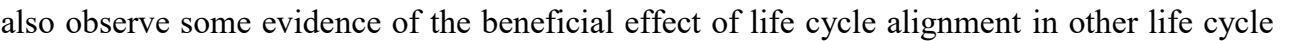

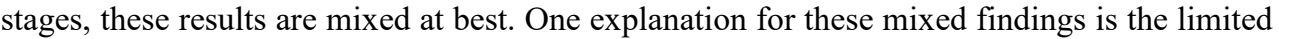

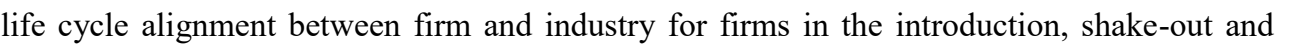

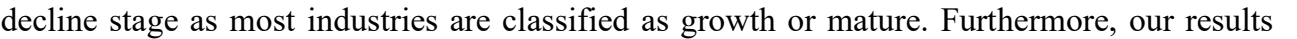

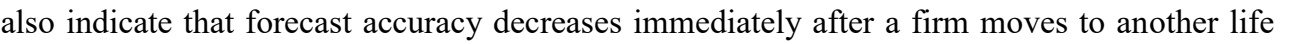

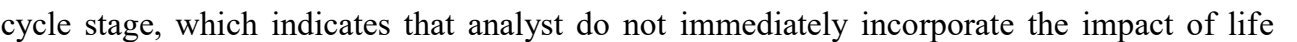

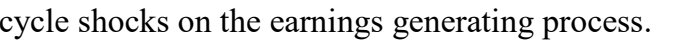

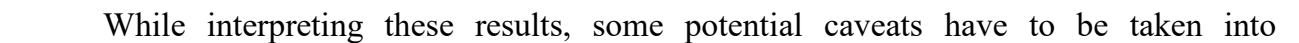

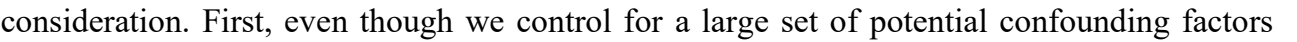

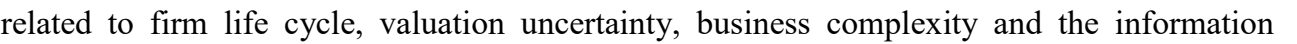

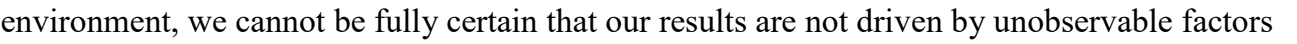

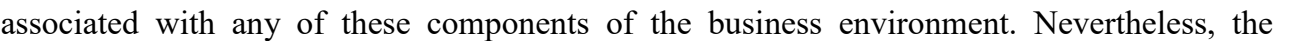
ए

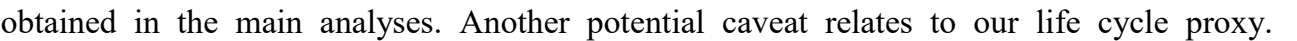

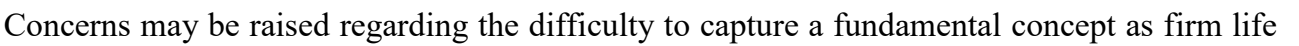

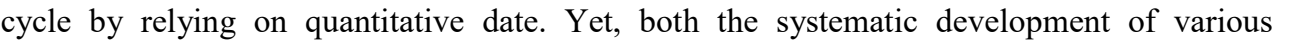
accounting measures across the life cycle stages that can be observed when using Dickinson's 
ए ए।

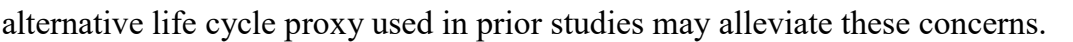

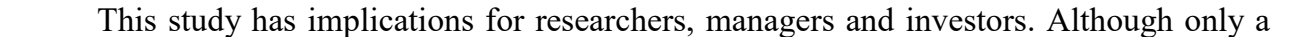

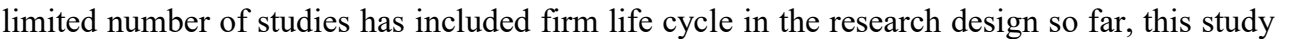

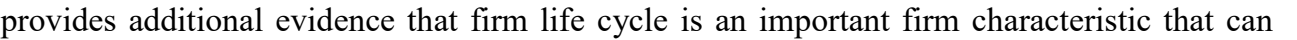

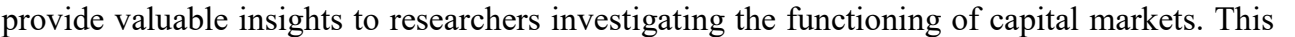

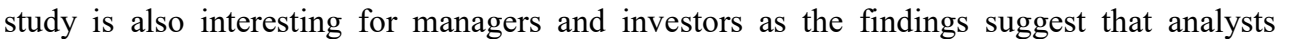

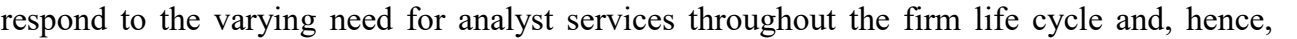

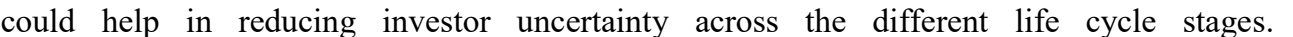




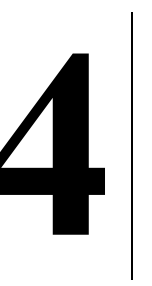

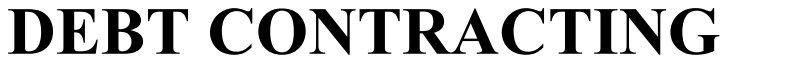

ㅁำ

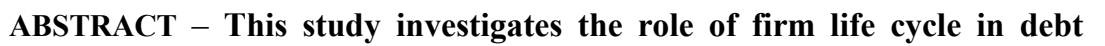

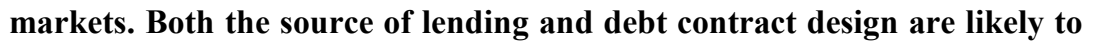

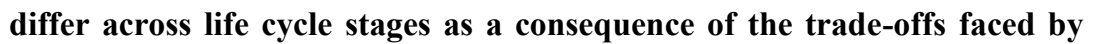
$\square \square \square\|\square \square\| \square \square \square \square \square \square \square \square \square \square$ that arise from uncertainty about borrowers'

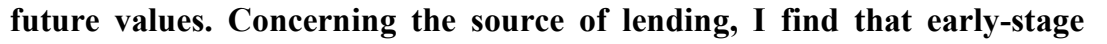

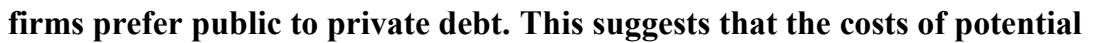

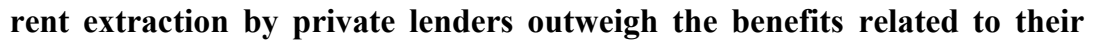

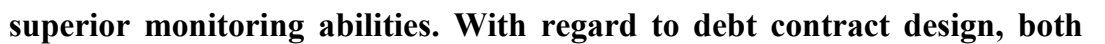

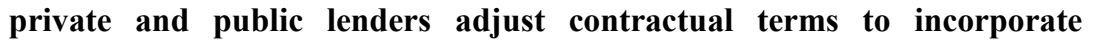

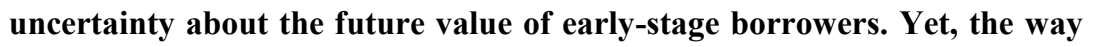

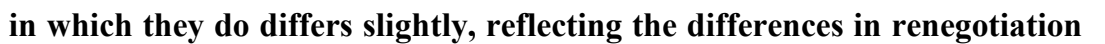

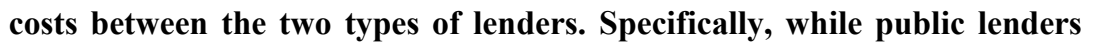

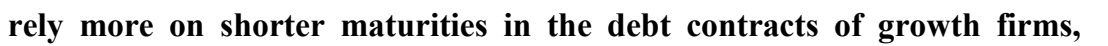

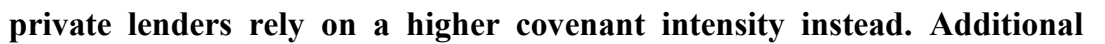

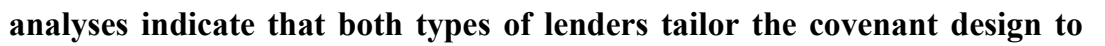

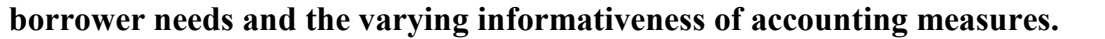

$\square$

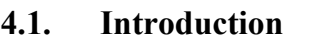

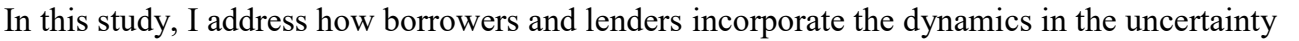

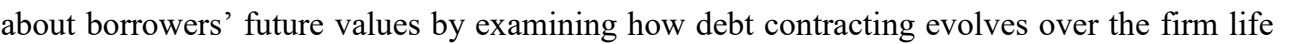

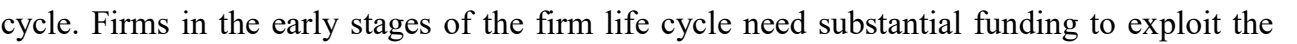

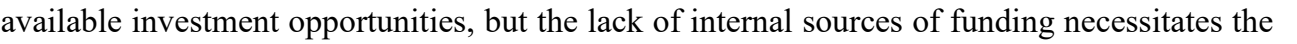

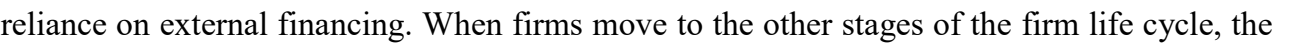

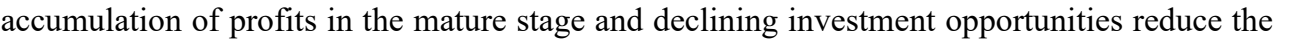

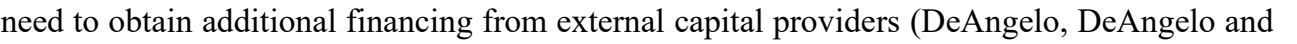

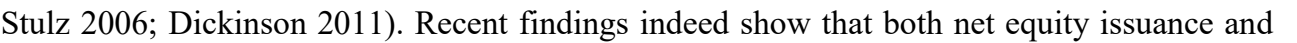

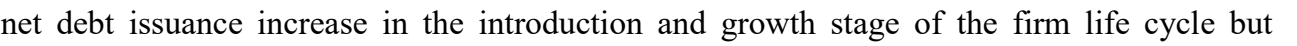

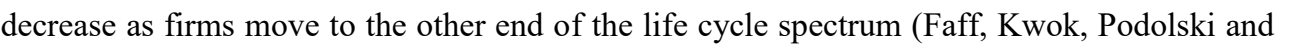

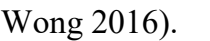

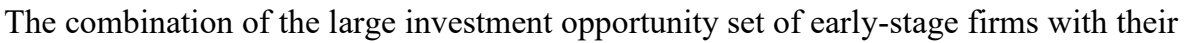

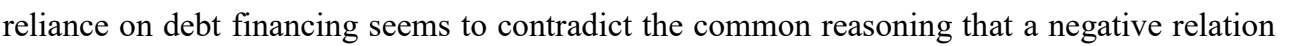

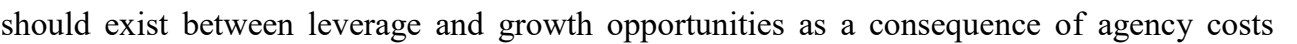

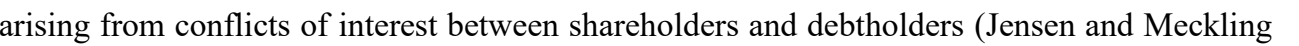

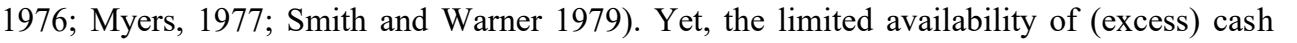

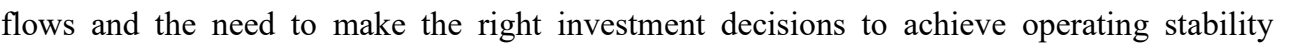

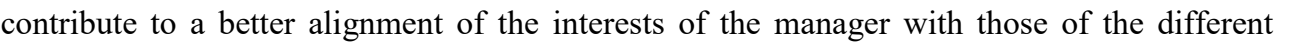

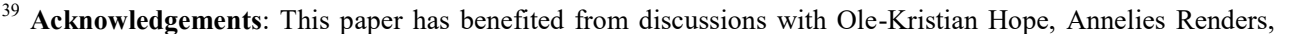

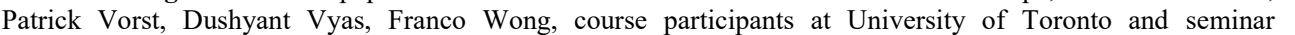
प Im

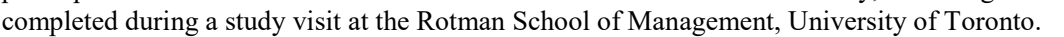




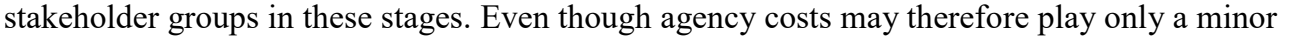

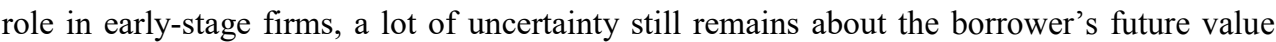

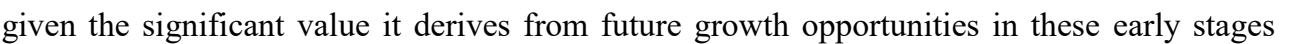

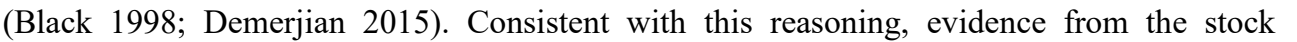
market indicates that heterogeneity in investor beliefs concerning firms' fundamental values is

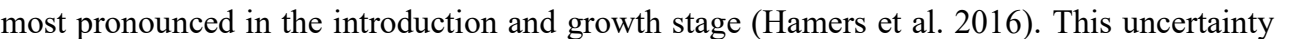
(1) contract design (from the lender's perspective).

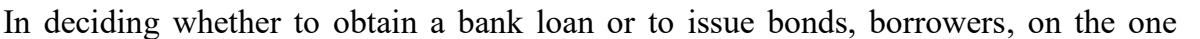

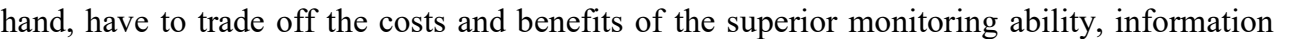

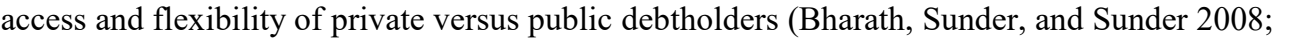

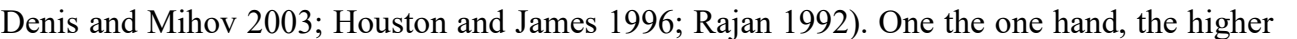

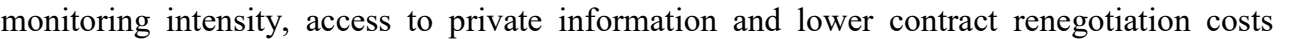

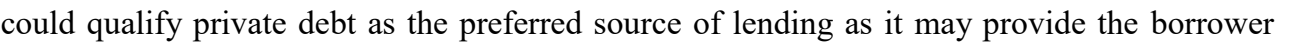

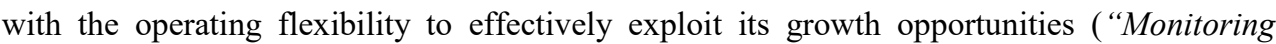

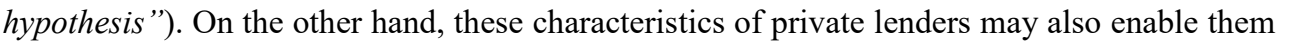

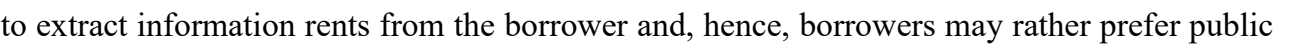

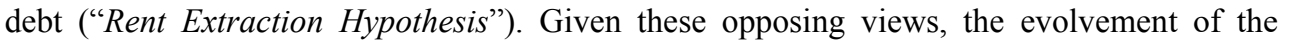

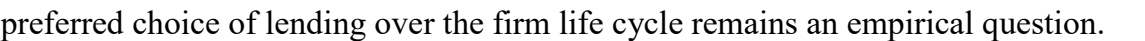

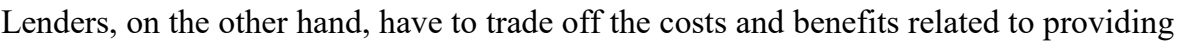

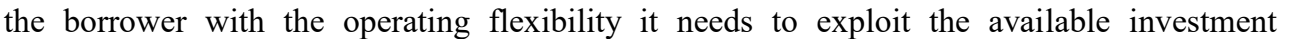

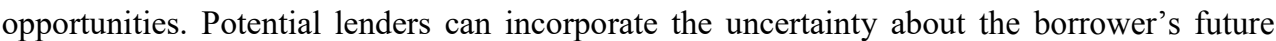

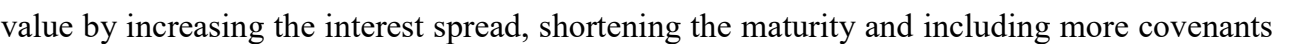
ए एव

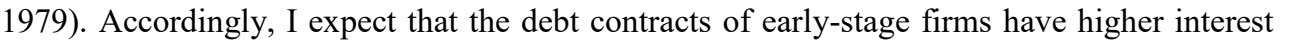

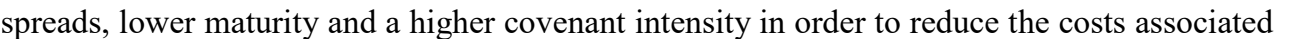

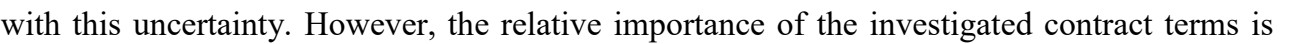

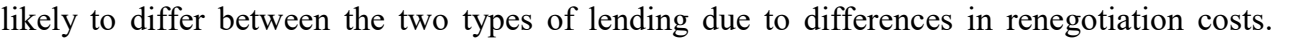

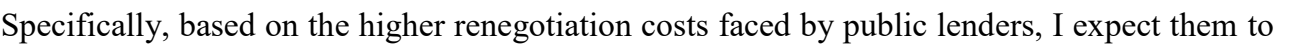

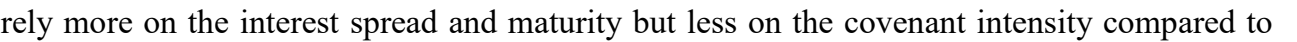

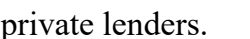

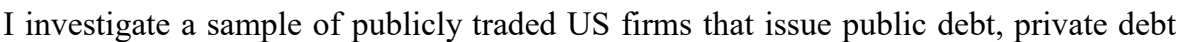

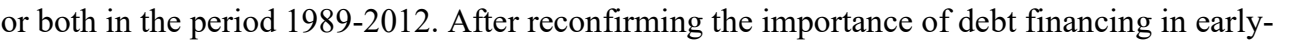

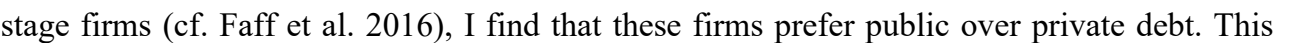

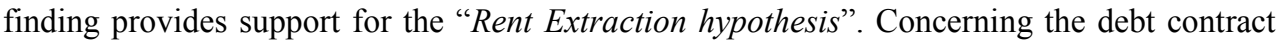

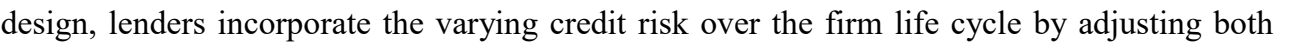
ए एव

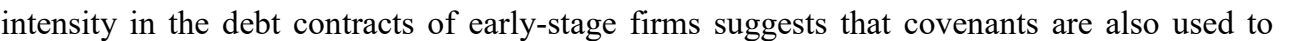

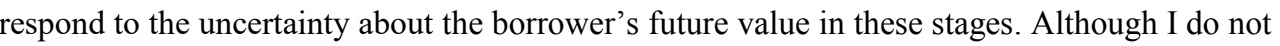
प

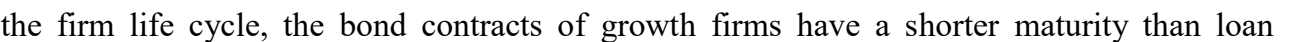

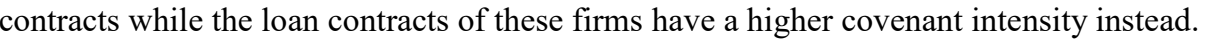

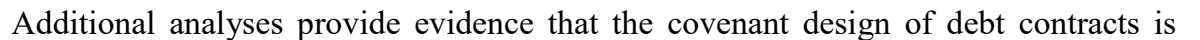

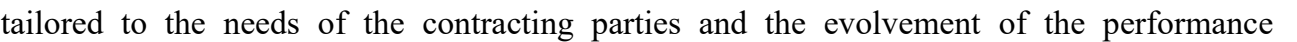




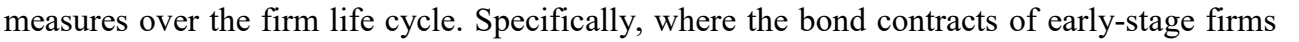

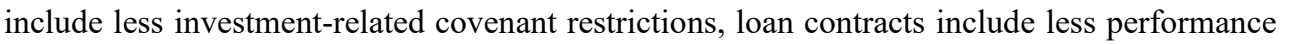

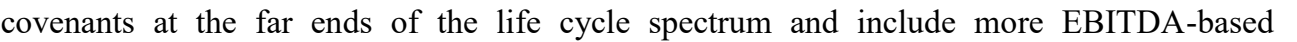

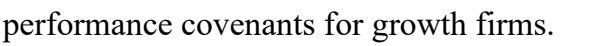

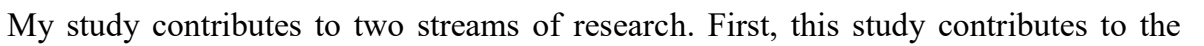

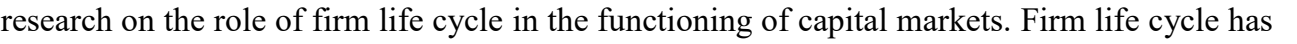

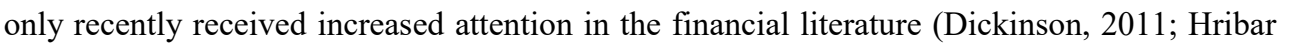

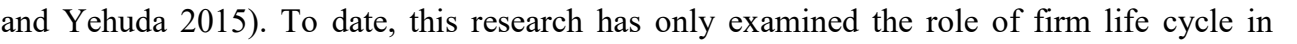

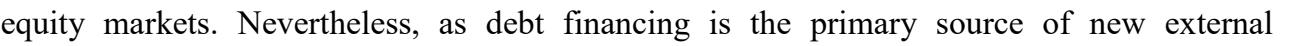

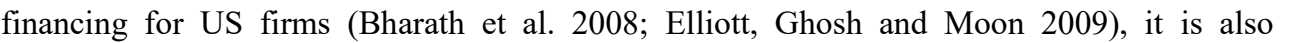

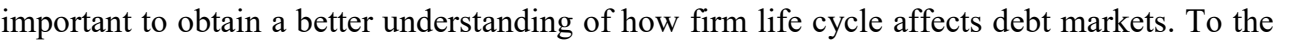

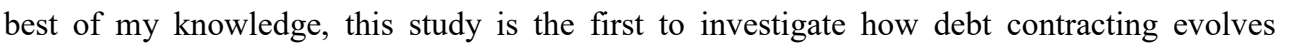

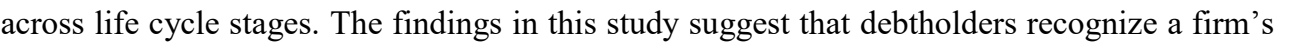

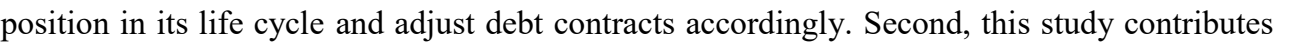

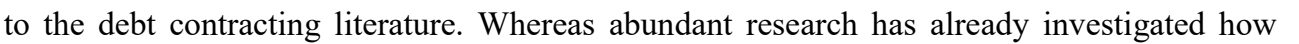

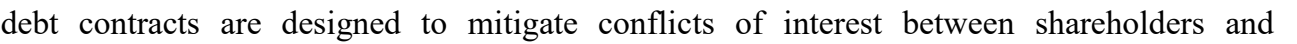

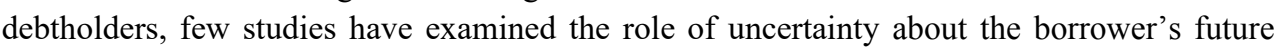

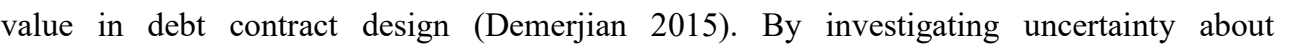

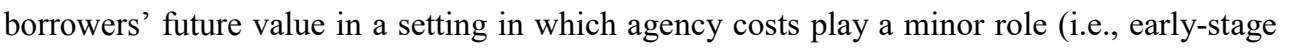

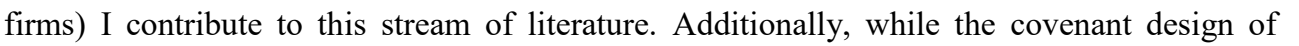

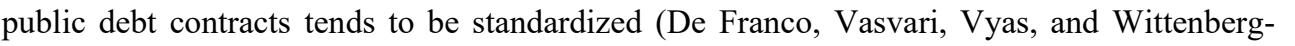

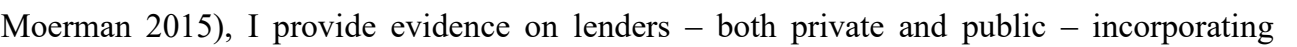
borrowers' needs and the varying informativeness of performance measures in the covenant

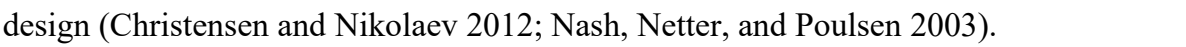

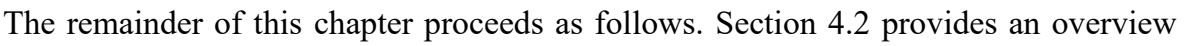

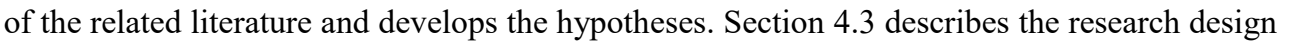

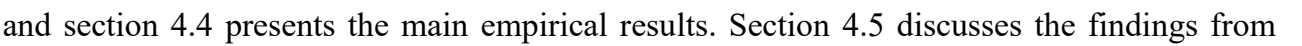

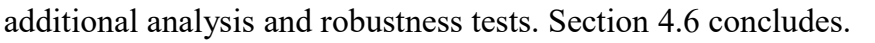

$\square$

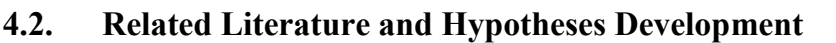

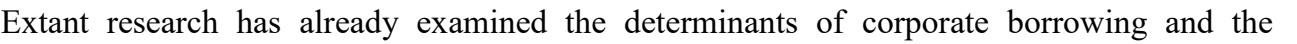

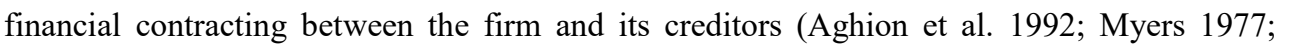

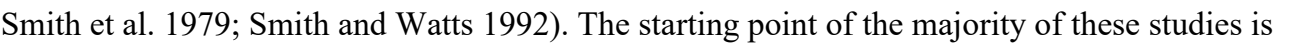

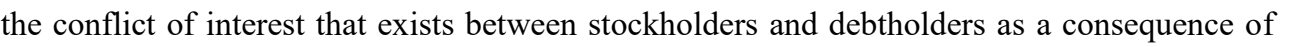

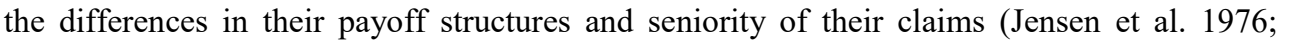

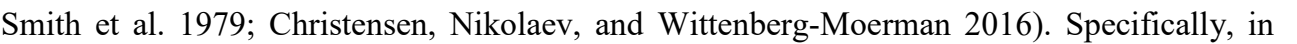

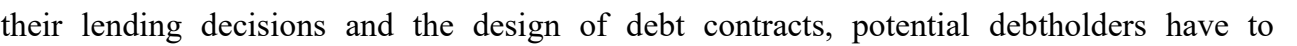

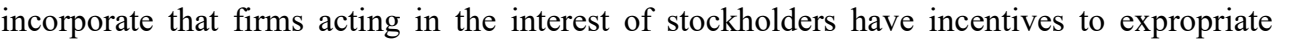

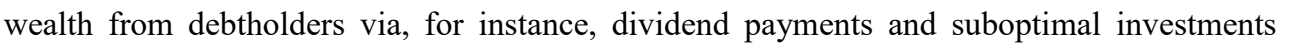

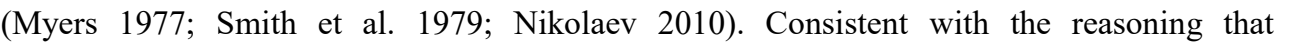

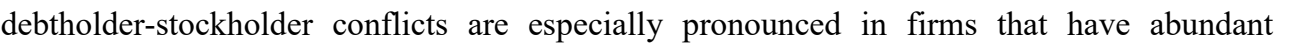

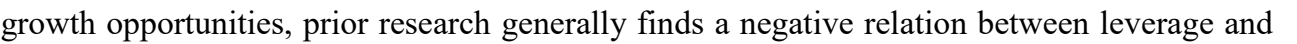

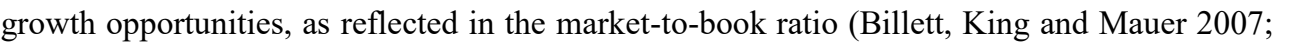

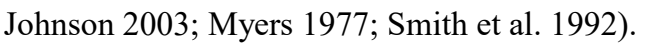




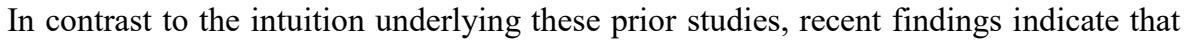

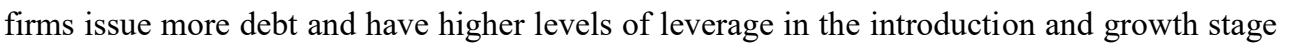

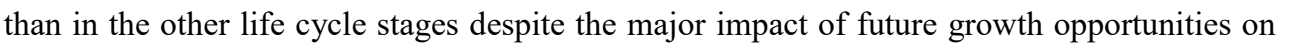

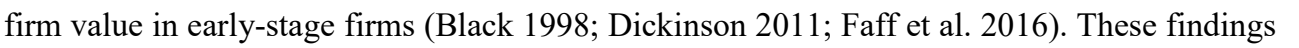

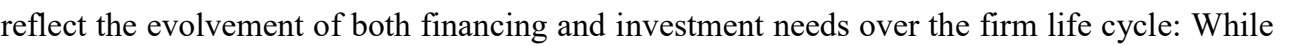

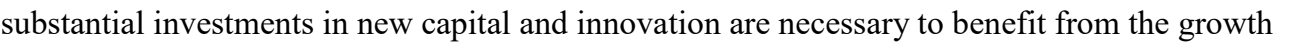

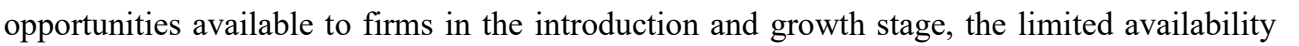

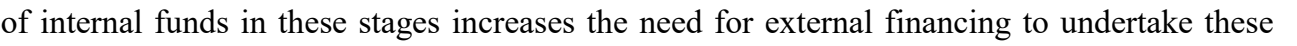

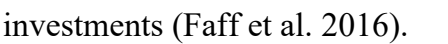

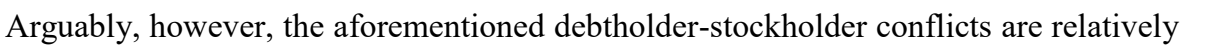

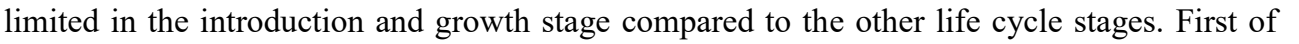

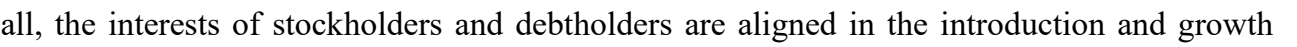

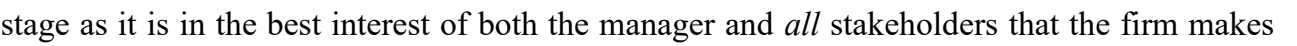

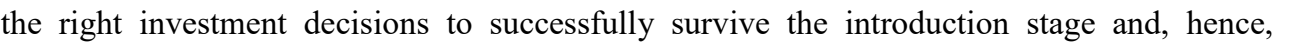

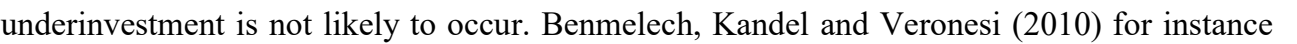

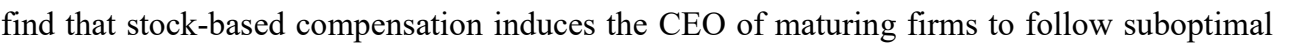

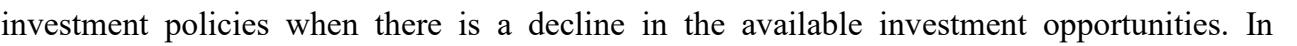

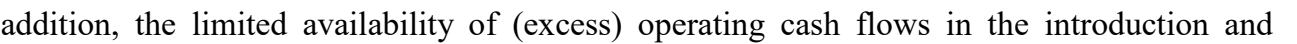
growth stage limit the firm's ability to overinvest in (risky) projects or to distribute $\square \square$

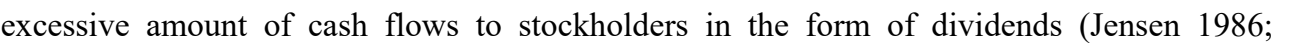

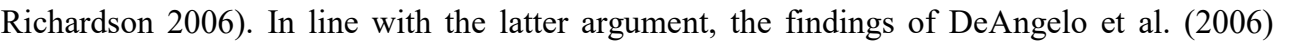

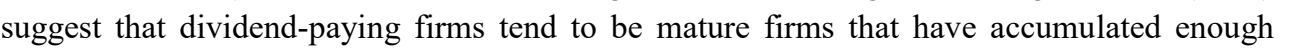

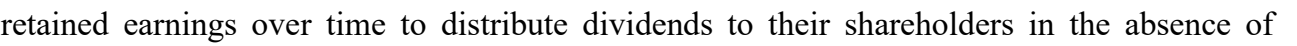

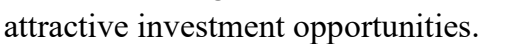

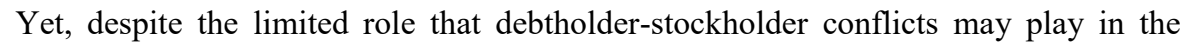

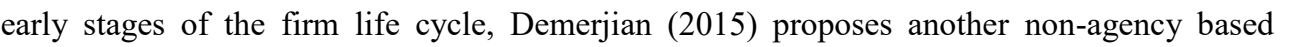

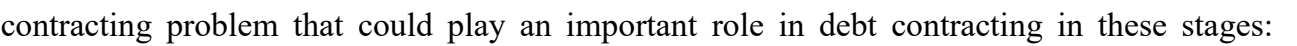
$\square$ ncertainty about the borrower's future value. In designing the debt contract, potential

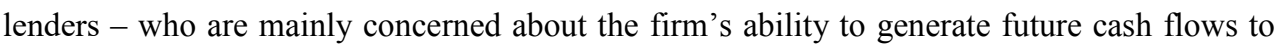

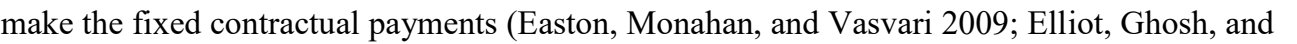

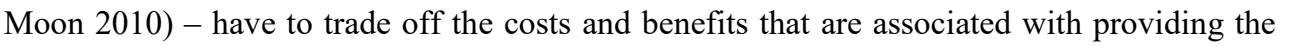

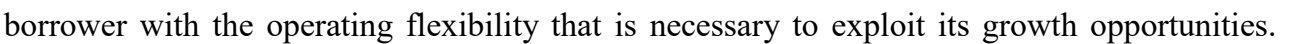

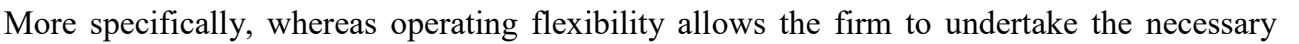
investments and, hence, could enhance the firm's ability to generate future cash flows, the

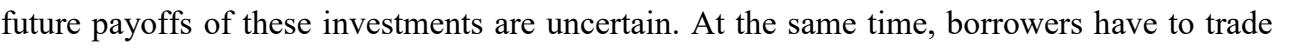

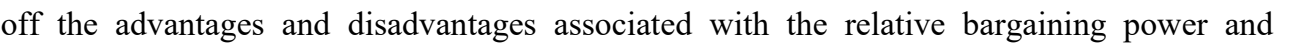

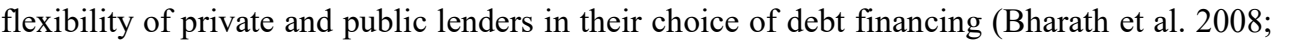

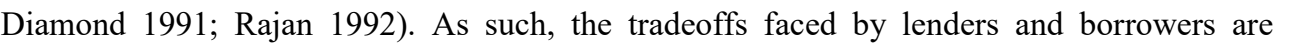

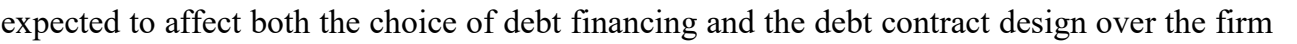
पाणाणाएणा

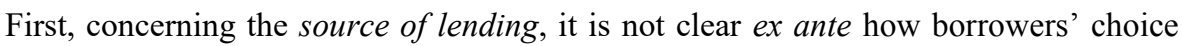

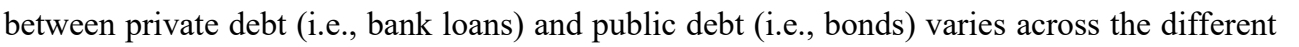
ए एणी 


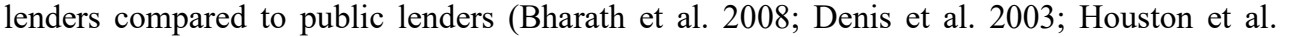

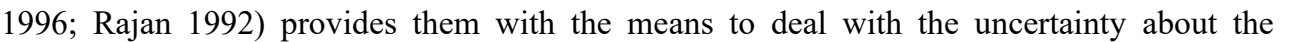

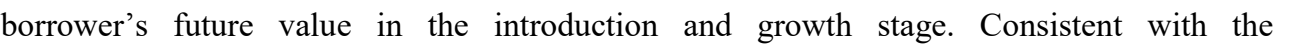

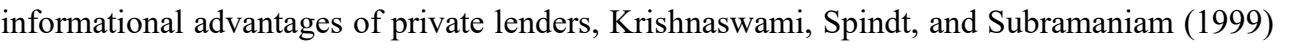

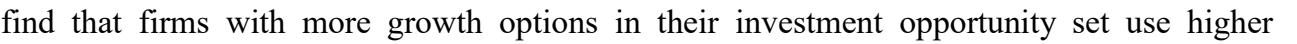

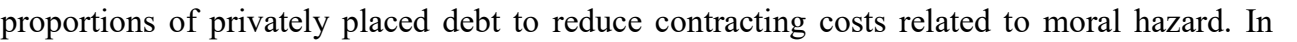

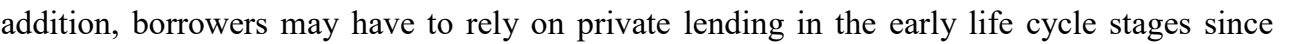

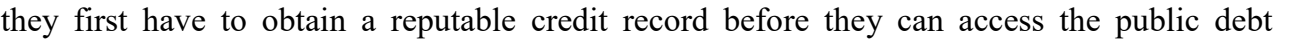

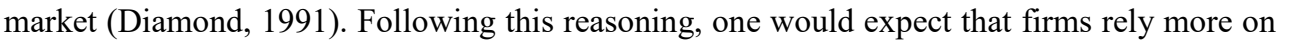

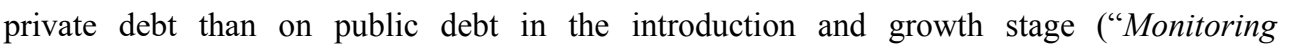
$\left.\square|| \Pi \mid\|\|^{\prime \prime}\right)$.

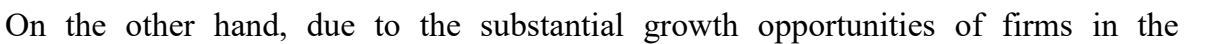
introduction and growth stage these firms are also more vulnerable to banks' bargaining $\square \square \square \square$ ver firms' profits (Bharath et al. 2008; Houston et al. 1996; Rajan 1992). More

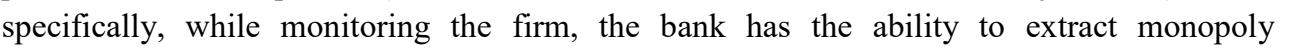
ए

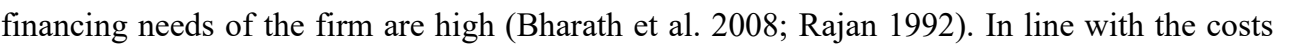

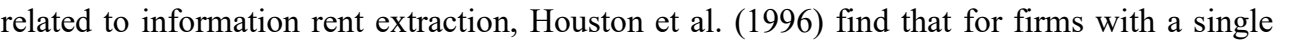

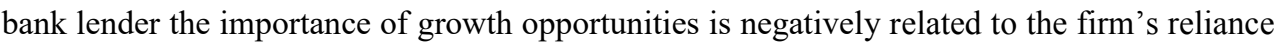

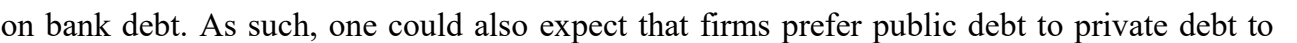
limit banks' information rent extraction during the introduction and growth stage (“ $\square \square \square \square$

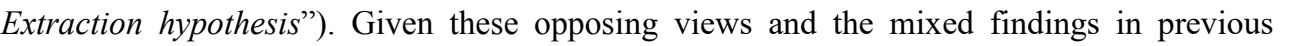

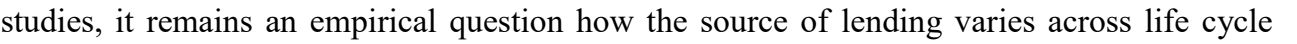

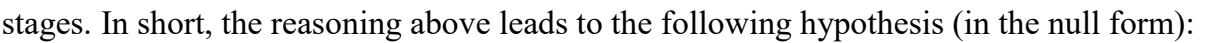

$\square$

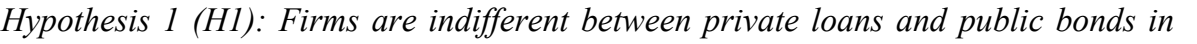

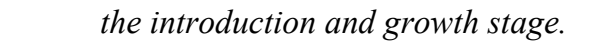

एा]

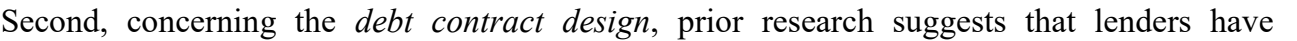

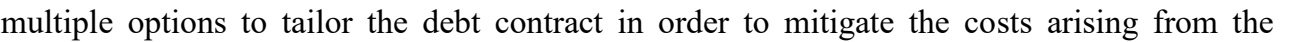
uncertainty about the borrower's future value, including debt covenant design, maturity of the

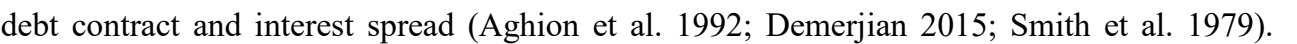

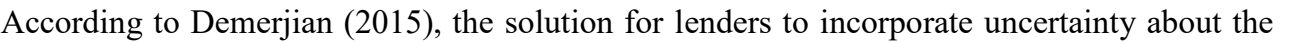
borrower's future value into the debt contract design lies in the flexibility of debt contracts, as

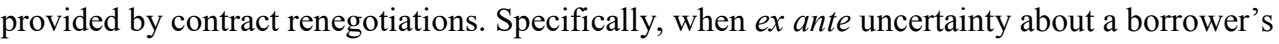

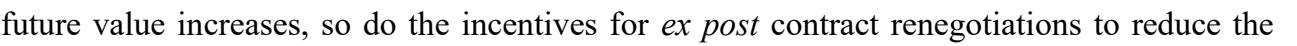

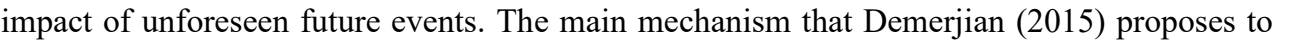

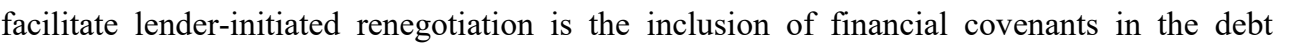

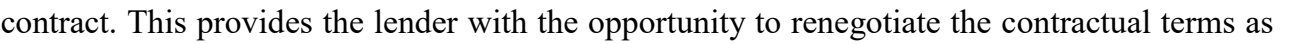

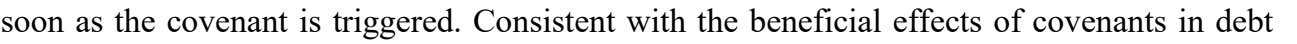

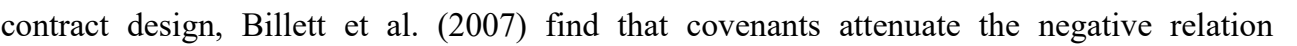

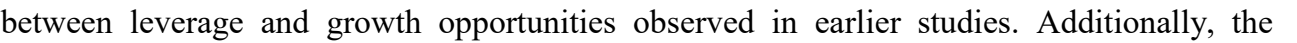
ए

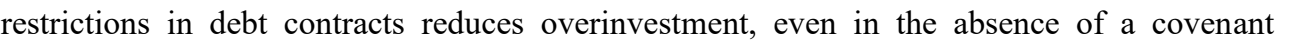




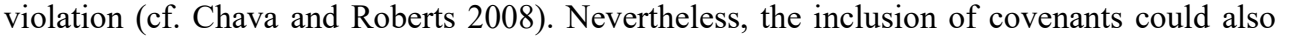
unduly restrict the firm's operating flexibility and, consequently, limit the ability to exploit

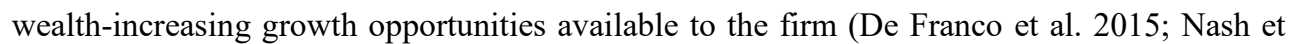

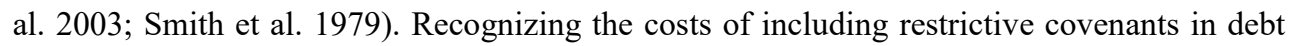

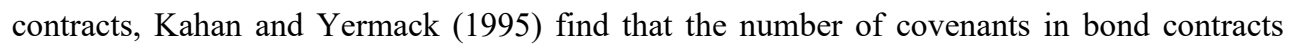

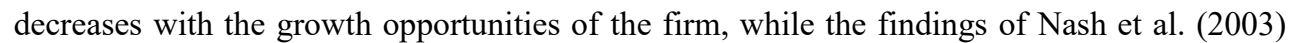

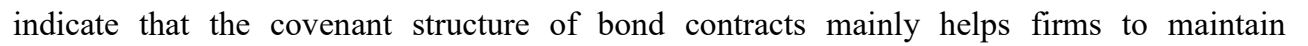
.

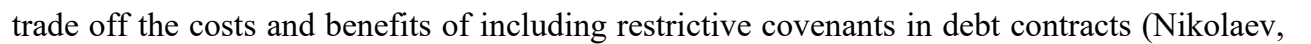

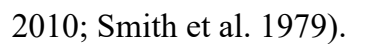

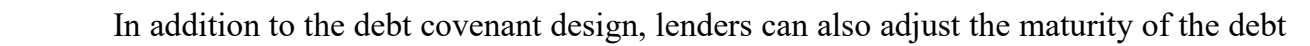

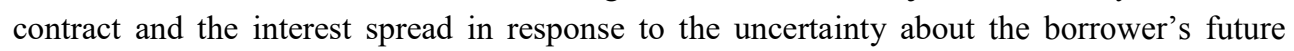

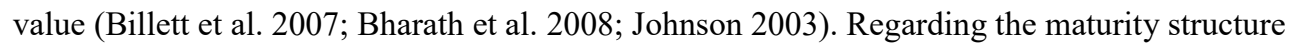

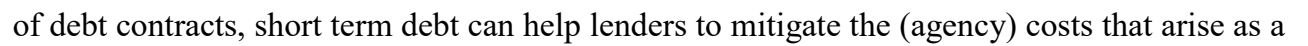
$\square\|\|\|\|\|\|\|\mid\|\|\square\|\|\| \square \square \square$ ptions in the firm's investment opportunity set and facilitates lenders' ability to negotiate new contractual terms (Barclay and Smith 1995; Demerjian 2015;

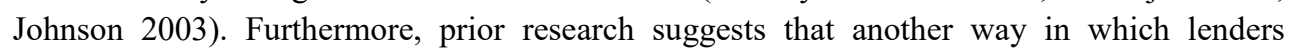
ए।

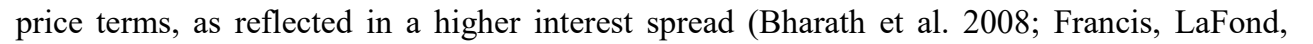

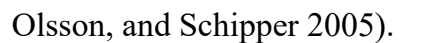

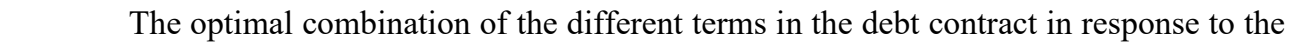

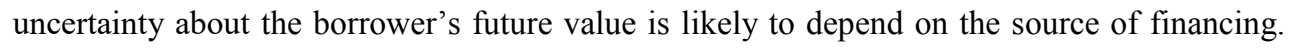

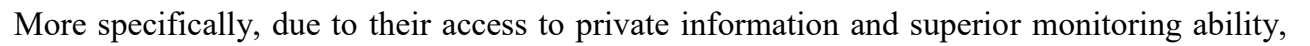

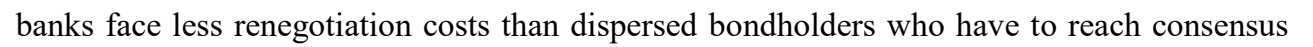

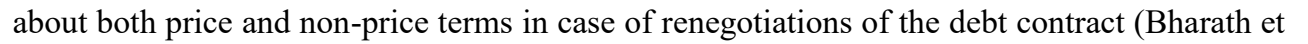

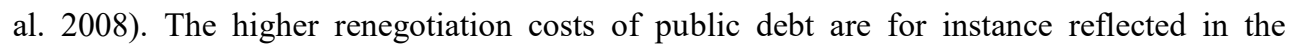

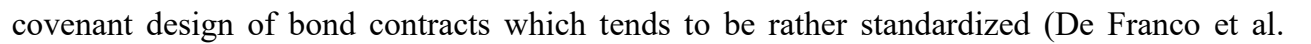

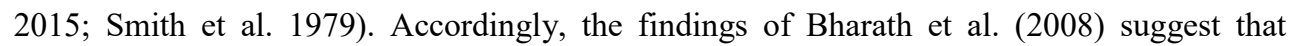

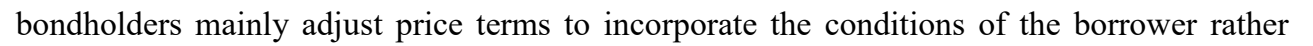

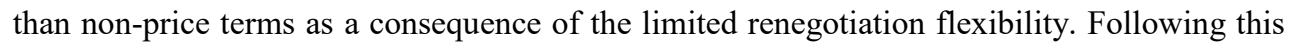

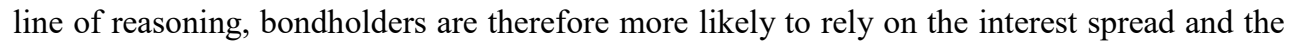

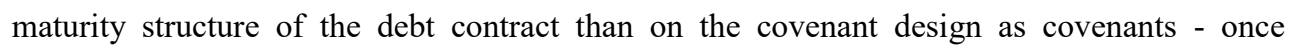

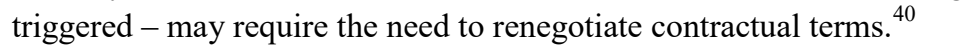

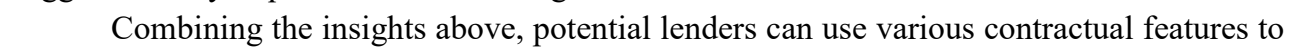

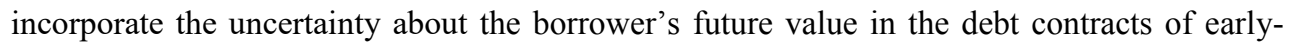

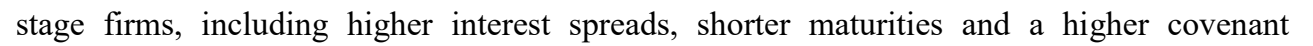

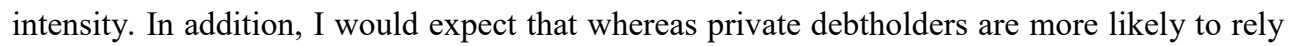

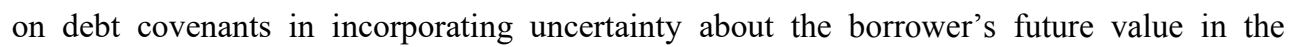

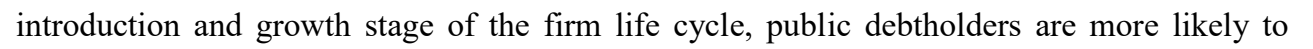

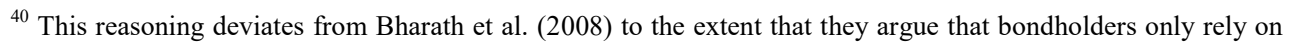

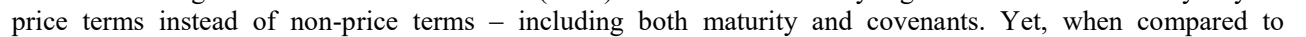

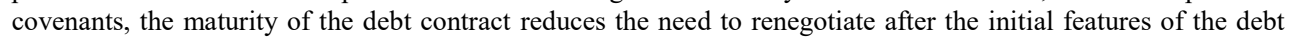

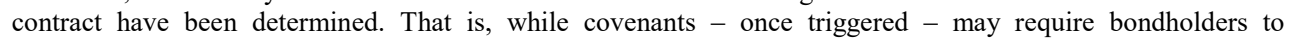

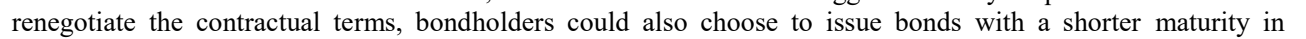
response to the uncertainty as to the borrower's future value.
} 


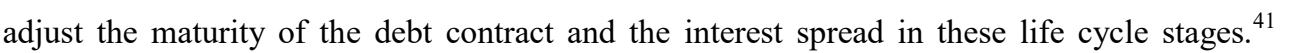

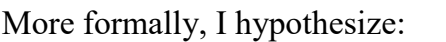

$\square$

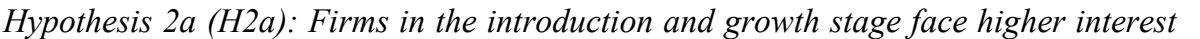

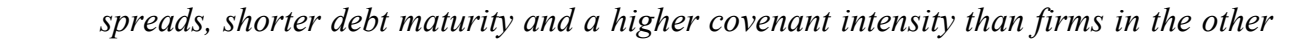

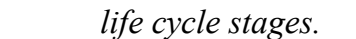

$\square$

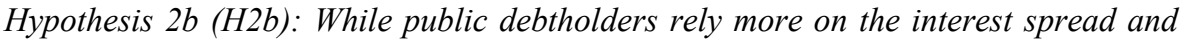

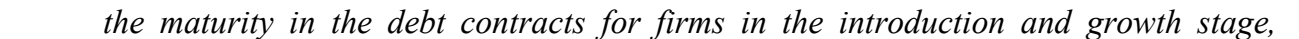

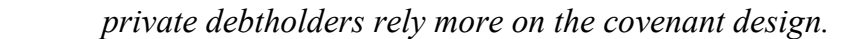

$\square$

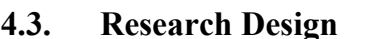

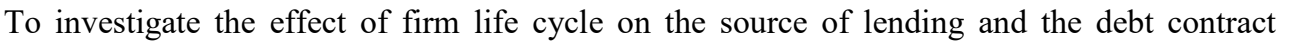

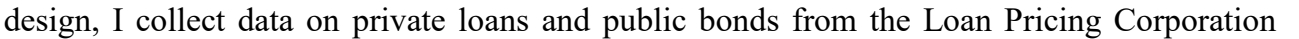

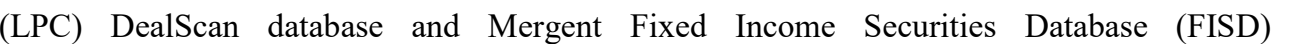

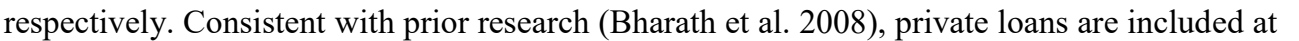

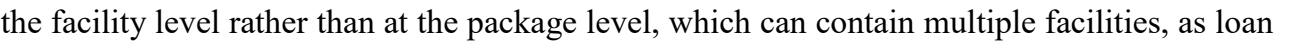

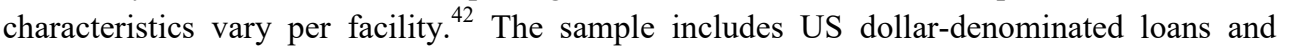

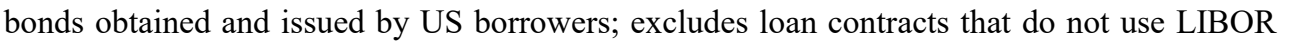

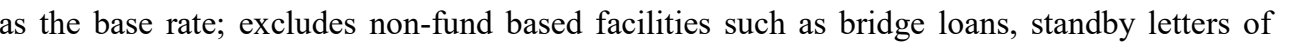

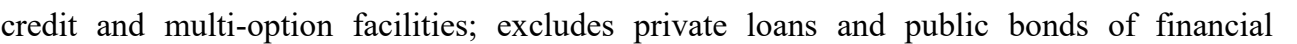
ए ए

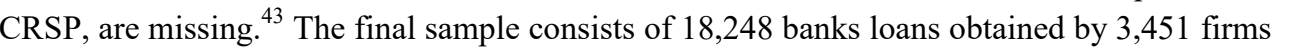

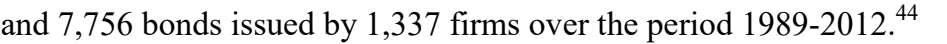

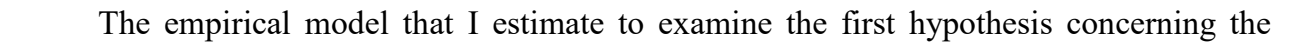

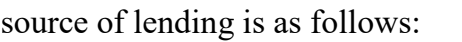

$\square$

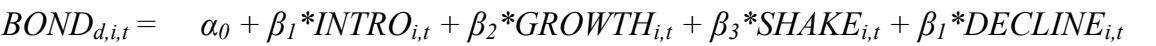

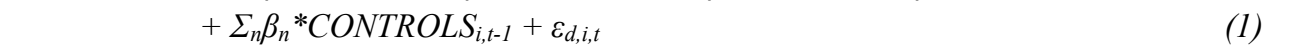
$\square$

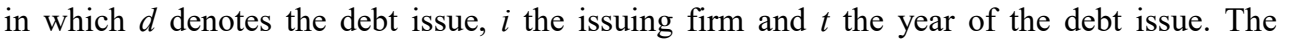

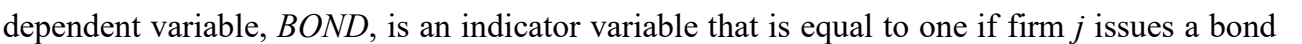

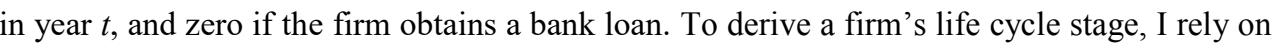

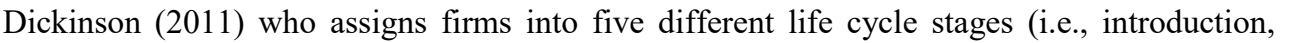

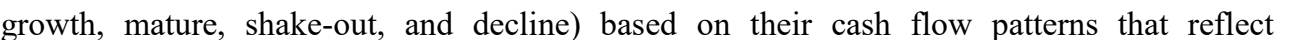

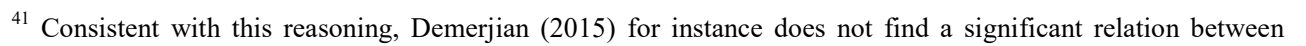

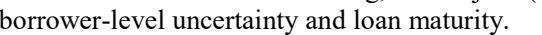

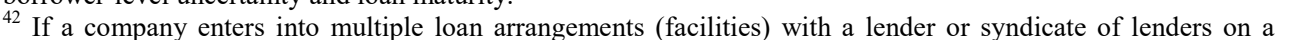
ए एव

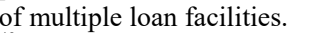

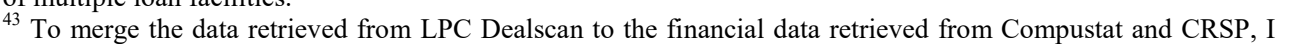

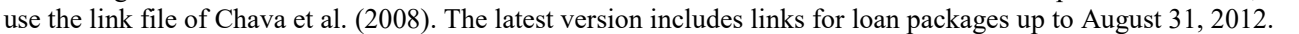

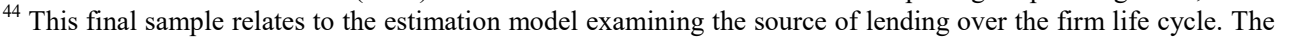

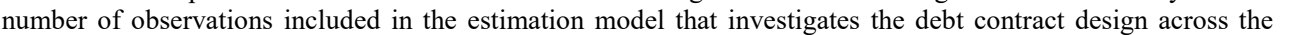
口

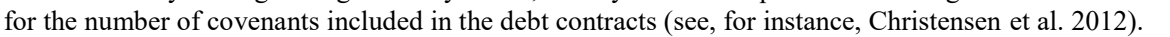




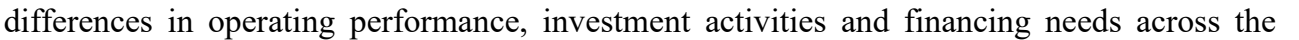

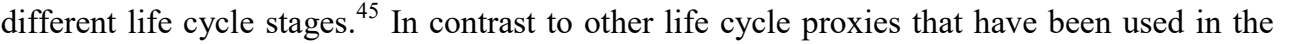

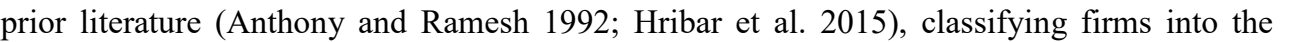

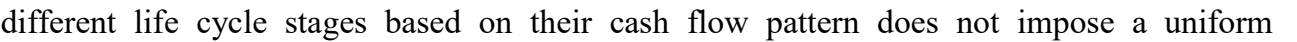

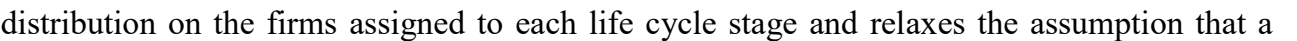

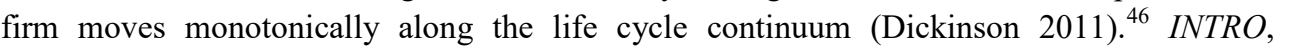

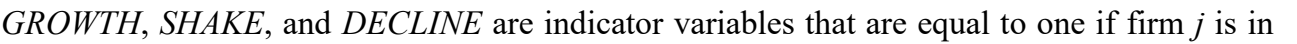

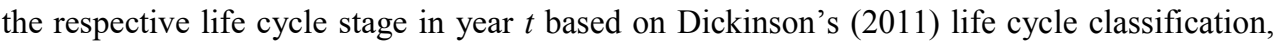

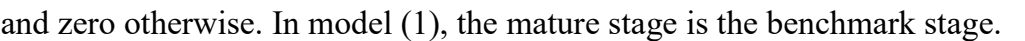

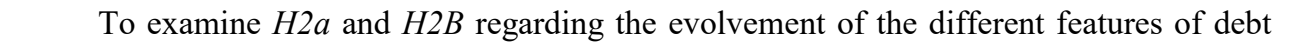

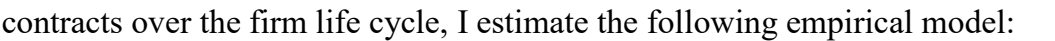

$\square$

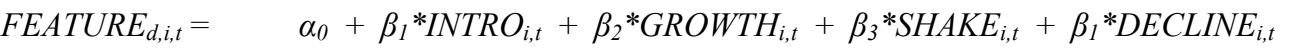

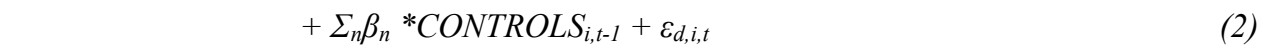

$\square$

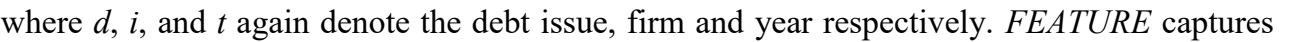

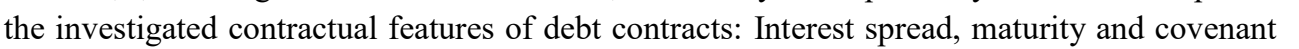

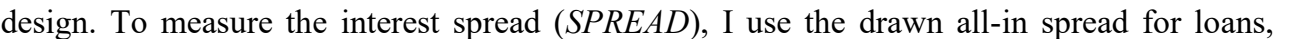
which is the spread between the borrower's drawn line of credits and LIBOR in basis points,

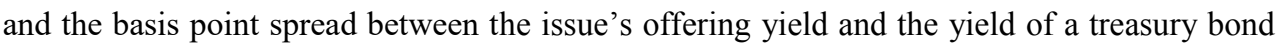

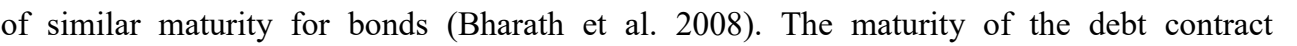

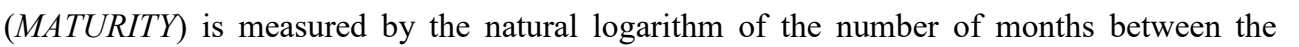

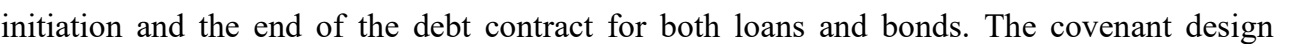

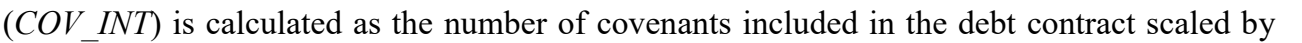

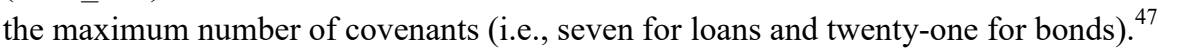

\footnotetext{
An overview of Dickinson's (2011) life cycle classification can be found in Tab

Despite the favorable properties of Dickinson's (2010) life cycle proxy over alternative life cycle proxies, I

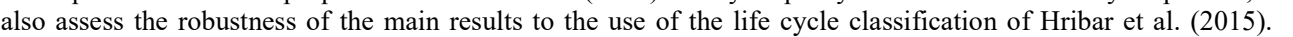

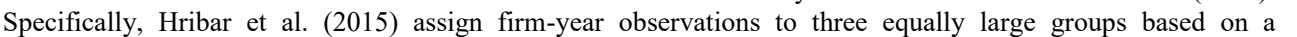

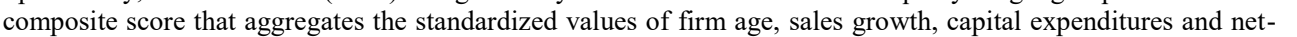

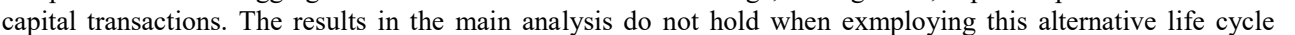

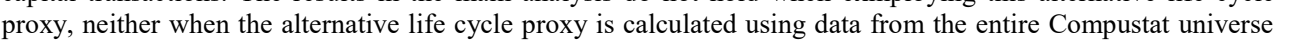

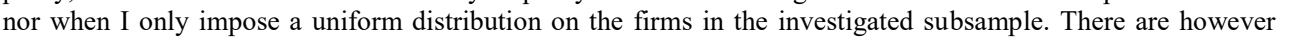

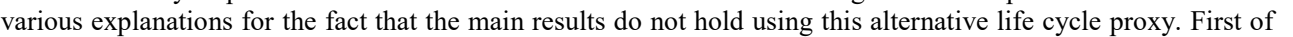

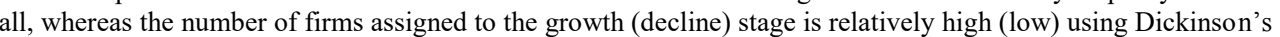
ב

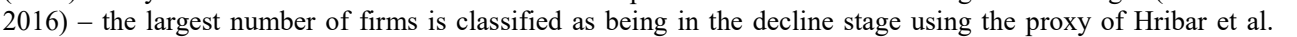
ए ए

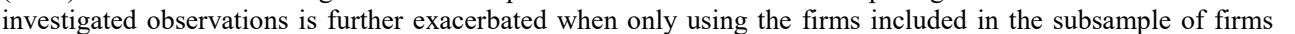
ए

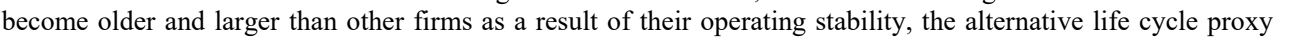

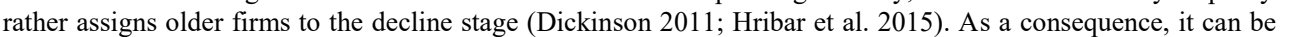

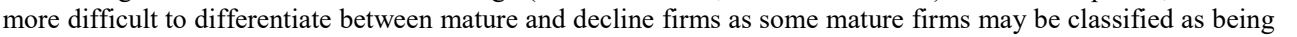

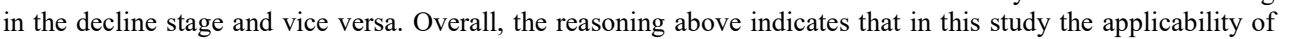
the life cycle classification of Hribar et al. (2015) is limited compared to Dickinson's (2011) cash flow

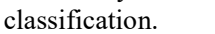

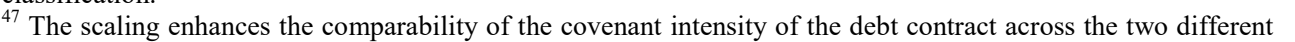

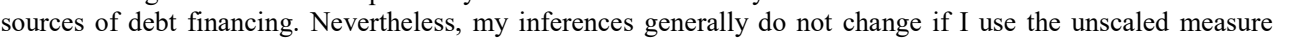

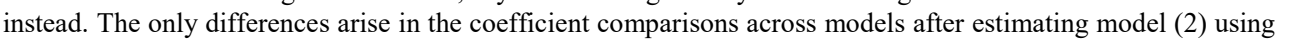




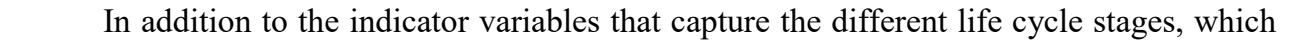

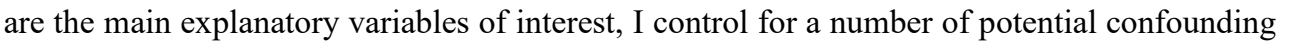
प

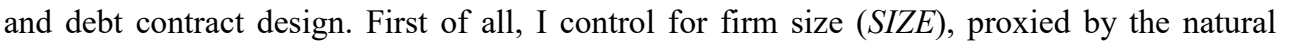

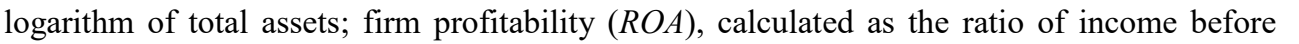

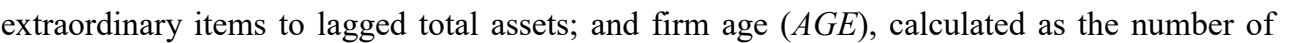

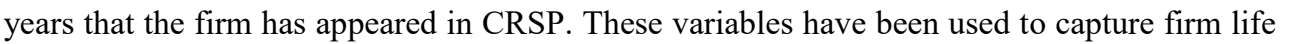

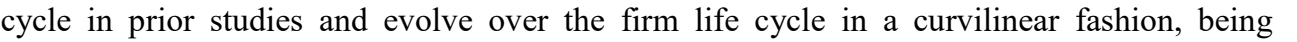

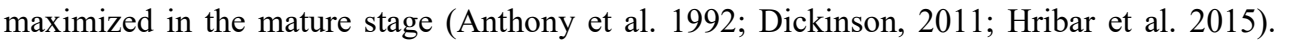

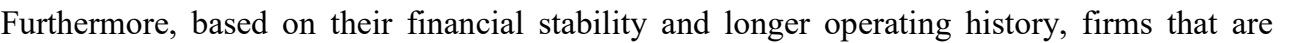

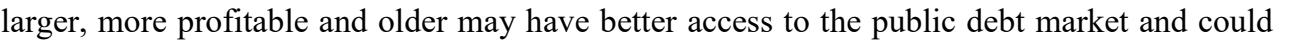

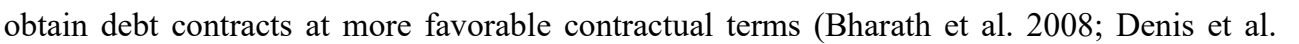

\section{3; Krishnaswami et al. 1999). I also control for the borrowers' investment opportunity set}

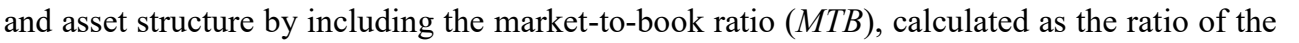

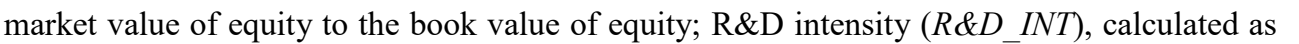
प

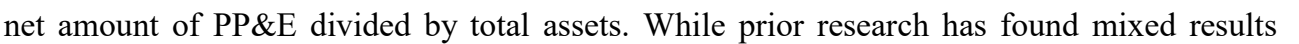

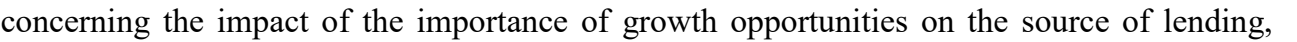
प

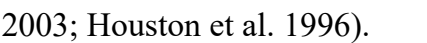

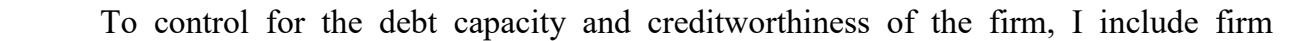

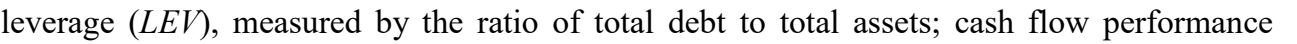

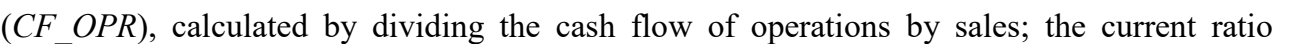

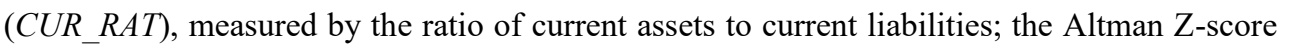

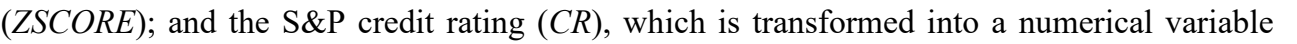

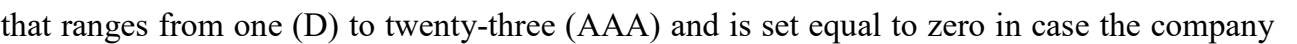

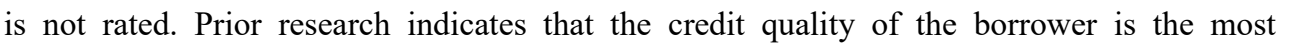

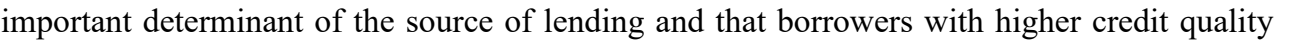

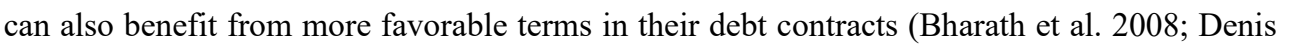

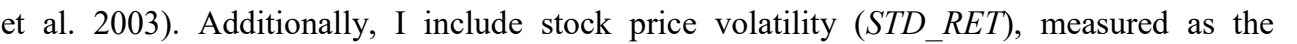

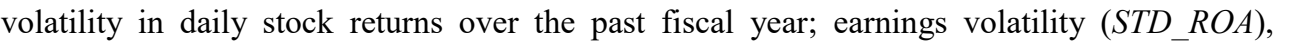

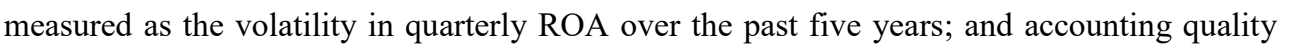

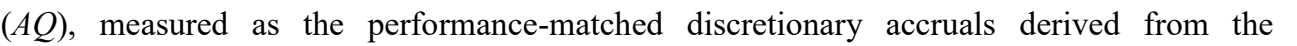

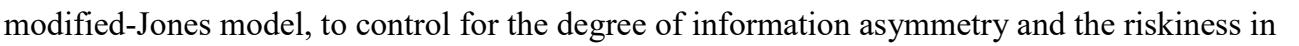

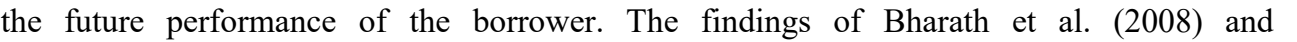

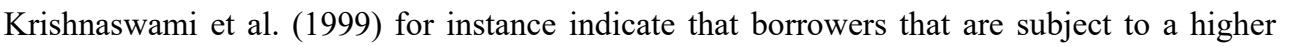

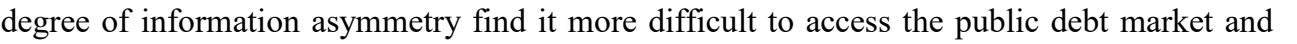

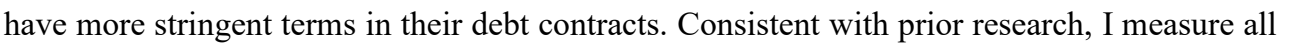

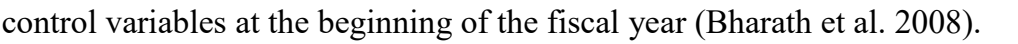

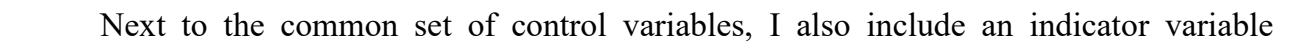

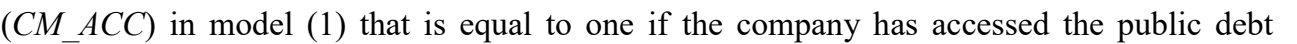

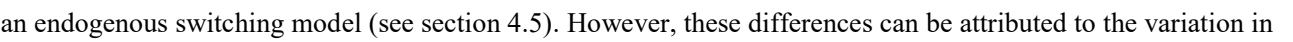

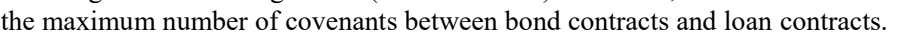




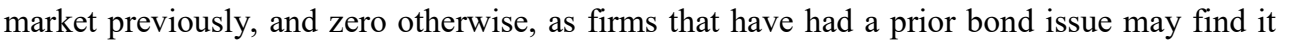

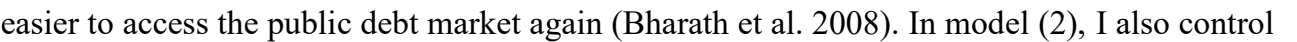

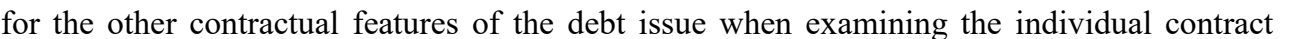

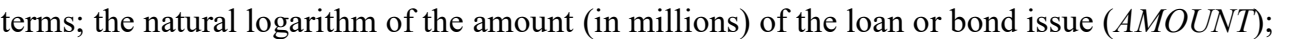

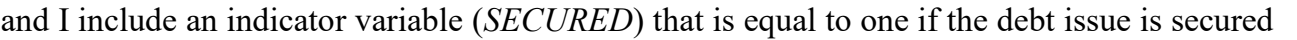

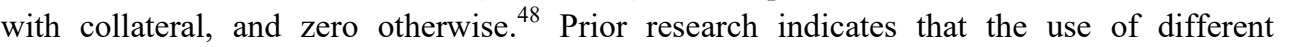

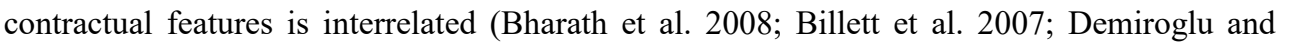

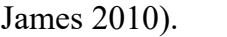

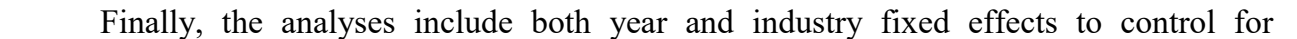

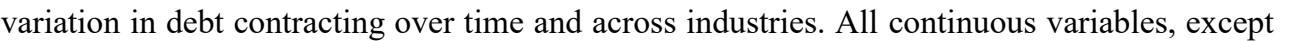

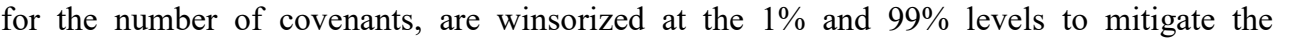

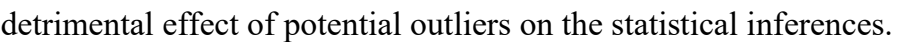

$\square$

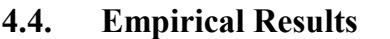

$\square$

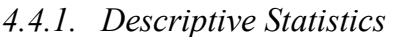

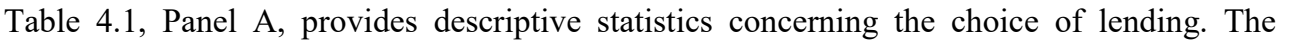

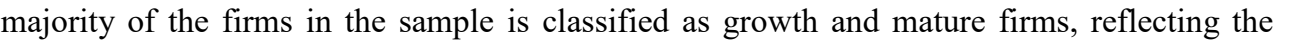

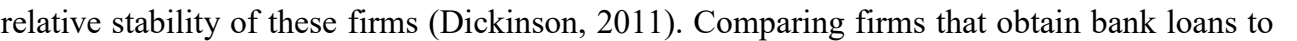

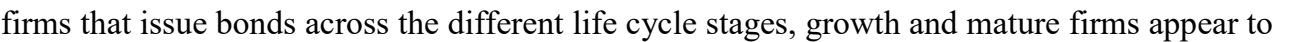

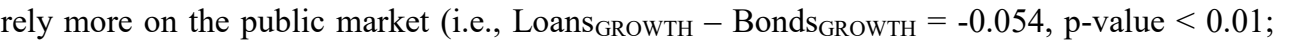

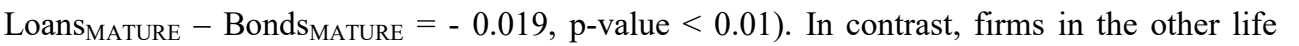

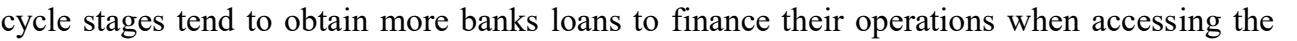

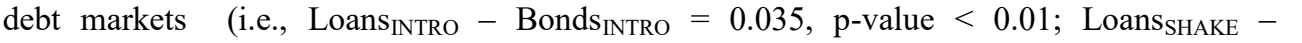

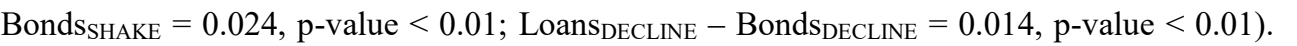

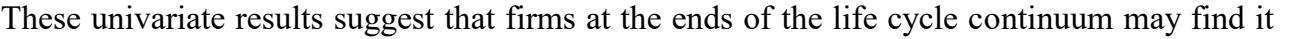

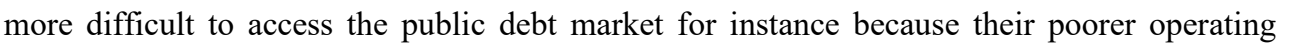

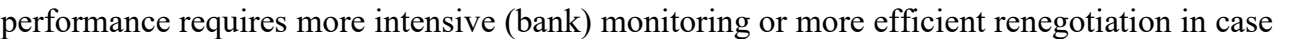

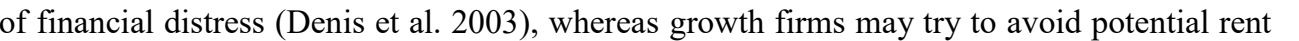

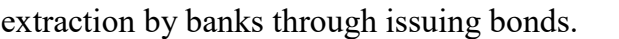

$\square \quad \square$
$\square \quad \square$

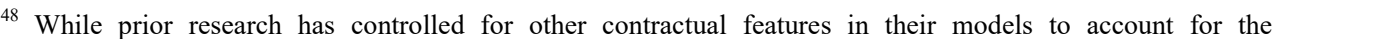
प "

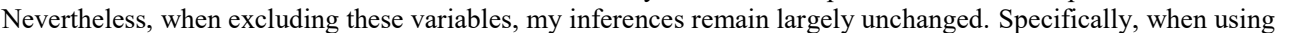

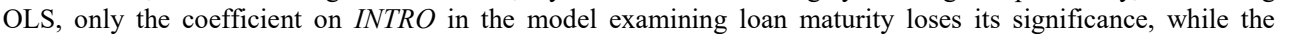

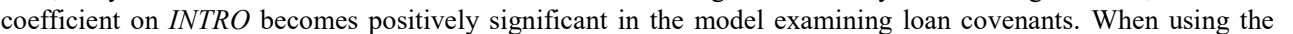

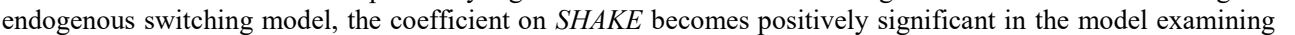

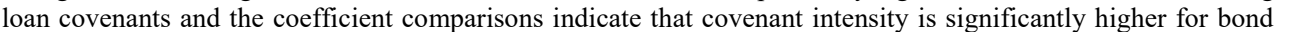

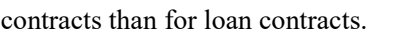




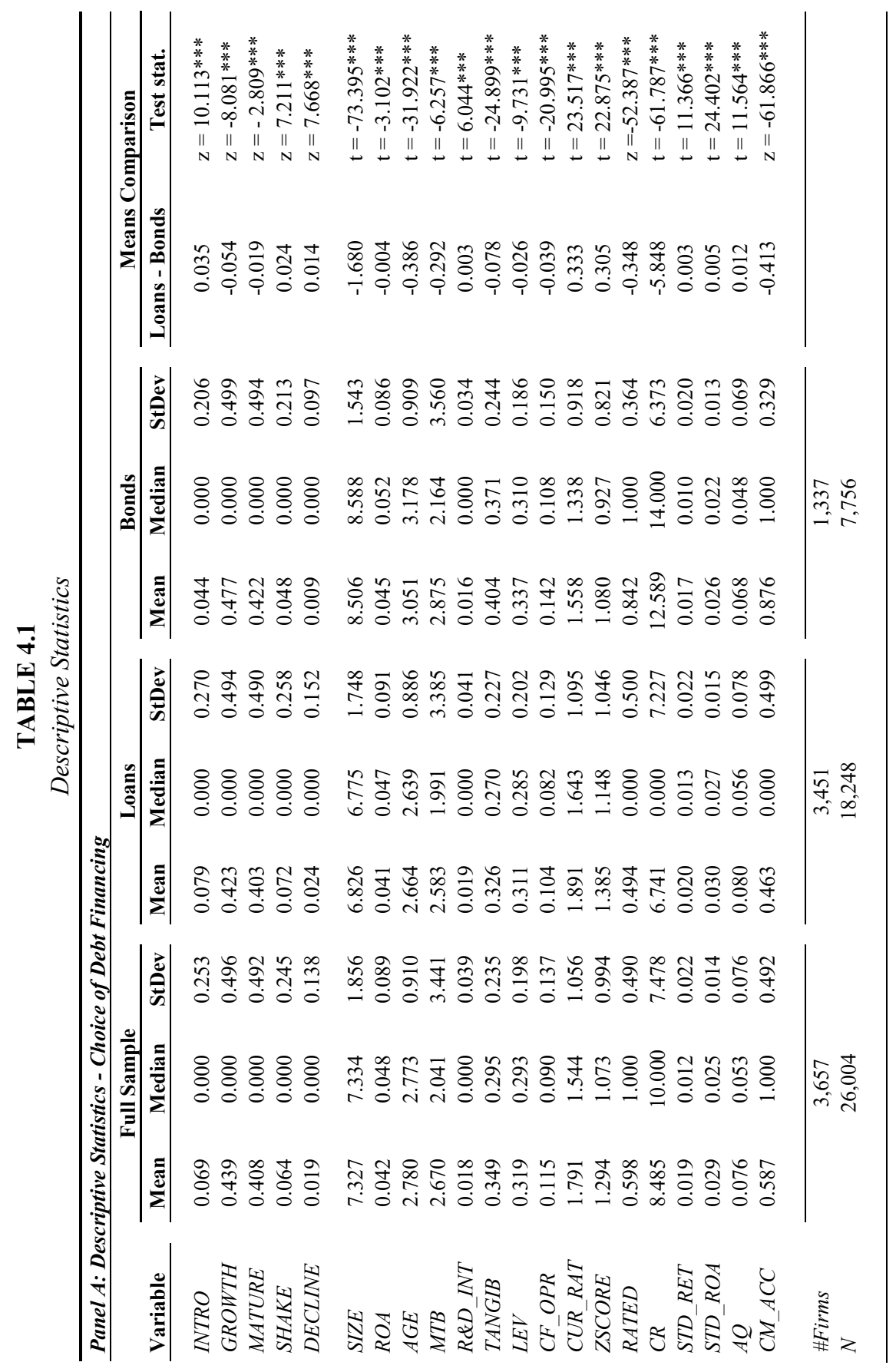




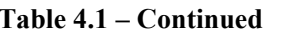

\begin{tabular}{|c|c|c|c|c|c|c|c|c|}
\hline \multicolumn{3}{|c|}{ Panel B: Loan Characteristics } & \multicolumn{2}{|c|}{ (11] } & 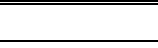 & 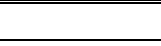 & 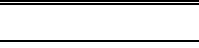 & 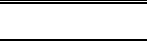 \\
\hline पमाणमाण & $\llbracket$ & 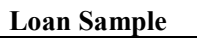 & $\square$ & $\square\|\| \square$ & $\mathbb{E} \quad \square \square \square \square$ & $\llbracket \square \square \square \square \square$ & 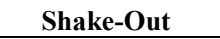 & 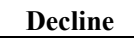 \\
\hline 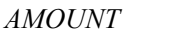 & & $\square \mid \square \square$ & & $\square \| \square$ & $\square \| \square \square$ & $\square|\square| \square$ & $\square \mid ण \square$ & 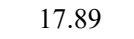 \\
\hline 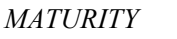 & & 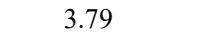 & & $\square ण 1$ & 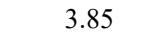 & 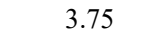 & 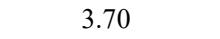 & एणा \\
\hline 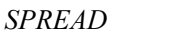 & & $\square 1 \|$ & & $\square 10$ & 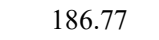 & $\square 1 \square \square$ & $\square 1 \Pi \square$ & 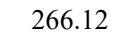 \\
\hline 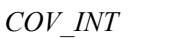 & & $\square \square$ & & $\square \square$ & $\square \square$ & पणा & $\square \mathrm{पाए}$ & पाएा \\
\hline$\square \square \mathbb{~}$ & & पाणप & & $\square \square$ & 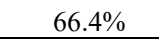 & पापाप्र & पाणिए & $\square \mathrm{पणि}$ \\
\hline$\square \square$ & & 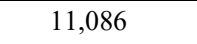 & & $\square \square$ & 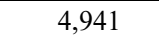 & 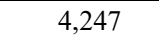 & $\square \square$ & $\square \square$ \\
\hline Panel C: Bonc & $\operatorname{con}$ & teristics & & II] & 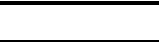 & 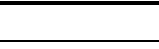 & $\begin{array}{l}\square \square \\
\end{array}$ & 四 \\
\hline पपाणापाप & $\llbracket$ & 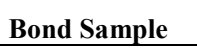 & $\square$ & $\square\|\| \square$ & $\llbracket \square \square \square \square \square$ & $\llbracket \square \square \square \square \square$ & 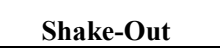 & 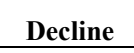 \\
\hline 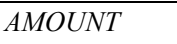 & & $\square ण \square$ & & $\square \square \square$ & 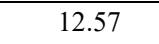 & 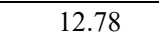 & $\square ण \square$ & पाण \\
\hline$\square \square \square \square \square \square \square \square$ & & 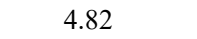 & & 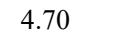 & $\square ण 1$ & $\square \square \square$ & 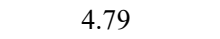 & एणा \\
\hline 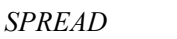 & & $\square \| \Pi \square$ & & पाणा & पाणा & $\square \| \Pi \square$ & पाला & पालाप \\
\hline प्रणपाणी & & $\square \square \square$ & & पणाए & 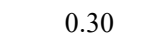 & 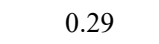 & पाणा & पणा \\
\hline$\square \square \square$ & & $\square \square \square \square$ & & $\square \square \square \square$ & $\square \square \square$ & $\square ण \square \square$ & $\square \square \square$ & $\square \square \square \square$ \\
\hline$\square \square$ & & 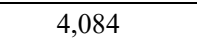 & & $\square \square$ & 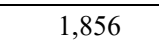 & 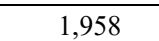 & $\square \square \square$ & $\square \square$ \\
\hline 四 & $\llbracket$ & & $\square$ & & $\llbracket \mathbb{\square}$ & $\llbracket \mathbb{1}$ & $\llbracket \square$ & 四 \\
\hline
\end{tabular}

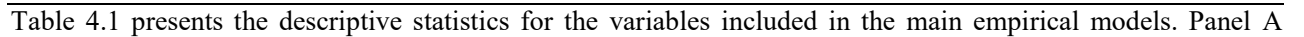
एण

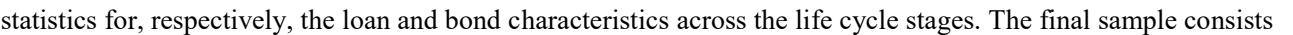

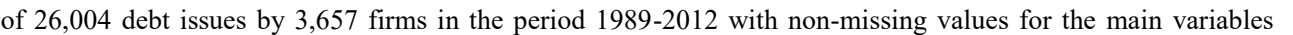

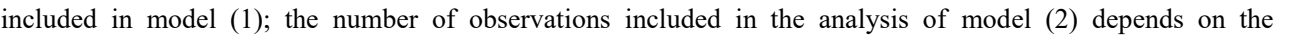

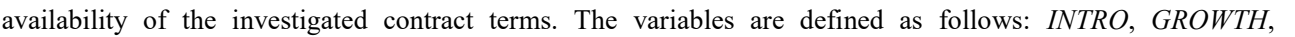

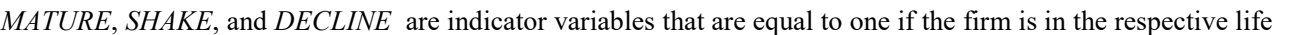
cycle stage based on Dickinson's (2011) life cycle classification, and zero otherwise; $\square=0$

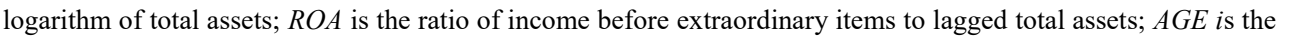

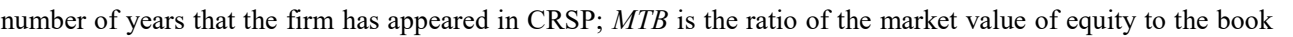

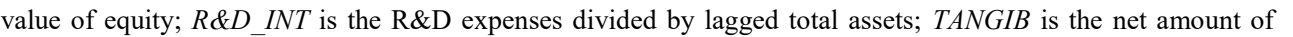

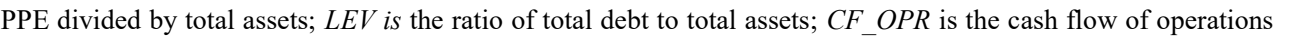

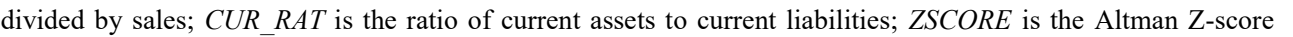

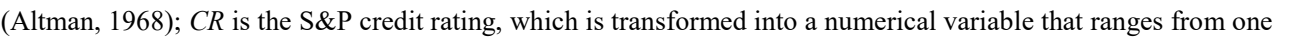

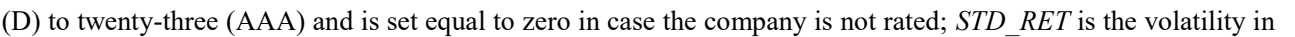

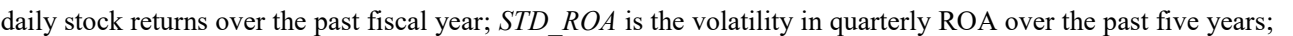

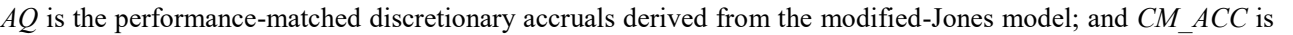

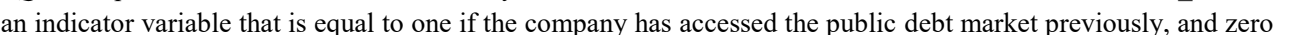

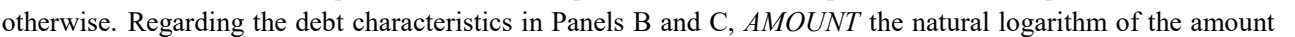

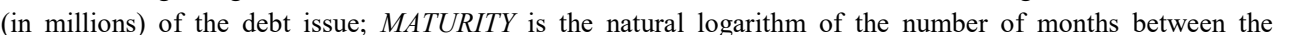

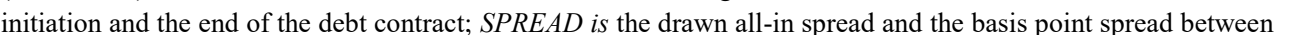
the issue's offering yield and the yield of a treasury bond of similar maturity

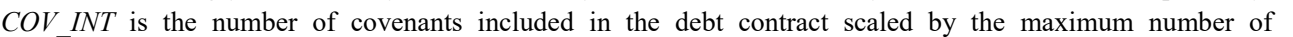

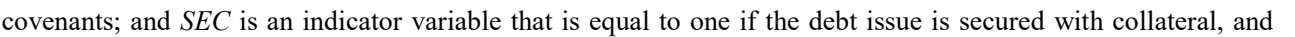
पणमाणमाणा

$\square$

$\square$

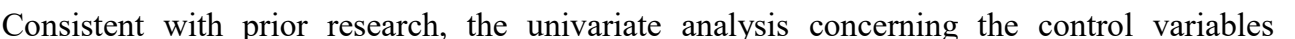

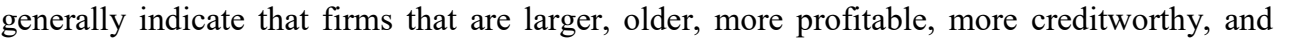

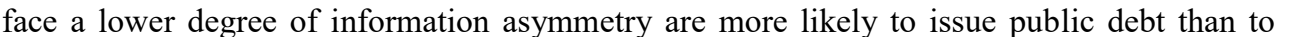

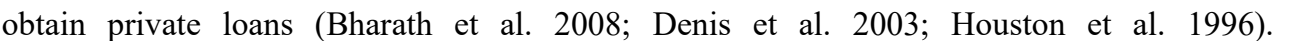

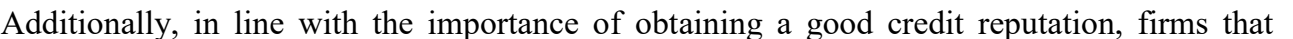




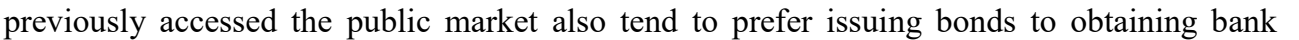

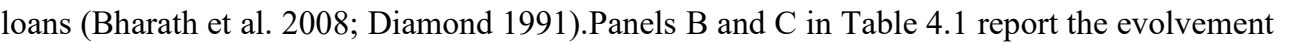

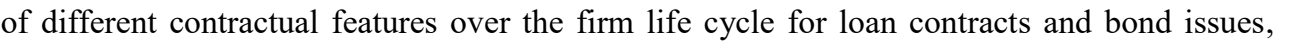

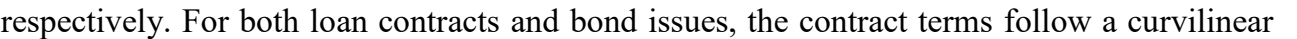
ए

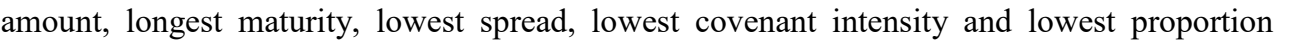

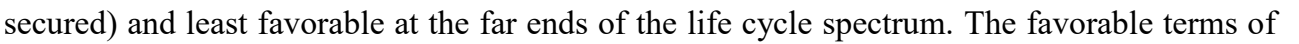

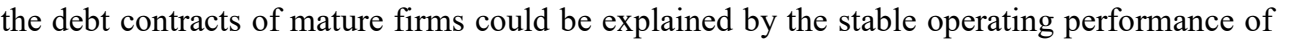
ए

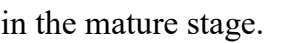

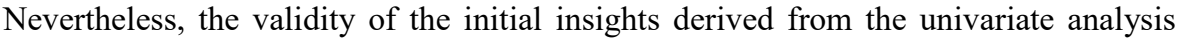
पाएण

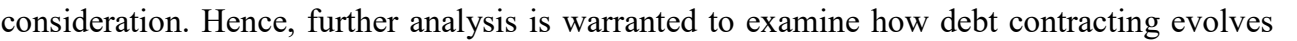

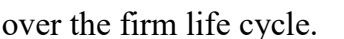

$\square$

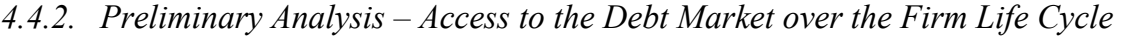

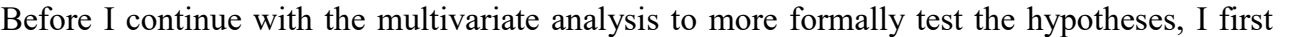

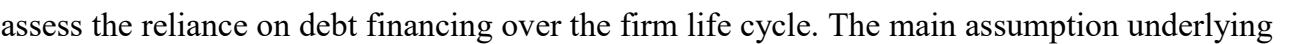

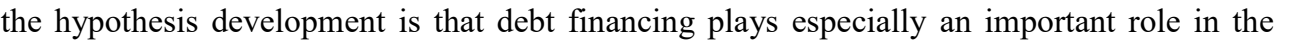

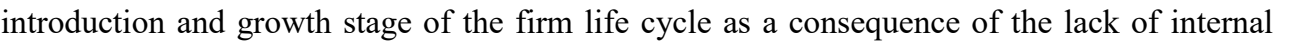

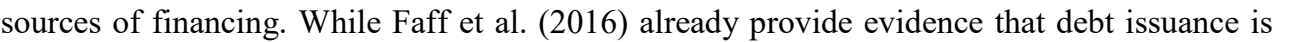

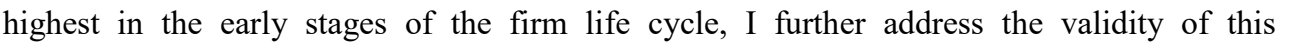

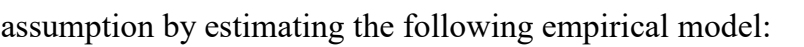

$\square$

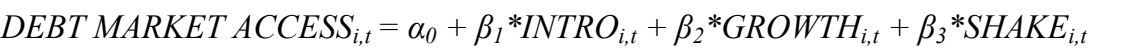

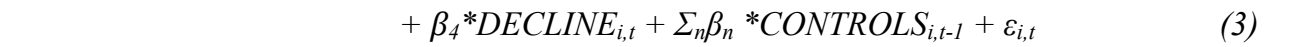
$\square$

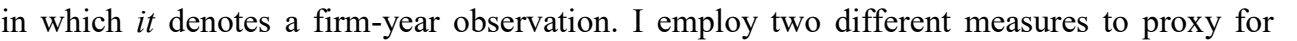

firm's

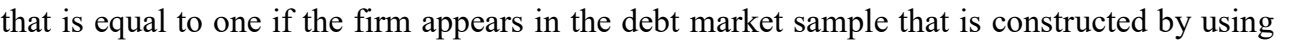

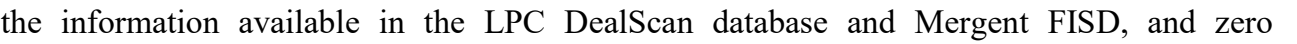

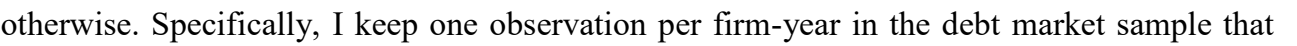

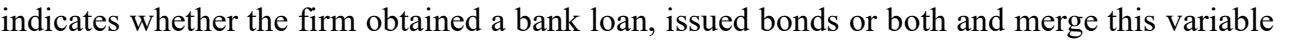
ए ए

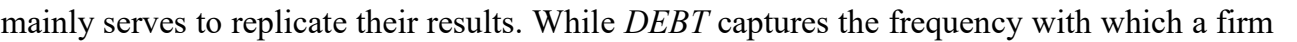

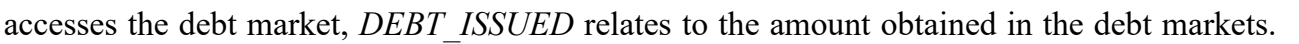

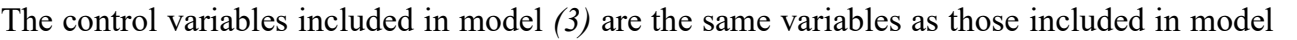

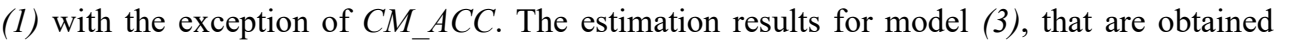

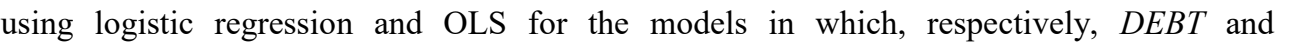

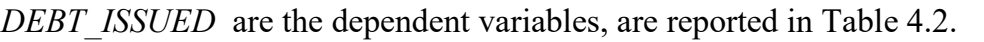

$\square$

$\square$ 
प्रण पणाप

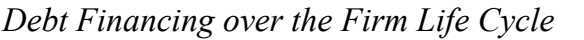

\begin{tabular}{|c|c|c|}
\hline \multirow[t]{2}{*}{ 四 } & \multicolumn{2}{|c|}{$\mathbb{I} \quad$ प } \\
\hline & $\square 1 \mathbb{\square}$ & एाए \\
\hline पणाणाप & $\square \square \square \square \square$ & 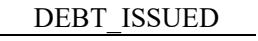 \\
\hline \multirow[t]{2}{*}{ 四口田 } & पण口मा & पामाएम \\
\hline & पाणाए & ए।णाए \\
\hline \multirow[t]{2}{*}{ 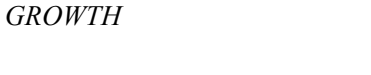 } & पामापा & पामापा \\
\hline & 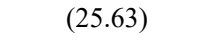 & एापाए \\
\hline \multirow[t]{2}{*}{$\square \square \square \square \square$} & एणाम & एामापा \\
\hline & एवाणा & 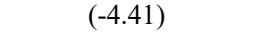 \\
\hline \multirow[t]{2}{*}{ 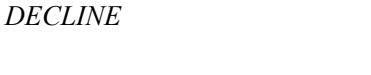 } & पाणाम & पामापा \\
\hline & एणाएा & पाणाए \\
\hline \multirow[t]{2}{*}{$\square \square \square$} & पणामा & एणामा \\
\hline & पाणापा & पण口卄ा \\
\hline \multirow[t]{2}{*}{$\square \square \square \square$} & पणामा & पामाएम \\
\hline & पाणाएा & पाणाए \\
\hline \multirow[t]{2}{*}{$\square \square \square \square$} & पामाएम & पाणामा \\
\hline & 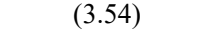 & 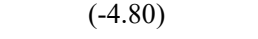 \\
\hline \multirow[t]{2}{*}{$\square \square \square \square$} & 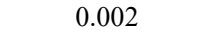 & $\square \amalg|П| \square$ \\
\hline & एणाए & पाणाप \\
\hline \multirow[t]{2}{*}{ 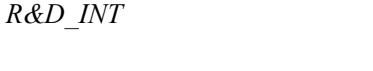 } & एणाणामा & पाणमाप \\
\hline & 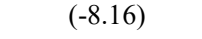 & 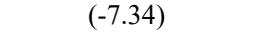 \\
\hline \multirow[t]{2}{*}{ 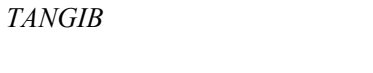 } & पाणा111 & पामा \\
\hline & एणाणाए & पण口ण \\
\hline \multirow[t]{2}{*}{ 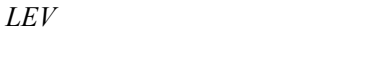 } & पामामा & 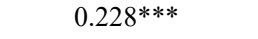 \\
\hline & पापाएा & ए।णाए \\
\hline \multirow[t]{2}{*}{ 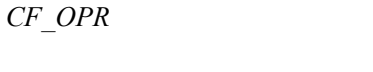 } & 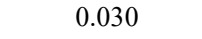 & पामामा \\
\hline & पाणाए & पणाणा \\
\hline \multirow{2}{*}{ 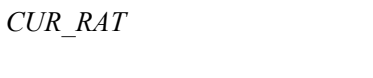 } & पाणामाम & पामापा \\
\hline & एणाएा & पण口卄ा \\
\hline \multirow[t]{2}{*}{ 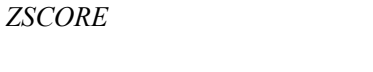 } & पाणाम & पाणाए \\
\hline & एणाणा & पणाणा \\
\hline \multirow[t]{2}{*}{$\square \square \square$} & पामामा & पणामाप \\
\hline & पाणाए & पण口卄ा \\
\hline \multirow[t]{2}{*}{ 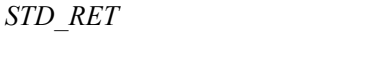 } & एमाणमाम & पणमापा \\
\hline & एणाएा & एणाएण \\
\hline \multirow[t]{2}{*}{ 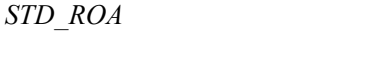 } & पणाम & पाणाम \\
\hline & एणा10 & 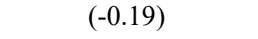 \\
\hline \multirow[t]{2}{*}{$\square \square \square$} & पामा & पण口卄 \\
\hline & पाणा & पाणाए \\
\hline \multirow[t]{2}{*}{ 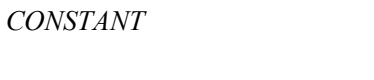 } & एण口卄|मा & पण口म \\
\hline & 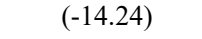 & पाणाएा \\
\hline 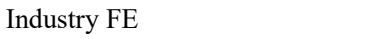 & $\square \square \square \square$ & $\square \square \square \square$ \\
\hline 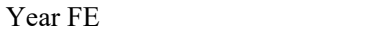 & $\square \square \square \square$ & $\square \square \square \square$ \\
\hline 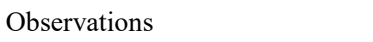 & 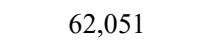 & पाणा \\
\hline 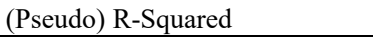 & 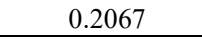 & $\square[11$ \\
\hline 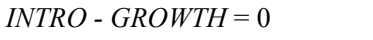 & पपाणामाप & 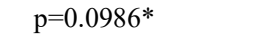 \\
\hline 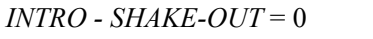 & 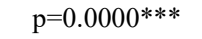 & पापामापा \\
\hline 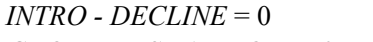 & 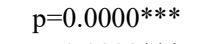 & पाणामापा \\
\hline 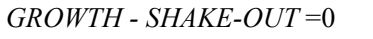 & पापाताप & पापामापा \\
\hline 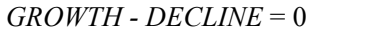 & 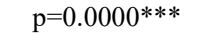 & 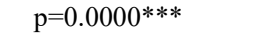 \\
\hline
\end{tabular}




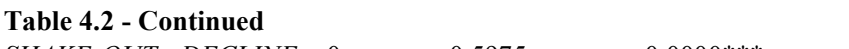

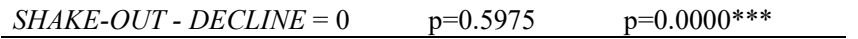

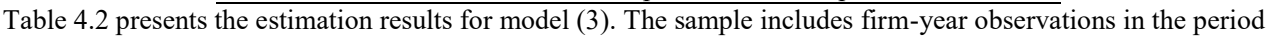

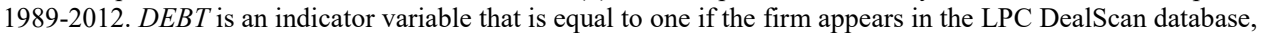

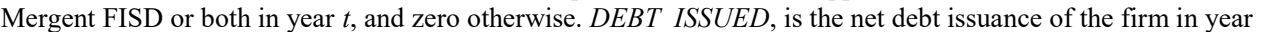
ए

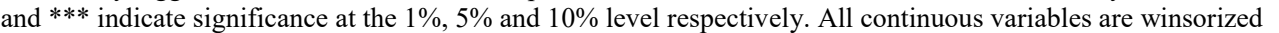

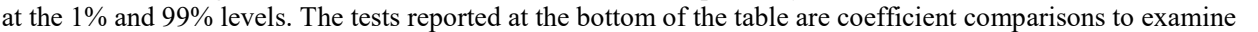
ए ए

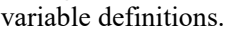

$\square$

$\square$

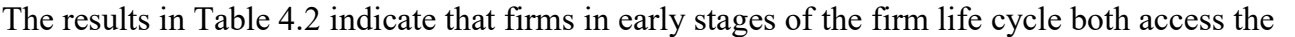

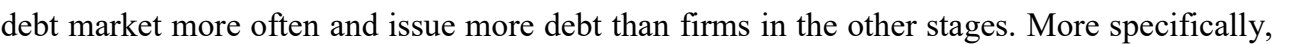
ए ए।

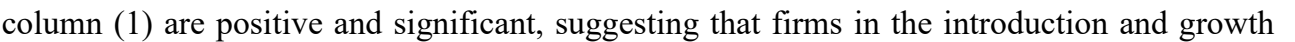

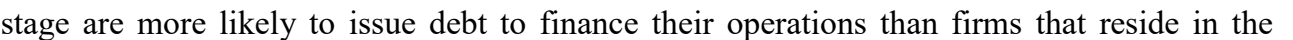

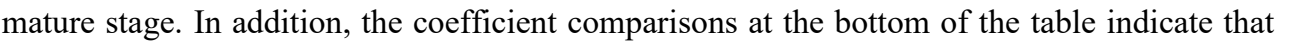

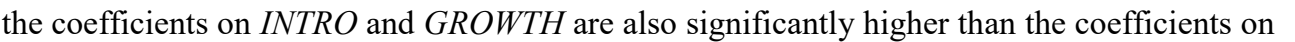

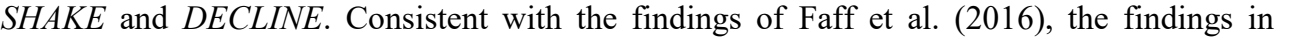

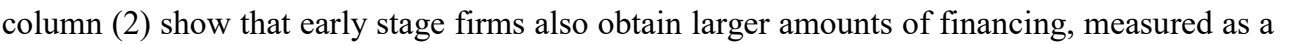

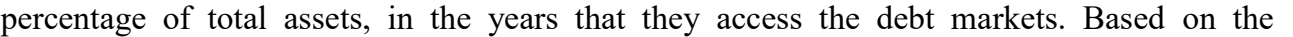

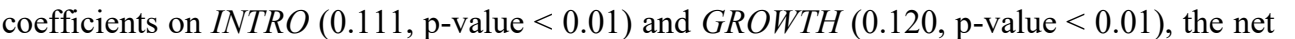

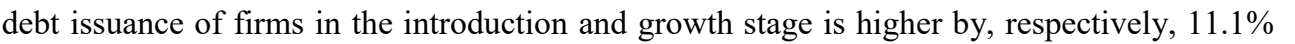

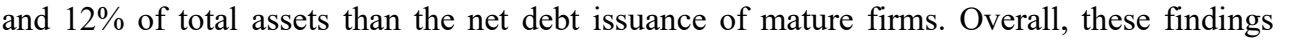

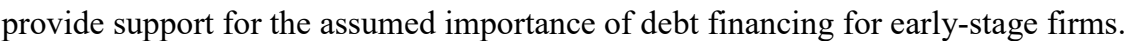
$\square$ 


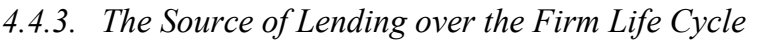

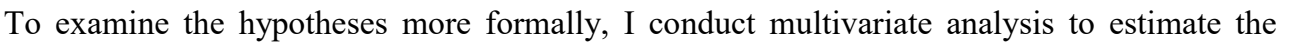

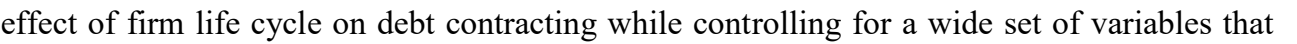

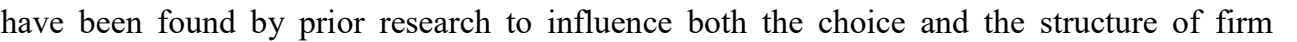

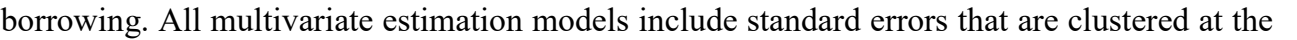

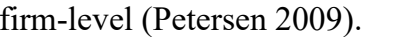

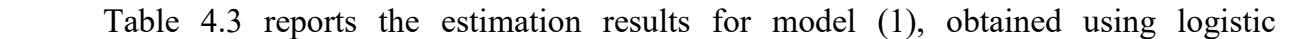

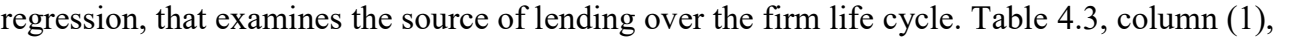

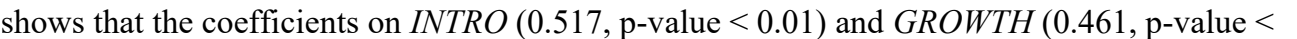

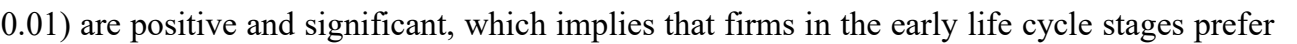

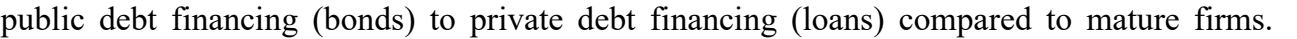

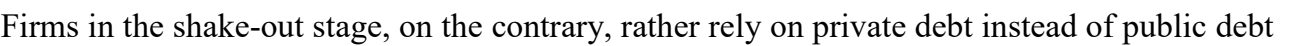

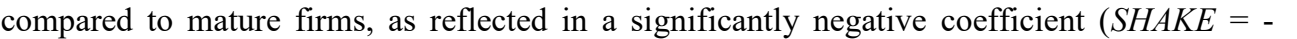

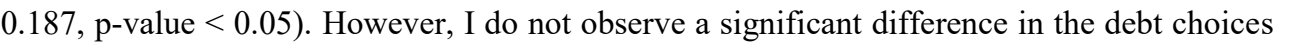

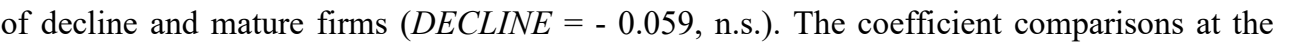

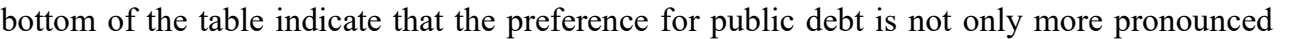

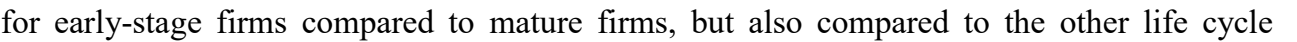

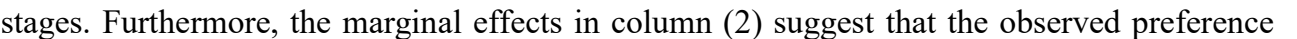

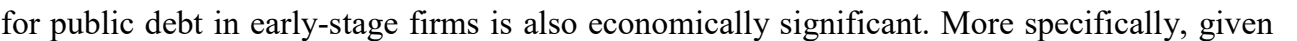

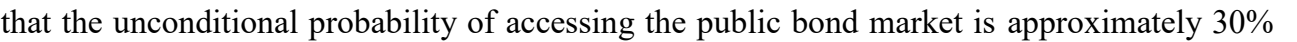

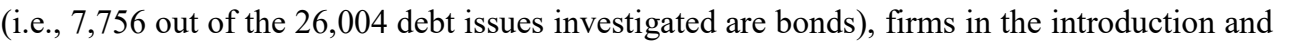

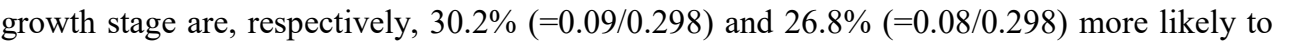

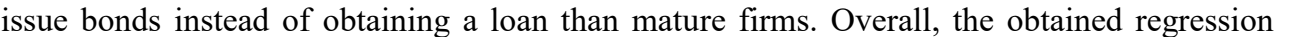

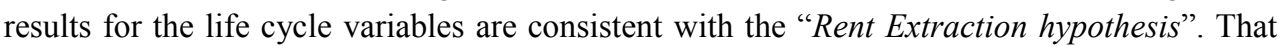

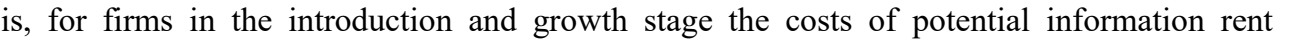

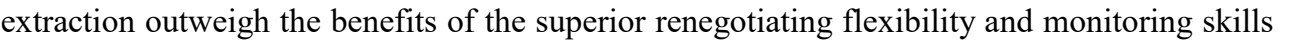

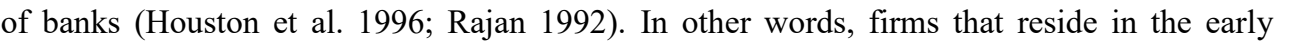
stages of the firm life cycle prefer public debt to private debt to avoid banks' rent extracti $\square \square \square \square$

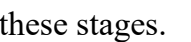

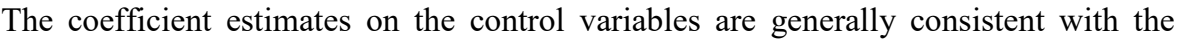

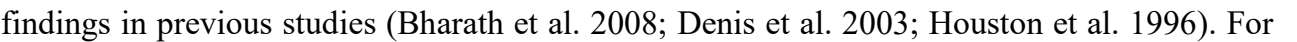

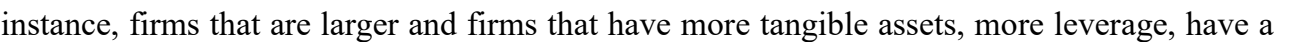

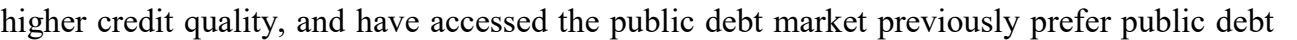

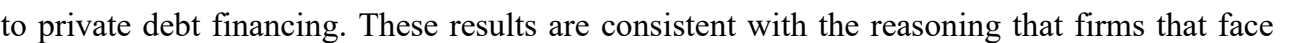

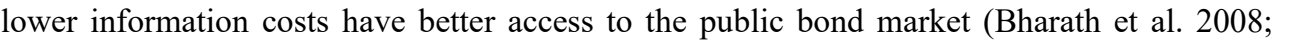

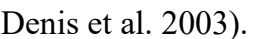

$\square$ 


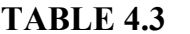

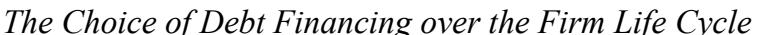

\begin{tabular}{|c|c|c|c|c|}
\hline 四 & 四 & $\square \square$ & 四 & $\mathbb{1 1}$ \\
\hline पणापणा & 四 & $\square \square \square \square \square$ & 四 & 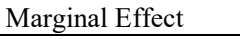 \\
\hline \multirow[t]{2}{*}{ एविएव } & & एणाएम & & 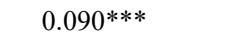 \\
\hline & & एणाए & & एणामा \\
\hline \multirow{2}{*}{ 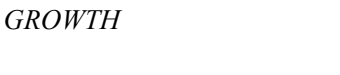 } & & पणमामा & & पामामा \\
\hline & & एणाएा & & एणाएण \\
\hline \multirow[t]{2}{*}{ प्वप्र० } & & एणामा & & एणाएा \\
\hline & & पणाणा & & पापापा \\
\hline \multirow{2}{*}{ 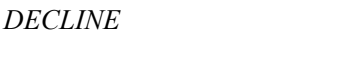 } & & पापाम & & पाणाए \\
\hline & & 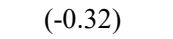 & & $\square \| \square \mid \mathbb{~}$ \\
\hline \multirow[t]{2}{*}{ 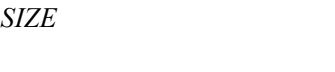 } & & 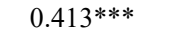 & & 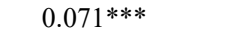 \\
\hline & & $\square|\square| \mathbb{~}$ & & पाणापा \\
\hline \multirow{2}{*}{ प्म० } & & पाणाए & & एामाए \\
\hline & & पण口卄ामा & & $\square\|\| \mathbb{~}$ \\
\hline \multirow[t]{2}{*}{ प्०० } & & एणाए & & एणाए \\
\hline & & पण口ाप & & एणामा \\
\hline \multirow[t]{2}{*}{$\square \square \square \square$} & & पामाप्म & & पामाप \\
\hline & & पाणाए & & 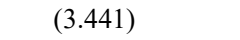 \\
\hline \multirow[t]{2}{*}{ 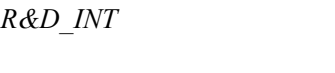 } & & 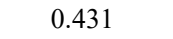 & & 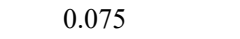 \\
\hline & & एणाए & & एणामा \\
\hline \multirow[t]{2}{*}{ 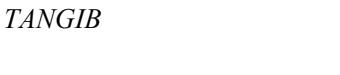 } & & पामामा & & पामामा \\
\hline & & एणाएा & & 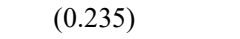 \\
\hline \multirow[t]{2}{*}{$\square \square \square \square$} & & 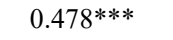 & & 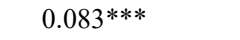 \\
\hline & & एणाएण & & एणामा \\
\hline \multirow[t]{2}{*}{ प्र०० } & & पाणाए & & पाणाए \\
\hline & & पणापाएव & & पापापा \\
\hline \multirow[t]{2}{*}{ 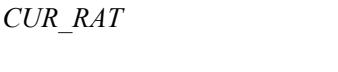 } & & 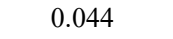 & & $\square \square \square$ \\
\hline & & पणापा & & एणतापा \\
\hline \multirow{2}{*}{ 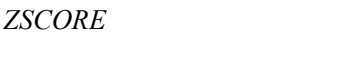 } & & पाणाए & & पाणाए \\
\hline & & पणाएा & & एपामा \\
\hline \multirow[t]{2}{*}{ प०० } & & पणमापा & & पणमाएम \\
\hline & & एणाएा & & एपामा \\
\hline \multirow{2}{*}{ 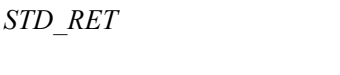 } & & पाणा & & पाणाए \\
\hline & & एणाएा & & एापापा \\
\hline \multirow[t]{2}{*}{ 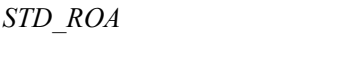 } & & पणामा & & $\square \square|| \square$ \\
\hline & & एपापा & & एापापा \\
\hline \multirow[t]{2}{*}{$\square \square \square$} & & 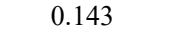 & & 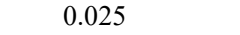 \\
\hline & & एणाएा & & एापापा \\
\hline \multirow[t]{2}{*}{ प००णम० } & & पएमापम & & पण口मा \\
\hline & & 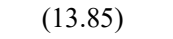 & & पापापा \\
\hline \multirow[t]{2}{*}{ 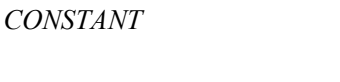 } & & एणमापम & & \\
\hline & & पण口卄ाम & & \\
\hline 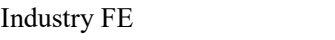 & & $\square \square \square$ & & \\
\hline 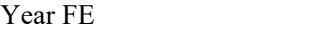 & & $\square \square \mathbb{Q}$ & & \\
\hline 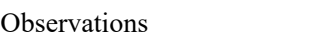 & & 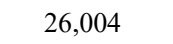 & & \\
\hline पषणपाणम & & पापाप & & \\
\hline 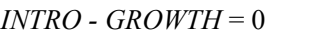 & & 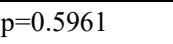 & & \\
\hline 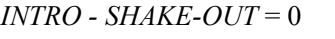 & & 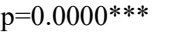 & & \\
\hline 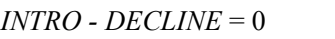 & & 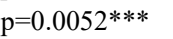 & & \\
\hline
\end{tabular}




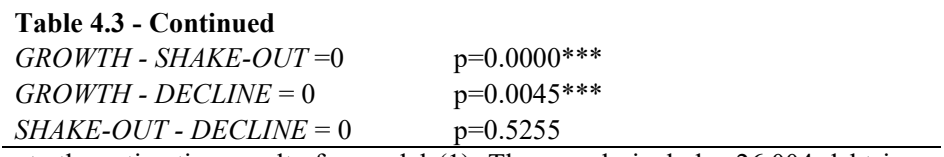

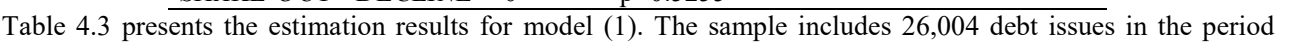

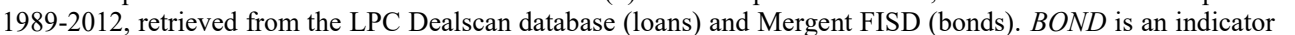

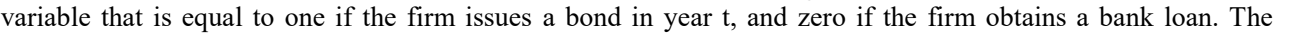

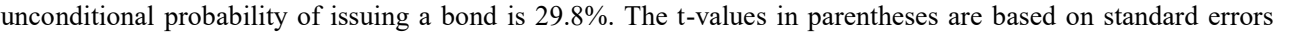

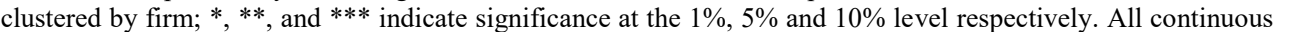

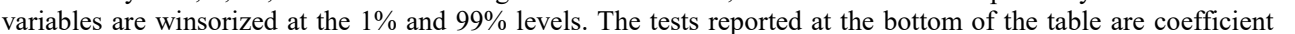

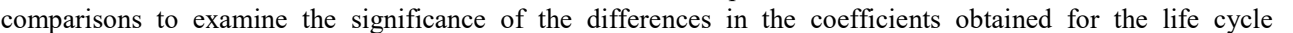

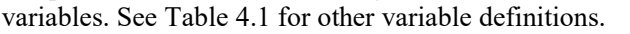

$\square$

$\square$

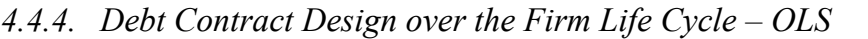

So far, the analyses show that firm life cycle affects both firms' access to the debt markets

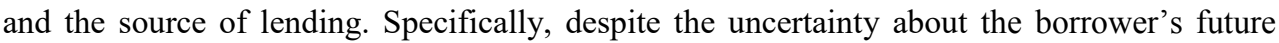

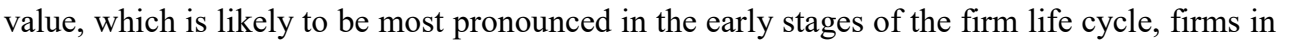

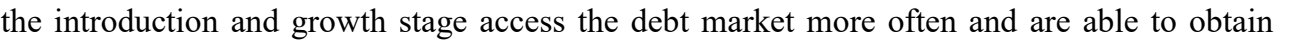

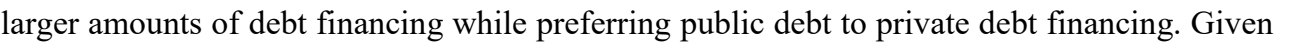

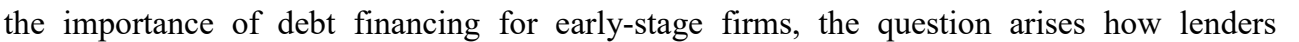

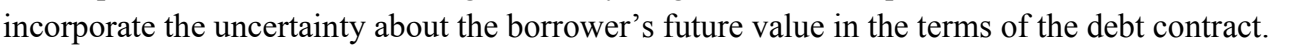

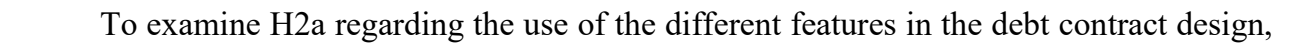
ए

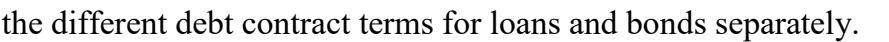

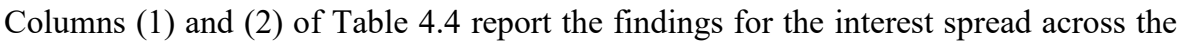

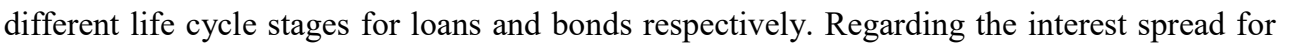

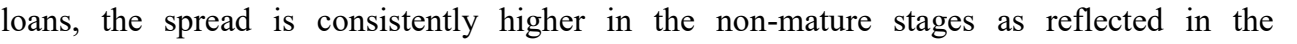

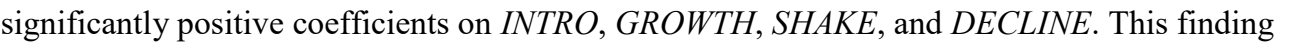

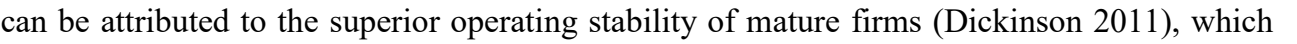

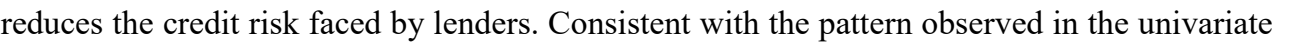

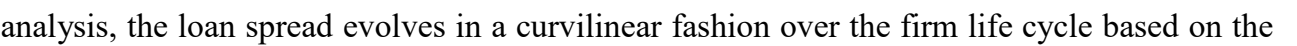

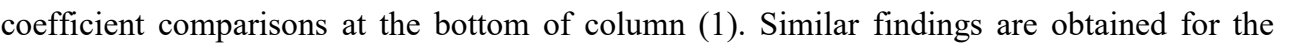

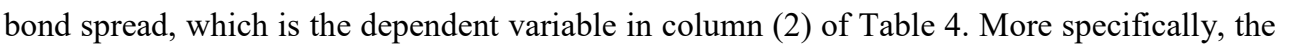

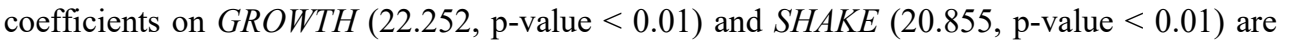

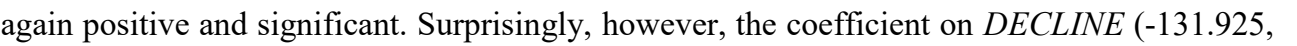

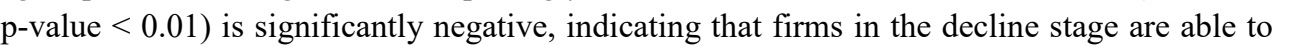

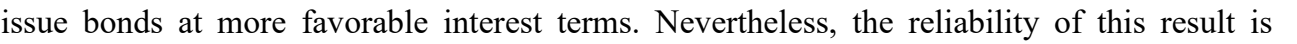

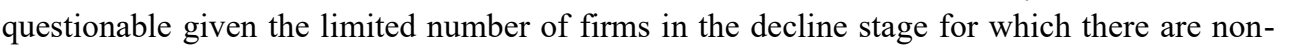

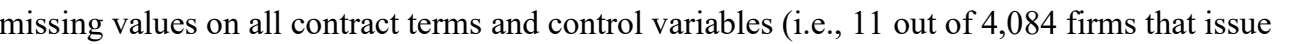
एणाणाय

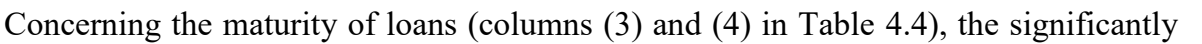

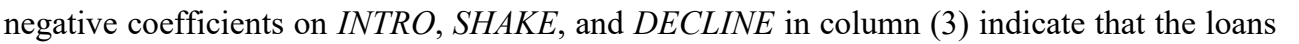

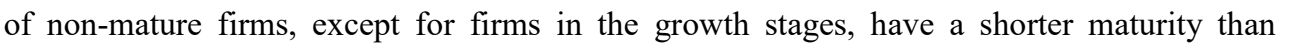

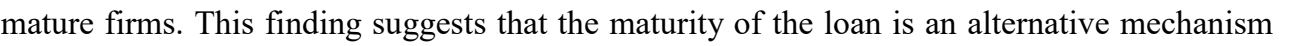

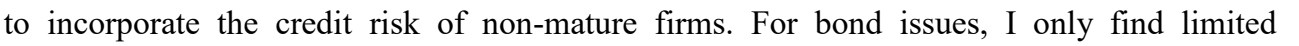

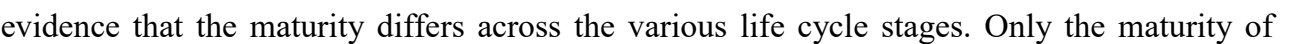




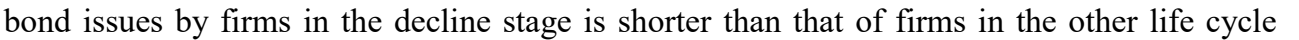

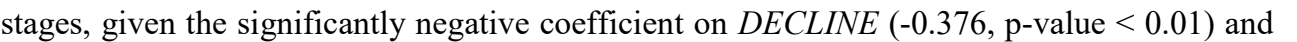
ए ए।

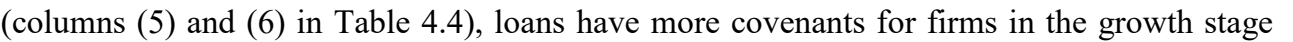

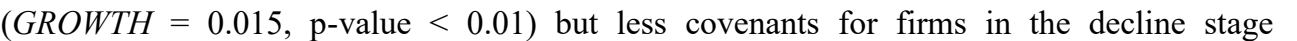

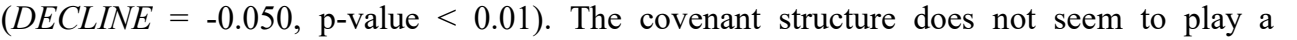

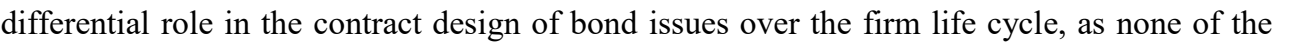
ए

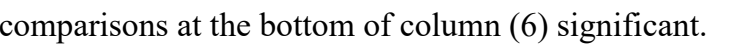

\begin{tabular}{l}
\hline \\
\hline
\end{tabular}

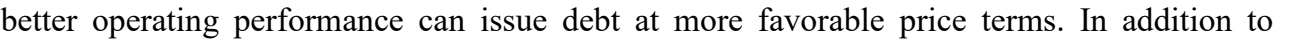

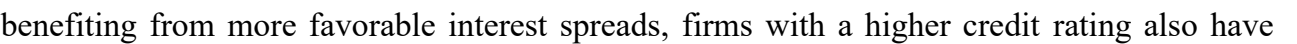

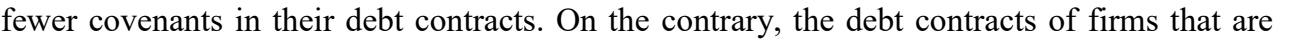

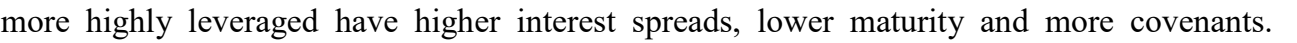

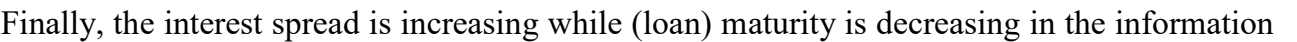

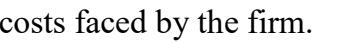

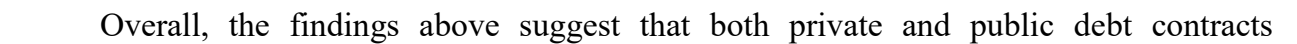

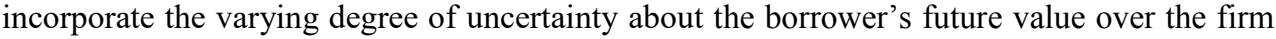

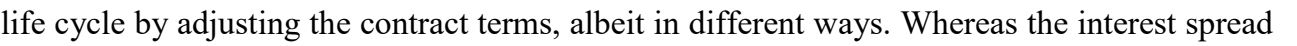

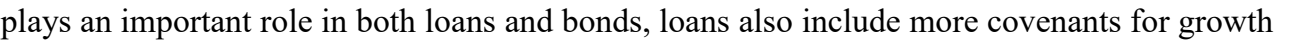

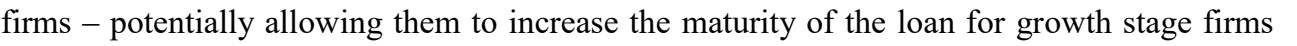

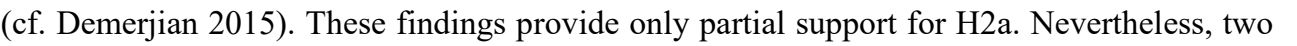

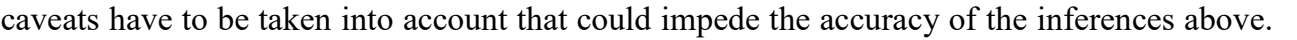

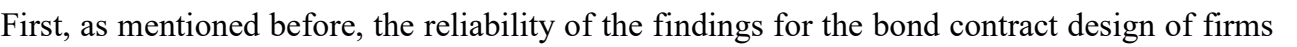
ए ए

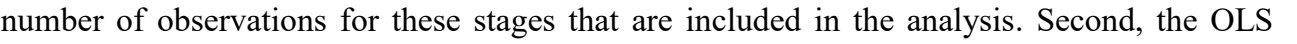

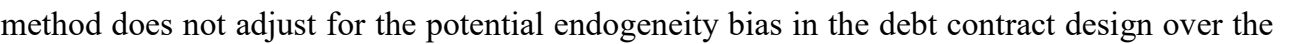
ए ए

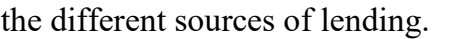




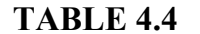

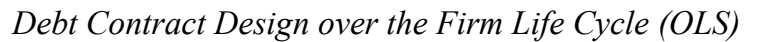

\begin{tabular}{|c|c|c|c|c|c|c|c|c|}
\hline \multirow[t]{3}{*}{ 四 } & \multicolumn{8}{|c|}{ 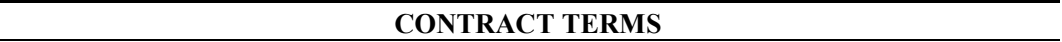 } \\
\hline & \multicolumn{2}{|c|}{\begin{tabular}{ll|l} 
\\
\end{tabular}} & \multicolumn{3}{|c|}{ 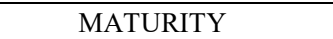 } & \multicolumn{3}{|c|}{ 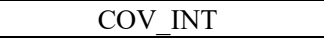 } \\
\hline & 血四 & 血四 & 睍 & $\mathbb{I}$ & 血四 & 血四 & $\llbracket$ & 血四 \\
\hline 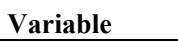 & $\square \square \square \square \square$ & $\square \square \square \square \square$ & $\square \square \square \square \square$ & $\llbracket$ & $\square \square \square \square \square$ & $\square \square \square \square \square$ & $\llbracket$ & $\square \square \square \square \square$ \\
\hline \multirow[t]{2}{*}{ 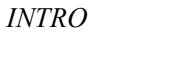 } & पाणाणाए & 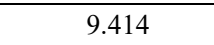 & पाणाए & & एवाणा & पाणाए & & पाIII \\
\hline & पाणा & पण口冋 & पण口卄ा & & 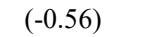 & पाणा & & पण口冋 \\
\hline \multirow[t]{2}{*}{ 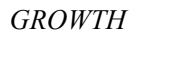 } & पामापा & पायाए & पामा & & एणाए & पागाप & & एणाए \\
\hline & एणाण & पाणाण & पणाण & & 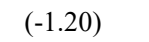 & पाणाण & & एणाण \\
\hline \multirow[t]{2}{*}{ पणिएव } & पाणाणाप & 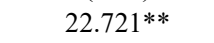 & एणाएा & & पाणाए & पाएा & & पणाए \\
\hline & एणाய & एण口冋 & पण口ण & & पण口冋 & पाणा & & 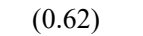 \\
\hline \multirow[t]{2}{*}{ 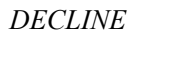 } & पाणा1ाप & एाणाए & खणाणा & & एणाणाए & एणाएा & & पणाए \\
\hline & एणा। & एण口冋 & पण口卄ा & & एणाण & एणाणा & & पणाए \\
\hline \multirow[t]{2}{*}{$\square[\square \square$} & पणा1ण & एणाणाए & पाणाए & & पणाए & एणाएा & & पणाया \\
\hline & पणाणा & एणाणा & एणा।ण & & पणाण & पण口卄ा & & घणाणाए \\
\hline \multirow[t]{2}{*}{$\square \square \square \square$} & एणाएा1ए & एणाणाएा & पणाए & & पणाए & पणा। & & पाणाणा \\
\hline & पणाणाए & एणाणा & पाणाण & & पणाण & पणाणा & & एणाणाए \\
\hline \multirow[t]{2}{*}{$\square \square \square \square$} & एणा।ाए & पणाए & पाणा1ाए & & पणाए & एवाए & & एवाए। \\
\hline & पण口卄ा & एणाएव & पण口冋ा & & पाणा & 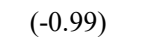 & & एवाणाए \\
\hline \multirow[t]{2}{*}{$\square \square \square \square$} & एणामा & एवाण & एवाणा & & एवाणाए & पाणाए & & एाणााए \\
\hline & 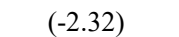 & एणा山ा & पण口卄ा & & एणाणाए & 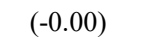 & & एवाणाए \\
\hline \multirow[t]{2}{*}{ 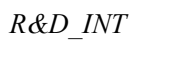 } & पण口ा & एाणाए & एवाणाए & & वाणा & एणा & & एवाए \\
\hline & 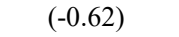 & एण口冋 & एण口冋口 & & एणाய & 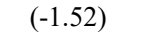 & & एणाणाए \\
\hline \multirow[t]{2}{*}{ 맘ㅁ } & घणाए & पाएा & 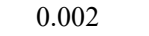 & & पामाए & एण口冋ए & & एणाए \\
\hline & 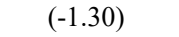 & 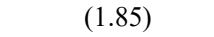 & யாய & & ஐण口冋 & 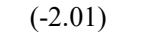 & & 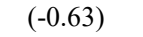 \\
\hline \multirow[t]{2}{*}{$\square \square \square$} & पाणमाएम & पाயामा & $\square \square \square \square \square$ & & पाणाए & एवामाए & & एणाएम \\
\hline & एणाणा & पाயाण & एणाய & & 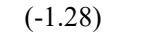 & एणाய & & एणाய \\
\hline \multirow[t]{2}{*}{ 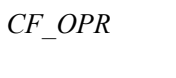 } & एणாம & घாயாПए & एणाए & & एणा & एणाए & & एणा \\
\hline & 血四1四 & एणा山ा山 & एणाய & & एणाய & एणाய & & एणाய \\
\hline \multirow[t]{2}{*}{ 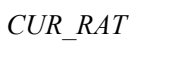 } & ஐயாПए & घणए & एवापा & & एणाएा & एणाएप & & एणाए \\
\hline & एणमाण & पण口冋 & पण口冋 & & एणाய & एणा & & पण口冋 \\
\hline \multirow[t]{2}{*}{ 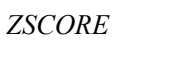 } & पाणा & एणाए & एणाए & & एाणा & एणाए & & एणाए \\
\hline & 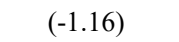 & पणाणाण & पणाणाण & & पणाणाण & एणाणा & & 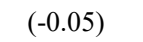 \\
\hline$\square \square \square$ & पाणाएा & एणागाए & पाणाए & & पणाए & एणाया & & एणापा \\
\hline & पण口卄ाण & पणाणा & पण口卄ाण & & पणाण & एणाणाए & & पण口卄ाण \\
\hline 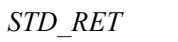 & 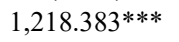 & 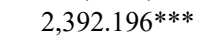 & खायाए & & एवाणाए & एवाया & & पायाए \\
\hline & पणाणाण & पणाणा & पण口卄ा & & पण口卄ाण & एणाणा & & पाயाए \\
\hline 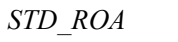 & पाणायाए & पाणापाए & एणामा & & पाणाए & एणामा & & एणाएा \\
\hline & पण口冋 & 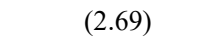 & 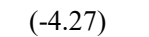 & & पण口卄l & पाणाणा & & एवाणाए \\
\hline$\square \square \square$ & पणाण & पाणाएा & पणाणाए & & पाणाए & एणाए & & पणाए \\
\hline & पाणा & 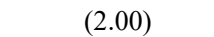 & पणाणा & & 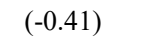 & 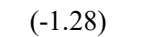 & & एणा四 \\
\hline 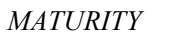 & पाणामाप & पाणाए & & & & एणागए & & एणाणा \\
\hline & पणाण & पणाणा & & & & पाणाएा & & एण口冋|ण \\
\hline 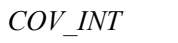 & पायायाए & एाणा & पणागए & & एणामा & & & \\
\hline & एणाणा & एणाणाण & एणाण & & एणाणाण & & & \\
\hline 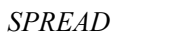 & & & पालाप & & पणागा & पागाप & & एणाए \\
\hline & & & पणाणा & & एणाएा & पण口ाण & & पणाणाण \\
\hline 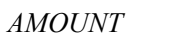 & घणाएाए & पणाएण & पालापा & & पणाए & एणाए & & पणाएण \\
\hline & पण口卄ा & पाणाण & एणाएा & & पणाण & एणाणा & & एणाए \\
\hline 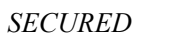 & पाणाणाप & 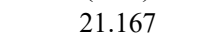 & पणागाए & & पाणाण & पणाणाए & & पायाए \\
\hline & एाणाण & पणाणा & पणाणा & & पणाणाण & पाणाण & & पणाण \\
\hline 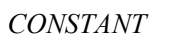 & पायायए & पणाण & पणागए & & पणाणाए & वणाण & & पणाए \\
\hline & एवाण & पणाणा & एणाயा & & एणाएा & एवापा & & एवाणा \\
\hline
\end{tabular}




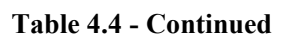

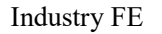

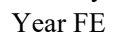

पणा

पाI

$\square \square \square$

$\square \square \square$

口प⿴囗十

पवण

밈

पाषा

पाएव

पणणाणाणाण

पाप⿴囗十丁口卄

पाणाए

पाणा

पाणा

$\square \square \square$

पाष

पाष

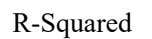

पणाए

$\square 10$

पाणा।

पणाए

पणाए

पणाए

पाणाप्र

$\square 1010$

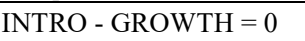

पाणापाएा

$\square 1010$

$\square \square$

पणाए।

$\square 1$

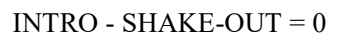

पाणाणाए

प्रण

पाणाणा

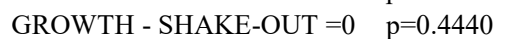

$\square \square \mid 1111$

पापापापाए

पाII $\square$

पाणाप्त्र

$\square 1010$

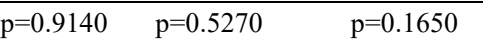

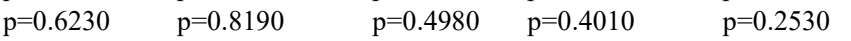

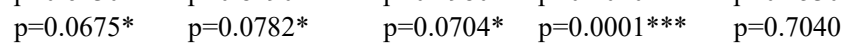

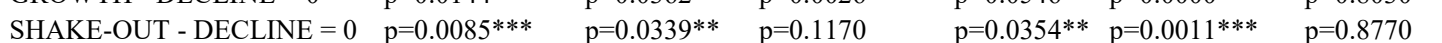

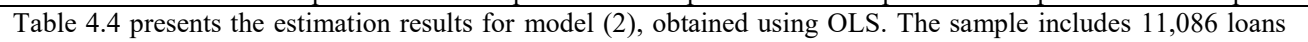

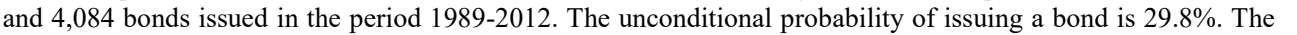

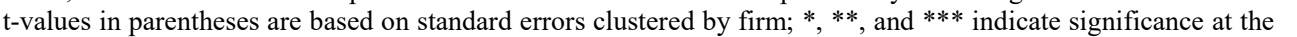

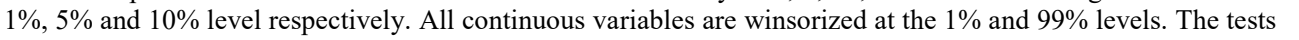
ए

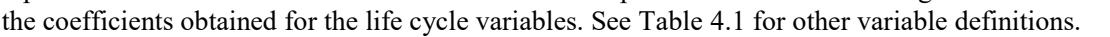
$\square$

$\square$

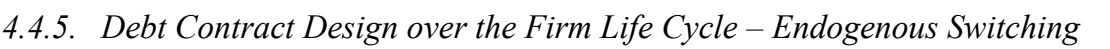

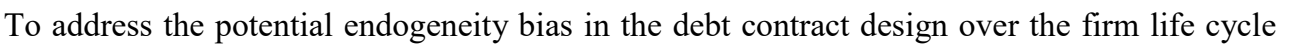

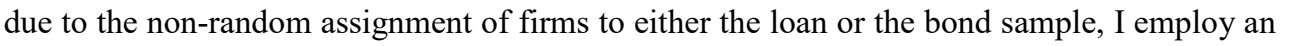

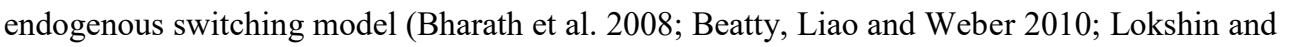

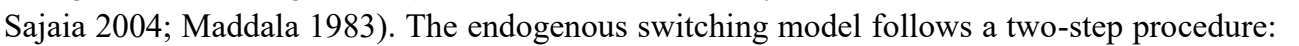

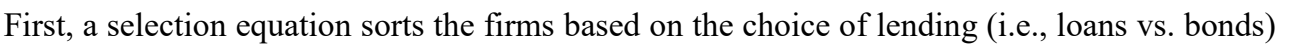

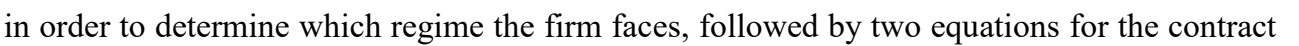

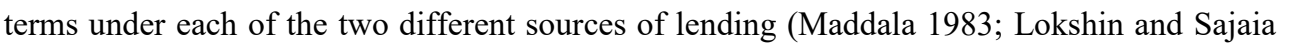

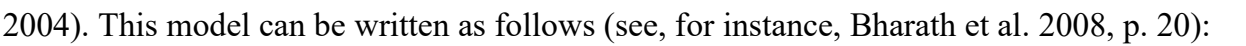
$\square$

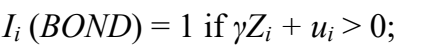

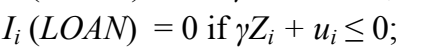

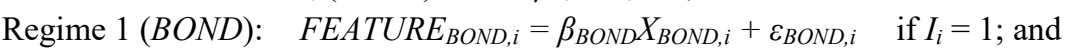

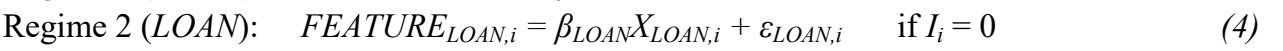
$\square$

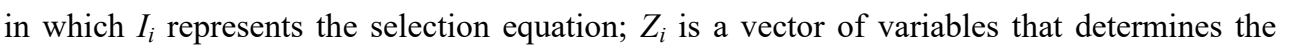

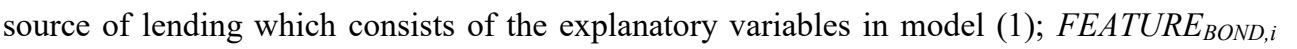

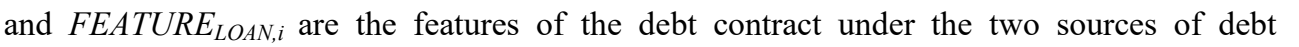

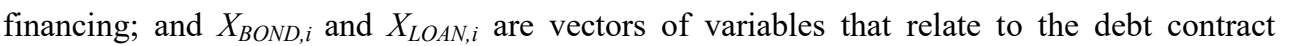

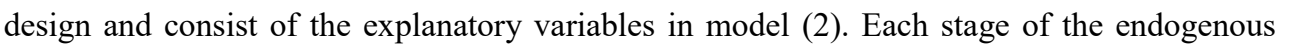

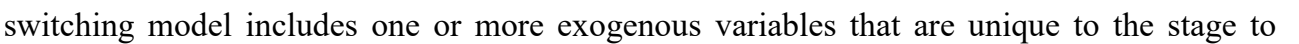

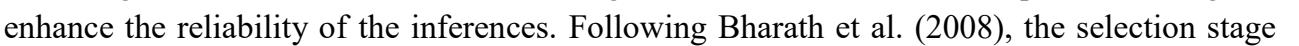

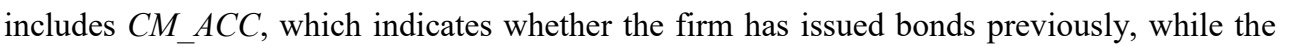

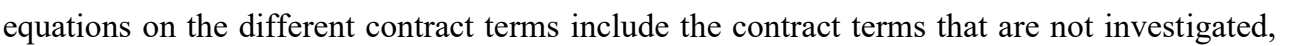

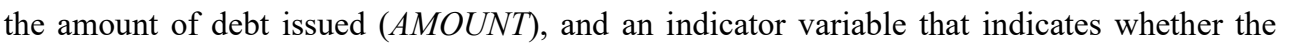

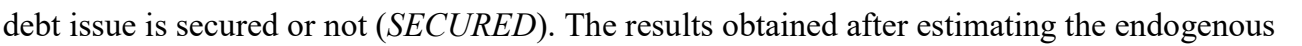

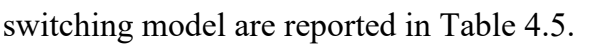




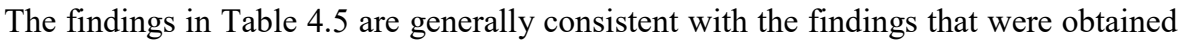

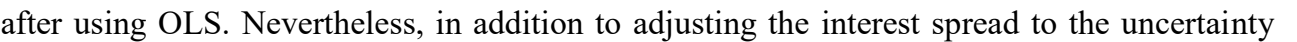

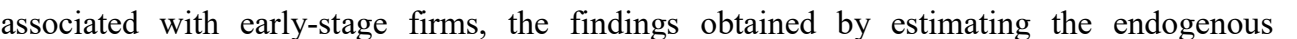

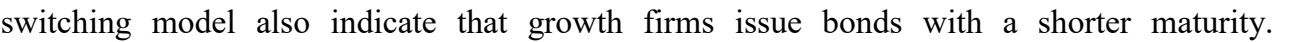

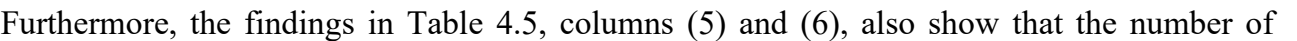

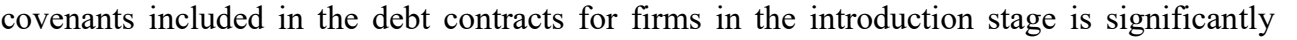

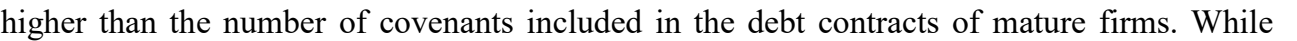

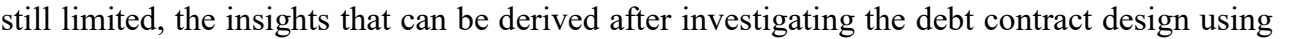

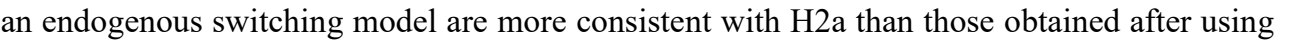

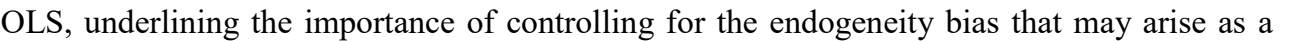

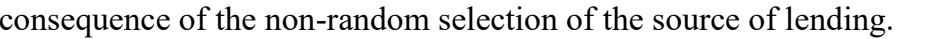

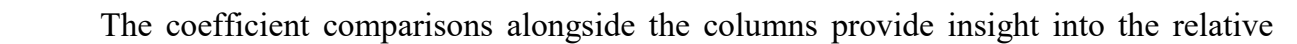

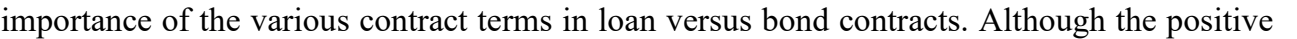

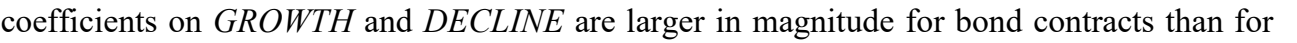

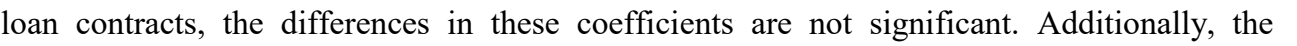
ए ए

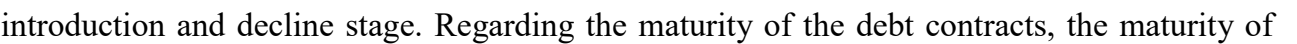

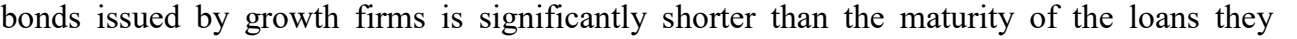

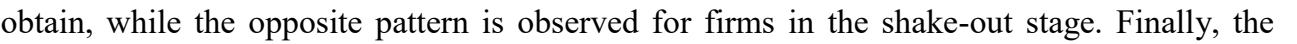

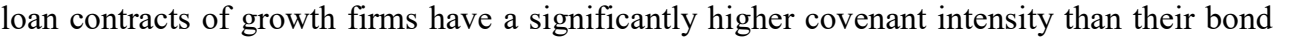

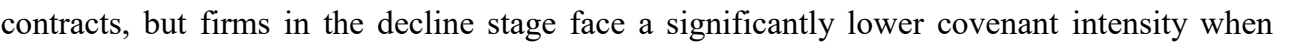

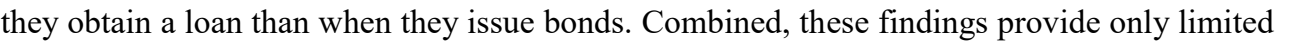

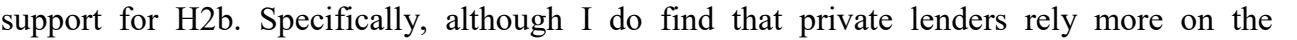

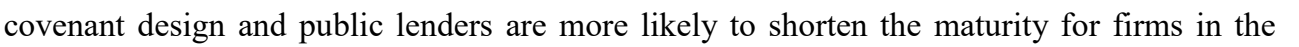

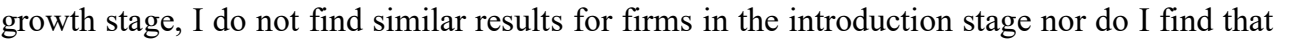

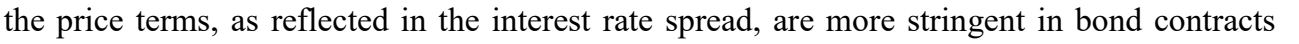

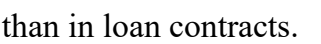




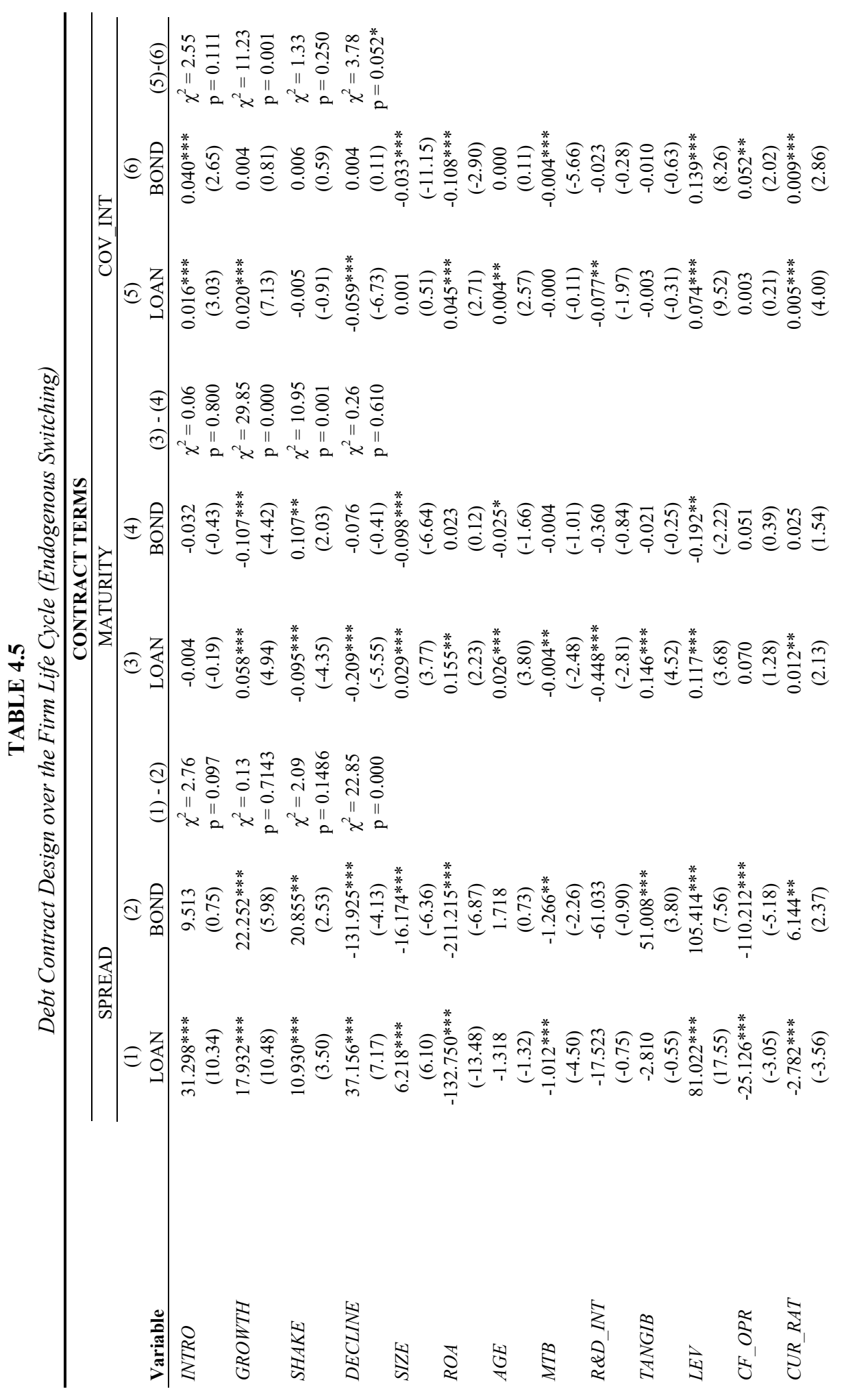


$\square$

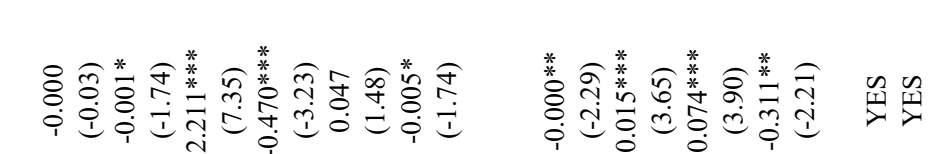

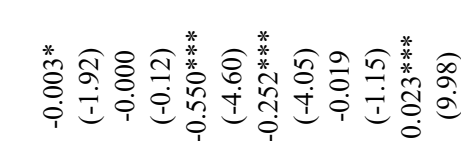

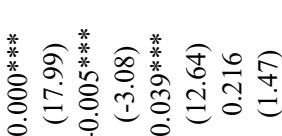

闻聞聞闻

回国聞聞聞

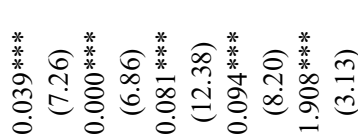

1

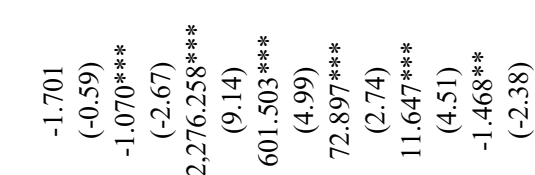

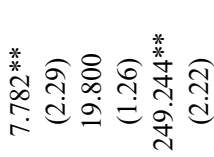

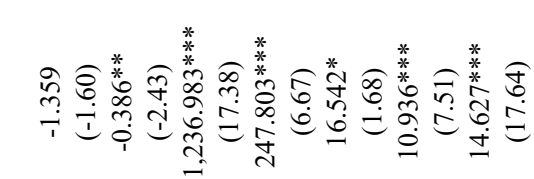

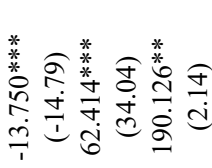

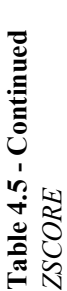

自目目目目目目目盲目目目目目目

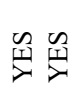

照昌

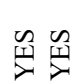

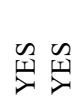

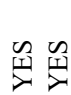

冒目

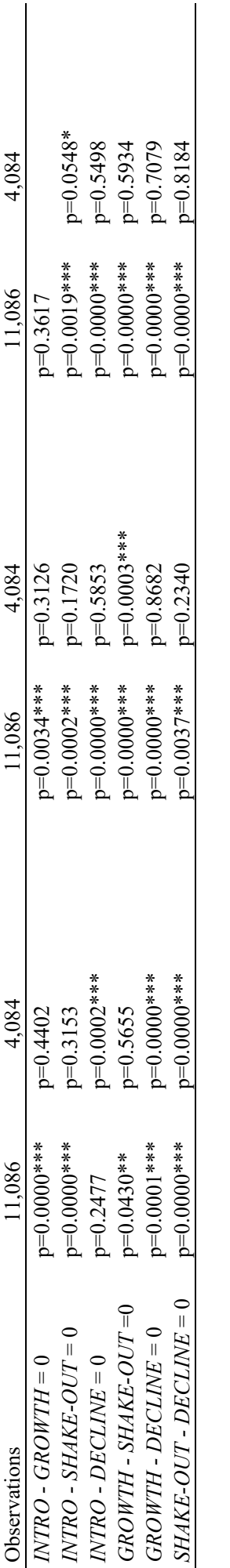




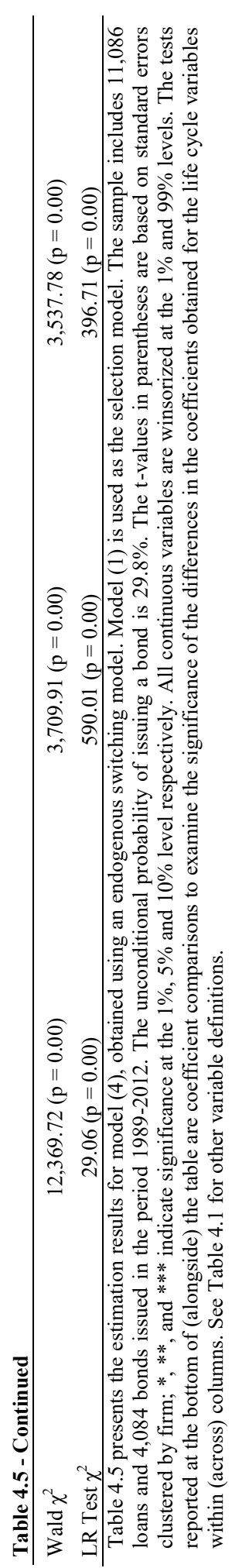




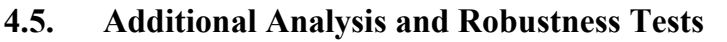

$\square$

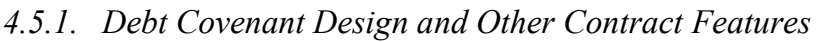

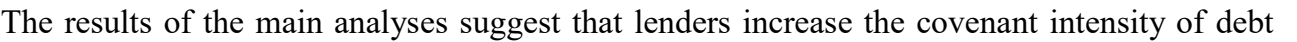

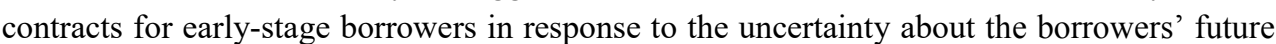

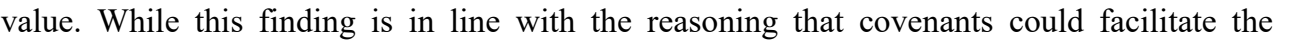

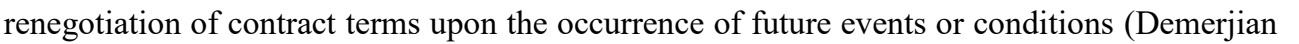

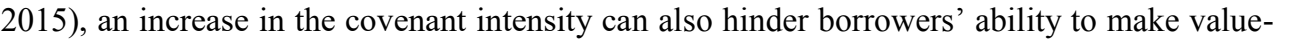

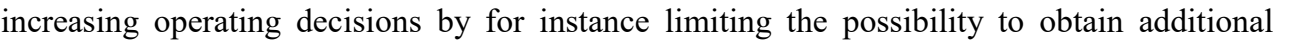

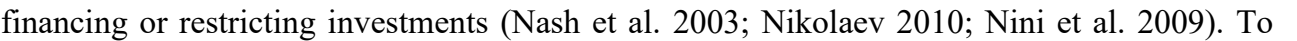

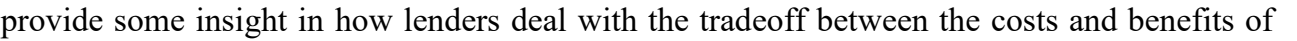

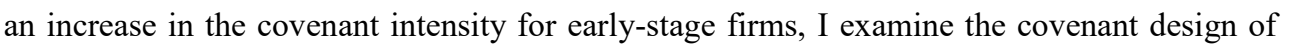

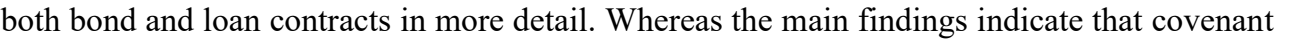

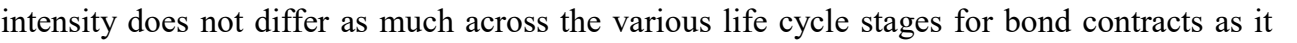

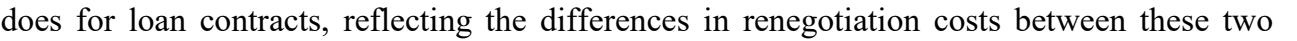

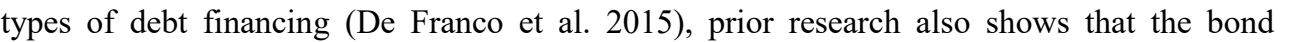

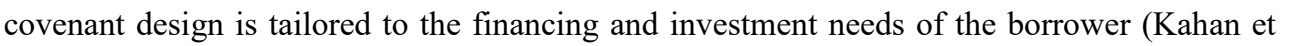

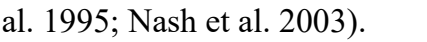

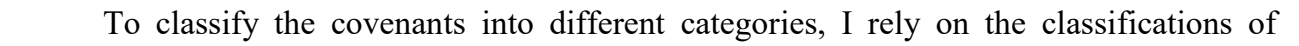

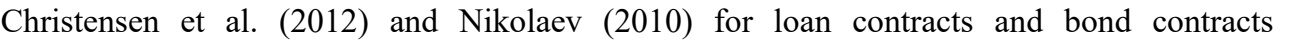

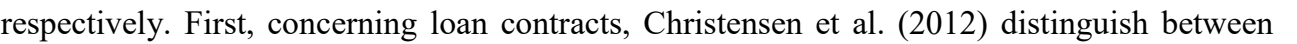

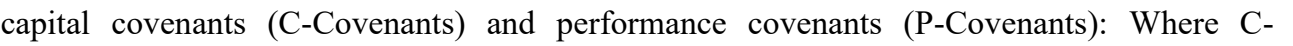

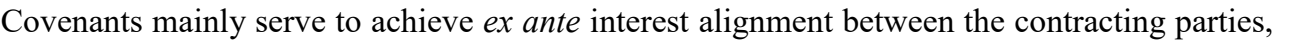

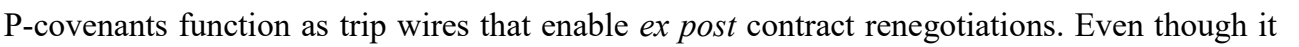

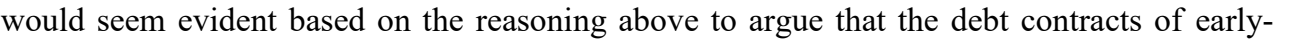

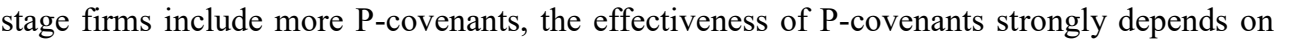

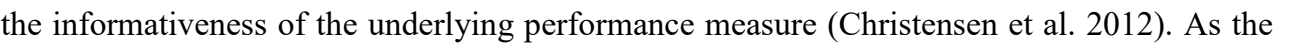
ए ए

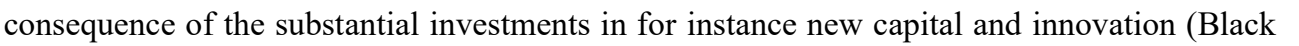

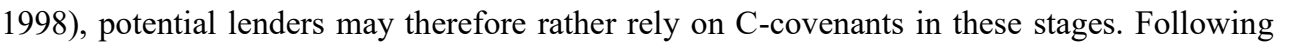

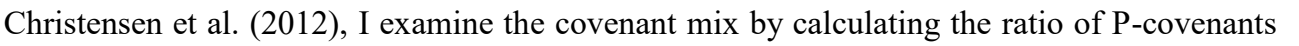

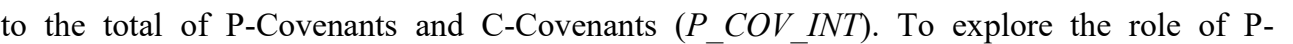
ए

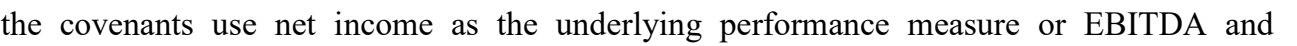

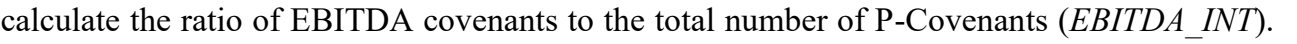

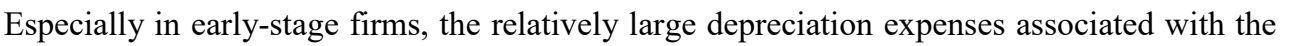

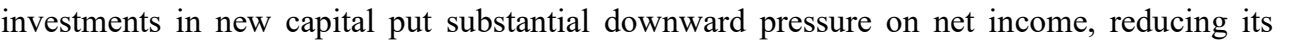

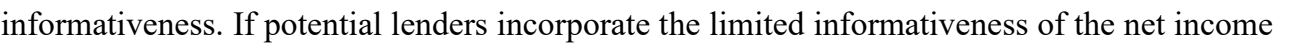

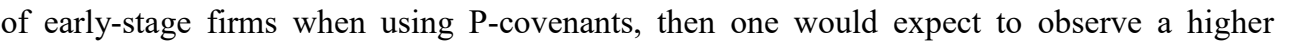

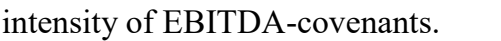

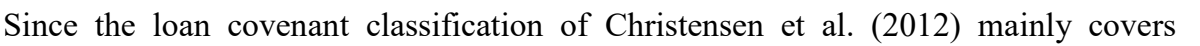

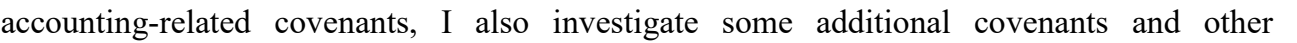

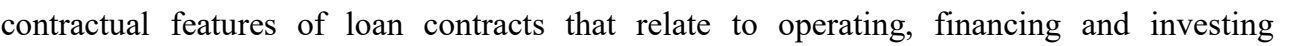

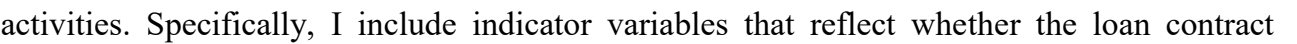




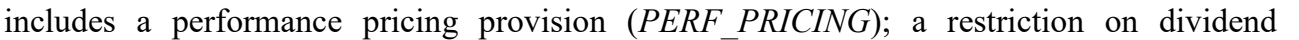

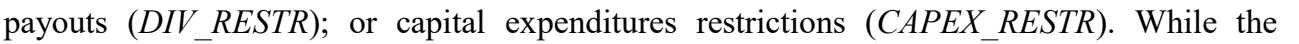

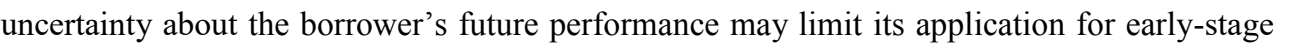

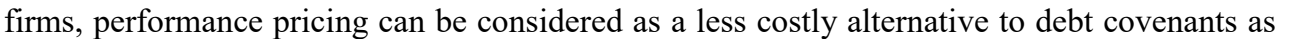

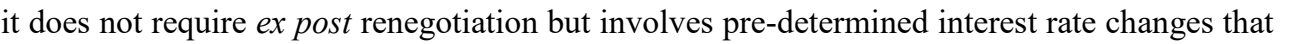

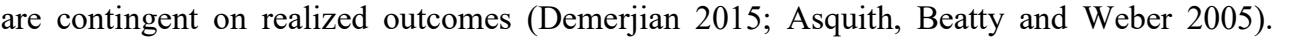

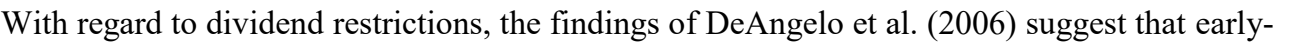

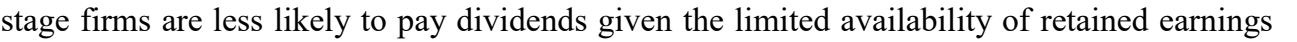

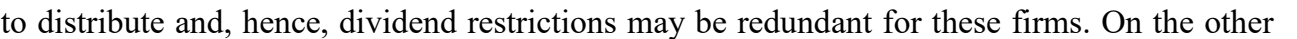

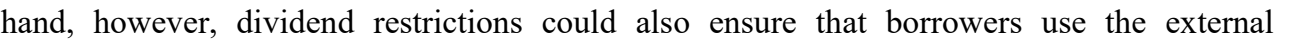

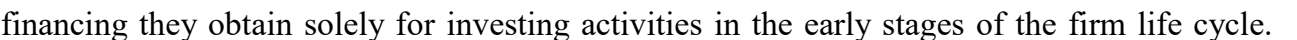

Finally, Nini et al. (2009) find that capital expenditure restrictions reduce the borrower's

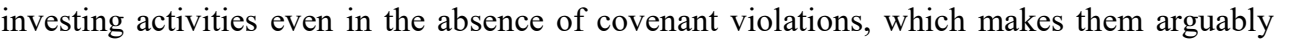

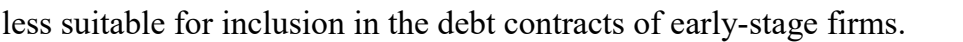

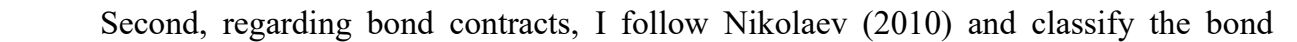

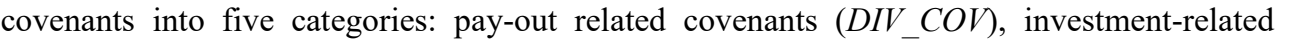

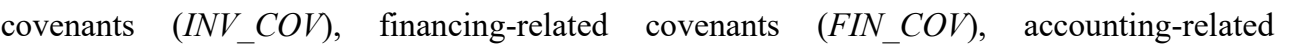

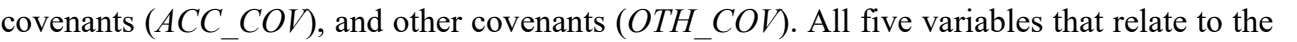

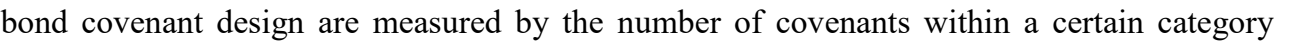

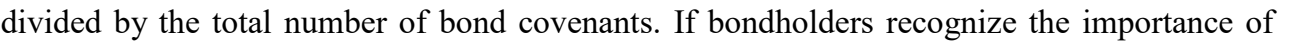

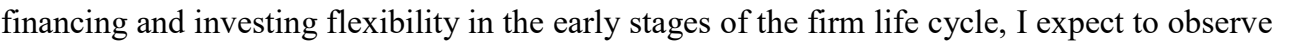

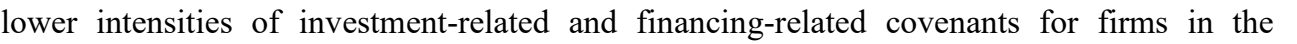

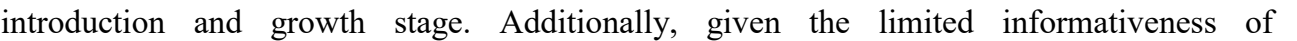

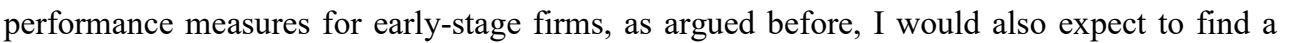

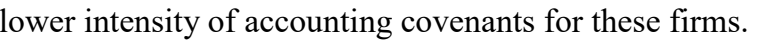

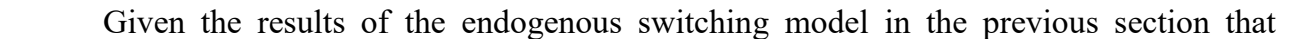

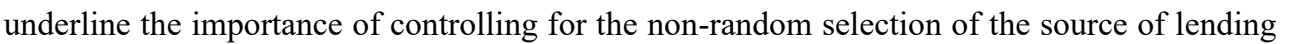

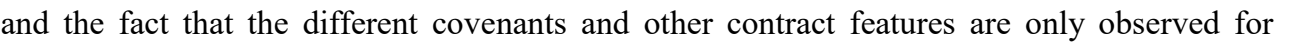

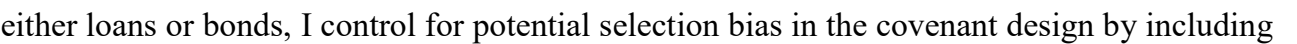

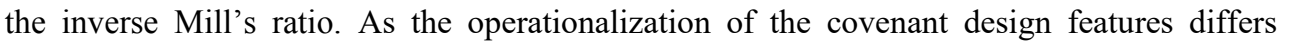

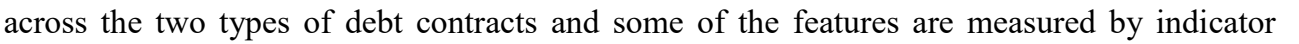

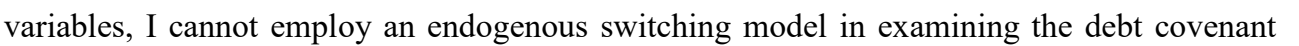

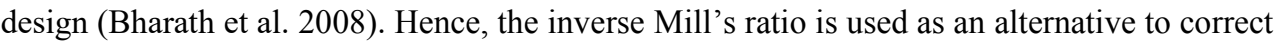

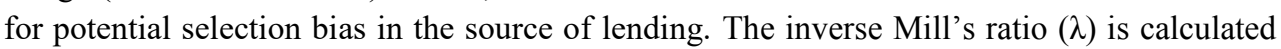

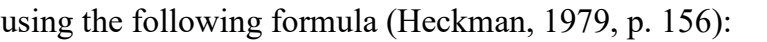
$\square$

$\lambda\left[\frac{\phi\left(Z_{i}\right)}{1-\Phi\left(Z_{i}\right)} \square \quad \square \quad \square \quad \square \quad \square \quad \square \quad \square \quad \square \quad \square \quad \square \quad \square \quad \square \quad \square \quad \square \quad \square \square \square\right.$ $\square$

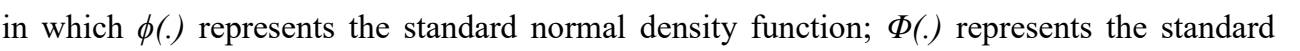

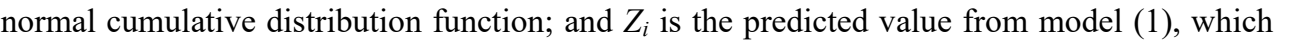




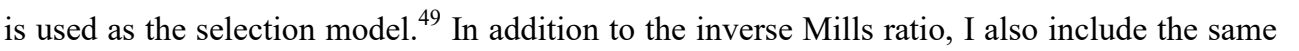

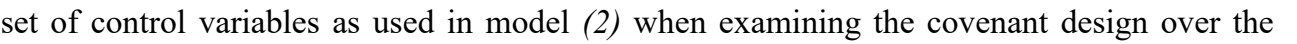

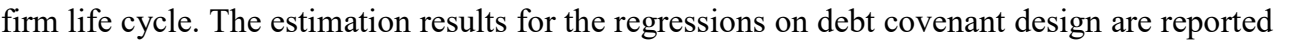
एणापणाणापा

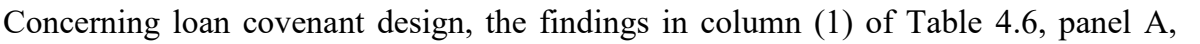

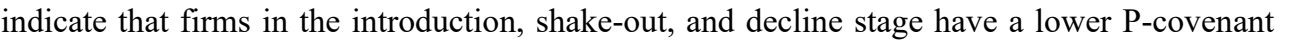

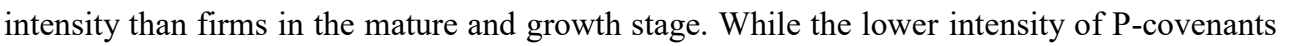

\section{could limit lenders' ability to renegotiate the contract terms, this finding is in line with the}

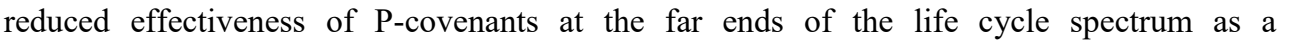

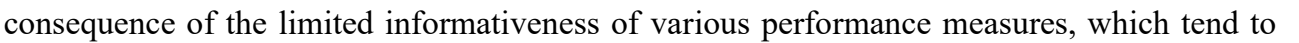

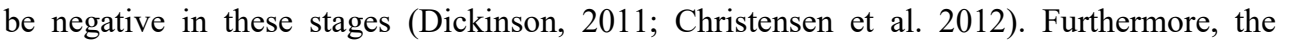

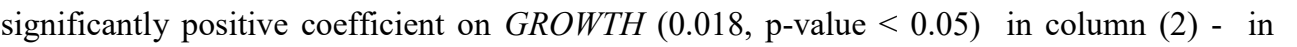

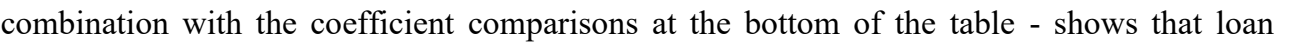

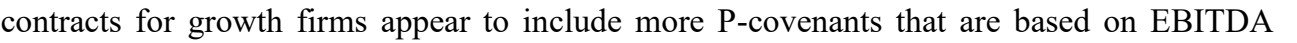

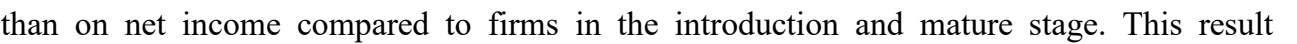

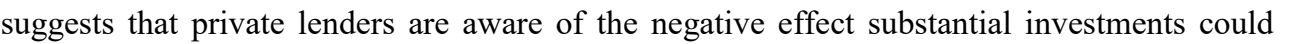

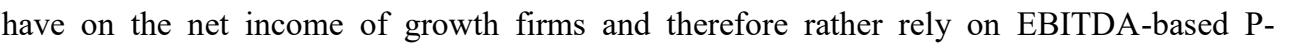

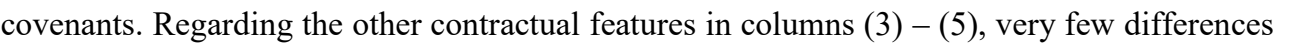

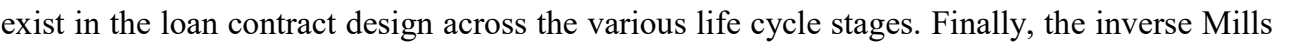

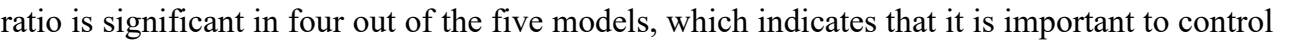

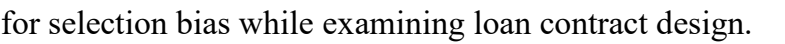

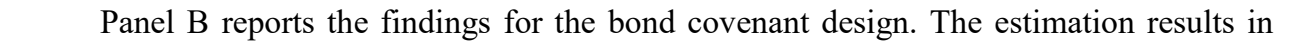

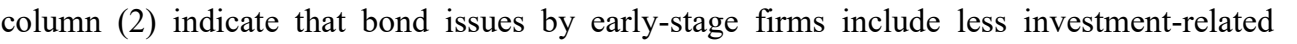

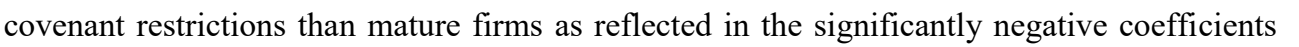

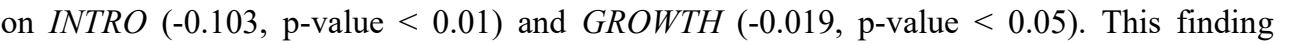

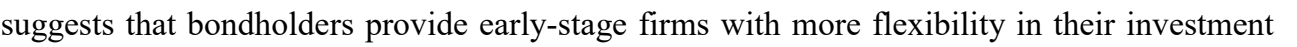

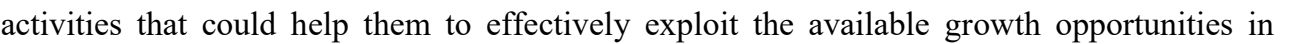

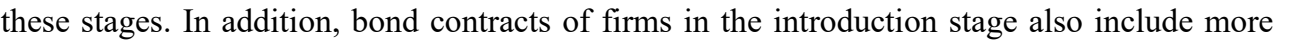

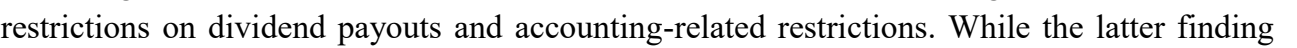

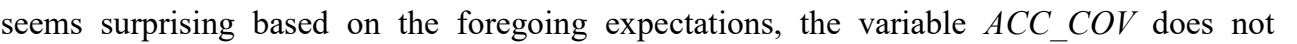

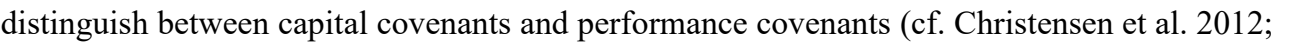

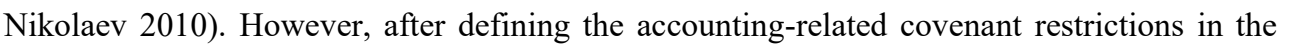

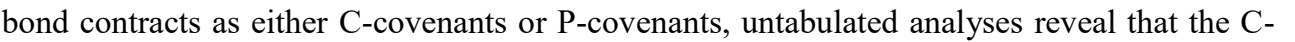

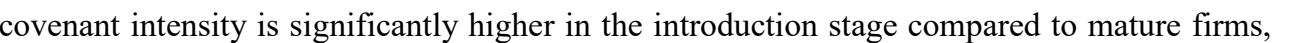

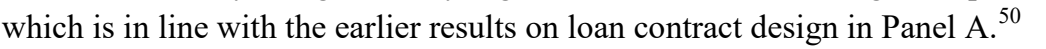

$\square$

$\square$

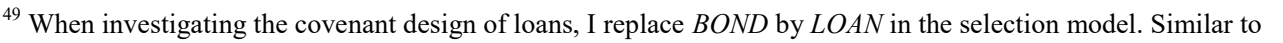

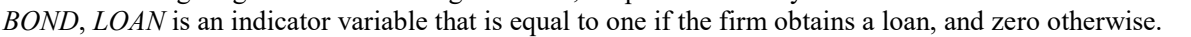

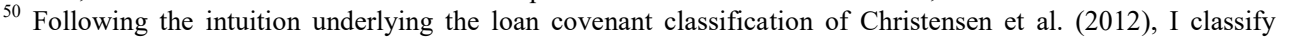

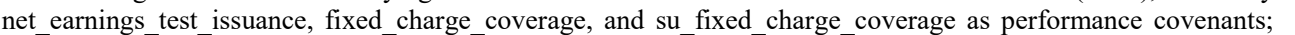

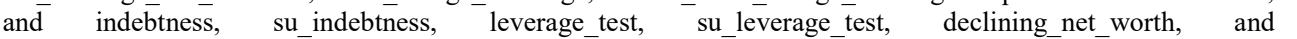

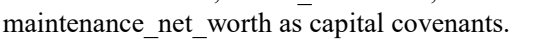




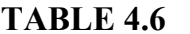

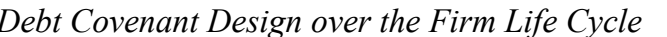

\begin{tabular}{|c|c|c|c|c|c|}
\hline \multicolumn{6}{|l|}{ Panel A: Loan Covenant Design } \\
\hline 四 & पा山 & $\square \square$ & पापा & पापा & 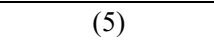 \\
\hline 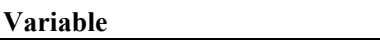 & 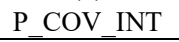 & 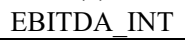 & 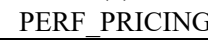 & 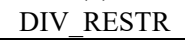 & 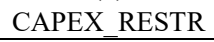 \\
\hline \multirow[t]{2}{*}{ 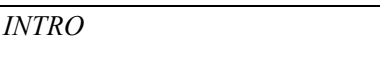 } & पाயामाए & 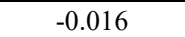 & पाणाए & 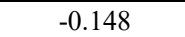 & पाणाए \\
\hline & एणाणाए & 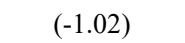 & पणाणा & 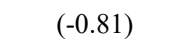 & पाणाण \\
\hline \multirow{2}{*}{ 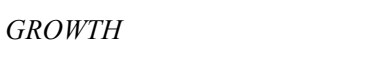 } & $\square ण 1 \square$ & पणाए & एणाए & $\square ण 11$ & एणाए \\
\hline & पण口卄ा & पाणाए & 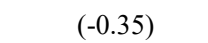 & पाणाण & पण口卄ा \\
\hline \multirow[t]{2}{*}{ प्राप्रा } & एणाएा & एणाए & एणाए & पणामा & पणाए \\
\hline & एण口冋एण & 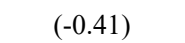 & 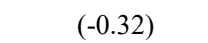 & एणाएण & पाणाण \\
\hline \multirow[t]{2}{*}{ 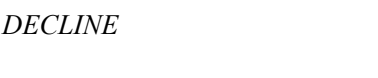 } & एणाएा & पाणाए & एणाए & $\square \square \square$ & एणाए \\
\hline & एणाणा & एणाणा & 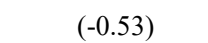 & एणाण & पण口卄ा \\
\hline \multirow[t]{2}{*}{ 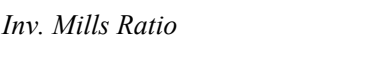 } & पाणा11ए & पाणाए & घामाए & पाणाणा & पाणाएा \\
\hline & एणाएा & एणाण & एणाएण & एणाएा & पण口卄ाए \\
\hline \multirow[t]{2}{*}{ 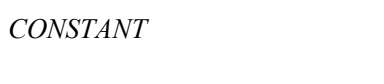 } & पणाए & पणाणाए & पाणाएा & पणाए & एणाए \\
\hline & पाणाण & एणाणा & पणाणा & पणाण & पण口卄ाण \\
\hline 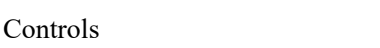 & $\square \square \square \square$ & $\square \square \square \square$ & $\square \square \square$ & $\square \square \square \square$ & $\square \square \square \square$ \\
\hline 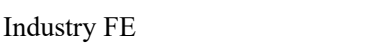 & $\square \square \square \square$ & $\square \square \square \square$ & $\square \square \square \square$ & $\square \square \square \square$ & $\square \square \square \square$ \\
\hline 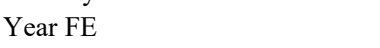 & $\square \square \square$ & $\square \square \square$ & $\square \square \square$ & $\square \square \square$ & $\square \square \square$ \\
\hline पणயणाणाए & पाणा & पणाम & पणाए & पणाए & पाणा \\
\hline 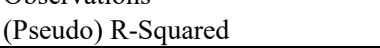 & 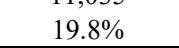 & $\square ण 0 \square$ & $\square ण \square \square$ & $\square ण \square \square$ & 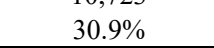 \\
\hline 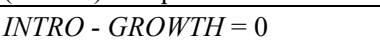 & $\square \square ण\|ा\|$ & पाणाणाप & 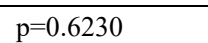 & $\square \square \square \square \square$ & 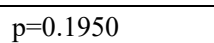 \\
\hline 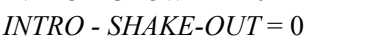 & $\square \square \mid ण 11 \square$ & $\square \square \square ा ए \square$ & $\square \square \square \square \square$ & $\square \square \square \square \square$ & $\square \square \square ा ए$ \\
\hline 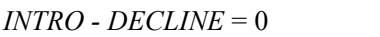 & पाणाएण & पाणाए & पाणाएण & पाणामा & पाणाएण \\
\hline 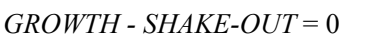 & $\square \square \square\|ा\| \square$ & पालाएम & $\square \square \square ा 1 \square$ & $\square \square\|ा\| \square$ & 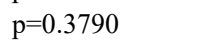 \\
\hline 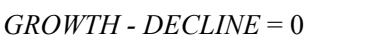 & $\square \square \square ा \| ा \square$ & $\square \square \square ा ए$ & 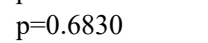 & $\square \square \square म ा \square$ & 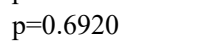 \\
\hline \begin{tabular}{|c|c|c|} 
\\
\end{tabular} & $\square[1011111$ & $\square \square \| 11 \square$ & $\square \square \| 111$ & $\square \square\|1\| \square$ & $\square \square \square \mid \square$ \\
\hline \multicolumn{6}{|c|}{ Panel B: Bond Covenant Design } \\
\hline 四 & $\square$ & $\square \square$ & पा⿴囗十丁口卄 & पा⿴囗十丁口卄 & पा山 \\
\hline 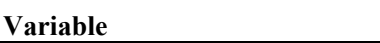 & 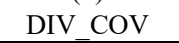 & 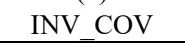 & 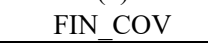 & 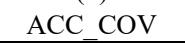 & 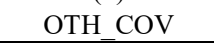 \\
\hline \multirow[t]{2}{*}{ 四田 } & $\square \square 111$ & एणाएाए & 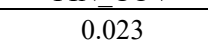 & $\square \square 11 \square$ & $\square \square \square$ \\
\hline & एणाएा & एणाएण & एणाएा & एणाएा & एणाण \\
\hline \multirow[t]{2}{*}{ 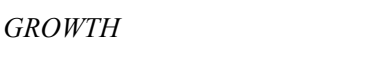 } & $\square ण 11$ & पाणाए & $\square ण 11$ & पणाए & $\square ण 11$ \\
\hline & पाणाण & एणाएा & पण口冋 & एवाण & पाणाए \\
\hline \multirow[t]{2}{*}{ प्राप्र } & पणाएण & $\square+10$ & एणाए & 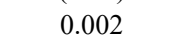 & एणाए \\
\hline & पणाणा। & एणाए & 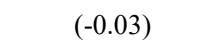 & एणाखण & एणाणाए \\
\hline \multirow[t]{2}{*}{ 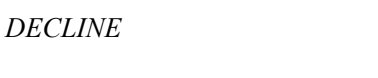 } & पणाए & पणाए & एणाए & 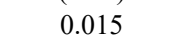 & एणाए \\
\hline & पाणाण & पणाखण & 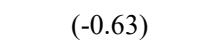 & एणाखण & एणाणा \\
\hline \multirow[t]{2}{*}{ 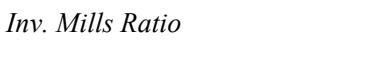 } & 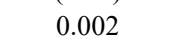 & घणाएम & $\square ण 1 \square$ & एणाए & पणाएम \\
\hline & पणाण & एणाणा & एणाखा & 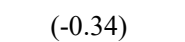 & एणाய \\
\hline \multirow[t]{2}{*}{ 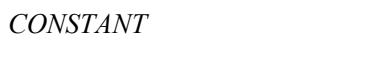 } & $\square ण 10$ & पाणाएा & एणाए & $\square ण 10$ & 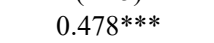 \\
\hline & पणाणा & पाणाण & पणाणा & पणाणा & पाणाण \\
\hline 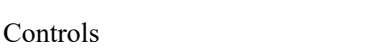 & 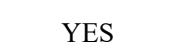 & 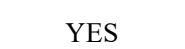 & जमाप & जमाप & जमाप \\
\hline 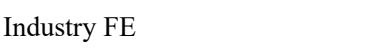 & $\square \square \square \square$ & $\square \square \square \square$ & 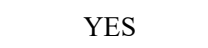 & $\square \square \square \square$ & 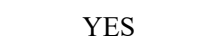 \\
\hline 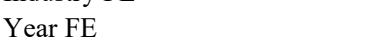 & $\square \square \square \square$ & $\square \square \square \square$ & 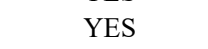 & $\square \square \square \square$ & 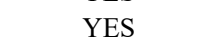 \\
\hline 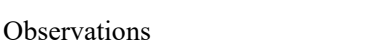 & पणाए & पणाए & पणाए & पणाए & पणाए \\
\hline 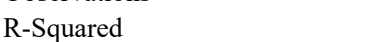 & $\square \mid ण \square \square$ & $\square ण \| \square$ & $\square ण \square \square$ & $\square ण \square \square$ & $\square ण \| \square$ \\
\hline
\end{tabular}




\begin{tabular}{|c|c|c|c|c|c|}
\hline 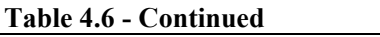 & $\square$ & $\square$ & $\square$ & $\square$ & $\square$ \\
\hline 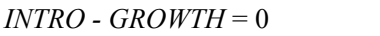 & पापाणा110 & पाणा1ापाए & 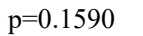 & 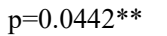 & पाणाएा \\
\hline 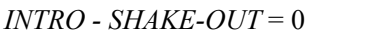 & पाणा111 & पणमाणाए & एणाणाए & पणमाणाए & पणाणा \\
\hline 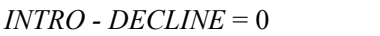 & पाणाए & एमाणाए & एणाणए & पाणाएा & पाणामाए \\
\hline 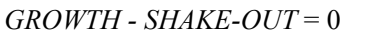 & पाणाए। & पाणाएा & पाणाएण & पाणामा & पाणामा \\
\hline 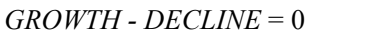 & पाणाए & पणाणा & एणाणए & पाणाएा & पालामा \\
\hline 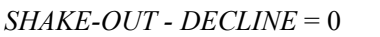 & पाणाणा & पाणाणा & पाणाएा & $\square \square ण 110$ & पाणाणा \\
\hline
\end{tabular}

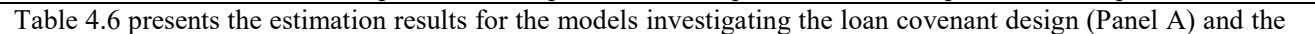

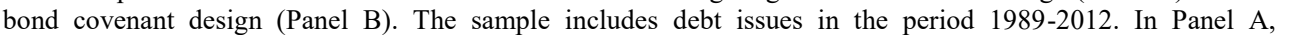

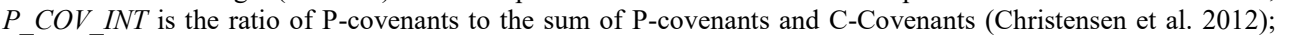

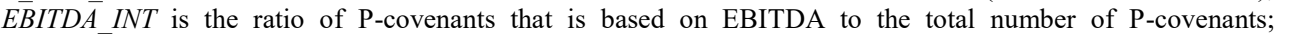
b

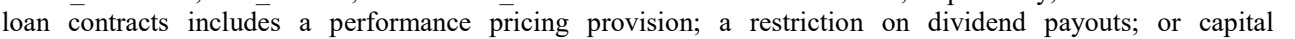
एण

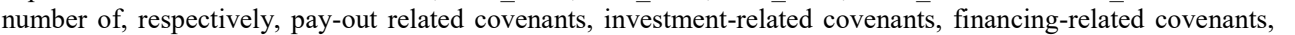

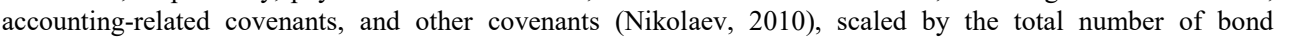

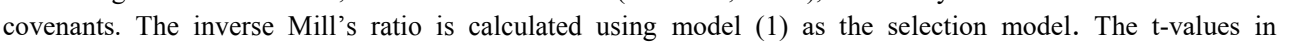
एण

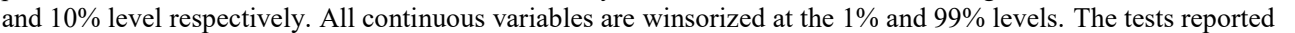

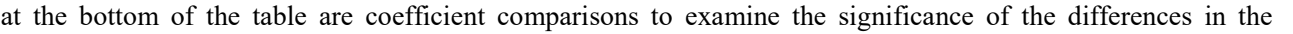

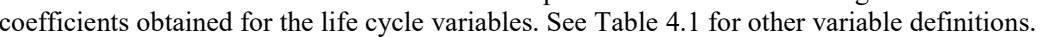
$\square$

$\square$

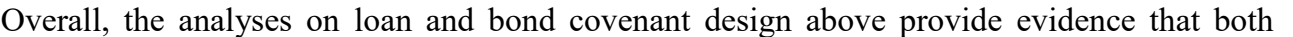

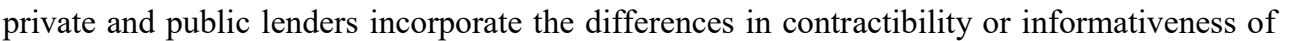

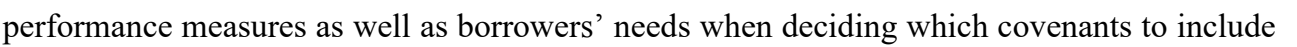

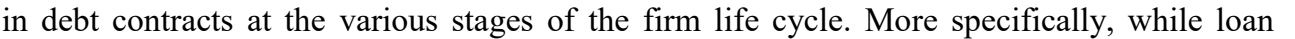

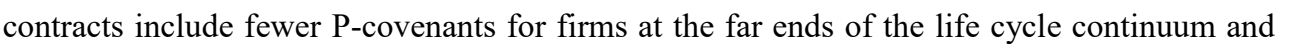

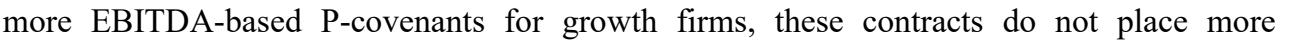

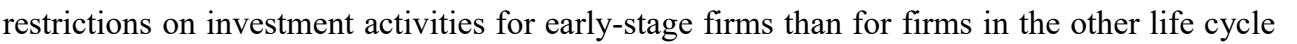

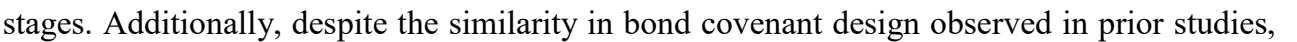

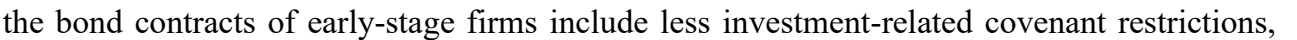
reflecting borrowers' need for investment flexibility in these stages (De Franco et al. 2015;

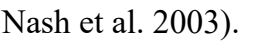

$\square$

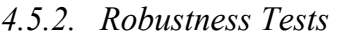

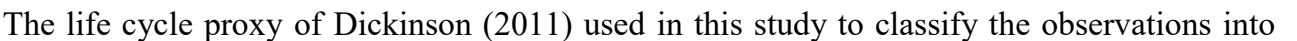
the different life cycle stages relies on the systematic pattern in firms' cash flows. Even

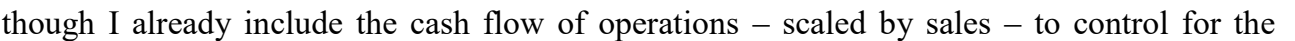
borrower's ability to make the fixed contractual payments in the short run (Easton et al.

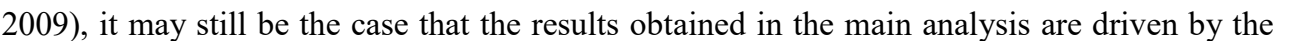

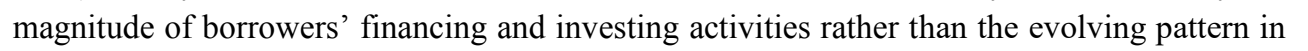

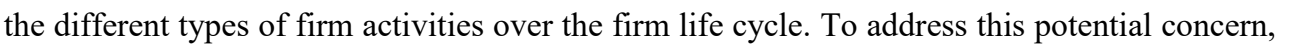

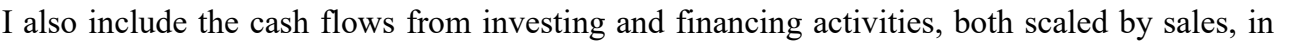

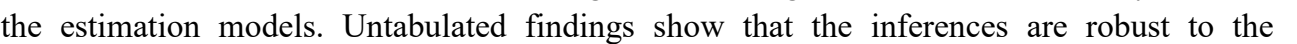

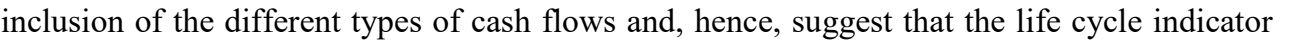

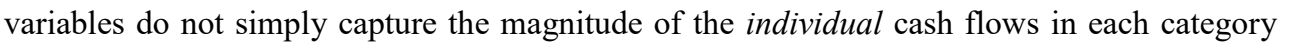

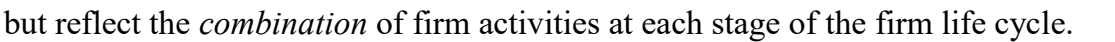




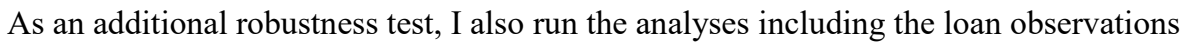

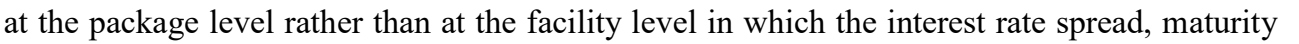

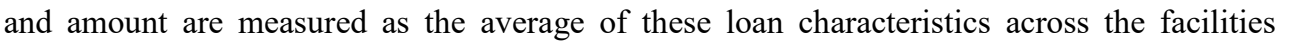

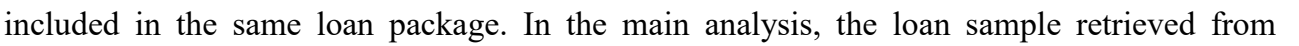

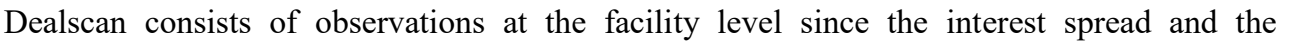

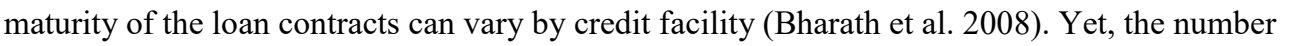

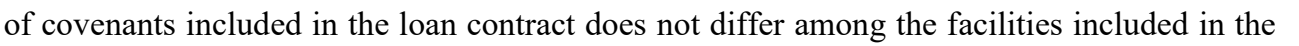

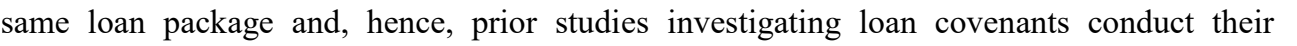

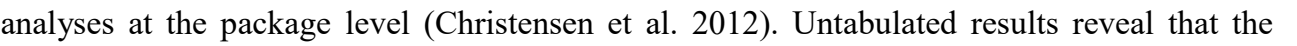

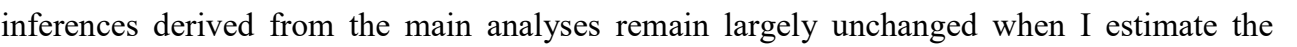

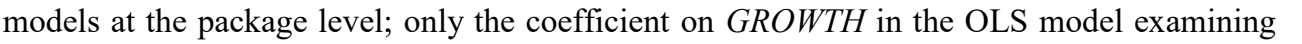

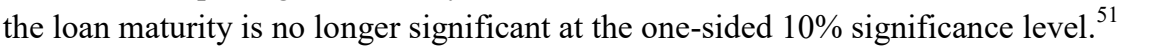

$\square$

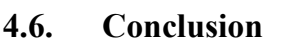

In sharp contrast to the negative relation between firms' investment opportunity sets and

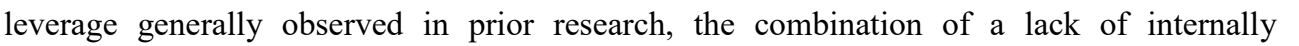

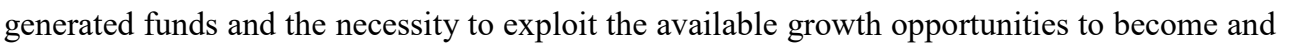

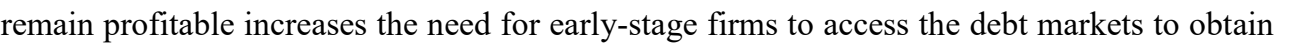

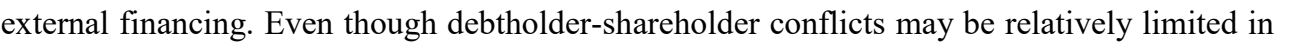

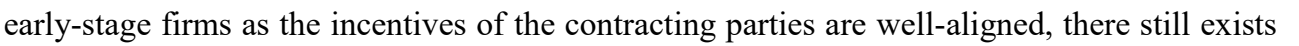

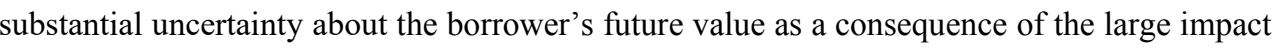

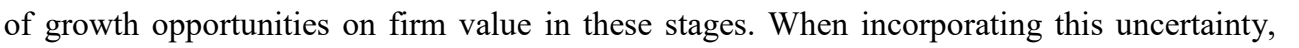

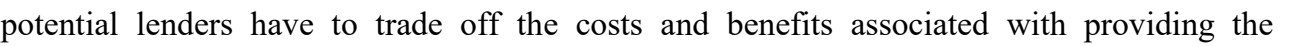

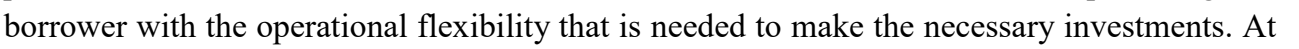
ए

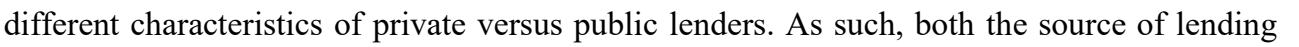

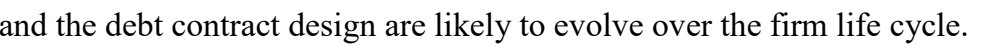

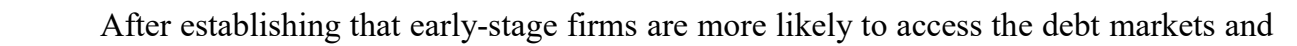

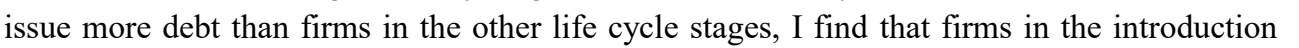

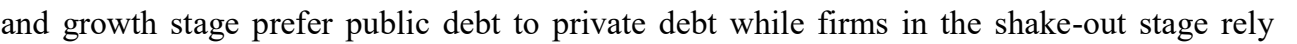
more on private debt. This finding is consistent with the "Rent Extraction hypothesis" which

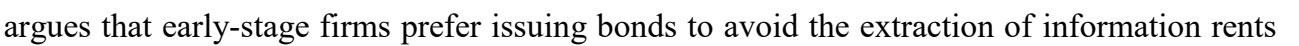

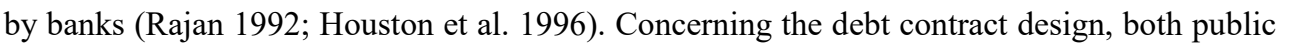

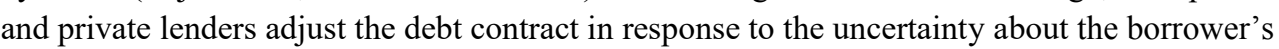

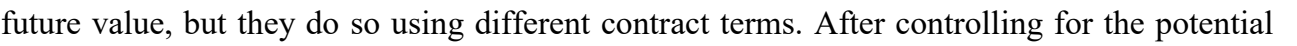

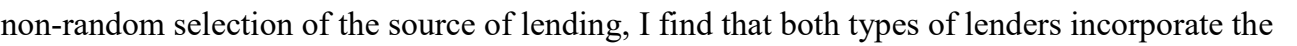

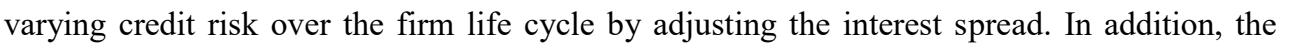

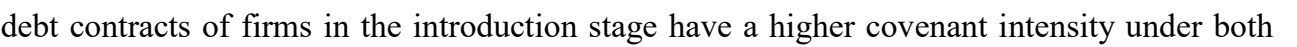

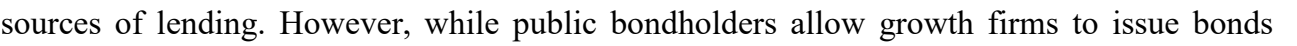

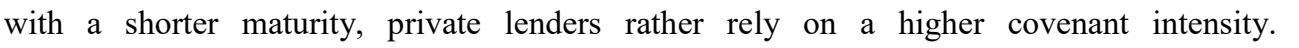

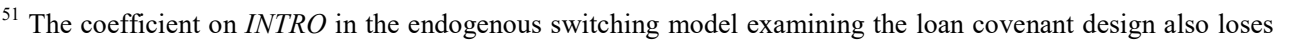

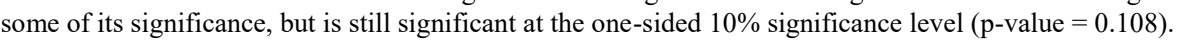




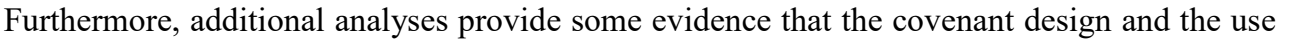

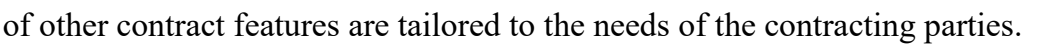

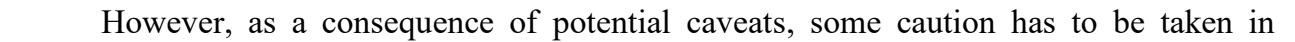

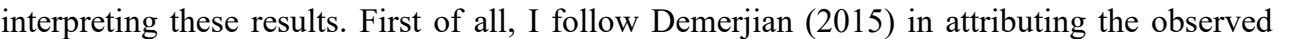

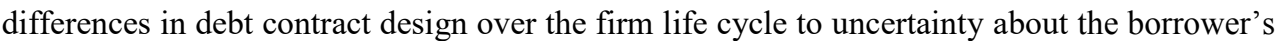

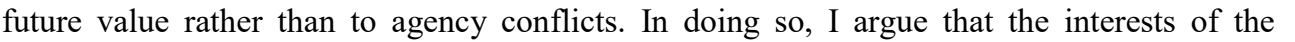

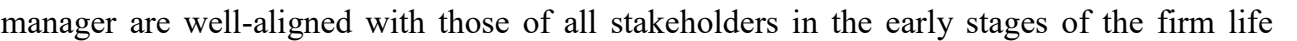

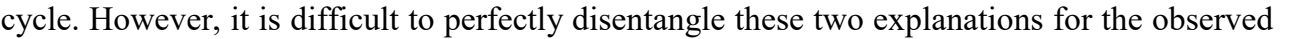

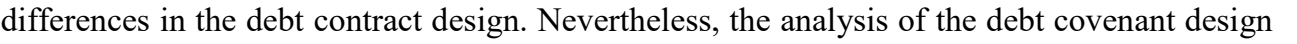

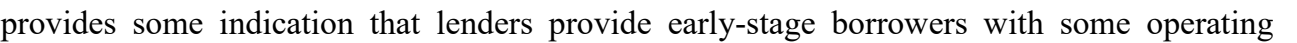

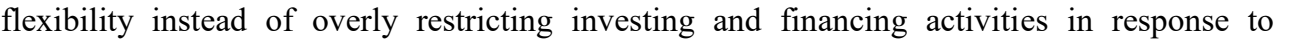

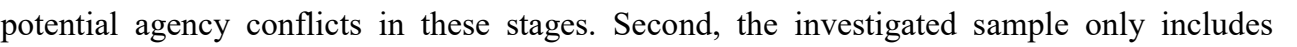

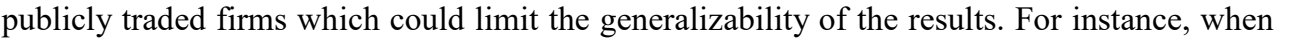

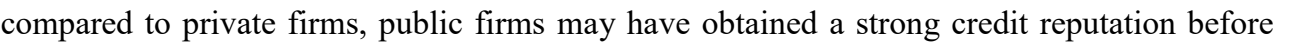

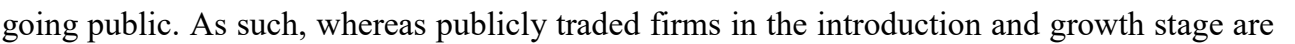

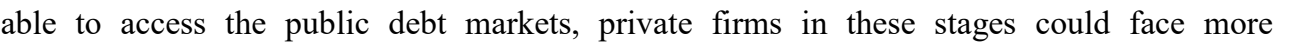

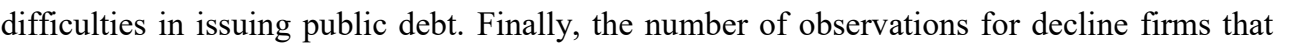

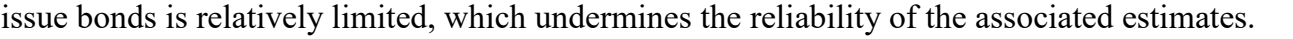

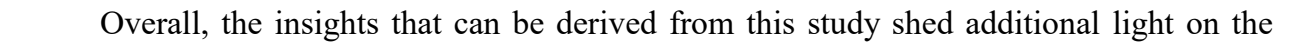

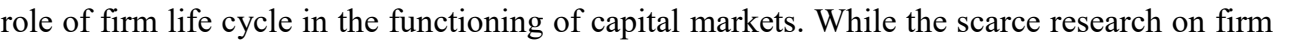

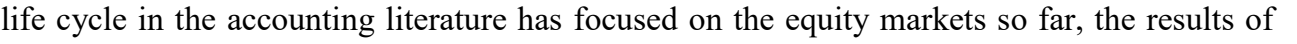
ए एव

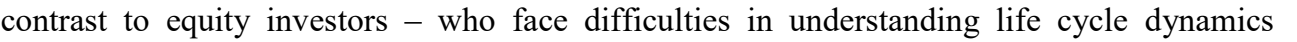

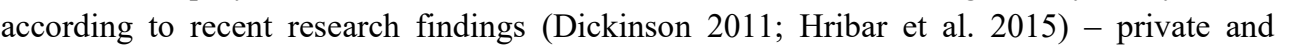

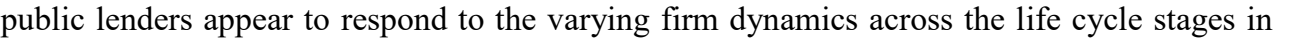

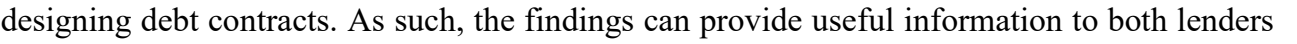

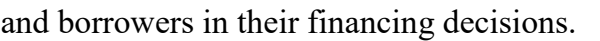




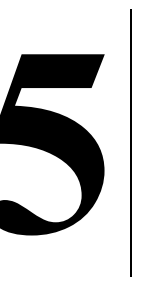

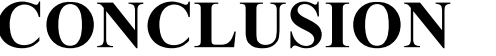

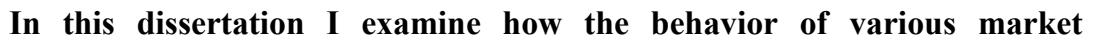

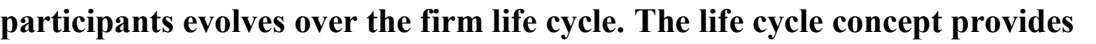

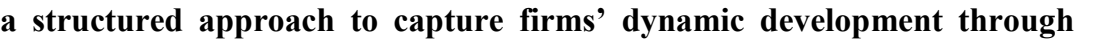

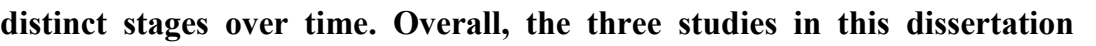

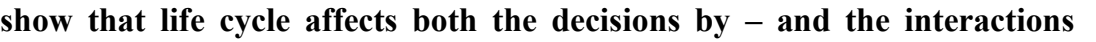

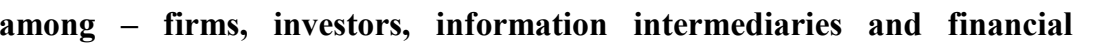

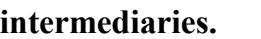

$\square$

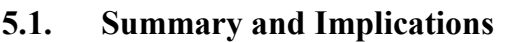

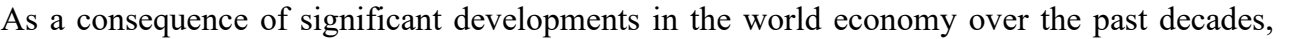

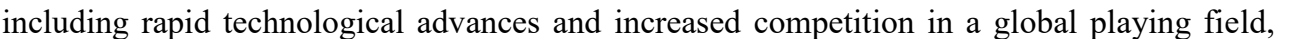

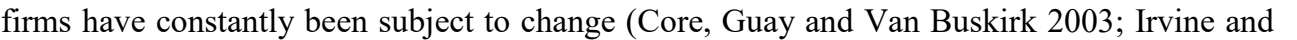

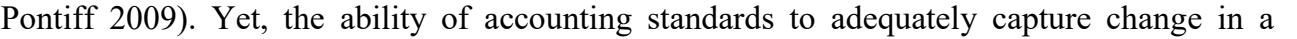

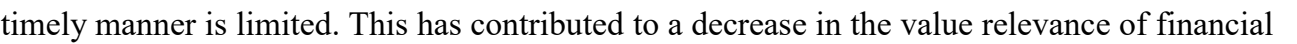
ए

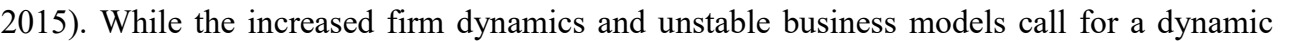

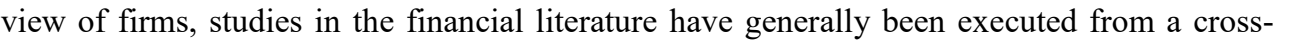

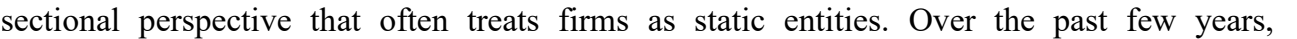

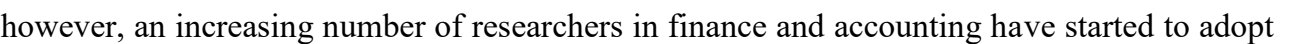

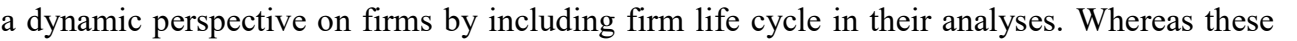

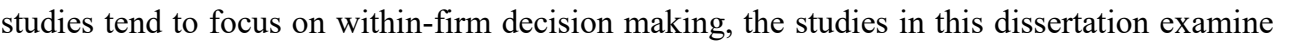

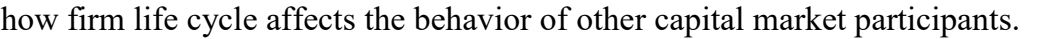

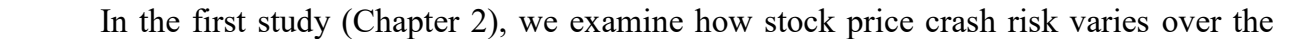
ए

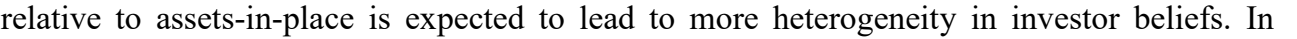

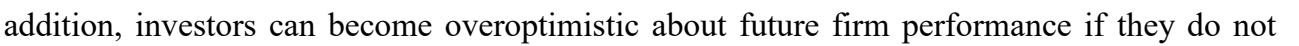

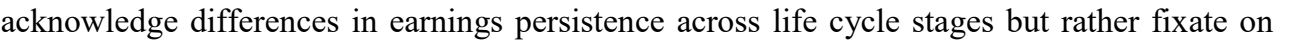

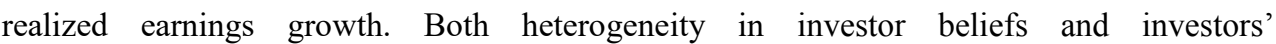

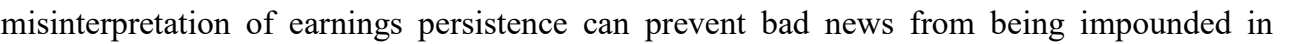

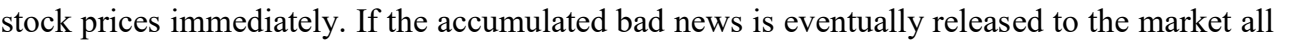

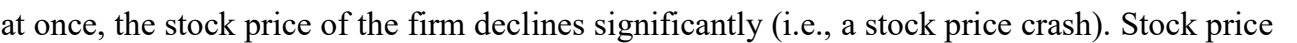

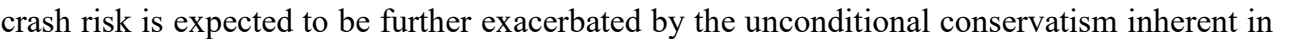

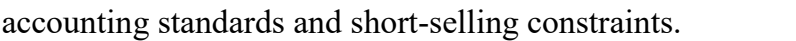

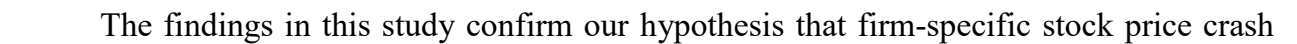
ए

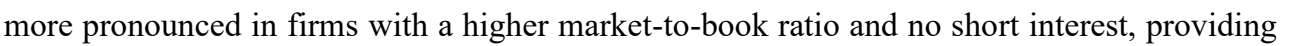

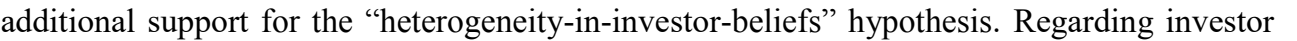

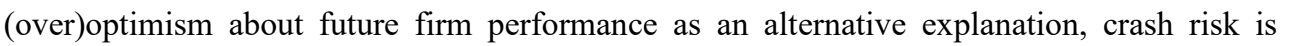

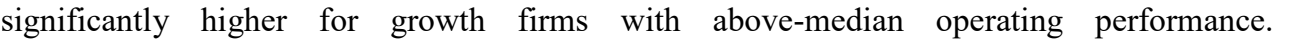

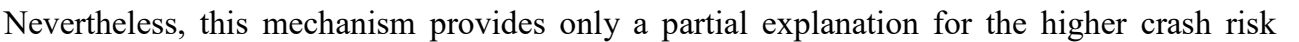

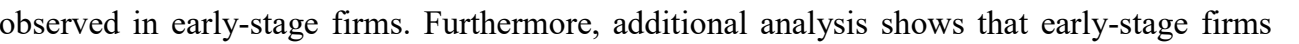




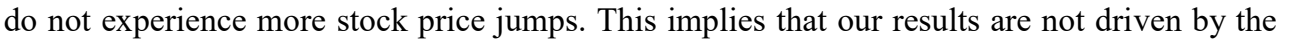

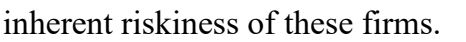

\begin{aligned} \hline \\ $\square\end{aligned}$

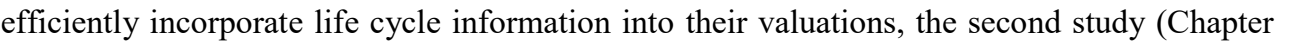

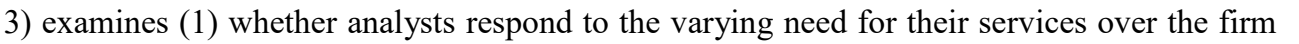

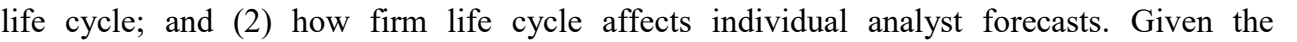

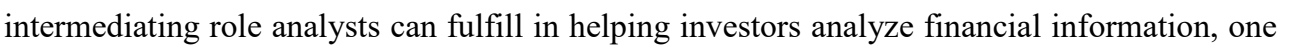
ए

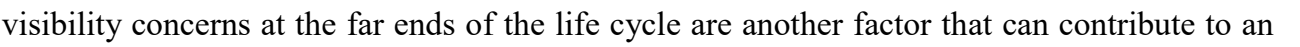

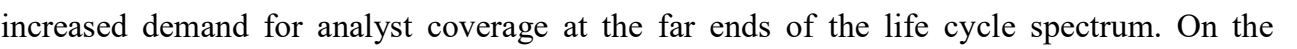

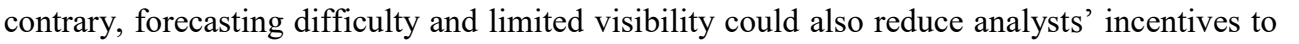
प

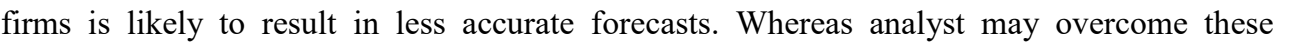
ए

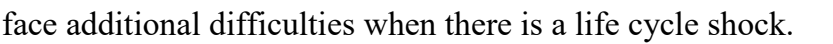

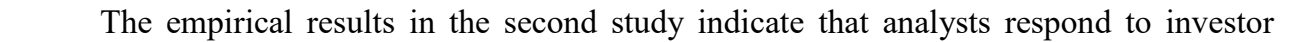

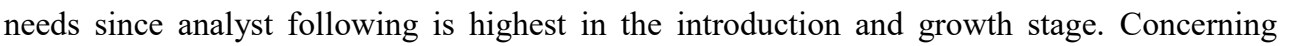

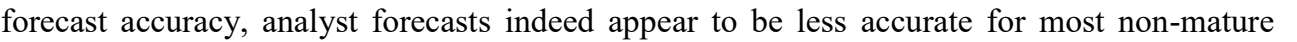
ए

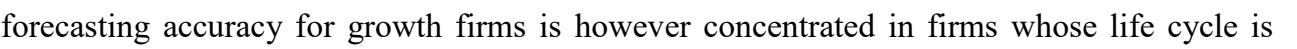

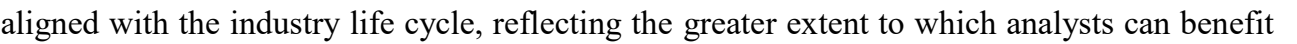

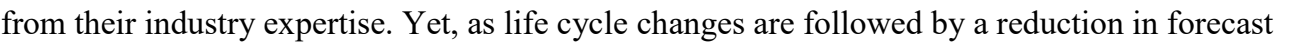

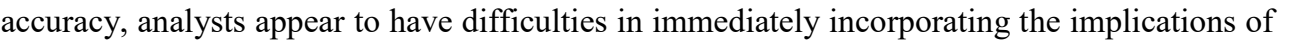

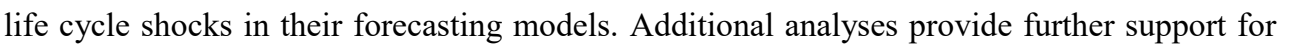
ए

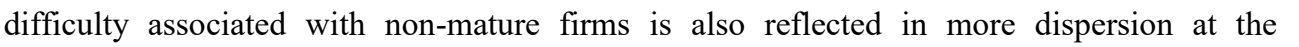

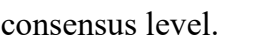

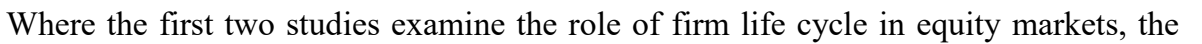

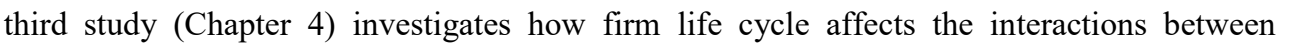

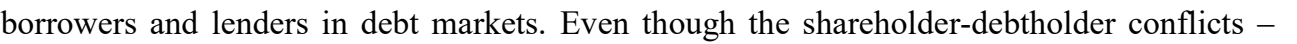

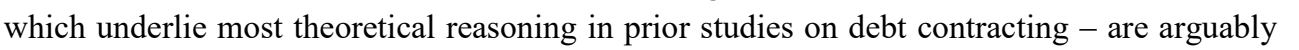
(1)

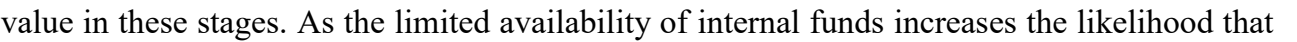

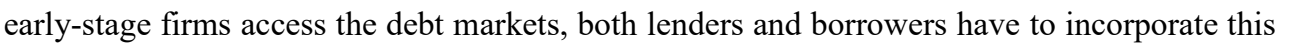

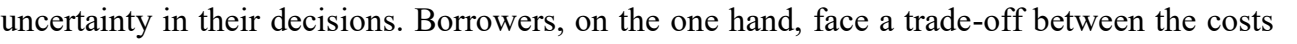

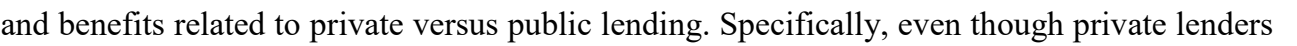

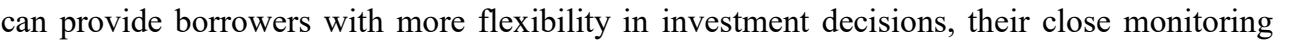

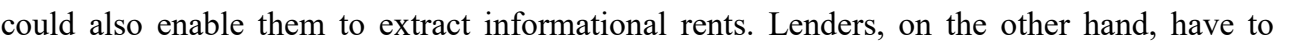

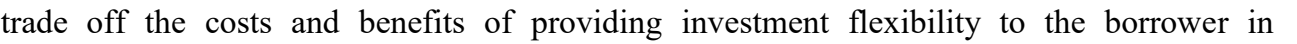

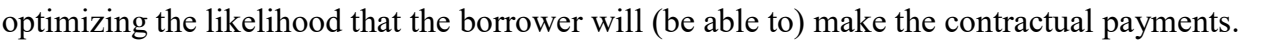

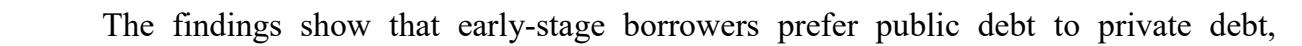

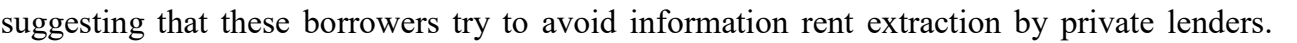

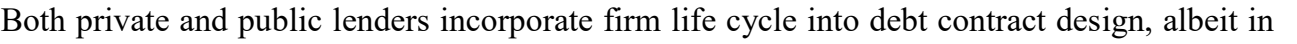

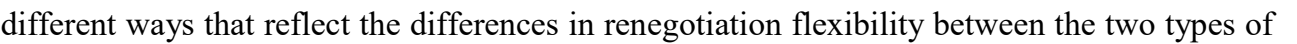




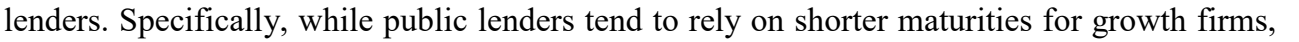

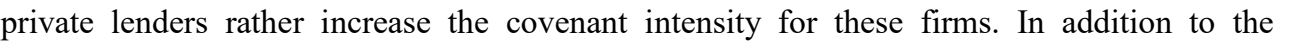

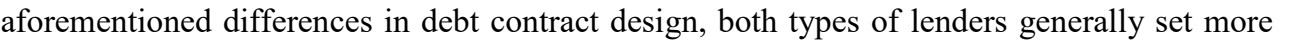

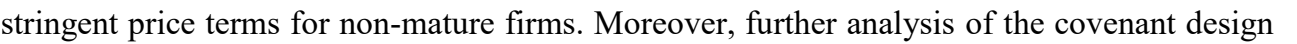

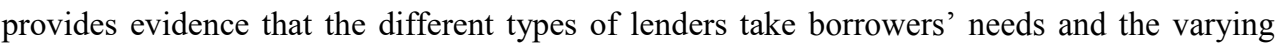

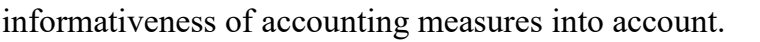

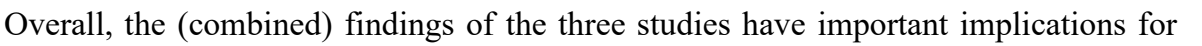

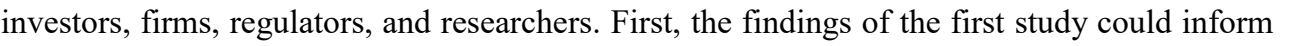

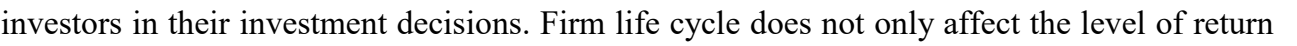

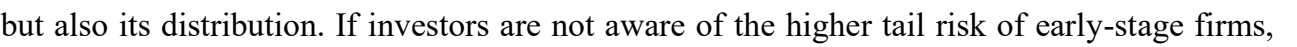
ए

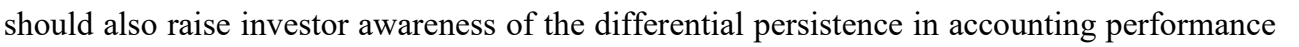

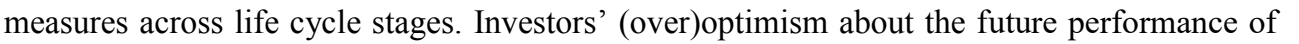

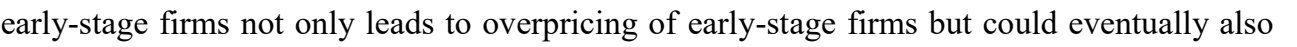

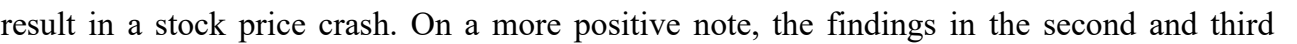

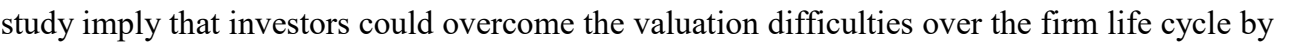

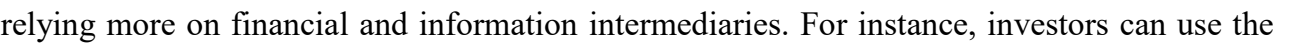
ए

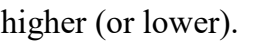

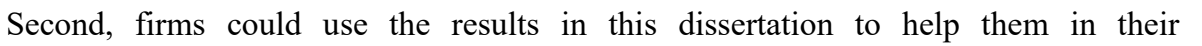

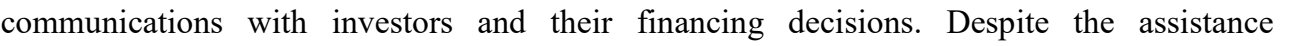
एणी

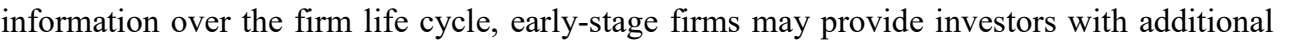

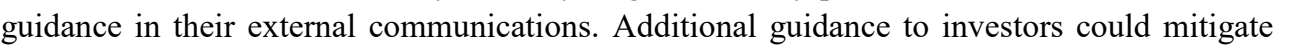

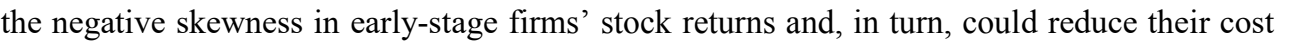

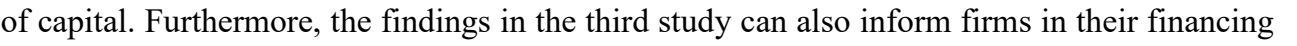

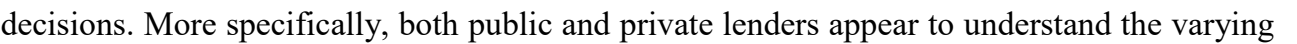

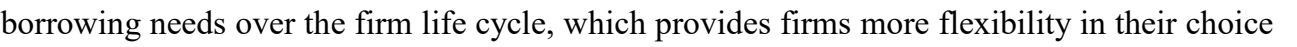

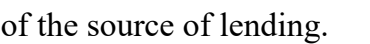

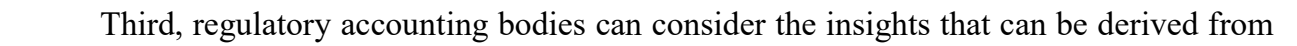
ए एव

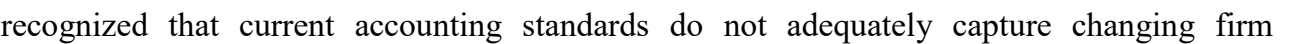

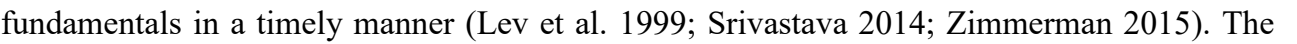
ए

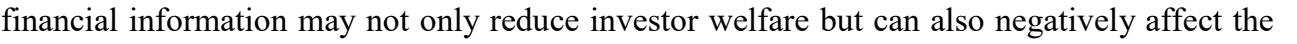

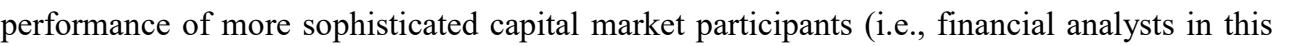

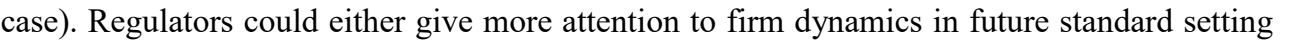

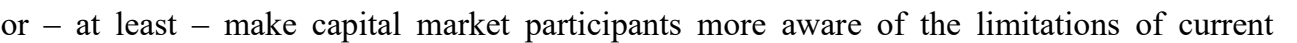

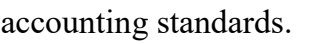

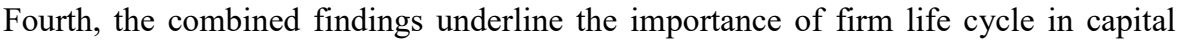

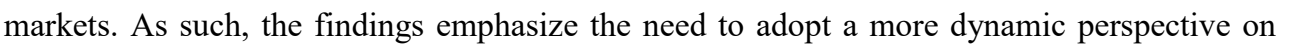

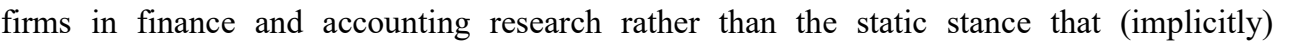

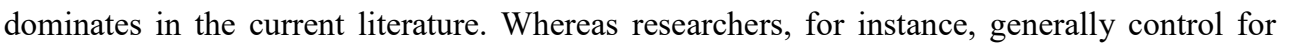




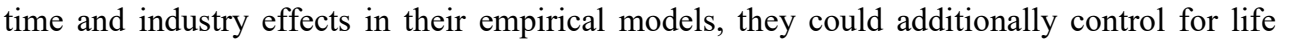

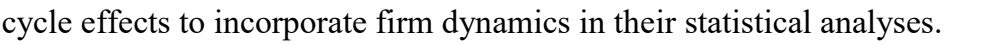

$\square$

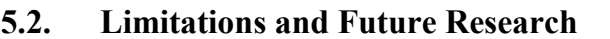

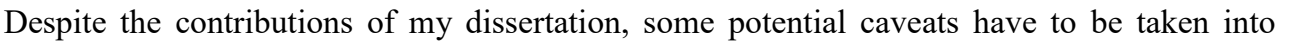

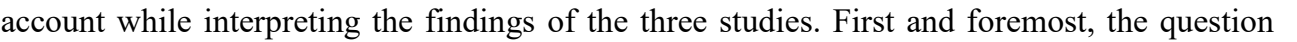

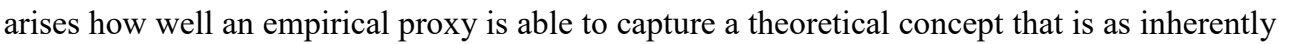

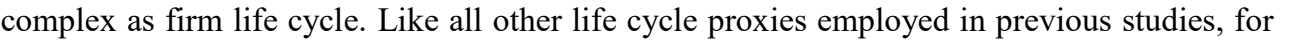
ए ए

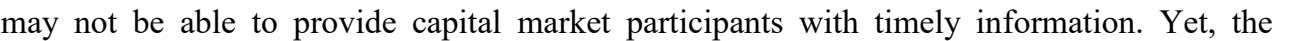

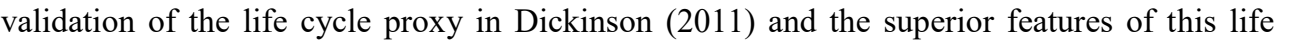

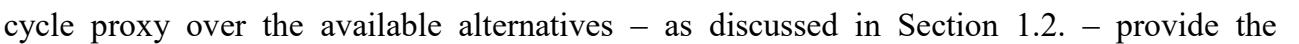

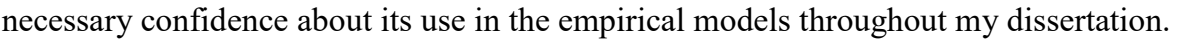

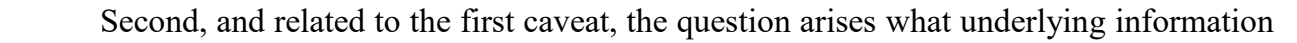

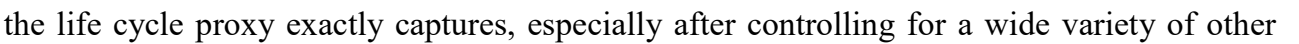

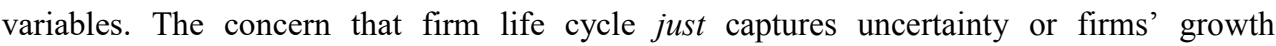

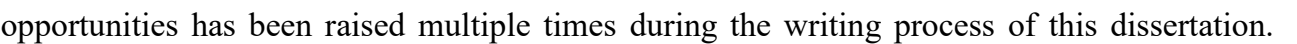

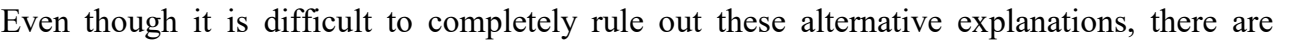

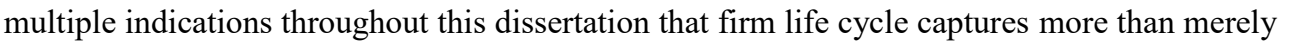

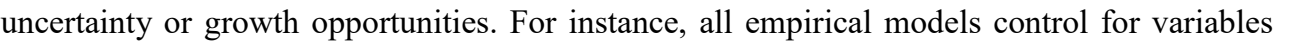

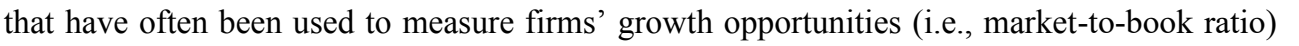

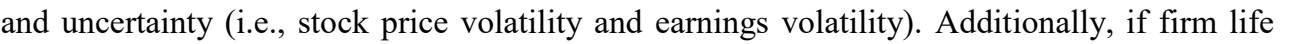

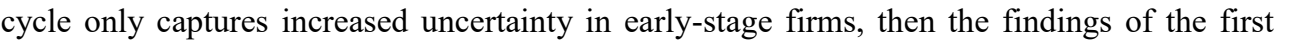

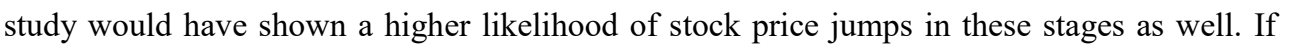

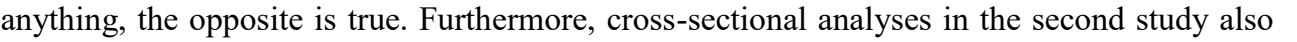

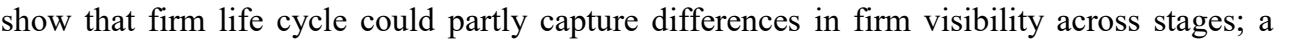

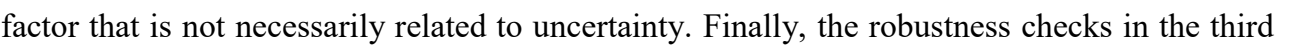

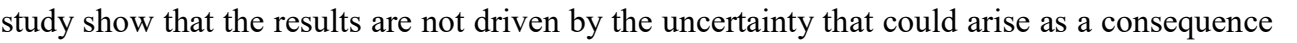

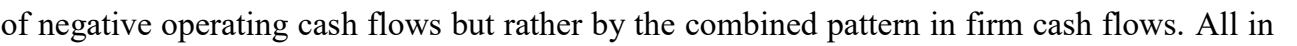

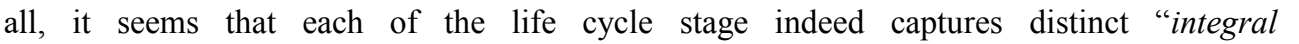

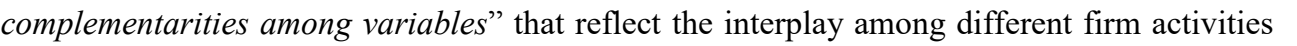

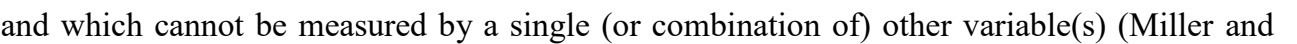

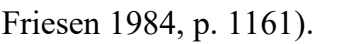

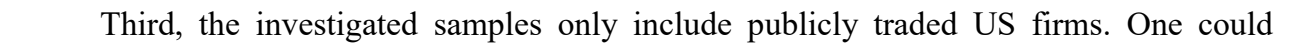

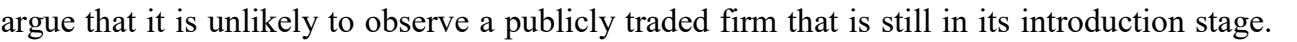

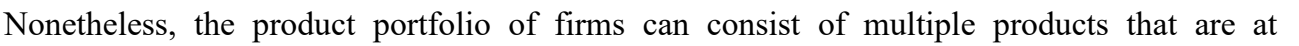

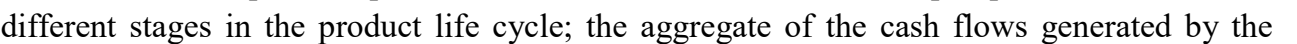

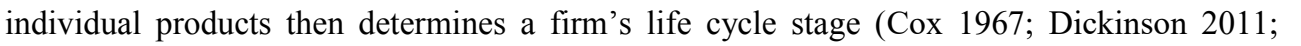

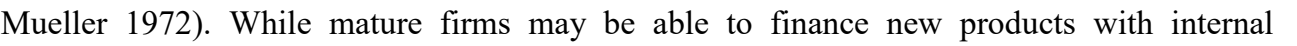

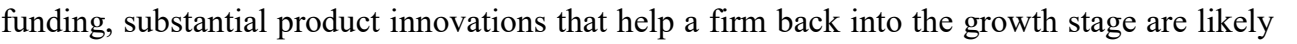

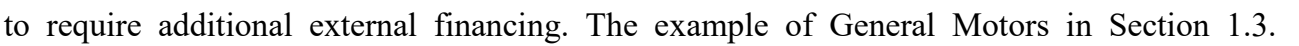

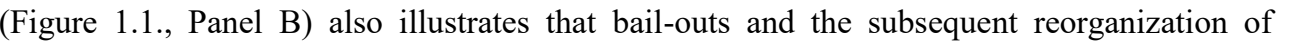

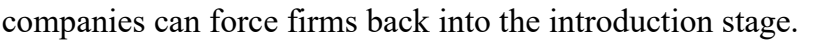




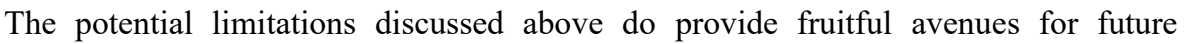

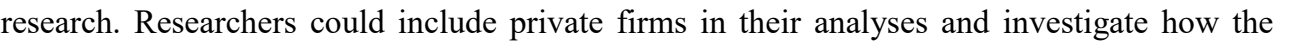

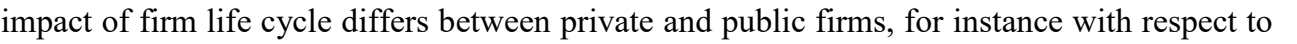

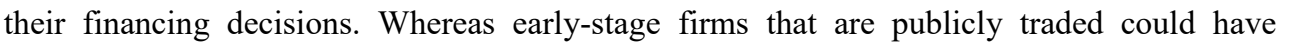

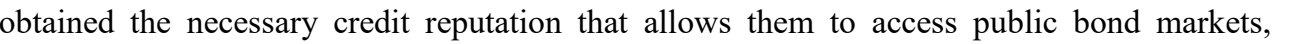

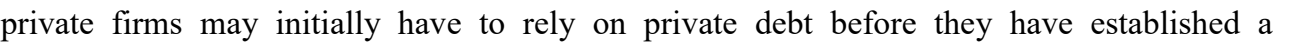

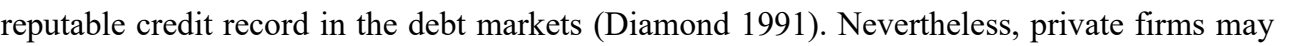

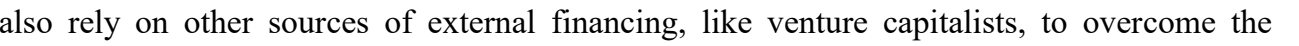

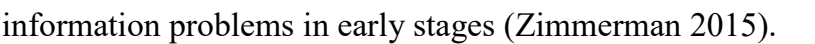

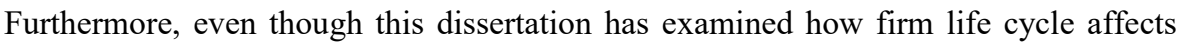

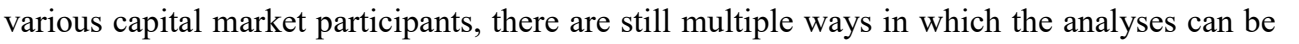

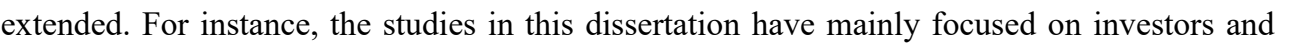
ए

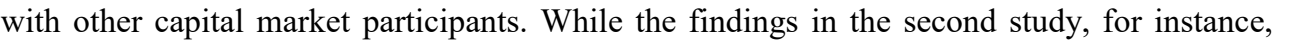

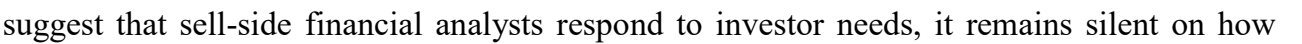

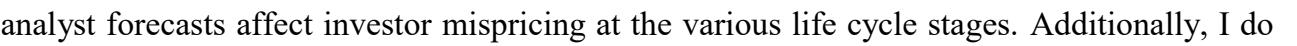

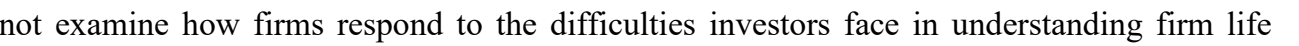

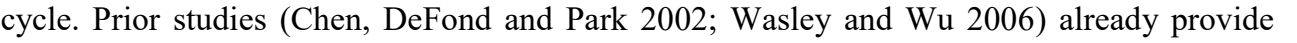

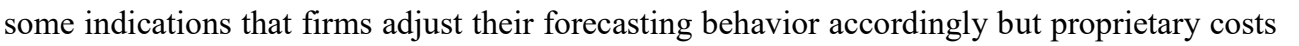

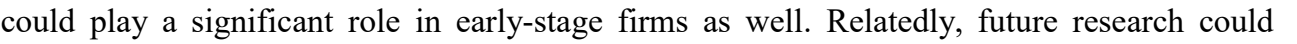
ए ए।

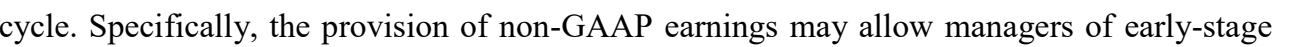

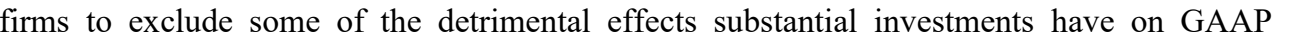

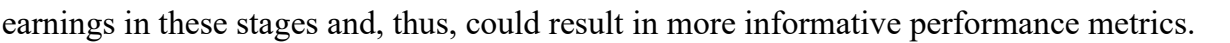

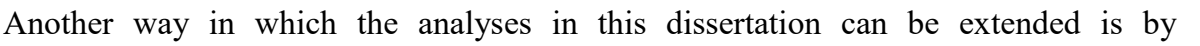

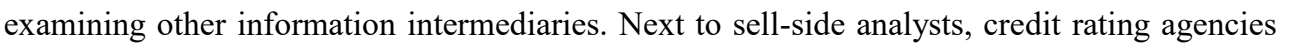

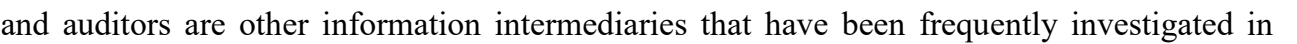

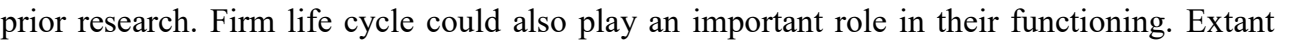

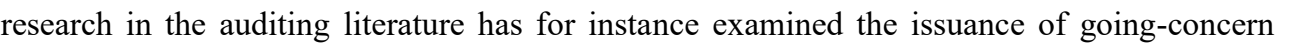

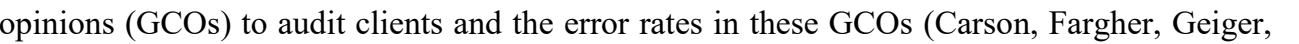

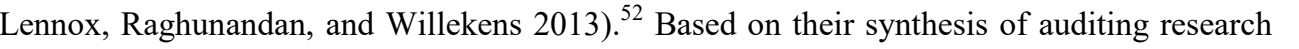

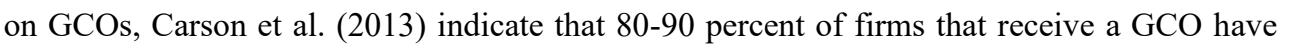

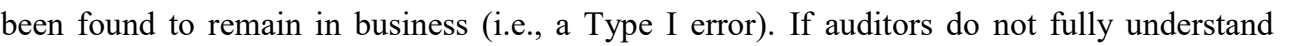

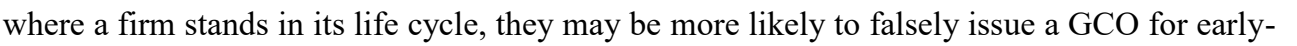

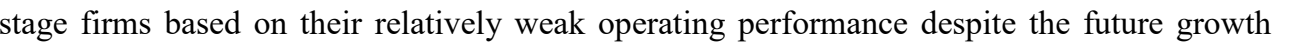

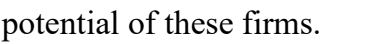

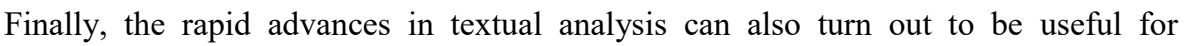

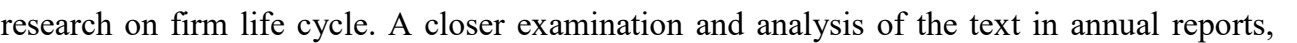

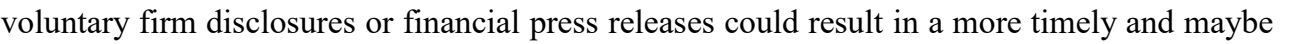

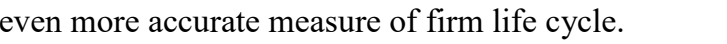

\footnotetext{
(A) Section 341, paragraph .02), an auditor has to issue a GCO if "there is substantial doubt about the entity's ability to continue as a going concern for a reasonable period of time, not to

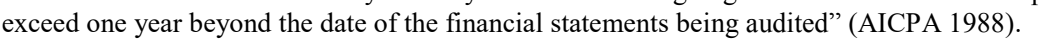





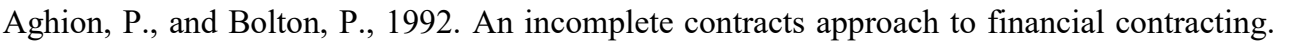

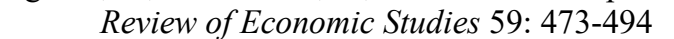

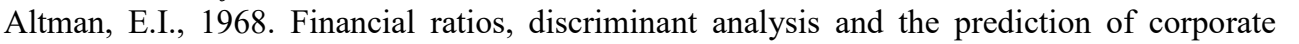

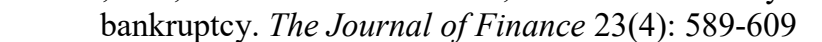

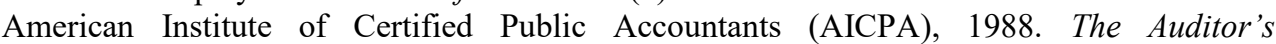

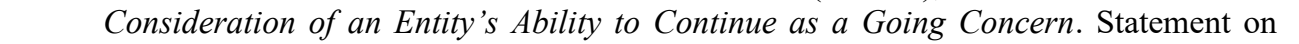

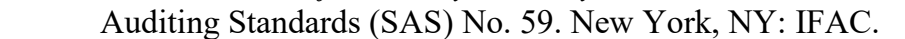

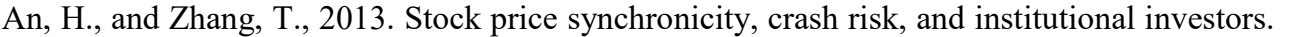

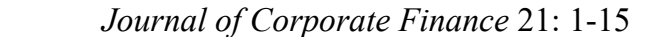

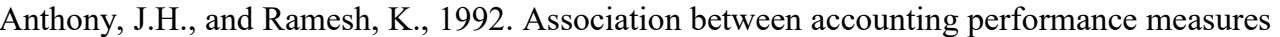

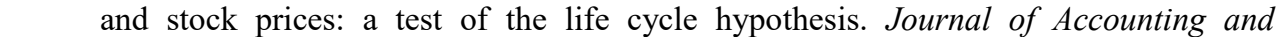

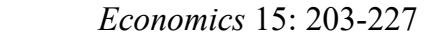

Arikan, A.M., and Stulz, R.M., 2016. Corporate acquisitions, diversification, and the firm's

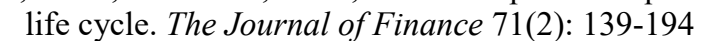

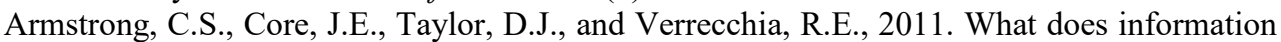

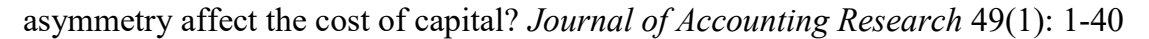

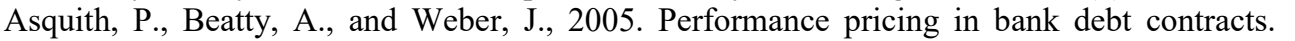

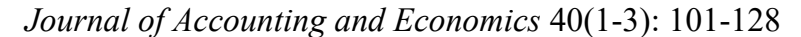

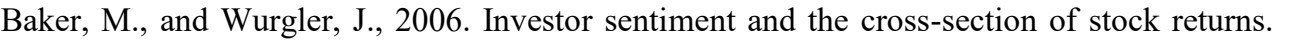

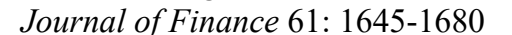

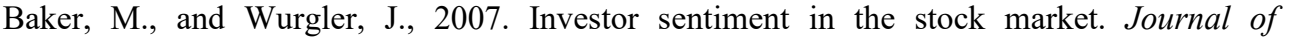

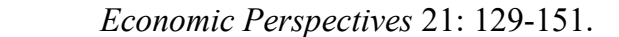

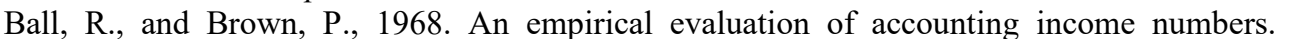

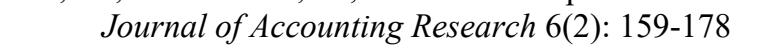

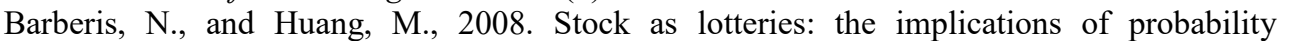

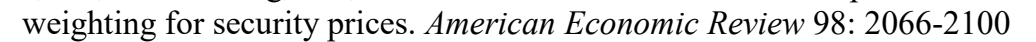

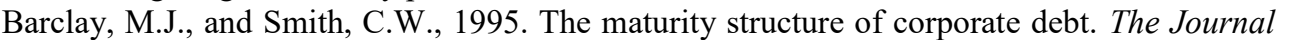

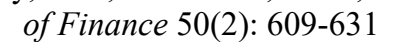

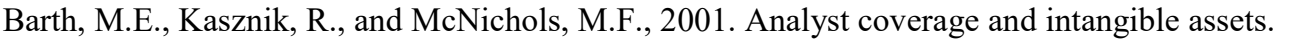

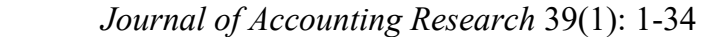

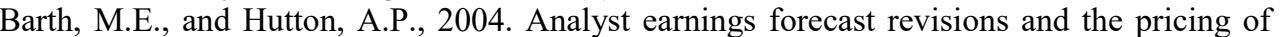

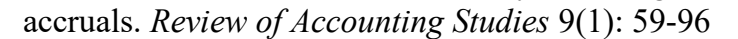

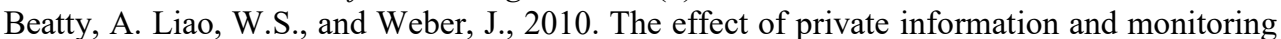

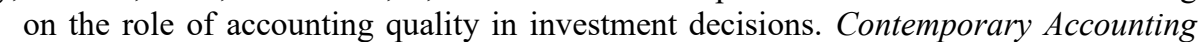

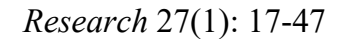

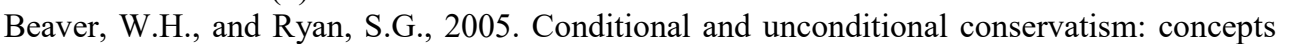

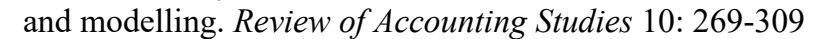

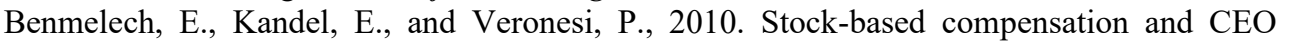

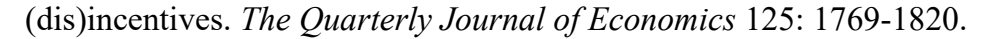

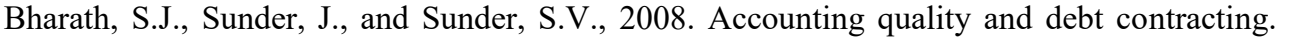

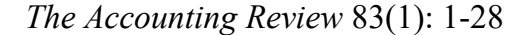

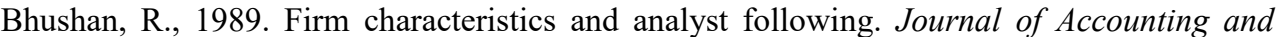

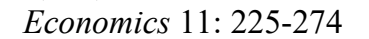

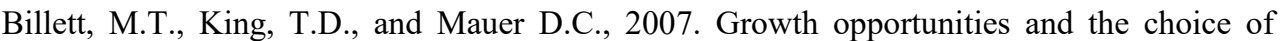

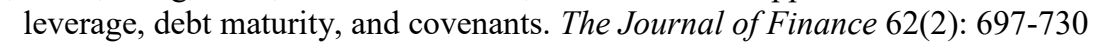

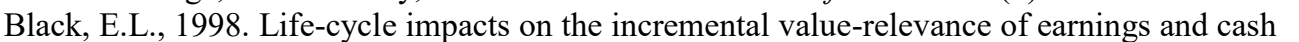

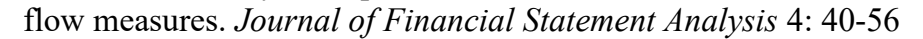

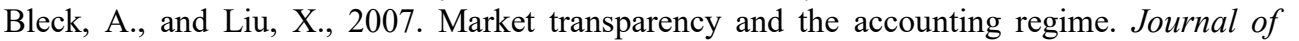

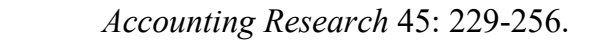




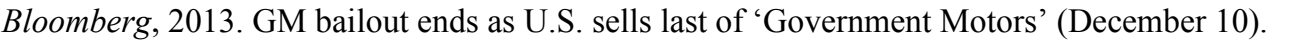

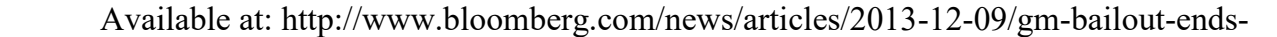

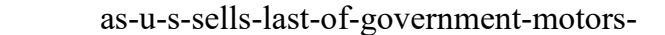

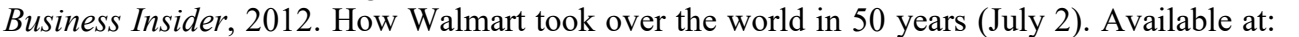

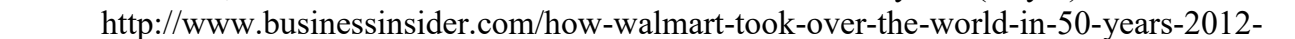

$\square \quad \square ा \| \square \square \square$

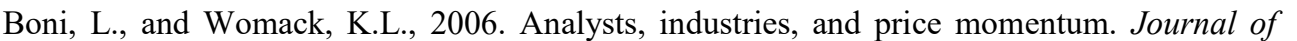

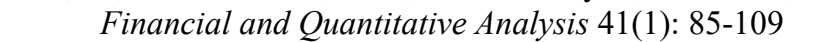

Bradshaw, M.T., 2015. Analysts' forecasts: what do we know after decades of work? $\square \square\|\| \square \square$ एा।ाण

Brown, L.D., Call, A.C., Clement, M.B., and Sharp, N.Y., 2015. Inside the "black box" of

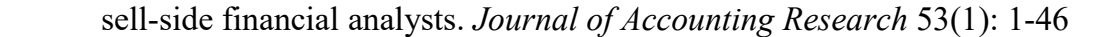

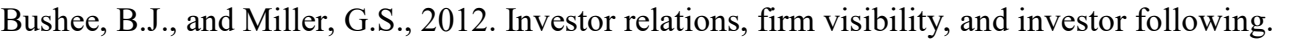

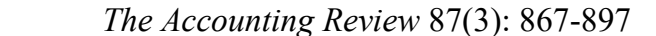

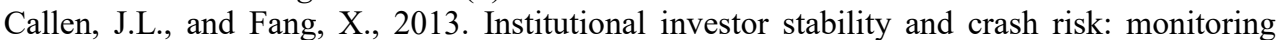

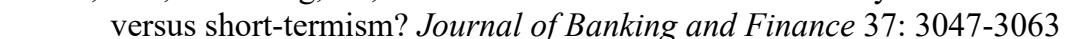

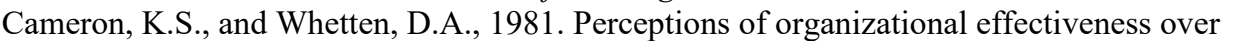

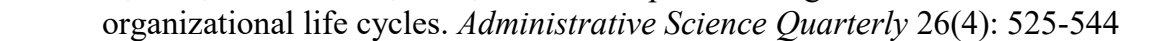

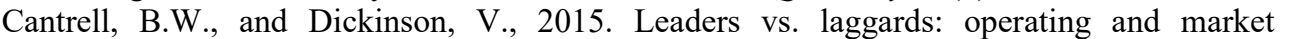

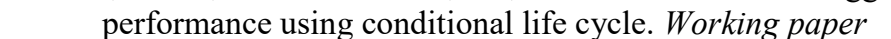

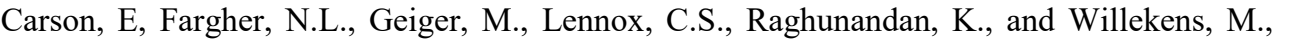

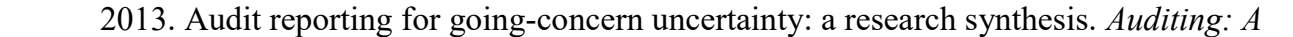

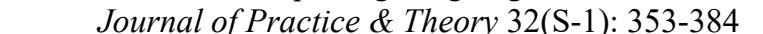

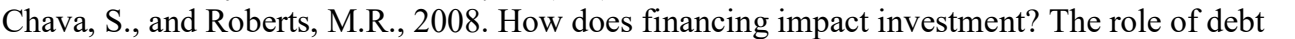

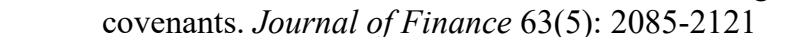

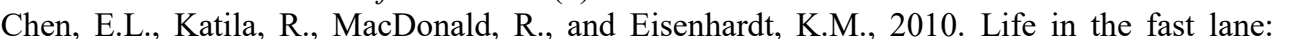

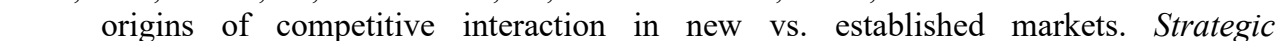

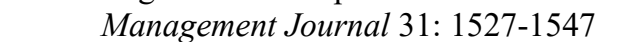

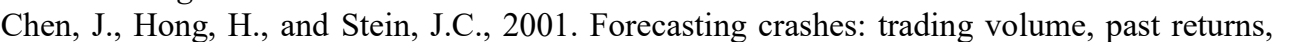

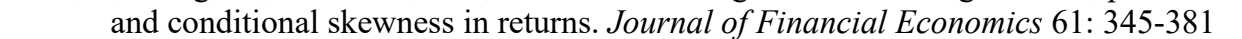

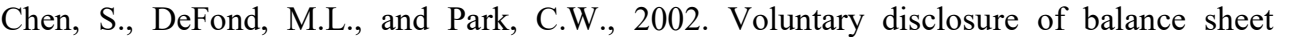

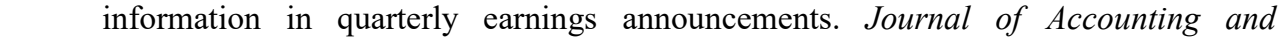

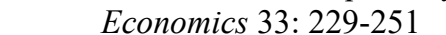

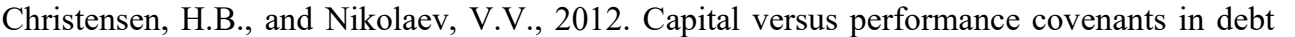

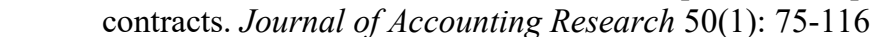

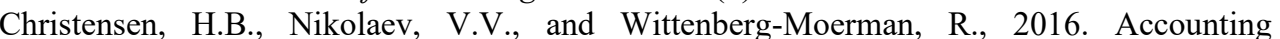

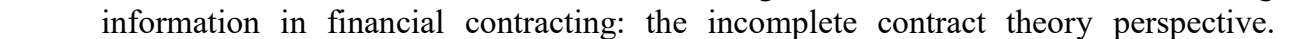

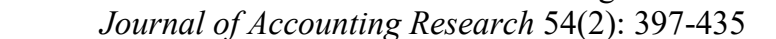

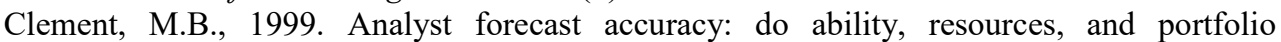

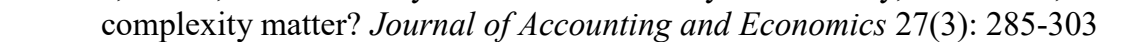

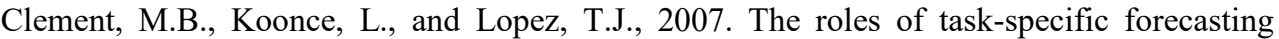

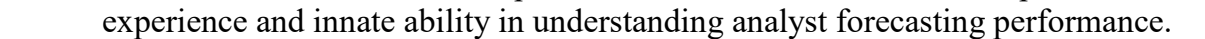

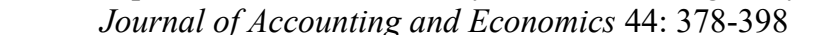

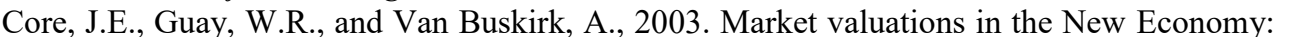

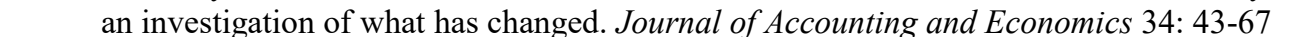

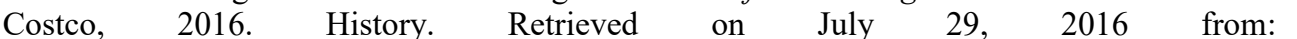

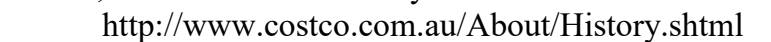

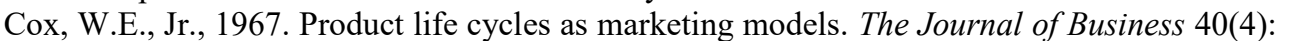

$\square \quad \square 1 \| \square \square$ 


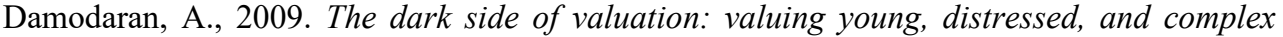

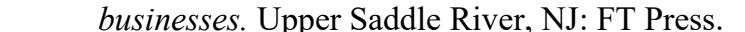

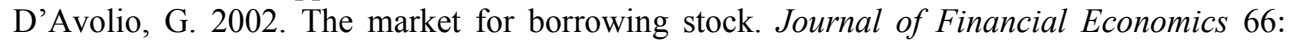

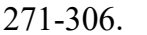

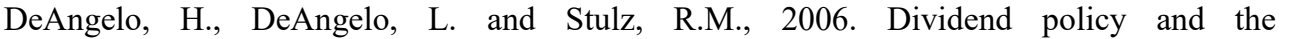

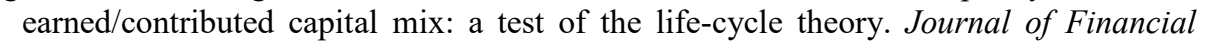

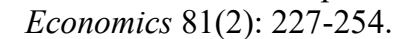

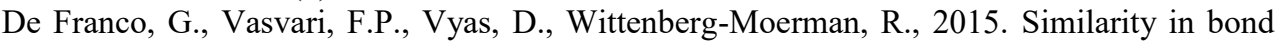

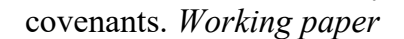

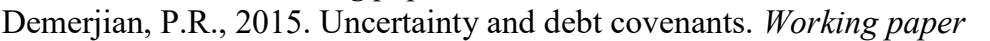

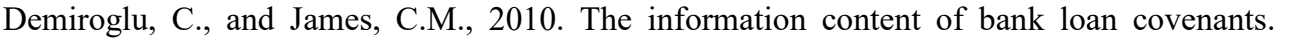

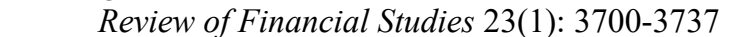

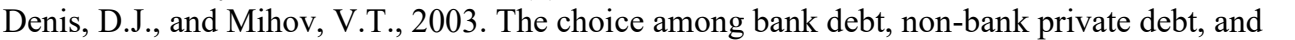

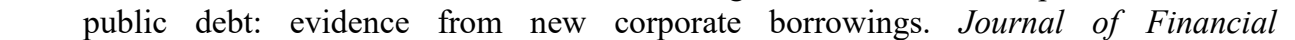

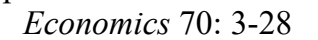

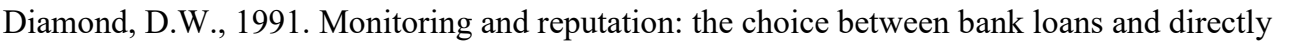

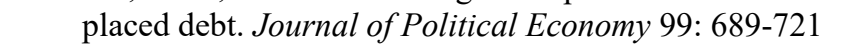

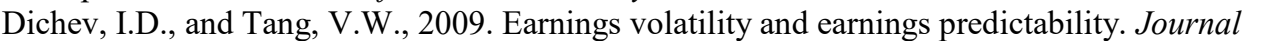

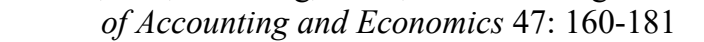

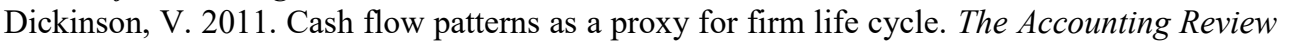

$\square \quad \square|\Pi| 1 \mid \| 111 \square$

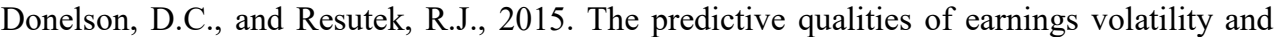

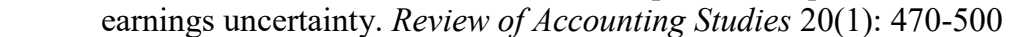

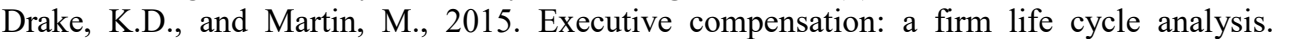

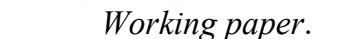

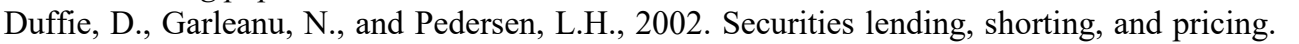

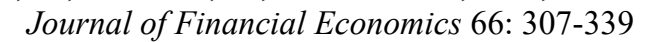

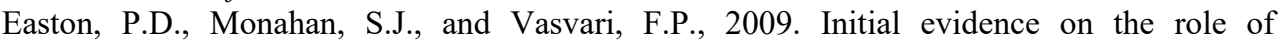

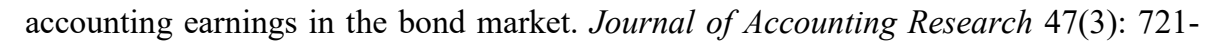
$\square \square \mid \square$

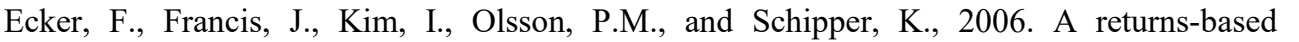

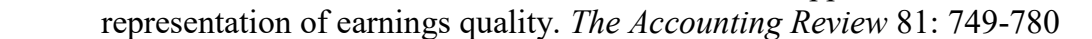

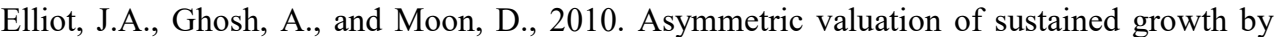

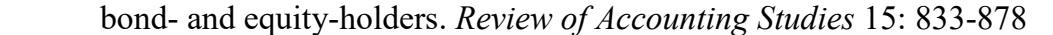

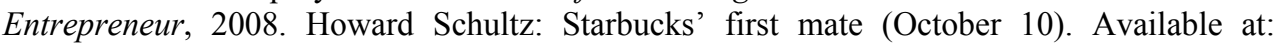

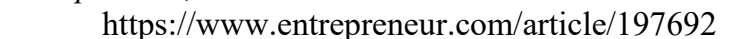

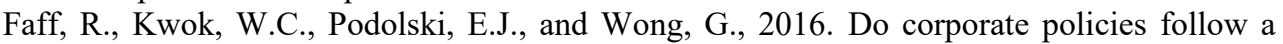

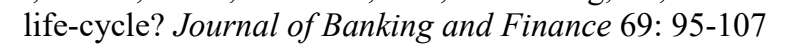

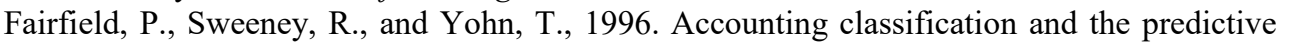

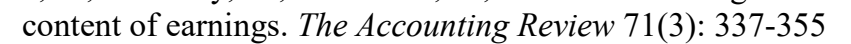

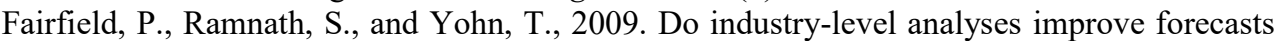

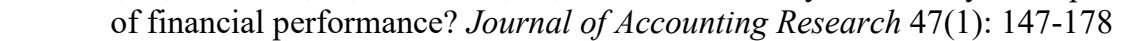

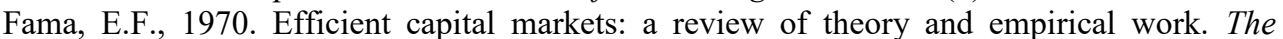

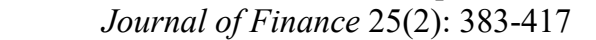

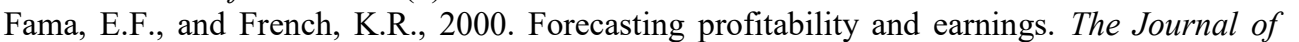

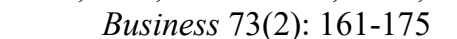

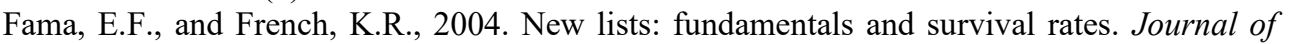

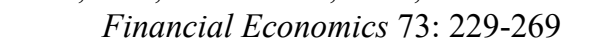


$\square \square\|\backslash\| \square \square$ Starbucks and McDonald's winning strategy (April 25). Available at:

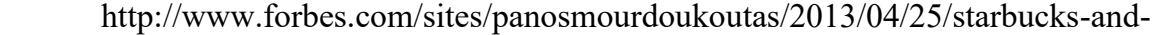

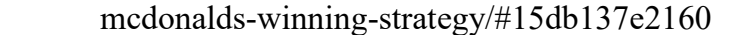

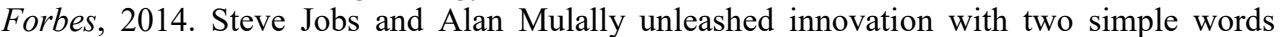

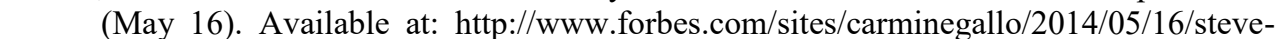

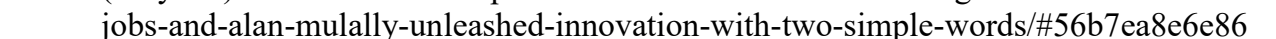

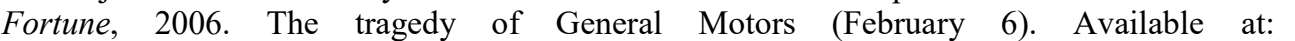

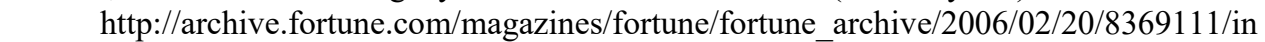

$\square \quad \square 10 \square \square$

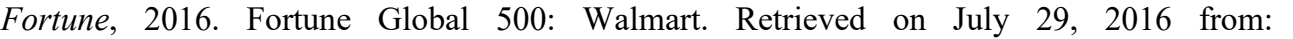

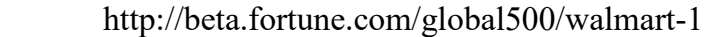

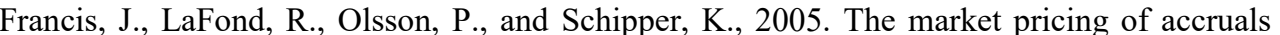

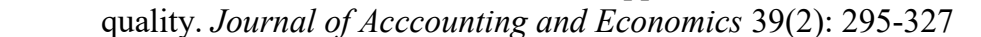

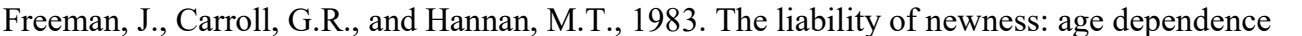

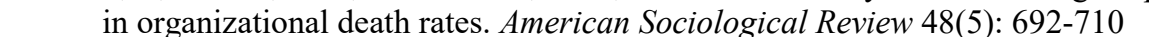

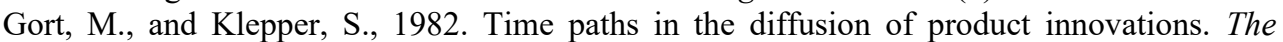

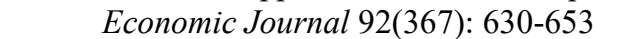

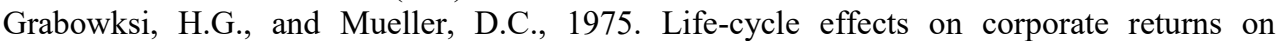

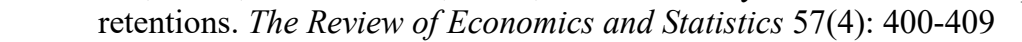

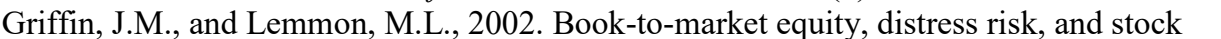

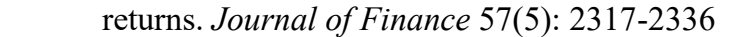

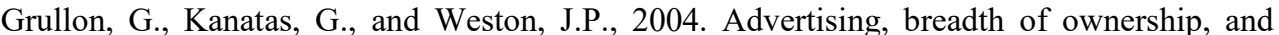

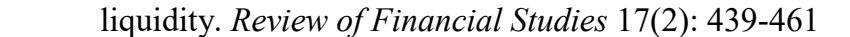

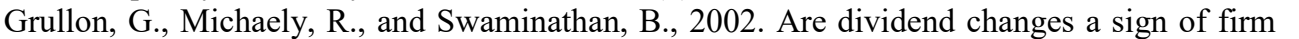

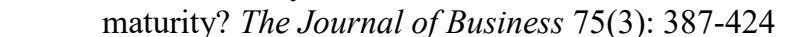

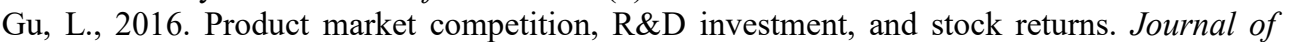

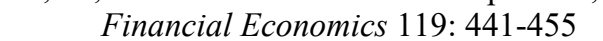

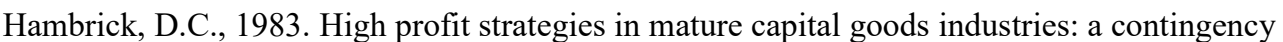

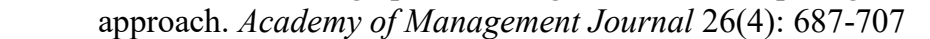

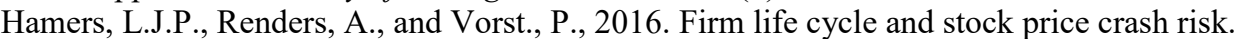

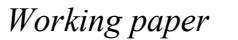

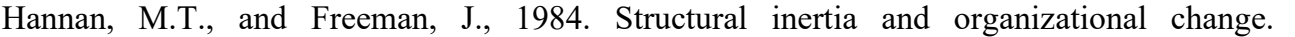

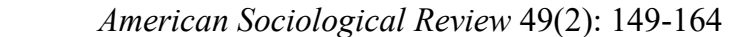

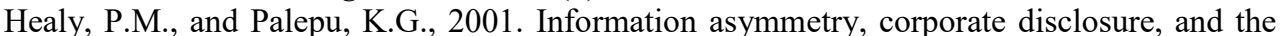

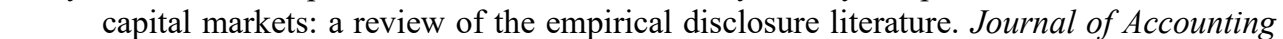

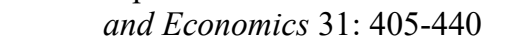

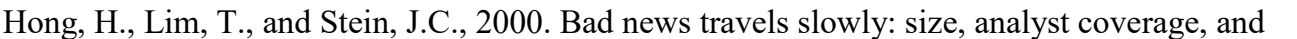

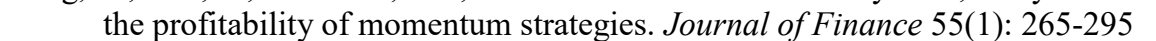

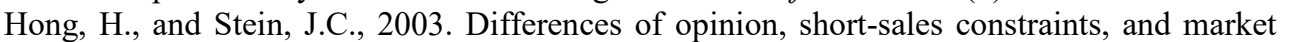

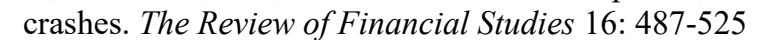

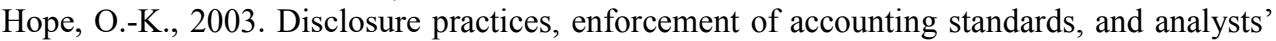

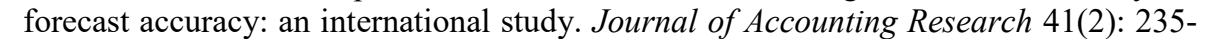
$\square \square \mid \square$

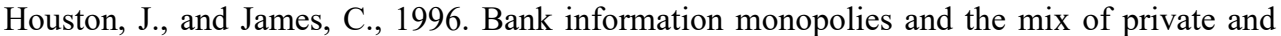

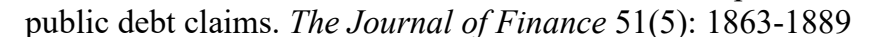

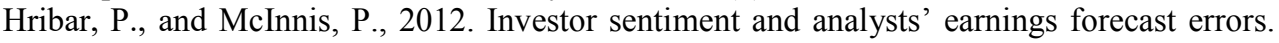

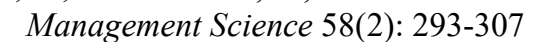

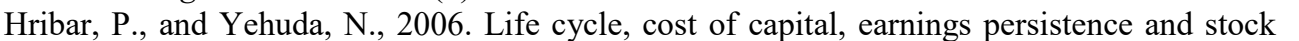

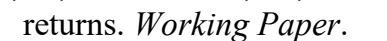




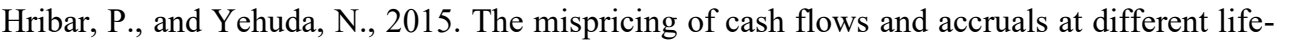

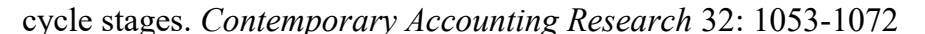

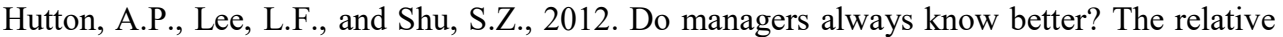

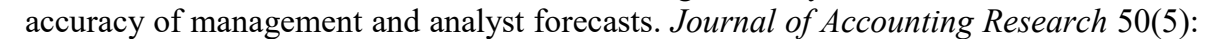
$\square \square|||||| \mid$

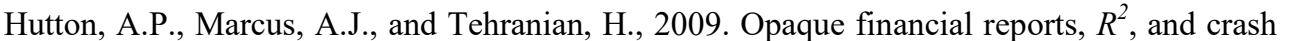

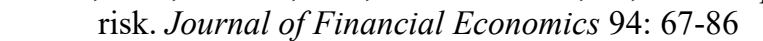

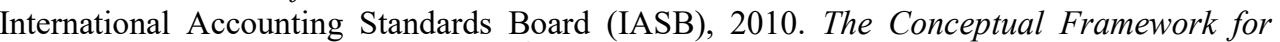

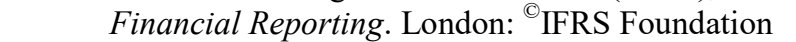

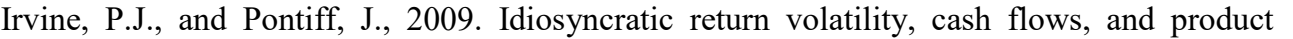

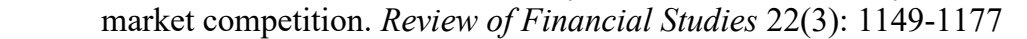

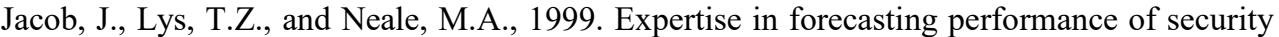

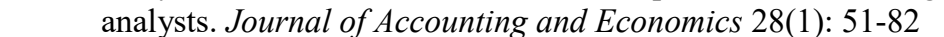

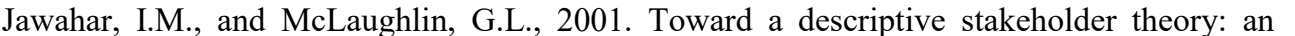

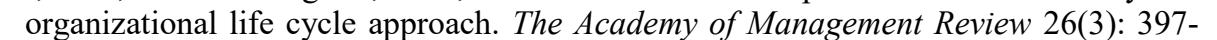
$\square \square \square$

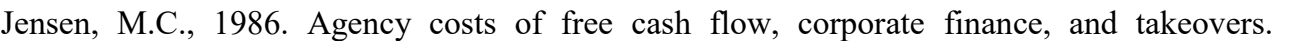

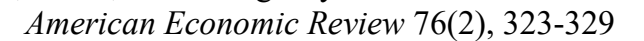

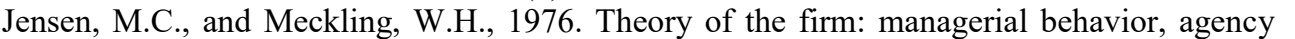

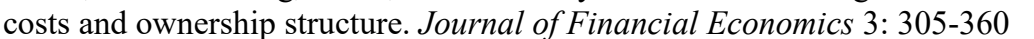

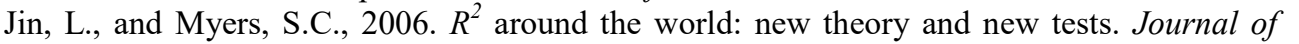

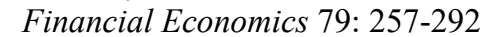

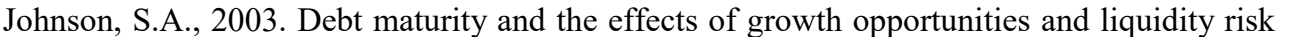

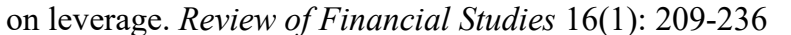

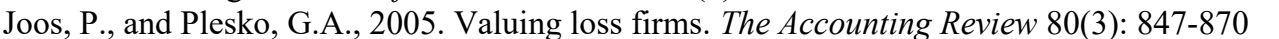

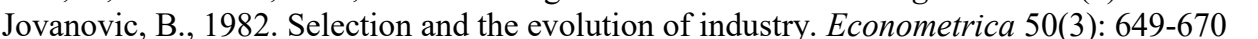

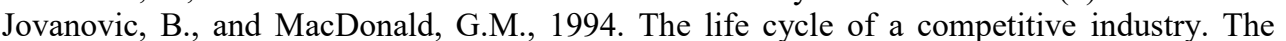

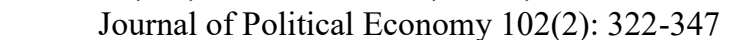

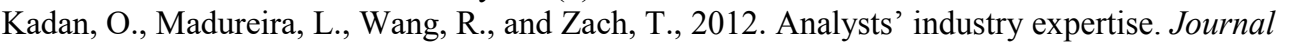

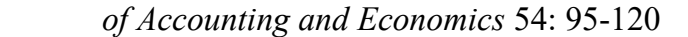

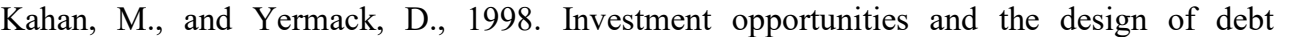

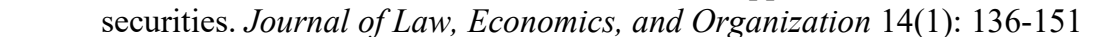

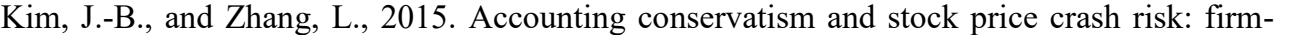

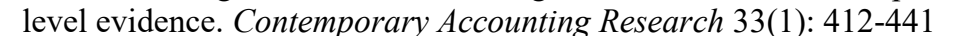

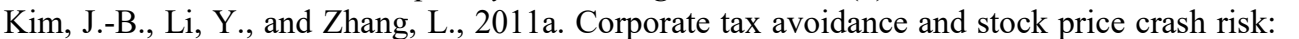

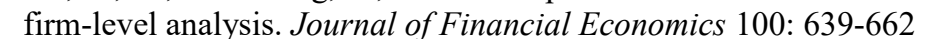

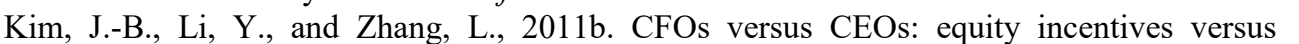

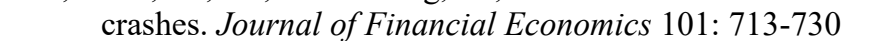

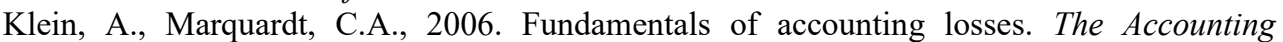

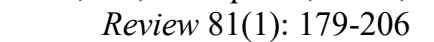

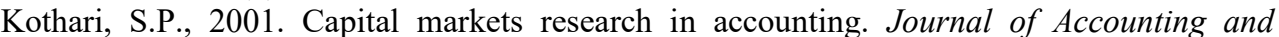

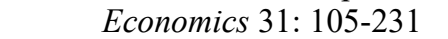

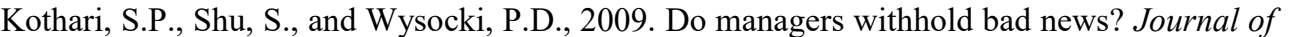

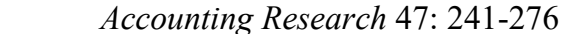

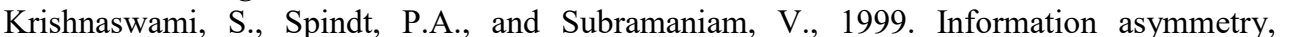

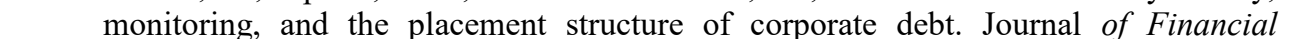

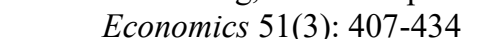

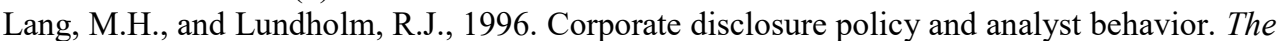

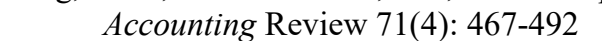




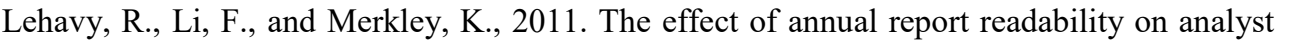

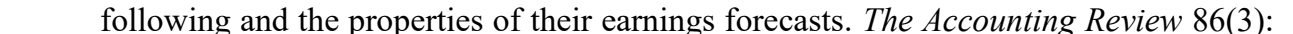

$\square \quad \square 11 \square म \square$

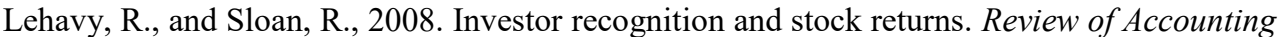

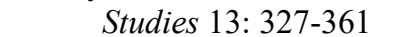

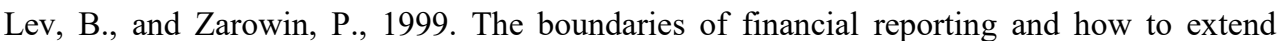

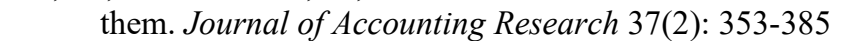

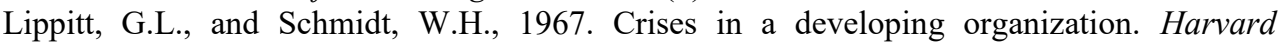

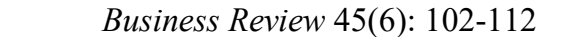

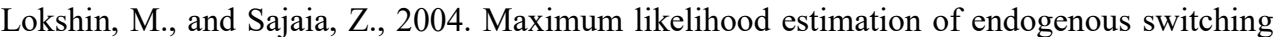

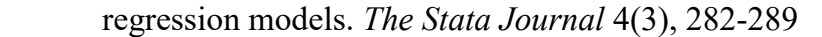

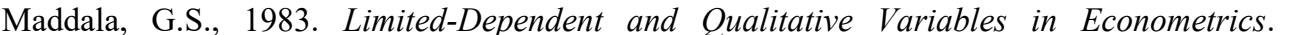

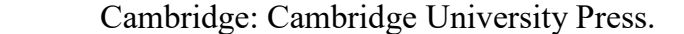

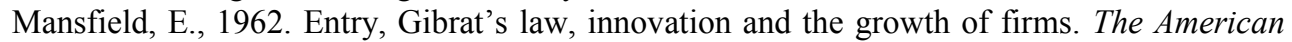

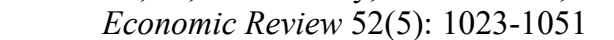

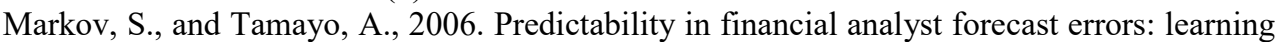

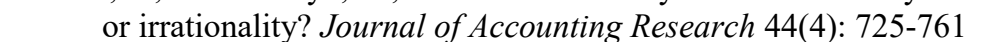

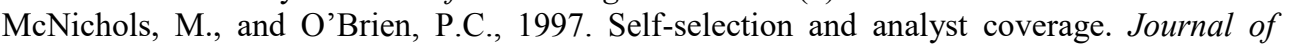

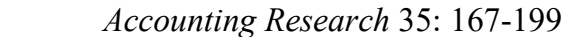

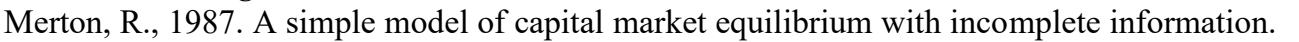

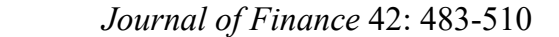

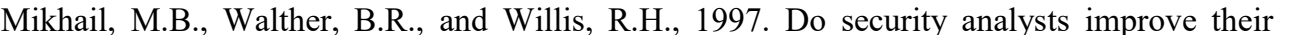

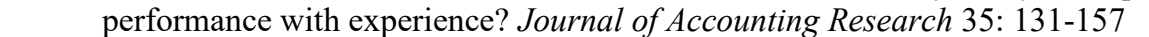

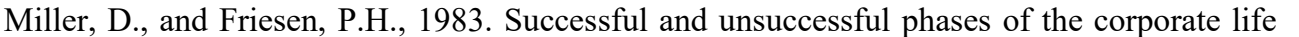

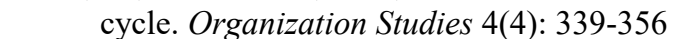

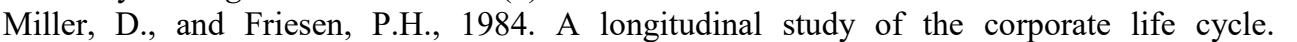

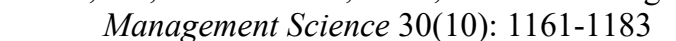

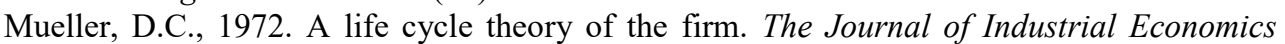

$\square \quad \square 1010110110$

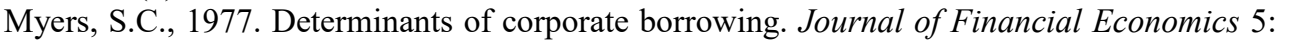

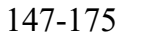

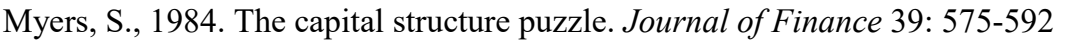

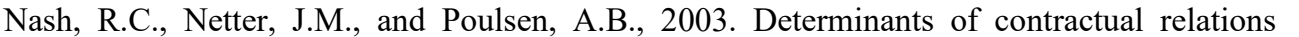

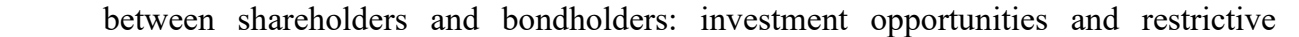

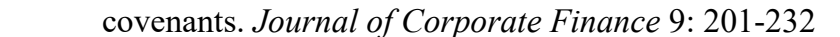

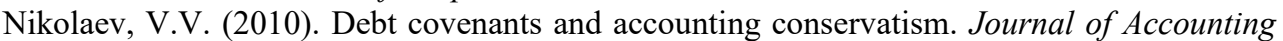

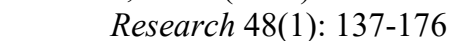

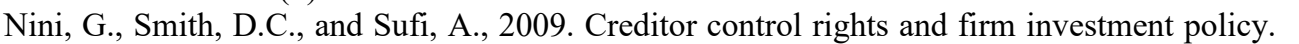

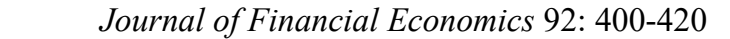

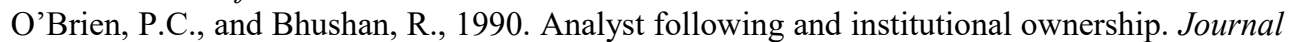

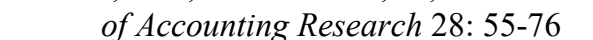

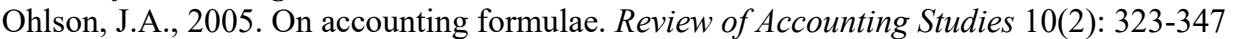

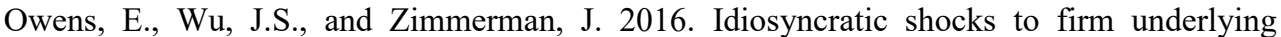

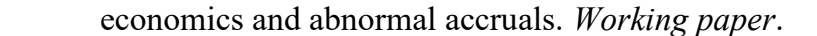

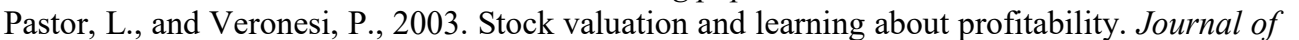

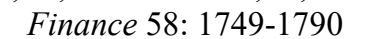

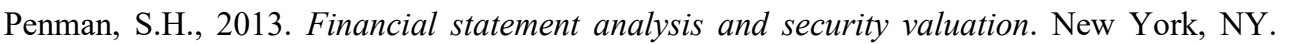

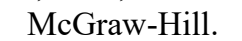

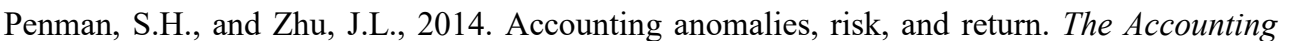

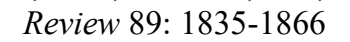




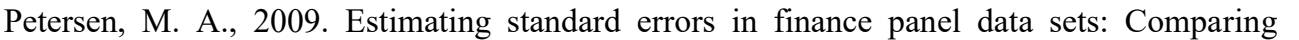

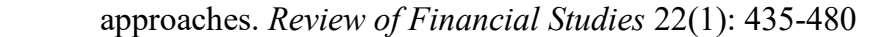

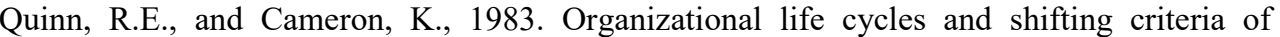

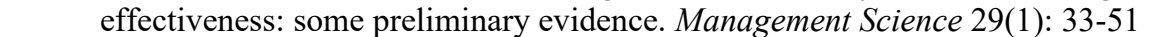

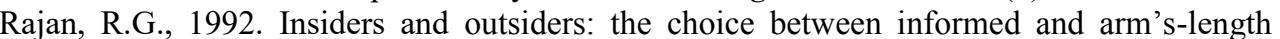

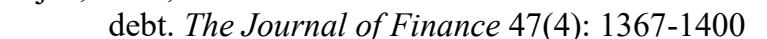

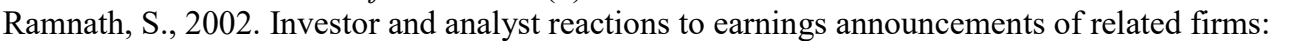

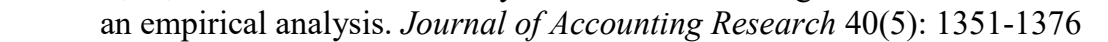

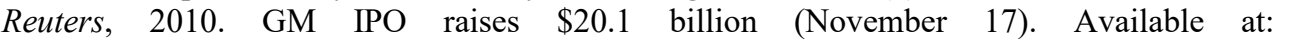

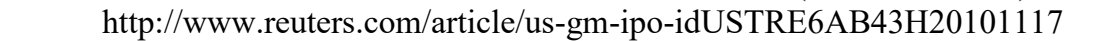

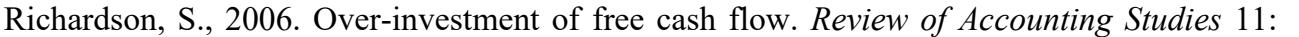

$\square \quad \square \square \square \square \square$

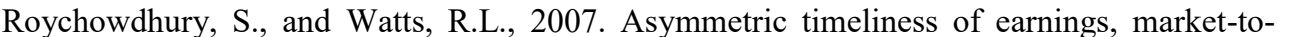

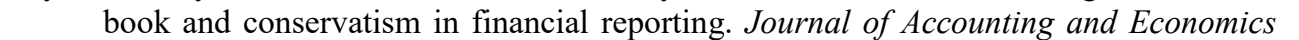

$\square \quad \square|\Pi| \Pi \mid \square$

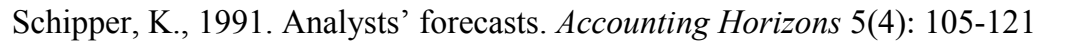

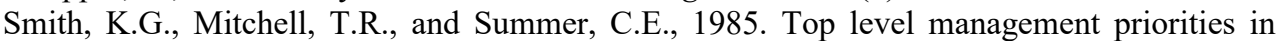

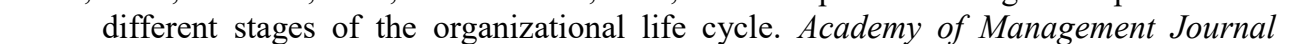

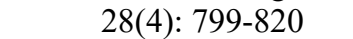

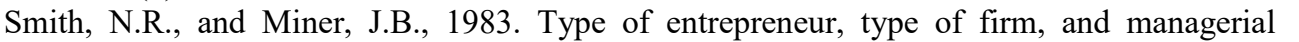

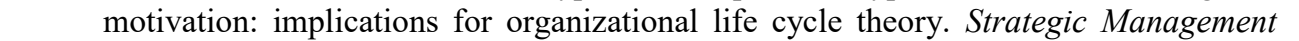

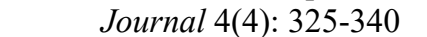

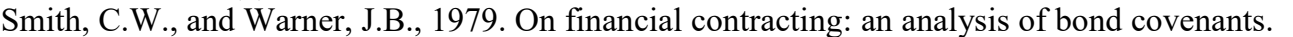

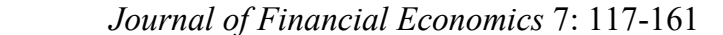

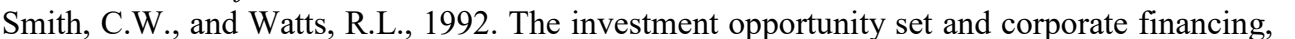

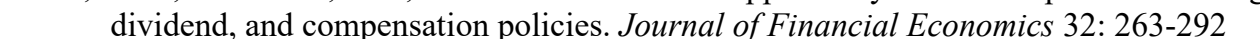

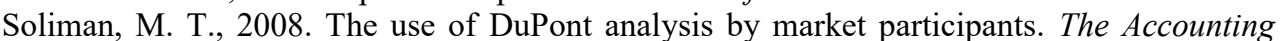

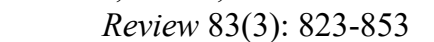

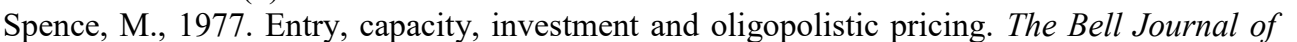

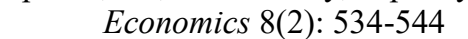

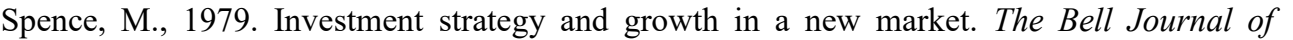

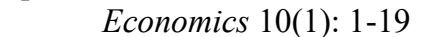

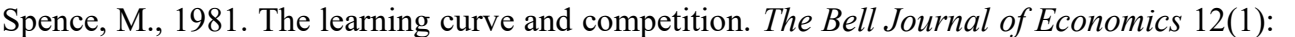

$\square \quad \square \square \square \square$

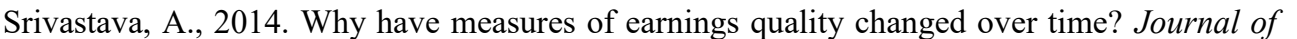

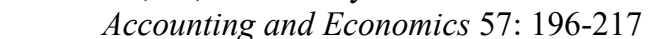

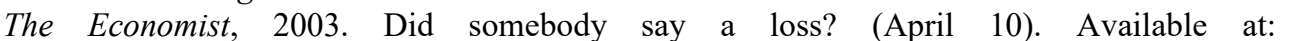

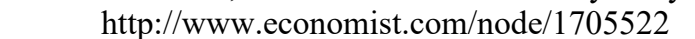

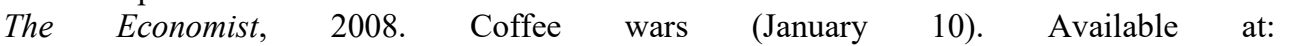

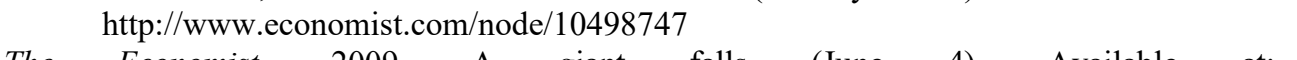

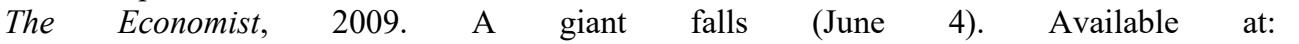

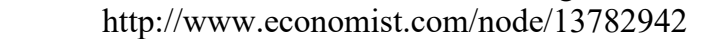

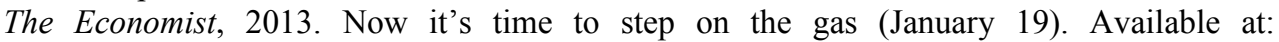

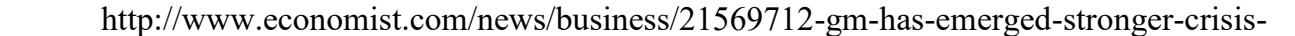

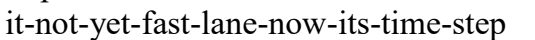

$\square \square\|\square \square\| \square \square$, 2015. All aboard the McDonald's rollercoaster (January 9). Available at:

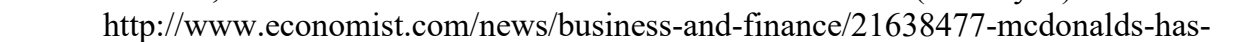

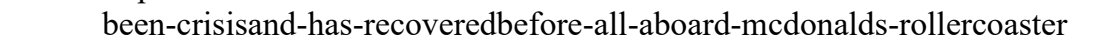

$\square$ 


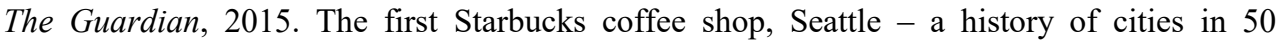

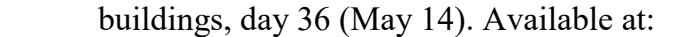

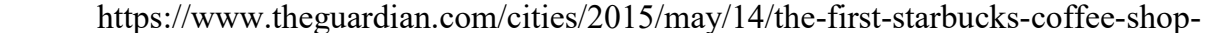

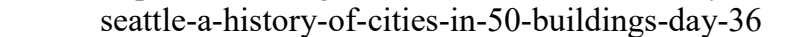

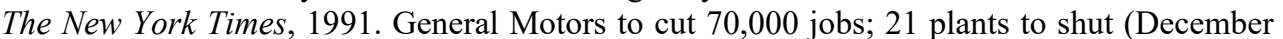

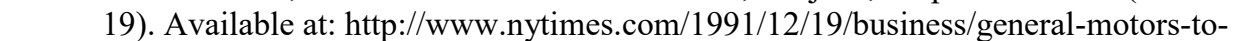

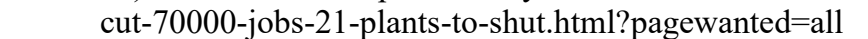

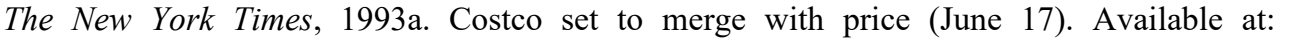

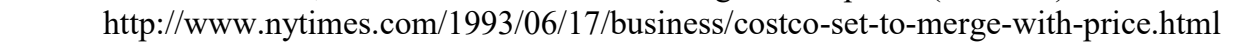

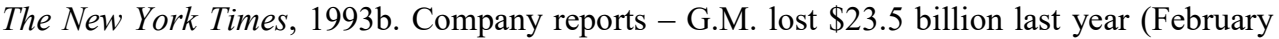

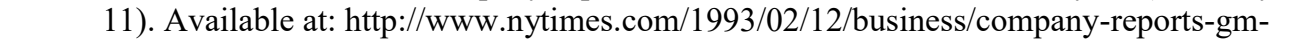

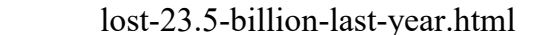

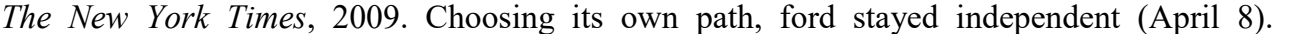

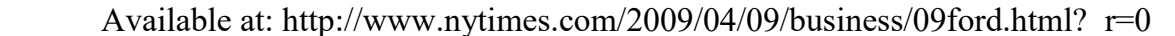

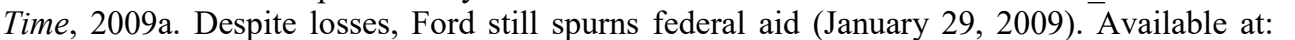

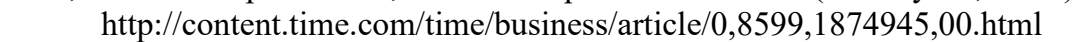

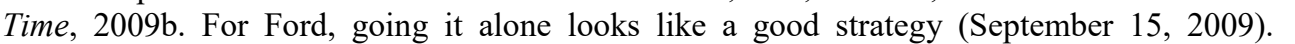

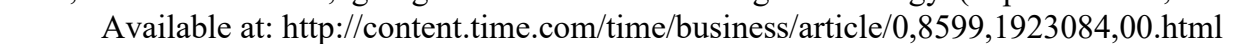

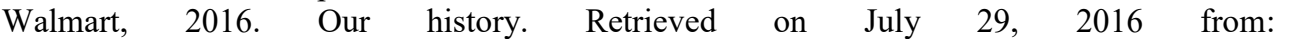

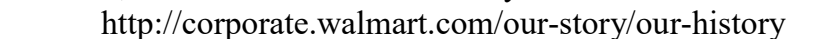

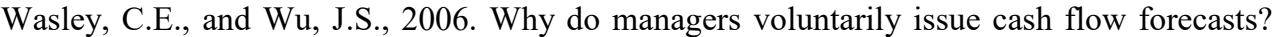

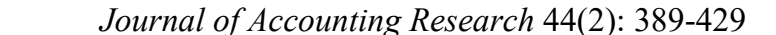

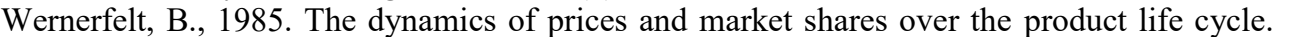

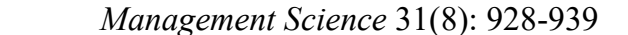

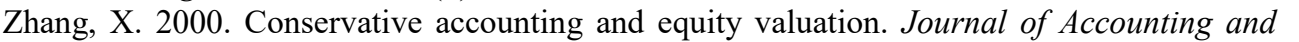

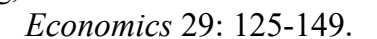

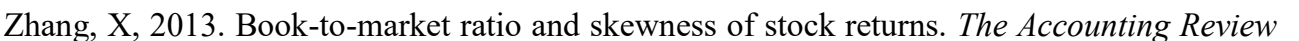

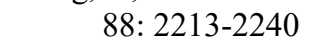

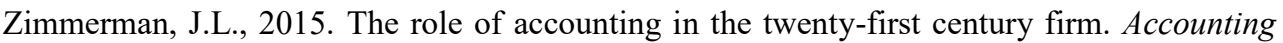

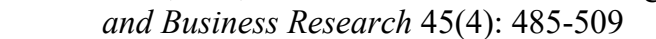




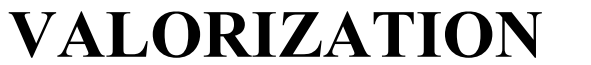

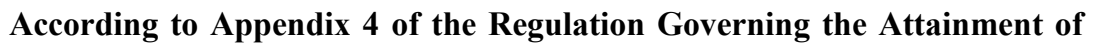

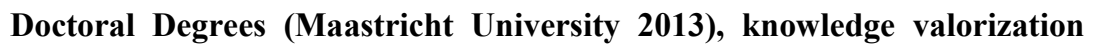
refers to the "process of creating value from knowledge, by making

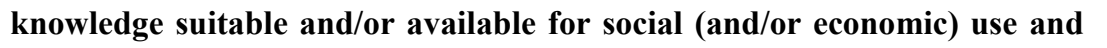

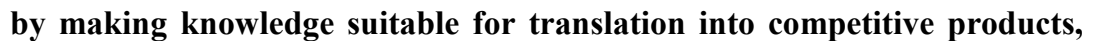
services, processes and new commercial activities" (adapted definition

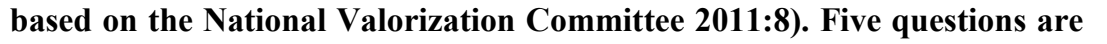

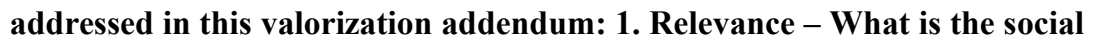

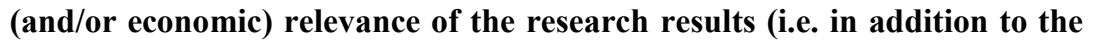

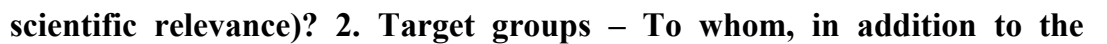

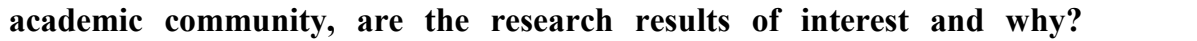

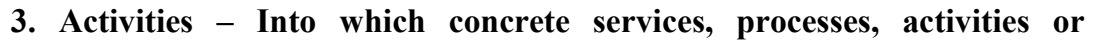

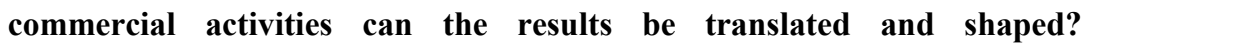

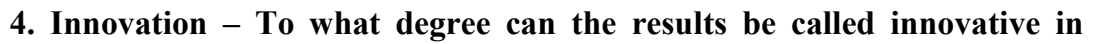

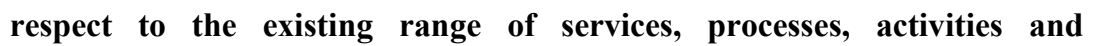

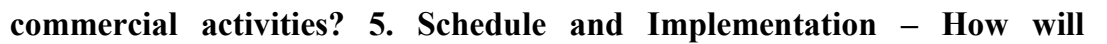

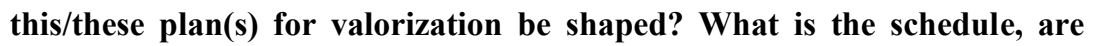

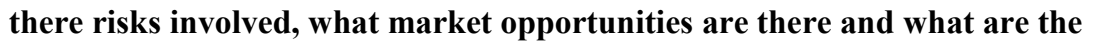

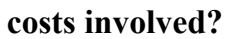

\section{$\square$}

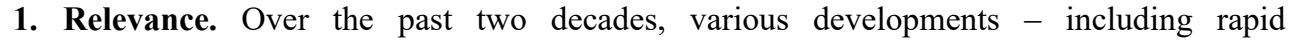

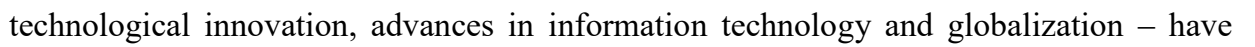

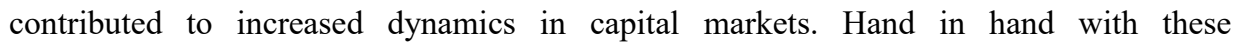

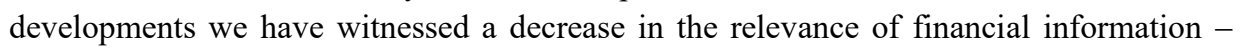

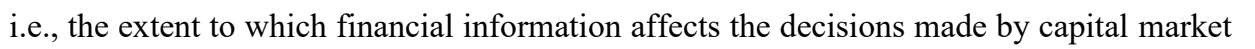

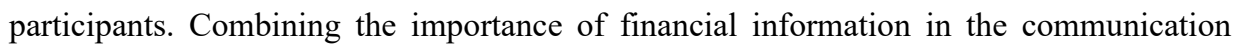

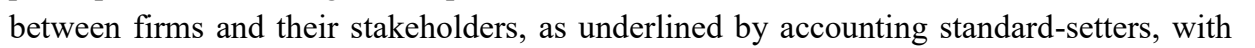

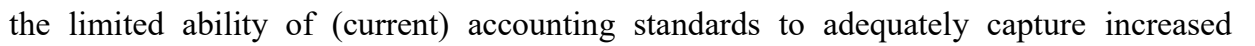

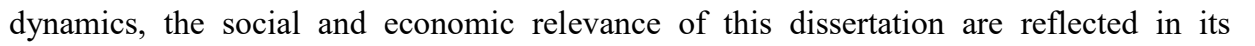

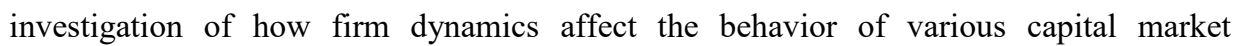

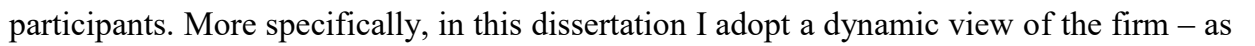

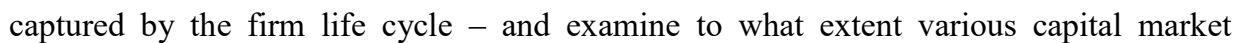
participants incorporate and understand a firm's evolvement over time. Making capital

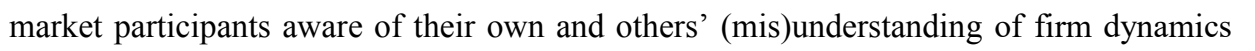

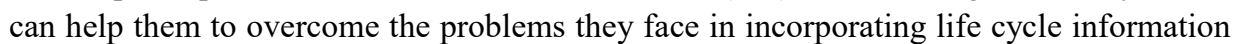

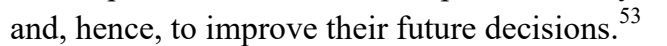

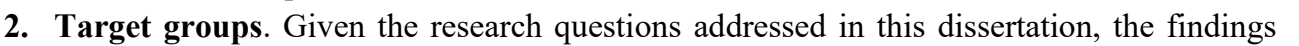

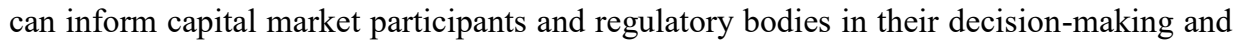

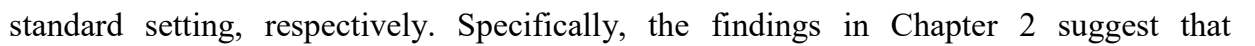

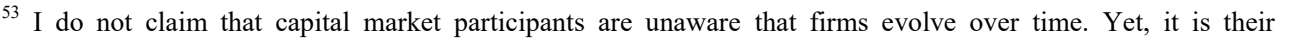

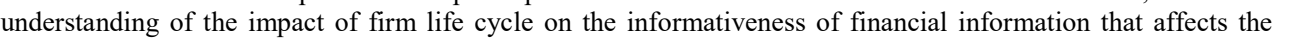

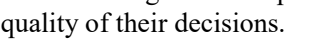


investors' limited understanding of firm life cycle can lead to substantial welfare losses as

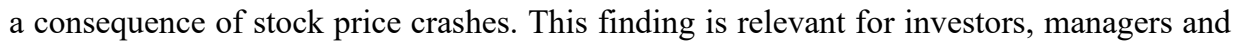

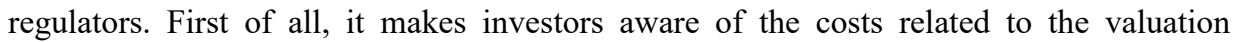

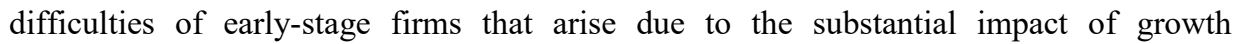

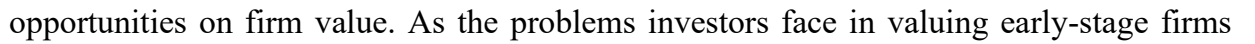

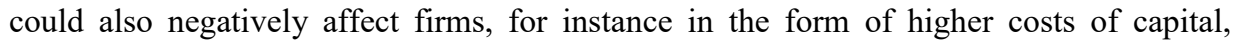

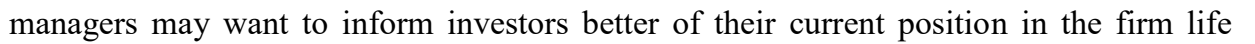

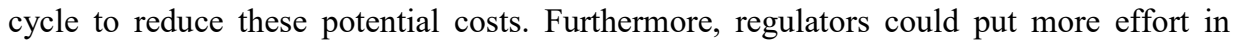
(further) increasing investors' awareness of the limitations of current accounting standards

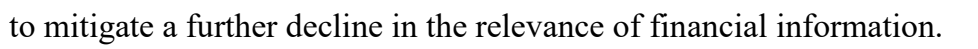

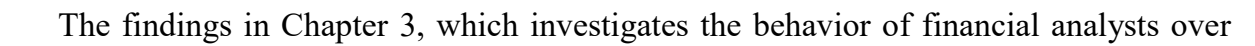

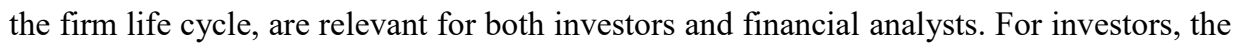

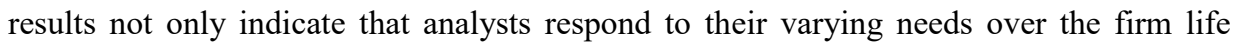

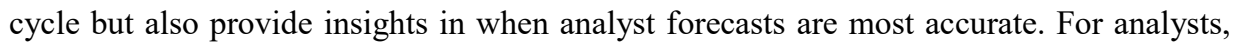

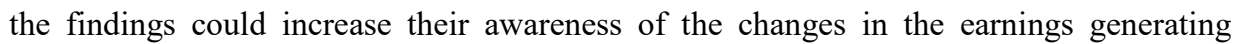

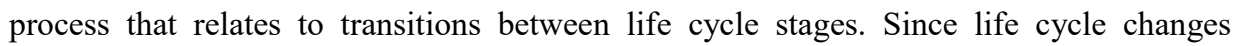

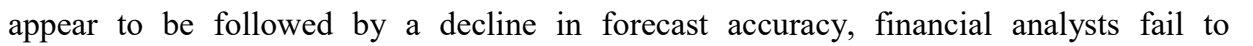

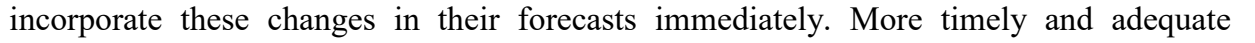
एण

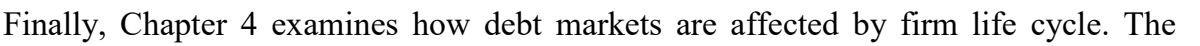

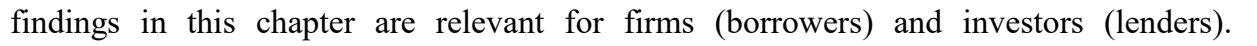

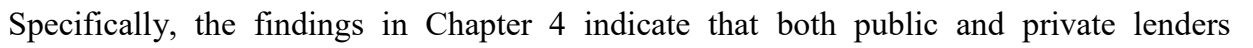
ए।

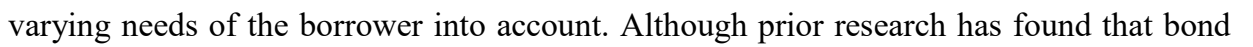

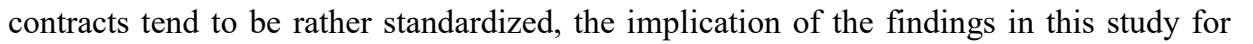

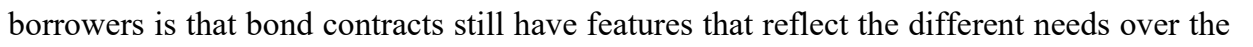

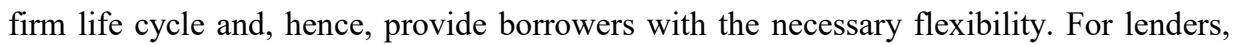
एवा

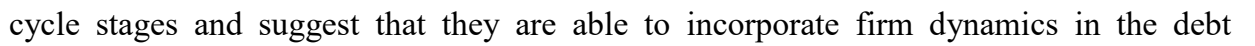

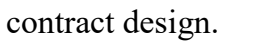

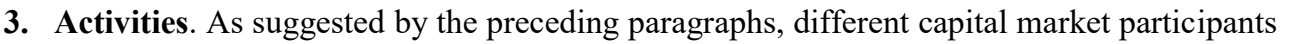

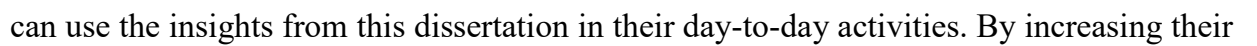

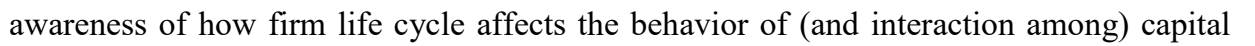

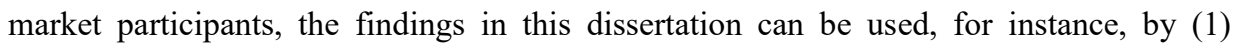

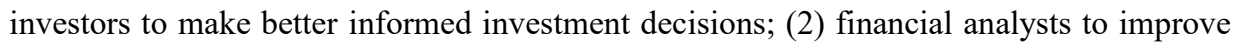

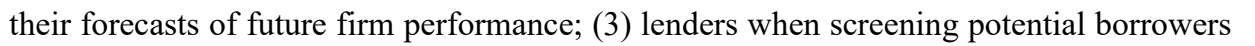

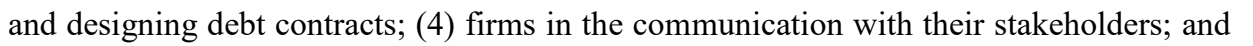

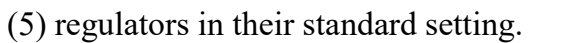

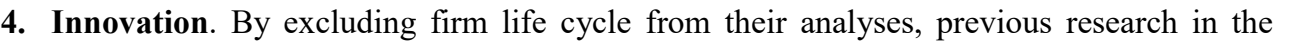

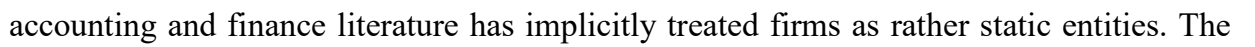
increased dynamics in capital markets and firms' business models, however, require the $\square$

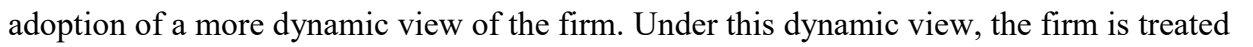

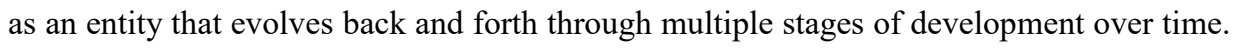

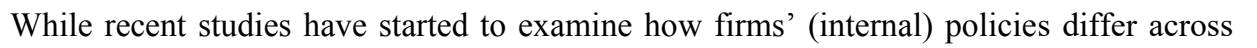


एव

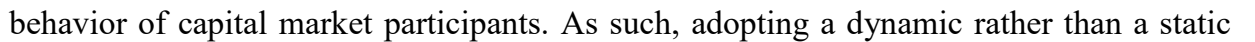

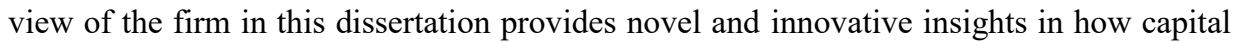

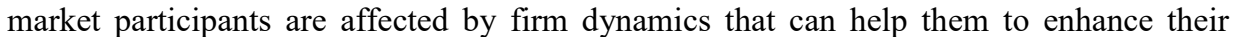

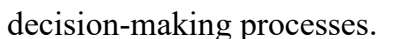

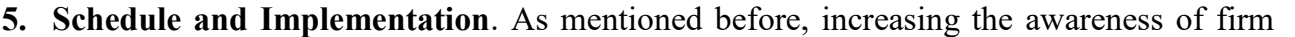

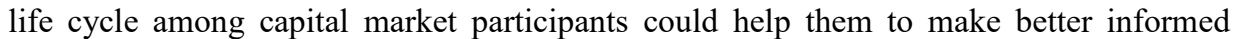

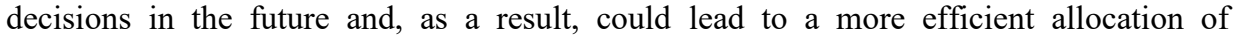

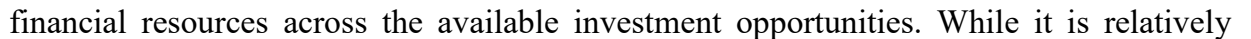
easy to derive a firm's current life cycle stage from publicly available financial statements

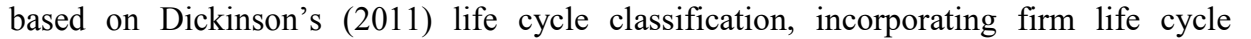
पाए।

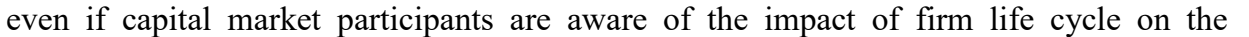

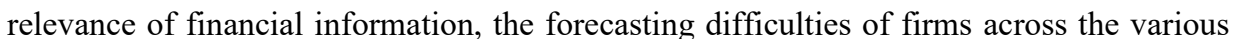

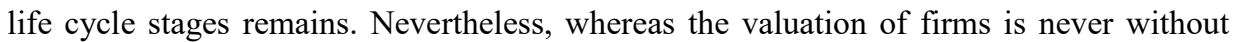

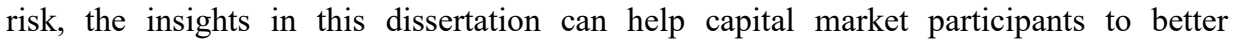
ए।

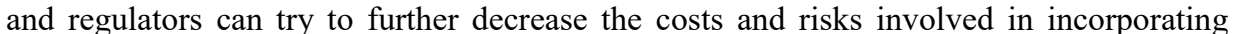
firm life cycle information by providing or requiring more information on firms' expected $\square \| \backslash$ opment (conditional on their life cycle stage). Yet, despite the managers' superior

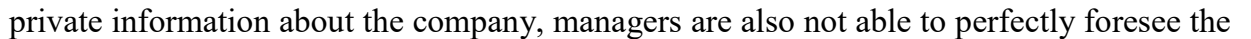

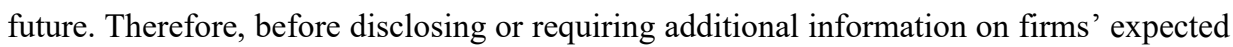

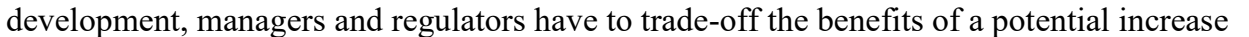

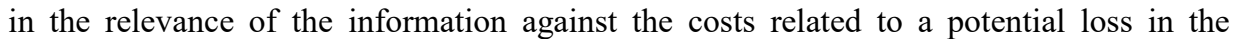
प

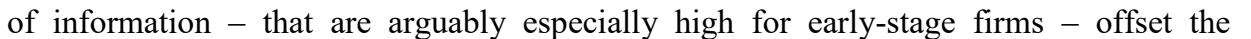

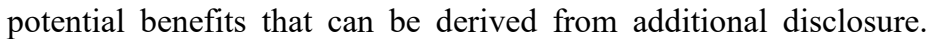




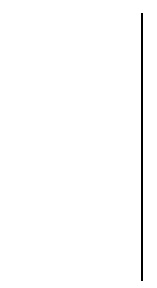

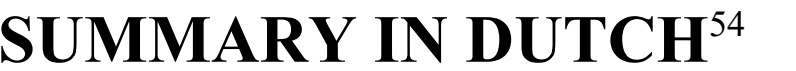

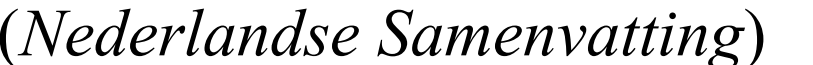

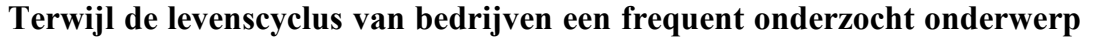

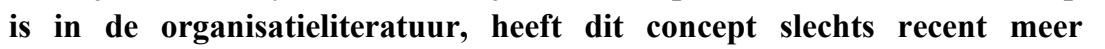

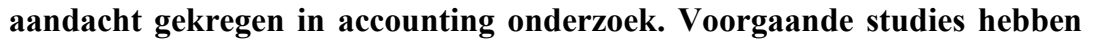

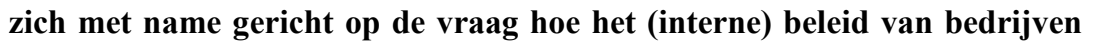

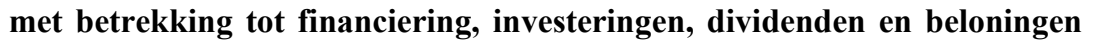

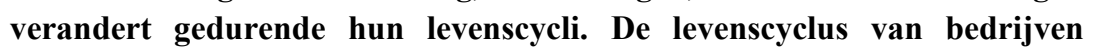

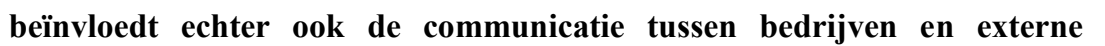

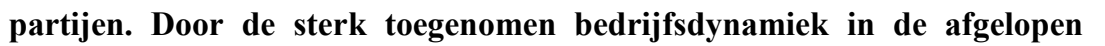

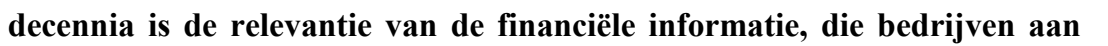

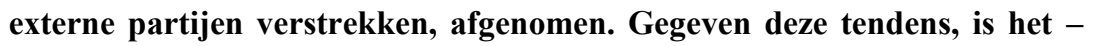

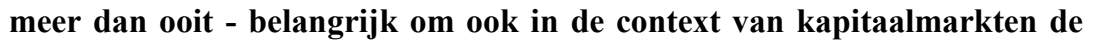

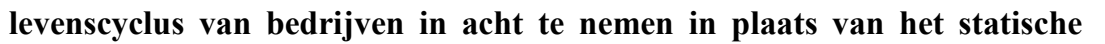

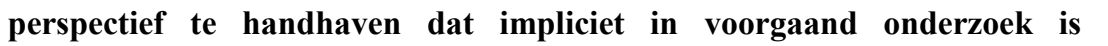

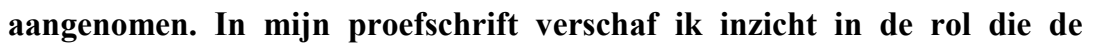

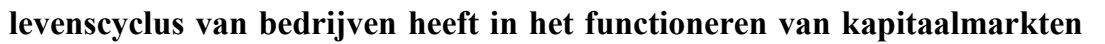

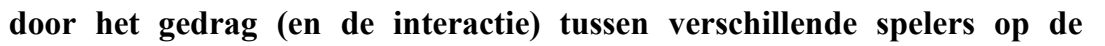

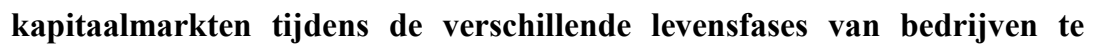

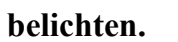

$\square$

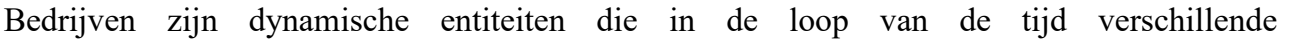

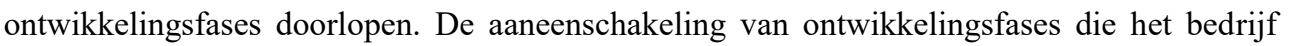

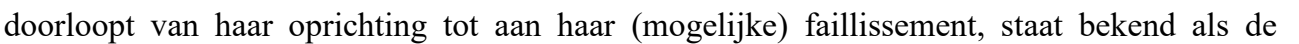

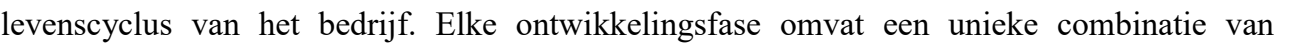

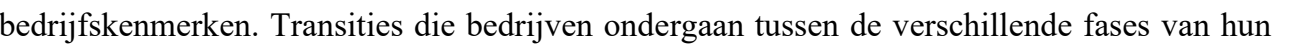

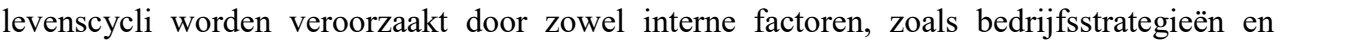

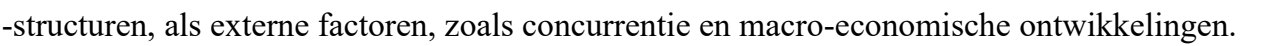

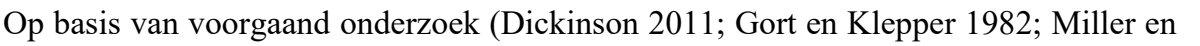

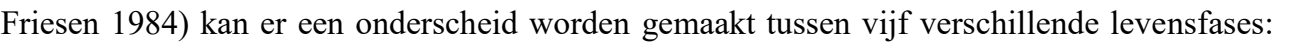

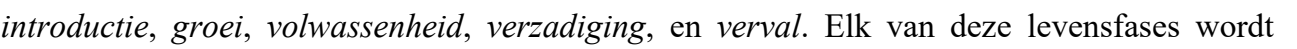

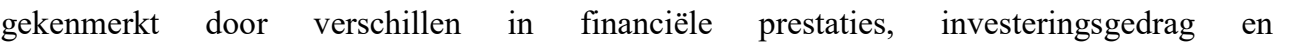

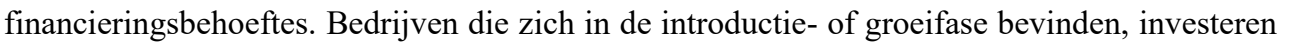

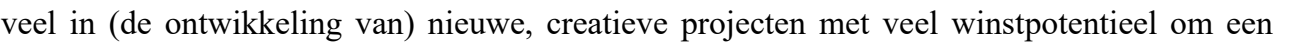

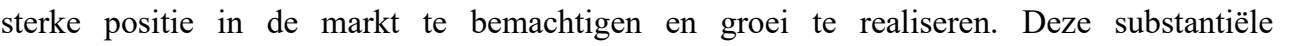

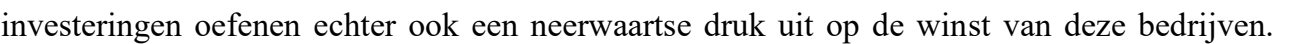

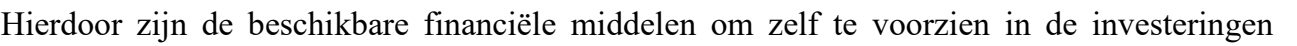

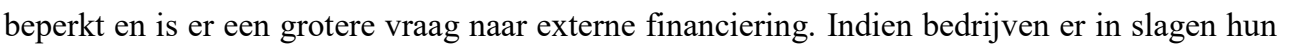

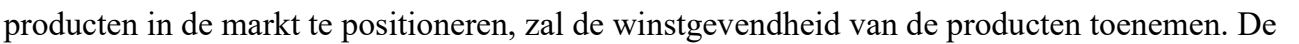

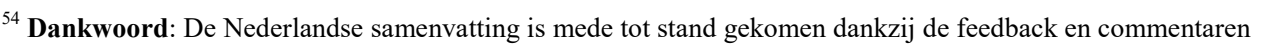

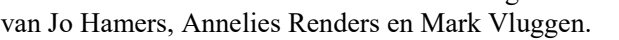




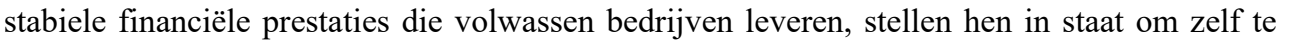

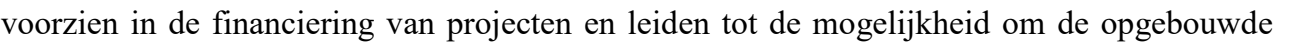

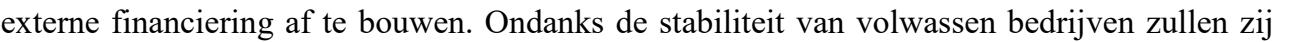

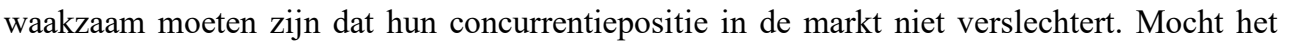

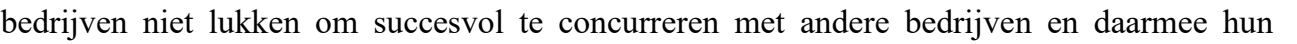

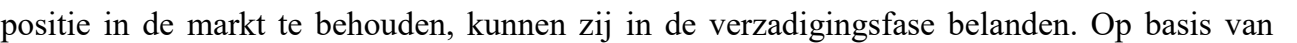

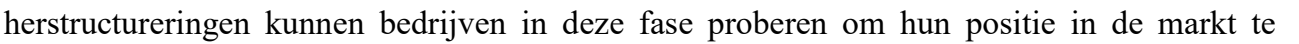

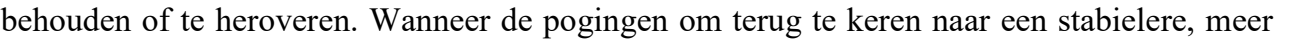

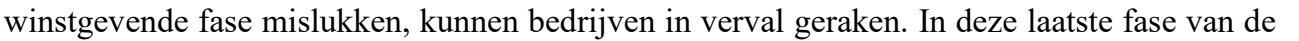

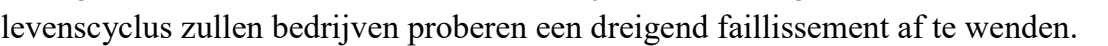

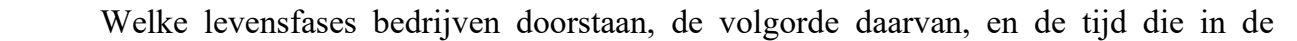

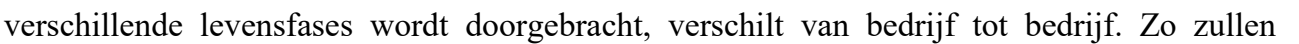

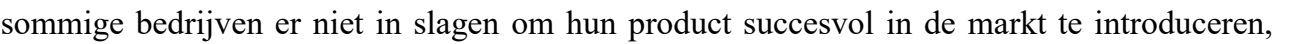

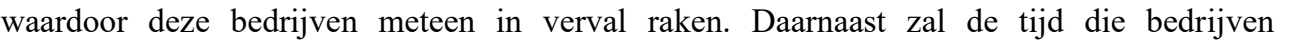

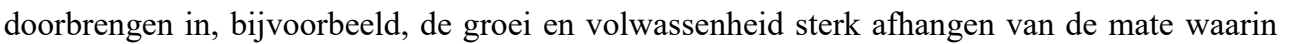

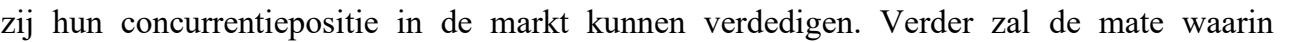

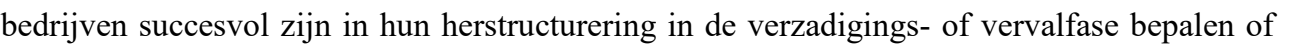

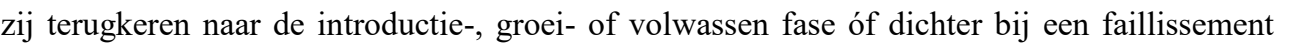
प

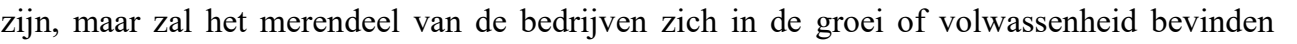

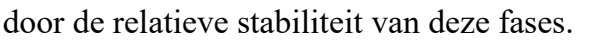

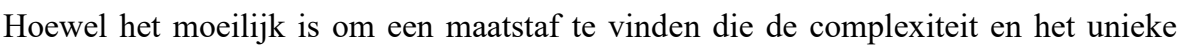

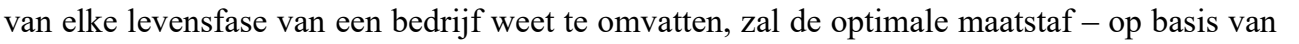

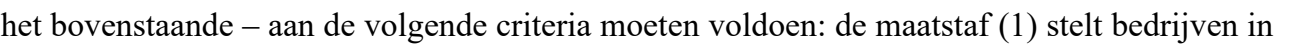

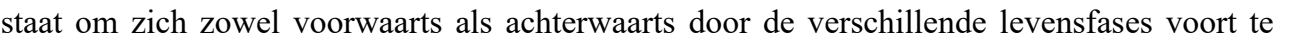

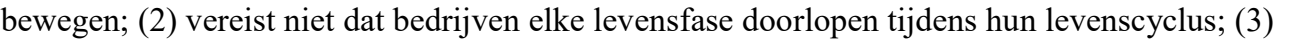

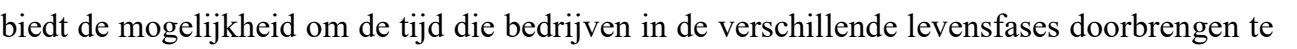

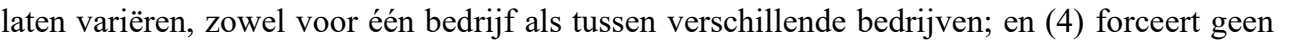

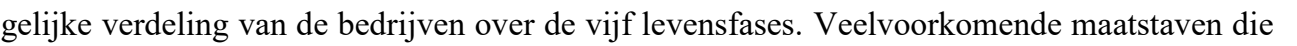
ए एव

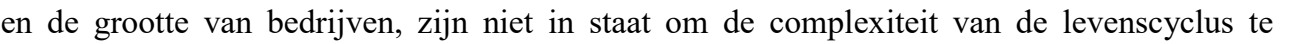

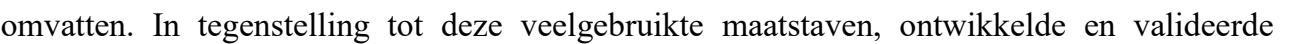

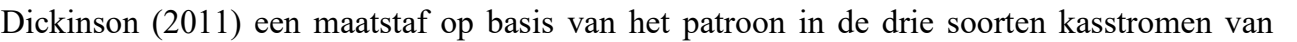

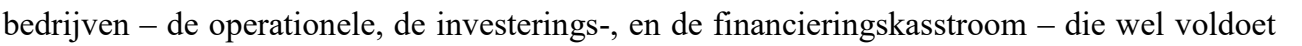

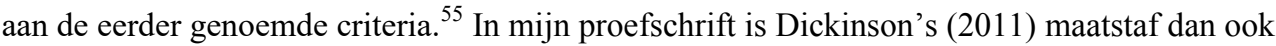

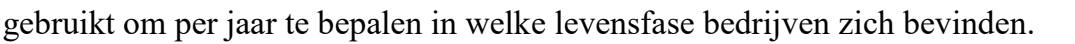

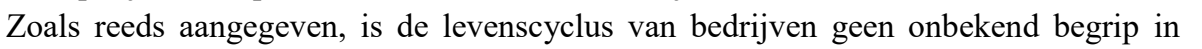

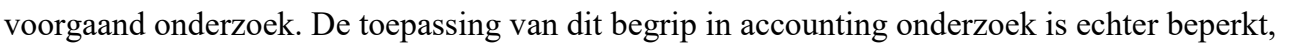

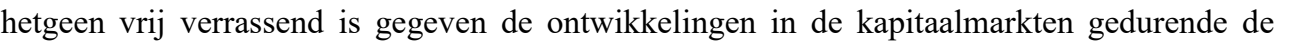

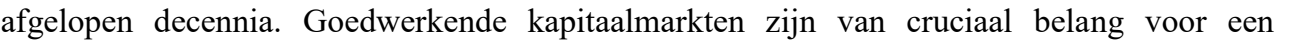

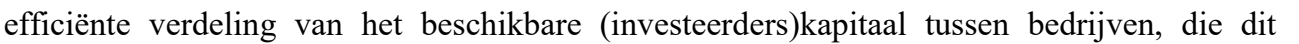

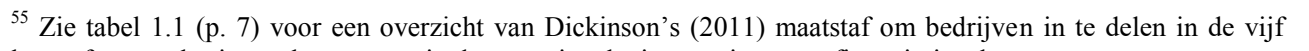

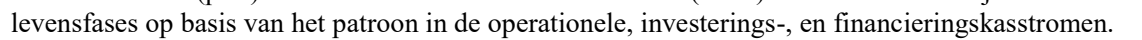




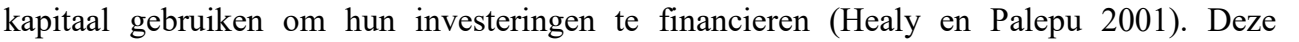

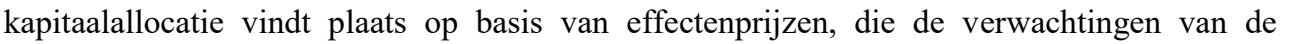

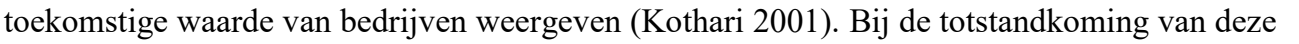

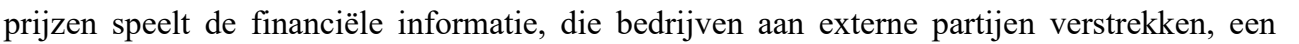

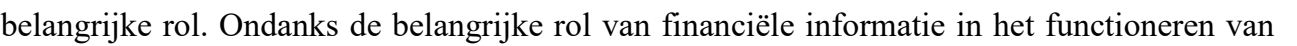

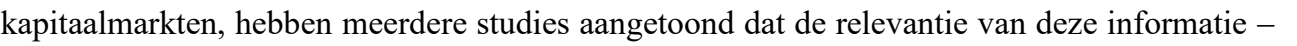

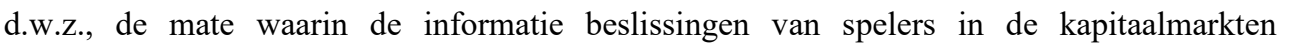
पाயमाप-

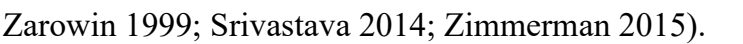

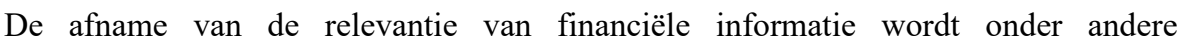

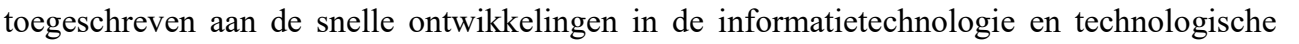

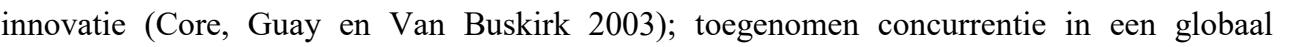

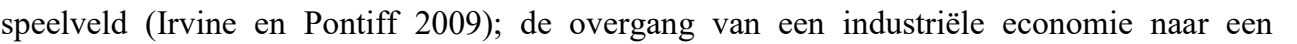

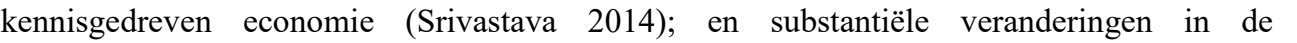

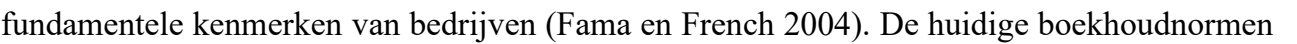

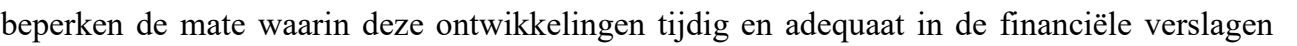

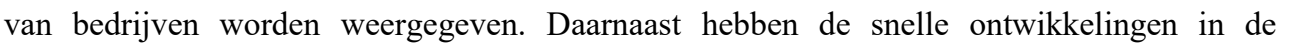

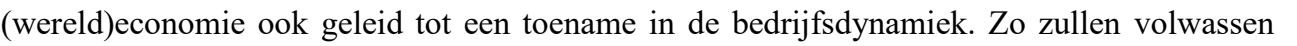

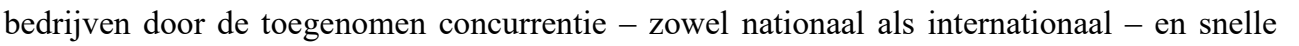

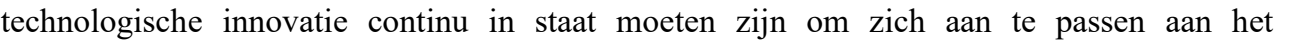

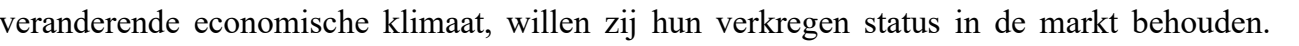

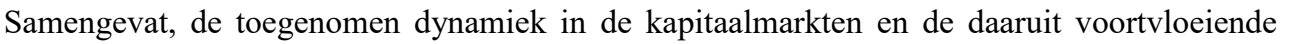

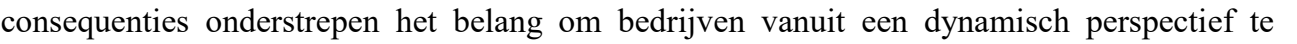

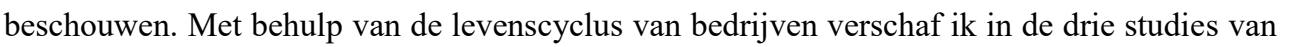

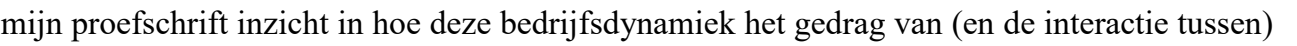

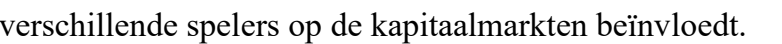

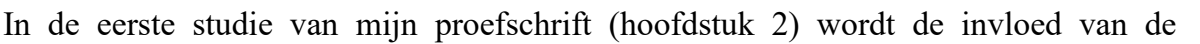

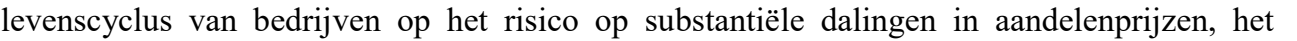

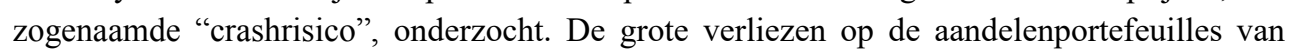

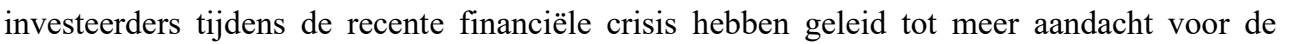

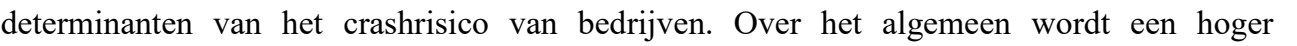

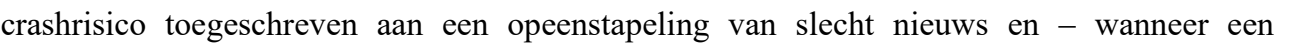

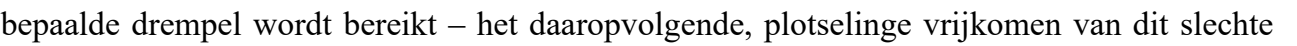

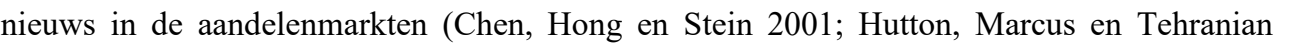

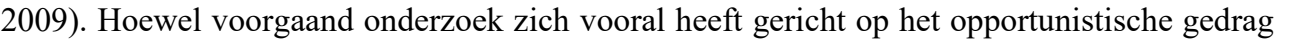

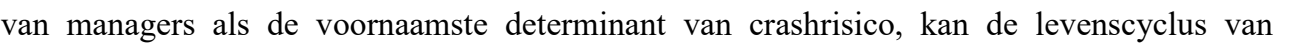

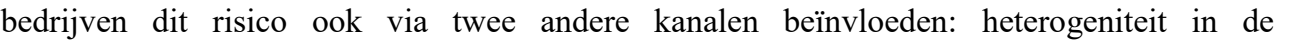

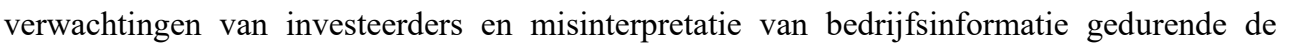

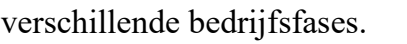

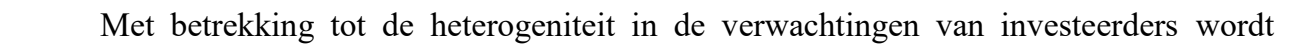

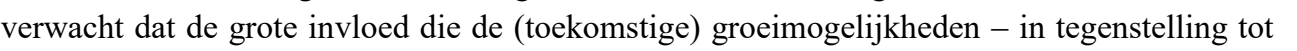

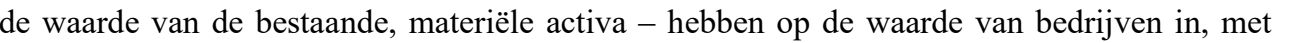

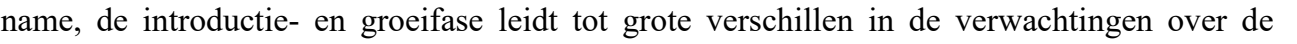

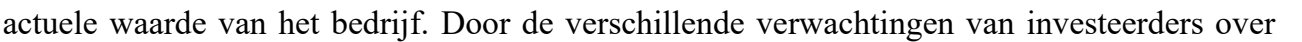




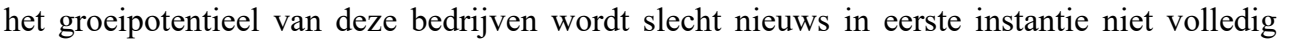

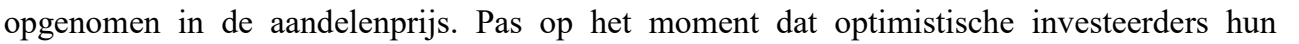

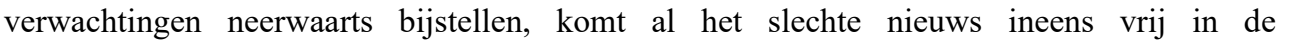

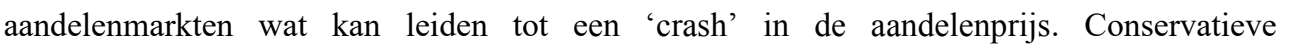

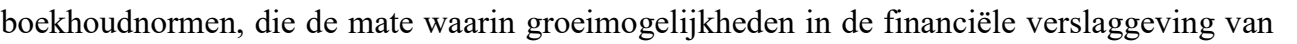

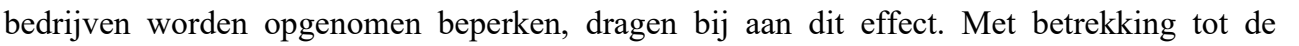

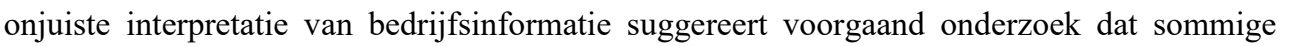

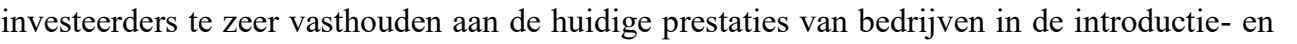

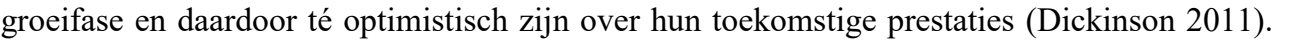

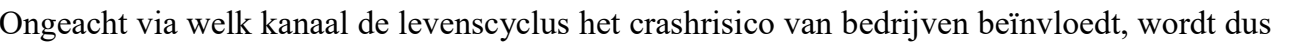

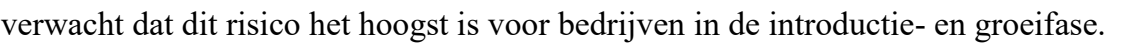

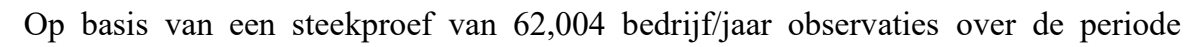

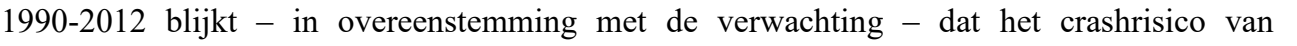

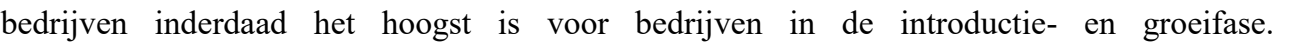

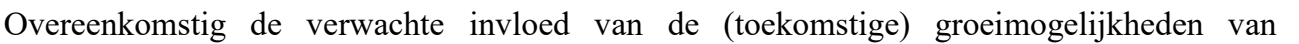

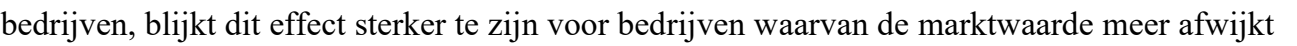

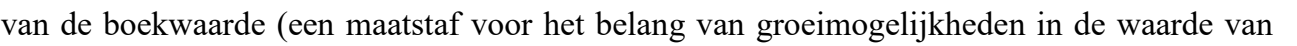

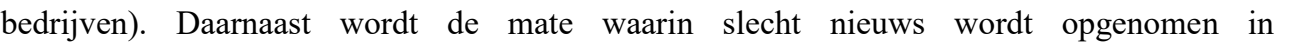

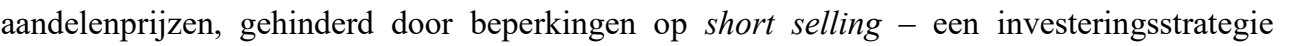

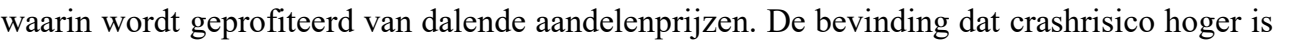

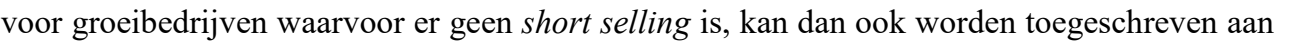

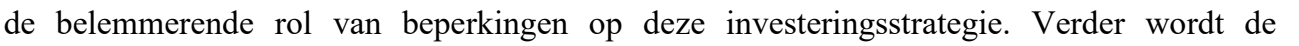

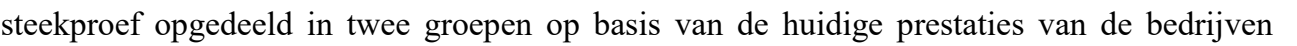

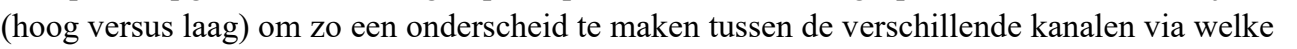

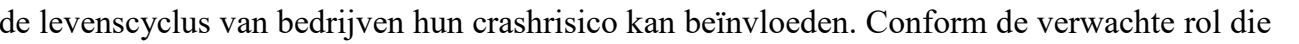

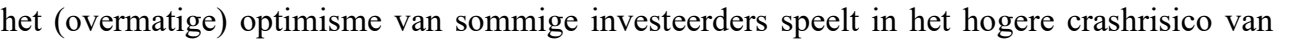

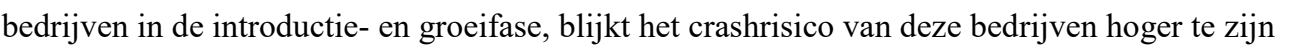

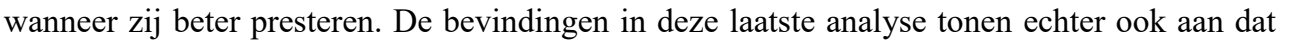

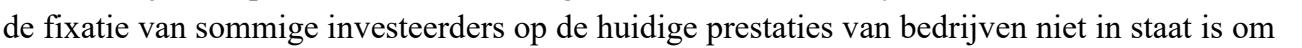

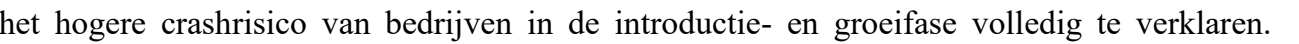

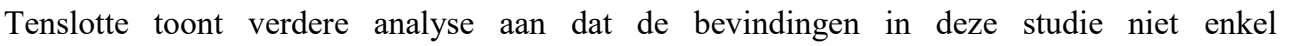

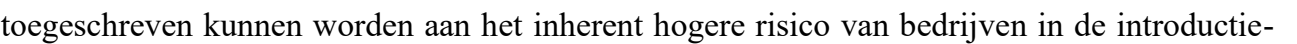

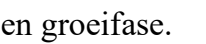

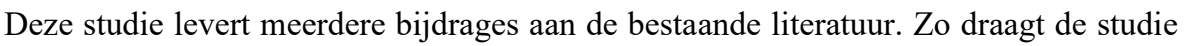

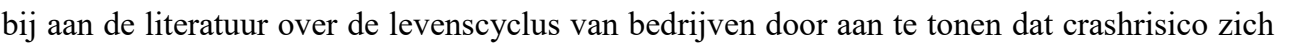

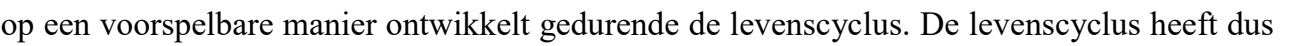

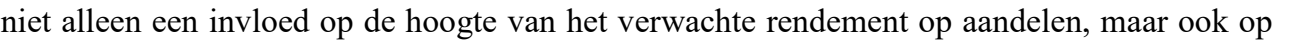

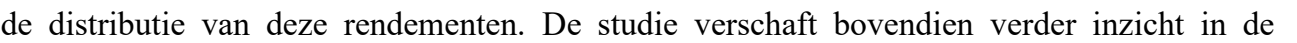

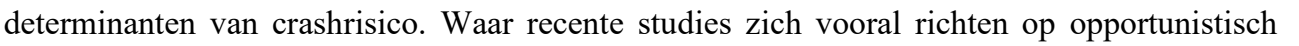

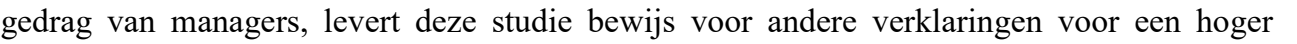

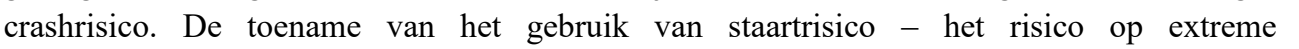

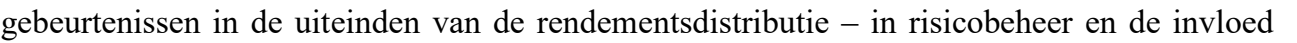

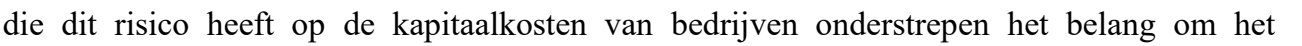




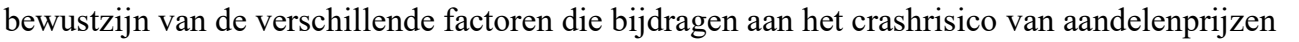
एणाणाणामा

ய

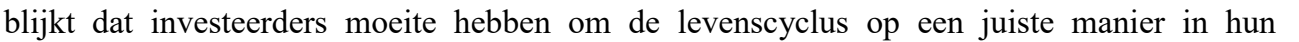

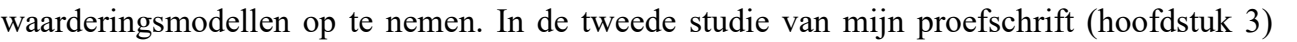

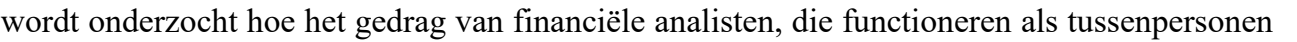

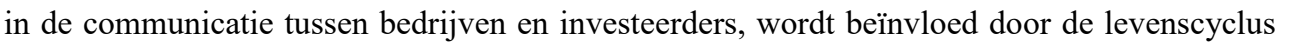

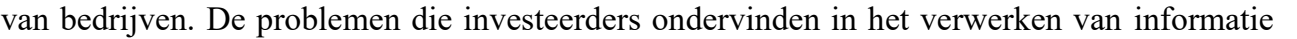

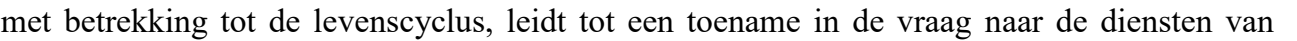

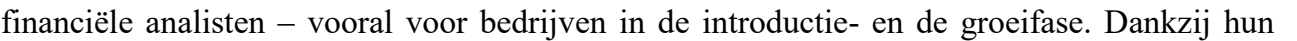

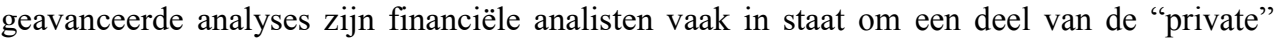

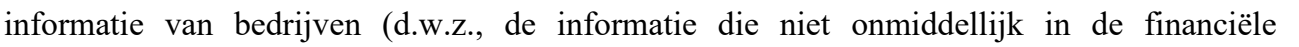

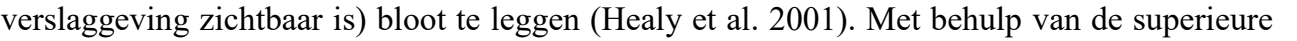

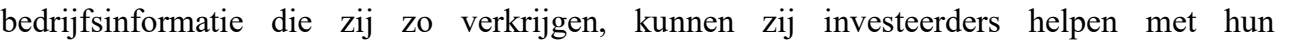

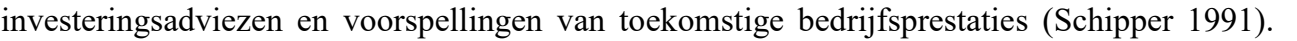

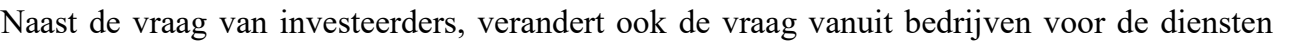

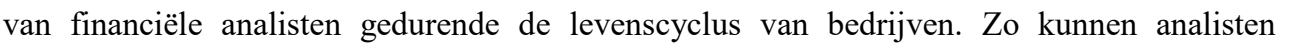

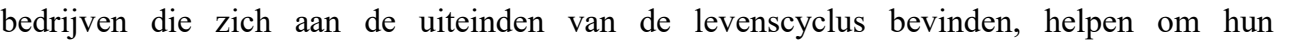

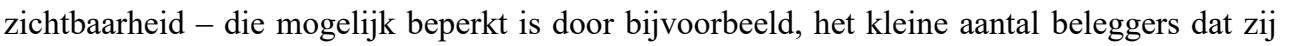

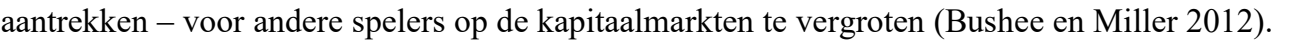

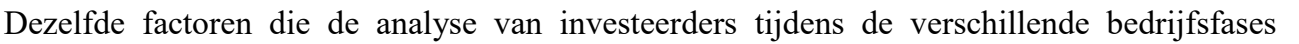

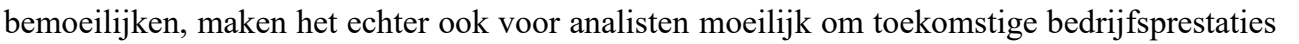

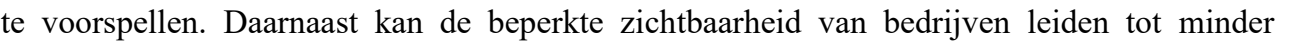

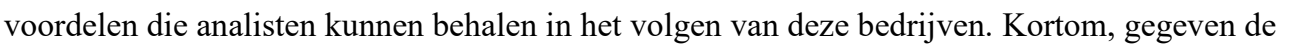

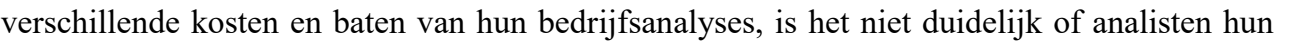

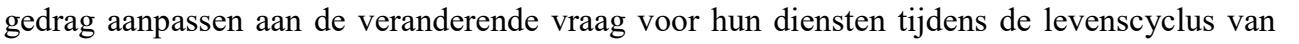

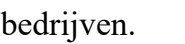

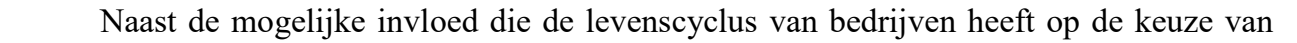

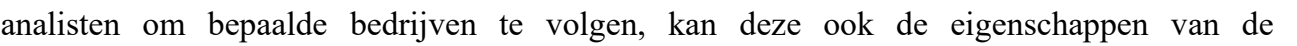

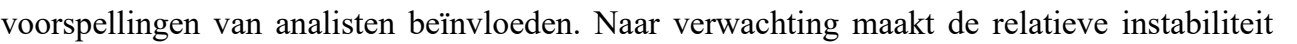
पाए।

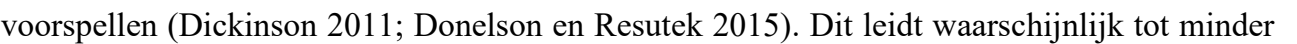

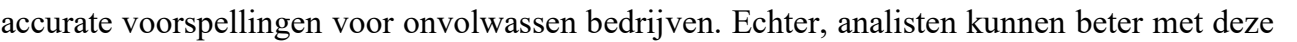

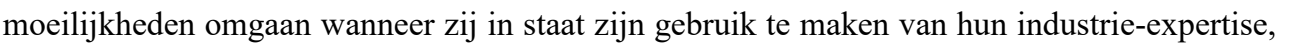

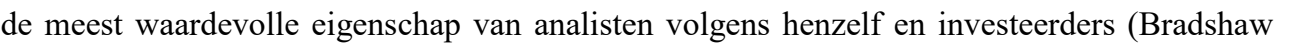

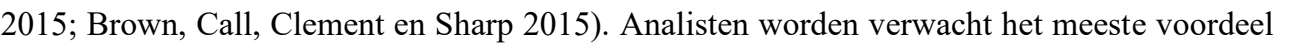

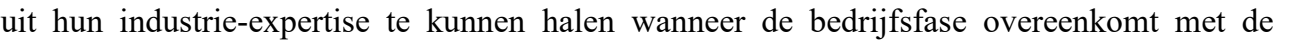

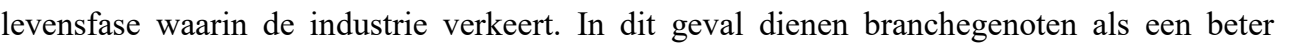

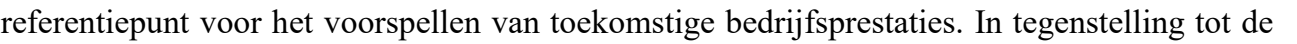

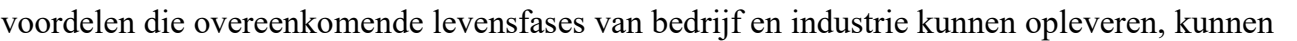

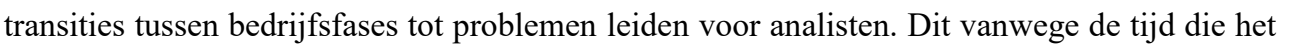

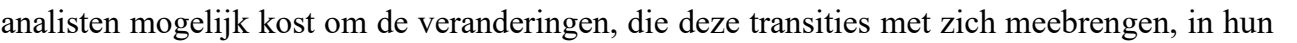

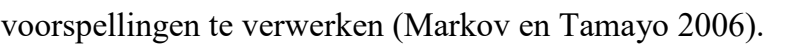




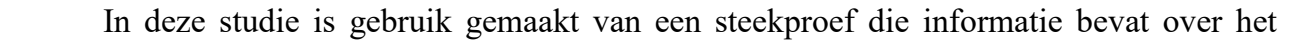

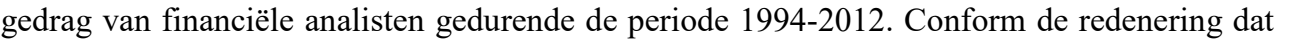

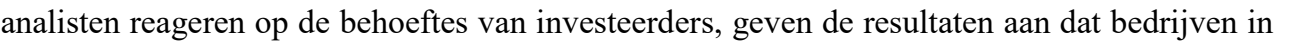

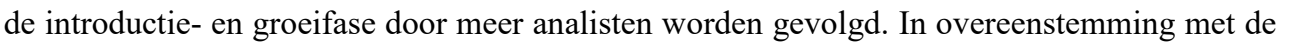

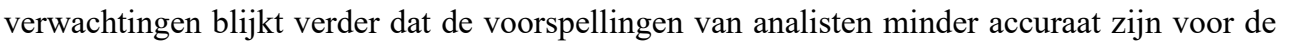

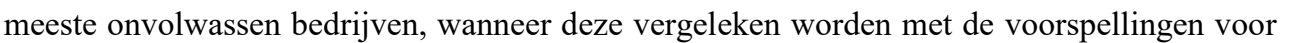
प

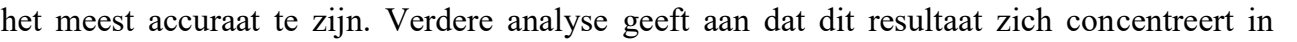

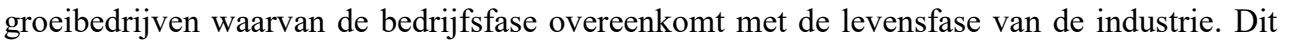

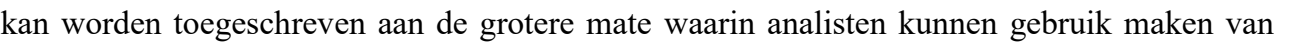

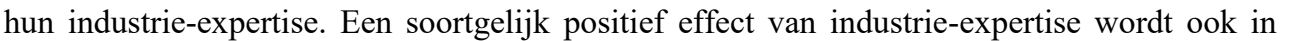

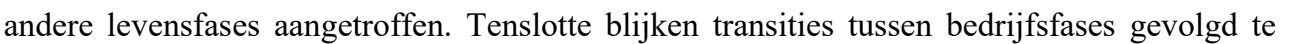

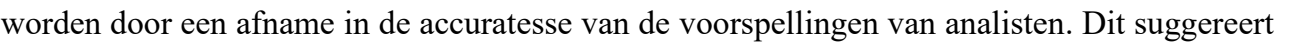

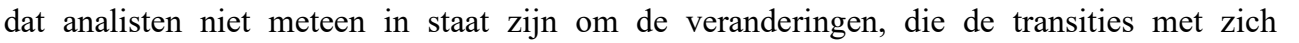

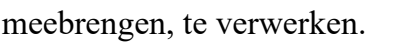

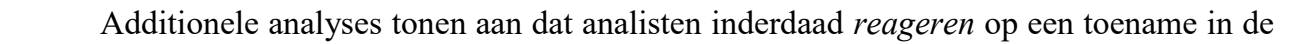

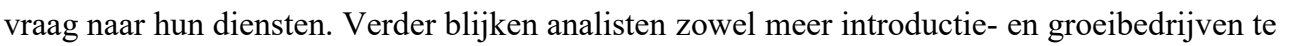

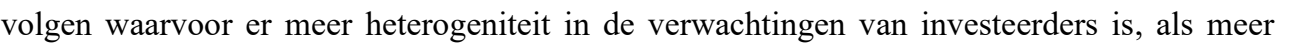

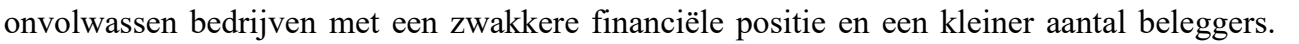

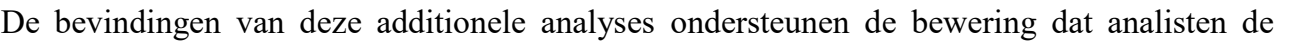

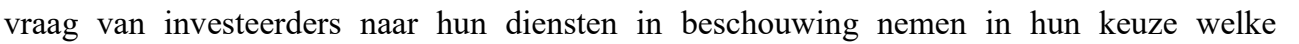

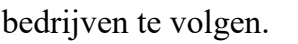

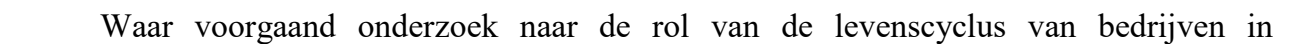

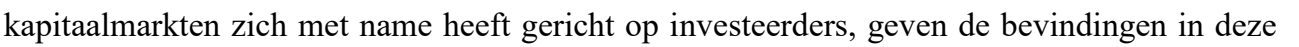

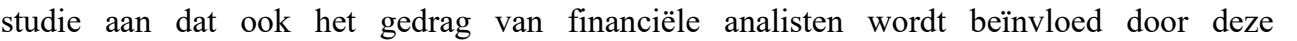

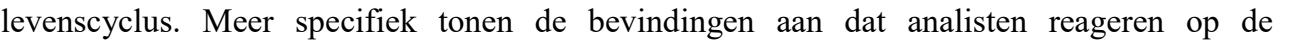

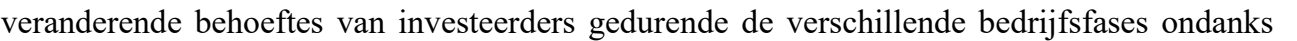

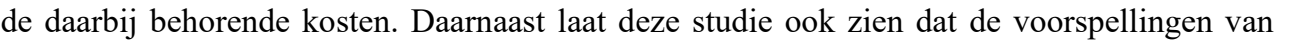

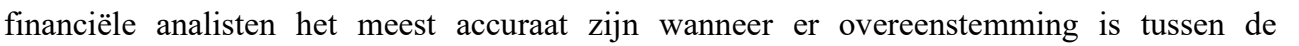

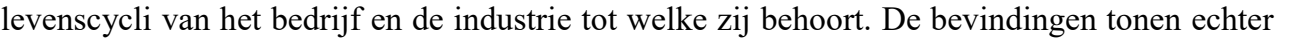

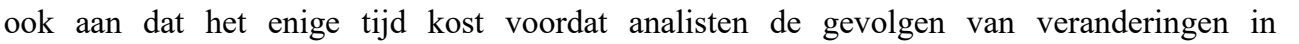

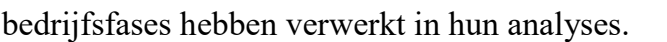

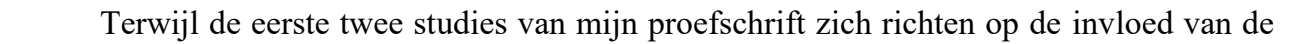

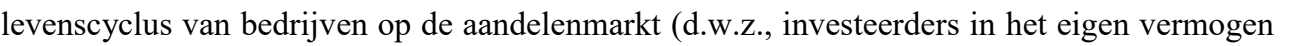

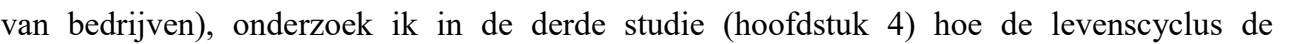

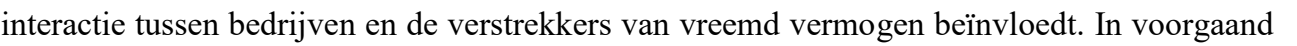

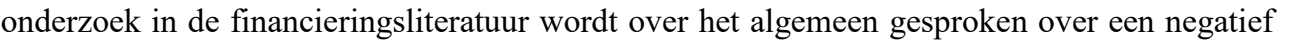

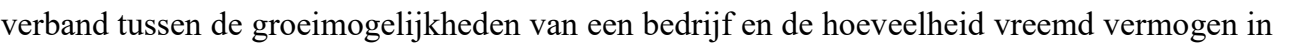

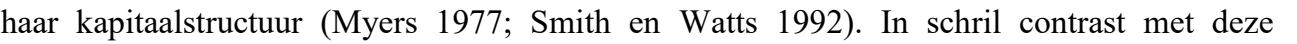

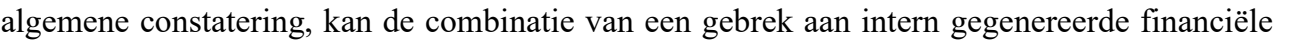

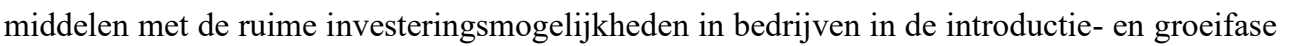

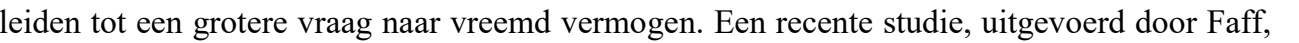

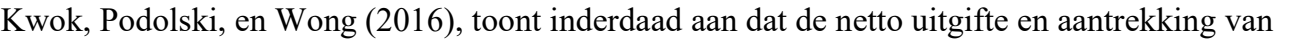

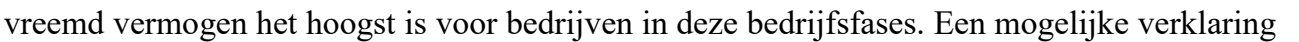




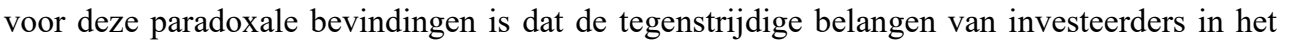

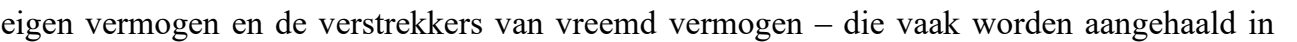

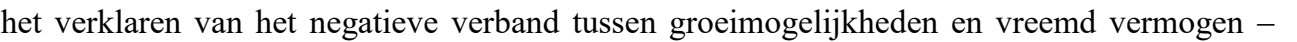

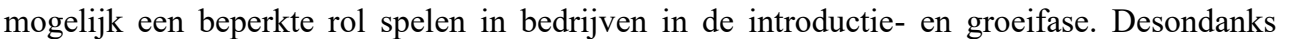

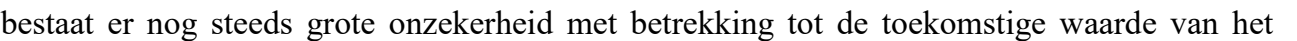

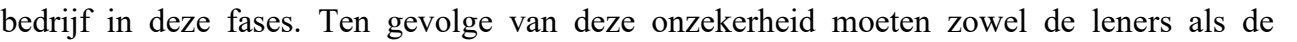

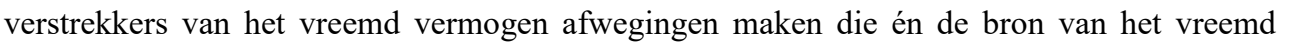

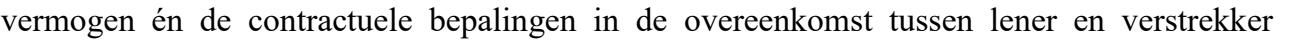
पाणाणाएा

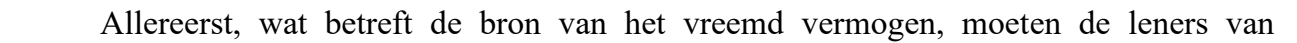

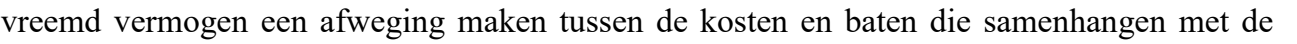

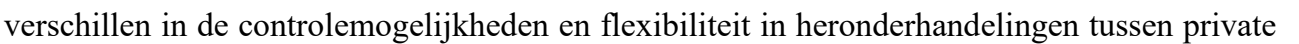

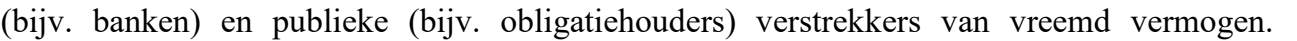

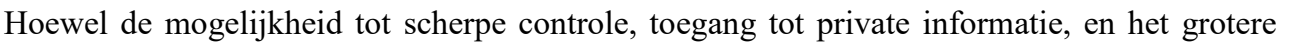

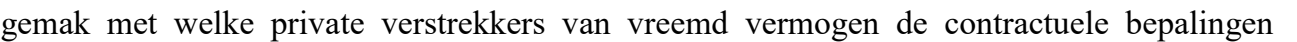

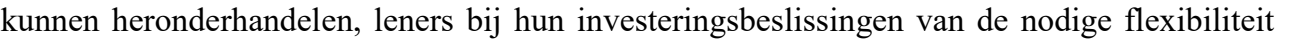

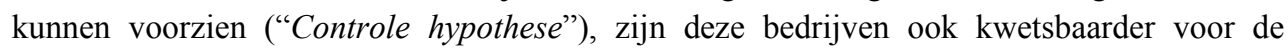

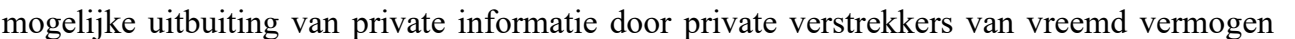

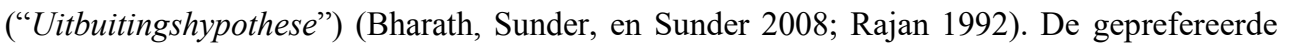

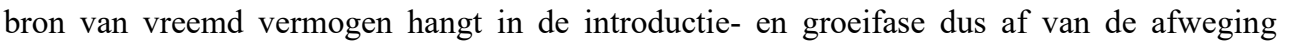

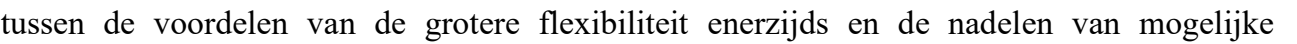

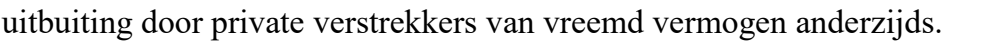

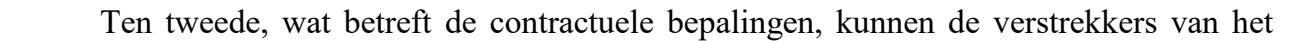

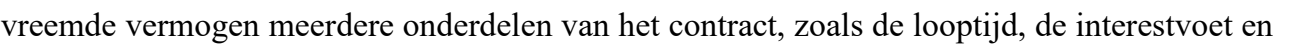

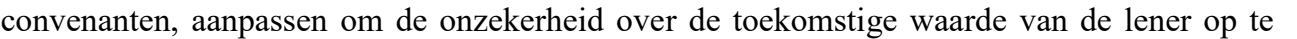

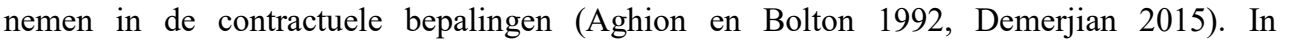

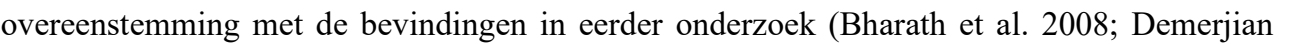

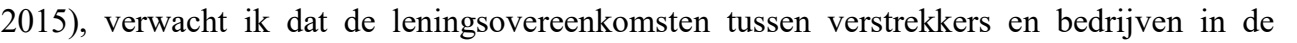

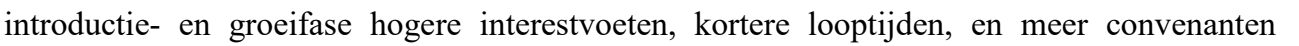

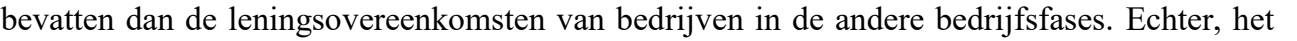

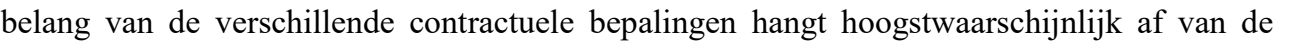

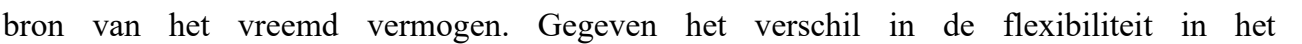

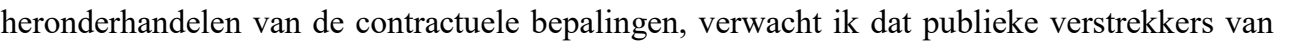

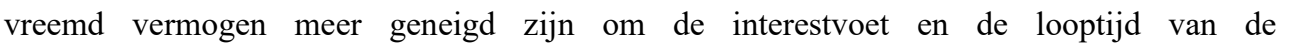

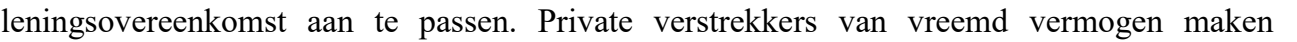

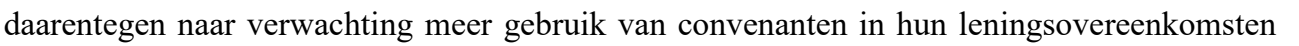

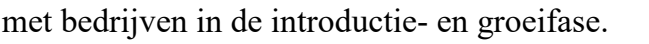

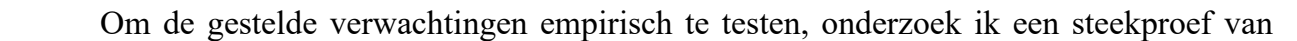

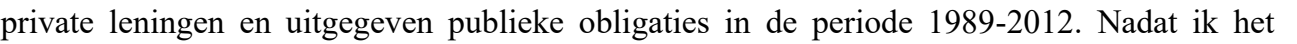

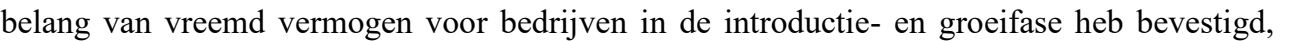

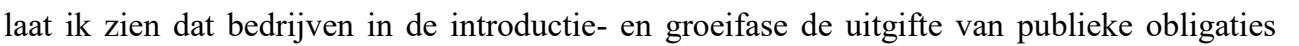

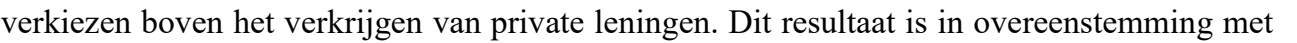

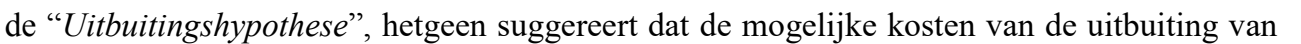

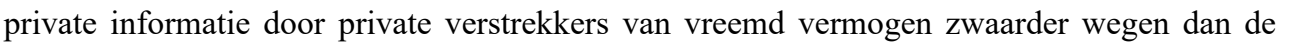




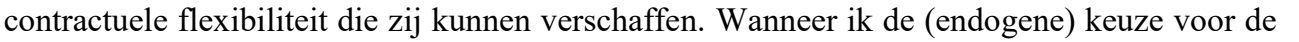

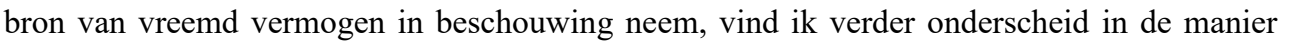

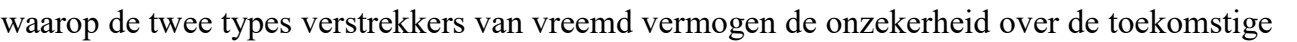

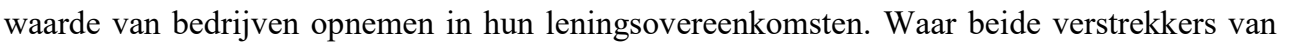

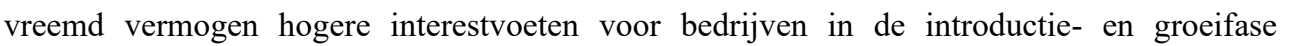

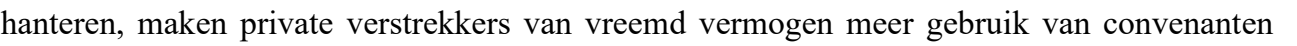

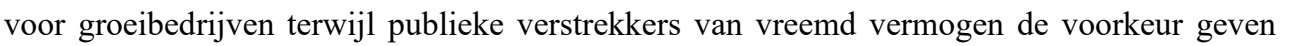

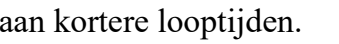

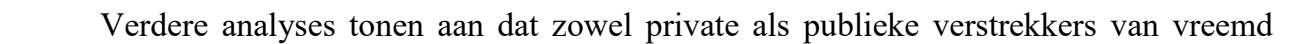

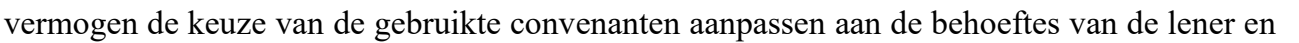

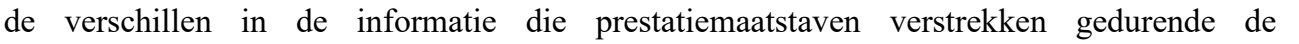

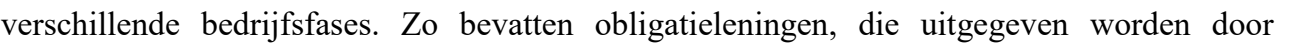

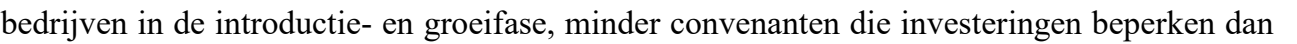

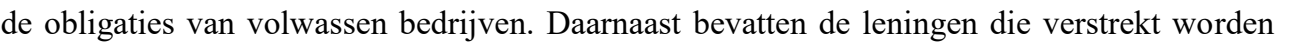

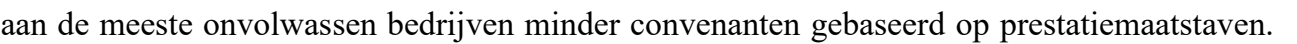

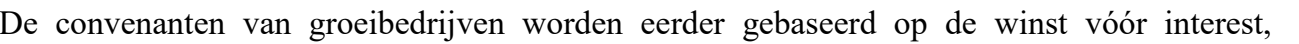

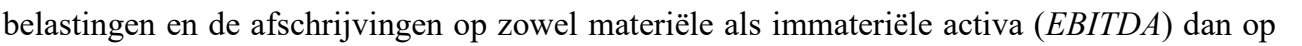

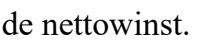

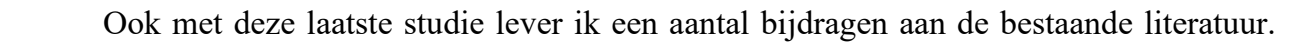

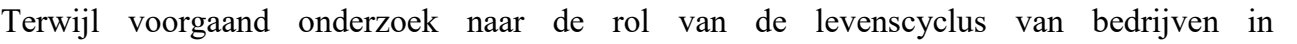

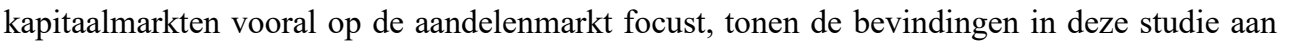

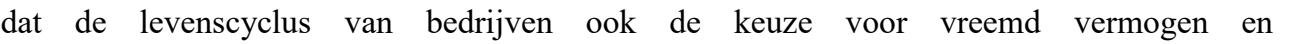

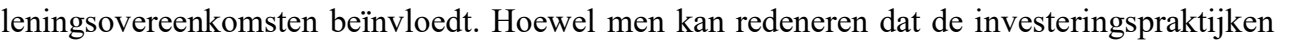

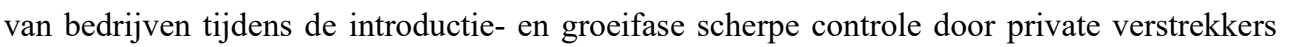

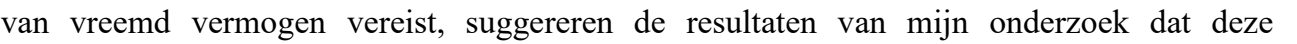

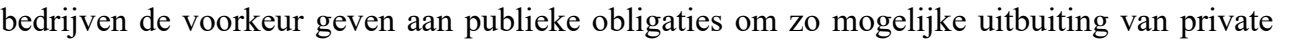

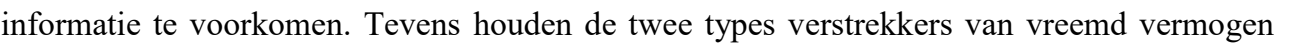

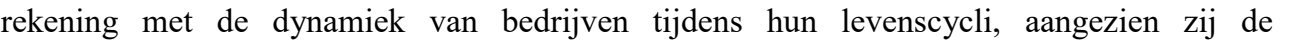

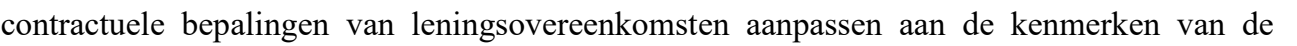

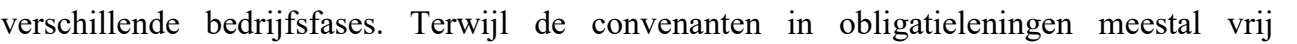

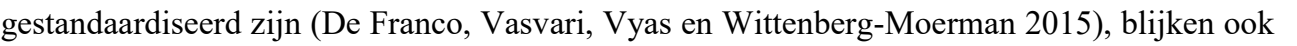

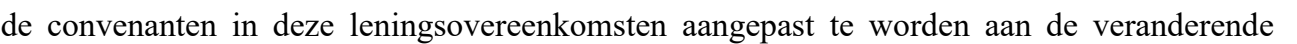

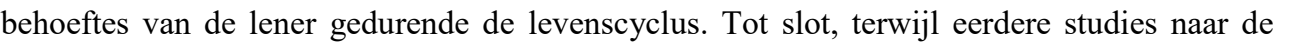

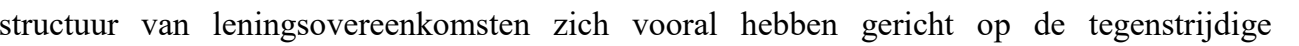

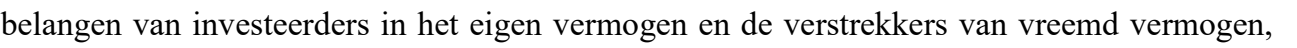

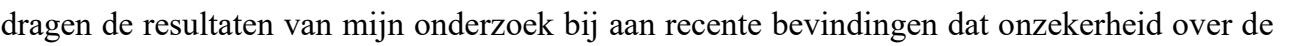

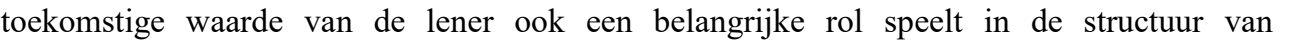

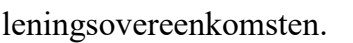


$\square$

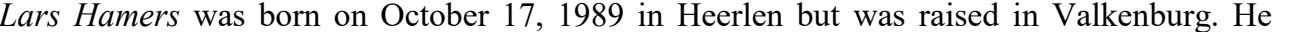
started his Bachelor's studies in Economics and Business Economics at the School of Business and Economics, Maastricht University in 2008. During his Bachelor's studies, he

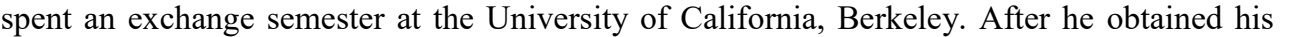

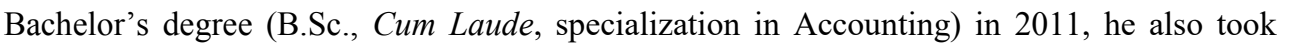

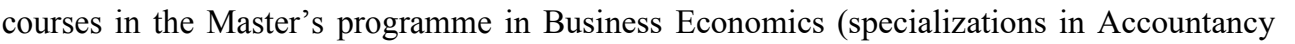

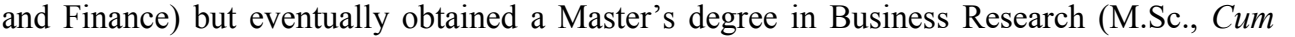

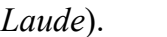

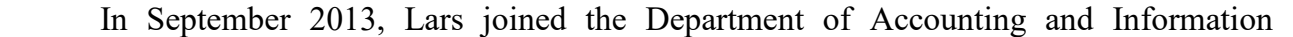

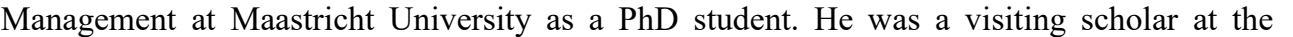

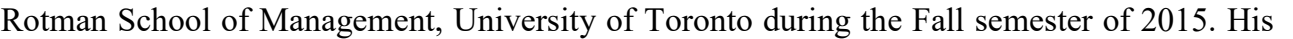

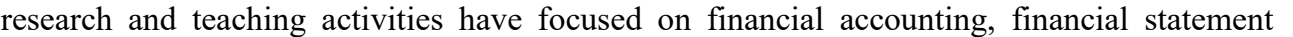

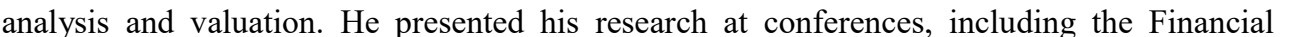

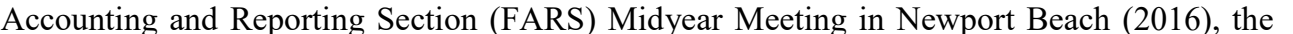

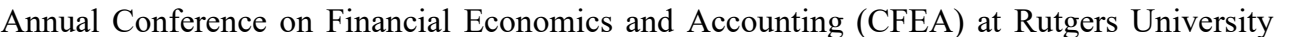
ए

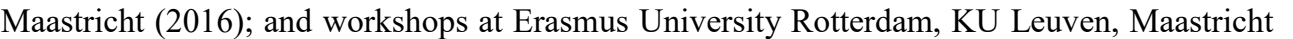

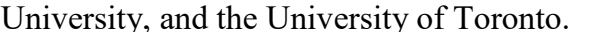

